\title{
FEMINISMO/S 18
}

Salud pública desde la perspectiva de género: hitos e innovación María Teresa Ruiz Cantero (Coord.)

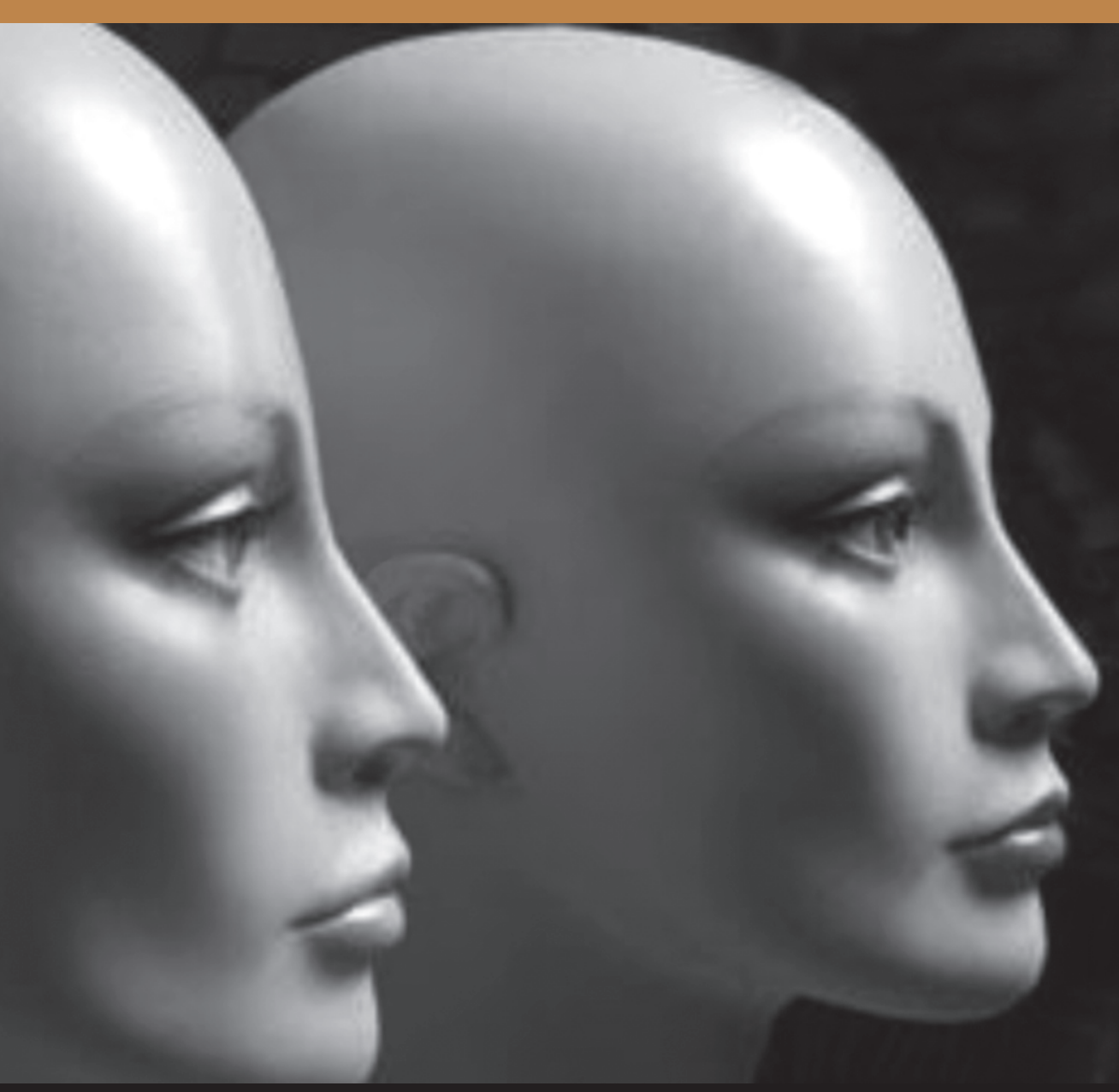

C. Centro de Estudios 



\section{FEMINISMO/S}

Revista del Centro de Estudios sobre la Mujer de la Universidad de Alicante

Número 18, diciembre de 2011

\section{Salud pública desde la perspectiva de género: Hitos e innovación}

María Teresa Ruiz Cantero (Coord.) 



\title{
FEMINISMO/S \\ Revista del Centro de Estudios sobre la Mujer de la Universidad de Alicante
}

\author{
Revista Semestral \\ Editada por el Centro de Estudios sobre la Mujer de la Universidad de Alicante \\ con la colaboración del Vicerrectorado de Planificación Estratégica y Calidad
}

Número 18, diciembre de 2011

\section{CONSEJO EDITORIAL}

Directoras: Carmen MAÑAS VIEJO Y M ${ }^{a}$ del Mar ESQUEMBRE VALDÉS (Universidad de Alicante) Secretaria: Nieves MONTESINOS SÁNCHEZ (Universidad de Alicante)

Vocales: $\mathrm{M}^{\mathrm{a}}$ Teresa Ruíz CANTERo (Universidad de Alicante)

Purificación HERAS GONZÁLEZ (Universidad Miguel Hernández)

$\mathrm{M}^{a}$ Isabel PeÑalver Vicea (Universidad de Alicante)

Carmen OlaRIA DE GUSI (Universitat Jaume I)

\section{CONSEJO ASESOR}

Mabel Burín (Universidad de Ciencias Empresariales y Sociales, Buenos Aires)

Silvia CAPORAlE Bizzini (Universidad de Alicante)

Angels CARABí (Universitat de Barcelona)

Pilar CUder Domínguez (Universidad de Huelva)

Joaquín DE JUAN (Universidad de Alicante)

$\mathrm{M}^{\mathrm{a}}$ José FRAU LLINARES (Universidad de Alicante)

Eddy GIL DE MEjÍA (Fachhochschule Oldenburg/Ostfriesland/ Wilhelmshaven University

of Applied Sciences)

$\mathrm{M}^{\mathrm{a}}$ Victoria Gordillo Álvarez-Valdés (Universidad Complutense de Madrid)

Albert GRAS (Universidad de Alicante)

Marina MAYORAL (Universidad Complutense de Madrid)

Mónica Moreno SeCo (Universidad de Alicante)

Montserrat PALAU (Universitat Rovira i Virgili)

$\mathrm{M}^{\mathrm{a}}$ Dolores Ramos (Universidad de Málaga)

$\mathrm{M}^{\mathrm{a}}$ Dolores Reventós (Universidad de Murcia)

Carmen RIERA (Universitat de Barcelona)

Ana SÁNCHEZ TORRES (Universitat de València)

Begoña San Miguel Del Hoyo (Universidad de Alicante)

Marta SegarRa (Universitat de Barcelona)

Cristina Segura Graiño (Universidad Complutense de Madrid)

Julia Sevilla (Universitat de València)

$\mathrm{M}^{\mathrm{a}}$ Carmen SIMÓN (CSIC)

Ruth TeUbál (Universidad de Buenos Aires)

Meri TORRAS (Universitat de Barcelona) 


\section{REDACCIÓN}

Centro de Estudios sobre la Mujer de la Universidad de Alicante

Campus de Sant Vicent del Raspeig

Apdo. 99 E-03080 Alicante

Tel. 965909415 - Fax 965909658

e-mail: cem@ua.es -web: www.ua.es/cem

\section{SUSCRIPCIÓN}

Centro de Estudios sobre la Mujer de la Universidad de Alicante

Campus de Sant Vicent del Raspeig

Apdo. 99 E-03080 Alicante

Tel. 965909415 - Fax 965909658

e-mail: cem@ua.es -web: www.ua.es/cem

Precio de cada ejemplar: $12 €$

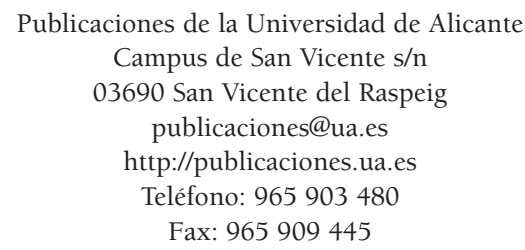

Edita:

Centro de Estudios sobre la Mujer de la Universidad de Alicante con la colaboración del Vicerrectorado de Planificación Estratégica y Calidad

Cuenta con una Ayuda para la Publicación de Revistas Científicas del Vicerrectorado de Investigación, Desarrollo e Innovación

ISSN: 1696-8166

Depósito legal: A-910-2003

Diseño de portada: candela ink Maquetación: Marten Kwinkelenberg

Feminismo/s no se identifica necesariamente con los contenidos de los artículos firmados. Prohibida

la reproducción total o parcial de los artículos sin la autorización previa.

Feminismo/s se encuentra indexada en la base de datos del ISOC del CINDOC y en el LATINDEX.

También se encuentra recogida en DICE, In-RECS y MLA. 


\section{ÍNDICE}

María Teresa Ruiz Cantero

Introducción

Lucía Mazarrasa Alvear y Carlos Álvarez-Dardet Díaz

Entrevista con dos Salubristas: Desarrollo de las mujeres y Cuestiones

de género en su historia de vida

Interview to two public health specialists: Women development and gender issues

in their history of life

\section{María Luisa Jiménez Rodrigo}

Mujeres, abandono de consumo de tabaco y barreras de género

Women, withdrawal of tobbaco consumption and gender barriers

Gladys Rocío Ariza Sosa

Hacia la definición de la violencia en las relaciones de pareja como un problema de salud pública en Medellín a comienzos del siglo XXI

Towards the definition of violence in couple relationships as a public health problem in Medellín at the beginning of the 21st century

\section{Fauhn Minvielle e Isabel Goicolea}

Women's right to health in the Anglo-Caribbean: Intimate partner violence, abortion and the State

El derecho a la salud de las mujeres en el Anglo-Caribe: violencia del compañero íntimo, aborto y el Estado

Alberto Martín-Pérez Rodríguez

“¿Dónde vas a ir tú con SIDA?”. Intersecciones entre la infección por VIH y la violencia del compañero íntimo.

«You have AIDS, who is going to want you around?» Intersections between HIV infection and intimate partner violence

María Luisa Panisello Chavarria, Inma Pastor Gonsalbez, María Luisa Mateu Gil y Anna Panisello Tafalla

Análisis de la perspectiva de género en los planes directores del departamento de salud de la Generalitat de Catalunya

Analysis of gender perspective in the directive plans of health department of Generalitat de Catalunya 
Mercedes Carrasco Portiño, Natalia Papi-Gálvez, María Teresa Ruiz

Cantero, Vicent Clement Gómez y José Fernández Saez

La Encuesta Nacional de Salud como herramienta de medición de la doble carga de trabajo en España. Comparación con la Encuesta de Población Activa.

The Spanish National Health Survey as measurement tool of double workload in Spain. Comparison with the Spanish Active Population Survey

Vita Ascensió Arrufat Gallén y Rosa María Marín Torrens

Propuesta de indicadores para un perfil sobre salud de las mujeres en la Comunidad Valenciana.

Proposal of indicators for a women's health profile in Comunidad Valenciana

Elvira M. Melián

En la Barca de Caronte. (La menopausia o la gran transformación)

At the Boat of Charon. (Menopause or the great transformation)

Gema Lasarte Leonet

La maternidad en el imaginario de las escritoras vascas

Maternity in the imaginarium of female Basque writers

María Eugenia Galiana-Sánchez y Josep Bernabeu-Mestre

Género y desarrollo profesional: Las enfermeras de salud pública en la España del período de entreguerras, 1925-1939.

Gender and professional development: public health nurses in the interwar Spain, 1925-1939

Clara Victoria Giraldo Mora y María Eugenia Arango Rojas

Efectos de las representaciones sociales de las mamas sobre la prevención del cáncer mamario en un grupo de mujeres colombianas

Effects of the social representation of breasts upon the breast cancer prevention in a group of Colombian women

$$
* * *
$$

\section{Las expertas recomiendan lecturas sobre...}

The experts recommend reading about...

Construir salud, construir género: ¿Por qué la investigación cualitativa es una metodología sensible al género? Comentarios de María del Mar García-Calvente y Jorge Marcos Marcos del artículo: The weaker sex? Exploring lay understandings of gender differences in life expectancy: A qualitative study. Soc Sci Med 2008; 67: 808-16. De: C Emslie, K Hunt.

Building health, building gender: Why qualitative research is a gender-sensitive methodology? Commentaries by María del Mar García-Calvente and Jorge Marcos Marcos on the article: The weaker sex? Exploring lay understandings of gender 
differences in life expectancy: A qualitative study. Soc Sci Med 2008; 67: 808-16.

By: C Emslie, K Hunt

Morbilidad diferencial entre mujeres y hombres. Comentarios de Carme Valls-Llobet del artículo: Sex and gender factors in medical studies. Implications for health and clinical practice. JAMA. 2003; 289: 397-400. De: VW Pinn

Differential morbility between women and men. Commentaries by Carme Valls on the article: Sex and gender factors in medical studies. Implications for health and clinical practice. JAMA. 2003; 289: 397-400. By: VW Pinn

Un modelo ecológico integrado para comprender la violencia contra las mujeres. Comentarios de Carmen Vives Cases del artículo:

Violence against women: An integrated, ecological framework.

Violence against Women 1998; 4: 262-290. De: L Heise

An integrated ecological model to understand violence against women.

Commentaries by Carmen Vives on the article: Violence against women:

An integrated, ecological framework. Violence against Women 1998; 4: 262-290.

by: L Heise

Desigualdades sociales en la asociación entre el estado civil y/o de pareja y la salud de los trabajadores en España. Comentarios de Lucía Artazcoz del artículo: Social inequalities in the association between partner/marital status and health among workers in Spain. Soc Sci Med 2011; 72:600-7. De: L Artazcoz, I Cortès, C Borrell, V EscribàAgüir, Cascant L.

Social inequalities in the association between partner/marital status and health among workers in Spain. Commentaries by Lucía Artazcoz on the article: Social inequalities in the association between partner/marital status and health among workers in Spain. Soc Sci Med 2011; 72:600-7. by: L Artazcoz, I Cortès, C Borrell, V Escribà-Agüir, Cascant L.

Medicina en femenino universal. Comentarios de Consuelo Miqueo del libro: El sentido de la enfermedad. Un viaje del alma. Ed. Kairós: Barcelona, 2006: De J Shinoda Bolen

Medicine in universal feminine. Commentaries by Consuelo Miqueo on the book: The meaning of illness. A journey of the soul. Ed. Kairós: Barcelona, 2006: By J Shinoda Bolen

Feminización de la Medicina y tiempo de trabajo. Comentarios de Ana Delgado y Lorena Saletti-Cuesta del artículo: Women in Medicine: A Four-Nation Comparison. J Am Med Women Association 2002; 57 : 185-190. De: JE McMurray, G Angus, M Cohen, P Gavel, J Harding, J Horvath, E Paice, J Schmittdiel, K Grumbach ....

Feminization of Medicine and working time. Commentaries by Ana Delgado and Lorena Saletti-Cuesta on the article: Women in Medicine: A Four-Nation Comparison. J Am Med Women Association 2002; 57: 185-190. By: JE McMurray, G Angus, M Cohen, P Gavel, J Harding, J Horvath, E Paice, J Schmittdiel, K Grumbach 
Y nuestras jóvenes investigadoras recomiendan...

And our young researchers recommend...

El estatus social de las mujeres y su impacto en la salud de la población. Comentarios de Mercedes Carrasco-Portiño del artículo: Women's status and child well-being: a State-level analysis. Soc Sci Med 2006: 63: 2999-3012. De: KC Koenen, A Lincoln, A Appleton

Social status of women and its impact on the health of population. Commentaries by Mercedes Carrasco-Portiño on the article: Women's status and child well-being: a State-level analysis. Soc Sci Med 2006: 63: 2999-3012. By: KC Koenen, A Lincoln, A Appleton

Sensibilidad de género en la investigación sobre políticas sanitarias.

Comentarios de Erica Briones Vozmediano del artículo: Sensibilidad de género en la formulación de planes de salud en España. Lo que pudo ser y no fue. Gac Sanit 2004; 18: 36-46. De: R Peiró, N Ramón, C Álvarez-Dardet, C Colomer, C Moya, C Borrell, A Plaséncia, E Zafra y MI Pasarín

Gender sensibility in research about health policies. Commentaries by Erica Briones Vozmediano on the article: Gender sensibility in the health policies formulation in Spain. What could have been but never was. Gac Sanit 2004; 18: 36-46. By: R Peiró, N Ramón, C Álvarez-Dardet, C Colomer, C Moya, C Borrell, A Plaséncia, E Zafra and MI Pasarín

Un marco teórico para analizar el sesgo de género en la investigación epidemiológica: Haciendo visible lo invisible. Comentarios de Elisa Chilet Rossell del artículo: A framework to analyse gender bias in epidemiological research. J Epidemiol and Community Health 2007: 61 (Suppl II): ii46-ii53. De: MT Ruiz-Cantero, C Vives-Cases, L Artazcoz, A Delgado, MM García-Calvente, C Miqueo, I Montero, R Ortíz, E Ronda, I Ruiz, C Valls.

A theoretical framework for analyse gender bias in epidemiological research: making visible the invisible. Commentaries by Elisa Chilet Rossell on the article: A framework to analyse gender bias in epidemiological research. J Epidemiol and Community Health 2007: 61 (Suppl II): ii46-ii53. By: MT Ruiz-Cantero, C VivesCases, L Artazcoz, A Delgado, MM García-Calvente, C Miqueo, I Montero, R Ortíz, E Ronda, I Ruiz, C Valls 


\title{
SALUD PÚBLICA DESDE LA PERSPECTIVA DE GÉNERO: HITOS E INNOVACIÓN
}

\author{
MARÍA TERESA Ruíz CANTERO \\ Universidad de Alicante
}

\section{Introducción}

Los estudios sobre la salud pública en España han proliferado en las últimas décadas, poniendo algunos, de ellos, de manifiesto que las mujeres, la población de menor nivel socioeconómico o las áreas con mayor privación material presentan unos indicadores de salud que denotan una peor situación. De ahí el interés que tiene para la salud pública el comprender y aplicar la perspectiva y el análisis de género. El elemento común que comparten el enfoque de la Salud Pública y la perspectiva de género es su consideración SOCIAL, lo que permite que el ANALISIS DE GÉNERO pueda tener lugar con relación a problemas y situaciones de salud de las mujeres y los hombres.

La salud de las mujeres y los hombres es diferente pero también desigual: diferente porque existen factores de tipo biológico y fisiológico que tienen distintas implicaciones en su salud; desigual porque hay factores sociales que establecen diferencias evitables, y por ello injustas, en la salud de ambos sexos.

Es en este último concepto en el que se centra el presente número de la revista feminismos, cuyas/os autoras y autores proceden de diferentes instituciones de Andalucía, Aragón, Cataluña, Comunidad Valenciana, Madrid y País Vasco, e internacionales, como Colombia y Suecia. Son las Universidades los centros de trabajo de las/los autoras/es más frecuentes (Universidad de: Antioquia, Nacional de Colombia, País Vasco, Rovira i Virgili, Sevilla, Umeå, Zaragoza y Alicante). También, participan profesionales de la Agencia de Salud Pública de Barcelona, Centro de Análisis y Programas Sanitarios de Barcelona, Conselleria de Sanidad de la Comunidad Valenciana, Escuela Andaluza 
de Salud Pública, Escuela Nacional de Sanidad, Hospital de Madrid y Secretaría del Plan Nacional sobre el SIDA.

A lo largo de la lectura de los artículos se podrá observar como sus autoras/es han aplicado la perspectiva de género en las investigaciones o sus análisis, mediante la adopción de alguno de los tres niveles de observación establecidos a partir de los sistemas de género; los cuales reflejan los procesos que subyacen bajo las desigualdades sociales basadas en las diferencias socialmente construidas en función del sexo. Desde los niveles de observación las autoras y autores de los artículos han caracterizado al género como un componente de la identidad personal, como base de los valores normativos de la sociedad, y/o como un principio organizador de la estructura social (posición social de las mujeres y los hombres).

Para orientar la lectura quiero recordar, que el género como componente de la identidad individual, hace referencia al sentido que las personas tienen de sí mismas frente a la identidad social, que son las categorizaciones de las personas efectuadas por los otros. La identidad propia es una auto-percepción que puede estar más o menos cerca del modelo social de referencia. En este sentido, por otra parte, se entiende que el género está en la base de los valores normativos de la sociedad; y que la identidad social de género se constituye a partir de los patrones sociales asociados a características aparentes, corpóreas y visibles proyectadas sobre los grupos sociales, en concreto, el de las mujeres y de los hombres. Responde a lo que se considera, de forma estereotipada, lo femenino y lo masculino en una sociedad. Y por otra parte, el género se puede entender también como principio organizador de la estructura social, mediante el cual, las actividades de mujeres y hombres en una sociedad están segregadas en función de su sexo. En este nivel de observación se incluyen los estudios sobre la posición de las mujeres y hombres en las sociedades, el acceso a los recursos y la distribución de los mismos. Se incluyen los análisis que consideran al género un criterio de estratificación social, como los relacionados con el trabajo reproductivo (cuidados y doméstico) y remunerado, la doble jornada o la segregación del mercado laboral. Destacan tres escenarios en los que existe un reparto de tareas por sexo, mediante los que se pueden observar los efectos de la división sexual del trabajo: vida familiar-domésticapersonal o privada, vida profesional-laboral o pública, e interacción de ambas vidas, con sus implicaciones en la distribución del tiempo y la sobrecarga de trabajo.

Este número consta de cuatro partes. La primera parte ( Entrevista con dos Salubristas: Desarrollo de las mujeres y cuestiones de género en su historia de vida») tiene por objetivo recordar hitos, situaciones, barreras y evolución 
de la emancipación de las mujeres españolas en nuestra historia reciente y que tanto han influido en la salud de las mismas, así como también, sin duda, en la salud de los hombres españoles. Es a través del transcurso de las vidas de los protagonistas de esta sección, Lucía Mazarrasa Alvear y Carlos Álvarez-Dardet Díaz, que aprendemos a apreciar cómo ha afectado, en tanto que individuos y personas, la complejidad de los valores sociales, una vez transformados en toma de decisiones y acciones por parte de familiares, compañeros de estudios y trabajo, y políticos. Agradezco las lúcidas e inteligentes respuestas y reflexiones a mis preguntas. Hace años supe que una Catedrática de Universidad de Medicina Preventiva y Salud Pública aún en activo, no pudo serlo hasta que se eliminó una normativa por la que para alcanzar este puesto era preciso ser militar. Afortunadamente, la democracia ha ido allanando el camino hacia la igualdad, por el cual transitan profesionales de la salud pública como Carlos Álvarez-Dardet y Lucía Mazarrasa, que van por delante desbrozando los márgenes y apartando las piedras y obstáculos que aún dificultan la igualdad de género y sus consecuencias en la salud pública. He admirado siempre su capacidad profesional, y especialmente su compromiso social y activismo político.

La segunda parte está compuesta por «artículos originales» que aportan nuevos datos y conocimiento sobre problemas de salud pública de gran interés en la actualidad como la violencia de género, el SIDA, el aborto, o el tabaco; así como otros centrados en temas clásicos vistos por una mirada nueva acerca de la maternidad, la menopausia, o sobre los efectos de la representación social de las mamas en la prevención de cáncer mamario. También se incluyen artículos centrados en el análisis de género de herramientas de uso institucional, como los planes directores de salud, la encuesta nacional de salud, e indicadores para realizar un perfil de salud de las mujeres. Son artículos operativos, de los que se puede aprender método para la aplicación de la perspectiva de género. Este apartado contiene un artículo sobre el desarrollo profesional en una profesión sanitaria imprescindible, la enfermería; el cual tiene su complemento en el siguiente apartado, con uno de los ensayos sobre un artículo acerca del desarrollo profesional en medicina.

Una serie de ensayos que hacen referencia a artículos, que podríamos decir son de lectura obligada para aprender sobre la perspectiva y el análisis de género, componen La tercera parte, denominada «Las expertas recomiendan lecturas sobre ...» En efecto, expertas de alguna rama de la salud y la salud pública; así como en la aplicación de la perspectiva y el análisis de género, nos ilustran en cómo hacerlo, mediante un ensayo breve en el que comentan un artículo o libro que han seleccionado, y que recomiendan leer por considerarlo relevante para tal fin. Se incluyen análisis y reflexiones sobre la relación 
entre características demográficas como el estado civil y/o de pareja y su relación con la salud de los y las trabajadores(as), la morbilidad diferencial, el desarrollo profesional dentro de medicina, y de cómo construir y ayudar a la promoción de la salud a través de la perspectiva de género. Además de aprender con la lectura del propio artículo referido, quienes se interesan por cómo aplicar el análisis de género, pueden aprender con las razones y argumentos utilizados por las expertas.

Dada la aspiración de que este número de la revista FEMINISMO/S llegue y su uso sea de utilidad a las y los jóvenes investigadoras/es, se ha incluido la cuarta parte cuyo objetivo es darles la voz. Para ello, con el mismo formato de la tercera parte, tres jóvenes investigadoras en salud pública han escrito con maestría un ensayo en el que cada una nos propone la lectura de un artículo del que han aprendido cómo aplicar la perspectiva de género o hacer análisis de género.

Para acabar. En el número 18 de la revista FEMINISMO/S se encuentran múltiples elementos de ayuda para aprender qué es esto de la perspectiva y el análisis de género, y su aplicación concreta en el ámbito de la salud pública. Parte del conocimiento ha sido producido, por ser objeto de interés de la historia y parte es objeto de interés científico actual: la mujer como objeto del conocimiento científico, la mujer como agente de cuidados de salud, las profesiones y las mujeres. Ambos contienen útiles en la innovación científica. Los textos incluidos aquí se ubican en algunas de las corrientes epistemológicas feministas donde conceptos y métodos se dan la mano; así que no está de más recordar que debemos investigar ateniéndonos a algunas de estas corrientes epistemológicas feministas existentes; tal que las principales: el empirismo feminista, el punto de vista o de partida feminista (feminism standpoint), y el postmodernismo feminista. 


\title{
ENTREVISTA CON DOS SALUBRISTAS: DESARROLLO DE LAS MUJERES Y CUESTIONES DE GÉNERO EN SU HISTORIA DE VIDA
}

\author{
LuCía MAZARRASA Y CARLOS ÁlVAREZ-DARDET \\ REALIZADA POR: Ma TERESA RUÍZ CANTERO \\ Universidad de Alicante
}

¿Ha cambiado el trato a las mujeres desde tu infancia/entrada a la Universidad? ¿Cómo era España tratando a las mujeres entonces y como es ahora? ¿Hay diferencias?

Lucía (L): El trato ha cambiado desde un punto de vista formal, y porque las leyes se han modificado mucho. Recuerdo, por ejemplo, que no pude entrar a la Universidad, porque la carrera de Enfermería se estudiaba en Escuelas privadas, al menos en Madrid. Es más, las mujeres no podíamos entrar en las escuelas de ATS masculinas que se hacían en la Universidad. En esto ya había un trato diferencial importante. Generalmente las Escuelas de Enfermería tenían unas condiciones de pago, de trabajo de prácticas y de estancias como si fuéramos enfermeras profesionales casi, con una dedicación exclusiva. Mientras, los chicos podían ir a la Universidad, y tenían un trato igual que el resto de los estudiantes universitarios. Más luego la disciplina, y todo lo que lo que eran los contenidos hacia la formación y el trabajo. Había una increíble represión sexual hacia las mujeres. En nuestra formación se daban cosas tan extraordinarias como que el profesor de anatomía nos dijo que no nos iba a enseñar el aparato reproductor masculino. No lo estudiamos, pero lo consultamos todas, por lo menos yo. Trato diferencial importante y además totalmente absurdo.

Y Sí, si que hay diferencias entre aquella época y ahora. Estos ejemplos de enfermería ya no ocurrirían. Ha cambiado muchísimo. 
Carlos (C): Cuando yo era niño las mujeres no tenían libertad de movimientos, ni de uso de su patrimonio, por supuesto el aborto era ilegal y no se podían obtener anticonceptivos, se añadía al androcentrismo de las sociedades de la época, el franquismo con su carga de nacional catolicismo, y el aislamiento internacional en el que Franco había sumido al país.

Fue precisamente de niño cuando tuve conciencia de que el trato hacia las mujeres era injusto. He tenido la suerte de tener tres hermanas por lo que su punto de vista, conversaciones, y las perspectivas de las mujeres siempre han sido muy próximos para mí. Los niños de mi clase solían por la tarde cuando salíamos y por la calle! Cogerles el culo, que se decía allá (dar una palmada en las nalgas) a las niñas cuando pasaban. La observación de que a las niñas esto no les hacia ninguna gracia era obvia. Gritaban y te llamaban «guarro y asqueroso», pero pronto en casa y por mis hermanas entendí que era un trato injusto, muy molesto y violento. De esta manera empecé a sentir por vez primera solidaridad intra-género. Creo que soy el único de mi cohorte que nunca hizo eso, lo que me valió por supuesto adjetivos de «maricón»; cosa que también me dio mucho pensar. Fue la razón de que hiciera mi tesis doctoral años mas tarde sobre los problemas de salud de los varones homosexuales. En mi mente infantil consideraba a los homosexuales como mas educados que los heteros (entonces decíamos machotes); pues a lo que se veía no hacían cosas de ese tipo, y esto me gustaba de ellos.

La manera de vestir de las mujeres en aquella época -fantásticamente recreada en la serie Mad men- era muy peculiar: se ajustaba mucho las formas en falda y busto, pero muy tapadas. De niño, me llamaba la atención lo del velo para ir a misa. La verdad es que me gustaba la prenda y no entendía porque no lo podíamos llevar los niños. Mi madre tenía unos velos preciosos. Por supuesto cuando exprese ese sentimiento me volvieron a llamar maricón esta vez en casa iy.... mi propia madre! Fue más doloroso que en el colegio. Las cristianas han llevado velo hasta antes de ayer, y no solo para entrar en la iglesia. Llevar el pelo suelto y a la vista se consideraba también indecoroso en Europa en los años 40 y 50 del siglo XX. Las mujeres recatadas, o sea todas o casi todas, solían usar pañuelo en la cabeza.

Creo que lo más relevante en términos de dominación de las mujeres era la extensísima y poderosa red informal de dominación que establecían los hombres; en la que colaboraban denodadamente algunas piezas clave en la sumisión doméstica como eran los curas y muchos médicos. Cualquier hombre podía ser un dictador porque tenía el apoyo de todos los demás. Es esta red machista la que se esta resquebrajando poco a poco en nuestros días; y 
que produce, como resistencia al cambio, la trágica lista de mujeres asesinadas que estamos viviendo.

¿Imponían los hombres su voluntad sobre las mujeres? Si sí ¿Y cómo eran esos hombres que imponían su voluntad sobre las mujeres? ¿Y cual es la situación ahora?

L: Pues sí, los hombres imponían su voluntad explícitamente sobre las mujeres; aunque dependiendo del tipo de hombre. Mi padre no quería que yo estudiara Enfermería, prefería que estudiara Farmacia, porque pensaba que Enfermería no tenía prestigio suficiente. Pero por supuesto no me lo impuso. Tal vez porque mi madre me apoyó. En cualquier caso, nunca nos impuso a mí ni a mis hermanas su opinión sobre que hacer o no hacer o que estudiar. En mi caso, no tuve problemas con mi familia, ni con mi padre, ni con el resto de mis hermanos. A lo mejor mi hermano mayor si pretendía ser un poco el delegado de mi padre. Pero, me opuse muchísimas veces a comportamientos que él nos quería exigir. Por ejemplo, si quería ver una película para mayores de 16 años, y yo tenía 14, pues iba a ver esa película; independientemente de que mi hermano y yo discutiéramos sobre si podía o no ir. O sea, que teníamos una libertad bastante grande, quizá por las circunstancias familiares que no eran las habituales de las familias españolas. Otro ejemplo se relaciona con la disciplina de estar a las diez en casa que mis amigas tenían que cumplir, y nosotras no. Podíamos viajar. Viajamos al extranjero desde la adolescencia. Estuvimos trabajando en Francia e Inglaterra. Éramos una excepción en el entorno, y creo que es porque en mi familia las mujeres han tenido bastante autoridad.

Hoy es muy posible que no lo hagan explícitamente; pero siguen habiendo mecanismos de imposición no explícitos, pero si implícitos, que condicionan a las mujeres, quienes estamos más supeditadas por socialización a ver que es los que quieren los hombres. Estamos más pendientes de la opinión de los hombres, y los hombres están menos de nuestra opinión o de nuestros deseos. Depende también mucho de la experiencia personal de cada quién.

C: Claro que la imponían véase lo que he puesto en el párrafo anterior. Las mujeres pasaban de sus padres a sus esposos, en una relación de dominación. Eran consideradas menores de edad. La fuerza de la mirada me llamaba mucho la atención de niño; y como la mayoría de los hombres no daban ordenes explicitas, sino que con una mirada tipo «cine negro» conseguían lo que querían, o advertían de los peligros de desviaciones de conducta. 
En la actualidad hay decisiones importantes que sigue estando en manos de los hombres, y las decisiones «más cotidianas» son de las mujeres.

\section{¿Recuerdas alguna historia que te marcara especialmente?}

L: Ya te he comentado dos anécdotas. Ejemplos de mi historia personal: recuerdo que un día mi padre me dijo que tenía que cambiar la rueda del coche por mi misma, y que no me lo podían hacer mis hermanos. Yo me tenía que valer por mí misma.

También recuerdo que mi madre nos decía siempre que teníamos que estudiar. Ser autónomas y que nunca dependiéramos del matrimonio. Ella era muy contraria al matrimonio quizá por su experiencia personal. Siempre gozó de muchísima libertad por parte de su padre. En los años 40 después de la guerra y antes de casarse viajó por Marruecos, Italia, Palestina. Era una mujer que estudiaba, sabía idiomas, trabajó en lo que pudo cuando se separó, y decidió no ser una «mujer de» y no quedarse sometida a la voluntad del matrimonio convencional. Era deportista y nos inculcó el deporte.

En la historia profesional: recuerdo que siendo alumna de prácticas en el quirófano de la Fuente Chaos en Madrid tuve que instrumentar una operación de gangrena en una pierna, que había que cortar. En el quirófano los roles están muy marcados: el cirujano, que es el que pide el instrumental, y la instrumentista enfermera que es la que se lo da de una manera especial para que lo pueda coger sin problemas. Pues el cirujano me pidió el bisturí, y pese a que yo fui a cogerlo, él se adelantó y cogió el bisturí por donde estaba la hoja, y se cortó. Se asustó porque estábamos hablando de una gangrena. Y yo pensé, ¡horror!, si confieso que he metido la pata (que no era así) me la voy a cargar, tengo que enfrentar esta situación. Y ¿cómo?, pues diciéndole: «mire usted, se ha adelantado a coger el bisturí cuando yo todavía no se lo había puesto en la mano como es preceptivo, y lo siento, pero usted ha cometido un error. Pese a mis 18 años y sus treinta y pico; pensé que si no hacía valer mi opinión e imposición en ese momento, podría caerme una gorda. El cirujano no dijo nada. Creo que se extrañó de mi reacción, y aceptó, porque no se esperaba que una alumna «enfermerita» se atreviera a plantarle cara muy educadamente, por supuesto, al señor cirujano. Recuerdo que todo el mundo se quedó como diciendo, y ésta ¿adónde va?

A lo largo de mi carrera profesional como enfermera algunas veces he tenido que enfrentarme a la opinión de algún médico que pensaba yo que tenía que haber hecho un comportamiento $\mathrm{X}$, y lo he tenido que tratar con el jefe superior. Estas situaciones son violentas porque son graves. Recuerdo discutir con la Comisión Médica cuando tenía la responsabilidad de la formación 
continuada en el hospital Ramón y Cajal. Por ejemplo, discutir el presupuesto que tenía que destinarse a la formación del personal de enfermería que éramos un porcentaje mucho más elevado que el de los médicos. Se extrañaban que yo discutiera en esos términos. Como diciendo, aquí viene la «enfermerita» esta a decirnos como se tiene que organizar el presupuesto. Pues si!, lo decía, lo discutía y lo acordábamos, y teníamos el apoyo del resto de las supervisoras o de las enfermeras adjuntas. Pero yo tengo la sensación de que siempre se extrañaban de que por ser mujer y por ser enfermera pudiera hablar en esos términos de igual a igual en una Comisión Medica. Te estoy hablando de los años 70 , finales de los 70. En este momento no estoy en esa situación, pero se cómo funciona, como el feminismo te desvela cuáles son los mecanismos de poder y de control. Esto te hace estar en una posición diferente, para poder saber cómo manejarte y cómo manejar las cosas sin llevarte unos «apechugones» tremendos.

C: Si, de enfrentarme al androcentrismo puro y duro pero no es de mi infancia o juventud es de ahora. Cuando empecé a hacer investigación sobre violencia de género en la Universidad hace unos 8 años, escribí un artículo en el diario El País que se titulaba, parafraseando a Miguel Lorente, «mi marido me pega lo normal». Bueno, pues, empecé a recibir anónimos por correo electrónico y en papel. Los mensajes eran terribles. Me llamaban «traidor»; e incluso me mandaron un texto sobre sexualidad sádica; como diciendo: «no sabes que te pierdes». Las organizaciones de hombres «contra la teoría de género» también llegaron a llamarme por teléfono. Tuve incluso miedo físico. Esto es un ejemplo del problema que tenemos por delante en la lucha por la igualdad. Los hombres están organizados, no tienen siglas y no reivindican sus atentados porque no hace falta. Cada asesinato es un acto para amedrentar, y un metalenguaje que va dirigido no solo a la mujer asesinada sino a toda la sociedad... Hasta que no tengamos esto claro y haya jueces que vayan contra las sub-culturas varoniles no acabaremos con este terrorismo. Hacer apología del machismo debería igualarse penalmente a hacer apología del terrorismo.

¿Dónde está la prioridad de las mujeres en estos momentos para alcanzar la igualdad real?

L: En la formación e interiorización de sus derechos y de sus deseos. También, los hombres tienen que interiorizar y socializarse, en que ya no tienen tantos privilegios, y no pueden seguir viviendo a costa de sus privilegios, y de las mujeres. Pero es complicado sobre todo para los hombres; y también para 
muchas mujeres a quienes todavía este mensaje no les llega. Son muchos siglos de tener interiorizado el sometimiento a estos privilegios de los hombres.

La siguiente prioridad es que las mujeres tengan buena formación, que en este momento ya la tenemos. Y que las mujeres sean capaces de tener un trabajo estable donde puedan desarrollarse, promocionarse; y no tengan que renunciar a él, por el hecho de ser madres, o tener hijos. Todavía es algo prioritario que tenemos que asumir. Claro, depende mucho de que mujeres estemos hablando. Las mujeres que tienen un trabajo y una formación están en una mejor situación. Pero, las jóvenes todavía no se dan cuenta de las desigualdades que siguen existiendo. Por ejemplo, cuando hay una promoción para subir de categoría o de más responsabilidad en el trabajo (lo cual conlleva un mejor sueldo) no son conscientes que todavía no están en la misma situación de igualdad. O cuando llega el momento de casarse o de formar una pareja. En el momento de tener un hijo, ahí se les cae los palos del sombrajo, porque se dan cuenta que todo cambia. Priorizan su maternidad y el cuidado. Mientras que los hombres, incluso los que aparentemente eran más igualitarios, siguen con su prioridad laboral y su vida; y si pueden tener tiempo y un poquito de espacio pues ayudan a la mujer a realizar las tareas de cuidados.

C: En el caso de España la prioridad es desmontar esta red difusa de machismo que igual mata a las mujeres que se mete con las ministras jóvenes. El machismo en público debería ser delito, hasta que no abordemos esto no se conseguirán avances. En España es delito apoyar en público a ETA, pero cualquier comentarista de la COPE o Intereconomía cada día hace «bromas» machistas, y nadie les dice nada. Esta «conjura de los necios» va a boicotear cualquier intento de igualdad real.

Las mujeres en España además soportan una carga de discapacidad mayor que los hombres. Es lo que se ha denominado muy gráficamente «longevidad minusválida». Soportan también una fracción injustamente grande de la carga de cuidados a personas mayores y dependientes. Mi madre antes de morir pasó unos años con necesidad de cuidados grande. En estos años que repartimos la carga entre mis hermanas y yo nunca me encontré por la calle una pareja como mi madre y yo. Es decir, un hombre adulto con su madre mayor ambos de paseo. Las señoras mayores que encontrábamos iban invariablemente acompañadas de mujeres, muchas de ellas extranjeras, o de sus hijas o nueras. Este escurrir las responsabilidades filiales de los hombres les quita si queréis trabajo; pero, sobre todo les impide desarrollarse como seres humanos con afectividad plena. 
Asimismo las mujeres sufren discriminación en los servicios sanitarios, disfrutando mucho menos que los hombres de la capacidad redistributiva del Sistema Nacional de Salud. Conforme aumenta la tecnología y el gasto sanitario va aumentando la proporción de varones y disminuyendo el de mujeres. Las desigualdades de género, que interactúan con las de clase y grupo étnico son sin duda las más relevantes en nuestro país.

\section{Por qué no ha habido aún una mujer presidenta en España?}

L: Por una parte porque los partidos políticos no se atreven a presentar una mujer como presidenta. Los partidos de izquierda sobre todo, que todavía creen en la política como mecanismo de transformación importante, no creen suficientemente en las mujeres. A los partidos de derecha, como no creen tanto en la política, sino que creen más en la estructura del poder que viene de las empresas, de los negocios, del dinero, les da igual poner una mujer. De hecho, hay muchas mujeres en España que han sido presidentas de Comunidades Autónomas, y curiosamente creo que todas han sido de opciones políticas conservadoras.

C: Por que la conjura de los necios lo impide. Cualquier mujer que destaque en política va a ser criticada con saña sobre todo si es de izquierdas. Además, la historia social de España, su déficit democrático hace que el movimiento feminista estuviera congelado durante 50 años, y que el sufragismo no haya tenido la importancia que tuvo en países de mayor tradición democrática. El legado de las pioneras como Clara Campoamor para el voto, o Maria de Guzmán (primera mujer en obtener un Doctorado en España) no ha podido seguirse adecuadamente.

No estoy preconizando la revolución, ni cambios drásticos. Pero si, que se respeten normas básicas de igualdad como es no denostar a alguien por razón de su sexo. Pongamos un ejemplo aparentemente alejado: hace 30 años nadie en España respetaba los pasos de cebra, ahora se respetan mucho más, ¿ Cómo se ha conseguido? Millones y millones de personas se han atrevido a reivindicar su derecho de paso con preeminencia sobre el del coche en los pasos de cebra, y ha acabado habiendo un cambio cultural. Vivir la vida es como cruzar la calle, hay que hacerlo reivindicando nuestros derechos.

\section{¿España está preparada para tener una mujer presidenta?}

L: Sí, la sociedad lo vería de una manera normal. Fíjate, lo han visto en otros países donde hay mucha más desigualdad entre hombres y mujeres, como 
puede ser India, o con Indira Gandhi, o Argentina, o países africanos donde hay mujeres que ya son presidentas de sus países. En Europa estaba la señora Thatcher, y está la señora Merkel. No hay ningún impedimento a qué también gobierne una mujer en España. El impedimento viene más de la estructura de poder dentro de los partidos políticos, que no de la sociedad.

La participación política en el Parlamento ha subido gracias a poner un imperativo legal que es que las candidaturas tienen que ser más representativas de las mujeres, sino no hubieran subido por sí mismas. Esto es un hecho comprobado empíricamente.

C: Desgraciadamente aun no, si linchan en los medios a las ministras, como Bibiana Aido o Leyre Pajín, imagínate a una presidenta.

\section{¿Qué retos existen en otras profesiones?}

L: Son los mismos que para todo el mundo. Si tuviéramos más formación en lo que es el feminismo, en lo que el feminismo nos ha explicado de cómo funciona el poder, las estructuras de poder y la estructura de desigualdad en que se basa, pues eso nos daría muchas más luces a muchas más mujeres para poder superar esto. También para que los hombres se dieran cuenta de que tienen que renunciar (no sé si es la palabra) a los privilegios que tienen hasta ahora.

Y en Medicina ha cambiado mucho. Hay muchas mujeres. Cuando empecé en la Escuela Nacional de Sanidad a dar clases en el Master de Salud Pública, en los años 80 y mitad de los 90, eran mayoritariamente hombres, y ahora es todo lo contrario. Esto ha cambiado. Ha dado un vuelco. Por lo tanto, una cosa es la participación en las profesiones, y otra el poder o la capacidad de gestión o de decisión que tengan las mujeres en las profesiones, y en las estructuras de poder de la organización del trabajo, que son dos cosas muy distintas. Estamos viendo ahora como en la tramitación de los convenios colectivos y en su negociación no dan cabida a los planteamientos de las mujeres sindicalistas. Nos están diciendo que se está quitando todo aquello que tenga que ver con mejoras para las condiciones de trabajo de las mujeres. Esto es la realidad!

\section{¿Cómo pueden funcionar las mujeres en el poder cuando son minoría?}

L: Tendrían que tener una relación muy estrecha con las asociaciones y las bases de mujeres. Esto es una laguna que todavía existe. No solamente con las de sus partidos políticos correspondientes. Más conexión con las mujeres 
y el movimiento feminista sobre todo, pues falta todavía esta sintonía. Te voy a poner un ejemplo. Hace unos días, varias asociaciones feministas hemos hecho un acto en el Congreso de los Diputados a raíz de la discusión que está habiendo sobre la ley de pensiones. La portavoz del grupo parlamentario del Partido Popular en la ponencia sobre las pensiones, nos vino a decir que habían tenido contactos con asociaciones de viudas ¡Como si fueran solamente las viudas las que reciben pensiones! Pero que con las asociaciones de mujeres no habían tenido ninguna reunión, que no se les había ocurrido. Figúrate, que cosa más increíble! Son pocas, pero encima, desconocen o no se les pasa por la idea de que hay un movimiento asociativo muy importante que está diciendo cosas. Otros partidos también dijeron algo parecido, a excepción de Izquierda Unida que había recogido en sus propuestas, el manifiesto y las propuestas que teníamos las asociaciones en este tema de las pensiones. Las asociaciones de mujeres tenemos propuestas; y no solamente las de viudas; porque si eres «viuda de», viuda de un hombre, se te tiene en cuenta, pero si eres una mujer por ti misma, a la hora de las pensiones parece que no tienes problemas específicos, cuando es grave lo que está ocurriendo con el tema de las pensiones de las mujeres en este momento. Ya sabes que reciben una cuantía muchísimo menor en general. Tanto, por tiempo de cotización, como por la estructura del trabajo, etc. Esto refleja una realidad, que todavía las estructuras políticas están muy lejos de la ciudadanía. Y no te digo ya, de la ciudadanía femenina.

En cuanto al poder político. Con las cifras del Parlamento, sabemos que no puede haber un balance de menos del 40 y más del 60 por ciento de un sexo respecto al otro. Sin embargo, nos hemos dado cuenta que esta legislación todavía es un poco rácana con respecto a las mujeres, porque en realidad muchas propuestas que nosotras hacemos, o parte del movimiento feminista que está interesado precisamente en el tema de la intervención en las políticas públicas, es que hubiera representación del 50\%. Por ejemplo, las candidaturas podrían empezar por que las mujeres estuvieran en el número impar. El número impar significa que la primera es una mujer. Para hacer realmente cambios radicales en la sociedad se podría hacer esto. Son opiniones en gran parte del movimiento feminista que por supuesto los partidos políticos no asumen porque son estructuras muy masculinizadas todavía. Por lo tanto, se han dado pequeños pasos en el imperativo legal, pues van mejorando la situación en los Parlamentos, en las Concejalías, en las Comunidades Autónomas; pero, todavía hay un montón de municipios, en especial los que tienen menos de 3000 habitantes, en donde se eximen de aplicar la legislación de las candidaturas balanceadas. Y son un montón de Ayuntamientos de zonas rurales, 
unos 2000 o 3000, donde las mujeres están trabajando y donde tienen unos planteamientos estupendos. Pero sin embargo, la ley las obvia. La ley deja aparte a las mujeres como si por el hecho de vivir en municipios pequeños fueran minusválidas, o sea que todavía hay muchísimas cosas que hacer y que hay que cambiar en este país.

C: Organizándose mejor y participando mas en los medios. España que fue el sitio donde se fundo probablemente una de las primeras organizaciones de mujeres del mundo (mujeres libres, de la Primera Internacional) tiene aún pocas asociaciones de mujeres.

En Occidente (y España está en occidente) se piensa en el poder como algo que se obtiene mediante el control de otros o con riqueza. ¿Hay otros tipos de poder? Si sí, ¿puedes sugerir formas para que yo o cualquier otro pueda cultivarlo?

L: Si que hay otro tipo de poder y hay que conocerlo, pues el poder no es algo que tienen unos pocos. El poder es más democrático, más horizontal. Es la capacidad de decisión que tenemos muchas y muchos, y que hay que canalizar dando posibilidades a todo el mundo. Celia Amorós explicaba hace tiempo, como el poder es algo que transita entre grupos. Entre grupos organizados. Y unos grupos quieren tener el control, y otros lo que quieren es repartir mejor los beneficios y los derechos, y también las obligaciones, y no para controlar a unos sobre otros. Cultivar esta última forma de poder es tener una socialización más en lo comunitario, en una idea de compartir lo que una persona tiene con las otras, más que de retener o poseer. Y compartirlo desde el ámbito familiar hasta el más social de participación, en el que cada cual esté. No tener esa mentalidad tan competitiva, sino más de complicidades y de aportar cada quién, y entre todas las personas conseguir objetivos más o menos comunes. Claro, los intereses de cada grupo están ahí, y eso no lo puedes evitar. Pero son formas diferentes, que parten de una socialización más en el compartir que en el tener.

C: Tenemos que desvelar el mundo doméstico al espacio público. En España, un hombre puede, por ejemplo, no pagar la pensión de divorcio a su ex mujer y sus hijos, y ocupar un puesto político; o incluso, ser un agresor (pensar en que la famosa lista de Bono, el ex presidente de la Comunidad de Castilla-La Mancha, nunca se puso en marcha). Creo que el gran déficit democrático que tenemos es que la Constitución no ha entrado aun al interior de las casas. Cuando la famosa «Ley Corcuera» de la patada en la puerta, Izquierda 
Unida saco unos azulejos que rezaban «la constitución protege cada rincón de esta casa». Yo siempre argumente que esto era falso. Habría que conectar lo doméstico con lo público, y reivindicar cuestiones domésticas en el espacio público. Lo que Giddens llamaba democracia de los afectos.

\section{¿Qué piensas del poder de la maternidad?}

L: Yo no he querido ser madre biológica ni real. El poder de las madres o de la maternidad es muy grande. Pero también pasa una factura muy grande a las mujeres. Ha habido en nuestra tradición cultural un canto metafórico a la maternidad, como que es la vía de realización exclusiva de las mujeres, y quién no es madre no es una mujer plena, no conoce todo, y realmente se pierde una gran parte de la vida. Esta mentalidad continúa estando ahí. A lo largo de la historia, muchas mujeres han optado por la no maternidad, por las razones que fueran, y no por eso han dejado de ser mujeres. No es tan natural ni normal que las mujeres quieran ser madres, y menos por el hecho de querer ejercer un poder.

La maternidad te da un poder, a veces mal ejercido. Según mi experiencia personal, la mejor herencia que he tenido de mi madre es que no ha sido la típica madre española "gallinópolis». O sea, de estas gallinas cluecas que tienen siempre alrededor a sus hijos porque si no los tienen no saben qué hacer de su vida. Todavía las madres españolas ejercen mucho de madres. Percibo que todavía las madres tienen unas exigencias de una maternidad maravillosa. El caso es que me parece que ese tipo de maternidad les ahoga a ellas, y también ahoga su relación con sus hijos. Por supuesto, es una percepción muy general. Pero, que cuando he trabajado en otros países, por ejemplo en Suiza, Inglaterra o Estados Unidos, no he tenido. Pienso por ello, que el poder de la maternidad tiene dos filos. Podría ser un poder maravilloso si se creyera en la autonomía y la independencia de las personas o de los hijos y de las hijas. Pero puede ser también un poder nocivo para las mujeres.

Al amplio grupo de mujeres que han decidido por la no maternidad (un $10 \%$ de la población?) siempre se le ha hecho invisibles. No sé exactamente las razones porque no hay muchos estudios. Pero, me resulta curioso que nunca se hable de las mujeres solteras, o de las que no tienen ganas de tener hijos o no se han planteado nunca la maternidad como un aspecto vital de su vida. Habría que ver si las mujeres a lo largo de la historia han tenido hijos porque no les quedaba más remedio y porque era su función sin plantearse otra alternativa.

En las que actualmente teniendo la posibilidad de elegir, eligen ser madres, habría que averiguar si realmente es una elección tan libre, o tan clara, o 
más bien viene dada por la fuerza de la costumbre, y por la tradición. Habría que preguntar a las mujeres que tienen hijos, y también a las que no han querido ser madres, para entender mejor esos mecanismos sociales.

A lo mejor las funciones que ejercemos en el trabajo, las mujeres que no queremos tener hijos o no nos planteamos una maternidad biológica ni familiar, están más relacionadas, y evidentemente lo están, con el tema del cuidado, como la enseñanza, la enfermería, incluso la medicina o el trabajo social. Pero, el cuidado es una cosa y la maternidad es otra; pues el cuidado lo pueden ejercer las madres y los padres. Es decir, tendríamos que estar hablando del cuidado de maternidad y de paternidad; $y$, hasta ahora siempre se asocia la maternidad al cuidado, pero nunca hemos asociado la paternidad al cuidado que deberían de hacer, o al no cuidado,¿QQue significa la paternidad y el cuidado?

C: Obviamente es algo poderoso. Dice la antropología que el androcentrismo proviene de cuando los hombres se dieron cuenta en la era agrícola de que las mujeres controlaban la maternidad, lo que les impedía a estos controlar la herencia de la tierra en un $100 \%$. Es sin duda una hipótesis interesante.

Lo que si sabemos es que la ciencia durante siglos ignoró el papel de las mujeres en la reproducción. A las mujeres se les consideraba meros receptáculos de unos homúnculos que se «engendraban» en los testículos de los hombres, y que se depositaban como una semilla -semen- en el útero en donde crecían. A las mujeres se les imaginaba como receptores pasivos y no fue hasta hace muy poco que se aceptó su papel de mitad de responsables biológicas en el proceso. Me fastidia que en pleno siglo XXI se siga usando el verbo engendrar con el origen tan tremendamente androcéntrico que tiene.

¿Qué opinas sobre el movimiento feminista? ¿Cómo ves su futuro? ¿Se está renovando a la velocidad que se necesita? ¿Crees que ha influido en la mejoría de la salud de las mujeres? ¿En qué sentido?

L: Pertenecemos a una generación de activismo político por las circunstancias, tal vez, de edad. Porque vivimos y nos socializamos en una dictadura. Porque había que cambiar ese régimen político a un régimen democrático en el que estuvieran presentes los derechos de las mujeres.

El movimiento feminista, y las mujeres actualmente, están viviendo otra situación totalmente distinta. El pensamiento feminista está muy florecido. Hay muchísima reflexión, bibliografía y debate en el pensamiento feminista, y actualización. Está pendiente de los problemas sociales a nivel global. O sea, que el pensamiento feminista, sí está dando, o está buscando soluciones y 
respuestas globalmente a la sociedad. Otra cosa es, el movimiento organizado feminista con una incidencia política, porque de eso se trata. El movimiento feminista no es solo un movimiento feminista que se preocupe de la identidad de las mujeres y de los hombres. En este sentido, el movimiento feminista no es tan diferente del resto de los movimientos sociales.

Las sociedades occidentales y democráticas, hoy día, tienen una laguna de democracia participativa y real. En concreto, en nuestro país, estamos teniendo muchas dificultades para esos cauces de participación real con la administración, con la política. Que esos cauces funcionen con agilidad implica que tienen que haber recursos humanos y presupuestarios para ello. Las que estamos en un movimiento feminista somos voluntarias. Tenemos nuestras actividades de trabajo, y familiares y personales, y además tenemos nuestra implicación en el trabajo voluntario. Por tanto, tenemos un ritmo distinto que la administración, o que los partidos políticos que son estructuras formalizadas. Nuestras estructuras no las tenemos tan formalizadas, aunque a través de las asociaciones que existen están suficientemente formalizadas.

El problema no es del movimiento feminista, que también puede tener problemas, sino que, no hay verdaderamente una sociedad democrática participativa. Parece que ahora con las nuevas tecnologías de la información se va a solventar este problema. Aunque no lo veo así, porque pueden circular mensajes e información, pero esto es distinto de tomar decisiones colectivas y moverse hacia un mismo camino.

Respecto al futuro, faltan estructuras de participación que es algo que atañe a toda la sociedad. Pero, hay mucha gente joven en este momento que está teniendo mucha, y muy buena, formación a partir de las estructuras universitarias, de los Centros de Estudios de la Mujer que hay en las diversas Universidades, a partir de los Organismos de Igualdad, de todo el trabajo que vienen realizando en formación el movimiento y las asociaciones feministas en el país. Ahí hay un caldo de cultivo de muchísima gente implicada en todo ello. La cuestión está en cómo se organiza toda esa gente. Es ese el reto que tienen los Centros de Estudios de la Mujer. Tienen toda esa población que va a hacer esos estudios, pero como conectarlo luego con el movimiento político. Es un reto en el que estamos muchas mujeres y algunos hombres, viendo como se hace. Conectar a la gente que tienen una buena formación en el pensamiento feminista. Ellas tienen ahora que buscar cual es su modo de participación política. Por ejemplo, las asociaciones de nuestra generación siempre estamos diciendo que tenemos que renovar, y que tiene que entrar gente joven. Pero, es difícil encontrar a la gente joven, y están, pero están en otras formas de organización, que ellas saben cuáles son y cómo quieren que sean. Y los partidos 
políticos, la administración, tendrán que dar cuenta de las nuevas necesidades que se les planteen. El reto de una democracia más participativa lo tenemos que hacer entre todos, y está pendiente. No son buenos tiempos parece ser, o sí, porque estas crisis económicas nos hacen espabilar.

C: Por supuesto que ha influido en la mejoría de la salud. Gracias al movimiento de mujeres se han podido llevar a la agenda política determinadas cuestiones que afectan a la vida y salud de unas y otros. Sería un interesante estudio para nuestro grupo ¿ha sido el feminismo bueno para la salud? Podría adelantar la hipótesis de que si, que el ser dueño de tu destino es bueno para la salud de la gente. Volviendo al pasado, el famosísimo libro de las «mujeres de Boston» que circulaba en los años 70 era un libro de salud de las mujeres.

Fuiste testigo de toda la transición hacia la democracia ¿Cuáles han sido los hitos importantes durante este período para la salud de las mujeres?

L: El tema de la anticoncepción centró muchísimo tiempo de trabajo del movimiento feminista, que se consiguió legislativamente solo en el 78. Todo lo que tuvo que ver con el derecho al aborto, el derecho a decidir sobre la maternidad, que ha sido un debate que quedó desde que se legisló sobre el aborto en 1983. Y en la actualidad, que ha habido un gran debate también en el movimiento feminista, porque la propuesta que está vigente en este momento con la Ley, a muchas nos parece que es insuficiente, que tiene grandes lagunas, y que estamos no solo por el derecho, sino porque esa aplicación del derecho sea en los servicios que existen en la sanidad pública. Por desgracia, estamos viendo que la administración no toma nota, no interesa, y se sigue privatizando.

El tema de la privatización de los servicios de la salud de las mujeres es una constante que sigue ahí. No se ha cambiado esa dinámica. Se tiene que poner orden en cuanto a la educación curricular tanto en lo que atañe al aborto, como a la educación en sexualidad, en los derechos sexuales y reproductivos. Mientras gran parte de la educación de este país siga privatizada, pese a estar subvencionada por el sector público, no creo que se avance demasiado en esa línea.

Hay otro tema importante, que es el malestar de las mujeres: la morbilidad auto percibida. En los años 80 hubo un intento con toda la reforma de atención primaria, de que el tipo de atención que se prestara, o que se pretendía prestar, fuera más integral, en lo que lo psicológico y lo social estuviera presente al igual que lo biológico. Pero, hemos visto como ha ido a la deriva. Cada vez más el sistema sanitario sigue respondiendo a un modelo biologicista, 
positivista, que tiene poco en cuenta las necesidades emocionales. El dolor psíquico es un dolor, por lo tanto el sistema sanitario tendría que prevenirlo, y que actuar sobre el mismo. Quedan tareas pendientes por hacer, en los planes de atención, en los protocolos de actuación, ante los procesos de enfermedad.

Los cambios fundamentales habidos hacia la salud de las mujeres, como son la anticoncepción y la salud mental o emocional de las mujeres siguen igual. A estas asignaturas pendientes, se le suma todo lo que tiene que ver con los determinantes sociales y de género, en cómo influyen en la salud, pues todavía no se tiene en cuenta a la hora de planificar actuaciones preventivas desde el sistema sanitario, y, desde otras políticas que tienen que ver con la salud, aunque no siempre se tienen que hacer desde el sistema sanitario como bien sabemos.

Otro asunto interesante que se ha empezado a hacer visible en estos años es el del cuidado a las personas dependientes, y a los enfermos crónicos o mentales, etc. Se ha visibilizado el coste que tiene en la salud de las cuidadoras sobre todo. Pero, sin embargo, lo que se propone desde el sistema sanitario es que las cuidadoras cuiden mejor. Se les da información o formación para que sean mejores cuidadoras, pero no para que dejen de ser cuidadoras. Es decir, no se han puesto recursos ni servicios para el cuidado de las personas en su casa. Es más, con todos estos sistemas de hospitalización a domicilio, de cirugías ambulatorias, lo que está recayendo cada vez más, es más cuidado en el seno de la familia, a realizar por las mujeres, y es una tendencia que se ha incrementado. Pero, no se han incrementado suficientemente los servicios de apoyo al cuidado en el seno del domicilio, y no se está haciendo mucho aparte de la ley de dependencia. La famosa ley de dependencia que lo que ha hecho es dar una paguita a algunas mujeres que además las pagan las personas a las que cuidan, con lo cual tienen ya otro sistema de control adicional: «Ahora ya encima te pago, por lo tanto tienes que hacer más lo que yo diga, o estar dependiendo de mí». Además, vuelve a reproducir el sistema de que las mujeres permanezcan en el cuidado. Es una legislación que, en principio, para las personas que necesitan cuidados mejora, pero tengo muchas dudas de que haya mejorado para las mujeres cuidadoras.

C: La consecución de un Sistema Nacional de Salud como planteaba la Ley General de Sanidad es el hito más importante para la salud de los españoles, hombres y mujeres. Esta ley es hija del movimiento de Salud para Todos en el año 2000, de los años 70, en la OMS, UNICEF y UNESCO. Naciones Unidas, por el movimiento de los no alineados, fue gobernada durante algunos años por dirigentes escandinavos que transfirieron sus ideas de Estado del 
Bienestar a todo el mundo. También, el desarrollo del concepto de desarrollo humano por Amartya Sen, que luego permitió ajustarlo por sexo (Desarrollo de Género) es para mí un hito muy relevante en la salud de las mujeres de todo el mundo.

¿Quiénes han sido tus grandes maestras (incluidos las que te provocaron conmociones no siempre agradables?

L: Empezaría por Begoña San José. Es una mujer extraordinaria, con una militancia clarísima, que no te deja tranquila porque siempre te está removiendo cosas. Ella es y ha sido sindicalista, feminista, y ha participado siempre en el movimiento de mujeres con una energía y una capacidad intelectual extraordinaria. Algunas veces me conmociona porque es difícil, a veces, poder seguirla en todo lo que propone y en todas las actividades que es capaz de generar; y que, como voluntarias en nuestra asociación tenemos que seguir. Es una gran maestra en ese sentido, en como confluye en ella el pensamiento y el activismo político. Para mí, ha sido una referencia y lo seguirá siendo en el futuro. Pero dentro del movimiento feminista han sido muchísimas las mujeres que han sido maestras, y que me han aportado un montón. Celia Amorós, Rosa Cobo, te diría tantas y tantas, que han participado durante estos años que yo he estado integrada en el asociacionismo.

A nivel más institucional, para mí también ha sido una referente Begoña López Dóriga, con la que llevo trabajando muchos años desde la Escuela Nacional de Sanidad, y desde el Instituto de la Mujer. Es una persona de la que aprendes mucho, porque tienen una capacidad de reflexión muy importante, y de ver aspectos que normalmente no se ven, con respecto a la salud de las mujeres. También ha hecho grandes aportaciones de manera no tan formal. Para mí ha sido interesante seguir contando con ella a la hora de reflexionar en los temas profesionales de la salud de las mujeres.

Otra gran maestra para mí es Virginia Maquieira, profesora de la Universidad Autónoma de Madrid, que con sus escritos y su manera de ser, también aprendo mucho. Hay algunas más también, no querría cerrarme. Y en el campo de la enfermería, para mí, no sé si maestras; pero muy compañeras. Me han aportado mucho a nivel de la teoría de la enfermería, fundamentalmente: Concha Germán y Cristina Francisco. Con ellas he tenido muchos encuentros, mucho trabajo en común en la enfermería, desde hace muchísimos años, y esto, ha concluido en que, nos une una gran amistad ahora. Desde esta alianza, desde lo profesional a la amistad he aprendido mucho de ellas dos. Hay otras enfermeras por supuesto que sí. Pero de las que compaginen esta doble mirada: enfermería y feminismo; enfermería/género, son ellas dos las 
que me han supuesto mayor influjo, y con las que me sigo encontrando muy bien trabajando con una gran complicidad en las propuestas que hacemos. Para mí esto es muy importante.

Y sobre todo he aprendido en el conjunto de nuestras discusiones y planteamientos dentro de las organizaciones en donde he tenido que ir, representando a mi asociación, junto con otras organizaciones de mujeres. Por ejemplo, cuando tuvimos todos los debates de la Conferencia de Pekín en el 95 he conocido a mujeres extraordinarias. También de otros países y otros lugares.

C: Mis hermanas que ya las he citado. Todas mis parejas han sido feministas, quizás porque las he seleccionado. Mi mujer, Concha Colomer ${ }^{1}$ y nuestra hija Marina también lo son, y llevan sus ideas no solo en casa reivindicando igualad sino a sus trabajos (una sanitaria, la otra artista). En la Universidad (gracias al Centro de Estudios de la Mujer) he aprendido mucho, y estoy aun aprendiendo; y hace años trabajando con una colega, Asunta Silvestre, aprendí que analizando datos esto que hacíamos de ajustar por sexo escondía injusticias, porque escondía los problemas de salud propios de las mujeres. Por suerte, trabajo en un grupo de investigación con un núcleo de género y salud muy vigoroso. Esto hace también aprender, y en nuestro grupo soy el único hombre, o sea que son muchas las mujeres que me han enseñado.

Que las mujeres dediquen tiempo y energías al trabajo productivo puede causar frustración dentro del hogar y las familias ¿Cuánto tiempo se pueden contener esa frustración entre los suyos? ¿Cuáles pueden ser las consecuencias?

L: Por mi experiencia personal, creo que cada vez la sociedad es más compleja, o hay más exigencias desde el punto de vista laboral, como desde el punto de vista familiar, y no se llega a todo. Hay una sensación de agobio, que no sé si tiene algo que ver con las nuevas tecnologías de la información, a partir de las que pensamos que podemos asumir más cosas de las que la cabeza nos puede permitir. Es una fantasía, es una ilusión que está ahí, y presiona de una manera terrible. Esto en las mujeres, unido a esa dedicación, a esa perfección que se busca en el tema familiar, pues a lo mejor las consecuencias sí son de agobio, de estrés, de que nadie tiene tiempo para nada, y yo creo que eso es

1. El dia 9 de abril de 2011, de manera inesperada murió Concha Colomer en este texto quiero hacer publico mi respeto por su legado profesional y mi gran cariño personal hacia ella, le debo mucho, a su memoria, quizás alguien pueda estar interesado en leer la carta de despedida que le escribí. http://conchacolomer.blogspot.com/2011_04_01_ archive.html 
algo que acaba pasando factura. También porque dices «como no tengo tiempo para nada no hago nada», o «ya no puedo más» y producen la sensación de queme.

Lo que te ayuda al trabajar en grupo con otras mujeres es precisamente ordenar estas prioridades. Por eso me parece importante que no nos quedemos en el ámbito cerrado de la familia, sino que tengamos otros espacios de trabajo en conjunto con más mujeres, o con otras mujeres, y es muy posible también que con otros hombres. La manera de arreglar la frustración, creo que es ordenar a través de esos espacios de reflexión conjunta, y ordenar a lo que podemos llegar o no. No es fácil hacerlo.

C: El orden androcéntrico se esta disolviendo. Es una cuestión de derechos, las mujeres deben tener exactamente los mismos derechos que los hombres. Me parece que la solución está en usar mejor los recursos familiares. Ya está bien de enfocar el problema como una huida de las mujeres y no como una ausencia estructural de los hombres. La fertilidad, la obesidad de los niños, muchísimas cosas se relacionan con que las mujeres trabajan en el sector productivo remunerado, y es un argumento falaz.

\section{¿Eres optimista respecto a la conciliación familiar?}

L: No soy optimista la verdad, porque todas las medidas de conciliación familiar que conocemos van dirigidas a que las mujeres concilien mejor, pero no parece que los hombres entren mucho por la conciliación. Aunque, hay algunos datos que son muy interesantes de como los hombres se han sumado a, por ejemplo, los permisos de paternidad, si bien son muy escasos todavía. Estamos pidiendo que los permisos de paternidad sean más amplios, para que los hombres tengan esa oportunidad. La conciliación la veo complicada pues también depende de la ciudad en la que vivas. Las cifras dicen que siguen faltando espacios y lugares, que siguen faltando plazas de guardería, o centros educativos para los más pequeños (de 0 a 3 años).

Siguen faltando ayudas para la dependencia. Ante esta situación, no, no soy muy optimista en relación a esta conciliación, porque sobre todo falta mucho para que los hombres realmente la asuman. Tengo ejemplos a mi lado de familias de sobrinas jóvenes mías. Una es a base de tener todo el día la batalla puesta, y eso le hace que ponga unas energías tremendas con su pareja, que es un tipo que está muy bien, pero porque ella está poniendo los puntos sobre las íes, con exigencia. Si las mujeres tenemos que ser las responsables de exigir a los demás, sobre todo en la familia, llega un momento que te cansas. No sabes si al final es mejor decir «bueno mira ya lo hago yo si tengo que estar todo 
el día pidiendo y exigiendo», porque es agotador. En cambio, la otra sobrina ha decidido que ahora es el tiempo de la maternidad, y que se dedica a ella plenamente, como si no se pudiera hacer otra cosa a la vez. Siguen existiendo los dos modelos de parejas, o de conciliación familiar: aquella conciliación que se hace a costa de las mujeres, porque no se plantea un cambio; o aquella que plantea el cambio en la conciliación, exigiendo más participación de sus parejas, y eso tiene un coste. O sea, no es una exigencia, es algo normal, pero como exige tanto esfuerzo en ese sentido digo que es una exigencia. Veo que tiene esa repercusión del cansancio, del agotamiento, y que siempre recae la pérdida de oportunidad, o el exceso de trabajo, en las mujeres.

Además no soy optimista por que se pone todo el hincapié en lo que tienen que hacer las personas; pero no en lo que las políticas sociales tienen que hacer con respecto a crear condiciones laborales, y de recursos, para el cuidado a las personas dependientes. Mientras esto no cambie de una manera drástica, no le veo mucho futuro a la conciliación sinceramente. Conciliación a costa del esfuerzo de las mujeres, pues como siempre.

C: Claro que si, no podemos supeditar una cuestión de derechos humanos a cuestiones de gestión. Es difícil el cambio cultural pero no imposible sobre todo hay que evidenciar a quien benefician las resistencias.

\section{Para Lucía ¿De qué hablas cuando hablas de los hombres con otras profesionales? \\ Para Carlos ¿De qué hablas cuando hablas de las mujeres con otros profesionales?}

L: Creo que de lo más fundamental que estamos hablando, es de que los hombres no quieren perder los privilegios, no quieren asumir el tema del cuidado, que siguen manteniendo sus privilegios a costa de ejercer una presión, cuando no una violencia a las mujeres. Esos son los temas universales. Pero, también se habla de que los hombres están haciendo algún pequeño cambio.

Dentro del movimiento feminista nos planteamos muchas veces que en teoría nosotras tenemos que trabajar insertadas en el resto del movimiento social, no como un aparte. Pero que es complicado porque enseguida te puedes desviar a otros temas que no son como es la situación de las mujeres de entre una problemática concreta. De todas formas, en la asociación en donde trabajo como voluntaria sí que intentamos mantener este contacto con el resto de los movimientos sociales, pues nos parece fundamental. Aunque tenemos tanto que trabajar entre mujeres en las políticas, para que cambien 
la situación de discriminación de las mujeres, que no hacemos tanto lo de integrarnos con otras plataformas sociales.

C: De violencia, de desarrollo de género, de interacción género-clase, de la relación de la reproducción con la producción y la ecología. De las mujeres y el planeta como grandes subsidios en la economía. Del efecto en las mujeres de los recortes en el sector publico.

¿Hay un triunfo de las mujeres? Han transcurrido unos años, la segregación se mantiene y aún nos enfrentamos todavía a problemas muy serios ¿Cómo afecta a la salud de las mujeres?

El hacer frente a todas estas nuevas exigencias afecta en el sentido de la tensión, del agobio, de un malestar que se tiene, porque los modelos donde nos insertamos en la vida laboral son todavía muy masculinizados en la forma de trabajo, de pensamiento, de como se toman las decisiones; y parece que somos unas recién llegadas, y que siempre estamos pidiendo permiso o un espacio. Todavía hay una falta de naturalidad en ello. Eso supone un peso grande. Llevas una carga que se puede manifestar en malestar, en dolores en la espalda, en malas posturas, en que a veces no llegas a proponer todas las cosas que quisieras porque a saber cómo van a caer. Ese tipo de cosas.

El triunfo de las mujeres es más aparente que real, sinceramente, porque todos los datos nos indican, que hay algunas mujeres que se han colocado y hemos colocado en buenas posiciones con el esfuerzo del pensamiento y dirección feminista. Pero, eso no es el triunfo del total de las mujeres; porque si vemos otros indicadores sociales como, por ejemplo, el tema de retribuciones, o el del progreso de oportunidades en el trabajo, o el del reparto de las tareas y de las responsabilidades del cuidado, o el de estar en los lugares donde se toman decisiones, pues realmente es un triunfo bastante limitado. Ahora bien, como sensación y como idea de que las mujeres han triunfado y que qué más quieren, y qué más piden, pues creo que es un movimiento o una percepción social que es muy peligrosa, porque procede del machismo más recalcitrante aunque no se expresa en esos términos.

Tendría mucho cuidado y sería muy prudente cuando hablamos de si hay un triunfo de las mujeres, porque no está llegando ese triunfo y esa igualdad a grandes capas de la población, a grandes capas de mujeres; y no te digo ya en nuestro país, pero si hablamos del mundo no soy muy optimista. Recientemente, los acontecimientos que están pasando en Egipto y en Túnez nos están diciendo que a las mujeres una vez más las están dejando excluidas de las comisiones que se están montando para hacer los cambios democráticos que 
se están produciendo, o se quieren producir. Y nos están diciendo las mujeres en Egipto que las están excluyendo. Por eso digo que sería muy prudente al hablar del triunfo de las mujeres.

A nivel global parece mentira que con toda la tecnología disponible todavía haya esas tasas de mortalidad materna tan espantosas en muchísimos países: en África, en América Latina, en Asia. Nos encontramos con problemas como el de la violencia. Tenemos los datos en España y, siguen muriendo mujeres. En este último año parece que más. Pero, las muertes son la punta del iceberg. Las mujeres han alcanzado cotas de autonomía y de independencia, y quieren y saben lo que quieren. Pero, hay muchos hombres que todavía no les entra en la cabeza esto, y se revuelven, y por eso las violenten quizá más, con más saña. Eso es lo que está pasando en España y en Europa. Pero, figúrate todo lo que sabemos de lo que está pasando en México, Guatemala, Nicaragua. En fin, en los países Latinoamericanos, donde por fortuna hay un movimiento muy fuerte de mujeres que están liderando la visibilización de estos horrores. Sin embargo, no se están tomando muchas medidas, o si se toman medidas son inadecuadas porque sigue ocurriendo este genocidio de mujeres. El feminicidio de las mujeres. Este problema global que afecta a todas las mujeres, en mayor o menor cuantía, y con mayor o menor gravedad. Ahora lo conocemos, y sus mecanismos, pero todavía no hay medidas para afrontarlos suficientemente. Y menos con estos recortes derivados de la crisis. Nos están contando muchas mujeres en Concejalías de Ayuntamientos, en Concejalías de la Mujer, que las restricciones presupuestarias se aplican por ahí. No digo yo que no se recorte por otros lados, pero en esto no se debía de recortar, porque la situación de las mujeres no es nada boyante. Y, cada vez, se tienen que enfrentar más a esta violencia que permanece, que cada vez toma formas de agresividad más fuertes. Sobre todo en algunos lugares del mundo. Es un problema gravísimo, de tal manera que la cooperación internacional debería de priorizar este tema de forma clara, y no solamente como una cosa que atañe a las mujeres, pues atañe a toda la sociedad. Nosotras las mujeres, y el movimiento de mujeres, si le damos importancia. Pero, a nivel mundial y a nivel de las políticas internacionales y de las políticas públicas, la verdad es no, y esto es un problema muy gordo.

Otro tema de salud que es muy grave es la infección de VIH/SIDA que sigue creciendo en las mujeres, también en nuestro país. Es consecuencia de su posición de subordinación ante el ejercicio de la sexualidad. La vía que más ha aumentado es el contagio por vía heterosexual, y eso quiere decir que las mujeres todavía no nos protegemos lo suficiente, o no tenemos capacidad para tomar medidas. En muchos países desde luego no tienen ni una sola 
oportunidad para poder protegerse. La pobreza que se asocia muchísimas veces a la situación de infección y de contagio sigue estando ahí, y las mujeres en todo el mundo somos más pobres. Pero, a medida que los países son menos desarrollados o son más pobres, esa desigualdad es todavía mucho mayor. Por lo tanto, las mujeres se enfrentan a situaciones realmente dramáticas.

Además de los anteriores problemas, nos enfrentamos a problemas como el tema del malestar, del cansancio, de la malnutrición. La malnutrición es un tema muy frecuente en las mujeres. Los embarazos muy tempranos. Niñas que quedan embarazadas y que se las expulsa del colegio, como ocurre muchas veces en países africanos. No te digo ya, tantas niñas y, niñitas que se enfrentan a estas prácticas tradicionales tremendas de las mutilaciones genitales. Estos son problemas que están pendientes ahí en la agenda mundial, y que se están visibilizando. La realidad es que se está cambiando muy, muy lentamente.

C: Es paradójico porque aunque hay problemas y graves, las mujeres se saben con futuro, saben que están dando pasos adelante con gran sentido de coherencia como diría Aarón Antonovsky, y esto les mejora la salud. A los hombres les pasa lo contrario. Lo suyo es un imperio en declive con el que no se puede sentir empatía, si eres varón en estos momentos o sientes rabia o sientes vergüenza, son ambos sentimientos negativos. Cabe pronosticar un aumento de las enfermedades mentales en los varones y una mejora en las mujeres.

L: Me parece que el tono de mi entrevista es un poco pesimista, pero, no querría dar esa impresión. Creo que es real. Soy optimista en el sentido de que creo que hay que estar integradas en un movimiento activo, en un movimiento político, y que ahí las mujeres tenemos todavía mucho trabajo por hacer. En el trabajo, nuestros planteamientos van teniendo eco y ocupando espacios sociales muy importantes, y eso va a tener efectos en un futuro. Pero a veces el futuro es tan lejano que nos impide ver el camino. Está claro que este panorama hace que tengamos que redoblar nuestros esfuerzos, o que tengamos que seguir trabajando y no por ello nos van a disuadir. Esta es mi posición, las cosas irán cambiando a través de los procesos. 


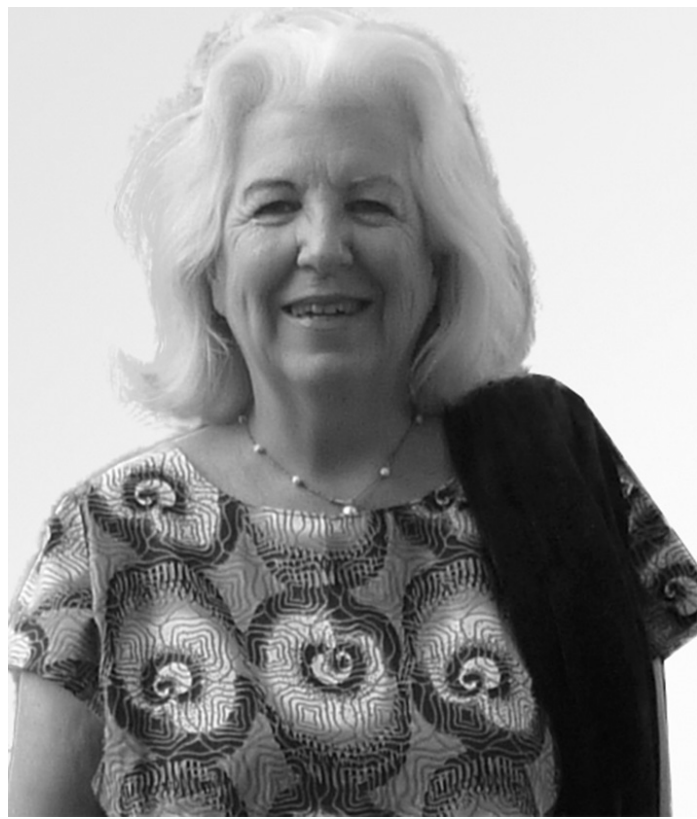

Lucía Mazarrasa

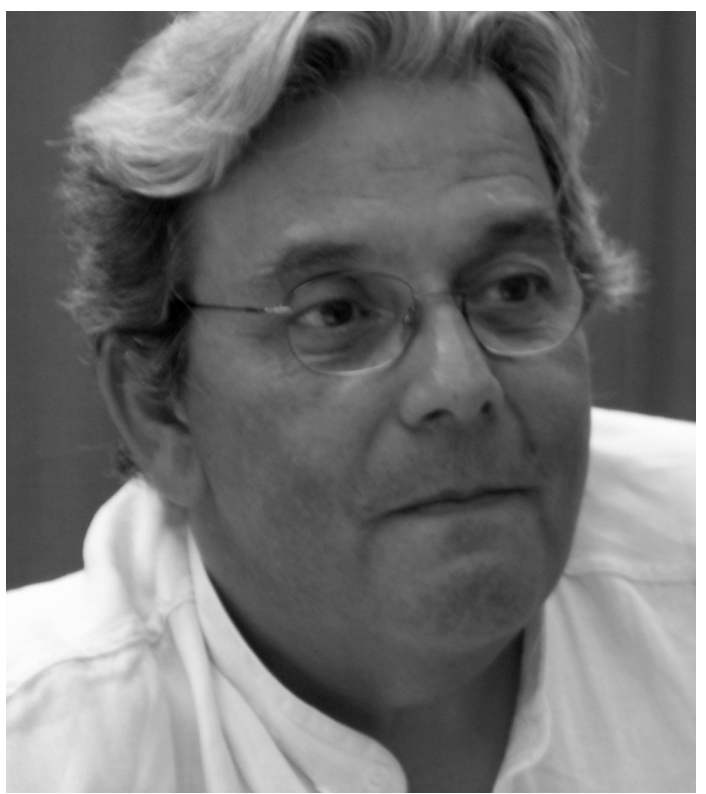

Carlos Álvarez-Dardet

Feminismo/s 18, diciembre 2011, pp. 15-37 



\title{
MUJERES, ABANDONO DE CONSUMO DE TABACO Y BARRERAS DE GÉNERO
}

\author{
MARÍA LUISA JIMÉNEZ RODRIGO \\ Universidad de Sevilla
}

Recibido/12/09/2011

Aceptado/24/11/2011

\section{Resumen}

El objetivo de este trabajo es analizar, desde una perspectiva de género, los obstáculos que dificultan el cese del consumo de tabaco entre las mujeres. Se utilizó una metodología multimodal basada en la explotación secundaria de la Encuesta Nacional de Salud y en el análisis de entrevistas en profundidad realizadas a una muestra intencional de mujeres fumadoras y exfumadoras. Las mujeres, en general, presentan menores tasas de abandono de consumo de tabaco respecto a los varones. Son las mujeres mayores de 45 años y de menor estatus socioeconómico las que muestran mayores dificultades para dejar de fumar. Se observan como principales barreras para dejar el tabaco las creencias asociadas a la adicción y a los riesgos sobre la salud así como la pérdida de los beneficios sociales, emocionales y corporales del consumo de tabaco. También se discute sobre la influencia de sesgos de género en las políticas sanitarias y la desigualdad de género en el acceso a los recursos.

Palabras clave: Abandono del consumo de tabaco, mujeres, desigualdad de género, investigación cualitativa.

\begin{abstract}
This paper aims to analyze from a gender perspective obstacles that hinder smoking cessation among women. A multimodal methodology is applied based on secondary research upon the Spanish National Health Survey and in-depth interviews delivered to an intentional sample of smokers and ex-smokers women. Women present lower smoking cessation rates than men. Specifically, greatest difficulties to smoking cessation are showed by female over 45 year-old and those of low socioeconomic status. The main barriers for quitting smoking seem linked to beliefs about addiction and
\end{abstract}

Feminismo/s 18, diciembre 2011, pp. 39-65 
health effects of tobacco as well as loss of social, emotional and physical benefits attached to smoking. Also, influences of gender biases in health policy and unequal access to resources are discussed.

Keywords: Smoking cessation, women, gender inequality, qualitative research. 


\section{Introducción}

En los últimos años se ha producido una radical transformación de la imagen social del consumo de tabaco. Esta practica, que hasta hace relativamente poco tiempo constituía un comportamiento normalizado dentro de las rutinas cotidianas de interacción social, ha pasado a ser objeto de una creciente regulación, medicalización y estigmatización. De forma que dejar de fumar se ha establecido no sólo como una cuestión de salud sino también como una cuestión de integración social, donde las personas que no deciden o no pueden dejar de fumar son cuestionadas en su racionalidad, moralidad y/o debilidad al contravenir los dictados sociales de los nuevos estilos de vida saludables que se imponen como norma en las sociedades postmodernas ${ }^{1}$. Sin embargo, no todas las personas y grupos muestran las mismas probabilidades para dejar de fumar, como así lo indican las estadísticas, registrándose en particular importantes diferencias entre mujeres y hombres. Si observamos las tendencias de abandono del consumo de tabaco se aprecian pautas sociológicas que, lejos de la aleatoriedad o del influjo de rasgos individuales (biológicos o de personalidad), reflejan la influencia de lo social y, en particular, del género. Así, se han evidenciado diferencias por sexo, grupos de edad, clase social, nivel educativo y etnia ${ }^{2}$.

1. Bauman, Zygmunt y MaY Tim: Pensando sociológicamente. Buenos Aires, Nueva Visión, 2009.

2. JARVIS, Martin. «Gender Differences in Smoking Cessation: Real or Myth?». Tobacco Control 3 (1994), pp. 324-28. GraHAM, Hilary y HunT, Sonja. «Women's Smoking and Measures of Women's Socioeconomic Status in the United Kingdom». Health Promotion International, 9:2 (1994), pp. 81-88. OSLER, Merete; PRESCOTT, Eva; GODTFREDSEN, Nina; et al. «Gender and Determinants of Smoking Cessation: A Longitudinal Study». Preventive Medicine 2 (1999), pp. 57-62. FERNÁNDEZ, Esteve; SCHIAFFINO Ana; GARCÍA, Montse; et al. "Widening socio-economic inequalities in smoking cessation in Spain, 1987-1997». Journal of Epidemiology and Community Health 55 (2001), pp. 729-730. HUISMAN, Martijn; KUNST Anton; MACKENBACH, Johan. «Inequalities in the prevalence of smoking in the European Union: comparing education and income». Preventative Medicine 40 (2005), pp. 756-764. GRAHAM, Hilary; FRANCIS, Brian; INSKIP, Hazel; et al. «Socioeconomic lifecourse influences on women's smoking status in early adulthood». Journal of Epidemiology and Community Health 60 (2006) pp. 228-233.

Feminismo/s 18, diciembre 2011, pp. 39-65 
Desde el punto de vista de género, esta variabilidad es especialmente significativa ya que, en comparación con los varones, las mujeres presentan tendencias y características particulares y divergentes en cuanto al proceso de abandono, caracterizado por su menor intensidad y retraso histórico. Si los varones empezaron en España a dejar el tabaco de forma especialmente marcada e ininterrumpida a partir de los ochenta del pasado siglo, la prevalencia de consumo femenino de tabaco sólo comienza a reducirse, si bien muy levemente y sólo entre algunos grupos, con la entrada del siglo $\mathrm{XXI}^{3}$. Además, diversos estudios determinan que las mujeres parecen experimentar mayores dificultades para dejar el tabaco, a pesar de declarar en mayor medida que los varones su intención de abandonarlo y de intentarlo más veces ${ }^{4}$. Como subrayó Bobbie Jacobson, pionera en el análisis feminista de los usos contemporáneos del tabaco, las distintas tasas de abandono que mujeres y hombres muestran en los países industrializados evidencian las desigualdades de género que operan en la distribución de las probabilidades para dejar de fumar, estructurándose una «jerarquía social, racial y sexual» donde las mujeres, y concretamente las de menor estatus socioeconómico, ocupan una posición de desventaja ${ }^{5}$. Esto conlleva importantes implicaciones desde el punto de vista de las desigualdades en salud ya que, teniendo presente la evidencia científica sobre los efectos del humo de tabaco sobre la salud y su conformación como la principal causa evitable de mortalidad en los sociedades avanzadas ${ }^{6}$, determinados grupos sociales están acumulando mayores riesgos de enfermar y de morir -como ya se observa en el aumento de la incidencia de cáncer de pulmón entre las mujeres ${ }^{7}-\mathrm{y}$ que pueden acrecentarse si estas desigualdades persisten.

3. FernándeZ, Esteve; SCHIAFFino Ana; García, Montse; et al. «Prevalencia del consumo de tabaco en España entre 1945 y 1995. Reconstrucción a partir de las Encuestas Nacionales de Salud». Medicina Clínica (Barc) 120:1 (2003), pl4-6. Y datos de las Encuestas Nacionales de Salud disponibles en la web del Ministerio de Sanidad, Política Social e Igualdad: http://www.msc.es/estadEstudios/estadisticas/encuestaNacional/

4. Wetter, David; KenFord, Susan; SMith, Stevens; et al. «Gender Differences in Smoking Cessation». Journal of Consulting and Clinical Psychology 67:4 (1999), pp. 555-62. McKEE, Sherry; MACIEJEWSKI, Paul; FALBA, Tracy; et al. «Sex Differences in the Effects of Stressful Life Events on Changes in Smoking Status». Addiction 98 (2002), pp. 847-55.

5. JACOBSON, Bobbie. The Ladykillers: Why Smoking Is a Feminist Issue. London, Pluto Press, 1982.

6. ORGANIZACIÓN MUNDIAL DE LA SALUD. Convenio Marco de la OMS para el Control del Tabaco. Geneva, OMS, 2003.

7. Ministerio de Sanidad, Política Social e Igualdad. Estadísticas de Mortalidad por causa de muerte: España y comunidades autónomas.

$<$ http://www.msps.es/estadEstudios/estadisticas/estadisticas/estMinisterio/mortalidad/mortalidad.htm>, consultado el 15-6-2011. Concretamente, la tasa de mortalidad 
Este escenario revela la necesidad y la pertinencia de avanzar en la comprensión de la influencia del género, no sólo en cuanto al inicio y mantenimiento del consumo de tabaco -respecto a lo cual existe una amplia literatura, sobre todo internacional-, sino también y de forma específica en relación a su abandono. Para ello es preciso superar visiones reduccionistas del fenómeno como una cuestión meramente individual y fisio-psicológica anclada en la adicción ${ }^{8}$, para ampliar la mirada hacia la influencia de otros factores estructurales, simbólicos y prácticos que marcan que el proceso de renunciar al consumo de tabaco sea diferente y desigual en mujeres y en hombres. En este sentido, se ha destacado la existencia de desigualdades en el acceso a los recursos y apoyos sociales, económicos e informacionales necesarios para dejar de fumar. Ann Oakley ha señalado que la persistencia del consumo de tabaco entre las mujeres embarazadas no responde a un modelo individual sino que está fuertemente determinada por su posición social y material y, concretamente, por los apoyos sociales para reducir su estrés ${ }^{9}$. Así también, la importancia de la condición socioeconómica ha sido advertida en otros estudios, subrayando que las mujeres con menores recursos económicos y menor nivel educativo presentan menores tasas de abandono ${ }^{10}$. Estudios más recientes han mostrado el impacto del desempleo y la privación material en unas menores probabilidades de dejar el tabaco entre mujeres jóvenes ${ }^{11}$.

Junto a los elementos estructurales, los factores culturales ligados al peso de los roles de género y de los estereotipos sexistas pueden obstaculizar el abandono femenino de tabaco. En primer lugar, en lo que se refiere a la reproducción de sesgos de género en el esfuerzo diagnóstico y terapéutico de enfermedades y dolencias fuertemente masculinizadas ${ }^{12}$, que también afectan

femenina por tumor maligno de pulmón se ha doblado desde 1990, pasando de un 6,6 a 12,3 en 2007. En relación a los varones, la tasa de mortalidad por esta causa aunque considerablemente más alta, muestra unos valores relativamente estabilizados en torno a 80, si bien en los últimos diez años se aprecia una ligera reducción, llegando al 77,6.

8. Como tradicionalmente se ha establecido en su abordaje biomédico. AMERICAN PSYCHIATRIC ASSOCIATION, Manual diagnóstico y estadístico de los trastornos mentales. DSM-IV TR. Barcelona, Masson, 2001.

9. OAKLEY, Ann. «Smoking in Pregnancy: Smokescreen or Risk Factor? Toward a Materialist Analysis». Sociology of Health E Illness 11 (1989), pp. 311-335.

10. Graham, Hilary y DER, Geoff. «Patterns and Predictors of Tobacco Consumption among Women». Health Education Research 14:5 (1999), pp. 611-18. OsLER, Merete; et al. Op.cit.

11. Weden, Margaret; Astone, Nan y BISHAI, David. «Racial, ethnic, and gender differences in smoking cessation associated with employment and joblessness through young adulthood in the US». Social Science and Medicine, 62:2 (2009), pp. 303-316.

12. Ruiz Cantero, Teresa; Ronda, Elena; y Álvarez Dardet, Carlos. «The importance of study design strategies in gender bias research: the case of respiratory disease

Feminismo/s 18, diciembre 2011, pp. 39-65 
al cáncer de pulmón y otras afecciones respiratorias. Manifestaciones de ello las encontramos en la infrarrepresentación de las mujeres en los ensayos clínicos sobre cáncer de pulmón ${ }^{13} \mathrm{o}$ en la insensibilidad de género presente en las políticas públicas e intervenciones sanitarias sobre tabaquismo, que tienden a ignorar las experiencias y problemáticas de las mujeres fumadoras más allá del embarazo ${ }^{14}$. El androcentrismo ligado a la definición del problema del consumo de tabaco ha hecho también que las mujeres, al fumar con menor intensidad o variedades bajas en nicotina, se sientan más seguras frente a sus efectos ${ }^{15} \mathrm{y}$ menos conscientes de los riesgos en comparación con los varones ${ }^{16}$.

En interacción con el componente androcéntrico de la construcción del problema del tabaquismo, que termina invisibilizando las experiencias y necesidades de las mujeres fumadoras, se produce una hipervisibilización de las mismas como consecuencia de la esencialización de su salud y sus cuerpos a la esfera sexual-reproductiva ${ }^{17}$. Esto ha derivado en la focalización de los esfuerzos sanitarios para promover el abandono del consumo de tabaco entre las mujeres en el embarazo y, en particular, en los efectos sobre la salud del feto ${ }^{18}$.

management in primary care». Journal of Epidemiology \& Community Health 61 Suppl 2:ii (2007), pp. 11-16.

13. JAGSI, Reshma; Motomura, Amy; Amarnath, Sudha; et al. «Under-representation of women in high-impact published clinical cancer research», Cancer 114:15 (2009), pp. 3293-3301.

14. Christofides, Nicola: «How to Make Policies More Gender Sensitive», en: Jonathan Samet y Soon-Young Yoon (eds.): Women and the Tobacco Epidemic. Challenges for Epidemic-Challenges for the 21st Century. Geneva, World Health Organization, 2001, pp. 165-76. DedobBeleER, Nicole; BÉland, François; ConTAndRIOPOUlos, André-Pierre; et al. «Gender and the Social Context of Smoking Behaviour». Social Science \& Medicine 58:1 (2004), pp. 1-12.

15. NERÍN, Isabel. «El tabaquismo en la mujer: Una atracción fatal». Archivos de Bronconeumonología, 41:7 (2005), pp. 360-362.

16. LUNDBORG, Peter y ANDERSON, Henrik. «Gender, risk perception, and smoking behavior». Journal of Health Economics, 27 (2008), pp. 1299-1311. LI, Quian; DRESLER, Carolyn; HECK Julia; et al. «Knowledge and beliefs about smoking and cancer among women in five European countries». Cancer Epidemiology, Biomarkers \& Prevention 19 (2010), pp. 2811-20.

17. IM, Eun-Ok. «A feminist critique of research on women's work and health». Health Care for Women International 21 (2000), pp. 105-19. InHORN, Marcia, y WHitTLE, Lisa. «Feminism meets the "new" epidemiologies: Toward an appraisal of antifeminist biases in epidemiological research on women's health». Social Science \& Medicine 53 (2001), pp. 553-67.

18. OAKLey, Ann. Op.cit. Christofides, Nicola. Op.cit. BerRidge, Virginia. «Constructing Women and Smoking as a Public Health Problem in Britain: 1950-1990s». Gender \& History 13:2 (2001), pp. 328-48. 
Otra dimensión importante a considerar en las diferencias de género en los procesos de abandono se refiere a los significados y utilidades que para las mujeres fumadoras comporta el uso de cigarrillos y que pueden actuar como poderosas barreras para dejar el tabaco. Numerosos estudios han mostrado que fumar reporta a las mujeres importantes ventajas como el control del estrés y la ansiedad y el control del peso corporal que pueden impedir el abandono del cigarrillo ${ }^{19}$. De igual modo, se ha observado que las mujeres que logran dejar de fumar tienen mayores dificultades para mantener la abstinencia, recayendo con más frecuencia que los hombres, sobre todo por el mayor impacto de eventos estresantes y del miedo a engordar ${ }^{20}$. También se ha constatado que las mujeres que muestran mayores resistencias a las presiones corporales y estéticas dejan en mayor medida el tabaco ${ }^{21}$.

Partiendo de estos antecedentes, este trabajo pretende profundizar en el análisis de los factores de género que inciden en el abandono del consumo de tabaco entre las mujeres. Para ello, se explora, en primer lugar, las diferencias entre los sexos en las tasas de cesación del uso de cigarrillos, indagando en las diferencias en función de la edad y la clase social. En segundo lugar, se analizan desde una perspectiva cualitativa los discursos de las mujeres fumadoras y exfumadoras en torno a su práctica tabáquica para desvelar los sentidos, motivaciones e interpretaciones que ayuden a comprender las barreras que pueden dificultar el abandono del consumo de tabaco en el contexto de su vida cotidiana.

\section{Metodologia}

Se ha empleado una metodología multimodal, combinando los enfoques cuantitativo y cualitativo y el análisis de datos secundarios y primarios. Por una parte, se ha procedido a la explotación estadística de la Encuesta Nacional

19. JACOBSON, Bobbie. Op.cit. WALDRON, Ingrid. «Patterns and Causes of Gender Differences in Smoking». Social Science \& Medicine 32:9 (1991), pp. 989-1005. GREAVES, Lorraine. Smoke Screen: Women's Smoking and Social Control. Fernwood Publishing, Halifax, 1996. AGHI, Mira; Asma, Samira; YeOnG, Chng Chee et al.: «Initiation and Maintenance of Tobacco Use», en: Jonathan Samet y Soon-Young Yoon (eds.): Women and the Tobacco Epidemic. Challenges for Epidemic-Challenges for the 21st Century. Geneva, World Health Organization, 2001, pp. 48-68.

20. GRITZ, Ellen; NiElSEN, Ingrid y BROOKS, Lisa. «Smoking Cessation and Gender: the Influence of Physiological, Psychological, and Behavioral Factors». Journal of American Medical Women's Association 51:1-2 (1996), pp. 35-42. McKeE, Sherry; MACIEJEWSKI, Paul; FALBA, Tracy; et al. Op.cit.

21. ZUCKER, Alyssa y LANDRY, Laura. «Embodied Discrimination: The Relation of Sexism and Distress to Women's Drinking and Smoking Behaviours». Sex Roles 56 (2007), pp.193-203.

Feminismo/s 18, diciembre 2011, pp. 39-65 
de Salud de 2006 que nos ha permitido estimar las tasas de abandono ${ }^{22}$ y describir las características de las pautas de cesación en función del sexo junto a otras variables significativas como la edad o la clase social. Para ello se ha accedido a los microdatos proporcionados por el Ministerio de Sanidad, Política Social e Igualdad que han sido analizados estadísticamente mediante el programa SPSS v. 15.

Por otra parte, se ha realizado un análisis del discurso de mujeres fumadoras y exfumadoras obtenido a partir de 32 entrevistas en profundidad llevadas a cabo en el ámbito geográfico de Andalucía oriental ${ }^{23}$. La selección de las mujeres que conforman la muestra responde a un procedimiento intencional basado en criterios donde se buscó la heterogeneidad por edad y momento en el que se iniciaron en el consumo de tabaco, nivel socioeconómico y roles laborales y familiares. Las participantes fueron localizadas en variados contextos: centros educativos, asociaciones de mujeres, colectivos profesionales y redes sociales de la investigadora y su entorno. El proceso de selección de nuevas informantes se fue intercalando con el análisis e interpretación de las entrevistas ya realizadas, lo que fue guiando la definición de las características de las siguientes informantes, buscando la mayor diversidad de experiencias. La selección finalizó al llegar a la saturación y redundancia de los datos en torno a las categorías centrales de análisis. En las entrevistas, con una duración entre una hora y media y dos horas de media, se exploraron las trayectorias de consumo de tabaco dentro del contexto biográfico y social de las participantes, atendiendo de forma abierta y flexible a los siguientes temas cardinales: percepción del uso de tabaco, experimentación e inicio, habituación, entornos y circunstancias de consumo, sentidos y ventajas, costes y problemas, productos tabáquicos y abandono. Los datos fueron analizados desde la perspectiva de la teoría fundamentada, utilizando como apoyo al análisis el programa informático Atlas.ti v.4.

22. El cálculo de las tasas de abandono se ha realizado en relación a la población que ha mantenido contacto con el tabaco; es decir, se han estimado a partir del cociente entre el número de personas exfumadoras y la suma del número de personas que fuman actualmente y que han fumado en el pasado. Esta precisión es importante porque habitualmente se calculan las tasas de abandono respecto al total de la población, lo que ha dado lugar a una subestimación de los índices de abandono femenino. JARVIS, Martin. Op.cit.

23. Estos resultados forman parte de una investigación cualitativa más amplia sobre la feminización del uso de tabaco que dio lugar a la tesis doctoral de la autora: Mujeres y tabaco: la feminización del consumo de cigarrillos en España. Universidad de Granada, 2007. 


\section{Diferencias de género en el abandono del consumo de tabaco: lo que dicen las encuestas}

Las encuestas disponibles indican que las mujeres, en términos generales, no están dejando de fumar en la misma medida que los varones. En 2006, la tasa femenina de abandono se sitúa casi diez puntos porcentuales por debajo de la masculina (un $37,9 \%$ frente a $48,9 \%$ ), si bien se observan importantes diferencias entre los grupos de edad (gráfico 1).

Gráfico 1. Tasas de abandono del consumo de tabaco según sexo y grupos de edad. Porcentajes respecto al total de personas que han fumado alguna vez.

España, 2006

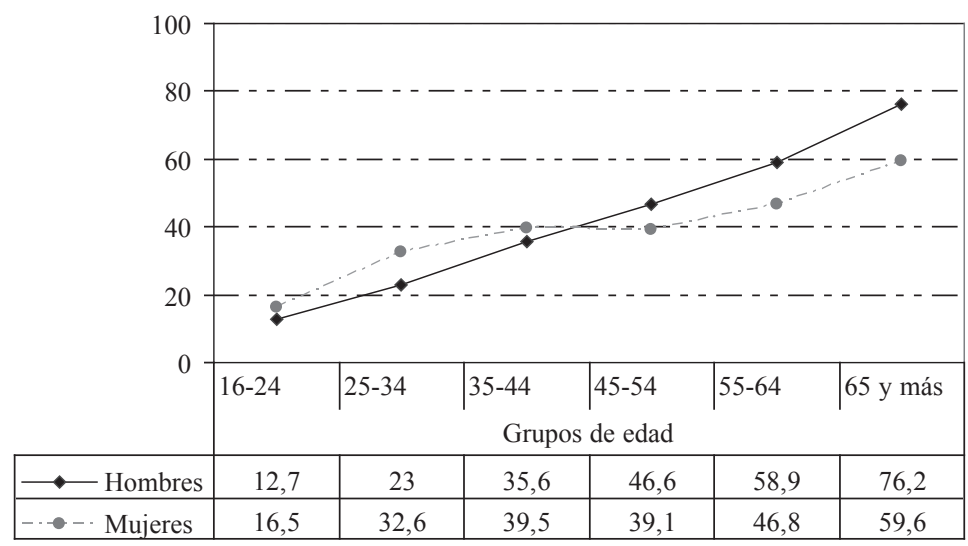

Fuente: Elaboración propia a partir de los datos de la Encuesta Nacional de Salud, 2006.

En el grupo de 16 a 44 años, son más las mujeres las que dejan de fumar, haciéndose máxima la brecha entre los sexos a favor de éstas en el grupo de edad de 25 a 34 años. A partir de los 45 años, esta relación se invierte y la tasa masculina de abandono supera a la femenina y la brecha a favor de éstos se incrementa, sobre todo en los grupos de mayor edad ${ }^{24}$. El ciclo vital se conforma así en un factor central para entender los procesos de abandono de consumo

24. Es importante visibilizar la situación de las fumadoras mayores de 45 años, que forman un colectivo donde el consumo de tabaco se ha incrementado de forma notable en los últimos quince años. Según las Encuestas Nacionales de Salud, la prevalencia de consumo de tabaco entre las mujeres de 45 a 64 años se ha duplicado desde 1993 (con un $10,3 \%$ ) a 2006 (con un 20,9\%). En cambio, entre los hombres de ese grupo de edad ha bajado de un $47 \%$ a un $34 \%$.

Feminismo/s 18, diciembre 2011, pp. 39-65 
de tabaco entre las mujeres. Es precisamente en la etapa reproductiva cuando las mujeres dejan el cigarrillo en mayor medida que los hombres. Luego parece estabilizarse para incrementarse a partir de los 55 años, aunque por debajo de la tendencia masculina.

Junto a la edad y el género, la clase social interviene decisivamente en las probabilidades de dejar de fumar, que se elevan conforme aumenta el nivel socioeconómico (tabla 1). Son los varones $-\mathrm{y}$, en menor grado, las mujeresde clases sociales más altas quienes dejan el tabaco con mayor facilidad, mostrando las brechas de género más reducidas. Por otra parte, entre las clases trabajadoras -manuales y no cualificadas- las mujeres muestran las mayores dificultades para dejar de fumar, observándose las brechas más amplias entre los sexos. A la vista de los datos, podemos afirmar que las desigualdades de género en cuanto al consumo de tabaco se acentúan en los niveles socioeconómicos más bajos, lo que se corresponde con lo observado en otros contextos

Tabla 1. Tasas de abandono del consumo de tabaco según sexo y clase social. Porcentajes respecto al total de personas que han fumado alguna vez. España, 2006

\begin{tabular}{|c|c|c|c|}
\hline Clase social $^{\mathrm{a}}$ & Mujeres & Hombres & ${\text { Brecha de } \text { género }^{\mathrm{b}}}^{\text {Clase I }}$ \\
\hline Clase II & 51,5 & 57,5 & 0,90 \\
\hline Clase III & 45,4 & 50,5 & 0,90 \\
\hline Clase IVa & 44,3 & 52,0 & 0,85 \\
\hline Clase IVb & 36,8 & 47,5 & 0,77 \\
\hline Clase V & 31,7 & 42,6 & 0,74 \\
\hline Total & 30,9 & 44,6 & 0,69 \\
\hline
\end{tabular}

${ }^{a}$ La clase social se refiere a la persona adulta seleccionada. Clase I: Directivos/as de la administración pública y de empresas de 10 o más asalariados/as. Profesiones asociadas a titulaciones de $2^{\circ}$ y 3 er ciclo. Clase II: Directivos/as de empresas de menos de 10 asalariados/as. Profesiones asociadas a una titulación de ler ciclo universitario. Técnicos/ as superiores. Artistas y deportistas. Clase III: Empleados/as de tipo administrativo y profesionales de apoyo a la gestión administrativa y financiera. Trabajadores/as de los servicios personales y de seguridad. Trabajadores/as por cuenta propia supervisores/as de trabajadores/as manuales. Clase IVa: Trabajadores/as manuales cualificados/as. Clase IVb: trabajadores/as manuales semicualificados/as. Clase V: Trabajadores/as no cualificados/as.

${ }^{\mathrm{b}} \mathrm{La}$ brecha de género se ha calculado a partir del cociente entre el porcentaje referido a hombres y el porcentaje referido a mujeres. Un valor inferior a 1 indica que la probabilidad de las mujeres para dejar de fumar es menor a la de los varones; y cuanto más cercano sea el valor a 1 se produce una mayor paridad.

Fuente: Elaboración propia a partir de los datos de la Encuesta Nacional de Salud 2006. 
sobre la creciente correlación entre desventaja económica, desigualdades de género y persistencia del consumo de tabaco ${ }^{25}$.

En relación a la participación en el mercado laboral, se observa entre las mujeres una mayor tasa de abandono, principalmente entre jubiladas y pensionistas, y seguidamente entre las dedicadas al trabajo doméstico y con empleo; mientras que son las mujeres estudiantes las que muestran mayores dificultades para dejar de fumar (tabla 2). Las mayores brechas de género a favor de las mujeres se ubican entre aquellas que se encuentran fuera del mercado laboral; es decir, las mujeres en desempleo, estudiantes y dedicadas al trabajo doméstico exhiben mayores probabilidades, en comparación con sus homólogos varones, para cesar en su consumo tabáquico. En cambio, entre el grupo de personas jubiladas y pensionistas, la brecha se invierte a favor de los hombres, lo que está relacionado también con el impacto de la variable edad.

Tabla 2. Tasas de abandono del consumo de tabaco según sexo, relación con la actividad y ocupación. Porcentajes respecto al total de personas que han fumado alguna vez. España, 2006

\begin{tabular}{|l|c|c|c|}
\hline \multicolumn{1}{|c|}{ Relación con la actividad } & Mujeres & Hombres & $\begin{array}{c}\text { Brecha de } \\
\text { género }\end{array}$ \\
\hline Trabajando & 37,2 & 38,7 & 0,96 \\
\hline En desempleo & 34,4 & 28,7 & 1,20 \\
\hline Jubilado/a - pensionista & 48,4 & 70,3 & 0,69 \\
\hline Estudiante & 20,5 & 15,4 & 1,33 \\
\hline $\begin{array}{l}\text { Dedicados/a principalmente al trabajo } \\
\text { doméstico }\end{array}$ & 38,9 & 33,3 & 1,17 \\
\hline Ocupación & Mujeres & Hombres & $\begin{array}{c}\text { Brecha de } \\
\text { género }\end{array}$ \\
\hline $\begin{array}{l}\text { Empleador/a (empresario/a o } \\
\text { profesional con asalariados/as) }\end{array}$ & 40,6 & 51,7 & 0,79 \\
\hline $\begin{array}{l}\text { Empresario/a sin asalariados o } \\
\text { trabajador/a independiente }\end{array}$ & 37,1 & 55,2 & 0,67 \\
\hline Ayuda familiar & 35,3 & 45,5 & 0,78 \\
\hline Asalariado/a fijo/a & 43,1 & 51,9 & 0,83 \\
\hline Asalariado/a eventual o interino/a & 31,3 & 32,9 & 0,95 \\
\hline Miembro de una cooperativa & 32,6 & 46,7 & 0,70 \\
\hline Total & 37,9 & 48,3 & 0,78 \\
\hline
\end{tabular}

Fuente: Elaboración propia a partir de los datos de la Encuesta Nacional de Salud 2006.

25. Graham, H. et al. Op. cit.

Feminismo/s 18, diciembre 2011, pp. 39-65 
Entre mujeres y hombres con trabajo remunerado, a nivel global no se aprecian diferencias significativas, aunque cuando se detalla el tipo de ocupación aparecen discrepancias entre los sexos. Así, en todas las categorías ocupacionales, excepto en la de personal asalariado temporal y con muy poca diferencia respecto a los varones, las mujeres muestran menores tasas de abandono. Estos resultados, si bien convendría un análisis más detallado de las interacciones entre las variables, apuntan que los mayores obstáculos para abandonar el consumo de tabaco entre las mujeres se encuentran relacionados con su participación en el mercado laboral, vinculados principalmente a situaciones de exclusión -en el caso de las mujeres en desempleo- y precariedad.

Además del examen de las pautas de cesación, es preciso ahondar en el plano subjetivo, es decir, cómo las personas exfumadoras racionalizan e interpretan el abandono de su práctica, encontrando significativas diferencias entre los sexos en cuanto a los motivos declarados para dejar de fumar (tabla 3). El consejo médico y las molestias sentidas por el consumo de tabaco, tanto en su salud como en su rendimiento general, son motivos más prevalentes entre los varones. En cambio, la decisión ligada a la propia voluntad y el embarazo constituyen motivos significativamente más importantes para las mujeres.

Tabla 3. Motivos para dejar de fumar según sexo. Porcentajes. España, 2006

\begin{tabular}{|l|c|c|}
\hline & Mujeres & Hombres \\
\hline Se lo aconsejó el médico ** & 5,4 & 18 \\
\hline Sentía molestias por el tabaco ** & 13,8 & 23,6 \\
\hline $\begin{array}{l}\text { Aumentó su grado de preocupación por los efectos del } \\
\text { tabaco sobre su salud }\end{array}$ & 16,3 & 15,3 \\
\hline Embarazo ** & 15,6 & 0 \\
\hline Sentía que disminuía su rendimiento general ** & 2,9 & 4,5 \\
\hline Lo decidió solo, por propia voluntad * & 62,6 & 58,7 \\
\hline Otros motivos & 8 & 8,2 \\
\hline
\end{tabular}

* Diferencias estadísticamente significativas $<0.05$;

** Diferencias estadísticamente significativas $<0.01$

Fuente: Elaboración propia a partir de los datos de la Encuesta Nacional de Salud (2006).

Si consideramos la instancia de donde proviene la disposición de dejar de fumar -ya sea del propio individuo, ya sea de agentes exteriores al mismo-y el locus de aplicación de dicha disposición -sobre el cuerpo en su totalidad o sobre una parte de éste-, podemos articular un modelo compuesto de dos ejes 
en el que se ubican las motivaciones que parecen operar de forma diferencial en mujeres y de hombres (cuadro 1).

Cuadro 1. Motivaciones para el abandono del tabaco en mujeres y hombres

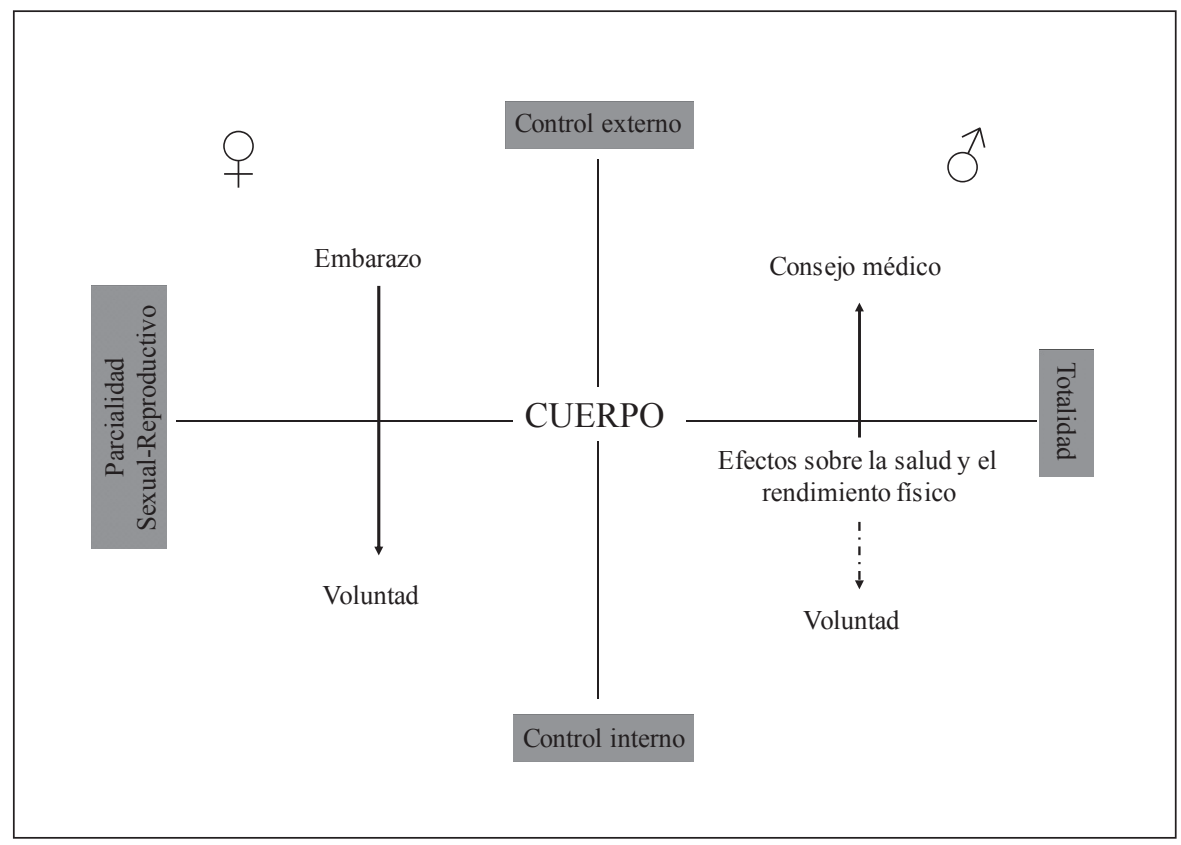

Fuente: Elaboración propia

El abandono masculino se inserta en mayor medida dentro de unas coordenadas de control externo, condicionado por instancias sanitarias que operan sobre la totalidad del cuerpo. El sometimiento al control médico se produce fundamentalmente por una preocupación sobre los efectos del consumo de tabaco sobre la salud, y sobre todo, por su experiencia directa. Los hombres dejan de fumar más por su salud y se sienten reforzados en su decisión por los agentes sanitarios; lo que puede contribuir a unas mayores probabilidades de éxito para dejar de fumar de forma definitiva. En cambio, el abandono femenino se ubica principalmente en el terreno del control interno, por lo que dejar de fumar depende en un porcentaje significativo de la voluntad de las propias mujeres. Y a menudo esta decisión no responde a una preocupación por su propia salud sino que se localiza en una esfera parcial de su cuerpo, la sexualreproductiva, atendiendo a los efectos del tabaco sobre el feto durante el embarazo. Esta idea es reforzada por gran parte de las intervenciones sanitarias 
orientadas específicamente a las mujeres y que se centran en la gestación como campo prioritario de actuación frente al tabaquismo femenino (cuadro 2). Aunque una proporción importante de mujeres afirma haber dejado de fumar durante el embarazo, los estudios evidencian que un porcentaje significativo de mujeres embarazadas -variable según los estudios entre un 30 y un 50\%no logra dejar de fumar durante la gestación ${ }^{26}$. Y un alto porcentaje de las mujeres que lo consiguen recaen en el cigarrillo después del parto ${ }^{27}$.

Cuadro 2. Carteles para la deshabituación tabáquica orientados a fumadoras embarazadas
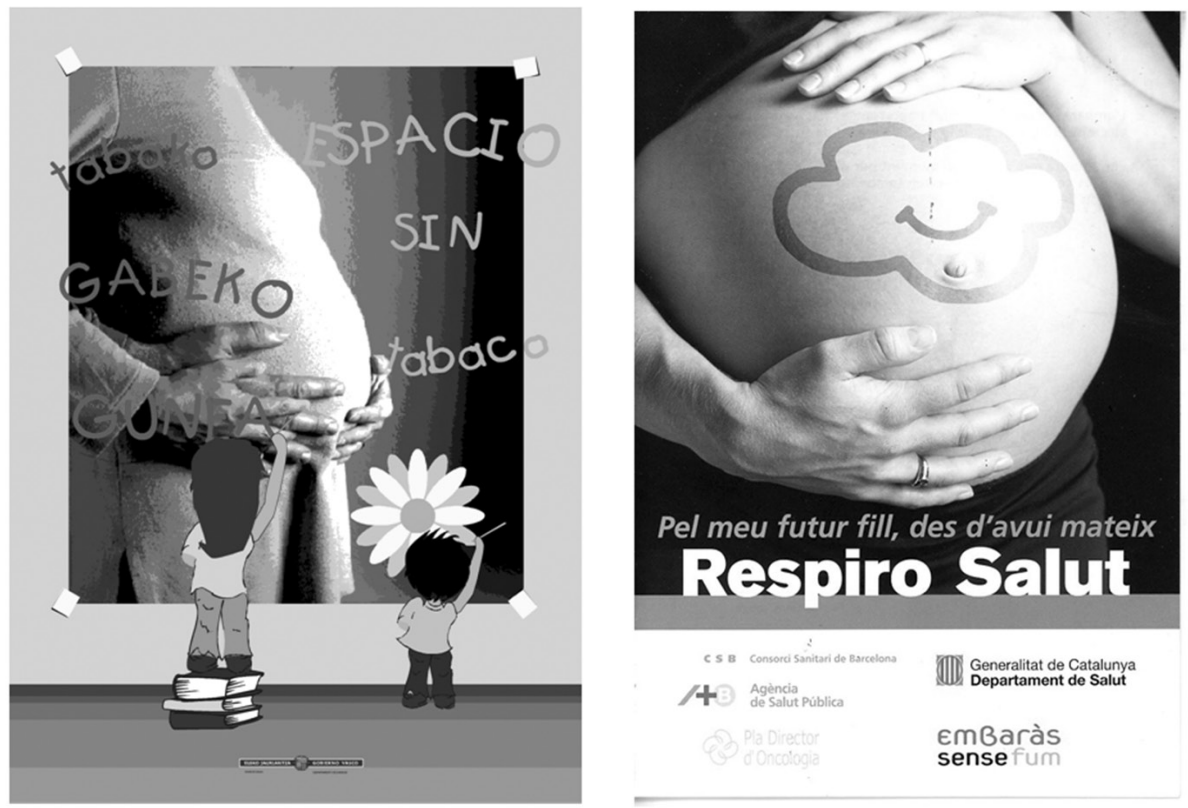

26. JANÉ, Mireia; Nebot, Manel; BerJAno, B.; et al. «Factores determinantes del abandono del tabaquismo durante el embarazo». Medicina Clínica (Barc) 114 (2000), pp. 132-5. MartíneZ-Frías, María Luisa; RodrígueZ-PInILla, Elvira; Bermejo, Eva y Grupo Periférico del ECEMC. «Consumo de tabaco durante el embarazo en España: análisis por año, comunidades autónomas y características maternas». Medicina Clínica (Barc) 125 (2005), pp. 86-92. AmezCUA-Prieto, Carmen; Espigares-RodríGUEZ, Elena; MozASMORENO, Juan; et al. «Modificación del consumo de tabaco durante el embarazo: incidencia y factores asociados». Clínica e Investigación en Ginecología y Obstetricia, 35:6 (2008), pp. 194-201.

27. JANÉ, Mireia. 2004. «Mujeres y tabaco: aspectos ligados al género». Adicciones 16(Supl. 2):115-30. 
Conviene detenernos en el «consejo médico» por sus substanciales implicaciones en la configuración del tabaquismo como problema de salud pública y en los sesgos de género que parecen ir asociados a éste. Dejar de fumar por consejo médico es más frecuente en los hombres de todas las edades, pero sobre todo, a partir de los 45 años. En las mujeres, en cambio, no llega al $10 \%$ entre las mayores de 55 años (tabla 4). Por clase social, la influencia del consejo médico se incrementa conforme aumenta el nivel socioeconómico de los varones, no apreciándose una correlación clara en las mujeres, si bien entre éstas el consejo médico se sitúa en todos los niveles socioeconómicos significativamente por debajo respecto a los hombres. Aunque con estos datos no podemos llegar a desvelar si estas discrepancias se deben a un desajuste de provisión del consejo médico o a un problema de interiorización de éste por parte de los sujetos que acuden a la consulta médica, sí que apuntan una influencia de sesgos de género y de clase social en la efectividad y equidad de las intervenciones sanitarias en este ámbito.

Tabla 4. Porcentaje de mujeres y hombres que abandonan el consumo de tabaco por consejo médico, según nivel socioeconómico y grupos de edad

\begin{tabular}{|l|c|c|c|c|c|c|}
\hline $\begin{array}{c}\text { Nivel } \\
\text { socioeconómico }\end{array}$ & Clase I & Clase II & Clase III & Clase IVa & Clase Ivb & Clase V \\
\hline Hombres & 12,8 & 12,2 & 16,7 & 18,6 & 23,1 & 22,4 \\
\hline Mujeres & 4,4 & 3,9 & 3,9 & 8,0 & 5,5 & 5,9 \\
\hline Grupos de edad & $\mathbf{1 6 - 2 4}$ & $25-34$ & $35-44$ & $45-54$ & $55-64$ & 65 y más \\
\hline Hombres & 3,9 & 2,5 & 6,7 & 12,3 & 18,6 & 28,0 \\
\hline Mujeres & 1,4 & 3,8 & 4,2 & 4,8 & 9,7 & 10,4 \\
\hline
\end{tabular}

Fuente: Elaboración propia a partir de los datos de la Encuesta Nacional de Salud (2006).

Hemos dejado aparte un motivo fundamental para las mujeres, el embarazo, declarado por un $15 \%$ de las exfumadoras. Este motivo es más prevalente entre las mujeres de 24 a 44 años, y que dicen haber dejado el tabaco por esta razón un 22-23\%. Por clase social no se aprecian grandes diferencias. Pero profundizaremos en esta cuestión en el siguiente epígrafe.

\section{Barreras para el abandono del consumo de tabaco: la voz de las priopias mujeres}

Los datos procedentes de encuestas nos ofrecen datos muy relevantes sobre las tendencias de abandono entre los sexos, pero poco nos dicen acerca de las significaciones que subyacen a la práctica de fumar cigarrillos y a su 
interrupción. Esto exige una vía de aproximación diferente a partir de técnicas de investigación cualitativas que ayuden a desvelar los sentidos, experiencias e interpretaciones manifestados por las propias mujeres y que pueden contribuir a la comprensión de las barreras que impiden su abandono del tabaco.

\section{1. «A mí me gustaría dejarlo, pero no puedo»: El poder de la adicción}

Gran parte de las fumadoras declara que les gustaría dejar de fumar, pero expresan su «imposibilidad» de hacerlo por la adicción que experimentan hacia esta sustancia. "Es que es una adicción tan fuerte...", afirman muchas de ellas. El «poder de la adicción» se exterioriza claramente cuando la fumadora la enfrenta a su voluntad de dejar el tabaco, ya que gran parte de ellas han intentado dejar de fumar en varias ocasiones, "pero siempre caigo y fumo». Esta adicción es descrita en analogía con otras drogodependencias y es habitual en los discursos de las fumadoras que aparezcan el término «droga»y otras expresiones más propias del uso de sustancias ilegales -como «drogadicta», «mono» o «enganche»- para referirse a su propio consumo.

Las mujeres fumadoras valoran su habituación tabáquica mayoritariamente en términos de dependencia y no de enfermedad, que sería el otro elemento preponderante en la construcción biomédica del problema del tabaquismo. Esto conlleva importantes implicaciones. Primero, en relación con los procesos de estigmatización y devaluación de la mujer fumadora, reafirmando los estereotipos de «mujer adicta», frecuentemente asociado a las mujeres que usan drogas. Y segundo, en lo que se vincula a las estrategias de abandono del consumo de tabaco, porque la creencia en la fuerza de la adicción hace menos probable que se decida dejar de fumar, porque es algo que escapa a su control. También, es menos probable recurrir a los servicios médicos en busca de apoyo como consecuencia de la estigmatización de la drogodependencia que opera más duramente en las mujeres. Se aprecia en los discursos de las mujeres fumadoras como un factor decisivo para dejar de fumar es la «voluntad», valorada como la única vía para superar un proceso adictivo. Y muchas de ellas se escudan en su «falta de voluntad» como justificación del mantenimiento de su hábito.

\section{2. «Fumar está asociado con todas las cosas de la vida»: Los beneficios del consumo de tabaco}

La adicción al tabaco es interpretada por las propias mujeres como una dependencia más «psicológica» que fisiológica. Pero si profundizamos en sus discursos y experiencias con el tabaco, descubrimos cómo lo psicológico está 
enredado con lo social y que, sobre todo, esta dependencia se articula no tanto en relación a los efectos farmacológicos de la nicotina como a los beneficios sociales, emocionales y corporales derivados del consumo de cigarrillos:

«Pero, sobre todo, yo creo que es un hábito muy psicológico, que se asocia con todas las cosas de la vida, con un montón de cosas, ¿no? Pues se asocia con el café, se asocia con la conversación, se asocia con la capacidad de hablar mejor, se asocia con la capacidad para tranquilizarte. O sea, que es una cosa que es muy psicológica también. Es una asociación y tú estableces esa asociación con un montón de cosas cotidianas, normales en tu vida, ¿no?» (E15, 32 años, fumadora diaria, licenciada universitaria, en paro, vive con su pareja).

La dependencia al tabaco sólo puede ser entendida en el contexto social donde se desarrolla y toma sentido en conexión con las experiencias de los sujetos y la interpretación que éstos hacen de las mismas. El uso de drogas como práctica social adquiere formas y sentidos variables tanto en el tiempo como en el espacio, de manera que sus efectos, ventajas y utilidades -y el modo en el que son percibidos y valorados- dependen de circunstancias sociales y de los marcos estructurales y normativos de género. En el caso del consumo de tabaco, éste conlleva importantes ventajas y beneficios para las mujeres, situándose como una estrategia eficaz, accesible y altamente funcional para cubrir sus necesidades y expectativas en relación a las demandas de la feminidad y como respuesta al estrés derivado de la incompatibilidad de roles.

Fundamentalmente, pueden identificarse tres amplios conjuntos de beneficios para las mujeres. En primer lugar, los beneficios sociales, que son especialmente valorados por las fumadoras; de hecho gran parte de ellas se definen como «fumadoras sociales», incluso cuando su frecuencia de consumo es diaria e intensiva. Fumar presenta una utilidad social y emocional en relación con los sentimientos de pertenencia y sintonía social, que además incrementa la autoestima, la seguridad y el placer de las fumadoras en su interacción. Las mujeres entrevistadas afirman la importancia de fumar como práctica facilitadora de las relaciones sociales:

«A mí se me da mal lo de estar con mucha gente. En el plano social a mí me cuesta mucho relacionarme y con el cigarro es mucho más fácil porque si fumas: «Hola, ¿qué tal?, ¿tienes un cigarro?», «Vale gracias, no sé qué...». Y también cuando estás con el cigarro tampoco tienes que hablar tanto, mientras fumas, el humo, lo enciendes... a lo mejor preguntas cuatro cosas del tabaco... Es una forma de conocer gente». (E26, 23 años, fumadora ocasional, estudiante universitaria, vive con familia de origen)

Algunas de ellas cuentan que sus «recaídas» han tenido una causa social, al no saber «cómo relacionarse» sin fumar en circunstancias fuertemente estructuradas por el consumo de tabaco -contextos de ocio o ciertos ambientes de

Feminismo/s 18, diciembre 2011, pp. 39-65 
estudio o de trabajo- o por «necesitar» esa ayuda en la relación social cotidiana. Para las mujeres, los beneficios sociales adquieren una dimensión especial al configurarse el cigarrillo como una herramienta de gestión corporal y social y de manifestación de ciertas expresiones de la feminidad. Aunque esta funcionalidad puede estar mutando en el contexto de creciente regulación de esta práctica y de devaluación de la persona fumadora.

Otro conjunto de beneficios se relacionan con los aspectos emocionales. Las mujeres valoran especialmente los efectos relajantes del tabaco y utilizan el cigarrillo para tranquilizarse y controlar su estrés. Pero hemos de situar las experiencias del estrés en sus marcos sociales y de género donde se desencadenan y se ubican las biografías personales. Las entrevistas analizadas revelan que las múltiples exigencias del éxito femenino en el terreno afectivo, corporal, social, académico y laboral -con frecuencia contradictorias- y los obstáculos y discriminaciones para alcanzar esas demandas desembocan en situaciones estresantes, o al menos expresadas como tales por las mujeres entrevistadas, que han derivado en la intensificación y cronificación de su consumo de tabaco. Es el caso del acceso a los estudios universitarios, pero sobre todo es la incorporación al mercado laboral -donde las mujeres ocupan posiciones más precarias e inestables- y los problemas de conciliación con las tareas domésticas y de cuidado los que marcan los usos del tabaco como «válvula de escape»:

«Es que tenía mucho estrés, pero mucho, mucho... Tenía en esa época, tres niños chicos y una cafetería... Pues eso era un estrés muy grande el que yo tenía... [...] Ahí sí que fumar me ayudaba a relajarme». (E10, 46 años, trabajadora de hostelería en paro, casada y con cuatro hijos).

El cigarrillo, a falta de otros recursos disponibles, se convierte en una herramienta eficaz y accesible para afrontar estos sentimientos: «Es algo que siempre tienes ahí». Pero, sobre todo, se trata de un consumo socialmente aceptado para afrontar el «malestar femenino», como también se observa con los usos de psicofármacos ${ }^{28}$.

Otro conjunto de beneficios del consumo de tabaco y que adquiere una significación específica en un marco de género son los ligados al control del peso corporal. El argumento de «prefiero seguir fumando a engordar» está presente en la mayoría de los discursos de las mujeres, y de forma mucho más marcada entre adolescentes y jóvenes. La pérdida de este beneficio, en el contexto de una sociedad donde el modelo corporal de la delgadez se ha impuesto

28. Romo, Nuria y GIL, Eugenia. «Género y uso de drogas. De la ilegalidad a la legalidad para enfrentar el malestar», Trastornos Adictivos 8:4 (2006), pp. 243-50. 
como clave del éxito femenino, no es fácil de asumir por las fumadoras. Esto se muestra, primero, en el rechazo a dejar de fumar por miedo a engordar, y segundo, en la vuelta al cigarrillo para recuperar el peso anterior cuando se ha engordado como consecuencia de su abstinencia.

«He dejado de fumar, varias veces. Así en serio, sin fumar, tres meses más o menos. [...]Pero volví a fumar porque empecé de exámenes en el instituto y tenía mucha ansiedad y entonces me dio por comer más y al comer más pues engordo más y volvemos al tema de la estética... Y dices: He engordado mucho y no quiero engordar más, y si sigo comiendo así, voy a seguir engordando. Sí que es una época, pero que me cuesta mucho trabajo adelgazar y paso». (E25, 20 años, estudiante de FP, fumadora diaria, vive con familia de origen)

Como vemos el miedo a engordar, la necesidad de mitigar el estrés cotidiano y el consumo de tabaco se convierten, para muchas mujeres, en un triángulo retroalimentado del cual es difícil de escapar.

\subsection{Mujeres + tabaco $=$ Embarazo: Creencias en salud y percepción de los riesgos}

Un interrogante que se puede plantear desde una postura eminentemente racional es cómo, a pesar del incremento del conocimiento y de la información sobre los efectos del consumo de tabaco en la salud, las mujeres continúan fumando. Además de las utilidades asociadas a los beneficios que fumar implica para las mujeres, es preciso explorar la percepción del riesgo de los efectos dañinos del consumo de tabaco y cómo esta percepción puede condicionar su posición frente al abandono de esta práctica.

En el discurso de las fumadoras se observan dos componentes. Primero, la creencia de que existe una sobreinformación sobre los efectos sobre la salud. Hasta tal punto que llega a perder su eficacia, como afirma una adolescente fumadora: «A mí no me van a quitar de fumar porque me pongan un anuncio de éstos: 'Mira estos son tus pulmones'. Ya lo sé, o sea, ya sé cómo son mis pulmones». Esta información se reduce fundamentalmente al cáncer de pulmón -enfermedad fuertemente estereotipada como masculina y adulta- por lo que las adolescentes y jóvenes no perciben este riesgo como probable ni inmediato.

Por otro lado, y paradójicamente respecto a la observación anterior, se advierte un amplio desconocimiento por parte de las mujeres fumadoras, especialmente de las más jóvenes, sobre los efectos concretos del consumo de tabaco sobre su salud y sus cuerpos más allá del embarazo. Es decir, cuando en la ecuación tabaco y salud se introduce el factor mujeres, entonces el resultado no es cáncer sino embarazo. Así, al preguntarse a las fumadoras por los efectos específicos del consumo de tabaco casi todas las respuestas se refieren 
a su impacto sobre el feto en la época de gestación. Dejando a un lado la dimensión sexual-reproductiva, en las entrevistas realizadas no emergen otras preocupaciones sobre cómo el consumo de tabaco puede afectar a su salud. Pocas mujeres fumadoras conocen que, además de padecer cáncer de pulmón o dolencias cardiacas, tienen más probabilidad que las no fumadoras de sufrir cáncer cervical, tener más riesgo de adelantar la menopausia, padecer osteoporosis o sufrir ataques al corazón si se toman anticonceptivos ${ }^{29}$. Sólo algunas fumadoras mayores de 45 años mencionan el riesgo de «tener problemas de huesos» y significativamente, muchas de ellas mencionan aspectos relacionados con el envejecimiento de la piel como secuela del consumo de tabaco en su salud.

La fuerte asociación entre tabaquismo y embarazo conlleva importantes consecuencias en la valoración global de los riesgos del consumo de tabaco. Primero, se entiende que los efectos del consumo de tabaco tiene sobre el cuerpo de la mujer son temporales, incidiendo en un período muy concreto: el embarazo. Pero, además, no afectan directamente a la mujer sino a la salud de su hijo o hija. Por esto, gran parte de las mujeres jóvenes afirman que dejarían de fumar, o al menos lo intentarían, en el momento de quedarse embarazadas: «Si yo me quedara embarazada dejaría de fumar, por supuesto. Me costaría la vida, pero lo dejaría».

Por otro lado, entre las mujeres entrevistadas que han sido madres, una parte reconoce que dejaron espontáneamente el consumo de tabaco al saber de su embarazo. La única estrategia con la que contaban era con su «fuerza de voluntad» y la principal motivación no causar daño a la criatura que esperaban:

«Yo cuando me quedé embarazada dejé de fumar por completo. Lo dejé por mí misma, no porque me lo dijera el médico. En el tiempo de embarazo no cogí ni un cigarro. En aquellos tiempos había bastante información. [...] Yo sabía que estaba embarazada y que fumar no era bueno para el niño y no fumé». (E8, 47 años, fumadora diaria, trabajadora en hostelería en paro, divorciada y con un hijo)

Las madres fumadoras entrevistadas no estiman los daños del consumo de tabaco como unos daños directos que puedan afectar a su propia salud, sino a la salud del hijo o hija que va a nacer. Esta percepción implica en la práctica se plantee el abandono del consumo de tabaco como un asunto estacional -circunscrito a los meses de embarazo y, posiblemente, al período de lactancia-y

29. ERnSter, Virginia; KaUfman, Nancy; NiCHTER, Mimi; et al. «Women and Tobacco: Moving From Policy to Action». Bulletin World Health Organization 78:7 (2000), pp. 891-901. 
reversible. De este modo, muchas de ellas retornan al cigarrillo tras dar a luz y/o finalizar la lactancia:

«No me costó trabajo reducir el tabaco cuando estaba embarazada, porque yo pensaba más en mi hijo que en mí. Pero que cuando nació ya la niña y ya no le daba el pecho pues me desaté. Empecé fumar como fumaba antes o incluso más...» (E11, 43 años, fumadora diaria, limpiadora, casada y con una hija)

La presión social y médica para que dejen el consumo de tabaco genera grandes conflictos a las madres que intentan -si bien algunas son incapaces de dejar totalmente el tabaco- reducir su consumo para que perjudique lo menos posible a su bebé. El abandono del consumo de tabaco durante el embarazo se define así como una obligación moral y social de la madre si no quieren ser etiquetadas de «malas madres», como manifiesta la siguiente informante, embarazada en el momento de la entrevista:

«También es que nos comen mucho el tarro de malas madres, de cuidarte poco, de mala salud... Y máxime si estás embarazada, de no cuidar tu salud. [...] Las mujeres tenemos el hándicap éste... sobre todo del embarazo. Ahora mismo, yo casi no me atrevo a fumar en público... porque, no solamente porque yo me intento limitar, sino también por la gente. Y todavía no se me nota mucho, pero cuando esté más embarazada voy a sentir mucho más la censura de la gente. No sólo la que yo tengo, sino también la que voy a sentir del exterior, que la gente me va a mirar mal». (E15, 32 años, fumadora diaria, licenciada universitaria, en paro, vive con su pareja).

\section{4. «Voy a necesitar ayuda»: Barreras institucionales para acceder a los recursos}

A pesar de que las fumadoras entienden el abandono del consumo de tabaco en términos individuales y de resistencia psicológica, se percibe en su discurso la queja por la falta de apoyos sociales e institucionales que les faciliten este proceso. A este respecto, un sector de las mujeres entrevistadas -sobre todo las que ya llevan bastantes años fumando y han desarrollado un itinerario de altibajos en su consumo de cigarrillos- demanda «ayuda» para dejar el tabaco porque se ven incapaces de hacerlo por sí solas.

«Cuando yo diga de quitarme de fumar, yo sé que voy a necesitar ayuda. Porque yo muchas veces digo: «Ya no voy a fumar en este rato, el siguiente no me lo fumo». Y, a lo mejor, no me fumo ese cigarro, pero sí me fumo el siguiente y al momento me fumo otro para saber que yo he fumado». (E11, 43 años, fumadora diaria, limpiadora, casada y con una hija)

No se evalúan como suficientes los consejos de las autoridades sanitarias. Las fumadoras «ya saben» que fumar perjudica a su salud, pero lo que reclaman no es más información sino mecanismos y apoyos de ayuda que sean 
accesibles y compatibles con sus rutinas y necesidades. La certeza de necesitar ayuda exterior para dejar el tabaco se concreta en algunos casos con la demanda y utilización de ciertos recursos como cursos o terapias específicas. Las escasas mujeres entrevistadas que se han interesado por éstos se han encontrado con la dificultad de conciliar la asistencia a estos programas con sus responsabilidades familiares y laborales:

«También me apunté a un cursillo que estaba organizado por un sindicato para ver quién quería quitarse fumar y yo me apunté y convencí a tres o cuatro para que se apuntaran y nos apuntamos, pero dicho curso nunca se llegó a dar. Pero por lo menos si te lo ponen a tu alcance a lo mejor lo intentas, pero ¿qué hay?, ¿la unidad ésa del R.A, la unidad de tabaquismo o algo de eso? Pero claro, eso funciona por la mañana, si tú estás trabajando no puedes estar continuamente pidiendo permiso... Pues si en los centros laborales se hicieran estos cursos, por lo menos lo intentas... Pero tampoco se incentiva eso. No está al alcance. Tú tienes que buscarlo y esforzarte y no se incentiva para nada en los centros de trabajo. Por lo menos, en el mío no. (E9, 46 años, funcionaria, fumadora diaria, casada y con dos hijas)

\section{Conclusiones}

El reduccionismo biomédico del consumo de tabaco al problema del tabaquismo ha eclipsado su complejidad como práctica social, donde además de factores farmacológicos y fisiológicos operan también factores sociales, culturales, económicos y políticos, y específicamente de género, que marcan su distribución diferente y desigual entre la población, tanto a la hora de adoptar esta práctica como de abandonarla. Dejar o no dejar el tabaco no puede entenderse como una cuestión meramente individual, sino que se trata de una cuestión que está estructurada socialmente y marcada por el género junto a la edad y la clase social. De esta forma determinados grupos sociales ocupan posiciones de ventaja y de desventaja frente al abandono de consumo de tabaco. Así, el abandono de consumo de tabaco se configura como un asunto principalmente masculino, adulto y de sectores socioeconómicos elevados. Como han mostrado otros estudios, el consumo de tabaco en las sociedades avanzadas está crecientemente asociado a la desventaja social y económica ${ }^{30}$ y a las desigualdades de género ${ }^{31}$, lo que indica la persistencia de inequidades en el acceso a recursos y apoyos necesarios para poder dejar de fumar y que,

30. LAYTE, Richard y WhELAN, Christopher. «Explaining Social Class Inequalities in Smoking: The Role of Education, Self-Efficacy, and Deprivation». European Sociology Review 25 (2009), pp. 399-410.

31. JaCOBSON, B. Op. cit.; GREAVES, L. Op. cit.; ZuCKER, A. y LANDRY, L. op. cit.; Graham, H. et al. Op. cit. 
en definitiva, se traduce en desigualdades en salud. Los varones, especialmente aquéllos de mayor estatus socioeconómico, tienen mayores oportunidades económicas y sociales para abandonar el cigarrillo y acceder a nuevos estilos de vida, además de contar con mayor información y apoyos sanitarios para rechazar el consumo de tabaco y acceder a prácticas saludables ${ }^{32}$. Sin embargo, para las mujeres dejar de fumar plantea mayores dificultades, que se acentúan entre las mujeres mayores de 45 años y de clases trabajadoras manuales y no cualificadas.

Además de las diferentes tasas de abandono entre los sexos, se observan también diferencias en las motivaciones de mujeres y hombres para suspender su consumo de tabaco que indican un desajuste en la provisión de apoyo sanitario. Así se observa en los desequilibrios de la influencia del consejo médico, que pueden deberse a varios factores: por la menor frecuencia de consejo a las mujeres o por su infravaloración por parte de las fumadoras, pero que en cualquier caso es un indicador de que la población femenina no se está beneficiando de forma equivalente de los efectos de las intervenciones sanitarias. Al mismo tiempo, la focalización de los esfuerzos sanitarios centrados en las mujeres en el embarazo puede contribuir a reforzar la idea bastante extendida entre las fumadoras de restringir la interrupción de su consumo de tabaco a la época de la gestación, entendiéndose así como una cuestión temporal y reversible y cargada de fuertes conflictos morales. Así también, es importante atender a las creencias sobre la adicción y a las autopercepciones respecto a la misma que manifiestan las mujeres fumadoras y que terminan reduciendo el proceso de abandono de consumo de tabaco a una «cuestión de voluntad»; lo que puede reforzar estereotipos acerca de la debilidad anímica de las mujeres y limitar la búsqueda o aceptación de recursos externos. En relación a esto último, emerge como un obstáculo que también puede impedir el acceso a los recursos institucionales los problemas de tiempo derivados de las dificultades de conciliación familiar y laboral.

Junto a las desigualdades de género en el acceso a los recursos facilitadores del abandono del consumo de tabaco, una potente barrera para no suspender

32. A este respecto, resultan enormemente interesantes las interpretaciones sociológicas sobre la difusión de las modas y los nuevos estilos de vida que indican cómo su distribución social está marcada por una jerarquización social donde las clases más altas (y entre éstas, los hombres) son las que acceden en primer lugar a las nuevas prácticas y cómo éstas las abandonan y las sustituyen por otras cuando se expanden por el resto de grupos sociales. SimmeL, Georg, «La moda», en: Sobre la aventura. Ensayos de estética. Barcelona, Península, 2002. Así, el acceso a nuevos estilos de vida saludables se configura en las sociedades modernas como un importante elemento de distinción social. Collins, Randall: Cadenas rituales de interacción, Barcelona, Anthropos, 2009, pp. 397.

Feminismo/s 18, diciembre 2011, pp. 39-65 
el consumo de tabaco entre las mujeres se encuentra en que esta práctica continúa siendo altamente compatible y útil para hacer frente a las exigencias de la feminidad y de los roles de género. Fumar comporta para las fumadoras importantes beneficios sociales, emocionales y corporales, incluso en la actual época de creciente devaluación social y estigmatización de esta práctica y de quienes la portan. Estos beneficios deben ser entendidos dentro de los marcos estructurales y normativos de género y en un contexto de desigualdad de recursos y oportunidades para acceder a estilos de vida alternativos definidos como saludables. Fumar se configura así como una herramienta accesible y especialmente eficaz para las mujeres para controlar el estrés cotidiano, modular la sociabilidad y mantener el peso corporal. Frente a estos beneficios, se observa una infravaloración de los riesgos del consumo de tabaco sobre la salud, que se ven reducidos al embarazo y a enfermedades fuertemente masculinizadas como es el cáncer de pulmón.

Las barreras de género asociadas a dificultades específicas de las mujeres para poder dejar de fumar no pueden obviarse en las políticas sanitarias, puesto que suponen un importante de factor de inequidad en salud. Por ello, el análisis de género se convierte en una poderosa herramienta no sólo de diagnóstico y comprensión de los factores relacionados con el consumo de tabaco femenino sino también de intervención. El análisis de género puede ayudar a entender las especificidades del consumo de tabaco entre las mujeres, pero también a detectar sesgos androcéntricos y sexistas que pueden afectar a las políticas y prácticas sanitarias sobre consumo de tabaco. También es preciso atender a la reproducción y materialización de estos sesgos en las actitudes y creencias de las propias mujeres fumadoras que pueden dificultar su toma de conciencia en torno a los riesgos del consumo de tabaco sobre su salud y, en definitiva, su empoderamiento en salud. A este respecto es fundamental que las intervenciones sanitarias contribuyan a desmontar las creencias en torno a la adicción y el voluntarismo asociadas al abandono del consumo de tabaco y puedan ofrecer recursos que ayuden a contrarrestar los efectos perdidos del consumo de tabaco, concretamente en relación al control de peso y al manejo del estrés. Asimismo es prioritario combatir el esencialismo y los estereotipos sexistas que reducen la salud de las mujeres fumadoras al embarazo para contemplar adecuadamente los factores sociales y de género involucrados en los comportamientos adictivos ${ }^{33}$, incorporando una visión holística de la salud de

33. AdRIAN, Manuella. «How Can Sociological Theory Help Our Understanding of Addictions?». Substance Use \& Misuse 38 (2003), pp. 1385-423. 
las mujeres ${ }^{34}$, que a su vez reconozca la diversidad de experiencias femeninas y su intersección con otros ejes de desigualdad.

\section{Referencias bibliográficas}

ADRIAN, Manuella. «How Can Sociological Theory Help Our Understanding of Addictions?». Substance Use \& Misuse 38 (2003), pp. 1385-423.

AGHI, Mira; Asma, Samira; YEONG, Chng Chee et al.: «Initiation and Maintenance of Tobacco Use», en: Jonathan Samet y Soon-Young Yoon (eds.): Women and the Tobacco Epidemic. Challenges for Epidemic-Challenges for the 21st Century. Geneva, World Health Organization, 2001, pp. 48-68.

AmezCua-Prieto, Carmen; Espigares-RodríGuez, Elena; MozAs-Moreno, Juan; et al. «Modificación del consumo de tabaco durante el embarazo: incidencia y factores asociados». Clínica e Investigación en Ginecología y Obstetricia, 35:6 (2008), pp. 194-201.

Bauman, Zygmunt y MaY Tim: Pensando sociológicamente. Buenos Aires, Nueva Visión, 2009.

BerRIDGE, Virginia. «Constructing Women and Smoking as a Public Health Problem in Britain: 1950-1990s». Gender \& History 13:2 (2001), pp. 328-48.

BOTTORF, Joan; JOHNSON, Joy; IRWIN, Lori y RATNER, Pamela. «Narratives of Smoking Relapse: The Stories of Postpartum Women». Research in Nursing $\&$ Health 23 (2000), pp. 126-34.

CHRISTOFIDES, Nicola: «How to Make Policies More Gender Sensitive», en: Jonathan Samet y Soon-Young Yoon (eds.): Women and the Tobacco Epidemic. Challenges for Epidemic-Challenges for the 21st Century. Geneva, World Health Organization, 2001, pp. 165-76.

DedobbeleER, Nicole; BÉlAnd, François; Contandriopoulos, André-Pierre; et al. «Gender and the Social Context of Smoking Behaviour». Social Science E Medicine 58:1 (2004), pp. 1-12.

ERnSTER, Virginia; KAUfMAN, Nancy; NichTER, Mimi; et al. «Women and Tobacco: Moving From Policy to Action». Bulletin World Health Organization 78:7 (2000), pp.891-901.

FERnÁNDEZ, Esteve; SCHIAFFINO Ana; GARCíA, Montse; et al. «Widening socioeconomic inequalities in smoking cessation in Spain, 1987-1997». Journal of Epidemiology and Community Health 55 (2001), pp. 729-730.

34. BOtTORF, Joan; Johnson, Joy; IrWin, Lori y RATNER, Pamela. «Narratives of Smoking Relapse: The Stories of Postpartum Women». Research in Nursing \& Health 23 (2000), pp. 126-34.

Feminismo/s 18, diciembre 2011, pp. 39-65 
FERnÁNDEZ, Esteve; SCHIAFFInO Ana; García, Montse; et al. «Prevalencia del consumo de tabaco en España entre 1945 y 1995. Reconstrucción a partir de las Encuestas Nacionales de Salud». Medicina Clínica (Barc) 120:1 (2003), p14-6.

GraHAM, Hilary y HunT, Sonja. «Women's Smoking and Measures of Women's Socioeconomic Status in the United Kingdom». Health Promotion International, 9:2 (1994), pp. 81-88.

GraHAM, Hilary y Der, Geoff. «Patterns and Predictors of Tobacco Consumption among Women». Health Education Research 14:5 (1999), pp. 611-18.

GrAHAM, Hilary; FRANCIS, Brian; INSKIP, Hazel; et al. «Socioeconomic lifecourse influences on women's smoking status in early adulthood». Journal of Epidemiology and Community Health 60 (2006) pp. 228-233

GREAVES, Lorraine. Smoke Screen: Women's Smoking and Social Control. Fernwood Publishing, Halifax, 1996.

GritZ, Ellen; NiELSEN, Ingrid y BroOKS, Lisa. «Smoking Cessation and Gender: the Influence of Physiological, Psychological, and Behavioral Factors». Journal of American Medical Women's Association 51:1-2 (1996), pp. 35-42

HuISMAN, Martijn; KUnST Anton; MACKENBACH, Johan. «Inequalities in the prevalence of smoking in the European Union: comparing education and income». Preventative Medicine 40 (2005), pp. 756-764.

InHORN, Marcia, y WhitTle, Lisa. «Feminism meets the "new" epidemiologies: Toward an appraisal of antifeminist biases in epidemiological research on women's health». Social Science E Medicine 53 (2001), pp. 553-67.

IM, Eun-Ok. «A feminist critique of research on women's work and health». Health Care for Women International 21 (2000), pp. 105-19.

JACOBSON, Bobbie. The Ladykillers: Why Smoking Is a Feminist Issue. London, Pluto Press, 1982.

JagSi, Reshma; Motomura, Amy; Amarnath, Sudha; et al. «Under-representation of women in high-impact published clinical cancer research», Cancer 114:15 (2009), pp. 3293-3301.

Jané, Mireia; Nebot, Manel; Berjano, B.; et al. «Factores determinantes del abandono del tabaquismo durante el embarazo». Medicina Clínica (Barc) 114 (2000), pp. 132-5.

JANÉ, Mireia. 2004. «Mujeres y tabaco: aspectos ligados al género». Adicciones 16(Supl. 2):115-30.

JARVIS, Martin. «Gender Differences in Smoking Cessation: Real or Myth?». Tobacco Control 3 (1994), pp. 324-28.

LAYTE, Richard y WhElan, Christopher. «Explaining Social Class Inequalities in Smoking: The Role of Education, Self-Efficacy, and Deprivation». European Sociology Review 25 (2009), pp. 399-410.

LUndBorg, Peter y ANDERSON, Henrik. «Gender, risk perception, and smoking behavior». Journal of Health Economics, 27 (2008), pp. 1299-1311. 
LI, Quian; Dresler, Carolyn; HeCK Julia; et al. «Knowledge and beliefs about smoking and cancer among women in five European countries». Cancer Epidemiology, Biomarkers \& Prevention 19 (2010), pp. 2811-20.

MaCIEJEWSKI, Paul; FAlBA, Tracy; et al. «Sex Differences in the Effects of Stressful Life Events on Changes in Smoking Status». Addiction 98 (2002), pp. 847-55.

MartíneZ-Frías, María Luisa; RodríGueZ-Pinilla, Elvira; BerMEJO, Eva y Grupo Periférico del ECEMC. «Consumo de tabaco durante el embarazo en España: análisis por año, comunidades autónomas y características maternas». Medicina Clínica (Barc) 125 (2005), pp. 86-92.

NERÍN, Isabel. «El tabaquismo en la mujer: Una atracción fatal». Archivos de Bronconeumonología, 41:7 (2005), pp. 360-362.

OAKLEY, Ann. «Smoking in Pregnancy: Smokescreen or Risk Factor? Toward a Materialist Analysis». Sociology of Health E Illness 11 (1989), pp. 311-335.

ORGANIZACIÓN MUNDIAL DE LA SALUD. Convenio Marco de la OMS para el Control del Tabaco. Geneva, OMS, 2003.

Osler, Merete; Prescott, Eva; GodtFredsen, Nina; et al. «Gender and Determinants of Smoking Cessation: A Longitudinal Study». Preventive Medicine 2 (1999), pp. 57-62.

Romo, Nuria y GIL, Eugenia. «Género y uso de drogas. De la ilegalidad a la legalidad para enfrentar el malestar», Trastornos Adictivos 8:4 (2006), pp. 243-50.

Ruiz CANTERo, Teresa; Ronda, Elena; y Álvarez Dardet, Carlos. «The importance of study design strategies in gender bias research: the case of respiratory disease management in primary care». Journal of Epidemiology \& Community Health 61 Suppl 2:ii (2007), pp. 11-16.

Weden, Margaret; Astone, Nan y BishaI, David. «Racial, ethnic, and gender differences in smoking cessation associated with employment and joblessness through young adulthood in the US». Social Science and Medicine, 62:2 (2009), pp. 303-316.

Wetter, David; Kenford, Susan; SMith, Stevens; et al. «Gender Differences in Smoking Cessation». Journal of Consulting and Clinical Psychology 67:4 (1999), pp. 555-62.

WALDRON, Ingrid. «Patterns and Causes of Gender Differences in Smoking». Social Science \& Medicine 32:9 (1991), pp. 989-1005.

ZUCKER, Alyssa y LANDRY, Laura. «Embodied Discrimination: The Relation of Sexism and Distress to Women's Drinking and Smoking Behaviours». Sex Roles 56 (2007), pp.193-203.

Feminismo/s 18, diciembre 2011, pp. 39-65 



\title{
HACIA LA DEFINICIÓN DE LA VIOLENCIA EN LAS RELACIONES DE PAREJA COMO UN PROBLEMA DE SALUD PÚBLICA EN MEDELLÍN A COMIENZOS DEL SIGLO XXI
}

\author{
GLADYS ROCíO ARIZA SOSA \\ Universidad Nacional de Colombia
}

Recibido/12/09/2011

Aceptado/24/11/2011

\section{Resumen}

La violencia en las relaciones de pareja es un problema de salud pública, en el cual subyacen las construcciones culturales de género. El desarrollo metodológico de la tesis doctoral presentada, de carácter cualitativo, se basa en la teoría de la Representación social, articulada con la historia discursiva y los estudios críticos del discurso. En un proceso histórico complejo, el movimiento de mujeres de la ciudad de Medellín, en Colombia, logró posicionar la violencia en las relaciones de pareja como un problema social de dominio público, en un ambiente político de confrontación de representaciones sociales, entre la tradición, la transición y el cambio. Así, esta violencia se configura como evitable, mediante el despliegue comprometido y articulado de un conjunto de iniciativas de orden científico, político y social.

Palabras clave: violencia de pareja, violencia por pareja íntima, violencia conyugal, violencia contra la mujer, representaciones sociales, movimiento feminista, problema de salud pública.

\begin{abstract}
Intimate partner Violence is a public health problem, founded in the cultural gender constructions. The methodological development of this doctoral thesis is qualitative; it is based on social representation theory, it is articulated with the discursive history, and critical discourse studies. In a complex historical process, the women's movement in the Medellín city, in Colombia, managed to position intimate partner violence as
\end{abstract}


a social problem in the public domain, in a political environment of confrontation of social representations, among tradition, transition and change. Thus, this violence is configured as avoidable, through the committed and articulated deployment of a set of scientific, political and social initiatives.

Keywords: partner violence, intimate partner violence, spouse abuse, violence against the woman, social representations, feminist movement, public health problem. 


\section{Introducción}

La violencia en las relaciones de pareja es un problema de salud pública complejo, en el cual subyacen las construcciones culturales de género, pero que se diferencia de otros tipos de violencia por la índole y las dinámicas de las relaciones de poder en las cuales se produce. Empero, a partir de 1975 con la promulgación de la Década Internacional de la Mujer por la Organización de las Naciones Unidas, ONU, se advierte una tendencia a la transformación cultural, pues las instituciones políticas, los medios de comunicación y la sociedad en general, cada vez le prestan mayor atención a este tipo de violencia, dado que en el contexto internacional, nacional y por supuesto en la ciudad de Medellín, en Colombia, la labor del movimiento feminista ha logrado posicionarla como un atentado contra los derechos humanos de las personas afectadas, cuyos efectos trascienden del ámbito privado al público.

El proceso de construcción discursiva del concepto de violencia de pareja se inició a partir de los años sesenta del siglo XX, dada la intervención de las feministas radicales estadounidenses, quienes bajo la consigna, «lo personal es político» asumieron las movilizaciones que contribuirían a la transformación de las representaciones sociales de esta violencia, ${ }^{1}$ que ha pasado progresivamente de ser juzgada como un asunto inapelable, a ser considerada como un delito intolerable.

En cuanto a los actores, la información estadística, procedente de diferentes fuentes, demuestra que los hombres, como en otros tipos de violencia, son los principales agresores y las mujeres son las víctimas. ${ }^{2}$ Aunque cada vez se reconoce que ellas no son pasivas y ejercen diversas formas de resistencia, son quienes sufren las consecuencias más lesivas, para su salud y su desarrollo individual y social.

1. PULEO, Alicia. «Lo personal es político: el surgimiento del feminismo radical,» en AMORÓS, Celia y Miguel, Ana de (eds.): Teoría Feminista: De la Ilustración a la Globalización. De la ilustración al segundo sexo. Tomo 2, Del feminismo liberal a la posmodernidad, Madrid: Minerva ediciones, 2005, pp. 35-67.

2. INSTITUTO NACIONAL DE MEDICINA LEGAL, INML. Masatugó, Mujer que recibe lo malo para entregar lo bueno, 2004-2008, Forensis mujeres. Bogotá, INML, 2009.

Feminismo/s 18, diciembre 2011, pp. 67-92 
Esta investigación, de carácter cualitativo, tiene como objetivo general comprender las representaciones sociales de las personas agredidas, agresoras y quienes les atienden, sobre la violencia en las relaciones de pareja, en los contextos histórico, sociocultural, político y económico de la ciudad de Medellín, en la primera década del siglo XXI. ${ }^{3}$

Medellín, la capital del departamento de Antioquia, es considerada la segunda ciudad de Colombia por su densidad y composición demográfica, su importancia industrial, comercial, política, cultural e histórica. Situada al noroccidente del país en el Valle de Aburrá, en una extensión de 380,64km²; en el 2009 contaba con 2.317.336 habitantes de acuerdo a proyecciones del Departamento Administrativo Nacional de Estadísticas, DANE, basadas en el Censo del 2005. De estos, 1.091.252 eran varones (47.1\%) y 1.226.084 mujeres (52.9\%). ${ }^{4}$ Además de estas consideraciones, se eligió esta ciudad teniendo en cuenta su historia reciente de violencia, con los desafíos del presente de una integración social y cultural compleja, donde interactúan diferentes grupos sociales en situaciones de pobreza y desplazamiento, junto con sectores emblemáticos de las élites industriales y comerciales, con influencias económicas y políticas relevantes, tanto en los ámbitos nacionales como regionales y locales. A la vez es apreciable la presencia de sectores medios conformados por la intelectualidad, profesionales y artistas comprometidos con la modernización laicicista y la modificación de las relaciones de género, en cuanto a la formación académica, la participación política, la división sexual del trabajo y la conciliación entre la vida laboral y familiar.

Los movimientos sociales de la ciudad se han erigido como fuerzas progresistas empeñadas en los cambios democráticos. En estos movimientos, los feministas han jugado un papel importante, en lo pertinente a los derechos de las mujeres. Proyectos gestados por las feministas y acogidos por la administración municipal, como el de la Clínica de la Mujer, para atender con enfoque de género a las mujeres de la ciudad afectadas por las violencias de género, el cáncer, las enfermedades mentales, así como para garantizar la interrupción voluntaria del embarazo en los tres casos despenalizados por la

3. Este texto corresponde a un resumen enfocado en el tercer capítulo de la tesis doctoral en Salud Pública de la Universidad Nacional de Colombia (aprobada y laureada en 2011), de ARIZA SOSA, Gladys Rocío, titulada La violencia en las relaciones de pareja en Medellín y sus representaciones sociales, cuya directora de tesis es la doctora María Himelda Ramírez.

4. MEDELLÍN, Secretaría de Salud. Indicadores Básicos 2009. Situación de Salud de Medellín. Medellín, Secretaría de Salud, 2010, pp. 3. 
Corte Constitucional en Colombia, ${ }^{5}$ han revelado las tensiones entre la modernización laicicista y las tendencias culturales tradicionalistas de arraigo clericalista, que se han opuesto de modo férreo a la iniciativa, hasta tal punto que han impedido su ejecución.

En Colombia el conflicto social ha sido postulado por organizaciones y académicas como uno de los agravantes de la violencia en las relaciones de pareja. ${ }^{6}$ En este contexto, en Medellín, las organizaciones de mujeres de la ciudad resaltan que se ha tomado la violencia como mecanismo para enfrentar todo tipo de conflictos. ${ }^{\top}$

Se eligió la primera década del siglo XXI, siguiendo la propuesta de Victoria Camps de considerarlo el siglo de las mujeres, en el sentido de que es imperativo garantizar a un mayor número de las mismas, las grandes conquistas logradas en los terrenos de la educación, el trabajo y la política, pues es «...indiscutible que la igualdad conseguida es insuficiente. Han cambiado las leyes, pero no cambian las costumbres. O cambian tan lentamente que no lo apreciamos.» ${ }^{8}$ Asimismo esta década es de particular significación en Colombia, ya que en medio de la violencia política y social, se sintetizan los logros de un activismo precedente en la lucha por los derechos humanos en general y de las mujeres en particular, el desarrollo normativo e institucional y el avance en la formación de un campo social cada vez menos tolerante a la violencia.

La violencia en las relaciones de pareja se puede entender como un fenómeno complejo, dinámico y global en el cual se presentan conexiones, divergencias y tensiones entre diferentes posturas académicas, que abordan sus dimensiones culturales, económicas, sociales, políticas, de relaciones de género, clase y generación; por ello este estudio va más allá de un enfoque unidisciplinar. Como expresa la Carta de la transdisciplinariedad en su preámbulo:

Sólo una inteligencia que dé cuenta de la dimensión planetaria de los conflictos actuales podrá hacer frente a la complejidad de nuestro mundo y al

5. COLOMBIA, Corte Constitucional «Sentencia C-355/06,» «http://www.corte constitucional.gov.co/relatoria/2006/C-355-06.htm>, consultado el 5-02-2011.

6. PACHÓn, Ximena «La Familia en Colombia a lo largo del siglo XX,» en PUYANA Yolanda y RamíRez, María Himelda (eds.): Familias, Cambios y Estrategias, Bogotá, Universidad Nacional de Colombia, Facultad de Ciencias Humanas, Alcaldía Mayor de Bogotá, 2007, pp. 157-158.

7. MEDELLÍN, Alcaldía de. 1er Congreso Ciudadano. Conversemos sobre la vida y la legalidad, Memorias, Medellín, Alcaldía de Medellín, 2005, pp. 34-38.

8. CAMPS, Victoria. El siglo de las mujeres. Madrid: Ediciones Cátedra, Universitat de Valencia, Instituto de la mujer, 2003, pp. 13.

Feminismo/s 18, diciembre 2011, pp. 67-92 
desafío contemporáneo de la autodestrucción material y espiritual de nuestra especie. $^{9}$

Así, esta investigación desde la Salud Pública entabla un dialogo interdisciplinar y transdisciplinar con el feminismo, ${ }^{10}$ la historia,${ }^{11}$ la psicología social, ${ }^{12}$ el análisis de las políticas públicas ${ }^{13}$ y el Estudio Crítico de los Discursos ${ }^{14}$ de los medios de comunicación. La Salud Pública como especialidad heredera de la tradición de la Higiene Pública, se constituyó más claramente desde inicios del siglo XX, ${ }^{15}$ para resolver las inequidades sociales en el acceso a condiciones de vida y salud dignas, mediante las políticas sanitarias. En este punto, es importante precisar, que tan sólo desde la década Internacional de la Mujer, cuyo lema fue Igualdad, Desarrollo y Paz, los organismos especializados, asumieron de manera muy lenta a la mujer como sujeta de derechos, desde una perspectiva desarrollista, ${ }^{16}$ esto es para su integración a los llamados beneficios del desarrollo: producción, educación y trabajo, pero con una perspectiva maternalista. ${ }^{17}$ Esto significa que hacia finales de los años setenta y en los años ochenta del siglo XX, se inició el proceso de legitimación académica y política del enfoque de género, pero no necesariamente feminista y progresista. Desde la década del noventa, la Salud Pública feminista surgió como un campo interdisciplinario con un rumbo promisorio, dado que ha permitido reorientar la investigación en el área mediante el desarrollo de nuevos marcos teóricos y metodologías para abordar la salud y las relaciones entre las mujeres y los

9. ANES, José et al. Carta de la Transdisciplinariedad, (Arrábida, 1994), 〈www.filosofia.org/ $\mathrm{cod} / \mathrm{c} 1994$ tra.htm〉, consultado el 5-02-2010.

10. Miguel, Ana de «La construcción de un marco feminista de interpretación: la violencia de género,» Cuadernos de Trabajo Social 18 (2005), pp. 231-248, «www.ucm.es/BUCM/ revistas/trs/02140314/articulos/CUTS0505110231A.PDF>, consultado el 10-04-2007.

11. SCOTT, Joan. «Sobre el lenguaje, el género y la historia de la clase obrera.» Historia social, 4 (1989), pp. 81-98.

12. Moscovici, Serge. «Why a Theory of Social Representations?» in DeAux, Kay and PHILOGĖNE, Gina (eds.). Representations of the social; bridging theoretical traditions. Oxford, Blackwell, 2001, pp. 8-35.

13. Rотн Deubel, André Nöel. Políticas Públicas. Formulación, implementación y evaluación. Ediciones Aurora: Bogotá, 2002.

14. VAN DijK, Teun A. (comp.). El Discurso como interacción social. Estudios sobre el discurso II: Una introducción multidisciplinaria. Barcelona, Gedisa, 2000.

15. QUEVEDo Emilio et al. Café y gusanos, mosquitos y petróleo, Bogotá, Universidad Nacional de Colombia, Facultad de Medicina, Instituto de Salud Pública, 2004, pp. 27.

16. Peláez Mejía, Margarita María y Rodas Rojas, Luz Stella. La política de género en el Estado colombiano: Un camino de conquistas sociales, Medellín, Universidad de Antioquia, 2002, pp. 7-10.

17. LUNA, Lola G. Los movimientos de mujeres en América Latina y la renovación de la historia política, Centro de Estudios de Género, Mujer y Sociedad, Universidad del Valle, La Manzana de la Discordia, Santiago de Cali, 2003, pp. 85-100. 
hombres, con acciones colectivas, basadas en perspectivas diversas y articuladas, con el propósito de mejorar las condiciones de vida de los grupos discriminados por razones de género y orientación sexual. ${ }^{18}$

En cuanto a su metodología, esta tesis es de carácter cualitativo, en el sentido en que se propone un modelo comprensivo de la violencia en las relaciones de pareja tomando en consideración dimensiones del mundo simbólico, de los afectos, imaginarios y representaciones sociales implicadas en dicha violencia, en un contexto social y cultural específico como la ciudad de Medellín y en una temporalidad definida, que devela una transición en los discursos sociales al respecto.

Es pertinente señalar que la metodología que se adoptó para desarrollar el trabajo de campo en la investigación cualitativa propuesta por González Rey, enfatiza la imposibilidad tanto de subjetivar como de objetivar de forma absoluta el conocimiento. ${ }^{19}$ La investigación cualitativa es rigurosa, estable y consistente, aunque de un modo distinto al de la investigación cuantitativa. Los problemas de validez y de confiabilidad se resuelven por las vías de la exhaustividad, es decir del análisis detallado y profundo y del consenso intersubjetivo. ${ }^{20}$

Las fuentes primarias elegidas abarcaron entrevistas en profundidad con hombres y mujeres envueltas en relaciones violentas de pareja, grupos focales con personal que atiende casos de violencia en las relaciones de pareja en los sectores de salud, justicia y atención psicosocial, artículos de prensa alusivos a este tipo de violencia, publicados en dos periódicos regionales de la ciudad de Medellín, entre los años 2001 y 2008. Otras fuentes consultadas fueron bibliografía sobre historiografía de la violencia en las relaciones de pareja, así como las normas y políticas internacionales y colombianas sobre la violencia contra las mujeres.

La información recopilada en las entrevistas permitió interpretar las representaciones sociales y los discursos que inciden en las acciones de las personas participantes y en sus relaciones de pareja. Se efectuaron entrevistas

18. HAMmARSTRÖM, Anne «Why feminism in public health?» Scandinavian Journal of Public Health 27 no. 4, (1999), pp. 241-4, «doi 10.1080/140349499444951〉, consultado el 6-02-2011.

19. GONZÁLEZ REY, Fernando Luis. «El trabajo de campo en la investigación psicológica y el proceso de construcción de la información en la investigación cualitativa,» en Investigación cualitativa en Psicología. Rumbos y Desafíos, Sao Paulo, EDUC, 1999, pp. 97-158.

20. CASILIMAS, Carlos Sandoval, Investigación cualitativa, Bogotá, ICFES, 1996, pp. 42 y 192, 〈http://contrasentido.net/wp-content/uploads/2007/08/modulo4.pdf〉, consultado el 4-07-2011.

Feminismo/s 18, diciembre 2011, pp. 67-92 
con ocho mujeres y cinco hombres residentes en Medellín, quienes al momento del encuentro o con anterioridad estaban envueltos en relaciones de pareja violentas. Las entrevistas se facilitaron por la profesión médica de la investigadora, la cual le permitió acercarse a las y los informantes en un clima de confianza, quizás por la representación social del conocimiento y la ética que rodea esta profesión. Entre las limitaciones para la realización de las entrevistas de esta investigación, se pueden señalar las dificultades para localizar y comprometer de forma libre y voluntaria a las personas, quienes no recibieron ningún tipo de incentivo monetario por su participación. Además las experiencias subjetivas de las y los participantes fueron mediadas por sus relatos, con la dificultad dada por la posible distancia entre los discursos y las acciones. Otros factores, que incidieron en el proceso de recolección de la información, estuvieron determinados por la pericia de la investigadora y las resistencias de las personas entrevistadas, en un tema particularmente tan complejo y sensible, como la violencia en las relaciones de pareja, por la significación emocional y las evocaciones.

Es cada vez más común en el área urbana de Medellín, que las personas busquen solucionar sus conflictos de pareja a través de los servicios ofrecidos por diferentes instituciones de salud, justicia y de atención psicosocial. En esta interacción entran en juego las representaciones sociales del personal que labora en dichas instituciones. Por ello, se convocaron diez grupos focales con servidoras y servidores públicos que atienden a mujeres y hombres involucrados en relaciones de pareja violentas en la ciudad, en la red pública hospitalaria, en el sector de la Justicia y en organizaciones no gubernamentales, ONG, que promueven los derechos humanos de las mujeres como sujetas políticas. Los grupos focales fueron conformados en total por sesenta personas (44 mujeres y 16 hombres). Estos grupos permitieron discusiones flexibles estimuladas por la interacción entre sus integrantes quienes compartían afinidades laborales, de género y culturales. El trabajo con dos asistentes de investigación (una antropóloga y una abogada) permitió un análisis inicial conjunto y redefinir algunos aspectos para los subsiguientes encuentros. Entre las limitaciones de los grupos focales se pueden resaltar la dificultad para reunir a los participantes, debido a sus agendas laborales y en algunos de ellos, la tendencia de algunos sujetos a monopolizar el uso de la palabra, obstaculizando la expresión de las demás personas intervinientes.

Si bien las guías de las entrevistas y de los grupos focales no eran iguales, por razones tanto del objetivo de las mismas, como de las personas a quienes se dirigían, en su estructura se consideró en común, en primera medida un marco de referencia sobre el concepto y el contexto de la violencia en 
las relaciones de pareja, seguido de su forma de intervención y finalizando con propuestas de prevención. La cantidad de entrevistas, grupos focales y artículos de prensa se definió por la saturación teórica. Se empleó el análisis configuracional, ${ }^{21}$ de forma inductiva con ayuda del software Atlas Ti, como se explica a continuación.

Las transcripciones de las grabaciones de las entrevistas y de los grupos focales, así como los textos de los artículos de prensa, se codificaron inicialmente de forma abierta y luego axial. Los ejes analíticos para la codificación axial fueron la violencia en las relaciones de pareja y la sociedad, la perspectiva de género, la visibilidad, valoraciones y formas de intervención de esta violencia, las masculinidades, las feminidades, las relaciones de pareja, las formas de resolución de los conflictos y el poder en las parejas, el amor de pareja, la violencia en las relaciones de pareja y la sociedad, la consideración de esta violencia en el ámbito de la salud, de la justicia y de las ONG; las funciones educativas de los medios de comunicación y de quienes atienden a las víctimas y a los agresores.

Los códigos de análisis más frecuentes, de acuerdo a la determinación con el software, se relacionaron entre sí de forma gráfica en redes (denominadas networks en el Atlas Ti), para desarrollar las categorías emergentes. ${ }^{22}$ Posteriormente, se desarrolló un proceso de construcción dinámica de sistemas de relaciones de categorías. Este proceso expuso nuevos datos textuales que exigieron relecturas de la información, para desarrollar conceptos y explicaciones adicionales.

Las representaciones sociales que emergieron del estudio de los contenidos son de diversos órdenes y reflejan múltiples formas de interpretación del problema. A partir de las categorías y sus relaciones, se identificaron las representaciones sociales de la violencia en las relaciones de pareja de las fuentes documentales, entrevistas y grupos focales. Así mismo se identificaron los discursos en las cuales dichas representaciones entran en juego. ${ }^{23}$

Se realizó un análisis de la información, basado en una lectura compleja, en la cual se integran en un dialogo y una controversia las diferentes perspectivas teóricas elegidas. Así, el desarrollo metodológico permitió profundizar

21. GonZÁlez Rey, Op. Cit., pp. 97-158.

22. Justicia, Juan Muñoz, Análisis cualitativo de datos textuales con Atlas.Ti 5, Barcelona, Universidad Autónoma de Barcelona, 2005, pp. 45-78, «www.fcp.uncu.edu.ar/upload/ Atlas5_manual.pdf $>$, consultado el 30-06-2011.

23. CHAVES, Mariana, «Juventud negada y negativizada: Representaciones y formaciones discursivas vigentes en la Argentina contemporánea,» Ultima década 13, no. 23 (dic. 2005), pp. 09-32, 〈doi 10.4067/S0718-22362005000200002〉, consultado el 23-03-2008.

Feminismo/s 18, diciembre 2011, pp. 67-92 
en las subjetividades de las personas entrevistadas y de las participantes en los grupos focales, en relación con las representaciones sociales que guían sus acciones, tanto en lo que tiene que ver con las experiencias cotidianas e íntimas, como con su proyección en los ámbitos públicos, comunitarios y laborales.

Este artículo se concentra específicamente en el proceso por el cual la violencia en las relaciones de pareja se está configurando como un problema de salud pública en la ciudad de Medellín, lo cual se fundamentó especialmente en la revisión de bibliografía sobre la historiografía y la normatividad referentes al tema. De igual forma, para ilustrar la argumentación presentada, se hace referencia tangencial de algunos fragmentos concernientes al análisis cualitativo de los discursos obtenidos mediante revisión de la prensa regional, las entrevistas en profundidad y los grupos focales ya mencionados. Los resultados de la revisión de prensa, se tratan con mayor detalle en otras publicaciones, en las cuales se destaca que en la ciudad de Medellín, a comienzos del siglo XXI, se observan contextos de transición en los discursos y las representaciones sociales sobre las relaciones de género y la violencia en las relaciones de pareja. ${ }^{24}$

\section{La violencia en las relaciones de pareja como problema de salud pública}

El movimiento de mujeres de Medellín, en un proceso histórico complejo, ha avanzado en el posicionamiento de la violencia en las relaciones de pareja como un problema social y de salud pública, lo cual ha permitido fortalecer las identidades de las mujeres y de las nuevas masculinidades. Se propone la periodización de dicho proceso en tres etapas. ${ }^{25}$

La primera fase se sitúa entre 1975 y 1991. En el contexto del reconocimiento internacional de los derechos humanos de las mujeres por entidades como las Naciones Unidas, del surgimiento del feminismo radical norteamericano y europeo, a finales de la década de los setenta del siglo XX, se agrupan algunas mujeres y unos pocos hombres de Medellín, para reflexionar sobre la opresión patriarcal, los derechos humanos de las mujeres, el aborto, la violación, la sexualidad, el control de sus propios cuerpos y las tareas domésticas. La feminista antioqueña Cris Suaza, señala el asombro que le provocaba, en

24. ARIZA S. Gladys Rocío. «Las Representaciones sociales de la violencia en las relaciones de pareja en la prensa de Medellín en el siglo XXI,» Revista Venezolana de Estudios de la Mujer 14. no. 32. (ene-jun., 2009), pp. 71-98.

25. Araujo, Kathya, Guzmán, Virginia y MAuro, Amalia «El Surgimiento de la violencia doméstica como problema público y objeto de políticas,» Revista de la CEPAL 70, (2000), pp. 133-145, para la elaboración de este acápite del artículo, se tomó en consideración el caso chileno expuesto en este texto. 
los años setenta, el maltrato infringido por «muchos dirigentes y jefes políticos de izquierda» a sus parejas, quienes paradójicamente, eran abanderadas de las luchas por los derechos de las mujeres. ${ }^{26}$ Así en 1977, el editorial de la Revista Mujeres señalaba,

...en esta sociedad patriarcal, burguesa, racista, etc.,etc. somos ciudadanas de tercera categoría: confinadas, encarceladas, encarceladas en el «hogar dulce hogar», golpeadas, acalladas, insultadas, atemorizadas, sin palabra que decir, violadas, propiedad de nuestros padres, hermanos, maridos, amantes, novios, proxenetas... siempre, siempre menores de edad, con los derechos civiles y políticos recortados o negados...27

En 1978 el grupo de mujeres de la capital de Antioquia y el Aquelarre de Bogotá organizaron el Primer Encuentro feminista del país, en Medellín, al que asistieron aproximadamente 250 mujeres de toda la nación, pese a la oposición de diversos sectores, liderados por la Iglesia Católica. En 1981 se llevó a cabo el Primer Encuentro Feminista Latinoamericano en Bogotá. Dicho evento marcó un hito histórico pues declaró el 25 de noviembre como el día mundial de «No más violencia contra las mujeres» en honor a las hermanas Minerva, María Teresa y Patria Mirabal, cruelmente violadas, torturadas y asesinadas por agentes del servicio militar del régimen dictatorial de Trujillo, en República Dominicana el 25 de noviembre 1960. ${ }^{28}$ En uno de los volantes distribuidos en el encuentro, se proclamaba, la violación dentro del matrimonio como una de las manifestaciones de la violencia. ${ }^{29}$

En 1982, en la revista Brujas editada en Medellín, la socióloga Flora Uribe criticaba la homologación frecuente, en ese entonces, de la violación como la única forma de violencia contra la mujer e incluye en ésta «los golpes en el matrimonio. $»^{30}$ Organizaciones reconocidas por su trabajo feminista en la ciudad, como Vamos Mujer, tienen documentado como desde 1987, las mujeres de los barrios populares en Medellín, visibilizaron el maltrato físico que recibían de sus parejas, como un asunto problemático, que generaba diversas reacciones, las cuales fluctuaban entre respuestas pasivas y resistencias aguerridas. Es así como en 1989 en esta ONG, se hizo

26. Suaza VARgas, María Cristina, Soñe que soñaba. Una crónica del movimiento feminista en Colombia de 1975 a 1982, (Bogotá: AECID, JM limitada, 2008), 47.

27. «Editorial,» Revista Mujeres, no. 2, (Oct, 1977): 2, SuAzA VARGAS, María Cristina Op.Cit., anexo 6: CD ROM.

28. SuAzA VARGaS, María Cristina. Op.Cit., p. 55-57, 103.

29. COMITÉ organizador del 25 de noviembre, «No a la violencia contra la mujer,» volante, (Bogotá, 1981), en SuAza VARGas, María Cristina. Op.Cit., anexo 6: CD ROM.

30. LÓPEZ, Aura «No más violencia contra la mujer. Entrevista de Aura López a Flora Uribe y Clara Mazo,» Brujas, no. 1, (sep. 1982), pp. 27.

Feminismo/s 18, diciembre 2011, pp. 67-92 
manifiesto que este maltrato de pareja, también afectaba a sus propias asesoras y capacitadoras. ${ }^{31}$

La segunda fase de la construcción de la violencia en las relaciones de pareja en Medellín, como problema social y de salud pública se puede situar entre los años 1991 y 2002. Se inicia con la Constitución de 1991, hito histórico en el país, debido a que amplió el campo de acción de los Derechos Humanos, introdujo en el artículo 13 la igualdad entre hombres y mujeres como un derecho fundamental y consagró la prevalencia de «los tratados y convenios internacionales ratificados por el Congreso, que reconocen los derechos humanos y que prohíben su limitación en los estados de excepción, $»^{32}$ en el artículo 93.

Entre las organizaciones que han trabajado para enfrentar la violencia de género cabe destacar la Red Nacional de Mujeres creada en 1992, ya que desde sus orígenes, trabajó por hacer seguimiento al cumplimiento de la Convención Sobre la Eliminación de Todas las Formas de Discriminación Contra la Mujer, CEDAW ${ }^{33}$, adoptada en Colombia, mediante la Ley 51 de $1981 .{ }^{34} \mathrm{La}$ Red con una activa participación de mujeres de Medellín, en conjunto con otras organizaciones y redes de mujeres del país, ha incidido en la promulgación de normatividad para enfrentar la violencia contra ellas. ${ }^{35}$ La Ruta pacífica de las mujeres es otra organización del movimiento feminista, creada en 1996 para visibilizar los efectos del conflicto en la vida de las mujeres y

31. Ospina Murillo, Luz Stella, Betancur, Nidia Cristina y Morales, Piedad del Carmen. Hortelanas, Tejedoras, Alquimistas...Las Mujeres Vamos por el Mundo, Corporación Vamos Mujer - Aniversario 25 años Panel: Pacifismos y DDHH de las Mujeres, 〈http://www.vamosmujer.org.co/site/images/stories/pdf/objetivo3/HORTELANAS,\%20 TEJEDORAS,\%20\%20ALQUIMISTAS.pdf.pdf >, consultado el 25-07-2010.

32. COlOMBIA. Asamblea Nacional Constituyente, Constitución Política de Colombia. Bogotá, 1991, 〈http://web.presidencia.gov.co/constitucion/index.pdf〉, consultado el 21-01-2011.

33. Se denomina CEDAW por sus siglas en inglés, Convention on the Elimination of All Forms of Discrimination against Women.

34. COLOMBIA, Congreso de la República. «Ley 51 de 1981. Por medio de la cual se aprueba la «Convención sobre la eliminación de todas las formas de discriminación contra la mujer», adoptada por la Asamblea General de las Naciones Unidas el 18 de diciembre de 1979 y firmada en Copenhague el 17 de julio de 1980.» Diario Oficial, no. 35794, julio 7, 1981. http://www.alcaldiabogota.gov.co/sisjur/normas/Normal. jsp? $\mathrm{i}=14153$

35. RED NACIONAL DE MUJERES, Quienes somos, 〈http://www.rednacionaldemujeres. org/index.php?option=com_content\&view=article\&id=1\&Itemid=2〉, consultado el 28-03-2009. 
propenderpor una solución negociada al mismo. ${ }^{36}$ En sus publicaciones da cuenta de la magnitud y consecuencias de la violencia en las relaciones de pareja. $^{37}$

La Ley 294 de $1.996,{ }^{38}$ para prevenir, remediar y sancionar la violencia intrafamiliar, fue producto de un largo proceso que se inició seis años antes, en el que participaron principalmente los movimientos sociales de mujeres. No obstante, sus sucesivas reformas ocasionaron detrimento del espíritu protector y restaurador de los derechos de las víctimas que tenía originalmente, ya que tipificaron el delito de violencia intrafamiliar como querellable, desistible, conciliable y excarcelable, es decir como un «delito menor, $»^{39}$ instauraron la disminución de la severidad de las sanciones y el traslado de la competencia para dictar medidas de protección a las víctimas de violencia intrafamiliar de las instancias judiciales a las administrativas, esto es las Comisarías de Familia, cuyo número resultó claramente insuficiente para dar trámite a todos los casos denunciados.

En el contexto normativo de la Constitución de 1991, y gracias a la presión del movimiento feminista, en diferentes entidades territoriales colombianas, se crearon a su vez instancias encargadas de promover la aplicación de las políticas dirigidas a las mujeres, como la Subsecretaría de la Mujer de Antioquia, creada en 1992 y transformada en Consejería para la Mujer en 1996. ${ }^{40}$ En al año 2000 se creó la Secretaria de Equidad de Género para las mujeres de la Gobernación de Antioquia ${ }^{41}$, entidad especializada que con un presupuesto modesto, está encargada de coordinar la inclusión del enfoque de género en los planes, programas y proyectos de este Departamento.

El inicio de la tercera fase de la construcción de la violencia en las relaciones de pareja como problema social en Medellín se puede situar, en el 2002

36. RUTA PACÍFICA DE LAS MUJERES, Quienes somos, 〈http://www.rutapacifica.org.co/ home.html>, consultado el 22-07-2010

37. SÁNCHEZ, Olga Las violencias contra las mujeres en una sociedad en guerra, (Bogotá: Ruta pacífica de las mujeres, 2008), 39-75, 〈http://www.rutapacifica.org.co/las\%20 violencias.pdf, consultado el 22-07-2010.

38. COLOMBIA, Congreso de la República, «Ley 294 de julio 16, 1996. «Ley 294 de 1996. Por la cual se desarrolla el artículo 42 de la Constitución Política y se dictan normas para prevenir, remediar y sancionar la violencia intrafamiliar.» Diario Oficial no. 42.836, Julio 22, 1996. 〈http://www.secretariasenado.gov.co/leyes/L0294_96.HTM〉, consultado el 22-09-2010.

39. García Villegas, Mauricio. «Estado sin jueces,» El Tiempo, edición nacional 1, mayo 30, 2006, pp. 15.

40. Peláez Mejía, Margarita. Op.Cit., pp. 100-128.

41. CONSEJERÍA presidencial para la Equidad de la mujer, Gobernación de Antioquia, Secretaría de Equidad de Género para las Mujeres, http://www.antioquia.gov.co/ organismos/equidaddegenero/ppal.htm〉, consultado el 28-03-2009.

Feminismo/s 18, diciembre 2011, pp. 67-92 
con la creación de la Subsecretaría Metromujer, como una dependencia de rango medio de la Secretaría de Cultura Ciudadana, a cargo de implementar las políticas públicas orientadas a la equidad de género. ${ }^{42}$ En el 2007, dada la gestión de Metromujer y de los movimientos de mujeres de la ciudad, se crea la Secretaría de las mujeres de Medellín por Acuerdo del Concejo Municipal, ${ }^{43}$ con lo cual la capital de Antioquia se convirtió en la primera ciudad colombiana, con una dependencia del más alto nivel administrativo exclusivamente responsable de contribuir a la igualdad de derechos y oportunidades entre mujeres y hombres, tendiente a eliminar las prácticas discriminatorias que por razones de género, obstruyen el desarrollo político, social, económico y cultural de las mujeres del municipio. ${ }^{44}$

La Secretaría de las Mujeres en su estrategia de seguridad pública tiene como objetivo, «Garantizar el derecho de las Mujeres a una vida libre de violencia tanto en el espacio público como en el privado. $»^{45}$ Esto se materializa en diferentes proyectos que pretenden la movilización social, la gestión del conocimiento, el fortalecimiento institucional en justicia de género y el empoderamiento de las mujeres. En cuanto a la violencia en las relaciones de pareja merecen destacarse el programa Hogares de acogida, las campañas de comunicación pública, el consultorio jurídico, el acompañamiento a las unidades de atención de violencia como el Centro de Atención a las violencias sexuales, CAIVAS y el Centro de atención a la violencia intrafamiliar, CAVIF.46 El programa Hogares de Acogida, creado en el año 2006, ofrece una medida de protección temporal e inmediata, en un hogar de una familia contratada para ello, por un periodo de máximo seis semanas, a las mujeres que denuncien ante las autoridades competentes, situaciones de violencia intrafamiliar que pongan en riesgo su vida o la de sus hijos e hijas menores de 14 años. En

42. BOGOTÁ D.C. Secretaría General de la Alcaldía Mayor. «Proyecto de Acuerdo 309 de 2006 Concejo de Bogotá D.C. 'Por medio del cual se crea la Subsecretaría Distrital para la Mujer y se dictan otras disposiciones,'», 〈http://www.alcaldiabogota.gov.co/sisjur/ normas/Normal.jsp?i=21407 , consultado el 28-06-2010.

43. MEDELLÍN, Alcaldía. Secretaría de las mujeres, 〈http://www.medellin.gov.co/mujeres/ index.html >, consultado el 28-03-2009.

44. MEDELLÍN, Subsecretaria de Metromujer de la Alcaldía. «Presentación de Propuestas: Síntesis - Proyecto con resultados de la mentoría incorporados,» 〈www. americalatinagenera.org/.../trabajo-Flor_Maria_Diaz.doc〉, consultado el 28-06-2010.

45. MEDELLÍN, Alcaldía. Secretaría de las mujeres, «Programas y Proyectos,» 〈http://www. medellin.gov.co/alcaldia/jsp/modulos/N_admon/index.jsp?idPagina=301 $>$, consultado el 28-06-2010.

46. MEDELLÍN, Alcaldía. «Nuestras campañas,» 〈http://www.medellin.gov.co/alcaldia/jsp/ modulos/N_admon/campanas.jsp?idPagina=892>, consultado el 3-12-2010. 
este lapso se les brinda asesoría legal y psicológica, tanto a las mujeres como a sus parejas. ${ }^{47}$

En esta tercera fase es cuando la violencia en las relaciones de pareja, empieza a ser incluida como objeto de atención en las políticas contra la violencia en Medellín. En el año 2004 se creó el programa Prevención de la violencia en el Valle de Aburra, PREVIVA. Como producto de este trabajo, tras un proceso participativo siguiendo el modelo de Richmond ${ }^{48}$ para formular políticas públicas, en el cual se involucraron múltiples actores sociales provenientes de la academia, instancias gubernamentales y la sociedad civil, en el 2007 se promulgó por Acuerdo Metropolitano la Política Pública para la Promoción de la Convivencia y la Prevención de la Violencia en el Valle de Aburrá. ${ }^{49}$ Sin embargo, no incluyó la participación de las organizaciones feministas.

En el marco normativo, especial atención merece la Ley 1257 del 4 de diciembre de 2008, «Por la cual se dictan normas de sensibilización, Prevención y sanción de formas de violencia y Discriminación contra las mujeres. ${ }^{50}$ Esta Ley, considerada como un logro del proceso de interacción del movimiento social de mujeres y la Mesa de Legislación y Género, con la Bancada de las mujeres del Congreso colombiano, ratifica la legislación internacional sobre violencia contra las mujeres, en los ámbitos laboral, familiar y social. ${ }^{51}$ Además estableció el concepto de daño contra la mujer y su tipología, clasificándolo en psicológico, físico, sexual y patrimonial. Al cumplirse un año de promulgación de la Ley 1257, el balance efectuado por la Consejería Presidencial para la Equidad de Género, destacó la creación de las Mesas institucionales para erradicar la violencia contra las mujeres, en algunos departamentos como Antioquia, así como la elaboración de campañas de información, sensibilización y capacitación sobre la norma con

47. MEDELLÍN, Alcaldía. «Contrato con formalidades plenas no. 4700028364 de 2007», 〈http://www.contratos.gov.co/archivospucl/C/205001001/07-2-31442/C_ PROCESO_07-2-31442_205001001_296512.pdf>, consultado el 28-07-2010.

48. RichmOND Julius B «Building the next generation of healthy people,» Public Health Rep. 114, no.3, (May-Jun 1999), pp. 212-217, pmid:10476989, PubMed, 〈http://www.bases. unal.edu.co:2411/pubmed?term $=\% 22$ Richmond\%20JB\%22[Author], $\quad$ consultado el 29-03-2010. El modelo de Richmond de formulación de políticas públicas fue propuesto en la década del cincuenta del siglo XX, basado en la interacción de tres componentes: base de conocimiento, voluntad política y estrategia social.

49. PREVIVA, Política Pública para la promoción de la convivencia y la prevención de la violencia en el Valle de Aburrá. 2007-2015, Medellín: Facultad Nacional de Salud Pública, Universidad de Antioquia, 2007.

50. COlOMBIA, Congreso de la República, «Ley 1257 del 4 de Diciembre de 2008,» Diario Oficial no. 47.193. Diciembre 4, 2008, 〈http://www.unhcr.org/refworld/ docid/4961d9ca2.html>, consultado el 30-03-2009.

51. «Consejera Vásquez quiere plena implementación de ley 1257,», 〈http://equidad. presidencia.gov.co/Es/Prensa/2009/Paginas/091204a.aspx>, consultado el 29-06-2010.

Feminismo/s 18, diciembre 2011, pp. 67-92 
los sectores de salud, justicia y la comunidad general. ${ }^{52}$ Pese a que la ley está vigente, existe falta de claridad en cuanto a su financiamiento, por lo cual, aún no se logra su cabal cumplimiento, en especial en lo referente a atención integral de las víctimas, la protección mediante la reubicación de la vivienda que se estipuló en seis meses y la atención en salud mental. ${ }^{53}$

En esta tercera etapa, la violencia en las relaciones de pareja se ha convertido en un discurso que circula en diversos ámbitos y cada actor social lo expresa de diferentes formas. Así, la gran prensa de Medellín, en la primera década del siglo XXI, inscrita en la industria de producción cultural, se ocupa con frecuencia de la violencia en las relaciones de pareja; y en su función de construcción de la opinión pública juega un papel destacado tanto en lo concerniente a la reproducción de los estereotipos de género, como en la tensión de éstos con los contenidos polémicos, los cuales contribuyen a la formación de una masa crítica que incentiva ciertos cambios, con base en la popularización de los saberes académicos y políticos feministas. ${ }^{54}$

Es de resaltar que los medios de comunicación han asumido un papel preponderante en la fragmentación de los grupos sociales y sus identidades, en la generación de una cultura menos «parroquial y confesional» en la ciudad. Sin embargo, en algunos sectores la riqueza y el éxito económico, obtenidos aún de forma ilegal, se han erigido como fines en detrimento de valores que otrora tenían un gran poder cohesionador entre los "paisas $»^{55}$ como el esfuerzo, la honradez, el sacrificio personal, el respeto a la vida y a la dignidad personal. ${ }^{56}$

Por lo demás, en una ciudad con una industria de la moda muy destacada, los medios de comunicación también contribuyen a imponer unos estándares de belleza muy exigentes, alejados de las características morfológicas de la población de la región, pues la imagen corporal se ha convertido en un bien utilizado como una mercancía para lograr el ascenso social, en ambientes de

52. CONSEJERÍA presidencial para la Equidad de la mujer, Colombia: Comité de Seguimiento a Ley sobre Violencia y Discriminación contra las Mujeres, 〈http://equidad.presidencia. gov.co/Es/Prensa/2009/Paginas/091223d.aspx>, consultado el 28-03-2010.

53. DURÁn, Juanita «Consultoría para la implementación de la Ley 1257 de 2008, Implementación Ley de violencia contra las mujeres en materia de salud» s.l., Corporación Sisma Mujer, 2009, pp. 1-66.

54. ARIZA, Gladys. Op.Cit., p. 87-90.

55. Término que es una abreviatura de paisano, con el cual se designa a los habitantes del complejo cultural antioqueño en Colombia.

56. JURADO, Juan Carlos, «Problemas y tendencias contemporáneas de la vida familiar y urbana en Medellín,» Revista Historia Crítica, 25 (2003), 〈http://www.lablaa.org/ blaavirtual/revistas/rhcritica/25/veinticinco5.htm>, consultado el 20-09-2007. 
exclusión social, pobreza y violencia. ${ }^{57}$ Las mujeres, que con mucha frecuencia no pueden alcanzar estos estándares, se ven así expuestas a profundas tensiones e insatisfacciones consigo mismas y en sus relaciones de pareja.

No obstante que en los discursos emergentes divulgados en los medios de comunicación, se reconoce que la violencia en las relaciones de pareja es un delito, se señalan con frecuencia los altos índices de impunidad que presenta, como sus ambiguas, cambiantes y polémicas concepciones normativas. Basta señalar que en el 2011, la Ley de seguridad ciudadana transformó nuevamente la definición jurídica de esta violencia, que pasó de ser un delito que debía investigarse de oficio, sin que mediara denuncia, a ser querellable. ${ }^{58}$ Además aún se considera conciliable, es decir objeto de acuerdo «libre y voluntario» entre el perpetrador y la afectada, lo cual, dadas las frecuentes asimetrías de género entre ellos, dificulta la aplicación de las acciones punitivas, así como la garantía de la reparación integral de los derechos humanos de las víctimas.

En los canales públicos de la televisión regional y local se presentan contenidos alusivos a la violencia en las relaciones de pareja, con intenciones educativas, que difunden las campañas gubernamentales en torno a la prevención de la violencia contra las mujeres.

Desde el arte contemporáneo se visibiliza tal violencia, en exposiciones y eventos académicos sobre el tema, en escenarios culturales y universitarios diversos..$^{59} \mathrm{La}$ academia cada vez con mayor frecuencia y presentando diversas posturas ha liderado actividades de investigación, educación y de movilización sobre la violencia contra las mujeres. ${ }^{60}$ Las organizaciones de mujeres han promovido, como parte de las campañas contra la violencia, la elaboración y difusión de material videográfico, las expresiones musicales y los performances. ${ }^{61}$

La iglesia a través de la Pastoral Social en Medellín desde el año 2009 cada 25 de noviembre promueve campañas para erradicar la violencia contra

57. URIBE, Fernando. Anorexia. Los factores socioculturales de riesgo, Medellín, Universidad de Antioquia, 2007, pp. 114-117.

58. COLOMBIA. Congreso de la República. «Ley 1453 de 2011.» Diario Oficial no. 48.110. Junio 24, 2011.

59. BuILES, Mauricio «La Nueva compañía de los prohombres de la Patria,» Revista Arcadia 20 (mayo, 2007), 〈http://www.revistaarcadia.com/arte/articulo/la-nueva-companiaprohombres-patria/20748>, consultado el 20-11-2010.

60. Cock, Alejandro. Historia Centro Interdisciplinario de Estudios en Género, CIEG, Video, 14:32, SuRealidad Blog, publicado el 11-09-2006, «http://surealidad.blogspot. com/2006/09/historia-cieg.html>, consultado el 3-12-2010.

61. VAMOS MUJER, «Jóvenes conmemoran el 25 de noviembre,» 〈http://www. vamosmujer.org.co/site/index.php/herramientas/banco-de-noticias/200jovenesconmemoranel25denoviembres, consultado el 20-11-2010.

Feminismo/s 18, diciembre 2011, pp. 67-92 
las mujeres, enfocadas en la difusión de la Ley 1257 de $2008 .{ }^{62}$ Sin embargo, la influencia del poder clerical ocasiona que se sigan promoviendo representaciones sociales hegemónicas como la preservación de la unidad familiar, a costa de la tolerancia femenina a la violencia de pareja, pues se supone que la excelencia moral de las mujeres recibirá una recompensa divina.

La Secretaria de Educación, la Secretaria de Salud y la ESE Metrosalud, ${ }^{63}$ han implementado estrategias de educación sexual en las instituciones educativas públicas de la ciudad, para promover el desarrollo de la autonomía y la ciudadanía en la población estudiantil, a través de diversas expresiones artísticas. Uno de los temas que se aborda en esta estrategia es la violencia en las relaciones de pareja, de la que con frecuencia las y los estudiantes o bien son testigos o son víctimas. ${ }^{64}$

En la ciudad de Medellín se realizan múltiples consejos de violencia y seguridad ciudadana, como los de Vigilancia Epidemiológica, Seguridad Pública de las mujeres, en los cuales se expresan discursos en ocasiones encontrados, pues en algunos se clasifica con criterio epidemiológico androcéntrico la violencia en las relaciones de pareja, como parte de los «crímenes pasionales», término anacrónico, de difícil prevención y clasificado como de menor importancia, que otras formas de violencia social originadas en el narcotráfico y la pugna por el control de los territorios. Otros discursos como los expresados por las representantes de la Secretaría de las Mujeres parten de conceptos como violencias basadas en género y feminicidios. ${ }^{65}$

Pese a su número y a la convergencia de sus motivaciones, algunas de estas estrategias públicas aún son muy puntuales y por sus divergencias conceptuales, no siempre están articuladas entre sí, lo cual ocasiona duplicidad de esfuerzos e inversiones en algunos sectores y limita su impacto social.

62. SECRETARIADO Nacional de Pastoral Social, «Campaña de la no violencia contra la mujer 2009. 'La Dignidad de la mujer: Don que debemos proteger, cultivar y promover',» folleto, pp. 1-7, 〈http://pastoralsocial.org/images/contenido/documentos/ Folleto.pdf>, consultado el 3-12-2010.

63. La Empresa Social del Estado, ESE, Metrosalud es la red pública hospitalaria de la ciudad, cuenta con 50 puntos de atención para la población más pobre y vulnerable del municipio, aproximadamente 1.000 .000 de personas, 〈www.metrosalud.gov.co〉, consultado el 20-09-2010.

64. METROSALUD, «Sistematización de la experiencia: los centros de interés creativos, una obra de arte con y para la vida». Informe presentado a la Secretaría de Salud de Medellín, 2010.

65. MEDELLÍN, Alcaldía de. Secretaría de Gobierno, Comité de Vigilancia Epidemiológica de la Morbimortalidad Violenta en Medellín, «Actas 002-2009, 006-2009, y 01-2010,» Asimismo véase el «Informe de Gestión 2009» de dicho Comité. 
En síntesis, en Medellín la violencia en las relaciones de pareja se empieza a reconocer como problema de salud pública, por razones que se pueden agrupar en su significado, su impacto colectivo y la posibilidad de evitarla. En su significado cultural se considera el peso de las tradiciones regionales en las representaciones sociales hegemónicas, expresadas en posturas en las que convergen las tradiciones religiosas judeocristianas, los prejuicios sexistas y de clase, la popularización de saberes de origen científico, que perseveran en valores tradicionales frente a la familia, la indisolubilidad de las uniones, la valoración de la exclusividad sexual de la pareja, la heterosexualidad normativa, la división sexual del trabajo, la tendencia matriarcalista relativa, las masculinidades y las feminidades hegemónicas. En este sentido, Alicia un ama de casa, de 27 años, quien se hallaba en proceso de separación al momento de la entrevista, comentó:

Porque el hombre es trabajador y lleva todas las cosas a su casa, pero la mujer tiene que estar dedicada a sus hijos a su esposo, estar pendiente de ellos, y ellos no valoran eso, el trabajo de la casa no lo pagan, si lo pagan lo pagan con amor y respeto. El hombre puede ser fuerte, pero es más fuerte la mujer porque la mujer está ahí cuando la necesitan, su mamá, su hermana, su amiga, su novia. E1. ${ }^{66}$

Sin embargo, se advierten tendencias hacia el cambio y aún transiciones, acordes con la construcción de una modernidad que avanza hacia la formación de las y los sujetos de derecho, y la ciudadanía, expresadas en representaciones sociales emancipadas como la consideración de la violencia física de pareja como un delito, el cuestionamiento de la autoridad masculina en la pareja y de las relaciones alternas como privilegio androcéntrico, así como la aceptación de la intervención de terceros tanto familiares como institucionales, en la resolución de las disputas de pareja. Así Amparo, socióloga participante en un grupo focal, hizo énfasis en el control coercitivo de las mujeres por sus parejas,

Las mujeres adultas por ejemplo en los talleres hablan de múltiples violencias en sus relaciones de pareja, que van desde las agresiones físicas hasta muchas, muchas psicológicas que están referidas por ejemplo al control de cómo ella debe vestirse o no, si se motilan o no, una mujer decía «a mí mi esposo no me deja que yo me motile, él quiere que yo tenga el cabello largo, y si me motilo, me gano un problema con él y se queda un tiempo enojado sin hablarme» y manifestaba también como para ella, ese silencio de él en su casa la ponía en una situación

66. A las entrevistas se les asignó un código para identificarlas de acuerdo al orden en el cual se efectuaron del E1 al E13. El código de los grupos focales va de GF1 a GF10. Los nombres fueron cambiados, para garantizar el anonimato de las personas entrevistadas. Los fragmentos de las entrevistas y los grupos focales se presentan en cursiva para diferenciarlos fácilmente de las citas de las fuentes bibliográficas.

Feminismo/s 18, diciembre 2011, pp. 67-92 
muy incómoda, porque ella decía "es como si yo no existiera». Entonces la borra, entonces miren que ahí está el control del cuerpo, al derecho constitucional incluso a ejercer pues el derecho a la libre personalidad, hasta borrarla en su propia casa, ella decía «yo no puedo con eso, entonces mejor yo me dejo el cabello largo». GF8.

El impacto colectivo de la violencia en las relaciones de pareja se relaciona no sólo con el mayor reporte estadístico de víctimas afectadas en diferentes clases sociales y etnias, sino también con sus repercusiones en diversos espacios sociales. Esta violencia ocasiona desde afecciones de salud física y mental, hasta la disminución de la participación económica, política y social, e incluso feminicidios y suicidios como lo muestran los indicadores de ingresos, inserción laboral, morbimortalidad, educación, nutrición y años de vida saludable perdidos por las afectadas. El miedo constante, el stress, las lesiones traumáticas y el control coercitivo, desencadenan y empeoran diversos trastornos como hipertensión, diabetes, abortos, partos prematuros, enfermedades de transmisión sexual, depresión, desórdenes alimentarios y farmacodependencia. ${ }^{67}$ Asimismo, se reconoce que la violencia en las relaciones de pareja, tiene consecuencias negativas, sobre quienes la testifican: las hijas e hijos de las víctimas, así como de otros integrantes del grupo familiar.

Los efectos de esta violencia recaen inclusive en quienes la ejercen, pues pese a las tendencias al ocultamiento, a la negación de la responsabilidad, a la justificación de las agresiones, a cierta tolerancia social y a la impunidad, en ciertos casos se ven abocados a responder al medio social, así como ante la ley y la justicia, con el consiguiente menoscabo de su imagen ante las personas que les deben estimación y respeto como sus hijas e hijos, sus familias e incluso sus allegados, en consideración a la tipificación contemporánea de esta violencia como delito. Por lo demás, los agresores construyen un sumario, por así decirlo, que queda como una marca, aún en contextos de ambigüedad ética. Al respecto, Leonardo un entrevistado de 33 años, de ocupación mensajero, expresó,

Claro cada vez que yo he visto o he oído de la violencia de pareja eso me cae a mi, porque yo estado, yo he sido como aportador a esas cifras de parejas en ese tipo de problemas, de llegar a la violencia, al maltrato físico. Entonces cada vez que yo veo eso, o oigo eso me siento mal, porque yo también he estado en esto. [...] Que más que todo los hombres que uno se las quiere tirar como de macho,

67. GUIDO, Lea, «Violencia conyugal y salud pública: El sector salud y el derecho de las mujeres de vivir una vida sin violencia.» La Ventana, 15 (2002), pp. 231-262, 〈www. publicaciones.cucsh.udg.mx/pperiod/laventan/Ventana15/15_10.pdf〉, consultado el 15-09-2007. 
reconocer que uno también tuvo errores, reconocer que uno también tuvo la culpa. Y buscar ayuda cómo no darle pena de buscar ayuda, porque eso era lo que me daba temor a mí. Me daba pena venir a buscar ayuda era por eso, ser hombre y estar buscando ayuda psicológica ¡no! E11.

Para la Salud Pública, la violencia en las relaciones de pareja es evitable, ya que sus causas son socioculturales, es decir modificables: están ancladas no sólo en el terreno de lo personal, sino en los contextos históricos, socioculturales, políticos y económicos, en los cuales discurren las relaciones de pareja. Esto significa el abordaje de esta violencia desde estrategias integrales de promoción de la salud y prevención en todos sus niveles, especialmente antes de que se presente.

Como señala la socióloga Argelia Londoño, en Medellín se ha ido transformando la cultura, al paso que las mujeres se hicieron ciudadanas. Los movimientos de mujeres, los feminismos afro y popular, así como los movimientos juveniles fueron construyendo una ciudadanía colectiva, que lentamente ha ido posicionando la violencia contra las mujeres como un asunto de dominio público. Pese a los desarrollos legislativos, el acopio de estadísticas y los debates académicos, podría afirmarse que la prevención de estas violencias aún no puede considerarse plenamente una política pública, en tanto que socialmente no son valoradas como absolutamente intolerables. ${ }^{68}$ La formulación de normas es sólo un paso más, en el complejo proceso de definición de las políticas públicas, las cuales exigen no sólo acciones gubernamentales, sino también movilizaciones sociales en torno a acciones concretas, superando la mera indignación pasajera.

\section{Consideraciones finales}

Los planteamientos feministas han penetrado en los discursos sociales, en las políticas públicas y en los movimientos de mujeres, facilitando la visibilización de la violencia en las relaciones de pareja y su inclusión en las agendas públicas de la sociedad y el Estado. De igual forma, la construcción de representaciones sociales polémicas y emancipadas, visibles en los discursos de cada vez más amplios sectores de la sociedad, sobre las relaciones de género en las parejas y en las familias, ha incidido en la vida cotidiana, en lo que las personas esperan de sus parejas y por ende en los conflictos que se suscitan a su interior.

68. Londoño, Argelia «Experiencia en la construcción y aplicación de las Políticas Públicas con enfoque de género para la prevención de la violencia,» conferencia, Primer Seminario Medellín, Ciudad segura para las mujeres y mujeres seguras para la ciudad, Secretaria de las Mujeres de Medellín, noviembre 24, 2010.

Feminismo/s 18, diciembre 2011, pp. 67-92 
Es de destacar que en los discursos de los profesionales sociales y sanitarios, así como los pronunciamientos de los medios de comunicación, emergen representaciones sociales que ubican la responsabilidad de esta violencia, ya no únicamente en las mujeres víctimas, sino también en los hombres agresores e incluso en el Estado, los medios de comunicación y las instituciones sociales. Estos discursos develan un marcado énfasis en la judicialización (la denuncia, la demanda, la conciliación, el castigo al agresor), que se justifica por tratarse de un delito. No obstante, son aún insuficientes otros mecanismos como la prevención y la erosión cultural de las bases que sustentan la violencia en las relaciones de pareja, mediante estrategias que logren incidir en las resignificaciones de las masculinidades y las feminidades hegemónicas. Así como también, el compromiso de políticas públicas orientadas a garantizar el pleno goce de los derechos de las mujeres y la reparación integral a las víctimas.

Se destaca que uno de los obstáculos para implementar los instrumentos jurídicos y las estrategias contra la violencia en las relaciones de pareja es algún grado de resistencia política en el ámbito nacional y local, visible en la impunidad que rodea la violencia de género y en la destinación de los recursos técnicos, económicos y humanos suficientes, para que se trascienda la mera obligatoriedad formal de la aplicación de las normas. Esta resistencia se da por parte de ciertos actores sociales con liderazgos en la toma de decisiones, en campos sociales, económicos y políticos, que definen prioridades distintas, ya que aún existen remanentes de las concepciones que sitúan tal violencia en los ámbitos privados y como no relevantes.

El análisis de la violencia en las relaciones de pareja en Medellín, da cuenta de las posibilidades académicas, políticas y éticas, de las articulaciones entre la Salud Pública como campo de construcción de conocimiento y de acción política, de proyecciones transdisciplinares y las corrientes feministas contemporáneas, para lograr que el desarrollo conceptual de esta violencia como problema social se traduzca en políticas públicas que propicien la construcción de formas de ciudadanía, que permitan a cualquier persona constituir relaciones de pareja libres de violencias.

Estas acciones son complejas, dada la necesidad de abarcar tanto la constitución subjetiva individual como social, mediante políticas públicas intersectoriales, que incidan en las transformaciones de las tradiciones culturales y la ética civil pública expresadas en medidas tanto preventivas y educativas, como de atención judicial, sanitaria, psicosocial y económica. Finalmente es importante agregar que un enfoque de género flexible y no prescriptivo, 
transversal a todas las políticas públicas, permitiría avanzar en el logro de una sociedad más equitativa, sin discriminación y sin violencia.

\section{Agradecimientos}

Expreso mi gratitud y reconocimiento, en primer lugar, a las mujeres y hombres que aceptaron ser entrevistados de forma individual y colectiva, brindando relatos de eventos muy significativos e íntimos de sus vidas, tanto en ámbitos personales como laborales. Por la debida confidencialidad sus nombres quedan en la reserva.

A la Universidad Nacional de Colombia, a través de la Convocatoria Nacional de investigación, modalidad 5, apoyo a tesis de posgrado, y a la Empresa Social del Estado, Metrosalud, por la financiación de esta tesis doctoral.

\section{Referencias bibliográficas}

ANES, José et al. Carta de la Transdisciplinariedad, (Arrábida, 1994), 〈www.filosofia.org/cod/c1994tra.htm>, consultado el 5-02-2010.

ARIZA S. Gladys Rocío. «Las Representaciones sociales de la violencia en las relaciones de pareja en la prensa de Medellín en el siglo XXI,» Revista Venezolana de Estudios de la Mujer 14. no. 32. (ene-jun., 2009), pp. 71-98.

Araujo, Kathya, GuZMÁn, Virginia y MAUro, Amalia «El Surgimiento de la violencia doméstica como problema público y objeto de políticas,» Revista de la CEPAL 70, (2000), pp. 133-145

Builes, Mauricio «La Nueva compañía de los prohombres de la Patria,» Revista Arcadia 20 (mayo, 2007), 〈http://www.revistaarcadia.com/arte/articulo/lanueva-compania-prohombres-patria/20748>, consultado el 20-11-2010.

CAMPS, Victoria. El siglo de las mujeres. Madrid: Ediciones Cátedra, Universitat de Valencia, Instituto de la mujer, 2003, pp. 13.

CASILIMAS, Carlos Sandoval, Investigación cualitativa, Bogotá, ICFES, 1996, pp. 42 y 192, 〈http://contrasentido.net/wp-content/uploads/2007/08/modulo4. pdf >, consultado el 4-07-2011

CHAVES, Mariana, «Juventud negada y negativizada: Representaciones y formaciones discursivas vigentes en la Argentina contemporánea,» Ultima década 13, no. 23 (dic. 2005), pp. 09-32, 〈doi 10.4067/S0718-22362005000200002〉, consultado el 23-03-2008.

Cock, Alejandro. Historia Centro Interdisciplinario de Estudios en Género, CIEG, Video, 14:32, SuRealidad Blog, publicado el 11-09-2006, 〈http://surealidad.blogspot.com/2006/09/historia-cieg.html>, consultado el 3-12-2010

Colombia. Congreso de la República. «Ley 1453 de 2011.» Diario Oficial no. 48.110. Junio 24, 2011. 
DURÁN, Juanita «Consultoría para la implementación de la Ley 1257 de 2008, Implementación Ley de violencia contra las mujeres en materia de salud» s.l., Corporación Sisma Mujer, 2009, pp. 1-66.

García Villegas, Mauricio. «Estado sin jueces,» El Tiempo, edición nacional 1, mayo 30, 2006, pp. 15.

GONZÁlEZ REY, Fernando Luis. «El trabajo de campo en la investigación psicológica y el proceso de construcción de la información en la investigación cualitativa,» en Investigación cualitativa en Psicología. Rumbos y Desafíos, Sao Paulo, EDUC, 1999, pp. 97-158.

GuIDO, Lea, «Violencia conyugal y salud pública: El sector salud y el derecho de las mujeres de vivir una vida sin violencia.» La Ventana, 15 (2002), pp. 231-262.

HAMmARSTRÖM, Anne «Why feminism in public health?» Scandinavian Journal of Public Health 27 no. 4, (1999), pp. 241-4, 〈doi 10.1080/140349499444951〉, consultado el 6-02-2011.

INSTITUTO NACIONAL DE MEDICINA LEGAL, INML. Masatugó, Mujer que recibe lo malo para entregar lo bueno, 2004-2008, Forensis mujeres. Bogotá, INML, 2009.

JuRADO, Juan Carlos, «Problemas y tendencias contemporáneas de la vida familiar y urbana en Medellín,» Revista Historia Crítica, 25 (2003), «http://www. lablaa.org/blaavirtual/revistas/rhcritica/25/veinticinco5.htm〉, consultado el 20-09-2007.

Justicia, Juan Muñoz, Análisis cualitativo de datos textuales con Atlas.Ti 5, Barcelona, Universidad Autónoma de Barcelona, 2005, pp. 45-78, «www.fcp.uncu. edu.ar/upload/Atlas5_manual.pdf〉, consultado el 30-06-2011.

LONDOÑO, Argelia «Experiencia en la construcción y aplicación de las Políticas Públicas con enfoque de género para la prevención de la violencia,» conferencia, Primer Seminario Medellín, Ciudad segura para las mujeres y mujeres seguras para la ciudad, Secretaria de las Mujeres de Medellín, noviembre 24, 2010.

LunA, Lola G. Los movimientos de mujeres en América Latina y la renovación de la historia política, Centro de Estudios de Género, Mujer y Sociedad, Universidad del Valle, La Manzana de la Discordia, Santiago de Cali, 2003, pp. 85-100

MEDELLÍN, Alcaldía de. 1er Congreso Ciudadano. Conversemos sobre la vida y la legalidad, Memorias, Medellín, Alcaldía de Medellín, 2005, pp. 34-38.

MEDELLÍN, Secretaría de Salud. Indicadores Básicos 2009. Situación de Salud de Medellín. Medellín, Secretaría de Salud, 2010, pp. 3

Miguel, Ana de (eds.): Teoría Feminista: De la Ilustración a la Globalización. De la ilustración al segundo sexo. Tomo 2, Del feminismo liberal a la posmodernidad, Madrid: Minerva ediciones, 2005, pp. 35-67. 
Miguel, Ana de «La construcción de un marco feminista de interpretación: la violencia de género,» Cuadernos de Trabajo Social 18 (2005), pp. 231-248,

Moscovici, Serge. "Why a Theory of Social Representations?» in DEAux, Kay and PhilogĖNe, Gina (eds.). Representations of the social; bridging theoretical traditions. Oxford, Blackwell, 2001, pp. 8-35.

LÓPEZ, Aura «No más violencia contra la mujer. Entrevista de Aura López a Flora Uribe y Clara Mazo,» Brujas, no. 1, (sep. 1982), pp. 27

OsPinA Murillo, Luz Stella, BeTANCUR, Nidia Cristina y Morales, Piedad del Carmen. Hortelanas, Tejedoras, Alquimistas... Las Mujeres Vamos por el Mundo, Corporación Vamos Mujer - Aniversario 25 años Panel: Pacifismos y DDHH de las Mujeres, «http://www.vamosmujer.org.co/site/images/stories/pdf/objetivo3/ HORTELANAS,\%20TEJEDORAS,\%20\%20ALQUIMISTAS.pdf.pdf >, consultado el 25-07-2010.

PACHÓn, Ximena «La Familia en Colombia a lo largo del siglo XX,» en PUYANA Yolanda y RAMírez, María Himelda (eds.): Familias, Cambios y Estrategias, Bogotá, Universidad Nacional de Colombia, Facultad de Ciencias Humanas, Alcaldía Mayor de Bogotá, 2007, pp. 157-158.

PELÁez Mejía, Margarita María y RODAS ROJAS, Luz Stella. La política de género en el Estado colombiano: Un camino de conquistas sociales, Medellín, Universidad de Antioquia, 2002, pp. 7-10.

PUlEO, Alicia. «Lo personal es político: el surgimiento del feminismo radical,» en AMOrós, Celia y «www.ucm.es/BUCM/revistas/trs/02140314/articulos/CUTS0505110231A.PDF〉, consultado el 10-04-2007.

QUEVEDO Emilio et al. Café y gusanos, mosquitos y petróleo, Bogotá, Universidad Nacional de Colombia, Facultad de Medicina, Instituto de Salud Pública, 2004, pp. 27.

Richmond Julius B «Building the next generation of healthy people,» Public Health Rep. 114, no.3, (May-Jun 1999), pp. 212-217, pmid:10476989, PubMed, 〈http://www.bases.unal.edu.co:2411/pubmed?term=\%22Richmond\%20 JB\%22[Author] >, consultado el 29-03-2010.

Roth Deubel, André Nöel. Políticas Públicas. Formulación, implementación y evaluación. Ediciones Aurora: Bogotá, 2002.

SÁNCHEZ, Olga Las violencias contra las mujeres en una sociedad en guerra, (Bogotá: Ruta pacífica de las mujeres, 2008), 39-75, 〈http://www.rutapacifica.org.co/ las\%20violencias.pdf , consultado el 22-07-2010.

SCOTT, Joan. «Sobre el lenguaje, el género y la historia de la clase obrera.» Historia social, 4 (1989), pp. 81-98.

VAN Dijk, Teun A. (comp.). El Discurso como interacción social. Estudios sobre el discurso II: Una introducción multidisciplinaria. Barcelona, Gedisa, 2000.

Feminismo/s 18, diciembre 2011, pp. 67-92 
Suaza Vargas, María Cristina, Soñe que soñaba. Una crónica del movimiento feminista en Colombia de 1975 a 1982, (Bogotá: AECID, JM limitada, 2008), 47.

URIBE, Fernando. Anorexia. Los factores socioculturales de riesgo, Medellín, Universidad de Antioquia, 2007, pp. 114-117.

Feminismo/s 18, diciembre 2011, pp. 67-92 


\title{
WOMEN'S RIGHT TO HEALTH IN THE ANGLO- CARIBBEAN: INTIMATE PARTNER VIOLENCE, ABORTION AND THE STATE
}

\author{
FAUHN MinVIELLE \\ Umeå University \\ ISABEL GOICOLEA \\ Umeå University
}

Recibido/12/09/2011

Aceptado/24/11/2011

\begin{abstract}
Women's sexual and reproductive health is a public health concern globally, yet in the Caribbean region academic publications exploring this topic from a rights approach are uncommon. A document review was conducted based on the application of the Health Rights of Women Assessment Instrument to the strategic health plans of three Anglo-Caribbean countries. Gender was the underlying theme used to conduct a comparative analysis focusing on intimate partner violence, access to legal abortion and government commitment. The results reveal that important steps have been taken by all countries to address intimate partner violence and abortion, yet effective implementation is threatened by ambiguity in the states' approach to those issues as well as financial, social and infrastructural challenges. Accountability mechanisms are either lacking or underutilized and much remains to be done to effectively demonstrate governments' commitment to women's sexual and reproductive health and rights.
\end{abstract}

Keywords: Gender, Anglo-Caribbean, Abortion, Intimate partner violence, Sexual and reproductive rights, HeRWAI.

\section{Resumen}

La salud sexual y reproductiva de las mujeres es un tema clave de salud pública, sin embargo en la región del Caribe son escasas las publicaciones que exploran este tema desde un enfoque de derechos. En este artículo utilizamos el Instrumento de Health 
Rights of Women Assessment Instrument [Evaluación de Derecho a la Salud de las Mujeres] para analizar los planes estratégicos de salud de tres países del Caribe anglófono. Utilizando el género como eje transversal, realizamos un análisis comparativo de estos planes, poniendo énfasis en tres aspectos: la violencia de compañero íntimo, el aborto seguro y los compromisos estatales. Los resultados revelan que los tres países han tomado medidas importantes contra la violencia de compañero íntimo y para mejorar el acceso a aborto seguro; sin embargo la implementación efectiva de estas medidas queda amenazada por el enfoque ambiguo que los estados adoptan en estos temas, por factores socio-culturales, así como por limitaciones presupuestarias y de infraestructura. Los mecanismos de veeduría son escasos e infrautilizados, y queda mucho por hacer para que los gobiernos de estos tres países demuestren un compromiso real con los derechos sexuales y reproductivos de las mujeres

Palabras clave: Género, Caribe anglófono, aborto, violencia de compañero íntimo, derechos sexuales y reproductivos, HeRWAI.

Feminismo/s 18, diciembre 2011, pp. 93-112 


\section{Background}

The World Health Organization considers women's health to be an issue in need of special consideration, because «in many societies they are disadvantaged by discrimination rooted in socio-cultural factors [...] potential of or actual experience of physical, sexual and emotional violence (and) unequal power relationships between men and women ${ }^{1}$. Globally as well as in the Latin American and Caribbean region, the main causes of death among women aged 20-59 are maternal conditions, ischemic heart disease, stroke, tuberculosis and cancer².

Nonetheless, from a public health perspective, women's sexual and reproductive health remains an area of significant concern as existing data demonstrates that the leading causes of ill health and death for women of reproductive age are related to their sexual and reproductive health ${ }^{3}$. One thousand women die every day as a result of complications related to pregnancy and child birth ${ }^{4}$. Unintended pregnancies are estimated to be in the tens of millions each year, with many women resorting to unsafe abortions because legal restrictions deny them the option of a safe procedure, ${ }^{5}$. Intimate partner violence $\left(\mathrm{IPV}^{7}\right)$, the

1. <http://www.who.int/topics/womens_health/en/>, consulted on 28-02-2011.

2. <http://whqlibdoc.who.int/publications/2009/9789241563857_eng.pdf>, consulted on 02-03-2011.

3. <http://www.who.int/mediacentre/factsheets/fs334/en/>, consulted on 02-03-2011.

4. <http://www.who.int/mediacentre/factsheets/fs348/en/>, consulted on 02-03-2011.

5. Singh, S., Wulf, D., Hussain, R., Bankole, A. and SedGH, G. Abortion worldwide a decade of uneven progress. New York, Guttmacher Institute, 2009.

6. Klima, C.S., «Unintended pregnancy. Consequences and solutions for a worldwide problem». Journal of Nurse-Midwifery, 43 (1998), pp. 483-491.

7. This study focuses on violence perpetrated against women by current or former partners. Therefore the term IPV is used instead of domestic violence, which could refer to any type of violence within the family. However, the legal documents from the three countries favour the term domestic violence so when describing those documents that term will be used.

Feminismo/s 18, diciembre 2011, pp. 93-112 
most common form of violence against women ${ }^{8,9}$, is another public health and human rights violation facing women on a global scale ${ }^{9}$, irrespective of their socio-economic, religious or cultural backgrounds ${ }^{10}$. It is considered to be an important risk factor for women's health ${ }^{11}$ and is experienced by $15 \%$ to $71 \%$ of women during their lifetime ${ }^{9}$.

A discussion of women's sexual and reproductive health would be incomplete without acknowledging that gender inequality is of foremost importance. Whatever, we understand gender to be, it incorporates the affirmation that one group of human beings is privileged over another based on the creation of a social construction derived from alleged biological differences. This multi-dimensional and dynamic construction ${ }^{12}$ which is learned and consequently lived ${ }^{13}$ varies across cultures and times ${ }^{12}$. Gender relations, are concerned with the relationships that people, groups and institutions construct, and take place at individual, institutional and societal levels. While gender regimes and the gender order exert much influence on the individual practice of gender, the possibility also exists for groups and individuals to influence gender regimes and the gender order. This process is by no means instantaneous but requires time to develop ${ }^{12}$. The connections between the societal gender order, institutional gender regimes and gender relations at the individual level becomes especially relevant when exploring women's sexual and reproductive health and rights issues. In the case of IPV sexist gender orders get translated into legal systems that criminalize safe abortion and/or health systems that disregard issues of IPV.

Many of the issues that remain controversial and sensitive in public health research show deep connections with gender relations and disproportionately affect women, i.e. intimate partner violence (IPV) and the criminalization of abortion. Intimate partner violence and criminalization of abortion could

8. Garcia-Moreno, C., Jansen, H.A.F.M., Ellsberg, M., Heise, L. and Watts, CH. «Prevalence of intimate partner violence: findings from the WHO multi-country study on women's health and domestic violence». Lancet 368 (2006), pp. 1260-69.

9. SaltzMan, L.E., FAnslow, J.L., Mcmahon, P.M. And Shelley, G.A. Intimate partner violence surveillance: uniform definitions and recommended data elements version 1.0. Center for Disease Control, 1999

10. JEWKES, R. «Intimate partner violence: causes and prevention». Lancet 359 (2002), pp. 1423-9.

11. CAmpbell, J.C. «Health consequences of intimate partner violence». Lancet 359 (2002), 1331-6.

12. Connell, R.W. Gender. Cambridge, Polity Press, 2002.

13. FENSTERMAKER. S., WeSt, C. Doing gender, doing difference: Inequality power and institutional change. New York, Routledge, 2002. 
both be understood as consequences of unequal gender orders that place women (and women's problems) in subordinated positions.

\subsection{Women's right to health: what it is and how to assess it}

Women's right to health conveys the message that all women irrespective of their ethnic background, socio-economic status, being an urban or rural dweller are entitled to an effective health system which responds to their needs ${ }^{14,15}$. In that respect, individual women have a role to play as right holders while governments assume the role of duty bearers in relation to the right to health. As duty bearer, the government is responsible for and has a legal obligation to make available a health system which is accessible, acceptable and of good quality ${ }^{16}$. Moreover, states are also responsible for reducing inequalities that negatively affect the health of certain populations- the social determinants of health. Gender, together with social status, education or environmental factors, plays a key role in ensuring equal access to the right to health. It is therefore imperative that in their capacity as right holders, individuals -women-actively participate in matters related to their health system. As stated in the Declaration of Alma-Ata: "The people have the right and duty to participate individually and collectively in the planning and implementation of their health care» ${ }^{17}$.

Women's right to health was explicitly incorporated into international human rights documents with the Convention on the Elimination of All Forms of Discrimination against Women (CEDAW) in $1979^{18}$. The explicit distinction with regard to women's right to health was made due in large part to the barriers and multiple forms of discrimination which affect women's ability to exercise their right to enjoy the highest attainable standard of health ${ }^{19}$. CEDAW draws focus to issues of women's sexual and reproductive health, legally binding governments to address obstacles such as gender discrimination, gender based violence and restrictive laws, in order to ensure the provision

14. LEARY, V.A. «The right to health in international human rights law». Health and Human Rights 1 (1994), pp. 24-56.

15. HUNT, P., BACKMAN, G. «Health systems and the right to the highest attainable standard of health». Health and Human Rights 10 (2008), 81-92.

16. BRAVEman, P., GruSkin, S. «Poverty, equity, human rights and health». Bulletin of the World Health Organization 81 (2003), pp. 539-545.

17. <www.who.int/hpr/NPH/docs/declaration_almaata.pdf/>, consulted on 30-03-2011.

18. UN. Convention on the elimination of all forms of discrimination against women. New York, United Nations, 1979.

19. <http://www.ohchr.org/Documents/Publications/Factsheet31.pdf/> consulted on 19-02-2011.

Feminismo/s 18, diciembre 2011, pp. 93-112 
of essential services including, but not limited, to family planning, the promotion of healthy sexuality and access to safe abortion ${ }^{20}$. The United Nations International Conference on Population held in Cairo in 1994, officially recognized reproductive rights as human rights ${ }^{21}$, which are inalienable, emphasize equality and non discrimination as well as implying both entitlement and responsibility ${ }^{14,22,23}$.

In spite of the international recognition of the relevance of women's sexual and reproductive rights, research using a rights approach to investigate important aspects affecting women's health is limited globally and even more so in the Anglo-Caribbean context. Research and advocacy on women's sexual and reproductive rights has focused on legal frameworks and court litigation. Despite the achievements of these approaches, there is increasing recognition of the need to further develop mechanisms to monitor progressive realization and hold governments accountable. In order to fulfil this goal, human rights impact assessment instruments have been developed, aimed at bridging the gap between the right to health in theory (commitments made by states) and in practice (the ability of individuals and groups to realize those rights). Among these human rights impact assessment instruments, the Health and Rights of Women Assessment Instrument (HeRWAI) focuses exclusively on women's right to health and is based primarily on the contents of the Convention on the Elimination of all forms of Discrimination against Women (CEDAW). HeRWAI facilitates the realization of a systematic revision of policies in order to identify the gaps between the current situation regarding women's health and how the situation should be, based on the government's obligations to honour the human rights commitments it has made. Despite its usefulness it has rarely been used within academia, -for some exceptions Zaid ${ }^{24}$

20. Glasier. A., GÜlmezoglu, A.M., Schmid, G.P., Garcia Moreno, C. and Van Look, P.F.A. «Sexual and reproductive health: a matter of life and death». Lancet 368 (2006), pp. 1595-1607.

21. UN. International Conference on population and development. Cairo, United Nations, 1994.

22. Отто, D. «Linking health and human rights: A critical legal perspective». Health and Human Rights 1 (1995), pp. 272-281.

23. BRAVEMAN, P. «Social conditions, health equity, and human rights». Health and Human Rights 12 (2010), pp. 31-48.

24. ZAID, R. Gender reform action plan: A breakthrough for Pakistani women? A policy research using Health Rights of Women Assessment Instrument (HeRWAI) [dissertation]. Washington, University of Washington, 2007. 
and Goicolea ${ }^{25}$, and, to the extent of our knowledge, it has never been applied to the Caribbean context.

The purpose of this study is to explore the incorporation of women's right to health into the main health policy documents of St. Lucia, St. Vincent and the Grenadines and Guyana. The HeRWAI was used to make a comparative assessment of government commitment, focusing on two controversial women's health issues: intimate partner violence and access to legal abortion.

\section{Methods}

\subsection{Study Setting}

St. Lucia, St. Vincent and the Grenadines and Guyana are all middle income countries in the Anglo-Caribbean. The first two are island nations, while Guyana is the only Anglophone country in South America.

In the Anglo-Caribbean, the leading causes of death among women are quite similar to the global trend: non-communicable diseases such as cancers, cerebro-vascular disease, and heart disease. With regard to sexual and reproductive health, HIV and AIDS are of grave public health concern ${ }^{26}: 53 \%$ of people living with HIV in the Caribbean are women. The rate of unsafe abortion in the Caribbean is estimated at 16 per 1000 among women aged $15-44^{5}$. Official attempts by states to measure IPV are very recent $t^{27}$ and there are serious challenges to obtaining accurate estimates of this problem in the Caribbean ${ }^{28}$. However, the few available studies indicate that IPV is a serious concern in this setting ${ }^{29,30}$.

25. GoicolEA, I. Adolescent pregnancies in the Amazon Basin of Ecuador: a rights and gender approach to girls' sexual and reproductive health [dissertation]. Umeå, Umeå University, 2009.

26. Leading causes of death and mortality rates (counts and rates) in Caribbean Epidemiology Centre Member Countries (CMCs):1985 1990199520002009

27. Alméras, D., Bravo, R., Milosavljevic, V., Montaño, S. and Nieves, R. M. «Violence against women in couples: Latin America and the Caribbean. A proposal for measuring its incidence and trends». Mujer y desarrollo, (2004).

28. ECLAC. An evaluative study of the implementation of domestic violence legislation: Antigua and Barbuda, St Kitts/Nevis, Saint Lucia and Saint Vincent and the Grenadines (2001)

29. ARSCOTT-MiLLS S. «Intimate partner violence in Jamaica: A descriptive study of women who access the services of the Women's Crisis Centre in Kingston». Violence against Women 7 (2001), pp. 1284-1302.

30. Quamina-Aiyejina, L., Brathwaite, J.A. Gender-based violence in the Commonwealth Caribbean: An annotated bibliography. Centre for Gender and Development Studies, UWI, Mona \& UNIFEM Caribbean Office 2005.

Feminismo/s 18, diciembre 2011, pp. 93-112 


\subsection{Data Collection}

Central to data collection was the aforementioned HeRWAI. This tool was developed by Aim for Human Rights, and has previously been used for advocacy purposes in several countries. Its design permits the identification of gaps between 1) government commitments at the level of policies, and as stated in CEDAW, and 2) current fulfilment of women's right to health.

The instrument comprises six steps, which allow the researcher to explore several areas, linking government responsibility and women's right to health. Step one identifies and describes the policy, while step two explores the government commitment, and step three looks at the government's capacity to implement the policy. Step four concentrates on the impact of the policy on women's right to health, and step five explores state's obligations in relation to the policy. Finally, step six sums up with recommendations for informing key stakeholders and suggesting changes to the policy which could result in a better impact on women's health rights. Each step consists of a series of questions accompanied by explanatory notes to guide the researcher in obtaining the necessary information ${ }^{31}$.

In this study HeRWAI was applied to the five year strategic health plans of St. Lucia, St. Vincent and Guyana, which serve as the guiding documents for health related matters, since none of the studied countries had a national health policy. Data was collected primarily through an extensive online review of documents including the strategic health plans, budget addresses, the Constitutions of the respective countries, and reports from other relevant authorities, such as the WHO and CEDAW. Pertinent information was extracted and compiled in table format. This allowed the researchers to see the information for the individual countries alongside each other, and get an overall view of the similarities, differences as well as identifying gaps in the data.

Focus was placed on the areas of IPV, access to legal abortion and government commitment, as a way of broadening the debate on two - IPV and legal abortion- very controversial and sensitive topics by tackling them from a slightly less conventional perspective.

\section{Results}

A summary of the findings for each of the countries, St. Lucia, St. Vincent and the Grenadines and Guyana are presented according to the first three steps

31. Bakker. S., Plagman, H. Health rights of women assessment instrument. Utrecht, Aim for Human Rights, 2006. 
of the HeRWAI, namely policy description -focusing on the Health Strategic plans-, capacity to implement and government commitment -exploring international and national signed compromises, and focusing on abortion and IPV-, and capacity to implement.

\subsection{St. Lucia}

The aim of the Strategic Health Plan 2006-2011 is to «increase equity in health care delivery, effectiveness and efficiency in health care provision and ultimately increase health outcomes for the entire population.» It was developed on the basis of discussion in the 1990's surrounding the issue of health sector reform and the eventual Health Sector Reform Proposals in the year 2000. Among the programmes prioritized in the Plan were: Sexual and reproductive health, Child and adolescent health, and Violence and injuries including gender based violence.

Responsibility for the implementation of the Strategic Health Plan lies mainly with the Ministry of Health. However, it is ultimately distributed among several entities. Financing for the public health sector comes from government allocations, out of pocket expenditure and donors. There is not a sustainable plan in place for funding the health sector and for many years St. Lucia has experienced a chronic problem of acquiring and retaining adequate levels of health workers, particularly nurses. The budget allocation for health between 2006 and 2010 revealed that the majority of the funds were directed towards infrastructural improvements.

Regarding government's commitment to women's right to health, at the international level St Lucia ratified the CEDAW in 1990, and the Inter-American Convention on the Prevention, Punishment and Eradication of Violence against Women «Convention of Belem do Para» in 1995. Of six reports that should have been submitted to CEDAW between 1983 and 2003, only one combined report was submitted in 2005 and was followed in 2006 by the submission of a shadow report ${ }^{32}$. At the national level St. Lucia's Constitution does not make specific reference to the right to health, but the Strategic Health Plan explicitly recognizes the access to health services as a human right.

32. Shadow reports are created by NGOs and they supplement the information provided by official government reports to human rights committees. They may include issues that have been omitted or point out areas where the government may have misled the committee. As a result the committee is able to get overall view of the real situation. (http://wwwl.umn.edu/humanrts/iwraw/reports.html)

Feminismo/s 18, diciembre 2011, pp. 93-112 
Abortion is legal under limited circumstances - rape, incest, deformed foetus and to protect the life of the mother-, under any other circumstances it remains a criminal offence punishable by imprisonment. The amendments to this section of legislation to approve limited access to abortion were highly controversial and vehemently opposed. The use of contraceptive methods are supported and encouraged. However, the 2006 CEDAW shadow report indicated that tubal ligation requires the consent of the woman's spouse.

IPV is included in the portfolio of the Ministry of Gender Relations. Existing legislation addresses some aspects of this issue and reference is made to it within the Strategic Health Plan. The Domestic Violence Act of 1995 makes it possible for survivors of domestic violence to seek protections orders, which are granted by the Family Court. Additionally, the concept of marital rape is included as a sexual offence in the Criminal Code. There have been a number of actions aimed at sensitizing different sectors on the issue of domestic violence: community, police, members of the judiciary, and the education system. In addition, there is one Women's Support Centre fully funded and managed by the government, which offers shelter and support services to sufferers of domestic violence.

Some reports express concern about the implementation of the Domestic Violence Act due, in part, to delays in providing protection orders, understaffing of the police service, and a pervading societal attitude that domestic violence is, for the most part, a private matter.

\subsection{St. Vincent and the Grenadines}

The aim of the Strategic Health Plan 2007-2012 is «to improve the health status of the people of St. Vincent and the Grenadines.» It forms part of the wider vision of the health sector «to have a healthy population living in environmentally sound communities empowered with a holistic knowledge of health, developmental and environmental issues.» The strategic health plan makes specific reference to women's health and gender inequality affecting women's health by stating: "notwithstanding the strides made in empowering females to take control of their health, there continues to be inequities and dysfunctional gender relations denying females the right to control and make choices which can affect their sexual and reproductive health....among STIs, female infection rates double that of males». The strategic plan includes two programmes directly related to women's health: - reproductive health and women's health.

Health care is financed by the government through budgetary allocations, out of pocket expenditure and contributions from other entities both local and international. Between 2008 and 2010 there was an increase in the 
government's budget allocation for health. External funding is an important supplement to the national health budget and international agencies and governments played a key role in the development of the Strategic Health Plan, together with national governmental and non-governmental entities. There are difficulties within the health sector in maintaining an adequate number of skilled medical personnel, particularly emergency medical technicians and nurses.

St. Vincent and the Grenadines' international human rights commitments were established by its accession of the CEDAW in June 1981, and the International Covenant on Economic, Social and Cultural Rights in November of that same year. It also signed the Protocol to Prevent, Suppress and Punish Trafficking in persons, especially women and children in November 2002. On the regional level, it ratified the Inter-American «Convention of Belem do Para (1994)» in May 1996. Since it acceded to CEDAW in 1981, one government report has been submitted to the committee in 1991, and was resubmitted in 1994 with some additional information. No evidence of submission of shadow reports was found. At the national level, the Constitution does not contain any specific reference to the right to health, even if some sections may be relevant to the issue of women's right to health - the right to protection from inhumane treatment in section 5 , the right to protection from discrimination on the grounds of sex in section 13.

Abortion legislation permits the procedure in cases of rape or incest, to preserve the mental and physical health of the mother, to save the life of the mother, in cases of foetal impairment and for economic and social reasons. Another reproductive health procedure which requires approval by someone other than the woman herself is that of tubal ligation, for which a woman needs to first obtain spousal consent.

The Domestic Violence Act was passed in 1995 and makes provision for the protection of the victim. According to the St. Vincent and the Grenadines Human Rights Association, domestic violence cases are normally charged under assault, battery, or other similar laws. In addition, very often, domestic violence goes unpunished because of the choices that the women make. Police are often reluctant to respond and follow up on domestic violence cases which fall under the jurisdiction of the Family Court. Shelter support services are limited and provided by an NGO.

\subsection{Guyana}

The National Health Sector Strategy 2008-2012 aims «To provide equitable access to high quality and 'consumer-friendly' health services.» Among the priority 
health areas are: family health (formerly maternal and child health), HIV (together with tuberculosis and malaria), mental health, and health promotion and risk reduction. Several international actors play an important role in providing funding to the health system.

The country's health services are highly decentralized. Guyana's allocations to health have increased steadily from the beginning of the period (2008). The 2010 budget was the largest to date, however the majority was allocated to infrastructure and improving human resources. The government relies on external funding to help finance the health sector and, as such, donor agencies play an important role in the government's capacity for implementation. Much of the assistance has been directed towards HIV, in spite of the fact that there are other priority areas that the government would like to address.

Guyana ratified the International Convention on Economic, Social and Cultural Rights in February 1977, and the CEDAW in July 1980. On the regional level it ratified the Inter-American «Convention of Belem do Para 1994» in February 1996. It then acceded to the Protocol to Prevent, Suppress and Punish Trafficking in persons, especially women and children in September 2004. The government submitted three combined reports to CEDAW between the date of ratification and June 2003, all after the due dates.

Guyana's Constitution contains specific references to the right to health. One article addresses the right of every citizen to receive free medical attention, and in another it acknowledges that everybody is duty bound to participate in protecting the nation's health. On the right to non-discrimination, the Constitution is explicit with regard to women's right to be treated equally to men in all spheres of life in society, and goes further to state the illegality of discrimination against women on the basis of gender.

Regarding access to safe abortion, the Medical Termination of Pregnancy Act allows a woman to decide on having an abortion as long as she is psychologically fit to do so.

Domestic violence is not addressed in the strategic health plan; however, there is a National Policy on Domestic Violence (2008). This policy notes that women are the most commonly and seriously affected by domestic violence and recognizes gender stereotyping and discrimination as the root of this problem. Its main objective is to guide interventions and programmes geared towards preventing domestic violence and providing services to victims. The policy acknowledges that the terms domestic violence, family violence and intimate partner violence are used interchangeably. Some of the key areas the policy aims to address are monitoring and enforcing legal sanctions, 
providing services for survivors, involving the health sector, and educating the public on domestic violence. There is only one organization providing shelter to women suffering from domestic abuse, and between the years 20002006 it was forced to cease operation several times due to lack of funding and low occupancy.

\section{Discussion}

\subsection{Sexual and reproductive health and rights}

\subsubsection{Intimate Partner Violence}

The results reveal that all States under consideration have ratified CEDAW as well as the Inter-American «Convention of Belem do Para 1994». This provides the legal framework which requires States to implement laws, policies, programmes and services to address the issues of violence against women and, in the case of this study, IPV. However, IPV is hardly limited to the legal arena: enforced legal systems might contribute to reducing cases of IPV, but eradicating IPV needs to be based on challenging gender unequal relations.

Domestic Violence legislation has been in existence in all three States since the mid 1990s. Guyana is the only country which has, in addition to the Domestic Violence Act, a National Policy on Domestic Violence. NGO's continue to play an important role in the provision of support services to women suffering from IPV, especially in Guyana and St. Vincent and the Grenadines which, unlike St. Lucia do not have Support Centres which are fully funded and managed by the government. In spite of the current efforts, the instability of funding poses a threat to the availability and accessibility of services for women suffering from IPV.

The availability of shelter services in particular are limited and concentrated in or near the capital cities or urban areas. Although no practical investigation was conducted to confirm the effect of that situation on the accessibility of services, it is quite possible that this situation puts women who live in rural areas at an even greater disadvantage than their urban counterparts. Accessibility is a problem in all three countries; however, the geographical dynamics of St. Vincent and the Grenadines - a multi-island country- and Guyana - due to its size and the large proportion of rural dwellers - may further exacerbate the situation.

In spite of the steps taken in St. Lucia which, arguably, has the most comprehensive approach to IPV -police training, state run shelter, sensitization exercises, court based batterer intervention programme- the mechanisms of the justice system such as delays in providing protection orders and 
understaffing of the police service, are a cause for concern. According to Fenrich and Contesse ${ }^{33}$, such issues with the justice system are liable to have a negative impact on the public's view of domestic violence if they perceive from these actions that the government's representatives do not take the issue seriously. The findings also show that women hesitate to report IPV and that is likely an indication that the efforts of the State thus far have not met the expectations of those who need them most.

Based on the information gathered, the judicial system appears to play a central role with regard to IPV, as opposed to other sectors. This is an indication that the efforts to combat intimate partner violence are more reactionary than preventative. All three governments have at some point engaged in various sensitization campaigns and other related activities, however, the current situation is testimony to the need for a more sustained effort on a wider scale.

\subsubsection{Abortion}

Termination of a pregnancy is a controversial issue and religious factors play an important role in that debate in the Anglo-Caribbean ${ }^{34}$. Guyana has the most liberal legislation of the three countries and was only the second AngloCaribbean country, after Barbados, to enact the Medical Termination of Pregnancy Act in its current form in spite of strong opposition based on religious ideology ${ }^{35}$. Legislation in St. Lucia and St. Vincent and the Grenadines, in spite of being more restrictive than Guyana's, is among the most liberal in Latin America and the Caribbean ${ }^{36}$. Whereas the full effects of the change in abortion legislation are not clear, it is widely acknowledged that restrictive legislation on abortion is a major determinant of unsafe abortion ${ }^{37}$. Although all countries have exercised a certain degree of political will in addressing this issue, the legislation continues to be discriminatory in St. Lucia and St. Vincent and the Grenadines, and as such, a barrier to the women's right to health.

33. FENRICH, J., CONTESSE, J. «It's not OK»: New Zealand's efforts to eliminate violence against women. New York City, Fordham Law School, 2009.

34. Pheterson, G., Azize, Y. «Abortion practice in the northeast Caribbean: 'Just write down stomach pain».' Reproductive Health Matters 13 (2005), pp. 44-53.

35. NunES, F, E., DelPh, Y.M. «Making Abortion Law Reform Happen in Guyana: A Success Story». Reproductive Health Matters 3 (1995), pp. 12-23.

36. <http://www.guttmacher.org/pubs/IB_AWW-Latin-America.pdf/>, consulted on 12-03-2011.

37. Mundigo, A.I. «Determinants of unsafe induced abortion in developing countries», in I.K WARRINER and I.H.SHAH (Ed): Preventing unsafe abortion and its consequences: Priorities for research and action. New York, Guttmacher Institute, 2006, pp. 52-54. 


\subsubsection{Gender Structures}

Gender is an important part of the discussion on the rights approach to sexual and reproductive health. The discourse in the previous sections makes it evident that women are not provided with the array of services that would permit them to exercise their right to health. This study illustrates the individual, institutional and societal levels of gender relations as posited by Connell ${ }^{12}$. With regard to IPV, women are subordinated to the men who exercise power and control over them through violence. Those relations form part of the gender order of society and their emotional dimension is reflected in the very concept of IPV. The legislation on abortion and family planning -tubal ligation- in St. Lucia and St. Vincent and the Grenadines demonstrates the lack of decision making power that women have over their sexual and reproductive health. In both cases, permission has to be granted by another individual, most often a man. This state of affairs also demonstrates that at an institutional level, the gender imbalance of power is at best overlooked and at worst, condoned.

Characterizing the State as an institution opens the way for discussions of IPV from the perspective of a gender regime. The approach to IPV in all three countries is based on the Domestic Violence Act, except that Guyana is more advanced in also having a National Policy on Domestic Violence. The consistent use of the term domestic violence when referring to IPV gives the impression that this problem is conceived as a private one to be dealt with by the parties involved. Therefore the position of the State on the issue remains ambiguous, and IPV rooted in gender inequality continues to be overlooked. Guyana's National Policy which includes references to IPV is quite advanced in comparison to St. Lucia and St. Vincent and the Grenadines. Nonetheless, some of the practical problems highlighted, such as the reluctance of police officers to intervene as well as the reluctance of women to report reflect that societal norms have not been sufficiently impacted by the sensitization programmes, and other measures that have been taken by all three governments to address this problem.

\subsubsection{State commitment and accountability}

As previously mentioned, States Parties to CEDAW have an obligation to submit a report at four year intervals. This is a mechanism to establish accountability as well as being one of the factors which gives an indication of State commitment. Reporting in all countries has been inconsistent. However, St. Vincent and the Grenadines had the worst reporting status, not having submitted a report in over fifteen years, and only one since ratification, nearly 
thirty years ago. In terms of reporting it is evident that there has been a decided lack of accountability on the part of all three States. Mechanisms also exist to promote the active participation of civil society in the form of submission of shadow reports. However, such reports from the three countries have been virtually non-existent. London ${ }^{38}$ advocates very strongly that in order for paper commitments to treaties to be of any real value it is necessary to have an active civil society.

Another important aspect of being State Party to international human rights treaties is the creation of policies and programmes, as well as the addition of legal provisions, to promote the rights under consideration. To that end, Guyana's amendment to the Constitution which eliminates the need for separate legislation by automatically incorporating all human rights contained in the treaties that it signs, makes it the most progressive of the States in that regard. While this action is commendable, the actual relevance could only be determined by its incorporation into future policies and programmes and its practical impact on the lives and well being of the people whose right to health is not fully realized. The lack of specific reference to the right to health in the Constitutions of the other two States is a further indication of a certain level of ambiguity as it pertains to the right to health. Their Strategic Health Plans, on the other hand, reflect an intention to address several issues related to women's health, and in some cases, recognizing existing gender inequalities.

The principle of progressive realization, which requires governments to do everything possible to realize the right to health, is an important measure of state commitment. All three countries experience low resources and a lack of sustainable funding for the health sector and, consequently, programmes directed towards women's health. Financial and technical assistance has been sought from external actors in all cases, with particular attention being paid to physical infrastructure. However, one area of considerable concern for which evidence of progress is lacking is the retention of trained medical personnel to stem the problem of brain drain which plagues the Anglo-Caribbean.

\subsection{Methodological considerations}

While the authors are aware that governments are not the only actors in the realization of women's right to health, the discussion will focus mainly on the

38. LONDON, L. «What is a human rights approach to health and does it matter?» Health and Human Rights 10 (2008), pp. 65-80. 
role of governments, since the data was collected almost entirely from official documents representing government's perspective.

The heavy reliance on the review of documents available on the internet is a limitation of this study, although the use of this method also highlighted the difficulties in accessing as well as the unavailability of information that should be public. Further study on this issue could be enriched by interviews and on site review of documents not available online.

The social determinants of health are an important aspect of the right to health but in this study most of the focus was placed on gender while other determinants such as education level and income and ethnicity (in the case of Guyana) were not explored.

Chapman ${ }^{39}$ and Farmer ${ }^{40}$ make a valid argument that quite often in low income countries, external actors have more influence on a country's health budget than its own government. Although none of the countries in this study are low income, they could possibly be considered low resource and as such, a more in depth exploration of the relations with major external actors like the World Bank could have been beneficial to the study.

It is important in research for the findings to reflect what the study aimed to measure as well as being presented in such a way that a reader in another context can judge the transferability of those findings to his/her own context. The ability to adapt to what emerges from the data while leaving a clear decision trail that can be followed by another researcher is also important. The neutrality of the data is the final measure of trustworthiness and it implies that the conclusions should be obvious from the data ${ }^{41}$. An attempt was made to clearly state the sources used to acquire the data and how the findings would be distributed and addressed, in order to aid the reader in better understanding the author's research process and allowing the reader to come to their own conclusions.

\section{Conclusions}

The results indicate that, at the very least, there is a consciousness on the part of all three Anglo-Caribbean States included in the study, that women's health issues require special attention. This was evident in the inclusion of programmes specially targeting women's health not only from a sexual and

39. Chapman, A.R. «Globalization, human rights, and the social determinants of health». Bioethics 23 (2009), pp. 97-111.

40. FARMER, P. «Challenging orthodoxies: The road ahead for health and human rights». Health and Human Rights 10 (2008), pp. 5-19.

41. Lincoln, Y., GubA, E. Naturalistic inquiry. New York, Sage, 1985

Feminismo/s 18, diciembre 2011, pp. 93-112 
reproductive health standpoint but also, as in the case of St. Vincent and the Grenadines, by focusing on other areas. Several important steps have been taken to address two controversial problems impacting women's health; intimate partner violence and abortion. Nonetheless, there appears to be a certain level of ambiguity on the part of governments as well as financial, social and infrastructural challenges which pose a threat to the advancement of realizing women's right to health. In spite of the progressiveness exhibited thus far, it is imperative that states further consolidate their efforts and demonstrate consistent political will in order to avoid accusations of tokenism. In that regard, Human Rights Impact Assessment instruments such as the HeRWAI could be used by governments and civil society in a collaborative manner for the improvement of women's right to health.

\section{References Bibliográfiques}

Alméras, D., Bravo, R., Milosavljevic, V., Montaño, S. and Nieves, R. M. «Violence against women in couples: Latin America and the Caribbean. A proposal for measuring its incidence and trends». Mujer y desarrollo, (2004).

ARSCOTT-Mills S. «Intimate partner violence in Jamaica: A descriptive study of women who access the services of the Women's Crisis Centre in Kingston». Violence against Women 7 (2001), pp. 1284-1302.

BAKKER. S., Plagman, H. Health rights of women assessment instrument. Utrecht, Aim for Human Rights, 2006.

Braveman, P., Gruskin, S. «Poverty, equity, human rights and health». Bulletin of the World Health Organization 81 (2003), pp. 539-545.

BRAVEMAN, P. «Social conditions, health equity, and human rights». Health and Human Rights 12 (2010), pp. 31-48.

CAMPBELL, J.C. «Health consequences of intimate partner violence». Lancet 359 (2002), 1331-6.

CHAPMAN, A.R. "Globalization, human rights, and the social determinants of health». Bioethics 23 (2009), pp. 97-111.

Connell, R.W. Gender. Cambridge, Polity Press, 2002.

ECLAC. An evaluative study of the implementation of domestic violence legislation: Antigua and Barbuda, St Kitts/Nevis, Saint Lucia and Saint Vincent and the Grenadines (2001)

FARMER, P. «Challenging orthodoxies: The road ahead for health and human rights». Health and Human Rights 10 (2008), pp. 5-19.

FENRICH, J., CONTESSE, J. «It's not OK»: New Zealand's efforts to eliminate violence against women. New York City, Fordham Law School, 2009.

FENSTERMAKER. S., WeST, C. Doing gender, doing difference: Inequality power and institutional change. New York, Routledge, 2002. 
Garcia-Moreno, C., Jansen, H.A.F.M., Ellsberg, M., Heise, L. and Watts, CH. «Prevalence of intimate partner violence: findings from the WHO multicountry study on women's health and domestic violence». Lancet 368 (2006), pp. 1260-69.

Glasier. A., Gülmezoglu, A.M., Schmid, G.P., Garcia Moreno, C. and Van LOOK, P.F.A. «Sexual and reproductive health: a matter of life and death». Lancet 368 (2006), pp. 1595-1607.

GOICOLEA, I. Adolescent pregnancies in the Amazon Basin of Ecuador: a rights and gender approach to girls' sexual and reproductive health [dissertation]. Umeå, Umeå University, 2009.

Hunt, P., BACKMAN, G. «Health systems and the right to the highest attainable standard of health». Health and Human Rights 10 (2008), 81-92.

JEWKES, R. «Intimate partner violence: causes and prevention». Lancet 359 (2002), pp. 1423-9.

KLIMA, C.S., «Unintended pregnancy. Consequences and solutions for a worldwide problem>>. Journal of Nurse-Midwifery, 43 (1998), pp. 483-491.

LEARY, V.A. «The right to health in international human rights law». Health and Human Rights 1 (1994), pp. 24-56.

Lincoln, Y., GuBA, E. Naturalistic inquiry. New York, Sage, 1985

LONDON, L. «What is a human rights approach to health and does it matter?» Health and Human Rights 10 (2008), pp. 65-80.

Mundigo, A.I. «Determinants of unsafe induced abortion in developing countries», in I.K WARrINER and I.H.SHAH (Ed): Preventing unsafe abortion and its consequences: Priorities for research and action. New York, Guttmacher Institute, 2006, pp. 52-54.

Nunes, F, E., DELPH, Y.M. «Making Abortion Law Reform Happen in Guyana: A Success Story». Reproductive Health Matters 3 (1995), pp. 12-23.

OтTо, D. «Linking health and human rights: A critical legal perspective». Health and Human Rights 1 (1995), pp. 272-281.

Pheterson, G., AzIZE, Y. «Abortion practice in the northeast Caribbean: 'Just write down stomach pain».' Reproductive Health Matters 13 (2005), pp. 44-53.

Quamina-Aiyejina, L., Brathwaite, J.A. Gender-based violence in the Commonwealth Caribbean: An annotated bibliography. Centre for Gender and Development Studies, UWI, Mona \& UNIFEM Caribbean Office 2005.

Singh, S., Wulf, D., Hussain, R., Bankole, A. and Sedgh, G. Abortion worldwide a decade of uneven progress. New York, Guttmacher Institute, 2009.

Saltzman, L.E., FAnslow, J.L., Mcmahon, P.M. And Shelley, G.A. Intimate partner violence surveillance: uniform definitions and recommended data elements version 1.0. Center for Disease Control, 1999

UN. Convention on the elimination of all forms of discrimination against women. New York, United Nations, 1979. 
UN. International Conference on population and development. Cairo, United Nations, 1994.

ZAID, R. Gender reform action plan: A breakthrough for Pakistani women? A policy research using Health Rights of Women Assessment Instrument (HeRWAI) [dissertation]. Washington, University of Washington, 2007. 


\title{
«¿DÓNDE VAS A IR TÚ CON SIDA?». INTERSECCIONES ENTRE LA INFECCIÓN POR VIH Y LA VIOLENCIA DEL COMPAÑERO ÍNTIMO
}

\author{
AlberTo MARTíN-PÉREZ RODRÍGUEZ \\ Madrid
}

Recibido/12/09/2011

Aceptado/24/11/2011

\section{Resumen}

Este trabajo consiste en una prospección cualitativa sobre la intersección entre la violencia del compañero íntimo hacia las mujeres (VCI) y la infección por VIH a través de la percepción de siete profesionales de atención sanitaria y de ONG que trabajan con mujeres con VIH y/o con mujeres que sufren VCI en Madrid. Se realizaron entrevistas semiestructuradas y se analizaron los datos a través de procedimientos basados en la teoría fundamentada. Se identificó que la infección por VIH multiplica la violencia psicológica (chantaje, amenaza, desvalorización, etc.) por el estigma asociado a la infección y por algunos efectos secundarios de su tratamiento (lipodistrofia). Los discursos mostraron una visión disociada de los dos problemas de salud pública, lo que indica la necesidad de reconceptualizar la atención y planificación estratégica de ambos.

Palabras clave: VIH, sida, violencia del compañero íntimo (VCI), violencia de género, estigma, mujeres.

\begin{abstract}
This work consists of a qualitative exploration in the intersection of intimate partner violence (IPV) towards women and HIV infection through the perception of seven health care and NGO professionals seeing women with HIV infection and/or women suffering IPV in Madrid. Semi structured interviews were conducted and the data were analyzed using techniques based on the grounded theory. Interviews identified how HIV infection multiplies psychological violence (blackmail, threats, devaluation, etc.) because of HIV social stigmatization and some HIV treatments side effects
\end{abstract}


(lipodystrophy). Professionals' discourses showed a dissasociated vision of both public health problems, which suggests the need to re-conceptualize social and sanitary attention and strategic planning of both IPV and HIV.

Keywords: HIV, AIDS, intimate partner violence (IPV), stigma, women. 


\section{Introducción}

A medida que se combate la violencia del compañero íntimo (en adelante, $\mathrm{VCI}$ ) ésta va adquiriendo visos de mayor sutileza y se requiere profundizar en el conocimiento de sus formas y manifestaciones. En este trabajo se entiende la VCI hacia las mujeres tal como la define la Organización Mundial de la Salud: comportamientos dentro de una relación íntima que causan daños físicos, sexuales o psicológicos, incluyendo agresión física, coacción sexual, abuso psicológico y conductas de control ${ }^{1}$.

Numerosos organismos internacionales y nacionales han señalado la relación que se da entre la violencia contra las mujeres y la infección por VIH. Esta relación puede ser directa, por causas anatómicas y fisiológicas, a través de la violencia sexual o indirecta y por la dificultad de las mujeres que sufren violencia para negociar comportamientos preventivos y acudir a servicios de diagnóstico, prevención y tratamiento, así como por la coerción y manipulación emocional que caracterizan este tipo de relaciones. La percepción de estabilidad que proporciona la relación de pareja, a pesar de la violencia, podría tener más peso que el riesgo asociado a la negociación del preservativo, particularmente en los grupos de mujeres más vulnerables como las usuarias de drogas. No obstante, un reciente estudio no encontró una relación consistente entre la violencia física y sexual y el VIH en mujeres casadas de diez países, lo que indica la necesidad de más investigación para determinar las circunstancias en que dicha relación tiene lugar².

Así mismo, se ha mostrado que las mujeres con infección por VIH pueden estar en riesgo de sufrir violencia tras comunicar su estado serológico a sus compañeros. Para muchas mujeres infectadas, el estigma asociado al VIH implica una caída del ideal patriarcal de «buena mujer» y proveedora de cuidados, resignificándola como «mujer necesitada de cuidados y enferma», sospechosa de haber subvertido mandatos de género, invalidándolas como

1. <http://www.who.int/mediacentre/factsheets/fs239/en/index.html>, consultado el 08-10-2011.

2. HARLING, Guy, et al. «No Association between HIV and intimate partner violence among women in 10 developing countries» PLoS One 5 (2010) e14257. 
mujeres, haciéndolas más violentables y revictimizándolas 3 . Aunque los estudios con muestras concretas - mujeres reclusas, usuarias de drogas intravenosas (UDI), etc.- no indican que las mujeres con VIH sufran más violencia, se ha mostrado que, cuando la sufren, su intensidad y gravedad es más severa.

Algunas autoras han señalado una concurrencia de factores de riesgo comunes para sufrir VCI y para contraer el VIH: tener sexo desprotegido, padecer infecciones de transmisión sexual (ITS), tener múltiples parejas, intercambiar sexo por dinero o drogas, ser usuaria de drogas por vía intravenosa (UDI), tener pareja con VIH o con factores de riesgo para el VIH, revelar el estado serológico, o haber sufrido abusos sexuales en la niñez. Esta enumeración refleja la complejidad de la intersección entre el VIH y la VCI.

Muchos discursos consideran a la mujer más como un vector de la transmisión del VIH que como sujeto del problema y las intervenciones de prevención y cuidados se centran más en otros (hijos e hijas, parejas, clientes...) que en ellas. La mujer queda así invisibilizada como sujeto sexualmente activo y vulnerable ante el VIH. Estos discursos reproducen roles asignados a las mujeres que, para muchas, constituyen imperativos de género que impiden percibir su propia vulnerabilidad y poner en marcha estrategias de prevención. En las relaciones heterosexuales, el aislamiento, la dependencia y la historia previa o actual de violencia de género aumentan el peso de estos condicionantes ${ }^{4}$.

La prevalencia acumulada de VCI en población general mediante encuestas es muy variable por las diferencias metodológicas de los estudios. La encuesta de base poblacional realizada en la Comunidad de Madrid en 2004 con el cuestionario de la encuesta nacional francesa utilizada en el país vecino (ENVEFF), y validado en nuestra población, muestra que el 10,1\% de las mujeres que respondieron a la encuesta había sufrido en el año previo algún tipo de violencia psicológica, física o sexual por parte de su pareja o ex pareja, quedando desagregada la violencia de la siguiente forma: actitudes o conductas de abuso psicológico $(6,8 \%)$, violencia física $(2,4 \%)$, abuso sexual $(0,8 \%)^{5}$.

En la Comunidad de Madrid, el 68,3\% de los casos de sida diagnosticados en mujeres en 2008 se habían debido a la transmisión sexual. El informe del estudio piloto de nuevos diagnósticos de infección por VIH no dispone de

3. GARCIA, M $M^{a}$ Luisa, et al. A pelo gritao. Estudio cualitativo sobre vulnerabilidades, violencias y calidad de vida en mujeres seropositivas. Barcelona, Creación Positiva, 2005. p. 79

4. VelasCo, Sara. Protocolo de prevención de la transmisión heterosexual del VIH con enfoque de género en Atención Primaria. Madrid, Instituto de la Mujer. Ministerio de Trabajo y Asuntos Sociales, 2004. p 19.

5. SANCHEZ, José Luis (coord.). Guía de Apoyo en atención primaria para abordar la violencia de pareja hacia las mujeres. Madrid, Dirección General de Salud Pública y Alimentación. Consejería de Sanidad Comunidad de Madrid, 2008 pp. 10-11. 
información desagregada por sexo para las categorías de transmisión sexual heterosexual y UDI, indicando sólo que las mujeres representan el 19,5\% de los nuevos diagnósticos entre 2007 y $2009^{6}$.

A pesar de su relevancia, la literatura revisada que relaciona el VIH y la VCI evidencia falta de uniformidad en los instrumentos utilizados para medir la VCI. La dimensión psicológica del maltrato suele estar ausente en sus definiciones y utilizan muestras pequeñas y no poblacionales, excepto estudios en África o India y uno más reciente sobre 13.928 mujeres estadounidenses ${ }^{7}$. También son escasos los enfoques cualitativos que caracterizan la violencia de género hacia mujeres con VIH, destacando el de García ${ }^{8}$ que realiza dicha caracterización en un marco de objetivos más amplio.

Combatir la violencia de género es una prioridad de Salud Pública. La investigación y las líneas de trabajo iniciadas sugieren la necesidad de profundizar en las especificidades de la VCI en función de circunstancias personales y sociales como la discapacidad, la inmigración, la edad o el consumo de drogas. La infección por VIH en las mujeres también podría caracterizar de forma diferencial algunas manifestaciones de la VCI. Este trabajo se centra en esta intersección, proponiendo analizar la relación entre VCI y la infección por VIH a través de la percepción de profesionales que trabajan con mujeres en estas situaciones. En concreto se pretende conocer cómo se percibe y se describe la intersección entre la VCI y la infección por VIH, así como identificar oportunidades para un afrontamiento sanitario más efectivo de ambos problemas.

\section{Metodología}

Se realizó una prospección cualitativa empleando como marco epistemológico de género el enfoque integrado de género en salud en sus tres líneas9: la de salud de las mujeres; la de las desigualdades de género en salud y la línea del género como determinante de salud.

El trabajo de campo se realizó a través de entrevistas semiestructuradas, de hora y media de duración, a siete profesionales tomados como informantes

6. <http://www.madrid.org/cs/Satellite?c=PTSA_Multimedia_FA\&cid=1142573182082\& pagename=PortalSalud\%2FPTSA_Multimedia_FA\%2FPTSA_documentoWebeditpro $>$, consultado el 10-08-2010.

7. SAREEN, Jitender, et al. "Is intimate partner violence associated with HIV infection among women in the United States». General Hospital Psychiatry 31 (2009) pp. 274-278.

8. GARCÍA, $\mathrm{M}^{a}$ Luisa, et al. Op.cit.

9. VELASCO, Sara. Sexos, género y salud. Teoría y métodos para la práctica clínica y programas de salud. Madrid, Minerva Ediciones, 2009.

Feminismo/s 18, diciembre 2011, pp. 113-134 
clave por su trabajo con mujeres con infección por VIH y/o con mujeres que sufren violencia, bien en la red de atención sanitaria o en las ONG de Madrid.

Los perfiles profesionales corresponden a una médica de Atención Primaria, un trabajador social de un dispositivo de diagnóstico precoz en un centro de salud, un psicólogo clínico de una unidad hospitalaria de VIH; una médica de un Centro Municipal de Salud para jóvenes, una educadora (con infección por VIH) de un programa de acompañamiento hospitalario entre pares; una psicóloga de una ONG y una trabajadora social de una ONG. Los criterios para la definición de perfiles fueron los de amplitud o máxima diferenciación profesional, y su experiencia en los ámbitos de la VCI, la detección del VIH y la atención psicosocial a mujeres con VIH.

Se eligió a profesionales como informantes en vez de a las mujeres por las dificultades encontradas para acceder a mujeres con infección por VIH que hayan salido de la situación de violencia y por la falta de información de partida sobre algunos aspectos clave que permitieran orientar dichas entrevistas adecuadamente.

Las entrevistas fueron grabadas y transcritas para su análisis posterior. Los campos generales de análisis fueron: la visibilidad de las relaciones entre la VCI y la infección por VIH en la práctica profesional; la percepción social y personal de las mujeres con infección por VIH (imagen, sexualidad, relaciones, etc.) y sus diferencias con los hombres; los hitos relacionados con la enfermedad que pueden desatar episodios violentos; la caracterización de la VCI hacia mujeres con VIH (tipo, manifestación, intensidad...); el afrontamiento de la VCI y autocuidado en las mujeres con infección por VIH; las dificultades para cuidarse/ser cuidada y, por último, las oportunidades y dificultades para el abordaje conjunto de ambos problemas.

El análisis se llevó a cabo mediante procedimientos basados en la teoría fundamentada de Strauss y Corbin ${ }^{10}$, consistente en generar conceptos y categorías para la formulación de hipótesis y teorías a partir del análisis de los datos obtenidos.

Señalamos como limitaciones de este trabajo el pequeño número de profesionales que se entrevistó, y su falta de conocimiento experto simultáneo de VIH y violencia de género, a pesar de su sensibilización ante ambas problemáticas.

10. CORBIN, Juliet; STRAUSS, Anselm. «Grounded theory research: Procedures, canons, and evaluative criteria». Qualitative Sociology; 13 (1990), pp. 3-21. 


\section{Resultados}

En relación con la visibilidad de la intersección estudiada, se apreció que la visión de ambas problemáticas está disociada. Ello se debe a la identificación de la violencia por sus formas más extremas y a la invisibilidad de la violencia sexual dentro de la relación de pareja. Esta última podría, de hecho, ser una forma de VCI reiterada y mantenida en la vida de las mujeres con infección por VIH:

«Lo que pasa es que la gente piensa en la violencia sexual sólo como las violaciones en medio de la calle (...) En nuestras mujeres, al menos de una cierta edad para arriba (...) no se percibe como maltrato pero las relaciones sexuales no consentidas se dan como algo normal en su vida» (Médica de Atención Primaria).

Se mostró que las personas entrevistadas fueron identificando la relación entre VIH y VCI a medida que avanzaba la entrevista. Antes de la misma, se verbalizó la excepcionalidad de la VCI hacia las mujeres con VIH. La entrevista sirvió, así, para visualizar tanto la relación como la cotidianeidad de la violencia hacia estas mujeres:

«Cuando me llamaste para proponerme la entrevista me acordé de casos, de los más gordos, pero la verdad es que luego, pensando, hay un tanto por ciento importante de mujeres maltratadas. Sí. Te das cuenta que ahí ha habido alguna forma de maltrato. Si no un $50 \%$, que yo creo que más, han sufrido maltrato de una forma o de otra» (Psicólogo, Unidad Hospitalaria).

Las y los profesionales explican la vulnerabilidad de las mujeres con infección por VIH ante la VCI por el estigma social asociado a la infección. Este estigma se debe a sus formas de transmisión y a sus implicaciones respecto a los mandatos de género más tradicionales, y constituye una barrera importante para aceptar la enfermedad. Se generan sentimientos como la culpa, la vergüenza y aparece una imagen de sí mismas como «potenciales contaminantes» que refuerza una autopercepción negativa y de baja autoeficacia que ya suele estar presentes en las mujeres que sufren VCI.

«Muchas te dicen todavía que preferirían tener cualquier otra enfermedad, incluso un cáncer, aunque sea más grave, más agresivo para su salud... a nivel psicológico les cuesta más asumir el VIH que otras enfermedades que no son transmisibles, y desde ahí, se complica la asimilación del diagnóstico» (Psicóloga, ONG).

El estigma también puede explicar, al menos en parte, una fase que parece ser común en el proceso de reacción de la mujer infectada ante el diagnóstico y que consiste en negar el problema. Cuando esta fase es más intensa y mantenida en el tiempo, puede tener efectos negativos en la salud e implicar una 
progresión más rápida hacia el sida, ya que la atención sanitaria y social, o la toma de medicación, requieren un cierto nivel de aceptación. Además, tiene efectos en la VCI, puesto que la negación y la consecuente ocultación de la infección aíslan más a la mujer y la hacen más vulnerable al maltrato.

La estigmatización social hacia las mujeres con VIH es causa bien documentada de discriminación social y laboral, así como en el acceso a servicios sociales. En el caso de las mujeres con VIH que sufren VCI, el estigma puede ocasionar problemas de convivencia en recursos de alojamiento compartidos con otras mujeres maltratadas. Así pues, el estigma constituye una importante barrera para salir de la situación de violencia.

«En algunos pisos para mujeres que sufren violencia han puesto pegas por ser seropositivas (...) Por si iban a necesitar vajilla especial» (Trabajadora social, ONG).

«Eso ha pasado en algunos centros (...) porque existe ese miedo a la convivencia en el día a día... no digo que sea generalizado y que otras veces no se vuelquen, pero existe un tanto por ciento de la población que tiene un miedo que (...) es con el que hay que trabajar porque es el que deja a las personas con VIH más desprotegidas» (Psicóloga, ONG).

Un segundo aspecto que aportan las personas entrevistadas para explicar la vulnerabilidad de las mujeres con VIH ante la VCI son los cambios en el aspecto físico debidos a la redistribución de la grasa corporal (lipodistrofia y lipoatrofía facial) y que son efectos secundarios de algunos tratamientos antirretrovirales (TARV). Por su visibilidad y su asociación al VIH, la lipodistrofia (y la anticipación de su aparición) afecta negativamente a la integración laboral de las mujeres, a sus relaciones familiares y sociales o, lo más subrayado en las entrevistas, a su sexualidad y su autoimagen:

«Desnudarse delante de un hombre para algunas mujeres es un trauma. Una mujer (...) que se ve deforme, porque no es que tengas una arruga o dos, es que la lipodistrofia te deforma, pues con eso las mujeres han sufrido un gran shock y de hecho muchas mujeres han decidido no tener más relaciones sexuales» (Educadora de Pares, ONG).

Sin embargo, las mujeres que sufren VCI no suelen estar en posición de renunciar libremente a mantener relaciones sexuales. Y para otras muchas mujeres, la culpa, la inseguridad, los valores negativos incorporados en la identidad a causa de la infección crean un terreno abonado para la violencia y se fuerza la «entrega incondicional» en las relaciones afectivas y sexuales:

«Cuando tienes una relación de pareja, muchas mujeres con VIH asumen cosas con esa pareja que no deberían de asumir, o que no asumirían si no tuvieran $\mathrm{VIH} »$ (Educadora de pares, ONG) 
«Hay casos de mujeres que después de haber sufrido todo lo que sufrieron conocen a alguien, (...) que las trata muy bien y las quiere mucho. De esos casos hay bastantes. Y además que les cuesta que las puedan querer sin más» (Psicólogo, Unidad Hospitalaria).

Esta última frase muestra cómo muchas mujeres interiorizan la idea de que la infección por VIH les resta valor y las hace menos deseables y dignas de amor; ésta es una línea argumental que emplea el maltratador hacia la mujer con VIH.

Tanto por la aceptación de una enfermedad estigmatizada como por la dificultad percibida para establecer relaciones afectivas y de pareja futuras, se manifestó que las mujeres con VIH necesitan y demandan más apoyo psicosocial que los hombres, a pesar de la menor prevalencia de la infección en mujeres. Este tipo de apoyo psicosocial se señala, de hecho, como una estrategia de cuidados de gran importancia.

«A nivel de la unidad por completo igual hay más hombres que mujeres, pero a nivel de atención psicológica yo creo que la cosa está al 50\%» (Psicólogo, Unidad Hospitalaria)

«El número de sesiones que necesitan para asumir su enfermedad en un reciente diagnóstico, (...) a las mujeres les cuesta más, está claro. Y les cuesta más cuando no tienen pareja o cuando vienen de una ruptura (...) Hace poco una chica (...) que está rompiendo con la pareja me decía «creo que no estaría tan mal por la separación en este momento si no tuviera VIH». Encarar la búsqueda de una nueva relación se les hace más duro». (Psicóloga, ONG)

En relación con los autocuidados se indicó la idea de que la mujer con VIH se cuida para cuidar, en particular si existen otros casos de infección en la unidad familiar. Se incidió en que las mujeres con infección por VIH que sufren VCI son las que tienen más dificultades para cuidarse, en cualquier forma, mientras están en la relación de maltrato. Muchos autocuidados (la toma de la medicación, acudir a grupos de ayuda mutua, etc.) implican una cierta aceptación de la infección por VIH y una cierta visibilidad de la condición de seropositiva frente a terceros que pueden quedar comprometidas en situaciones de mayor aislamiento a causa de la violencia. El abordaje de la VCI y de sus efectos que fue planteado implicaría las mismas estrategias que se seguirían con cualquier mujer que sufra VCI, teniendo en cuenta lo específico del VIH:

«Trabajar con la visibilidad con las personas íntimas que la vayan a poder proteger, trabajar con la autoestima, crear lazos con otras mujeres con infección por VIH, trabajar la información, habilidades sociales (...) Es decir, en parte, además de lo relacionado con el VIH, el trabajo que se hace con una persona en situación de violencia» (Psicóloga, ONG).

Feminismo/s 18, diciembre 2011, pp. 113-134 
Respecto a cómo se manifiesta la VCI hacia las mujeres con VIH, las agresiones físicas parecen relacionarse en mayor medida con los casos en que la mujer, la pareja o ambos son consumidores de drogas mientras que en otros casos, aunque también pueda coexistir violencia física y sexual, es más frecuente la psicológica ya que la infección es utilizada como instrumento para ejercerla, como se muestra a continuación.

- Amenaza, chantaje, control y aislamiento: revelar el estado serológico a la pareja se configura como un momento crítico para la aparición del maltrato. Las dificultades señaladas para asimilar el diagnóstico a causa del estigma y el deseo de la mujer de ocultar su estado serológico permiten al maltratador chantajear a la mujer a través de amenazas de revelar a terceros, en distintos entornos, su condición de seropositiva, así como la de sus hijos o familiares en caso de que también tuvieran VIH. Además del efecto que esto tiene en el control de las relaciones sociales de la mujer y en su aislamiento, el coste social para ella, si la amenaza se cumple, puede ser altísimo:

«Destruir tu entorno social, donde tú no quieres que se sepa; en el restaurante donde comes cada día (...) «ten cuidado con ésta que tiene sida, no vaya a ser que...» (...) Y eso te mata socialmente. No te mata físicamente, pero te mata socialmente» (Educadora de Pares, ONG).

El chantaje será más viable cuanto más difícil sea para la mujer hacer visible hacia su entorno su estado serológico frente al VIH. Por ello, estas mujeres seguirían siendo vulnerables ante la violencia ejercida por sucesivas parejas:

«También es verdad (...) que estos maridos ya han fallecido a veces pero ellas siguen haciendo una vida en la que hubo una barrera y les cuesta mucho (...) relacionarse con su familia de origen, que hablen de lo que pasó, que puedan volver a abrirse» (Psicólogo Unidad Hospitalaria).

Ésta parece ser una forma de maltrato hacia las mujeres con infección por VIH comúnmente identificada y que la expansión de las nuevas tecnologías de la información y las redes sociales en Internet parecen haber potenciado. Su visibilidad en los discursos de las y los profesionales se debe a que probablemente tiene lugar cuando la mujer contacta con el sistema sanitario para un seguimiento clínico, farmacológico o para recibir apoyo psicosocial, a través del cual puede tomar conciencia de la relación de maltrato, y se encuentra en fases de preparación y/o acción para salir de la misma: 
«Cuando ella decide romper el vínculo e irse de casa estaba trabajando, cuidando a una persona en una casa, y él va y llama a la casa para decir que ella tiene VIH; (...) tener una información sobre ti y utilizarla como quiera si no estás conmigo» (Psicólogo Unidad Hospitalaria)

«El que abusa o maltrata utiliza todo lo utilizable, como otros aspectos de tu vida, o tal, el temor ¿no?, que tienen muchas mujeres de que se cuente esto o lo otro» (Médica de Atención Primaria).

En ocasiones, cuando la mujer está emprendiendo pasos para salir de una situación de violencia necesita ocultar al maltratador su diagnóstico, porque se percibe que la infección será un motivo más para el maltrato:

«Hay un caso en que ella pide un informe para pedir una orden de alejamiento y en ese informe (...) no tengo que poner nada de que ella tiene VIH, porque no quiere que él sepa que tiene VIH. Sabe que él se lo ha transmitido pero no quiere que él lo sepa por la posibilidad de que haya malos tratos» (Psicólogo, Unidad Hospitalaria).

Paradójicamente, en algunos casos, cuando se revela a la familia el estado serológico de la mujer, aunque ella no lo haya decidido así, el efecto, al desaparecer el peso de la amenaza, podría ser el contrario al perseguido por el maltratador y proporcionar una válvula que permita salir del aislamiento:

«Pues mira, ¿la verdad? se sintió relajada. Es curioso. «Muy bien, pues ahora que me siento obligada, yo por mi no lo habría dicho, pero ahora lo cuento, y tengo la oportunidad de hacerlo». Ella decía «es que estoy como liberada, porque lo he podido hablar con ellos, él casi me ha hecho un favor». Porque antes, lo que estaba haciendo él era, metiéndole miedo de contarlo, retenerla para que no le dejara. Recortando su relación con los familiares» (Trabajadora Social, ONG)

Este comentario muestra la importancia de favorecer la aceptación y dotar de estrategias a las mujeres para la revelación voluntaria y segura del diagnóstico ya que dar a conocer su situación puede ser una estrategia de protección frente al aislamiento.

- La incapacitación para la acción: cuando el maltrato está instaurado en la relación antes de la infección por VIH de la mujer o de su revelación a la pareja, la infección puede utilizarse para mantener a la mujer en dicha situación reforzando la idea de que, por sus implicaciones sociales, el VIH la incapacita para entrar en fases de preparación y acción que son previas a la salida de la situación de violencia, como indican Prochaska y Di Clemente 
en su modelo espiral de las etapas de cambio ${ }^{11}$. La diferencia con otras enfermedades crónicas es el estigma asociado al VIH que refuerza la sujeción de la mujer a la situación de violencia.

«Si muchas veces las preguntas serían «si le dejo, ¿dónde voy?, ¿cómo voy a mantener a mis hijos?, ¿dónde voy a trabajar, si no soy nadie»... Pues si a eso le añades el VIH aún condiciona más ¿no? Además es muy repetitivo por parte de los hombres en algunos casos de violencia de género: «¿dónde vas a ir tú, con sida?» (Educadora de Pares, ONG).

«Lo que ha hecho el diagnóstico es acrecentar esa violencia (...); saca al hombre una justificación más para ser violento y a ella una justificación para dejarse ser violentada (...) sabes todos los condicionantes sociales que conlleva tener VIH y ser mujer y que piensas que nadie te va a querer, que bastante es que él te quiera» (Educadora de Pares, ONG).

- La desvalorización: otro momento crítico para la aparición de VCI hacia estas mujeres ocurre cuando se manifiestan los efectos de la enfermedad o los efectos secundarios de algunos TARV, como la lipodistrofia, que aparte de su gravedad clínica y social se convierte en argumento para el maltrato a través del insulto y la descalificación que conducen a la desvalorización de la mujer.

«El insulto relacionado con el VIH: «sidosa, me das asco». La agresión verbal utilizando el VIH de forma directa " $i$ a ti quien te va a querer con lo que tienes? Ahora sólo puedes estar conmigo», utilizando el VIH como elemento fundamental de la agresión» (Psicóloga, ONG).

«Cuando se toma la medicación puede ser un momento de crisis en la evolución de la enfermedad. Y en el caso de personas que han sufrido cierto maltrato psicológico se me ocurre que puede tener que ver con la aparición de efectos secundarios, físicos, como la lipodistrofia y viene el «es que fíjate como estás, vaya piernas que tienes, ¿dónde vas con esa falda?», "ies que no te ves el cuerpo que tienes, dónde vas con eso?» (Psicóloga, ONG).

- Separación de hijos e hijas: se señaló cómo algunos maltratadores limitan el contacto entre la mujer con VIH y sus hijos, argumentando el riesgo de infección, por desconocimiento sobre las vías reales de transmisión o con la intención expresa de causar un daño a la mujer.

«Por ejemplo que el marido no las deje secarse con las toallas con las que se secan los hijos y cosas de esas, ¿no? (...) tienen una enfermedad infecto-contagiosa, (...) la información que reciben no les tranquiliza

11. Prochaska, James, et al. «Cómo cambia la gente. Aplicaciones en los comportamientos adictivos». RET. Revista de Toxicomanías 1 (1994), pp. 1-12. 
respecto a que puedan transmitírselo a sus hijos (...) y si a eso le añades que la pareja, (...) constantemente se lo está diciendo, pues esa creencia aumenta» (Educadora de pares, ONG)

En relación con el segundo objetivo que se perseguía de identificar oportunidades para afrontar de forma conjunta la VCI hacia las mujeres y la infección por VIH, el discurso de las personas entrevistadas sugirió que dicha integración podría realizarse a través de diversas estrategias en el contexto del diagnóstico de la infección por VIH y de la atención sanitaria a las personas con $\mathrm{VIH}^{12}$.

Por otra parte, se señaló la importancia de sensibilizar e informar al personal de todas las redes de recursos de atención a las mujeres que sufren violencia sobre la imposibilidad de transmisión del VIH en las condiciones comunes de la vida cotidiana, y lo injustificado de discriminar a las mujeres con VIH en estos recursos y servicios.

Así mismo, se señaló la conveniencia de sensibilizar y formar a las y los profesionales que trabajan en la detección y el abordaje de la violencia de género sobre las necesidades clínicas y psicosociales de las mujeres con VIH y sobre la especificidad de la VCI a la que son sometidas. También se señaló la importancia de visibilizar la vulnerabilidad frente al VIH de las mujeres mayores que sufren VCI:

«Esta señora que es la del marido que toda la vida, que es un hijo de tal, que ha sido un mal hombre por decirlo así, probablemente, vamos, con seguridad, ha tenido otras relaciones y si no dan signos de tener VIH, ni se lo hacemos a él, ni a ella. Lo asociamos a vida sexual activa» (Médica de Atención Primaria)

\section{Discusión}

A diferencia del estudio de García et al ${ }^{13}$ que infería de los discursos de las mujeres con infección por VIH entrevistadas la ausencia de una reflexión crítica sobre la violencia por parte de las y los profesionales que las atienden, en nuestros resultados se detecta esta asociación entre la VCI hacia las mujeres y el VIH. No obstante, la asociación no es espontánea sino que se va identificando más claramente a medida que avanza la entrevista. La percepción de excepcionalidad de la intersección previa a la entrevista se explica por la

12. MARTín-PÉREZ, Alberto, et al. «Detección de la violencia de pareja en las intervenciones diagnósticas y de atención sanitaria a mujeres con VIH en Madrid». Programa del XIV Congreso Nacional sobre el Sida. Infección por VIH, 30 años después Jun 15-17, Zaragoza (2011), P5.29.

13. GARCIA, Ma Luisa, et al. Op.cit., p. 79.

Feminismo/s 18, diciembre 2011, pp. 113-134 
identificación de la violencia por sus manifestaciones más extremas, quedando ocultos la violencia psicológica y el sexo no consentido en pareja, como en la mayoría de la literatura consultada. Sin embargo, la dimensión psicológica del maltrato es posteriormente la más señalada en los discursos. Todo ello apunta la necesidad de potenciar el afrontamiento conjunto de ambos problemas, hecho que puede lograrse desde la formación de profesionales y/o la adecuación de los instrumentos de registro de casos en los diferentes ámbitos de atención a estas mujeres.

No es posible concluir sobre las características sociodemográficas de las mujeres más afectadas por esta intersección a partir de los resultados de este trabajo, pero el eco común en los discursos es el eje de la marginalidad y la exclusión: las y los profesionales entrevistados hacen referencia a mujeres inmigrantes y jóvenes, UDI, mujeres españolas parejas de UDI o de inmigrantes. Se señala sin embargo, la invisibilidad de un grado más alto en la exclusión, pues llama la atención en los discursos la ausencia de referencia a las mujeres que ejercen prostitución y a las transexuales, muy vulnerables tanto a la infección como a la violencia ${ }^{14}{ }^{1516}$.

La aceptación de la infección, que influirá en los cuidados, en el inicio y adherencia a los TARV y, a la larga, en el pronóstico terapéutico, parece relacionarse más con los significados sociales de esta enfermedad que con los puramente clínicos. Los avances en los TARV y en la atención han hecho de la infección por VIH en el mundo occidental una enfermedad crónica y compatible con una esperanza de vida casi normal, mejorando la calidad de vida de las y los pacientes, y dificultando la transmisión del virus. Sin embargo, la percepción social del VIH ha sufrido pocos cambios significativos. Su estigmatización se explica por sus vías de transmisión y sus implicaciones respecto a los mandatos de género más tradicionales y a los atributos y exigencias de género más contemporáneos (belleza, disposición sexual, etc.) definitorios de la feminidad. Tener VIH supone un obstáculo más para que las mujeres que no han realizado un planteamiento crítico de este ideal inalcanzable de feminidad sientan que se acercan al mismo. Además, sigue siendo motivo

14. EL-BASSEL, Nabila, et al. «Correlates of partner violence among female street-based sex workers: substance abuse, history of childhood abuse and HIV risks». AIDS Patient Care and STDs 15 (2001) pp. 41-51.

15. ClEMENTS-NOLLE, Kristen, et al. «HIV prevalence, risk behaviours, health care use and mental health status of transgender persons. Implications for Public Health interventions». Am J Pub Health 9 (2001), pp. 915-921.

16. XAVIER, Jessica, et al. «An overview of US trans health priorities. A report by the Eliminating Disparities Working Group». National Coalition for LGTB Health; Washington (2004). 
de discriminación en distintos ámbitos. Esto explicaría la superior demanda identificada de apoyo psicosocial en mujeres y el mayor índice de mujeres negadoras. La negación aísla a la mujer de las redes sanitarias y sociales, haciéndola más vulnerable ante la VCI. En este sentido, la literatura relaciona la VCI hacia las mujeres con VIH con una carga viral elevada, menor recuento linfocitario y peor adherencia a los tratamientos. Esto a su vez, aumentaría el riesgo de discapacidad, sumando otro factor facilitador de la violencia.

El significado subjetivo de perder la belleza exigida a la mujer, en este caso por la enfermedad y/o por la lipoatrofia facial y lipodistrofia, pueden mantener a las mujeres en posiciones pasivas y sin oportunidad de hacer frente a la desvalorización. Unido a las dificultades señaladas para aceptar la enfermedad, al sentimiento de culpa y a la crisis por no poder responder a las exigencias de feminidad, puede causar mayor inseguridad y sumisión al varón, cuya imagen se sublima como alguien en quien refugiarse.

Parece, pues, recomendable abordar la asertividad y trabajar con la imagen corporal para afrontar las exigencias sociales de belleza y seducción con las mujeres que sufren lipodistrofia. Puede mejorar su calidad de vida, ya que la anticipación de la lipodistrofia podría disuadir de la toma de medicación y dificultar la adherencia. También puede facilitar el afrontamiento de la VCI centrada en la humillación derivada de estos efectos secundarios. Sin olvidar, en todo caso, su efecto real en la discriminación en distintos ámbitos y la necesidad de poner el acento en la propia situación de maltrato y no sólo en la autoestima de la mujer. La asociación entre la lipodistrofia y la VCI constituye un argumento más para la investigación en TARV con menos efectos secundarios, y para garantizar la igualdad en el acceso a las cirugías reparadoras, que está actualmente en uso tutelado en nuestro país, con el fin de valorar su inclusión en el catálogo de prestaciones del Sistema Nacional de Salud.

Valorar ventajas e inconvenientes de revelar el estado serológico frente al VIH en el entorno cercano para romper el aislamiento, pero sin comprometer la seguridad, podría ser una línea de trabajo con mujeres en fases de acción para salir de la situación de maltrato. Los inconvenientes pueden, en algunos casos, sobredimensionarse y mantener operativo el chantaje del maltratador.

Los resultados coinciden con la literatura en señalar la infección por VIH como un multiplicador de la violencia de género. La enfermedad o la discapacidad, en general, hacen a la mujer más vulnerable ante la VCI y la misma infección por VIH proporciona al maltratador argumentos específicos (chantaje, aislamiento, incapacitación para la acción, insulto e impedimento del contacto con hijos e hijas) para producir maltrato psicológico aunque éste estuviera presente antes de la infección. Esto subraya la importancia de entender la 
bidireccionalidad de la relación entre VIH y VCI, ya que en muchos casos será dicha violencia la que explique la infección de la mujer. García et al añade el rechazo $0^{17}$ de la pareja a la caracterización de la violencia cuya anticipación podría relacionarse también con la renuncia a las relaciones sexuales y afectivas identificada en nuestros resultados.

Para afrontar la intersección de la VCI y el VIH, algunas experiencias en otros países muestran la posibilidad de integrar la detección de VCI en servicios de diagnóstico de infección por VIH durante las sesiones de pre y post counseling de una cierta duración ${ }^{18}{ }^{19}$. Además, las unidades hospitalarias, por su contacto continuado con las y los pacientes con infección por VIH se configuran como un espacio en el que, de disponer de unidades de apoyo interdisciplinar, se podría abordar la VCI además de otras intervenciones de prevención y de mejora de la calidad de vida. Hay evidencias de que las mujeres con infección por VIH que sufren VCI muestran más episodios de hospitalización y peor pronóstico y tienen peores índices de salud mental, lo que aconseja implicar a la atención especializada. Además, incluir servicios relacionados con la violencia de género en el contexto de la atención a las personas con VIH muestra que su abordaje no es un tabú y que las y los profesionales de la sanidad están en posición de ayudar a las mujeres a salir de la situación de maltrato.

La discriminación hacia las mujeres con infección por VIH en los recursos y servicios sociales para mujeres que sufren VCI depende no sólo de las y los profesionales que la aplican sino de las instituciones que la sustentan. La décima Clasificación Internacional de Enfermedades (CIE) de la Organización Mundial de la Salud (OMS) codifica la infección por VIH en «diseases generally recognised as communicable or transmissible $»^{20}$. La traducción de la CIE realizada por la Organización Panamericana de la Salud (OPS) traduce, en nuestra opinión inadecuadamente, por «infecto-contagioso» ${ }^{21}$. De forma contradictoria, la propia OPS recomienda utilizar «transmisible» en vez de

17. GARCíA, Ma Luisa, et al. Op.cit., p. 64.

18. New York State Department of Health. «Guidelines for Integrating Domestic Violence Screening into HIV Counseling, Testing, Referral \& Partner Notification». Disponible en http://www.health.state.ny.us/nysdoh/rfa/hiv/guide.htm, consultado el 07-07-2010.

19. KLEIN, Susan, et al. «Screening persons newly diagnosed with HIV/AIDS for risk of intimate partner violence: early progress in changing practice». J Public Health Management Practice 14 (2008), pp. 420-428.

20. World Health Organization. Internacional Statistical Classification of Diseases and Related Health Problems. 10 Revision. Version for 2007. Disponible en http://apps.who.int/ classifications/apps/icd/icd10online/, consultado el 15-08-2010.

21. Pan American Health Organization. Clasificación Estadística Internacional de Enfermedades y Problemas Relacionados con la Salud (CIE-10). Caracas, 2008. 
«contagioso» para referirse al VIH por la carga moral de este último término y por sugerir que la transmisión es fácil ${ }^{22}$. Lingüística y médicamente el término «contagioso» puede ser correcto, pero se asocia con algo fuera del control humano, provocando miedos y situaciones de evitación injustificados ya que la evidencia científica muestra que la transmisión del VIH no se produce en actos de la vida cotidiana. Más allá de garantizar la no discriminación en estos recursos, se debería favorecer su función de apoyo a la adherencia a los TARV, así como la prevención de la infección por VIH dirigida a todas las mujeres usuarias de estos recursos, como muestran algunas experiencias identificadas en la literatura.

Por último, parece adecuado incorporar en los programas de sensibilización, formación y abordaje de la violencia de género la reflexión sobre las intersecciones de la VCI con la infección por VIH, en ambos sentidos. Para ello es necesario sumar voces como indican estos resultados y otras declaraciones y artículos revisados.

\section{Conclusiones}

Treinta años después de la aparición de los primeros diagnósticos de infección por VIH, la falta de visibilidad de su intersección con la VCI indica la necesidad de reconceptualizar la atención y la planificación estratégica de ambos problemas de Salud Pública, de establecer alianzas y de adaptar los sistemas de información y vigilancia epidemiológica actuales, como la Encuesta Hospitalaria de pacientes con VIH/sida, las encuestas regionales de salud o las encuestas de violencia, para poder dimensionar el problema.

La infección por VIH puede incrementar la vulnerabilidad de las mujeres ante la VCI y se puede utilizar para articular formas de maltrato psicológico sostenidas por el estigma asociado a la infección o por los efectos secundarios de su tratamiento.

Para combatir este estigma es necesario sensibilizar sobre la utilización del término «infecto-contagioso» para referirse a la infección por VIH en informes médicos y proponer alternativas, así como garantizar que su catalogación en el CIE no produzca discriminación en ningún tipo de servicio o recurso social ya que no existen evidencias que la justifiquen. El efecto de la lipodistrofia en la calidad de vida y en la VCI indica la necesidad de trabajar con las mujeres aspectos relacionados con la imagen corporal y la autoestima

22. Pan American Health Organization. «Terminología relacionada con el VIH: actualización 2006 de la OPS». 2006. Disponible en http://www.cisas.org.ni/files/vih.pdf, consultado el 15-08-2010. 
en los niveles de atención donde sea posible, así como de apoyar el trabajo de las ONG para la ayuda mutua y empoderamiento de las mujeres con VIH.

Aumentar la visibilidad de esta intersección y realizar un abordaje integrado requiere sensibilizar y formar a las y los profesionales que intervienen en los programas de diagnóstico de VIH y atención a las mujeres con VIH para la detección y abordaje de la $\mathrm{VCI}$, así como adecuar los protocolos y guías de actuación sobre la prueba rápida del VIH. Igualmente sería deseable la adecuación de documentos técnicos y formativos sobre violencia de género para visibilizar tanto la vulnerabilidad específica de las mujeres con infección por VIH como el riesgo de infección que implica la VCI, insistiendo particularmente en la vulnerabilidad, más oculta, de las mujeres mayores.

Es necesario profundizar en el conocimiento de algunos elementos básicos de esta intersección desde la percepción de las propias mujeres con VIH que sufren o han sufrido $\mathrm{VCI}$, como pueden ser el efecto de la devastación causada por la violencia en el pronóstico de la infección, la adherencia al TARV, los cuidados y rutinas en salud, etc., teniendo en cuenta la causalidad y efectos acumulativos de la concurrencia de VCI, otras manifestaciones de la violencia de género, el VIH, el uso de drogas y la salud mental.

\section{Referencias bibliográficas}

AguirRezABAL, Arrate; Fuster, Ma José; VAlEnCia, José. Integración laboral de las personas con VIH. Estudio sobre la identificación de las necesidades laborales y la actitud empresarial. Madrid, Fundación para la investigación y la prevención del Sida en España, 2009.

American Foundation for AIDS Research. Gender-Based Violence and HIV Among Women: Assessing the Evidence. Issue Brief No. 3. Washington, AmFAR, 2005.

BoILY, Marie Claude; BUVÉ, Anne; BAGGALEY, Rebecca. «HIV transmission in serodiscordant heterosexual couples». BMJ 340 (2010), c2449.

Clements-Nolle, Kristen; MARX, Rani; GuZMan, Robert; KatZ, Mitchell. «HIV prevalence, risk behaviours, health care use and mental health status of transgender persons. Implications for Public Health interventions». Am J Pub Health 9 (2001), pp. 915-921.

Cohen, Mardge; Deamant, Catherine; Barkan, Susan; Richardson, Jean; YOUNG, Mary; HOLMAN; Susan, et al. «Domestic violence and childhood sexual abuse in HIV infected women and women at risk for HIV». Am J Pub Health 90 (2000), pp. 560-565.

CORBIN, Juliet, STRAUSS, Anselm. "Grounded theory research: Procedures, canons, and evaluative criteria». Qualitative Sociology; 13(1) (1990), pp. 3-21. 
DaVILA, Yolanda; Bonilla, Elsa; GonZÁleZ-RamíREZ, Dolores; Grinsdale, Susan; Villarruel, Antonia. «Pilot testing HIV and intimate partner violence prevention modules among spanish-speaking latinas». JANAC 19 (2008), pp. 219-224.

El-BASSEL, Nabila; WitTe, Susan; WADA Takeshi; GILBERT, Louisa; WALlACE, Joyce. «Correlates of partner violence among female street-based sex workers: substance abuse, history of childhood abuse and HIV risks». AIDS Patient Care and STDs 15 (2001) pp. 41-51.

El-BAsSel, Nabila; Gilbert, Louisa; WU, Elwin; GO, Hyun; Hill, Jennifer, Hill. «Relationship between drug abuse and intimate partner violence: a longitudinal study among women receiving methadone». Am J Pub Health 95 (2005), pp. 465-470.

El-BASSEL, Nabila; Gilbert, Louisa; Wu, Elwin; Chang, Mingway; GoMes, Carla; VINOCOUR, Danielle, et al. «Intimate partner violence prevalence and HIV risks among women receiving care in emergency departments: implications for IPV and HIV screening» Emerg Med J 24 (2007), pp. 255-59.

García, Ma Luisa; Maragall, Margarita; Pineda, Montserrat; SolÉ, Nuria; VÁzQUEZ, Ma José. A pelo gritao. Estudio cualitativo sobre vulnerabilidades, violencias y calidad de vida en mujeres seropositivas. Barcelona, Creación Positiva, 2005.

GIElen, Andrea C; O'CAMPO, Patricia; FAdEN, Ruth; EKE, Agatha. «Women's disclosure of HIV status: experiences of mistreatment and violence in an urban setting». Women \& Health 25 (1997), pp. 19-31.

Gielen, Andrea C; Fogarty, Linda; O Campo, Patricia; Anderson, Jean; Keller, Jean; FADEN, Ruth. «Women living with HIV: disclosure, violence and social support». J Urban Health 77 (2000), pp. 480-491.

GIELEN, Andrea C. "Sexual violence and abuse in intimate relationships», en AmFAR: Women, Sexual Violence and HIV. New York, The American Foundation for AIDS Research, 2005, pp 9-11.

Gielen, Andrea C; MCDOnnell, Karen; O'CAMPo Patricia; Burke, Jessica. «Suicide risk and mental health indicators: do they differ by abuse and HIV status?» Women's Health Issues 15 (2005), pp. 89-95.

Gielen, Andrea C; Ghandour, Reem; Burke, Jessica; Mahoney, Patricia; MCDONNELL, Karen; O'CAMPO, Patricia. «HIV/AIDS and intimate partner violence: Intersecting women's health issues in the United States». Trauma, Violence, \& Abuse 8 (2007), pp. 178-198.

Global Coalition on Women and AIDS. Stop violence against women. Fight AIDS. What's real. Issue 2. Ginebra, 2005. Disponible en: http://data.unaids.org/Publications/IRC-pub07/jc1184-stopviolence_en.pdf, consultado el 15-09-2010.

Gruskin, Leslie; GAnge, Stephen; Celentano, David; Schuman, Paula; Moore, Janet; ZIERLER, Sally, et al. «Incidence of Violence against HIV-infected and 
uninfected women: findings from the HIV Epidemiology Research Study».J Urban Health 79 (2002), pp. 512-524.

Fuster, Ma José; Molero, Fernando; Gil, Lorena; Vitoria, Amaia, AguirrezABAL; Arrate; Kindelan, Antonio. Creencias y actitudes de la población española hacia las personas con VIH. Madrid, Fundación para la Investigación y la Prevención del Sida en España, 2010.

Harling, Guy; Msisha, Wezi; Subramanian S.V. «No Association between HIV and intimate partner violence among women in 10 developing countries». PLoS One 5 (2010), el4257.

Instituto de Derechos Humanos Bartolomé de las Casas. Universidad Carlos III, Madrid. Discriminación y VIH/SIDA 2005. Estudio FIPSE sobre discriminación arbitraria de las personas que viven con VIH o SIDA. Madrid, Fundación para la Investigación y la Prevención del Sida en España, 2005.

Jones, Allison S; Lillie-Blanton, Marsha; Stone, Valerie; Ip, Edward; ZHAng, Qiang; WILSON, Tracey. «Multi-dimensional risk factor patterns associated with non-use of highly active antiretroviral therapy among human immunodeficiency virus-infected women». Women's Health Issues 20 (2010), pp. 335-342.

Klein, Susan; Tesoriero, James; Leung, Shu-Yin J; Heavner, Karin; BirkHeAd Guthrie. «Screening persons newly diagnosed with HIV/AIDS for risk of intimate partner violence: early progress in changing practice».J Public Health Management Practice 14 (2008), pp. 420-428.

LAUGHON, Kathryn. «Abused African American women's processes of staying healthy». Western Journal of Nursing Research 29 (2007), pp. 365-384.

Liebschutz, Jane; Feinman, Gail; Sullivan, Lisa; Stein, Michael; Samet, Jeffrey. «Physical and sexual abuse in women infected with the human immunodeficiency virus. Increased illness and health care utilization». Arch Intern Med 160 (2000), pp. 1659.1664.

Martín-PÉREZ, Alberto; Lasheras, Luisa; Pires, Marisa. «Detección de la violencia de pareja en las intervenciones diagnósticas y de atención sanitaria a mujeres con VIH en Madrid». Programa del XIV Congreso Nacional sobre el Sida. Infección por VIH, 30 años después Jun 15-17, Zaragoza (2011), P5.29.

Medley, Amy; García-Moreno, Claudia; McGill, Scott; Maman, Susan. «Rates, barriers and outcomes of HIV serostatus disclosure among women in developing countries: Implications for prevention of mother-to-child transmission programmes». Bull World Health Organ 82 (2004), pp. 299-307.

New York State Department of Health. «Guidelines for Integrating Domestic Violence Screening into HIV Counseling, Testing, Referral \& Partner Notification». Disponible en http://www.health.state.ny.us/nysdoh/rfa/hiv/guide.htm, consultado el 07-07-2010 
Pan American Health Organization. «Terminología relacionada con el VIH: actualización 2006 de la OPS». 2006. Disponible en http://www.cisas.org.ni/files/ vih.pdf, consultado el 15-08-2010.

Pan American Health Organization. Clasificación Estadística Internacional de Enfermedades y Problemas Relacionados con la Salud (CIE-10). Caracas, 2008.

Prochaska, James; Di Clemente, Carlo; Norcross, John. «Cómo cambia la gente. Aplicaciones en los comportamientos adictivos». Revista de Toxicomanías 1 (1994) pp. 1-12.

Romero, Jorge del; Castilla, Jesús; Hernando, Victoria; Rodríguez, Carmen; GARCÍA, Soledad. «Combined antiretroviral treatment and heterosexual transmisión of HIV-1: cross sectional and prospective cohort study». BMJ 340 (2010), c2205.

Rose, Rachel; House, Amy, StePleman, Lara. «Intimate Partner Violence and its effects on the Health of African American HIV Positive Women». Psychological Trauma: Theory, Research, Practice and Policy 2 (2010), pp. 311-317.

Rountree, Michele; Pomeroy, Elizabeth; Marsiglia, Flavio. «Domestic violence shelters as prevention agents for HIV/AIDS?» Health \& Social Work 33 (2008), pp. 221-28.

Ruíz-PÉRez, Isabel; Plazaola-CAStaÑo, Juncal, Vives-CASES, Carmen. «Methodological issues in the study of violence against women».J Epidemiol Community Health 61 (2007), pp. 26-31.

SÁnCHEZ, José Luis; Pires, Marisa; EsCortell, Esperanza; DOMíngueZ, Julia; LASHERAS, María Luisa; LóPEZ, Sonia. Guía de Apoyo en atención primaria para abordar la violencia de pareja hacia las mujeres. Madrid, Dirección General de Salud Pública y Alimentación. Consejería de Sanidad Comunidad de Madrid, 2008.

SAREEN, Jitender; PAGURA, Jina; GRANT, Bridget. «Is intimate partner violence associated with HIV infection among women in the United States?». General Hospital Psychiatry 31 (2009), pp. 274-278.

TufTS, Kimberly; Clements, Paul T; Wessell, Judy. «When intimate partner violence against women and HIV collide: challenges for healthcare assessment and intervention». J Forensic Nurs 6 (2010), pp. 66-73.

Velasco, Sara. Protocolo de prevención de la transmisión heterosexual del VIH con enfoque de género en Atención Primaria. Madrid, Instituto de la Mujer. Ministerio de Trabajo y Asuntos Sociales, 2004.

Velasco, Sara. Sexos, género y salud. Teoría y métodos para la práctica clínica y programas de salud. Madrid, Minerva Ediciones, 2009.

World Health Organization. Gender Dimensions of HIV Status Disclosure to Sexual Partners: Rates, Barriers, Outcomes. A review paper. Geneva, WHO, 2003. 
World Health Organization. Internacional Statistical Classification of Diseases and Related Health Problems. 10 $0^{\text {th }}$ Revision. Version for 2007. Disponible en http:// apps.who.int/classifications/apps/icd/icd10online/, consultado el 15-08-2010. Xavier, Jessica; Hitchcock, Donald; Hollinshead, Susan, Keisling, Mara; Lewis, Yosenio; LOMBARDI, Emilia, et al. «An overview of US trans health priorities. A report by the Eliminating Disparities Working Group». National Coalition for LGTB Health; Washington (2004). Disponible en: http://www.transequality. org/PDFs/HealthPriorities.pdf

Zierler, Sally; Cunnigham, William; Andersen, Ron; Shapiro, Martin; BozzetTER, Sam; NAKAZONO, Terry, et al. «Violence victimization after HIV infection in a US probability sample of adult patients in Primary Care». Am J Pub Health 90 (2000), pp. 208-215. 


\title{
ANÁLISIS DE LA PERSPECTIVA DE GÉNERO EN LOS PLANES DIRECTORES DEL DEPARTAMENTO DE SALUD DE LA GENERALITAT DE CATALUNYA
}

\author{
$M^{a}$ LUISA PANISELlO CHAVARRIA, \\ INMA PASTOR GOSALBEZ Y M ${ }^{\mathrm{a}}$ LUISA MATEU GIL \\ Universidad Rovira i Virgili \\ AnNa PANisello TAFalla \\ Especialista en Medicina Familiar y Comunitaria. \\ Hospital Verge de la Cinta de Tortosa (Tarragona)
}

Recibido/15/07/2011

Aceptado/25/09/2011

\section{Resumen}

La perspectiva de género entra a formar parte de las políticas públicas para paliar las desigualdades entre hombres y mujeres. Los elementos que consideramos que tendrían que estar presentes en las políticas públicas con perspectiva de género son: la visibilidad de las mujeres, la participación paritaria en los organismos determinados, el lenguaje que no sea androcéntrico ni sexista, la transversalidad y los determinantes de género como construcción social. El objetivo de nuestro trabajo es analizar si la perspectiva de género está presente en los Planes Directores del Departamento de Salud de la Generalitat de Catalunya.

Palabras clave: Perspectiva de género, Planes Directores, Sistema Sanitario Catalán.

\begin{abstract}
Gender perspective becomes part of public policies to avoid inequalities between men and women. The elements that we believe would have to be present in public policies with gender perspective are: the visibility of women, equal participation, not andocentric or sexist language, transverse and gender determinants as social construction.

The aim of our study is to analyze whether the gender perspective is present in the Master Plan of the Department of Health of the Generalitat de Catalunya.
\end{abstract}

Keywords: Gender perspective, sanitary system, Master plans.

Feminismo/s 18, diciembre 2011, pp. 135-154 



\section{Introducción}

El análisis de género ha permitido poner en evidencia el androcentrismo de la ciencia, la lengua, la historia,... y poner de manifiesto la construcción social del género. Es a partir de este análisis y cuando las mujeres acceden a la formación, entrando a formar parte de los poderes públicos, no de forma anecdótica sino como miembros de una sociedad formada por hombres y mujeres, cuando se cuestiona la sociedad androcéntrica y los poderes públicos empiezan a formular políticas públicas introduciendo la perspectiva de género.

Las políticas públicas con perspectiva de género, como procesos por los que son elaborados e implementados programas de acción pública, es decir dispositivos políticos-administrativos coordinados en torno a objetivos explícitos, según Guzmán Virginia, ${ }^{1}$ buscan corregir la desigualdad que se genera en el sistema de género favoreciendo la equidad entre los hombres y las mujeres. »La institucionalización de las políticas públicas de género es el proceso mediante el cual una nueva práctica se incorpora a las instituciones del Estado, se hace estable, se reitera en el tiempo y por lo tanto permite, seguimiento y evaluación». ${ }^{2}$

Cada actuación del Estado puede tener un impacto diferente en la situación de los hombres y las mujeres y producir aunque sea de manera indirecta situaciones que perjudiquen la equidad de género de ahí la necesidad de introducir la dimensión de género en todas las actuaciones de las instituciones del Estado.

En cuanto a la interrelación de género y política hay que señalar que:

- La política está determinada por el sistema de género, actividad mayoritariamente masculina

- El sistema de género se mantiene y se reproduce por la intervención política.

1. GuZMAn,Virginia.La institucionalidad de género en el estado: nuevas perspectivas de análisis. Chile. CEPAL, Série Mujer y Desarrollo, núm 3, 2009.

2.AstelarRA, Judith, Veinte años de politicas de igualdad. Madrid. Ediciones Cátedra. 2005.

Feminismo/s 18, diciembre 2011, pp. 135-154 
- Cada actuación del estado puede tener un impacto diferente en la situación de los hombres y las mujeres y producir aunque sea de manera indirecta situaciones que perjudiquen la equidad de género. Hay que introducir la dimensión de género en todas las actuaciones de las instituciones del Estado. ${ }^{3}$

\section{Perspectiva de género en el sistema sanitario}

La Ley General de Sanidad de España (Ley 14/1986 del 25 de abril) tiene por objeto la regulación general de todas las acciones que permitan hacer efectivo el derecho a la protección de la salud, establece las bases de un modelo de ordenación sanitaria que se construye mediante la creación del Sistema Nacional de Salud, configurado por el conjunto de los Servicios de Salud de las Comunidades Autónomas, por lo tanto tiene un carácter descentralizador.

Así lo recoge la Ley 15/1990 de 9 de julio de Ordenación Sanitaria de Cataluña, siendo una de las finalidades de esta ley: «La atención integral de la salud que comprende: la promoción de la salud, la prevención de la enfermedad así como las acciones curativas y rehabilitadoras necesarias, colaborando en la reinserción social y garantizar la salud como un derecho inalienable».

En Cataluña se crea el Servei Català de la Salut como ente para llevar a cabo la organización y ordenación del Sistema Sanitario Catalán. En el artículo 62, nos habla del Plan de Salud de Cataluña y dice:

Las líneas directivas y de desarrollo de las actividades, los programas y los recursos del Servicio catalán de la salud para alcanzar sus fines constituyen el Plan de Salud de Cataluña. El Plan de Salud es el instrumento indicativo y el marco de referencia para todas las actuaciones públicas en la materia, en el ámbito de la Generalidad de Cataluña». (Art.62, apar.1)

Los planes de salud articulan las políticas de salud y se incluyen los principios, valores, objetivos y acciones a desarrollar durante el periodo de vigencia, definiendo lo que se considera problema de salud y la priorización de los mismos. En Cataluña se inician los planes de salud con el Documento Marco en 1991, a partir de esta fecha tenemos los siguientes planes (93-95, 96-98,992001,2002-2005 y Plan de Salud en el horizonte 2010). ${ }^{4}$

Los principales instrumentos de planificación estratégica del Departamento de Salud de la Generalitat de Cataluña son: El Plan de Salud, los Planes Directores y el Mapa Sanitario, Sociosanitario y de Salud Pública. El Plan de

3. Ibid. p. 31.

4. http://www.gencat.cat/salut/depsalut/html/ca/plasalut/index.html, última consulta $1-3-2011$. 
Salud determina las prioridades de salud que se estructuran como punto de referencia para la visión estratégica del Mapa. Los Planes Directores operativizan las prioridades del plan de salud, en base al artículo 64 de la Ley 15/1990 de 9 de julio, de ordenación sanitaria de Cataluña que establece que corresponde al Departamento de Salud formular los criterios generales de la planificación sanitaria y también fijar los objetivos, los índices y los niveles básicos a alcanzar en las materias que se incluyen en el Plan de Salud de Cataluña. El primer Mapa Sanitario de Cataluña se presentó en 1980 y el último publicado se aprobó por acuerdo de Gobierno GOV/2008 de 20 de mayo.

El Departamento de Salud priorizó seis materias, en base al análisis de la salud, los servicios sanitarios y del contexto socio económico del país, como planes directores para el periodo 2005-2007, que fueron el de la inmigración, el sociosanitario, el de salud mental y adicciones, la oncología, las enfermedades del aparato circulatorio, y la investigación en ciencias de la salud, aprobados por Decreto de 28 de febrero de 2006 (DOGC núm. 4584 de 2-3-2006). Por acuerdo de Gobierno el 18 de julio de 2006, se aprueban los Planes Directores 2005-07 con una vigencia de 3 años (DOGC núm. 4689-02/08/2006). ${ }^{5}$ En estos Decretos, el artículo 2 nos define los objetivos de cada Plan y en el apartado 2.2 señala:

En el desarrollo de estas funciones se hará el seguimiento y la validación del uso de la variante de género, de forma que se tengan en cuenta las especificidades de salud de las mujeres con el objeto de dar respuesta y ofrecer una atención integral ante sus necesidades.

En el artículo 7 nos habla del Consejo Asesor y en el apartado 7.2 señala:

En la composición del Consejo Asesor se procurará alcanzar la presencia de un número de mujeres que represente un mínimo del 50\% del total de personas miembros de este órgano colegiado.

La IV Conferencia Mundial de las Naciones Unidas sobre las Mujeres que tuvo lugar en Beijing (Septiembre, 1995) marca la línea que debe orientar toda acción de gobierno analizando los efectos desde el punto de vista del género de todas las políticas y programas.

La Organización Mundial de la Salud (OMS) elaboró en 2002, el documento que insta a los países miembros a elaborar estrategias para promover la integración del género en los sistemas de salud y nos relata la política de la OMS en materia de género: Integración de las perspectivas de género en la labor de la OMS. En la declaración introductoria Gro Harlem Brundtland, Directora

5. http://www.gencat.cat/salut/depsalut/html/ca/dir2154/index.html. Consultado 25-9-2010.

Feminismo/s 18, diciembre 2011, pp. 135-154 
General, señala que la integración de las perspectivas de género en la acción sanitaria obedece a un criterio justo de salud pública.

El documento refiere que la política de la Organización será velar para que todas las investigaciones, las políticas, los proyectos, los programas y las iniciativas en las que participe la OMS, incorpore las cuestiones de género.

Entre las metas y objetivos destacamos:

- Promover la equidad y la igualdad entre hombres y mujeres a lo largo de toda la vida

- Proporcionar información cualitativa y cuantitativa sobre la influencia del género en la salud y la atención de salud

- Promover la integración de los asuntos de género en los sistemas de salud.

En la Declaración del Milenio de Naciones Unidas y en otros acuerdos internacionales se reconoce la importancia de la igualdad de derechos entre hombres y mujeres y el derecho de todos a vivir sin sufrir discriminaciones en ninguna esfera de la vida, incluyendo el acceso a la atención de salud.

Recogiendo el sentir de estas Instituciones, en el estado español, la Ley Orgánica 3 / 2007, de 22 de marzo, para la Igualdad Efectiva de Mujeres y Hombres. (BOE núm. 71 Viernes 23 marzo 2007) en el Artículo 27, trata de la integración del principio de igualdad en la política de salud, y el Sistema Sanitario debería orientar sus acciones integrando la perspectiva de género para alcanzar la equidad y la igualdad entre hombres y mujeres.

Para alcanzar este fin, a nivel internacional, estatal y autonómico se han desarrollado guías en relación a la incorporación de la perspectiva de género tanto en las políticas públicas como en el ámbito de la salud y la investigación. ${ }^{6}{ }^{7}$

\subsection{Objetivo del estudio}

El objetivo de nuestro trabajo es analizar si la perspectiva de género está presente y de que manera se incorpora, en los Planes Directores del Departamento

6. Garcia Calvente Ma del Mar, Jiménez Rodrigo MáLuisa, Martínez Morante Emilia. Informe de revisión de guias sobre la incorporación de la perspectiva de género a las plíticas de investigación en salud. Observatorio de Salud de la Mujer (OSM). Dirección general de la agencia de Calidad del Sistema nacional de Salud. Secretaria General de Sanidad. Ministerio de Sanidad y Consumo. Escuela Andaluza de Salud Pública. 2005.

7. VELASCO ARIAS Sara. Recomendaciones para la práctica del enfoque de género en programas de salud. Observatorio de Salud de la Mujer (OSM). Dirección general de la agencia de Calidad del Sistema nacional de Salud. Secretaria General de Sanidad. Ministerio de Sanidad y Consumo Madrid 2008. 
de Salud de la Generalitat de Cataluña, siendo nuestra hipótesis de partida que la voluntad política de integrar la perspectiva de género en el Sistema Sanitario esta presente, pero esta no queda reflejada en la redacción incorporándose parcialmente en el diseño

\subsection{Metodología}

Se han analizado los Planes Directores para el período 2005-2007, que en la actualidad siguen estando en vigor. Estos son el de la inmigración, el sociosanitario, el de salud mental y adicciones, la oncología y las enfermedades del aparato circulatorio. Profundizaremos en este último por ser la primera causa de muerte en las mujeres. En el artículo. 2.2 de todos los Planes, señala:

En el desarrollo de las funciones se hará seguimiento y validación del uso de la variante de género, de forma que se tengan en cuenta las especificidades de salud de las mujeres con el objetivo de dar respuesta y ofrecer una atención integral ante sus necesidades.

Para realizar este análisis nos hemos basado en la «Guía para facilitar la incorporación de la perspectiva de género en los Planes Integrales de salud» de la Consejería de Salud (Junta de Andalucía, 2008), adaptándola a los objetivos de nuestro estudio. ${ }^{8}$

Los elementos que consideramos que deberían estar presentes en el diseño de una política pública con perspectiva de género son:

- Visibilidad: Los datos deben estar disgregados por sexos para posteriormente realizar el análisis de las diferencias encontradas con perspectiva de género.

- Participación: En las comisiones del Plan se procurará la paridad (Artículo 7 de los respectivos Planes). Revisaremos si los nombramientos de los equipos, planes directores, colaboradores / as del departamento, consejos asesores, comisión permanente, grupos de trabajo, órganos de participación tienen en cuenta paridad.

- Lenguaje y imágenes: Su uso no debe ser androcéntrico ni sexista

- Determinantes de género: Verificar si los elementos propios de género están presentes en la redacción de los diferentes Planes.

- Transversalidad: Si los Planes tienen en cuenta actuaciones transversales y con otras instituciones en relación al género

8. Amo Alonso, Mercedes. Guía para facilitar la incorporación de la perspectiva de género en los Planes Integrales de salud. Sevilla. Consejeria de Salud. 2008. 


\section{Analisis de la perspectiva de género de los planes directores}

\subsection{Análisis de la perspectiva de género: plan director de inmigración en el} ámbito de la salud

El Plan Director de Inmigración en el ámbito de la salud y su Consejo Asesor se crea por decreto 40/2006 de 14 de marzo y se publica en octubre de $2006 .{ }^{9}$ La misión del Plan Director de Inmigración (PDI) es la de mejorar la salud de la población inmigrada mediante la definición de un modelo de atención y organización de los servicios que permita al sistema de salud catalán hacer frente a la nueva situación planteada por el fenómeno de la inmigración.

En relación a la visibilidad de las mujeres en el redactado del Plan, en la descripción de la situación aparecen algunos datos desglosados por sexo. De las diferencias encontradas no se realiza el posterior análisis con perspectiva de género.

Los objetivos son genéricos y las mujeres sólo quedan reflejadas en los que hacen referencia a la salud sexual y reproductiva.

Al referirse a los contenidos de la formación la única referencia que se hace a la mujer inmigrante es la salud reproductiva.

En cuanto a la participación en el equipo del Plan Director hay una mayoría de mujeres ( $71,4 \%$ frente $28,5 \%$ de hombres), la relación se invierte con los colaboradores del Departamento de Salud (38, 1\% de mujeres frente 61,8\% de hombres). En cuanto a la composición de los grupos de trabajo según el sexo de los participantes hay que señalar que en los de salud internacional y sistemas de información la totalidad de los participantes son hombres (100\%) mientras que en las de mediación $(68,4 \%$ son mujeres) y acogida $(70,3 \%$ son mujeres).

En relación al lenguaje, en general sí que se tiene en cuenta el no invisibilizar a las mujeres, aunque hay veces que utiliza el masculino para referirse a los dos géneros (niños, hijos, mediadores,....). La imagen que utiliza en la portada y en el folleto es el de una doctora auscultando a una niña.

En relación a la perspectiva de género, no referencia bibliografía relacionada con el género pero sí material editado por el Instituto Catalán de las Mujeres (ICD). No se tiene en cuenta que los determinantes de salud de los hombres y las mujeres son diferentes y por tanto también las necesidades de salud. Se limita a la salud sexual y reproductiva en relación a las mujeres, formulando sólo objetivos en relación a la salud materno

9. Pla Director d'Immigració en l'Àmbit de la Salut. Direcció General de Planificació i Avaluació 2006. Barcelona. 
infantil, enfermedades de transmisión sexual y cáncer de cuello de útero. Se formulan objetivos específicos que impulsan la búsqueda de indicadores sensibles al género en las interrupciones voluntarias del embarazo, embarazos en adolescentes, mutilación genital femenina, salud sexual y reproductiva.

Las propuestas de actuaciones para alcanzar los objetivos explícitamente no tienen en cuenta la perspectiva de género ni disminuir los sesgos de género en el conocimiento existente.

El Plan promueve acciones para lograr la formación con perspectiva de género en todos los perfiles profesionales.

Cabe destacar que en lo referente a las mujeres se limita a la salud sexual y reproductiva y las mutilaciones genitales femeninas.

Se han revisado otros documentos en relación a las mujeres emigradas ya que es el sector de la población donde la invisibilidad por razón de género es más evidente. En relación a la transversalidad este Plan no contempla la integración de la perspectiva de género de forma explícita como uno de los ejes en todos los apartados del Plan Director, pero comparando con los otros Planes podemos decir que es el Plan que más trabaja de forma transversal con otros Departamentos y sobre todo con el ICD. En concreto el Plan Integral de Acogida (PIA) que forma parte del Plan Director, no hace referencia al género en ningún objetivo. Pero nos habla de la elaboración de material de apoyo e información de acogida con el $\mathrm{ICD}^{10}$. Esto constituye un ejemplo de trabajo transversal en materia de género. Dentro de la colección «Cuadernos del Instituto» del ICD el $\mathrm{n}^{\circ} 5$ está dedicado a las mujeres emigradas. Este cuaderno nos señala la situación de las mujeres emigradas que son mujeres pobres, de otro país, otra etnia y trabajadoras, estos elementos influyen en la feminización de la pobreza, hay un techo de cristal para estas mujeres. ${ }^{11}$

También refiere que cuando se habla de inmigración se olvida del porcentaje de mujeres emigradas y que una vez más estamos ante una nueva invisibilización de las mujeres. En cuanto a la salud destaca la necesidad de la incorporación de la temática del proceso migratorio, las enfermedades específicas (depresiones,...) y la importancia que tendría tratar el tema desde una perspectiva de género. Siguiendo las iniciativas del ICD, cabe destacar que en el «Plan de acción de gobierno en políticas de mujeres (2008-2011)» se contempla las acciones en relación a la inmigración que tiene que llevar a cabo el Departamento de Salud.

10. http://www20.gencat.cat/portal/site/icdones. Consultado el 9-10-2010.

11. SIPI, Remei. ARAYA, Mariel. Les dones migrades. Generalitat de Catalunya. Institut Català de les Dones. Barcelona. Quaderns de l'Institut 5. (2007). 
Otro ejemplo de esta transversalidad lo constituye las actuaciones formativas del ICD, en el catálogo de talleres, uno hace referencia a «Mujeres y salud: espacios de participación» A si mismo en el tríptico de bienvenida a Cataluña donde explica los derechos de las mujeres en referencia a la salud. «Derecho a la salud y a decidir sobre el propio cuerpo», nos habla del derecho a la salud, de la planificación, los embarazos y el parto. En cuanto a Salud e inmigración el Departamento de Salud tiene el listado de protocolo y guías.

Mención especial es todo el tema de la mutilación genital femenina, que para el gobierno de la Generalitat del momento fue objeto de especial atención. Como ejemplo hay que citar una publicación del Departamento de Salud sobre el tema, la prevención y atención. Como política transversal, se ha revisado el Pacto Nacional por la Inmigración (PNI). «Un pacto para vivir juntos y juntas». Firmado por los Sindicatos, representantes de la Mesa de ciudadanía e inmigración y por todos los grupos parlamentarios a excepción del Partido Popular, en Barcelona en diciembre de 2008.

Entre los principios del PNI figura:

- Incorporar la perspectiva de género durante todo el proceso y como herramienta de análisis y de planificación.

El PNI apuesta por mantener la coordinación entre los entes locales y los servicios de salud y la voluntad comunitaria y participativa de trabajo en el territorio para llevar a cabo los proyectos elaborados desde el Plan Director de Inmigración en el ámbito de la salud.

\subsection{Análisis de la perspectiva de género: plan director sociosanitario (PDSS)}

El Plan Director Sociosanitario y su Consejo Asesor se crea por Decreto 39/2006 de 14 de marzo. Diario oficial de la Generalidat Núm 4594. El Plan Director considera la atención sociosanitaria como aquella que se dirige a los colectivos referidos en el Plan: personas mayores, personas con enfermedad de Alzheimer u otras demencias, pacientes con otras enfermedades neurológicas que pueden cursar con discapacidad y personas en situación de final de la vida, haciendo especial mención a la atención prestada a las personas en situación de mayor riesgo y / o vulnerabilidad en procesos, crónicos o agudos, con diferentes grados de discapacidad y cualquier etapa del ciclo vital. ${ }^{12}$

En relación a la visibilidad de las mujeres dentro del Plan, en la descripción de la situación hay datos disgregados por sexo que nos muestran las diferencias que existen respecto a la morbimortalidad, estilos de vida, dependencias

12. Pla Director Socioanitario. Direcció General de Planificació i Avaluació 2006. Barcelona. 
en relación al sexo. No hay un análisis posterior de las diferencias de estos datos, sólo se limita a describirlas. En cuanto a la participación en el equipo del Plan Director hay una mayoría de mujeres (71,4\% frente 28,5\% de hombres), la directora del PDSS es una mujer. La proporción de los colaboradores del Departamento de Salud es de 44\% de mujeres frente 56\% de hombres. En cuanto a la composición de los grupos de trabajo en relación al sexo de los participantes, en el caso del grupo de Demencia y Geriatría el 53,8\% son mujeres y en el grupo de Cuidados Paliativos son mujeres el 56,2\%.

En relación al lenguaje, en general este Plan utiliza el masculino para referirse a los dos géneros (cuidador, enfermo, médicos, enfermeros, trabajadores sociales,...) La imagen que utiliza en el folleto es de un señor mayor con una niña (se supone el abuelo con la nieta).

En relación a la transversalidad, no contempla la integración de la perspectiva de género, de forma explícita como uno de los ejes en todos los apartados del Plan director. En relación a la perspectiva de género no cita bibliografía al respecto. La descripción de la situación no se traduce en ninguna propuesta ni objetivo para disminuir el sesgo relacionado con el género. La única propuesta donde aparecen las mujeres es en el hecho de ser cuidadoras (situación relacionada con el rol tradicional). No hay ninguna propuesta de investigación en relación al género y el problema de salud determinado por el Plan Director.

Tampoco queda constancia de la promoción, de forma explícita, de acciones para lograr la formación con perspectiva de género en relación al PDSS, para ningún perfil profesional.

\subsection{Análisis de la perspectiva de género: plan de salud mental y adicciones} (PDSMA)

El Plan Director de Salud Mental y Adicciones y su Consejo Asesor, se crea por el Decreto 30/2006 de 28 de febrero. (DOGC núm. 4584).

La salud mental ha sido declarada recientemente una prioridad en el seno de la Unión Europea (Declaración de Helsinki, enero de 2005). Esta declaración señala que hay que enfocar los graves problemas de salud mental desde las políticas públicas con una perspectiva integradora. El riesgo de mala salud mental es más elevado en las mujeres en todos los grupos de edad y va aumentando a medida que bajamos en la clase social. La OMS define la salud mental (SM) como un estado de bienestar en el que el individuo es consciente de sus capacidades, puede enfrentarse a las exigencias normales de la vida y trabajar de forma productiva y fructífera, y es capaz de contribuir a su comunidad. La misión del Plan Director de salud mental y adicciones es decidir, planificar, 
ejecutar y evaluar las acciones más efectivas y los recursos más apropiados para la mejora de la salud mental de la población. Los proyectos e intervenciones definidos en este Plan apuntan a los siguientes objetivos del Plan de Salud de Cataluña en el horizonte 2010:

A. Problemas de salud mental

B. Consumo excesivo de alcohol

C. Consumo de drogas no institucionalizadas ${ }^{13}$

En relación a la visibilidad, como primera dimensión de la perspectiva de género, en el análisis de la situación, el Plan disgrega los datos de morbilidad y mortalidad por sexo, esta disgregación refleja que los trastornos mentales son un problema de salud donde las diferencias en las prevalencias de los problemas son visibles en relación al sexo, pero esta evidencia no va seguida de un análisis de las posibles causas de esta diferencia.

Las propuestas de actuación y los objetivos del plan director no tienen en cuenta los resultados del análisis de los datos disgregados ni la perspectiva de género. Dentro del objetivo: «Promoción de la salud mental y prevención de los trastornos mentales y las adicciones» nos señala que hay que incorporar la perspectiva de edad y género, pero después no se formula ningún objetivo específico que impulse la búsqueda de indicadores sensibles al género. En el objetivo operativo 3.3 en relación a la salud mental de los adultos contempla la elaboración de un proyecto de prevención y detección precoz de mujeres maltratadas en el marco interdepartamental coordinado por el ICD, esto sería otro ejemplo de transversalidad.

Sólo en el objetivo operativo de «Promocionar la investigación clínica» entre los proyectos de investigación figura el «Proyecto de investigación sobre los maltratadores de género, abuso infantil».

En los proyectos a priorizar, en uno hace mención a incluir programas de prevención y detección precoz en las unidades integrales de violencia de género y en otro de incorporar los aspectos de atención psiquiátrica y psicológica a las mujeres maltratadas.

En relación a la participación, en el registro de actores (así lo denomina el Plan) del Plan, la presencia de mujeres es importante (equipo del Plan 60\% de mujeres). Debemos señalar que en la composición de los grupos de trabajo que están formados en relación a las etapas del ciclo vital (infantil, adolescencia, adultos y ancianos), las mujeres forman parte de forma mayoritaria en el

13. Pla Director de Salut Mental i addiccions de Catalunya. Direcció General de Planificació i Avaluació 2006. Barcelona. 
grupo de trabajo de infantil $(73,6 \%)$, el grupo de adolescentes $(64,8 \%)$ y en el de las personas mayores $(52,6 \%)$ pero en el grupo de adultos la presencia de mujeres es menor $(38,4 \%)$.

En relación al lenguaje utilizado no visibiliza igual a hombres y mujeres. La imagen visual de la portada y del folleto refleja la presencia de mujeres y hombres en diferentes etapas del ciclo vital.

No hay referencias explícitas en la bibliografía utilizada que haga mención a la relación del género con la salud mental y sus problemas así como con las adicciones

\subsection{Análisis de la perspectiva de género: plan director de oncología}

Los Objetivos generales que se marca el Plan director de oncología son:

1. Reducir la incidencia y la mortalidad en cáncer en Cataluña.

2. Mejorar la calidad de vida en todo el proceso.

3. Mejorar la accesibilidad, garantizando el diagnóstico precoz y un tratamiento apropiado y de calidad.

4. Mejorar la información y comunicación entre ciudadanos, pacientes, familiares, profesionales, gestores y políticos. ${ }^{14}$

En relación a la visibilidad, los datos referentes a la morbi-mortalidad están disgregados por sexo pero no así las referentes a los factores de riesgo ni los ingresos hospitalarios. No se realiza ningún análisis de los datos para buscar relaciones con el género.

En relación a la participación, las personas que participan en la elaboración del Plan (Actores del Plan), el Equipo del Plan (42,8\% de mujeres) y los colaboradores del departamento ( $41,3 \%$ de mujeres) se puede hablar de paridad en la composición, no así en el Consejo Asesor (17,6\% de mujeres frente a $82,3 \%$ de hombres) ni en la comisión permanente (25\% de mujeres frente a $75 \%$ de hombres).

Observamos gran variación en cuanto a la composición por sexo en los grupos de trabajo, el de psico-oncología está formado por un 83,3\% de mujeres y en el del cuello uterino 76,1 de mujeres (forman parte de este grupo una representante del ICD, una de «La Xarxa de Dones per la Salut» y una de la coordinadora de Usuarios de la Salud), frente al de radioterapia que son un $11 \%$ las mujeres y el de anatomía patológica que el 100\% son hombres.

14. Pla Director d'Oncologia. Direcció General de Planificació i Avaluació 2006. Barcelona.

Feminismo/s 18, diciembre 2011, pp. 135-154 
El lenguaje empleado en la redacción del plan utiliza generalmente el masculino para referirse a los dos sexos.

En cuanto a las imágenes se constata que en la portada del Plan y del tríptico aparece una mujer de mediana edad.

En la bibliografía referenciada no aparece ninguna cita de ninguna publicación en referencia al cáncer y el sexo / género.

En relación a la transversalidad, no se contempla la integración de la perspectiva de género, de forma explícita como uno de los ejes, en todos los apartados, del plan director. Pero hay una representante del ICD, una de red de Mujeres por la Salud y una de la coordinadora de Usuarios de la Salud en un grupo de trabajo. En la formulación de objetivos no se tiene en cuenta que los determinantes de salud y los factores de riesgo son diferentes para los hombres y las mujeres. En los objetivos del Plan no se tiene en cuenta la relación del género con el cáncer de mama, que es el más frecuente en las mujeres y que causa más mortalidad.

Tampoco se promueven acciones para lograr la formación con perspectiva de género en todos los perfiles profesionales.

\subsection{Análisis de la perspectiva de género: plan director de las enfermedades del aparato circulatorio (PDMAC)}

En la presentación de éste se indica que el Plan de las enfermedades del aparato circulatorio (PDMAC) es el instrumento de información, estudio y propuesta mediante el cual el Departamento de Salud determina las líneas directrices para impulsar, planificar, coordinar y evaluar las actuaciones a desarrollar en el ámbito de la promoción de la salud de las enfermedades del aparato circulatorio (enfermedades cardiovasculares y vasculares cerebrales). La prevención, el tratamiento y la rehabilitación, tienen el objetivo de mejorar la calidad de vida de los afectados. ${ }^{15}$ El PDMAC reparte sus objetivos, estrategias y prioritarios en dos Planes: Plan Director de enfermedad cerebro-vascular y el Plan Director de enfermedad cardiovasculares Como ya hemos se ha indicado, el estudio que da lugar a este artículo ha profundizado en el Plan Director de las Enfermedades cardiovasculares.

En el momento de redactar el Plan Director numerosas publicaciones, en diferentes revistas científicas, ponían en evidencia que las diferencias biológicas y el género como construcción social, influye en el proceso de las Enfermedades Cardiovasculares (ECV) y en la falta de esfuerzo terapéutico hacia

15. Pla Director de les Malalties de l'Aparell Circulatori.. Direcció General de Planificació i Avaluació 2006. Barcelona. 
las mujeres. En el decreto de creación del Plan Director y de su Consejo Asesor, tras señalar las funciones del mismo, nos dice que el desarrollo de estas funciones se hará teniendo en cuenta el género y las especificidades de salud de las mujeres para ofrecer una atención integral. En relación a la visibilidad, la base de cualquier planificación es partir del análisis de la situación para poder analizar los datos con validez, por tanto hay que tenerlos disgregados por sexo. El Plan nos presenta una descripción de la morbilidad y mortalidad disgregada por sexo pero no recoge los factores de riesgo en relación a las morbilidades señaladas disgregados por sexo y tampoco realiza un posterior análisis de estos datos buscando indicadores de género. Se limita a una descripción de datos. En un artículo de la Gaceta Sanitaria en el 2004, se publicaba:

La Cardiopatía Isquémica es un proceso multifactorial, hay evidencias de que está relacionada con determinados factores de riesgo, como la HTA, las dislipemias, la diabetes mellitus, el consumo de tabaco o el sedentarismo. Estos factores de riesgo pueden actuar de manera diferente entre mujeres y hombres, lo que señala la importancia de establecer pautas de actuación preventiva y terapéutica diferentes según el sexo y con perspectiva de género. ${ }^{16}$

En 1991 en la Revista Española de Cardiología publicaba un artículo titulado «Supervivencia en los 10 años de una cohorte de 736 pacientes con un primer infarto de miocardio: ¿Diferencias entre sexos?» En el que apuntaba diferencias que en estudios posteriores se han evidenciado, como la mayor mortalidad de las mujeres en la fase aguda asociado entre el grado de Killip y el sexo, presentando las mujeres peores puntuaciones que los hombres; así como la relación de una peor situación basal en relación a los factores de riesgo coronario, en el estudio presentado, la hipertensión arterial y la diabetes era más frecuente entre las mujeres ${ }^{17}$. En una publicación del Journal of the American Medical Association (JAMA). 1998, llegaban a la conclusión de que: «En este estudio de población, las mujeres experimentan más letalidad y gravedad en el primer infarto agudo de miocardio que los hombres, independientemente de la comorbilidad, la edad, anterior o la angina de pecho.»

«La tasa de mortalidad tras un primer infarto es mayor en las mujeres. A los 28 días después de haber sufrido el infarto más del 18\% de las mujeres

16. Rohlfs i, García M, Gavaldà L, Medrano M J, Juvinyà D, Baltasar A.»Genero y cardiopatía isquèmica».Gaceta Sanitaria, 18(2004), pp 54-64.

17. Marrugat J SAla J, Ribalta A. et al. «Supervivencia a los 10 años de una cohorte de 736 pacientes con un primer infarto de miocardio: ¿Diferencias entre sexos?». Revista española de Cardiologia. 44 (1991), pp.297-305.

Feminismo/s 18, diciembre 2011, pp. 135-154 
morían frente un $8 \%$ de los hombres y 6 meses después casi un $26 \%$ de las mujeres había muerto frente a un $12 \%$ de los hombres». ${ }^{18}$

Las mujeres tardan más en acudir al hospital, y tardan más en ser atendidas y en recibir tratamiento trombolítico. ${ }^{19}$

En relación a la presentación de la Cardiopatia isquémica (CI), en el artículo referenciado anteriormente, «Género y Cardiopatía Isquémica» nos señala:

Las manifestaciones clínicas de la CI se han estudiado más intensamente y específicamente en el hombre que en la mujer. Así, el cuadro clínico considerado como típico en el hombre (dolor precordial desencadenado por el esfuerzo, con irradiación a la mandíbula y / o brazo, acompañado de síntomas vagales, como náuseas o vómito y disnea) no tiene por qué corresponder al de la mujer a la que tiende a definirse erróneamente como atípico o anormal.

Esta característica no se refleja en el Plan Director y puede estar relacionada con la tardanza de las mujeres al pedir atención y en la falta de esfuerzo terapéutico. En el Plan Director no aparecen datos referentes a la clase social y sexo en relación a la morbilidad y mortalidad. No todos los datos están disgregados por sexo y no se realiza el posterior análisis de los datos.

En relación a la participación de los diferentes «actores» del plan (según lo llama el Plan) la composición en relación al sexo del Equipo del Plan es $42,8 \%$ mujeres frente a $57,1 \%$ hombres, en cuanto a los colaboradores / as del Departamento de Salud las mujeres representan el 42,5\% frente a 57,4\% de hombres. En el Consejo Asesor las mujeres representan el 33,3\% frente a $66,6 \%$ hombres y algunos grupos de trabajo, sobre todo los que hace referencia en la parte de las enfermedades cardiovasculares (insuficiencia cardiaca, síndrome coronario agudo, formación en el síndrome coronario, angioplastias, código infarto) suponen un $100 \%$ de hombres.

En los grupos de trabajos de las enfermedades cerebro vasculares, en el de vasculares cerebrales el $10 \%$ son mujeres mientras que en el de rehabilitación el $71,7 \%$ son mujeres.

En las entrevistas en profundidad realizadas a las personas implicadas en la elaboración del Plan, les preguntamos si los profesionales que habían participado tenían formación en género o si se había previsto la incorporación de personas con formación en género y respondieron que no.

18. Marrugat J, Sala J, Masià R, Pavesi M, Sanz G, Valle V «Mortality Differences Between Men and Women Following First Myocardial Infarction». Journal of the American Medical Association (JAMA). 280 (1998), pp.1405-1409.

19. MARRUGAT, Jaume. SALAJJoan. ABOAL Jaime. «Epidemiologia de las enferedades cardiovasculares en la mujer». Revista Española de Cardiología. 59 (2006), pp. 264-74. 
El lenguaje utiliza el masculino para referirse a los dos sexos y la imagen que utiliza en la portada es de una persona difuminada que está corriendo. En relación a la bibliografía citada en el Plan, en el apartado de propuestas, de 6 citas 1 hace referencia al sexo / género en relación a la mortalidad del IAM, en el apartado del Mapa sanitario de 13 citas ninguna hace referencia el sexo / género. En la bibliografía general referenciada en el Plan, de 15 citaciones ninguna hace referencia al sexo/género y las enfermedades del aparato circulatorio. En relación al género como determinante en las ECV, no queda reflejado en el documento. En una de las líneas de actuación, al referirse al síndrome coronario agudo se señala la importancia de la rapidez y la coordinación en la atención ya que de esto dependerá el pronóstico y la evolución de la enfermedad. Se indica que para alcanzar estos objetivos se debe poner en marcha un proyecto, teniendo en cuenta de manera específica la perspectiva de género y señala como referencia bibliográfica del estudio REGICOR. Ningún objetivo se refiere a mejorar el tiempo entre la aparición del síntoma el pedir ayuda y la respuesta del sistema sanitario. Según las personas responsables de la elaboración del Plan, no se suministró documentación para facilitar la incorporación de la perspectiva de género a las personas implicadas en la redacción del Plan, y tampoco se incorporaron personas con formación de género para su elaboración.

En la formulación de los objetivos, no se tiene en cuenta los resultados de los datos disgregados, aunque los determinantes y factores de riesgo en relación a las ECV son diferentes en los hombres y las mujeres.

No se formulan objetivos específicos en cuanto a la búsqueda de indicadores sensibles al género. No hay ninguna propuesta para disminuir los sesgos de género con el conocimiento existente en relación a las ECV. Las mujeres siguen sin considerarse enfermas cardíacas invisibilizándose el riesgo.

\section{Discusión}

Después de haber analizado los Planes Directores del Departamento de Salud de la Generalitat de Cataluña, que en los DOGC (s) correspondientes en el artículo 2.2 nos señala:

En el desarrollo de estas funciones se hará el seguimiento y la validación del uso de la variante del género, de forma que se tengan en cuenta las especificidades de salud de las mujeres con el objeto de dar respuesta y ofrecer una atención integral ante sus necesidades.

En relación a la visibilidad no todos los datos están disgregados por sexo y las que están se quedan en una mera descripción sin el análisis posterior para poder relacionar las diferencias entre sexos en posibles factores relacionados 
con el género. En relación a la participación hay un porcentaje importante de mujeres en los equipos de los Planes Directores, cabe señalar el Plan Director de Inmigración y el Plan Director Sociosanitario en que el porcentaje de mujeres alcanza un $71 \%$, en este último la codirectora es una mujer, pero el porcentaje disminuye en los grupos de trabajo y queda reflejado las especialidades más masculinizadas (anatomía patológica, las relacionadas en cardiología,..) que no cuentan con ninguna mujer y las más feminizadas que la mayoría son mujeres como pueden ser rehabilitación, mediación, acogida, salud mental, y el grupo de infantil.

El lenguaje sigue siendo androcéntrico y en ocasiones sexista. Habría que tener en cuenta estas consideraciones en los redactados de los Planes. En relación a las imágenes que muestran los Planes (portada, folletos, trípticos,..) aparecen por igual hombres y mujeres y no se aprecian indicios sexistas.

En cuanto a la transversalidad sólo se trabaja con la IDC puntualmente, en el Plan de Inmigración, en el grupo de trabajo del cáncer del cuello uterino que también está incorporada la Red de Mujeres por la Salud y en un objetivo en relación a la violencia de género del plan de Salud mental que nombra el ICD. En relación al género como determinante no utilizan bibliografía en relación al género y el Plan Director determinado, sólo hay una referencia al Plan de las enfermedades cardiovasculares.

Los objetivos de los Planes son muy genéricos y no reflejan las diferencias descritas en el análisis de la situación.

Las personas que han intervenido en la redacción del Plan no han recibido formación en género ni se les ha proporcionado bibliografía en relación al género y el plan determinado.

Aceptamos nuestra hipótesis de partida que la voluntad política de integrar la perspectiva de género en el Sistema Sanitario Catalán, expresada en el artículo 2.2 de todos los Planes Directores, no queda reflejada en la redacción de los mismos y se traduce parcialmente en el diseño de los mismos.

\section{Referencias bibliográficas}

Agencia de investigación de la Sociedad Española de Cardiologia. Enfermedad cardiovascular en la mujer, estudio de la situación en España. Informe realizado para el Observatorio de Salud de la Mujer (OSM). Ministerio de Sanidad y Consumo. Madrid. 2008.

Amo Alonso, Mercedes. Guía para facilitar la incorporación de la perspectiva de génroen los Planes Integrals de salud. Sevilla.Consejeria de Salud. 2008.

AstelarRA, Judith, Veinte años de politicas de igualdad.Madrid.Ediciones Cátedra. 2005. 
Garcia Calvente $\mathrm{M}^{\mathrm{a}}$ del Mar, Jimenez Rodrigo Ma Luisa, Martinez Morante Emilia. Informe de revisión de guias sobre la incorporación de la perspectiva de género a las plíticas de investigación en salud. Observatorio de Salud de la Mujer (OSM). Dirección general de la agencia de Calidad del Sistema nacional de Salud. Secretaria General de Sanidad. Ministerio de Sanidad y Consumo. Escuela Andaluza de Salud Pública. 2005.

GuZMAN,Virginia.La institucionalidad de género en el estado: nuevas perspectivas de análisis.Chile.CEPAL,Série Mujer y Desarrollo,núm 3, 2009.

Generalitat de Catalunya, Pla de Salut de Catalunya a l'horitzó 2010. Departament de Salut. Barcelona: 2008.http://www.gencat.cat/salut/depsalut/html/ca/ plasalut/index.html, última consulta 1-3-2011.

Generalitat de Catalunya. Pla de polítiques de dones del govern de la Generalitat de Catalunya 2008-2011 Institut Català de les dones (ICD). Barcelona 2008.

Generalitat de Catalunya. Pla Director d'Immigració en l'Àmbit de la Salut. Direcció General de Planificació i Avaluació Barcelona. 2006.http://www.gencat. cat/salut/depsalut/html/ca/dir2154/index.html. Consultado 25-9-2010.

Generalitat de Catalunya. Pla Director Socioanitario. Direcció General de Planificació i Avaluació.Barcelona 2006.http://www.gencat.cat/salut/depsalut/html/ ca/dir2154/index.html. Consultado 25-9-2010.

Generalitat de Catalunya. Pla Director d'Oncologia. Direcció General de Planificació i Avaluació Barcelona 2006. http://www.gencat.cat/salut/depsalut/html/ ca/dir2154/index.html. Consultado 25-9-2010.

Generalitat de Catalunya. Pla Director de les Malalties de l'Aparell Circulatori.. Direcció General de Planificació i Avaluació.Barcelona 2006.http://www.gencat.cat/salut/depsalut/html/ca/dir2154/index.html. Consultado 25-9-2010.

MARRUGAT J SALA J, Ribalta A. et al. «Supervivencia a los 10 años de una cohorte de 736 pacientes con un primer infarto de miocardio: ¿Diferencias entre sexos?». Revista española de Cardiologia. 44 (1991), pp. 297-305.

Marrugat J, Sala J, Masià R, Pavesi M, SAnz G, VAlle V «Mortality Differences Between Men and Women Following First Myocardial Infarction». Journal of the American Medical Association (JAMA).280 (1998), pp. 1405-1409.

MARRUGAT, Jaume. SALA, Joan. ABOAL Jaime. «Epidemiologia de las enferedades cardiovasculares en la mujer». Revista Española de Cardiología. 59 (2006), pp. 264-74.

LEY 3/2007, de 22 de marzo, para la igualdad efectiva de mujeres y hombres. (BOE n ${ }^{\circ} 71$ de 23-3-2007)

ORGANIZACIÓN MUNDIAL DE LA SALUD (OMS). Integración de la perspectiva de género en la labor de la OMS. Ginebra 2002. http://whqlibdoc.who.int/ hq/2002/a78343_spa.pdf 
Peiró R, Ramon N, Álvarez-Dardet C, Colomer C, Moya C, Borell C, i altres. «Sensibilidad de género en la formulación de planes de salud en España: lo que pudo ser y no fue. Gaceta Sanitaria. 2004; 18(2).

ROHLfs I, Garcia M, GaVAldÁ L, Medrano MJ, Juvinyà D, BALtasar A.»Genero i cardiopatía isquèmica».Gaceta Sanitaria, 18(2004), pp 54-64.

Ruiz Cantero Ma Teresa, Papí Galvez Natalia.Guía de estadísticas de salud con enfoque de género. Análisis de internet y recomendaciones. Universidad de Alicante. 2007.

Ruiz-Czntero Maria Teresa, CARrasco Portiño Mercedes, ArTAzCoz Lucía. «Logros y retos de género de la Encuesta Nacional de Salud de 2006: análisis de los cuestionarios de adultos y hogar». Gaceta Sanitària, 25(1), pp6-12. 2011.

SIPI, Remei, ARAYA, Mariel. Les dones migrades.Generalitat de Catalunya.Institut Català de les Dones. Barcelona. Quaderns de l'Institut 5. (2007).

VElASCO ARIAS Sara. Recomendaciones para la práctica del enfoque de género en programas de salud. Observatorio de Salud de la Mujer (OSM). Dirección general de la agencia de Calidad del Sistema nacional de Salud. Secretaria General de Sanidad. Ministerio de Sanidad y Consumo Madrid 2008.

VELASCO ARIAS Sara. Informe sobre netodologia y determiantes psicosociales de género en enfermedadfes cardiovasculares de la Comunidad Valenciana Dirección General de salud pública Conselleria de Sanitat. Generalitat Valenciana, 2010. 


\title{
LA ENCUESTA NACIONAL DE SALUD COMO HERRAMIENTA DE MEDICIÓN DE LA DOBLE CARGA Y SOBRECARGA DE TRABAJO EN ESPAÑA. COMPARACIÓN CON LA ENCUESTA DE POBLACIÓN ACTIVA
}

\author{
MerCedes CARRASCO-PorTiÑO \\ Universidad de Alicante \& Universidad De Concepción (Chile) \\ NATALIA PAPÍ-GÁlVEZ \\ María TERESA Ruiz-CANTERO \\ ViCENTE Clemente GÓMEZ \\ JOSÉ FERNÁNDEZ SAEZ \\ Universidad de Alicante
}

Recibido/15/07/2011

Aceptado/29/09/2011

\section{Resumen}

Objetivo: Determinar si la ENS y la EPA de 2006 producen la misma información sobre labores del hogar y doble carga de trabajo en la población de 25 a 64 años, en ambos sexos.

Métodos: Comparación entre las ENS y EPA sobre la forma de recoger información de la doble carga de trabajo. Fuente: Preguntas ENS: actividad económica (C.1.2:categorías 1,2,6), dedicación labores del hogar (A.11:categorías 1,2,3). EPA: actividad económica (H.1:categorías 1,5). Descripción por sexo en España y Comunidades Autónomas (CC.AA).

Resultados: El 43,4\% de las mujeres según la EPA tienen doble carga de trabajo, pero solo un 0,7\% según la ENS. En los hombres el 31,5\% (EPA) y el 0,02\% (ENS). Alternativamente, cruzando a quienes afirman trabajar (C.1.2: categorías 1,2 ) con quienes realizan labores del hogar (A.11:categorías 1,2,3), la doble carga de ambas encuestas se aproxima (Hombres: ENS:31,7\%; EPA:31,5\%; Mujeres: ENS:46,3\%; EPA:43,4\%). 
Ambas encuestas ordenan de forma similar a las CC.AA según la doble carga de trabajo ( $\rho$ mujeres:0,770 ( $\mathrm{p}=0,001)$; phombres:0,647 ( $\mathrm{p}=0,003)$ ).

Conclusión: La pregunta de actividad económica de la ENS subestima la frecuencia de la doble carga de trabajo. Esta es parecida en ambas encuestas, si se cruzan los datos de quienes afirman trabajar con quienes realizan labores del hogar de la ENS. En este caso, ambas encuestas ordenan de igual forma a las CC.AA. La exclusión del adverbio «principalmente» de la categoría sobre dedicación a las labores del hogar de la ENS 2011 normalizará la pregunta sobre actividad económica respecto a las utilizadas en encuestas de salud internacionales y de CC.AA.

Palabras clave: Encuesta de Salud, Trabajo, Labores del hogar, España.

Abstract

Objective: To determine whether the Spanish Health Survey (SHS) and the Labour Force Survey (LFS) from 2006 provide the same information on homework and double burden of work (homework and paid work) in the population aged 25 to 64, for both sexes.

Methods: Comparative study between the SHS and the LFS on how colleting data on the double burden of work. Sources: SHS questions: economic activity (C.1.2:categories 1,2,6), homework (A.11:categories 1,2,3). LFS: economic activity (H.1:categories 1,5). Descriptive study in Spain and the Autonomous Communities.

Results: According to the LFS, $43.4 \%$ of women carry a double burden of work, but only $0.7 \%$ according to the SHS. For men, these figures were $31.5 \%$ (LFS) and $0.02 \%$ (SHS), respectively. Alternatively, double burden is similar in both surveys (Men: SHS:31.7\%; EAPS:31.5\%; Women: SHS:46.3\%; EAPS:43.4\%), when cross-referencing those engaged in productive work (C.1.2:categories 1,2) with those home worker (A.11:categories 1,2,3). Both surveys ranked the Autonomous Communities in similar order according to the double burden of work ( $\rho$ women: $0.770(\mathrm{p}=0.001)$; $\rho$ men: $0.647(\mathrm{p}=0.003))$.

Conclusion: The SHS question on economic activity underestimates the frequency of the double burden of work. This is similar in both surveys when cross-referencing data for those who claim to be economically active with those who report dedicating time to housework in the SHS. In this case, both surveys ranked the Autonomous Communities in the same order. The exclusion of the adverb «principally» from the category of responsibility for housework would bring the question on economic activity into line with international and Autonomous Communities Health Surveys.

Keywords: Spanish Health Survey, Economic activity, Homework, Spain. 


\section{Introducción}

La Encuesta Nacional de Salud realizada en 2006 (ENS-06) fue la primera que planteó entre sus objetivos recoger información que permitiera realizar análisis de la salud de la población desde la perspectiva de género ${ }^{1}$; lo que implica contar con información precisa sobre roles de género y división sexual del trabajo como determinantes de la salud. Es importante, porque existen estudios que detectan efectos perjudiciales en la salud de las mujeres que deben conciliar el trabajo remunerado con las responsabilidades adquiridas con la familia ${ }^{2,3}$. Las mujeres son afectadas por largas jornadas de trabajo en las que tienen experiencias diarias, resultado de las desigualdades de género en la distribución de las tareas domésticas ${ }^{4,5}$. Los problemas de salud comunes incluyen dificultad para dormir, de concentración, memoria e irritabilidad ${ }^{2}$, dolor de cabeza, mareos, mala percepción de salud ${ }^{2,6,7}$, dolencias musculares y esqueléticas ${ }^{8}$, y enfermedades crónicas y de salud mental ${ }^{9}$.

1. Ministerio de Sanidad y Política Social. Encuesta Nacional de Salud año 2006, Metodología. (Citado 18 de octubre 2011). Disponible en: http://www.msps.es/estadEstudios/ estadisticas/encuestaNacional/encuestaNac2006/metodENS2006.pdf

2. Artazcoz, Lucía, Artieda, L., Borrell, Carme, Cortés, Inma, BenaCh, Joan, García, V. «Combining job and family demands and being healthy». Eur J Public Health 14 (2004). pp.43-48.

3. Artazcoz, Lucía, Borrell, Carme, Cortés, Inma, EscribÁ-AgüIr, Vicenta, Cascant, L. "Occupational epidemiology and work related inequalities in health: a gender perspective for two complementary approaches to work and health research».J Epidemiol Community Health 61 (2007). pp. ii39-ii45.

4. Tовío, C. «Working and Mothering. Women's strategies in Spain». European Societies 3 (3) (2001). pp. 339-71.

5. García-Calvente, María del Mar, Mateo-Rodríguez, Inmaculada, Maroto-Navarro, Gracia. «El impacto de cuidar en la salud y la calidad de vida de las mujeres». Gac Sanit 18 (Supl 2) (2004). Pp.83-92.

6. ARTAZCOz, Lucía, BorRell, Carme, BENACH, Joan. «Gender Inequalities in helth among workers: the relation with family demands». J Epidemiol Community Health 55 (2001). pp. 639-47.

7. Rohlfs, Izabella, De Andrés, J., Artazcoz, Lucía, Ribalta, M., Borrell, Carme. «Influencia del trabajo remunerado en el estado de salud percibida de las mujeres». Med Clin (Barc) 108 (1997). pp. 566-71.

8. Torres Aguayo, Alexandra, PARAVic Klijn, Tatiana. «Morbilidad de la mujer trabajadora, servicio de salud Concepción, Chile». Cienc Enferm 11(1) (2005). pp. 73-84.

9. ARTAZCoz, Lucía, Borrell, Carme, BENACH, Joan, Cortés, Inma, RoHLFS, Izabella. «Women, family demands and health: the importance of employment status and socioeconomic position». Soc Sci Med 59(2) (2004). pp. 263-74.

Feminismo/s 18, diciembre 2011, pp. 155-171 
Varias son las fuentes de información que aportan datos sobre la división sexual del trabajo en España. Si el interés radica en precisar la población que se encuentra en esta situación, las encuestas sociológicas y económicas tienen una batería de preguntas más detallada, como sucede en la Encuesta de Población Activa (EPA). Pero, si el interés reside en poder determinar cómo y con qué intensidad la doble carga y la sobrecarga de trabajo influye sobre la salud de la población, encuestas como la Nacional de Salud (ENS) son la principal fuente de información. El proceso de elaboración de cuestionarios estructurados, normalmente con preguntas cerradas, no es sencillo, pues las encuestas tratan de identificar la compleja realidad social agrupando las preguntas dentro del cuestionario por ámbitos temáticos, y dentro de estos las preguntas se complementan para poder tener una visión mas cercana a la realidad. Por lo tanto, comparar cuestionarios de diferentes grupos de encuestas puede contribuir a enriquecer este proceso.

La mayor parte de las definiciones que utiliza la EPA relacionadas con la actividad económica provienen del contexto europeo. Su objetivo es «conocer la actividad económica en lo relativo al componente humano», estando orientada a aportar datos de las principales categorías poblacionales en relación con el mercado de trabajo, y a ofrecer indicadores comparables, especialmente con Europa. Mientras, la ENS, que valora la actividad económica desde la percepción del individuo, pues es esta la que influye en su estado de salud, pretende proporcionar información sobre la salud de la población para la toma de decisiones y la evaluación de políticas sanitarias. Sus preguntas sobre economía tienen interés para el análisis de los determinantes de la salud, y no una finalidad en sí misma.

Si bien la ENS no busca evaluar el número de mujeres con sobrecarga en España, no deja de proponerlo al incorporar preguntas que recoge información sobre trabajo productivo y reproductivo en el año $2006^{10,11}$ tomando como base la información procedente de todas las CC.AA. La ENS tiene 18 preguntas sobre el trabajo productivo y 13 sobre el trabajo reproductivo, mientras que la EPA tiene 84 y 8, respectivamente, existiendo una pregunta

10. Ministerio de Sanidad y Política Social. Encuesta Nacional de Salud 2006. Cuestionario Adulto (Citado 18 de octubre 2011) Disponible en: http://www.msps.es/estadEstudios/ estadisticas/encuestaNacional/encuestaNac2006/ENS_06_Adultos_definitivo.pdf

11. Ministerio de Sanidad y Política Social. Encuesta Nacional de Salud 2006. Cuestionario hogar (Citado 18 de octubre 2011) Disponible en:

http://www.msps.es/estadEstudios/estadisticas/encuestaNacional/encuestaNac2006/ ENS_06_Hogar_definitivo.pdf 
común, similar, sobre el trabajo productivo y reproductivo que permite realizar una comparación entre ellas.

Con la desaceleración de la economía en España y Europa desde $2008^{12}$ es importante analizar la presencia de ambos sexos en el mercado laboral, la doble carga y su impacto en la salud. Por ello, el interés de este trabajo es conocer los cuestionarios y comparar los resultados para valorar cual es la mejor manera de analizar la doble carga y la sobrecarga de trabajo, con el fin de poder analizar los problemas de salud asociados. El objetivo ha sido determinar si la ENS y la EPA del año 2006 producen la misma información sobre labores del hogar y doble carga de trabajo en la población de 25 a 64 años, en ambos sexos.

\section{Material y método}

Estudio descriptivo comparativo de instrumentos de medición del trabajo productivo y reproductivo, por sexo y Comunidad Autónoma, de dos fuentes de información: la Encuesta Nacional de Salud del año 2006 (ENS-06) y la Encuesta de Población Activa del mismo año (EPA-06).

La ENS-06 ha entrevistado a 30.043 personas mayores de 16 años (mujeres: 17.956; hombres: 12.087), estimando una población total para España de 44.339.152 personas $^{13}$. La EPA entrevistó en 2006 a un total de 637.480 personas mayores de 16 años que reside en viviendas familiares principales de todo el territorio nacional (mujeres: 328.833; hombres: 308.647), estimando una población total para España de 43.834 .794 personas $^{14}$.

La Figura 1 describe las preguntas de la ENS-06 (C.1.2 del Cuestionario de Hogar) y la EPA-06 (H.1) que se concentran en extraer similar información sobre la situación en que se encuentran las personas entrevistadas en la semana de referencia con relación al trabajo productivo y a la dedicación de las labores del hogar y las demás alternativas de respuestas ${ }^{11,15}$. Tanto en la metodología de la ENS como en el cuestionario general de la EPA se definen

12. Álvarez GonZÁleZ, José Antonio. «Cambio de ciclo y políticas económicas de estabilización: Una perspectiva en medio de la crisis». Hacienda Canaria 29 (2009). pp. 23-45.

13. Ministerio de Sanidad y Política Social. Encuesta Nacional de Salud 2006. Microdatos. (Citado 18 de octubre 2011). Disponible en: http://www.msps.es/estadEstudios/estadisticas/estadisticas/microdatos/frmListadoMicrodatos.jsp

14. Ministerio de Sanidad y Política Social. Encuesta Nacional de Salud 2006. Metodología detallada. (Citado 18 de octubre 2011). Disponible en: http://www.msps.es/estadEstudios/estadisticas/encuestaNacional/encuestaNac2006/metodENS2006.pdf

15. Instituto Nacional de Estadística. Encuesta de Población Activa. Cuestionario general (Citado 18 de octubre 2011). Disponible en: http://www.ine.es/daco/daco42/daco4211/ epacues05.pdf

Feminismo/s 18, diciembre 2011, pp. 155-171 


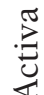

흠

$\frac{\pi}{\sqrt[3]{3}}$

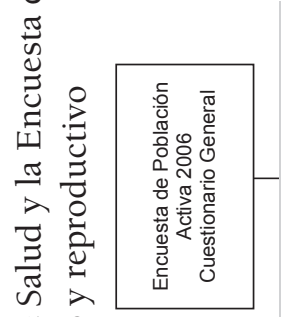

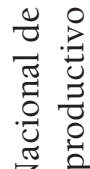

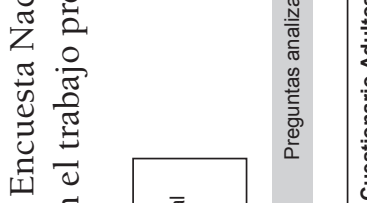

뜽

㫕

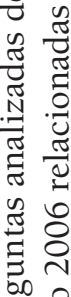

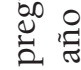

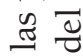

Ð

등

בֶ,

芯

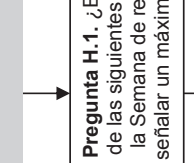

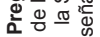
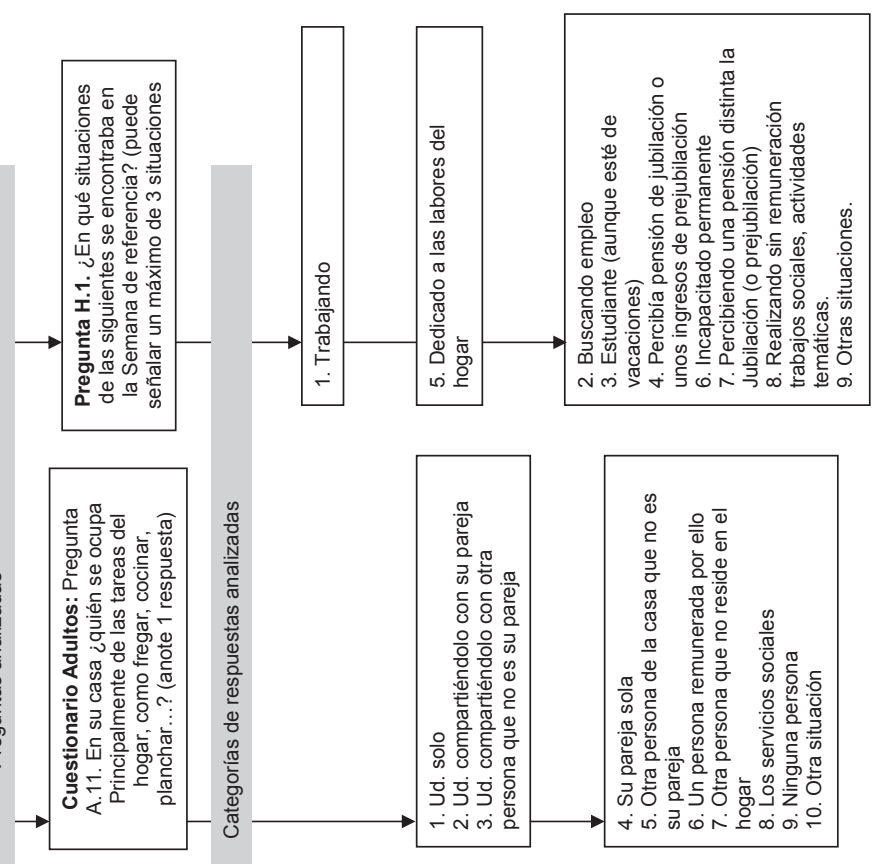

- ते ले
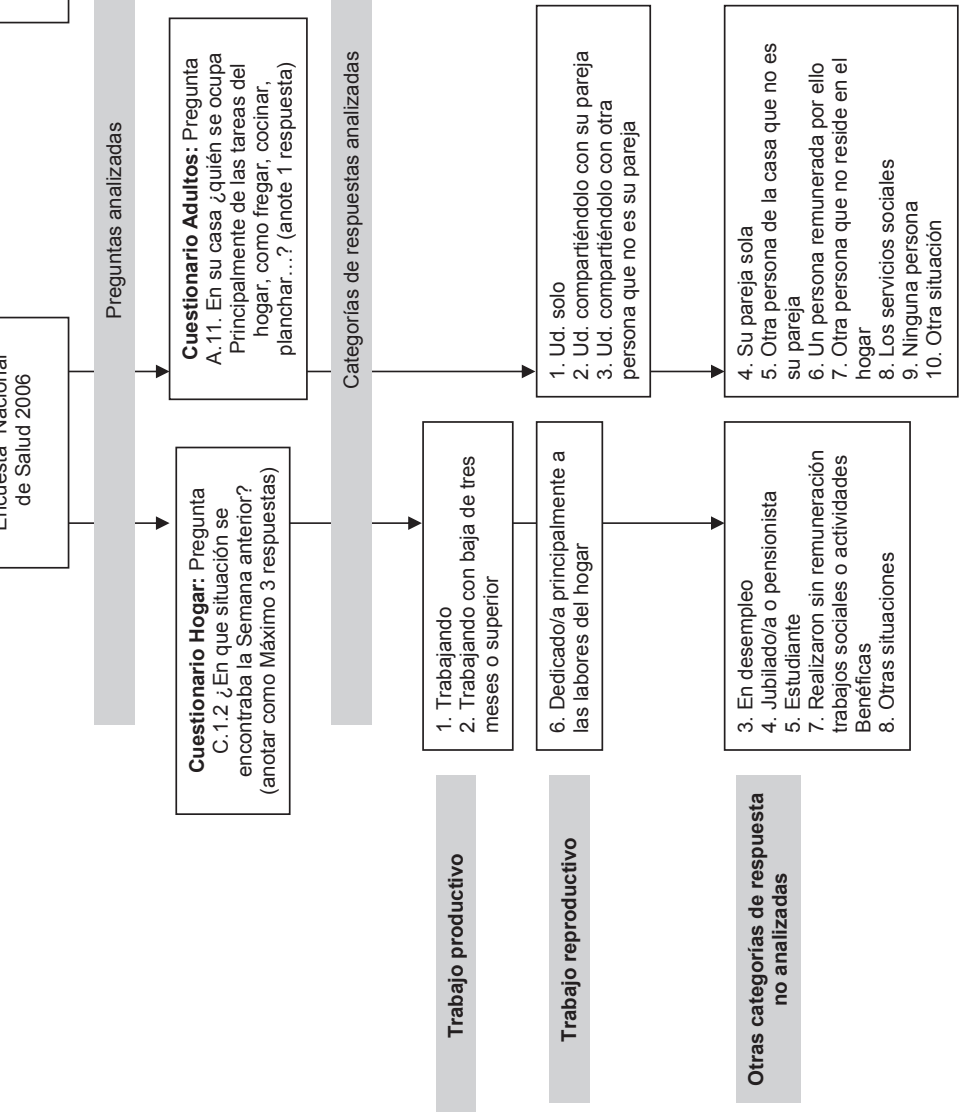

Feminismo/s 18, diciembre 2011, pp. 155-171 
con claridad los conceptos y se establecen criterios de ayuda a la persona entrevistada $^{14,15}$. Destacar, que ambas preguntas ofrecen la posibilidad de señalar hasta 3 respuestas a las personas entrevistadas.

Para la comparación de resultados de las preguntas C.1.2. y H.1 de ambas encuestas se consideraron las siguientes categorías de respuesta: 1) Dedicados/as principalmente a las labores del hogar; 2) Trabajando pero NO dedicados/as principalmente a las labores del hogar; 3) Trabajando y con dedicación/ dedicación principalmente a las labores del hogar; Como se puede observar en la Figura 1, la ENS incluye el adverbio principalmente a la alternativa de dedicación a las labores del hogar, no así la EPA.

Existe no obstante otra posibilidad de calcular la doble carga de trabajo a partir de la ENS. En concreto, cruzando a las personas que respondieron afirmativamente a las categorías trabajando (incluyendo a las que llevaban 3 meses de baja) de la pregunta C.1.2, con la pregunta A.11. del Cuestionario de Adultos sobre dedicación a las labores del hogar (Figura 1). Esta pregunta ofrece la posibilidad de señalar una sola respuesta a las personas entrevistadas.

Se describen los datos de forma desagregada por sexo y Comunidad Autónoma. Para la consecución del objetivo de este estudio se realizaron descripciones absolutas y relativas de las personas que se encontraban con trabajo remunerado, de las personas que se dedicaban a las labores del hogar, y de las personas que estando con un trabajo remunerado se dedicaban a las labores del hogar, tanto, solo, como compartiéndolo con su pareja o con otra persona que no sea su pareja.

Para garantizar que los totales obtenidos fueran compatibles con las cifras oficiales de población, los valores de las muestras para ambas encuestas se han ponderado mediante el factor de ponderación calculado a partir de la media del factor de elevación de las encuestas. Asimismo, para obtener unos porcentajes más comparables se ha restringido el análisis a las edades laborales de 25-64 años, al ser un intervalo de edad frecuentemente utilizado en diferentes estudios que tratan de analizar la doble carga de trabajo. Para calcular por porcentajes se utilizó como referencia la población de 25 a 64 años registrada en el padrón municipal.

Para determinar la correlación entre los resultados de doble carga de trabajo en ambas encuestas, se ha calculado el coeficiente de rangos de Spearman $(\rho)$ para los valores de hombres y mujeres. Análisis realizados con el programa Excel y la suite estadística SPSS 16.0. 


\section{Resultados}

Las Tablas 1 y 2 muestran las frecuencias del trabajo productivo y reproductivo en mujeres y hombres, respectivamente, y por CC.AA; a partir de la

Tabla 1. Magnitud de la dedicación a las labores del hogar, al trabajo remunerado y a la doble jornada de trabajo de las mujeres de 25 a 64 años

en España en el año 2006, según la Encuesta de Población Activa y la Encuesta Nacional de Salud ( ${ }^{a}$ )

\begin{tabular}{|c|c|c|c|c|c|c|c|}
\hline & $\begin{array}{l}\text { EPA Traba- } \\
\text { jando pero } \\
\text { NO dedi- } \\
\text { cadas a las } \\
\text { labores del } \\
\text { hogar }\end{array}$ & \begin{tabular}{|c} 
ENS Traba- \\
jando pero \\
NO dedica- \\
das princi- \\
palmente a \\
las labores \\
del hogar
\end{tabular} & $\begin{array}{c}\text { EPA Dedi- } \\
\text { cadas a las } \\
\text { labores del } \\
\text { hogar }\end{array}$ & $\begin{array}{c}\text { ENS Dedi- } \\
\text { cadas prin- } \\
\text { cipalmente } \\
\text { a las labores } \\
\text { del hogar }\end{array}$ & $\begin{array}{l}\text { EPA Tra- } \\
\text { bajando y } \\
\text { dedicadas a } \\
\text { las labores } \\
\text { del hogar }\end{array}$ & $\begin{array}{c}\text { ENS Tra- } \\
\text { bajando y } \\
\text { dedicadas } \\
\text { principal- } \\
\text { mente a las } \\
\text { labores del } \\
\text { hogar }\end{array}$ & Población \\
\hline & $\%$ & $\%$ & $\%$ & $\%$ & $\%$ & $\%$ & $\mathrm{n}$ \\
\hline Andalucía & 8,8 & 45,2 & 87,6 & 37 & 36,6 & 0 & 2.192 .047 \\
\hline Aragón & 9,1 & 57,6 & 88,7 & 30,8 & 50,1 & 2,2 & 347.269 \\
\hline Asturias & 18,5 & 55,1 & 76,6 & 30,8 & 32,6 & 1 & 315.538 \\
\hline I. Baleares & 14,9 & 64,7 & 81,6 & 21,6 & 49,1 & 0 & 289.387 \\
\hline I. Canarias & 8,4 & 51,1 & 87,9 & 31,5 & 45,7 & 0,3 & 582.127 \\
\hline Cantabria & 29,6 & 55,9 & 64,8 & 29,8 & 27,9 & 0,3 & 164.265 \\
\hline Castilla y León & 10 & 53,3 & 86,9 & 35,4 & 44,6 & 2,8 & 677.150 \\
\hline $\begin{array}{l}\text { Castilla La } \\
\text { Mancha }\end{array}$ & 8,8 & 46,6 & 88,5 & 43,6 & 38,2 & 1,1 & 498.620 \\
\hline Cataluña & 17,1 & 61,6 & 79,8 & 20,8 & 46,4 & 0,2 & 2.033 .914 \\
\hline C. Valenciana & 8,1 & 56,2 & 89,8 & 28,7 & 48,3 & 0,7 & 1.358 .099 \\
\hline Extremadura & 9,9 & 41,9 & 86,9 & 34,9 & 35,6 & 1,7 & 279.394 \\
\hline Galicia & 17,4 & 56,5 & 78,3 & 27,5 & 41,5 & 1,4 & 784.101 \\
\hline Madrid & 19,5 & 59,8 & 76,5 & 27,1 & 44,9 & 0 & 1.815 .774 \\
\hline Murcia & 9,8 & 48,8 & 87,8 & 41,9 & 43,8 & 1,1 & 365.965 \\
\hline Navarra & 9,5 & 57,2 & 88,9 & 35 & 55,4 & 5,8 & 167.543 \\
\hline País Vasco & 12,9 & 60,7 & 85,3 & 29,8 & 48,9 & 1 & 628.505 \\
\hline Rioja & 8,8 & 58,2 & 89,1 & 32,6 & 53,5 & 0 & 83.648 \\
\hline Ceuta & 7,5 & \multirow{2}{*}{36,5} & 88,3 & \multirow{2}{*}{42,5} & 30,5 & \multirow{2}{*}{1,1} & 19.502 \\
\hline Melilla & 16,5 & & 79,2 & & 20,3 & & 16.821 \\
\hline España & 13,1 & 54,8 & 83,6 & 30,4 & 43,4 & 0,7 & 12.619 .669 \\
\hline
\end{tabular}

(a) La EPA y la ENS ofrecen 10 y 8 categorías de respuestas, respectivamente, en la pregunta sobre la actividad económica, y ofrece la oportunidad de responder a 3 de estas categorías, las cuales no son excluyentes como pueden ser trabajando y dedicado/a (principalmente) a las labores del hogar. 
pregunta C.1.2 de la ENS y la pregunta H.1 de la EPA; y las diferencias entre ambas encuestas.

Trabajo productivo. Para el año 2006, según la ENS, el 54,8\% de las mujeres en España realizan trabajo productivo (sin dedicación a las labores del

Tabla 2. Magnitud de la dedicación a las labores del hogar, al trabajo remunerado y a la doble jornada de trabajo de los hombres de 15 a 64 años en España en el año 2006, según la Encuesta de Población Activa y la Encuesta Nacional de Salud ( ${ }^{a}$ )

\begin{tabular}{|c|c|c|c|c|c|c|c|}
\hline & $\begin{array}{l}\text { EPA Traba- } \\
\text { jando pero } \\
\text { NO dedi- } \\
\text { cadas a las } \\
\text { labores del } \\
\text { hogar }\end{array}$ & $\begin{array}{l}\text { ENS Traba- } \\
\text { jando pero } \\
\text { NO dedica- } \\
\text { das princi- } \\
\text { palmente a } \\
\text { las labores } \\
\text { del hogar }\end{array}$ & $\begin{array}{c}\text { EPA Dedi- } \\
\text { cadas a las } \\
\text { labores del } \\
\text { hogar }\end{array}$ & $\begin{array}{c}\text { ENS Dedi- } \\
\text { cadas prin- } \\
\text { cipalmente } \\
\text { a las labores } \\
\text { del hogar }\end{array}$ & $\begin{array}{l}\text { EPA Tra- } \\
\text { bajando y } \\
\text { dedicadas a } \\
\text { las labores } \\
\text { del hogar }\end{array}$ & $\begin{array}{c}\text { ENS Tra- } \\
\text { bajando y } \\
\text { dedicadas } \\
\text { principal- } \\
\text { mente a las } \\
\text { labores del } \\
\text { hogar }\end{array}$ & Población \\
\hline & $\%$ & $\%$ & $\%$ & $\%$ & $\%$ & $\%$ & $\mathrm{n}$ \\
\hline Andalucía & 50,5 & 75,5 & 35,6 & 0 & 26,8 & 0 & 2.239 .034 \\
\hline Aragón & 48,5 & 86,6 & 43,7 & 0,8 & 36,3 & 0,5 & 369.726 \\
\hline Asturias & 60,9 & 66 & 20,5 & 0,5 & 14,3 & 0 & 309.774 \\
\hline I. Baleares & 45,6 & 83,7 & 46,3 & 0,3 & 38,8 & 0 & 304.556 \\
\hline I. Canarias & 40,3 & 73,3 & 48,9 & 0,7 & 38,2 & 0 & 608.542 \\
\hline Cantabria & 66,5 & 77,6 & 19,7 & 0 & 15,2 & 0 & 166.043 \\
\hline Castilla y León & 53,4 & 78,7 & 36 & 0,1 & 29,5 & 0 & 712.585 \\
\hline $\begin{array}{l}\text { Castilla La } \\
\text { Mancha }\end{array}$ & 60,6 & 86,1 & 30 & 0 & 25 & 0 & 533.720 \\
\hline Cataluña & 49,4 & 84,8 & 42,2 & 0 & 36 & 0 & 2.124 .739 \\
\hline C. Valenciana & 44,7 & 84,4 & 47,8 & 0,2 & 38,3 & 0 & 1.408 .325 \\
\hline Extremadura & 52,3 & 79,5 & 33,8 & 0,3 & 23,9 & 0 & 294.492 \\
\hline Galicia & 53,1 & 75,8 & 34,2 & 0,7 & 24,9 & 0 & 771.655 \\
\hline Madrid & 55 & 82,7 & 36,4 & 0,2 & 31,3 & 0 & 1.759 .334 \\
\hline Murcia & 58,2 & 83,1 & 30,6 & 0 & 24,7 & 0 & 398.551 \\
\hline Navarra & 44,6 & 85,8 & 50 & 1,3 & 42,3 & 0,5 & 178.736 \\
\hline País Vasco & 44,9 & 77,6 & 47,3 & 0 & 38,8 & 0 & 636.271 \\
\hline Rioja & 49,7 & 85 & 42,7 & 0 & 36,3 & 0 & 91.841 \\
\hline Ceuta & 41,2 & \multirow{2}{*}{74,3} & 37,10 & \multirow{2}{*}{0} & 27,50 & \multirow{2}{*}{0} & 21.551 \\
\hline Melilla & 58,5 & & 24,70 & & 21,90 & & 18.196 \\
\hline España & 50,8 & 80,5 & 39 & 0,2 & 31,5 & 0,02 & 12.947 .671 \\
\hline
\end{tabular}

La EPA-06 y la ENS-06 ofrecen 10 y 8 categorías de respuestas, respectivamente, en la pregunta sobre la actividad económica, y ofrece la oportunidad de responder a 3 de estas categorías, las cuales no son excluyentes como pueden ser trabajando y dedicado/a (principalmente) a las labores del hogar.

Feminismo/s 18, diciembre 2011, pp. 155-171 
hogar), cifra superior a la recogida por la EPA, que es un 13,1\% (Tabla 1). La diferencia entre ambas encuestas es más marcada que la existente entre los hombres (ENS: 80,5\%; EPA: 50,8\%) (Tabla 2); aunque en unas CC.AA mas que en otras.

Trabajo reproductivo (dedicación a las labores del hogar). Por el contrario, se observa un menor porcentaje de respuestas en la dedicación a las labores del hogar en la ENS en comparación con la EPA. Según la ENS, el 30,4\% de las mujeres en España se dedican principalmente a estas labores, pero según la EPA, se dedica el 83,6\%. Algunas CC.AA. en la ENS tienen valores porcentuales de mujeres dedicadas a las labores del hogar de solo un cuarto de los alcanzados por la EPA en estas CC.AA, como las Islas Baleares (ENS: 21,6\%; EPA: $81,6 \%$ ) (Tabla 1). Lo mismo sucede en el caso de los hombres (Tabla 2), con el agravante de que en la ENS estos valores rondan el cero en prácticamente todas las CC.AA, y en España el valor es del 0,2\%. En la EPA sin embargo, el $39 \%$ de los hombres afirman tener dedicación a las labores del hogar, oscilando en las CC.AA. entre el 19,7\% de Cantabria y el 50\% de Navarra.

Doble carga de trabajo. La EPA ofrece información sobre las personas que realizan trabajo renumerado y se dedican a las labores del hogar conjuntamente a partir de la pregunta H.l, mientras que apenas se obtiene información a partir de las categorías «trabajando» y «dedicados/as principalmente a las labores del hogar» de la pregunta C.1.2 de la ENS. Así, en el total de España, según la ENS solo el 0,7\% de las mujeres tienen doble carga de trabajo, pero según la EPA es un 43,4\% (Tabla 1); y solo un 0,02\% de los hombres según la ENS y un 31,5\% según la EPA. (Tabla 2).

En la Tabla 3 sin embargo se muestra que la información sobre la doble carga de trabajo de la EPA coincide bastante con la obtenida del cruce de la categoría «trabajando» de la pregunta C.1.2 con la categoría de «dedicación a las labores del hogar» de la pregunta A.11 de la ENS. En concreto, para el caso de los hombres no se detectan diferencias significativas en el total de España, ya que realizan actividades relacionadas con la doble carga de trabajo un $31,8 \%$ según la ENS y un 31,5\% según la EPA. Aunque, se siguen detectando diferencias significativas también por este método para el caso de las mujeres, pues según la ENS en España un 46,3\% experimenta la doble carga de trabajo y según la EPA un 43,4\% ( $<<0,001)$.

Es importante destacar que ambas encuestas proporcionan una ordenación parecida de las CC.AA en función de los resultados que aportan sobre la doble carga de trabajo. Este hecho se constata para las mujeres, con un valor del coeficiente de rangos de Spearman igual a 0,770 estadísticamente significativo $(p=0,001)$, y también para los hombres $\rho=0,647(p=0,003)$. 
Tabla 3. Dedicación a las labores del hogar de hombres y mujeres trabajadores en España (25 a 64 años), según la Encuesta Nacional de Salud (ENS) y la Encuesta de Población Activa (EPA), 2006.

\begin{tabular}{|c|c|c|c|c|c|c|c|c|c|c|}
\hline \multirow{3}{*}{ CC.AA. } & \multicolumn{5}{|c|}{ Hombres } & \multicolumn{5}{|c|}{ Mujeres } \\
\hline & $\begin{array}{c}\text { Trabajan- } \\
\text { do y de- } \\
\text { dicados } \\
\text { princi- } \\
\text { palmente } \\
\text { a labores } \\
\text { del hogar } \\
\text { ENS } \\
\text { P.C. } 1.2^{* * *}\end{array}$ & \begin{tabular}{|c|} 
Traba- \\
jando \\
y dedi- \\
cados a \\
labores \\
del hogar \\
EPA \\
P.H.l
\end{tabular} & \begin{tabular}{|c|} 
Traba- \\
jando \\
y dedi- \\
cados a \\
labores \\
del ho- \\
gar: solo, \\
compar- \\
tiendo \\
con su \\
pareja o \\
con otra \\
persona \\
ENS \\
P.A.11*y \\
P.C. $1.2^{* *}$ \\
\end{tabular} & & $\begin{array}{l}\text { Pobla- } \\
\text { ción }\end{array}$ & $\begin{array}{c}\text { Trabajan- } \\
\text { do y de- } \\
\text { dicados } \\
\text { princi- } \\
\text { palmente } \\
\text { a labores } \\
\text { del hogar } \\
\text { ENS } \\
\text { P.C. } 1.2^{* * *}\end{array}$ & \begin{tabular}{|c} 
Traba- \\
jando \\
y dedi- \\
cados a \\
labores \\
del hogar \\
EPA \\
P.H.l
\end{tabular} & \begin{tabular}{|c|} 
Traba- \\
jando \\
y dedi- \\
cados a \\
labores \\
del ho- \\
gar: solo, \\
compar- \\
tiendo \\
con su \\
pareja o \\
con otra \\
persona \\
ENS \\
P.A.11* y \\
P.C.1.1.2*
\end{tabular} & & $\begin{array}{l}\text { Pobla- } \\
\text { ción }\end{array}$ \\
\hline & $\%$ & $\%$ & $\%$ & $p$ & $\mathrm{n}$ & $\%$ & $\%$ & $\%$ & $p$ & $\mathrm{n}$ \\
\hline Andalucía & 0 & 26,8 & 22,31 & $<0,001$ & 2.239 .034 & 0 & 36,6 & 37,8 & 0,4 & 2.192 .047 \\
\hline Aragón & 0,4 & 36,3 & 30,99 & 0,1 & 369.726 & 2,7 & 50,1 & 49,49 & 0,9 & 347.269 \\
\hline Asturias & 0 & 14,3 & 26,69 & $<0,001$ & 309.774 & 1,3 & 32,6 & 42,93 & 0,002 & 315.538 \\
\hline Baleares & 0 & 38,8 & 38,2 & 0,9 & 304.556 & 0,03 & 49,1 & 58,64 & 0,01 & 289.387 \\
\hline Canarias & 0,1 & 38,2 & 36,91 & 0,6 & 608.542 & 0,3 & 45,7 & 42,28 & 0,2 & 582.127 \\
\hline Cantabria & 0 & 15,2 & 33,89 & $<0,001$ & 166.043 & 0,4 & 27,9 & 46,05 & $<0,001$ & 164.265 \\
\hline Castilla León & 0 & 29,5 & 21,51 & $<0,001$ & 712.585 & 1,5 & 44,6 & 43,07 & 0,6 & 677.150 \\
\hline $\begin{array}{l}\text { Castilla La } \\
\text { Mancha }\end{array}$ & 0 & 25 & 31,26 & 0,004 & 533.720 & 1 & 38,2 & 42,41 & 0,1 & 498.620 \\
\hline Cataluña & 0 & 36 & 33,28 & 0,03 & 2.124 .739 & 0,1 & 46,4 & 49,77 & 0,01 & 2.033 .914 \\
\hline C. Valenciana & 0 & 38,3 & 31,83 & $<0,001$ & 1.408 .325 & 0,2 & 48,3 & 50,06 & 0,3 & 1.358 .099 \\
\hline Extremadura & 0 & 23,9 & 19,67 & 0,2 & 294.492 & 1,8 & 35,6 & 34,24 & 0,7 & 279.394 \\
\hline Galicia & 0,3 & 24,9 & 22,09 & 0,2 & 771.655 & 1,3 & 41,5 & 47,61 & 0,007 & 784.101 \\
\hline Madrid & 0 & 31,3 & 45,49 & $<0,001$ & 1.759 .334 & 0,1 & 44,9 & 51,21 & $<0,001$ & 1.815 .774 \\
\hline Murcia & 0 & 24,7 & 27,35 & 0,4 & 398.551 & 1,4 & 43,8 & 41,5 & 0,5 & 365.965 \\
\hline Navarra & 0,7 & 42,3 & 38,29 & 0,4 & 178.736 & 5,1 & 55,4 & 55,43 & 0,9 & 167.543 \\
\hline País Vasco & 0 & 38,8 & 47,48 & $<0,001$ & 636.271 & 0,9 & 48,9 & 52,03 & 0,2 & 628.505 \\
\hline La Rioja & 0 & 36,3 & 32,29 & 0,6 & 91.841 & 0 & 53,5 & 49,74 & 0,6 & 83.648 \\
\hline Ceuta y Melilla & 0 & 25,04 & 8,12 & $<0.001$ & 39.747 & 0,7 & 25,7 & 21,53 & $<0.001$ & 36.323 \\
\hline España & 0,04 & 31,5 & 31,77 & 0.5 & 12.947 .671 & 0,6 & 43,4 & 46,29 & $<0.001$ & 12.619 .669 \\
\hline $\begin{array}{l}\text { Coef. Rangos } \\
\text { Spearman }\end{array}$ & & $\rho 0,647$ & & & & & $\rho 0,77$ & 0,0 & & \\
\hline
\end{tabular}

Cuestionario de adultos de la ENS * Cuestionario de hogar de la ENS**

Feminismo/s 18, diciembre 2011, pp. 155-171 


\section{Discusión}

Este trabajo realiza un aporte metodológico de interés desde la perspectiva de género relacionado con la comparación de la información del trabajo productivo y reproductivo proporcionada por la ENS y por la EPA para el año 2006, inicialmente a partir de la cuestión sobre actividad económica (ENS: C.1.2 y EPA: H.1) compartida por ambas. Los porcentajes ofrecidos por esta pregunta en las dos encuestas son discordantes; tanto en las tareas productivas como en las reproductivas. La ENS reporta cifras de dedicación al trabajo productivo mayores que la EPA en ambos sexos, siendo las diferencias pequeñas en los hombres, y más marcadas en las mujeres. Esto sucede en el conjunto de España y en la mayoría de sus CC.AA. Por el contrario, la ENS alcanza frecuencias de dedicación al trabajo reproductivo menores que la EPA en ambos sexos. Esto es especialmente llamativo para el caso de los hombres, pues en la ENS los porcentajes rondan el cero en España y prácticamente todas las CC.AA, lo que podría ser debido entre otras razones, a la inclusión del adverbio «principalmente» en la formulación de la categoría sobre dedicación a las labores del hogar de la pregunta sobre actividad económica de la ENS, que no existe en la categoría semejante de la EPA. De hecho, al seleccionar a las personas que dicen trabajar en la pregunta sobre actividad económica de la ENS, e identificar quienes de ellas realizan tareas del hogar (solo/a, o compartiéndolo con la pareja u otra persona) a partir de una pregunta a propósito para obtener esta información (A.11), se obtienen resultados más concordantes con los de la EPA sobre la doble carga de trabajo para ambos sexos; pero sobre todo para las mujeres. Incluso, ambas encuestas ordenan a las CC.AA de igual forma respecto a la doble carga de trabajo, así como identifican mayor variación en los resultados por CC.AA para el caso de los hombres que para el de las mujeres. La ENS de 2006 mejoró sustancialmente la perspectiva de género al ampliar el ámbito temático relacionado con el trabajo reproductivo, además de otros ámbitos de la misma. Ligeros cambios puede mejorar más aún la información que aportarán las ENS sobre el trabajo reproductivo y, consecuentemente, sobre la doble carga de trabajo.

Ambas encuestas contienen más preguntas sobre el trabajo productivo y reproductivo que las analizadas, por lo que una de las limitaciones de este trabajo se relaciona con el riesgo de descontextualizar las preguntas sobre actividad económica (ENS: C.1.2 y EPA: H.1), no solo del resto de preguntas del mismo ámbito del cuestionario sino, y especialmente, también del objetivo y la metodología de cada una de las dos encuestas. No obstante, las preguntas seleccionadas permiten reflexionar de forma eficiente sobre la importancia de normalizar las fuentes de información, y las consecuencias de no hacerlo. Y 
de ahí la importancia de cruzar la categoría de respuesta «trabajando» de la pregunta C.1.2 de la ENS con la pregunta A.11 sobre «dedicación a las labores del hogar»; así como lo es para la lectura de este artículo, tener a mano la metodología de ambas encuestas ${ }^{14,15}$.

Además de su redacción, el número de categorías de la pregunta es diferente. La EPA tiene 9 categorías y 8 la ENS. Las categorías en la EPA son compatibles con estar trabajando, mientras que en la ENS trabajar es la suma de dos de las categorías (trabajando y trabajando con baja de 3 meses o superior), y hay otra categoría (incapacidad permanente) incompatible, por lo que en definitiva sólo 5 categorías de respuesta son compatibles. Por tanto, las probabilidades de escoger una categoría, permitiendo 3 categorías de respuesta como máximo, es diferente en ambas encuestas. No obstante, paradójicamente, los resultados muestran un comportamiento diferente al esperado, con un porcentaje de personas dedicadas a labores del hogar más elevado en la EPA, cuando las probabilidades de selección son menores. Este es el motivo que hizo sospechar que la forma en que está confeccionada esta alternativa de respuesta en la ENS -adverbio «principalmente» añadido dentro de la formulación de esta alternativa de respuesta: «dedicado/a principalmente a las labores del hogar»-pudiera dificultar a quienes responden el reconocerse en esta actividad, al tener que contemplar que la ENS se refiere a una dedicación principal, e induce a dar prioridad a la categoría de trabajo remunerado, aunque realicen ambas actividades. La consecuencia sería una disminución de la frecuencia del trabajo reproductivo y con doble carga de trabajo de las mujeres, y sobre todo de los hombres.

La dedicación a las labores del hogar es irrenunciable, normalmente tanto la realización como la planificación recae en las mujeres, y el hecho de que los hombres señalen, en una de las tres categorías que se dedica a las labores del hogar, no resuelve el problema de las horas y la responsabilidad en la dedicación, que es lo que diferencia hombres y mujeres. La ENS-06 ha mejorado su perspectiva de género, incorporando una sección para recoger información sobre las horas de dedicación al trabajo reproductivo ${ }^{16}$. Así pues por caer fuera de los objetivos de este trabajo, otra de las limitaciones es que esta única pregunta es insuficiente para identificar la población con doble carga de trabajo.

En los 15 países de la Unión Europea de los que se disponen datos homogéneos, las mujeres trabajan más tiempo que los hombres en el ámbito doméstico y menos en el mercado. En ningún país, la media femenina de horas

16. Ruiz-Cantero, María Teresa, Carrasco-Portiño, Mercedes, Artazcoz, Lucía. «Logros y retos de género de la Encuesta Nacional de Salud de 2006: análisis de los cuestionarios de adultos y hogar». Gac Sanit 25(1)(2011). pp. 6-12.

Feminismo/s 18, diciembre 2011, pp. 155-171 
dedicadas al trabajo remunerado y al estudio supera a las destinadas a los cuidados y tareas domésticas. El fenómeno opuesto ocurre con los hombres, empleando casi 2 horas más de media al trabajo remunerado que al doméstico, casi el mismo tiempo que las mujeres destinan de más al trabajo doméstico que al remunerado ${ }^{17}$.

En España, según la EPA-06, el 31\% de las mujeres que responde no trabajar en jornada completa, se debe a obligaciones familiares; cifra que en los hombres es del 3,5\% ${ }^{18}$. Por tanto, reconociendo que las mujeres trabajan diferente que los hombres, la inclusión del adverbio «principalmente» para las labores del hogar de la ENS presenta el inconveniente de no permitir medir la sobrecarga de trabajo en quienes dedicándose a las labores del hogar no consideran que lo hagan «principalmente». Será interesante comprobar en qué medida la eliminación de este adverbio de la categoría de respuesta «dedicación a las labores del hogar» que se efectúe en la ENS futura, aproxima los resultados sobre las labores del hogar y la doble carga y sobre carga de trabajo.

Cabe señalar como se refieren otras encuestas de salud a la pregunta sobre actividad principal de la persona encuestada. El enunciado sobre la ocupación de la Encuesta de Salud de Suecia incluye una alternativa sobre labores del hogar similar a la de la EPA, junto con el trabajo remunerado ${ }^{19}$. La General Lifesytle Survey del Reino Unido incluye una pregunta sobre el cuidado de la casa familiar junto con dos opciones de trabajo remunerado: jornada completa y parcial ${ }^{20}$. Estas opciones también están en la ENS pero no en la misma pregunta.

Considerando posibles ventajas de la normalización de las encuestas de salud realizadas en España y sus CC.AA. para realizar estudios comparativos, hay que destacar que las principales diferencias entre la ENS con encuestas como la vasca y catalana estriban en que no contienen este adverbio en la categoría de dedicación a las labores del hogar. Pero, contienen una pregunta

17. European Commission. Eurostat. How is the time of women and men distributed in Europe? Statistics in focus. Population and social condition.2006; 4: 1-12. (Citado 19 de octubre de 2011) Disponible en: http://epp.eurostat.ec.europa.eu/cache/ITY_OFFPUB/KS-NK-06-004/EN/KS-NK-06-004-EN.PDF

18. Instituto Nacional de Estadística. Encuesta de Población Activa 2006. Microdatos. (Citado 18 de octubre 2011) Disponible en: http://www.ine.es/prodyser/micro_epa.htm

19. Swedish National Institute for Public Health. National Survey of Public Health of Sweden. Health on Equal Terms? A Survey of health and living conditions in Sweden, 2007. (Citado 21 de octubre 2011) Disponible en: http://www.fhi.se/Documents/ English/Highlights/survey-English-2007.pdf

20. Office for Nacional Statistics. General Household Survey of United Kingdom. Household and Individual Questionnaries. Appendix E. 2007. (Citado 18 de octubre 2011). Disponible en: http://www.statistics.gov.uk/StatBase/Product.asp?vlnk=5756 
sobre la situación laboral, permitiendo solo una respuesta ${ }^{21,22}$; mientras que la EPA y la ENS permiten hasta tres respuestas posibles, dificultando el análisis y la comparación si los datos no están ponderados según el número de respuestas señaladas. Además, la encuesta vasca, en el cuestionario familiar incluye una primera para todos los miembros de la familia una pregunta sobre la frecuencia en la realización de las labores del hogar (35.i) y posteriormente incluye una pregunta sobre la situación laboral (36.b) ${ }^{22}$.

La ENS y la EPA tienen en común ser realizadas en y por el mismo contexto administrativo y su interés en recolectar datos cuantitativos o estadísticos de carácter oficial para objetivar la aplicación de políticas. Pero la EPA tiene distinto universo empírico y procedimiento metodológico a la ENS; por lo que no siendo del todo adecuado pretender utilizar una pregunta de la EPA, e introducirla en el cuestionario de la ENS para analizar los problemas de salud derivados de la doble carga de trabajo; según nuestro criterio merece la pena pensar en ello. En definitiva, como se comentó en la introducción, la mayor parte de las definiciones que utiliza la EPA relacionadas con la actividad económica provienen del contexto europeo hacia el que deberíamos tender también en las encuestas de salud.

La planificación de los contenidos recogidos en la ENS sin duda debe ser consistente con las encuestas precedentes por el respeto a las series temporales y por que posibilita la comparación entre encuestas. Pero, este hecho puede ser una barrera para identificar la relación entre el estado de salud y realidades sociales que han emergido desde las primeras encuestas, como la sobrecarga de trabajo de las mujeres con doble jornada por su incorporación creciente al mercado laboral.

\section{Referencias bibliográficas}

Álvarez GonzÁlez, José Antonio. Cambio de ciclo y políticas económicas de estabilización: Una perspectiva en medio de la crisis. Hacienda Canaria 29 (2009). pp. 23-45.

Artazcoz, Lucia, Artieda, L., Borrell, Carme, Cortés, Inma, BenaCh, Jan, GarCíA, V. Combining job and family demands and being healthy. Eur J Public Health. 14 (2004). pp. 43-48.

21. Generalitat de Catalunya. Departament de Salut. Encuesta de Salud de Catalunya, 2006. (Citado 18 de octubre 2011) Disponible en: http://www.gencat.cat/salut/depsa$\mathrm{lut} / \mathrm{html} / \mathrm{ca} / \mathrm{plasalut} / \mathrm{genecatdef2006.pdf}$

22. Gobierno Vasco. Departamento de Salud. (Citado 18 de octubre 2011). Disponible en:http://www.osanet.euskadi.net/r85escav/es/contenidos/informacion/encuesta_salud_cuestionarios/es_escav/adjuntos/individual.pdf

Feminismo/s 18, diciembre 2011, pp. 155-171 
Artazcoz, Lucía, Borrell, Carme, BenaCh, Joan, Cortés, Inma, Rohlfs, Izabella. Women, family demands and health: the importance of employment status and socioeconomic position. Soc Sci Med 59(2)(2004). pp. 263-74.

Artazcoz. Lucía, Borrell. Carme, Cortés. Inma, EscribÁ-AGÜIr. Vicenta, CASCANT. Lorena. Occupational epidemiology and work related inequalities in health: a gender perspective for two complementary approaches to work and health research. J Epidemiol Community Health 61 (2007) pp. ii39-ii45.

European Commission. Eurostat. How is the time of women and men distributed in Europe? Statistics in focus. Population and social condition. 2006; 4: 1-12. (Citado 19 de octubre de 2011) Disponible en: http://epp.eurostat.ec.europa. eu/cache/ITY_OFFPUB/KS-NK-06-004/EN/KS-NK-06-004-EN.PDF

García-Calvente, María del Mar, Mateo-Rodríguez, Inmaculada, MarotoNAVARro, Gracia. El impacto de cuidar en la salud y la calidad de vida de las mujeres. Gac Sanit 18 (Supl. 2)(2004). pp. 83-92.

Artazcoz, Lucía, Borrell, Carme, BenACH, Joan. Gender Inequalities in helth among workers: the relation with family demands. J Epidemiol Community Health 55 (2001). pp. 639-47.

Generalitat de Catalunya. Departament de Salut. Encuesta de Salud de Catalunya, 2006. (Citado 18 de octubre 2011) Disponible en: http://www.gencat.cat/salut/depsalut/html/ca/plasalut/genecatdef2006.pdf

Gobierno Vasco. Departamento de Salud. (Citado 18 de octubre 2011). Disponible

en:http://www.osanet.euskadi.net/r85escav/es/contenidos/informacion/encuesta_salud_cuestionarios/es_escav/adjuntos/individual.pdf

Instituto Nacional de Estadística. Encuesta de Población Activa. Cuestionario general (Citado 18 de octubre 2011). Disponible en: http://www.ine.es/daco/ daco42/daco4211/epacues05.pdf

Instituto Nacional de Estadística. Encuesta de Población Activa 2006. Microdatos. (Citado 18 de octubre 2011) Disponible en: http://www.ine.es/prodyser/ micro_epa.htm

Ministerio de Sanidad y Política Social. Encuesta Nacional de Salud año 2006, Metodología. (Citado 18 de octubre 2011). Disponible en: http://www.msps. es/estadEstudios/estadisticas/encuestaNacional/encuestaNac2006/metodENS2006.pdf

Ministerio de Sanidad y Política Social. Encuesta Nacional de Salud 2006. Cuestionario Adulto (Citado 18 de octubre 2011) Disponible en: http://www. msps.es/estadEstudios/estadisticas/encuestaNacional/encuestaNac2006/ ENS_06_Adultos_definitivo.pdf

Ministerio de Sanidad y Política Social. Encuesta Nacional de Salud 2006. Cuestionario hogar (Citado 18 de octubre 2011) Disponible en: http://www.msps. es/estadEstudios/estadisticas/encuestaNacional/encuestaNac2006/ENS_06_ Hogar_definitivo.pdf 
Ministerio de Sanidad y Política Social. Encuesta Nacional de Salud 2006. Metodología detallada. (Citado 18 de octubre 2011). Disponible en: http://www. msps.es/estadEstudios/estadisticas/encuestaNacional/encuestaNac2006/metodENS2006.pdf

Ministerio de Sanidad y Política Social. Encuesta Nacional de Salud 2006. Microdatos. (Citado 18 de octubre 2011). Disponible en: http://www.msps.es/ estadEstudios/estadisticas/estadisticas/microdatos/frmListadoMicrodatos.jsp

Rohlfs, Izabella, De Andrés, J., Artazcoz, Lucía, Ribalta, M., Borrell, Carme. Influencia del trabajo remunerado en el estado de salud percibida de las mujeres. Med Clin (Barc) 108(1997). pp. 566-71.

Ruiz-Cantero, María Teres, Carrasco-Portiño, Mercedes, Artazcoz, Lucía. Logros y retos de género de la Encuesta Nacional de Salud de 2006: análisis de los cuestionarios de adultos y hogar. Gac Sanit 25(1) (2011). pp. 6-12.

Swedish National Institute for Public Health. National Survey of Public Health of Sweden. Health on Equal Terms? A Survey of health and living conditions in Sweden, 2007. (Citado 21 de octubre 2011) Disponible en: http://www.fhi.se/ Documents/English/Highlights/survey-English-2007.pdf

Office for Nacional Statistics. General Household Survey of United Kingdom. Household and Individual Questionnaries. Appendix E. 2007. (Citado 18 de octubre 2011). Disponible en: http://www.statistics.gov.uk/StatBase/Product. asp? vlnk=5756

Toвío, C. Working and Mothering. Women's strategies in Spain. European Societies 3 (3) (2001). pp. 339-71.

Torres Aguayo, Alexandra, PARAvic Klijn, Tatiana. Morbilidad de la mujer trabajadora, servicio de salud Concepción, Chile. Cienc Enferm 11(1)(2005). pp. 73-84. 



\title{
PROPUESTA DE INDICADORES PARA UN PERFIL SOBRE SALUD DE LAS MUJERES EN LA COMUNIDAD VALENCIANA
}

\author{
Vita AsCENSió ARRUfat GALLÉN \\ Programas de Promoción de la Salud Centro de Salud Pública Castelló \\ ROSA MARIA MARÍN TORRENS \\ Jefa de Servicio de docencia Escuela Valenciana de estudios para la Salud
}

Recibido/15/07/2011

Aceptado/25/09/2011

\section{Resumen}

Con el fin de determinar el perfil de la salud del colectivo de mujeres de un área o departamento de salud, en este artículo se proponen indicadores básicos agrupados en: Situación Demográfica, Situación política y socio económica, Status de Salud, Modos de Vida, Medio Ambiente, Servicios para el Cuidado de la Salud y Políticas Públicas de desarrollo.

Palabras clave: Salud, perfil, mujeres, desarrollo.

\begin{abstract}
In order to establish the health profile of a group of women belonging to a health area or department, in this paper we put forward some basic indicators according to: Demographic Situation, Politic and Socioeconomic Situation, Health Status, Mode of Life, Environment, Health Service and Public Policies for Development.
\end{abstract}

Keywords: Health, profile, women's, development. 



\section{Introducción}

En el trabajo sobre «Principios generales para un perfil sobre mujer y salud», donde relacionamos los datos necesarios para la recogida de información que servirán para evaluar los progresos realizados en la salud de las mujeres en la Comunidad $^{1}$, se asumen los planteamientos de la Conferencia sobre la salud de las mujeres de Europa Central y del Este «La salud de las mujeres cuenta», realizada en Febrero de 1994. Estos se basan en los principios de Inversión en salud de las mujeres, Derechos humanos, Una vida saludable, Recursos para la Autonomía de las mujeres (empoderamiento), Servicios adecuados y acogedores para las mujeres y Relaciones de género.

Un indicador es un instrumento de medición construido teóricamente para ser aplicado a un conjunto de unidades de análisis con el propósito de producir un número que cuantifica algún concepto asociado a ese colectivo ${ }^{2}$. Y además es el reflejo de situaciones a tres niveles de aproximación. El primer nivel mide el estado de un evento específico, el segundo nivel es trazador de eventos afines y representa a un grupo mayor de indicadores de los cuales se considera representativo; y el tercer nivel es indicativo de situaciones mucho más generales que se suponen asociadas con el evento específico objeto de medición ${ }^{3}$.

Utilizar como unidad de análisis el hogar para conocer el diagnóstico de salud de una comunidad como se hace en las encuestas del Instituto Nacional de Estadística (INE) no aporta información sensible a la perspectiva de género. Tampoco aporta información por sexo de la población general si en los indicadores no se estratifica por sexo ${ }^{4}$. Por lo tanto, al referirnos a la perspectiva

1. Arrufat, Vita; Calvo, Consuelo. Guía para la elaboración del Perfil de Salud de las mujeres. Forum mujer trabajo y salud. Barcelona febrero 1995.

2. Guía para la elaboración del programa de la mujer en atención primaria de salud. Ministerio de Sanidad y Consumo. Colección Atención Primaria de Salud 4. Dirección General de Planificación Sanitaria. Madrid 1985.

3. Propuesta de un sistema de indicadores sociales de igualdad entre géneros. Ministerio de Asuntos Sociales. Serie estudios 39. Instituto de la Mujer. Madrid 1994.

4. Leticia Artiles. Critica desde la perspectiva de género al «Índice de equidad de la contribución financiera» Informe de la OMS 2000. El problema de la equidad financiera en

Feminismo/s 18, diciembre 2011, pp. 173-184 
de género lo hacemos entendiéndolo referido al significado social ${ }^{5}$ construido alrededor de la diferencia sexual, basado fundamentalmente en la división por sexo de los roles y el poder ${ }^{6}$. El objeto de interés en materia de género no es la mujer o el hombre, perse; son las relaciones de desigualdad social entre mujeres y hombres, y el impacto que esta desigualdad ejerce sobre la vida de las personas ${ }^{7}$.

Las mujeres, por su capacidad reproductora y capacidad como cuidadoras, requieren mayor atención de salud, por ello es necesario utilizar indicadores de salud poblacionales diferenciados por $\mathrm{sexo}^{8}$, aquí priorizamos los relativos a las mujeres.

El objetivo de este trabajo es proponer indicadores básicos a considerar para la realización de un diagnóstico de salud desde la perspectiva de género, para cuya identificación se han considerado las características: Relevancia, Perdurabilidad, Fácil comprensión, Viabilidad, Fiabilidad y Validez.

\section{Recomendaciones de indicadores de salud desde la perspectiva de género}

En una primera revisión se consideran indicadores necesarios: La Situación Demográfica, la Situación política y socioeconómica, el Estatus de salud, los Modos de vida (lifestyles), Medio ambiente, los Servicios para el cuidado de la salud y las Políticas de desarrollo.

La situación demográfica (tabla I): se considera necesaria para caracterizar la población de mujeres a estudiar y la proporción de hombres agrupados por edad, ambos datos de la pirámide de población. Los índices de nacimiento por

salud. Memorias del seminario internacional el derecho a la Salud y la Equidad en los servicios de salud. Bogota, abril 27 y 28 de 2001. Plataforma Interamericana de Derechos Humanos, Democracia y Desarrollo. Observatorio universitario de política social y calidad de vida, ALAMES. Octubre 2001 The need for Objetive and Subjetive Indicatorrs in Gender Statistics (Paper presented at the APEC Experts meeting on Gender, and Science and Technolofy, Manila, Philipines March 10-11, 1998.

5. Historia y género. Las mujeres en la Europa moderna y contemporanea. Edición a cargo de James S. Amelang y Mari Nash. Edicions Alfons el Magnànim. Institut Valencià d'estudis i investigació. 1990.

6. Medicines i Gènere. El torsimany necessari. Alizabeth Mora Torres, Albert Gras i Marti (coords.) Revista Feminismo/S del Centro de Estudios sobre la mujer de la Universidad de Alicante. Núm. 10, diciembre de 2007.

7. Estrategia europea para la salud y el desarrollo de la infancia y la adolescencia. Herramienta de género. WHO europe. 2007 documento de trabajoormation/

8. Los determinantes sociales de la salud. Los hechos probados. Richard Wilkison y Michael Marmot.Ministerio de Sanidad y Consumo. Secretaria General de Sanidad. Dirección General de Salud Pública. Subdirección General de Promoción de la Salud y Epidemiología. OMS Europa. 
Tabla I. Situación Demográfica

\begin{tabular}{|l|l|}
\hline I. 1 & Total población* \\
\hline I. 2. & Población de mujeres por grupos de edad. \\
\hline I. 3. & Porcentaje de mujeres en la población total. \\
\hline I. 4. & Porcentaje de población rural y urbana por sexos. \\
\hline I.5. & Índice de nacimientos por 1.000 habitantes en población rural y urbana. \\
\hline I. 6. & Índice de mortalidad natural por sexo por 100.000 habitantes. \\
\hline I. 7. & Crecimiento natural de la población. \\
\hline I. 8. & $\begin{array}{l}\text { Índice de fertilidad, abortos y natalidad por grupos de edad en población } \\
\text { urbana. }\end{array}$ \\
\hline I.9. & Índice de fertilidad abortos y natalidad por grupos de edad en población rural. \\
\hline I. 10. & Edad del primer matrimonio por sexos, en zona rural y urbana. \\
\hline I. 11. & Índice de matrimonios por 1.000 habitantes. \\
\hline I. 12. & Índice de divorcios por 1.000 habitantes en hombres y mujeres. \\
\hline
\end{tabular}

* datos de especial relevancia e interés. Obligado conocer.

zonas rural y urbana y la mortalidad que incluye los fallecimientos de hombres y mujeres, ambos forman parte del crecimiento natural de la población.

Los índices de fertilidad, abortos y natalidad en población rural y urbana se necesitan para conocer la salud sexual y reproductiva. Se incluyen también el índice de matrimonios y divorcios por sexo, para observar las diferencias entre hombres y mujeres en situaciones que pueden ser traumáticas. Influye en la selección la facilidad de recogida por provincias y municipios en la web del INE. ${ }^{9}$

La situación política y socio-economica (tabla II): se ha considerado interesante su recogida para identificar la capacidad de autonomía económica de las mujeres, primordial para el disfrute de los derechos humanos, y derechos de las mujeres. Algunos de los indicadores de este apartado como el porcentaje de escaños parlamentarios ocupados por mujeres, y el promedio de horas de trabajo de las mujeres incluyendo el trabajo remunerado y no remunerado, se han recogido en los informes del Instituto de la Mujer ${ }^{10}$. Algunos de los indicadores de este y otros apartados no pueden disponerse por sexos en los Departamentos de Salud, aún así se relacionan para ir creando conciencia de las diferencias y las aportaciones de los mismos en el análisis por sexos. El número de familias monoparentales se extrae del INE.

\footnotetext{
9. http://www.ine.es/

10. Consultada 21 marzo 2011, http://www.inmujer.es/ss/Satellite?pagename=InstitutoMu jer\%2FPage\%2FIMUJ_Home
} 
Tabla II. Situación política y socioeconómica

\begin{tabular}{|l|l|}
\hline II. 1. & PIB per cápita. \\
\hline II. 2. & Ingresos de las mujeres como porcentaje de los ingresos de los hombres. \\
\hline II. 3. & $\begin{array}{l}\text { Mujeres con trabajo, como porcentaje del total de población ocupada. Tasa } \\
\text { bruta de actividad y tasa corregida. Tasa bruta de empleo y tasa corregida. }\end{array}$ \\
\hline II. 4. & $\begin{array}{l}\text { Distribución numérica y porcentual de la población femenina por sectores de } \\
\text { actividad. Sectores de agricultura, industria, construcción y servicios. }\end{array}$ \\
\hline II. 5. & Mujeres en paro como porcentaje del total de parados de la población. \\
\hline II. 6. & Porcentaje de escaños parlamentarios ocupados por mujeres. \\
\hline II. 7. & Trabajo administrativo y de dirección, porcentaje de mujeres. \\
\hline II. 8. & Porcentaje de mujeres médico. \\
\hline II. 9. & $\begin{array}{l}\text { Porcentaje de mujeres que ocupan puestos de antigüedad en el sistema de salud. } \\
\text { (\% de jefaturas de servicio ocupados por mujeres). }\end{array}$ \\
\hline II. 10. & $\begin{array}{l}\text { Promedio de horas de trabajo en mujeres, incluyendo trabajo remunerado y no } \\
\text { remunerado. }\end{array}$ \\
\hline II. 11. & Nivel cultural por grupos de edad y sexo. Nivel de estudios \\
\hline II. 12. & $\begin{array}{l}\text { Familias monoparentales cuya cabeza sea mujer en relación al total de familias } \\
\text { monoparentales. (Mujeres con personas a su cargo: niños y/o adultos). }\end{array}$ \\
\hline II. 13. & Cartillas titulares de activos por sexo. \\
\hline II. 14. & Cartillas de pensionistas por sexos. \\
\hline II. 15. & $\begin{array}{l}\text { Porcentaje de catedráticas mujeres y número absoluto de catedráticas y } \\
\text { catedráticos en la Universidad local/es. }\end{array}$ \\
\hline II. 16. & $\begin{array}{l}\text { Ocupación y situación profesional: Población ocupada según tipo de ocupación } \\
\text { y sexo }\end{array}$ \\
\hline
\end{tabular}

El Status de salud (tabla III): se ha medido utilizando las 10 primeras causas de Mortalidad y las 5 primeras causas de morbilidad hospitalaria en mujeres, datos disponibles online $e^{11}$ que permiten la comparación. ${ }^{12}$

Se detallan indicadores de cobertura de los programas de salud dirigidos a mujeres y hombres, y los que se dirigen a la atención sanitaria de la función reproductora de las mujeres. La morbilidad sentida se selecciona por indicar la percepción de las mujeres y su entorno. Del INE se extraen indicadores utilizados para conocer la calidad de la atención a la maternidad, entre otros las defunciones por complicaciones del embarazo, parto y puerperio, la mortalidad neonatal precoz y tardía por sexo, mortalidad perinatal e infantil por

11. Consultado 21 de marzo 2011, http://www.ine.es/jaxi/menu.do?type=pcaxis\&path=/ $\mathrm{t} 15 / \mathrm{p} 414 \&$ file $=$ inebase $\& \mathrm{~L}=0$

12. Consultado 21 marzo 2011, http://www.ec.europa.eu/eurostat 


\section{Tabla III. Status de Salud}

\begin{tabular}{|l|l|}
\hline III. 1. & Diez primeras causas de mortalidad en la población femenina. \\
\hline III. 2. & Cinco primeras causas de morbilidad hospitalaria atendida en mujeres. \\
\hline III. 3. & Estancia media hospitalaria por sexo. \\
\hline III. 4. & $\begin{array}{l}\text { Cinco primeros programas con mayor número de usuarios incorporados } \\
\text { en atención primaria, según el Sistema de Información para la Gestión de } \\
\text { Atención Primaria (SIGAP) Actualmente SIP }\end{array}$ \\
\hline III. 5. & $\begin{array}{l}\text { Cobertura de los programas de seguimiento del embarazo, planificación } \\
\text { familiar y atención integral a la mujer climatérica, mujer mayor de 40 años. }\end{array}$ \\
\hline III. 6. & $\begin{array}{l}\text { Morbilidad sentida por las mujeres. Encuesta de salud de la población de área } \\
\text { de Salud }\end{array}$ \\
\hline III. 7. & Prevalencia de discapacidades y minusvalías por grupos de edad y sexo. \\
\hline III. 8. & Defunciones por complicaciones de embarazo, parto y puerperio. \\
\hline III. 9. & Mortalidad neonatal precoz por sexo. \\
\hline III. 10. & Mortalidad neonatal tardía por sexo. \\
\hline III. 11. & Mortalidad perinatal por sexo. \\
\hline III. 12. & Mortalidad infantil tardía o postneonatal por sexo. \\
\hline III. 13. & Mortalidad infantil por sexo. \\
\hline III. 14. & Tres primeras causas de mortalidad perinatal y su distribución porcentual. \\
\hline III. 15. & Esperanza de vida al nacer por sexo. \\
\hline III. 16. & Años potenciales de vida perdidos por sexos. \\
\hline III. 17. & $\begin{array}{l}\text { Número de mujeres ingresadas en larga estancia (más de un año) en } \\
\text { instituciones de salud mental. Residencias asistidas. Porcentaje de ingresos de } \\
\text { mujeres en larga estancia comparado con hombres. }\end{array}$ \\
\hline III. 18. & Cinco diagnósticos más frecuentes de salud mental en mujeres. \\
\hline III. 19. & $\begin{array}{l}\text { Índice de mortalidad por edad y sexo, a causa de suicidios o heridas auto- } \\
\text { inflingidas. }\end{array}$ \\
\hline III. 20. & Índice de mortalidad por accidentes de tráfico por sexos. \\
\hline III. 21. & Incidencia de las fracturas de cadera por sexo. \\
\hline III. 22. & $\begin{array}{l}\text { Indice de Mortalidad por accidentes laborales, según tipo de industria por } \\
\text { sexos. }\end{array}$ \\
\hline & \\
\hline
\end{tabular}

sexo. Tres primeras causas de mortalidad perinatal y su distribución porcentual se selecciona para conocer los problemas de salud más relevantes al inicio de la vida. Del INE obtenemos la Esperanza de vida al nacer por sexo y los Años potenciales de vida perdidos por sexo. Se selecciona el porcentaje de ingresos en unidades de larga estancia por sexos. Y los 5 diagnósticos de salud Mental más frecuentes en mujeres; así como; la mortalidad por suicidio lesiones auto-inflingidas. Para conocer la magnitud de las lesiones involuntarias se cuenta con el índice de mortalidad por accidentes de tráfico. En relación

Feminismo/s 18, diciembre 2011, pp. 173-184 
Tabla IV. Modos de Vida

\begin{tabular}{|l|l|}
\hline IV. 1. & Número de cigarrillos por sexo y edad. \\
\hline IV. 2. & Porcentaje de mujeres y hombres que practica algún deporte. \\
\hline IV. 3. & $\begin{array}{l}\text { Programas implantados en el área para la promoción de hábitos de vida } \\
\text { saludables en las mujeres }\end{array}$ \\
\hline IV. 4. & $\begin{array}{l}\text { Población protegida anual, por grupos de edad y sexo, en los programas de } \\
\text { Educación sexual incluyendo los talleres de sexo seguro y autoconocimiento } \\
\text { (de } 14 \text { a 20, 21 a 30, de 31 a 40, de 41 a 50, más de 51). }\end{array}$ \\
\hline IV. 5. & Prevalencia de lesiones por violencia domestica. \\
\hline IV. 6. & $\begin{array}{l}\text { Prevalencia de lesiones por agresiones sexuales. Aproximación al estudio de la } \\
\text { prevalencia de agresiones sexuales denunciadas en el juzgado. Diferenciando } \\
\text { entre violaciones y agresiones. }\end{array}$ \\
\hline IV. 7. & Número de grupos de autoayuda en mujeres. \\
\hline IV 8. & Porcentaje de recién nacidos que tienen un peso inferior a 2.500 gramos. \\
\hline IV. 9. & Porcentaje de niños alimentados con el pecho materno. \\
\hline IV. 10. & Porcentaje de prostitución femenina. \\
\hline IV. 11. & Distribución del consumo de alcohol por sexo. \\
\hline IV. 12 & Consumo de sustancia psicotrópicas por edad y sexo. \\
\hline IV. 13. & Uso de drogas ilegales por edad y sexo. \\
\hline
\end{tabular}

con la diversidad de empleo en la industria y agricultura en mujeres, se puede contar con la mortalidad por accidentes laborales. Un indicador indirecto de la gravedad de la osteoporosis puede ser la incidencia de las fracturas de cadera por sexo.

Los modos de vida (tabla IV): se pueden recopilar indicadores relevantes que suponen riesgo de enfermedad, como el consumo de tabaco, consumo de alcohol y sustancias psicoactivas, lesiones por violencia, agresiones sexuales, uso de medicamentos ilegales y porcentaje de prostitución femenina. E indicadores positivos como Programas de Educación para la salud implantados en el área o departamento de salud, población protegida anualmente por programas de educación sexual, número de grupos de autoayuda,y nombre y frecuencia de niños alimentados al pecho materno.

Medio ambiente (tabla V): Reconocemos que las mujeres inmersas en una comunidad determinada son un recurso ambiental de calidad del aire, agua y suelo a tener en cuenta para valorar la salud.

Servicios para el cuidado de la Salud (tabla VI): es prioridad contar con información sobre los cuidados de salud sexual y reproductiva, durante el embarazo y parto. También los recursos humanos profesionales y no profesionales, como los cuidadores para la salud. 


\section{Tabla V. Medio Ambiente}

\begin{tabular}{|l|l|}
\hline V. 1. & $\begin{array}{l}\text { Tendencias en la incidencia de enfermedades y efectos adversos atribuibles a la } \\
\text { polución del aire, tierra y agua. }\end{array}$ \\
\hline V. 2. & Incidencia de las enfermedades profesionales por sexo. \\
\hline V. 3. & $\begin{array}{l}\text { Cobertura de las revisiones de salud ocupacional por sectores de producción. } \\
\text { (azulejo, manipuladores de pesticidas, servicios, almacenes de naranjas, } \\
\text { exposiciones químicas,...). }\end{array}$ \\
\hline V. 4. & Número de playas en condiciones de calidad de agua de baño. \\
\hline V. 5. & Porcentaje de población cubierta por los servicios de potabilización de agua. \\
\hline V. 6. & Porcentaje de población con recogida sistemática de residuos sólidos urbanos. \\
\hline V. 7. & $\begin{array}{l}\text { Consumo de pesticidas y herbicidas en la provincia. (litros de pesticidas } \\
\text { consumidos por Hectárea cultivada) }\end{array}$ \\
\hline
\end{tabular}

\section{Tabla VI. Servicios para el Cuidado de la Salud}

\begin{tabular}{|l|l|}
\hline VI. 1. & $\begin{array}{l}\text { Métodos anticonceptivos instaurados por primera vez en el último año. Centro } \\
\text { de Salud Sexual y Reproductiva (CSSyR) }\end{array}$ \\
\hline VI. 2. & $\begin{array}{l}\text { Tasa de incidencia anual de esterilizaciones definitivas en hombres y mujeres. } \\
\text { CSSyR }\end{array}$ \\
\hline VI. 3. & Captación anual de mujeres por grupos de edad en los CSSyR \\
\hline VI. 4. & Ayuda por maternidad de la seguridad social a mujeres embarazadas \\
\hline VI. 5. & Incidencia de las enfermedades inflamatorias de pelvis. \\
\hline VI. 6. & Prevalencia de las enfermedades inflamatorias de pelvis. \\
\hline VI. 7. & $\begin{array}{l}\text { Índice comparativo de cesáreas en los alumbramientos de Castellón/Valencia/ } \\
\text { Alicante/P Valencià y España. }\end{array}$ \\
\hline VI. 8. & Número de licenciados/as en medicina por habitante. \\
\hline VI. 9. & Número de enfermeras por habitante. \\
\hline VI. 10. & Indicadores de calidad en el proceso de atención en el programa de la madre. \\
\hline VI. 11. & $\begin{array}{l}\text { Servicios específicos hospitalarios dedicados a las mujeres (ginecología } \\
\text { tocología, diagnostico de cáncer,...). }\end{array}$ \\
\hline VI. 12. & $\begin{array}{l}\text { Servicios de apoyo (gubernamentales y no gubernamentales) para las mujeres } \\
\text { que viven con HIV y SIDA. }\end{array}$ \\
\hline VI. 13. & Número de nacimientos de mujeres portadoras de HIV positivo. \\
\hline VI. 14. & Número de nacimientos de mujeres portadoras de HBs Ag. positivo. \\
\hline VI. 15. & $\begin{array}{l}\text { Alcance de la cobertura de los servicios de ayuda en el domicilio, } \\
\text { gubernamental y no gubernamental. Numero de ayudas a cuidadoras de } \\
\text { mayores de 65 años. Expresado en porcentaje de mayores de 65 años asistidos } \\
\text { en domicilio por mujeres }\end{array}$ \\
\hline VI. 16. & $\begin{array}{l}\text { Número de trabajadores sociales por habitante. Dependencia (Sanidad, } \\
\text { Bienestar Social, Municipales, otras) }\end{array}$ \\
\hline VI. 17. & Número de personas de ayuda en el domicilio por habitante. \\
\hline VI. 18. & Número de Psicólogos/as y pedagogos/as de servicios públicos por habitante. \\
\hline
\end{tabular}

Feminismo/s 18, diciembre 2011, pp. 173-184 


\section{Tabla VII. Políticas de Desarrollo}

\begin{tabular}{|l|l|}
\hline VII. 1. & Políticas y documentos políticos para promover la salud de las mujeres. \\
\hline VII. 2. & $\begin{array}{l}\text { Describir los esfuerzos actuales de reforma en particular en la provisión de } \\
\text { servicios de salud para las mujeres. }\end{array}$ \\
\hline VII. 3. & Progresos alcanzados en los objetivos específicos para la salud de las mujeres. \\
\hline VII. 4. & $\begin{array}{l}\text { Que temas de salud se han debatido y se han reflejado en los medios de } \\
\text { comunicación local. Análisis de los temas relacionados con la salud de la } \\
\text { mujer en un año de los periódicos locales. }\end{array}$ \\
\hline VII. 5. & $\begin{array}{l}\text { Descripción de las políticas que se han realizado y los mecanismos utilizados } \\
\text { con vistas a reducir las desigualdades en el estado de salud. }\end{array}$ \\
\hline VII. 6. & $\begin{array}{l}\text { Descripción de cada programa diseñado y realizado con el objetivo de } \\
\text { eliminar las diferencias entre sectores de la población en particular desde } \\
\text { 1990. Programas de salud y Protocolos implantados en el área/Departamento } \\
\text { de salud, con los correspondientes resultados según los indicadores de calidad } \\
\text { en el proceso, dependientes de la Conselleria de Sanitat. Programas en marcha } \\
\text { dependientes de los Municipios. Programas implantados por la Conselleria } \\
\text { Bienestar Social, Conselleria de Cultura Educació i Ciència y de la Direcció } \\
\text { General de la Dona. }\end{array}$ \\
\hline VII. 7. & Mujeres y hombres encarcelados. \\
\hline VII. 8. & Emigrantes hombres y mujeres, legales e ilegales. \\
\hline VII. 9. & Casas de acogida existentes para mujeres. \\
\hline
\end{tabular}

Políticas de desarrollo (tabla VII): Los indicadores seleccionados no se pueden obtener si al menos no hay Políticas de género. No es posible la atención a la salud continuada sin el recurso de las políticas específicas de Promoción de la Salud de las mujeres, ni sin programas de Promoción de la Salud dirigidos a las mujeres en las diferentes etapas de la vida con el fin de su empoderamiento. Se debe prestar especial atención a las situaciones de emigración, privación de libertad y la atención de las lesiones por violencia.

\section{Conclusión}

Actualmente hay ejemplos de aproximación al diagnostico de salud de las mujeres como los realizados desde la Unión Europea ${ }^{13}{ }^{14}{ }^{15}$, el Ministerio de

13. The state of women's health in the European Community. http://ec.europa.eu/health-eu/ my_health/women/index_en.htm

14. Egalité et non-discrimination. Rapport annuel 2006.Commission européenne. 2007 Année europeene de l'3galité des chances pour tous.

15. Closing the Gap: Satrategies for Action to tackle Health Inequalities in Europe. A European project from 2004 to 2007. Final Report (1/6/2004-31/5/2007) EuroHealthNet. (EuroHealthNet. Mejorar la equidad en materia de salud a través de los determinantes 
Trabajo y Asuntos Sociales ${ }^{16}{ }^{17}$, y el Observatorio de Salud de las mujeres ${ }^{18}$. Desde la Consellería de Sanitat ${ }^{19}$ y tomando como fuente la Encuesta de salud se han identificado algunos indicadores para mujeres en la edad adulta. Estos principios generales podrían servir para elaborar un perfil sobre mujer y salud. En especial, centrados en el área o departamento de salud, para que desde la Dirección General de la Mujer se coordine con municipios y Conselleria de Sanidad, en el Consejo de Salud del Departamento y apoye su realización para la totalidad de las áreas/Departamentos de Salud de la Comunidad Valenciana.

\section{Referencias bibliográficas}

Arrufat, Vita y Calvo, Consuelo. Guía para la elaboración del Perfil de Salud de las mujeres. Forum mujer trabajo y salud. Barcelona febrero 1995.

Colección Atención Primaria de Salud 4. Dirección General de Planificación Sanitaria. Madrid 1985.

Commission européenne. 2007 Année europeene de l'3galité des chances pour tous. Egalité et non-discrimination. Rapport annuel 2006.

EuroHealthNet. Closing the Gap: Satrategies for Action to tackle Health Inequalities in Europe. A European Project from 2004 to2007. Final Report (1/6/2004-31/5/2007)

Generalitat Valenciana. Consellería de Sanitat. Informes de Salud. Núm 108. Salud de la población de mediana edad (40-64 años) de la Comunitat Valenciana. Vicenta Escriba Agüir, Joan Quiles Izquierdo, Ana Fullana Montoro, Manuela Royo Marqués y Carlos Perelló Amorós.

JAMES, S. Amelang y NASH, Mari.(Edras) Historia y género. Las mujeres en la Europa moderna y contemporanea.. Edicions Alfons el Magnànim. Institut Valencià d'estudis i investigació. 1990.

Sociales de la Salud. Estrategias en áreas de actuación como Enseñanza, Empleo y bienestar Social, Plan de igualdad, Economia, MedioAmbiente, Vivienda, Turismo

16. Mujeres y hombres en España. 2007 y 2008 Apdo. Salud. Ministerio de Trabajo y Asuntos Sociales. INE

17. Mujeres y hombres en España 2007. INE. Ministerio de trabajo y Asuntos Sociales. Secretaria General de Políticas de Igualdad. Instituto de la mujer.18562006 Aniversario de estadística oficial española.

18. Informes Salud y Género. 2005. 2006. 2007-2008. Las edades centra les de la vida. OSM http://www.msc.es/organizacion/sns/planCalidadSNS/e02_t05.htm

19. Diferencias de género del estado de Salud de la población de mediana edad (40-64 años) de la Comunitat Valenciana. Informes de Salud. Núm 108. Servicio de Salud infantil y de la mujer. Sección de Climaterio y personas mayores. Vicenta Escriba Agüir, Joan Quiles Izquierdo, Ana Fullana Montoro, Manuela Royo Marqués y Carlos Perelló Amorós.Generalitat Consellería de Sanitat. 1 de. ISSN: 1139-6873

Feminismo/s 18, diciembre 2011, pp. 173-184 
Ministerio de Asuntos Sociales. Propuesta de un sistema de indicadores sociales de igualdad entre géneros Serie estudios 39. Instituto de la Mujer. Madrid 1994.

Ministerio de Trabajo y Asuntos Sociales. INE. Mujeres y hombres en España. 2007 y 2008 Apdo. Salud.

Ministerio de Trabajo y Asuntos Sociales. INE. Instituto de la Mujer. Secretaria General de Políticas de Igualdad. Mujeres y hombres en España 2007. 18562006 Aniversario de estadística oficial española.

Ministerio de Sanidad y Consumo. Secretaria General de Sanidad. Dirección General de Salud Pública. Subdirección General de Promoción de la Salud y Epidemiología. OMS Europa. Los determinantes sociales de la salud. Los hechos probados. Richard Wilkison y Michael Marmot.

MOrA TORRES, Alizabeth y Gras I MARTí, Alberti (coords.) Medicines i Gènere. El torsimany necessari Revista Feminismo/s del Centro de Estudios sobre la mujer de la Universidad de Alicante. Núm. 10, diciembre de 2007.pp

\section{Consulta páginas webs}

http://www.ine.es/

http://www.inmujer.es/ss/Satellite?pagename=InstitutoMujer\%2FPage\%2FIMUJ_ Home Consultada 21 marzo 2011, http://www.ine.es/jaxi/menu.do? type=pcaxis\&path=/t15/p414\&file=inebase

$\& \mathrm{~L}=0$ Consultado 21 de marzo 2011

http://www.ec.europa.eu/eurostat Consultado 21 marzo 2011

http://ec.europa.eu/health-eu/my_health/women/index_en.htm The state of women's health in the European

http://www.msc.es/organizacion/sns/planCalidadSNS/e02_t05.htm. Informes Salud y Género. 2005. 2006. 2007-2008. Las edades centrales de la vida. OSM

Estrategia europea para la salud y el desarrollo de la infancia y la adolescencia. Herramienta de género. WHO Europe 2007. documento de trabajoormation/ 


\title{
EN LA BARCA DE CARONTE (LA MENOPAUSIA O LA GRAN TRANSFORMACIÓN)
}

\author{
ELVIRA M. MELIÁN \\ Especialista en Endocrinología y Nutrición
}

Recibido/15/07/2011

Aceptado/25/09/2011

\section{Resumen}

La construcción occidental de la menopausia como una patología por «déficit hormonal» ha anulado hasta fechas recientes cualquier otro enfoque de este periodo fisiológico de transición vital. Conforme el argumento biomédico se tambalea se hace evidente que en el discurso sobre la menopausia cohabitan factores biológicos, culturales, sociales y psicológicos. La búsqueda de los potenciales aspectos positivos de esta edad, abre un nuevo horizonte a las mujeres contemporáneas, a la vez que ilumina la hasta ahora opaca intrahistoria colectiva del climaterio.

Palabras clave: mujer, menopausia, menstruación, terapéutica hormonal sustitutiva, prácticas culturales, histerismo, climaterio.

\begin{abstract}
The Occidental construction of menopause as a «deficient disease» has totally overwhelmed all other view of this normal transition of life. As the biomedical discourse gets weaker we realize that the meaning of menopause depends on biological, cultural, social and psychological factors. Looking at potentials and positive functions of menopause open a new horizon for contemporary women and, moreover, illuminate the previously opaque record of our collective climacteric history.
\end{abstract}

Keywords: women, menopause, menstruation, hormone therapy, cultural practices, hysterias, climacteric.

Feminismo/s 18, diciembre 2011, pp. 185-202 



\section{La Menopausia, un fenómeno bio-psico-socio-cultural}

Hay una cantidad, sin duda enorme, de mujeres,- tan grande que llega a pensarse que es muy rara la mujer que en más o menos grado escapa a esa condición-que después de algunos años de vida sexual activa presentan multitud de fenómenos de tipo nervioso sobre todo, cuyo origen hay que buscarlo en un ejercicio mal entendido (aunque se ajuste a las reglas de la moral en uso) de sus funciones sexuales. Desde este nuevo punto de vista se iluminan las idea modernas sobre la importancia del factor sexual en la génesis del histerismo ${ }^{1}$

En la segunda mitad del siglo XX mientras nuestro país languidece bajo la represión franquista, el mundo anglosajón lidera un cambio histórico en el acercamiento ideológico y científico a la menopausia tras siglos de oscurantismo. Por un lado aparecen los primeros trabajos sobre los aspectos liberadores de esta condición ${ }^{2}$ y, por otro, los primeros estudios científicos sobre los efectos de la caída de estrógenos tanto en la esfera ginecológica como fuera del aparato reproductivo ${ }^{3}$. En dichos estudios se diseccionan los efectos beneficiosos de estas hormonas a nivel cardiovascular, óseo y cerebral (memoria, sentido del bienestar y funciones cognitivas $)^{4}$. En pocos años la terapia hormonal sustitutiva pasa a ser considerada óptima para toda climatérica de no existir contraindicaciones 5 , y la medicalización de la menopausia alcanza su esplendor. Esta axiomática premisa se quebrará el 2001 con una inesperada revolución conceptual a raíz de un estudio en 16000 mujeres sanas entre 50 y 79 años demostrando mayor incidencia de muerte cardiaca, ictus y cáncer de

1. MARAÑón, Gregorio. La doctrina de las secreciones internas. Madrid, Biblioteca Corona, 1915, pp. 105.

2. Morrow-Lindberg, Anne. Gift from the sea. New York, Vintange books, 1983.

3. KRIEGER, Nancy y cols. «Hormone replacement therapy, cancer, controversies, and women's health: historical, epidemiological, biological, clinical and advocacy perspectives». J Epidemiol Commmunity Health 29 (2005) pp. 740-748.

4. GENAZZANI, Andrea y cols. «Estrogen, cognition and ageing». Human reproduction updates 13 (2007) pp. 175-187.

5. Existen varias formulas de terapia sustitutiva pero en esencia se administran estrógenos y gestágenos cíclicos para simular el ciclo menstrual.

Feminismo/s 18, diciembre 2011, pp. 185-202 
mama en la población tratada ${ }^{6}$. En adelante la indicación de tratamiento sustitutivo quedará limitada al subgrupo de posmenopáusicas tempranas en las que la intensidad de los sofocos por deprivación estrogénica acarree secuelas irreconciliables con la actividad cotidiana, tales como insomnio pertinaz y/o muy bajo nivel de energía ${ }^{7}$.

De forma paralela a la des-medicalización de la menopausia en Occidente hemos asistido en la última década a dos grandes cambios en la percepción de la misma: 1, esta etapa ha dejado de ser considerada patológica para posicionarse como un periodo fisiológico más de la existencia y 2 , se ha liberado a la menopáusica de su etiqueta de enferma psicosomática. En un extenso meta-análisis de las actitudes de las mujeres hacia su propia menopausia se demuestra que la mayoría no experimentan depresión durante esta transición $y$, de existir sentimientos negativos previos, tras atravesarla modifican positivamente su postura ${ }^{8}$. Pese a todo, la mujer occidental tomada como grupo teme mucho más esta transición que la de otras culturas. En nuestra sociedad el climaterio es una época de mudanza y síntomas habitualmente asociados al fallo ovárico como labilidad emocional o falta de motivación son frecuentemente debidos a razones extrínsecas al mismo ${ }^{9}$. Recordemos el impacto mutuo entre los universos hormonal y psicosocial: factores negativos como el estrés, la ansiedad o la baja autoestima aumentan la percepción de golpes de calor y sudoraciones nocturnas, que a su vez refuerzan a los primeros ${ }^{10}$. Un

6. Writing Group for the Women's Health Initiative Investigations. El WHI (Women's Health Initiative Study). «Risk and benefits of estrogens plus progestin in healthy postmenopausal women». JAMA 288 (2002) pp. 321-333.

7. BROWN, Jessica y cols. «Relations among menopausal symptoms, sleep disturbances and depressive symptoms in the midlife». Maturitas 62 (2), (2009) pp. 184-189; SCHMIDT, Peter y cols. «Sex hormones and mood in the perimenopause. Glucocorticoids and mood». Ann N.Y.Acad. Sci. 1179 (2009), pp. 70-85. *Si bien la edad fértil nos brinda dos claros de la influencia de las fluctuaciones estrogénicas sobre el ánimo:el síndrome de disforia premenstrual y la depresión postparto, no se han podido demostrar efectos beneficiosos de los estrógenos que justifiquen su uso habitual para tratar cambios psíquicos en posmenopáusicas. Aún en estas poblaciones seleccionadas se tiende al «mínimo tiempo,mínima dosis».

8. AYERS, Beberly y cols. «The impact of attitudes towars the menopause on women's symptom experience: a systematic review». Maturitas 65 (2010), pp. 28-36.

9. Me refiero por supuesto a la sintomatología psicosomática porque los sofocos y la sequedad vaginal se relacionan positivamente con la caída de estrógenos y no existen dudas sobre el mayor riesgo en posmenopáusica de osteoporosis o el mayor riesgo cardiovascular.

10. SERITAN, Andreea. y cols. «Self-reported anxiety, depressive, and vasomotor symptoms: a study of perimenopausal women presenting to a specialized midlife assessment center». Menopause 17 (2), (2010), pp. 410-415. 
campo extraordinario para los estudios bio-psico-socio-culturales en el futuro, sin duda ${ }^{11}$.

Marañón consideraba a la menopausia el postrero cataclismo que precede al «ocaso de la existencia» femenina, y a las fluctuaciones ováricas el origen último del histerismo. Hemos de concederle que también asumía una edad crítica en el varón, que hoy llamaríamos andropausia, sólo ausente en «algunos hombres privilegiados» y derivada de la disminución de la secreción testicular ${ }^{12}$. Más de un siglo después se describen en los hombres síntomas equiparables a los del climaterio femenino ${ }^{13}$, pero la palabra andropausia se indigesta. Es cierto que la menopausia es un cese brusco de la menstruación y la andropausia es un proceso progresivo. Pero ies tan brusco el climaterio, entendido como «los cambios biológicos, psicológicos y socioculturales asociados a la involución gonadal» como la menopausia? La respuesta es no.

La transición menopáusica es prolongada y empieza mucho antes de la última menstruación con fluctuaciones hormonales traducidas en variaciones del ciclo menstrual. De hecho podemos establecer tres etapas en el proceso completo: 1, un periodo transitorio de peri menopausia de años de duración que finaliza a los 12 meses de la última regla; la menopausia propiamente dicha que se define como los primeros 12 meses tras la última menstruación y la pos menopausia que a su vez es temprana hasta cumplir los 5 primeros años sin reglas y tardía desde entonces hasta la muerte ${ }^{14}$. Si consideramos la edad media de la menopausia en 51 años con un rango dentro de la normalidad entre los 45 a los 55 años nos damos cuenta de la amplitud del espectro. El climaterio sólo se puede considerar terminado en el 100\% de los casos a los 60 años. Estamos hablando pues de un período comprendido entre los 40 y los 60 años.

Bajo el significativo epígrafe «El decremento, y cremento mayor de la edad, que llaman término climaterio y las mudanzas del mismo» Oliva Sabuco apuntaba ya en el siglo XVI: «De la Leona dice Plinio que pare la primera vez cinco. La segunda quatro. La tercera tres y así hasta que pare uno solo, y de allí adelante se vuelve esteril. Este estado mayor no dura tiempo, por estas razones, porque

11. HunTER, Myra. «Bio-psycho-socio-cultural perspectives on menopause». Best practice E Research Cinical Obstetrical and Gynecology. 21 (2007), pp.261-274.

12. MARAÑón, Gregorio. «La edad crítica». Madrid, Ed. Ruiz Hernando, 1925.

13. Irritabilidad, insomnio, fatiga, depresión, ansiedad disminución del deseo sexual y un largo etcétera. Ver el artículo de SNYDER, Peter. «Decline in testicular function with aging». http://www.uptodate.com Wolkers Kluwer Ed, 2010.

14. CASPER, Robert.«Clinical manifestations and diagnosis of menopause». UPTODATE. com Op. cit.

Feminismo/s 18, diciembre 2011, pp. 185-202 
la luna no dura en estado, en el punto que es llena, luego esta en decremento ${ }^{15}$. Hoy los ciclos vitales se han desplazado arbitrariamente hacia la izquierda ${ }^{16}$ : los jóvenes de ayer se juzgan niños, los maduros jóvenes, los viejos maduros, y los ya ancianos entran en esa indefinible y políticamente correcta definición de «tercera edad». Sin embargo la Leona de Plinio se sigue volviendo estéril a los 50 años, como describiera Aecio de Amira en el 500 a.C ¿Por qué ocurre la menopausia?

La medicina evolutiva ha buscado razones para explicar este fenómeno de la especie humana que acontece en la mitad de nuestra esperanza de vida potencial (110 años) y muy por debajo de nuestra esperanza de vida media actual (actualmente entre los 80,5 y los 83 años en España) ${ }^{17}$. Desde esta perspectiva la menopausia puede ser contemplada como un "carácter» beneficioso -hipótesis adaptativas- o como un carácter neutro -hipótesis de coproducto $^{18}$. En el primer contexto el fenómeno menopáusico se considera subsidiario a transformaciones fundamentales en la evolución del género Homo, como el estrechamiento del canal del parto secundario a la bipedestación y el desarrollo encefálico. Con el fin de evitar riesgos perinatales el estrechamiento pélvico habría condicionado la expulsión de criaturas con menor tamaño craneal, y ambos procesos evolutivos en conjunto la necesidad de un mayor periodo de maduración cerebral posnatal. En este contexto la menopausia tiene un carácter protector para la progenie viva ${ }^{19}$. Entre las hipótesis adaptativas destacan la teoría de la «buena madre» para la cual la menopausia es una especie de "transacción-compromiso» de la naturaleza sacrificando un menor número de descendientes por mujer a una mayor salvaguardia de los existentes, y la «teoría de la abuela», que es una adaptación de la anterior en el contexto de familias extendidas ${ }^{20}$. Para las hipótesis que consideran la menopausia un co-producto neutro de la evolución, la disociación función ovárica/ esperanza de vida es un artefacto ances-

15. SABUCO, Olivia. Nueva filosofía de la Naturaleza del hombre. Madrid, 1728.

16. Sobre esta proyección del modelo lunar sobre la vida mortal -con sus fases de crecimiento, plenitud, decremento y ocultamiento- ver CiRLOT, Juan Eduardo. Diccionario de símbolos. Madrid, Ed. Ciruela (2003), p. 183.

17. Curiosamente acaba de descubrirse que esta longitud de vida pos reproductiva no es un fenómeno exclusivamente humano como se creía, y aparece en otros animales como el elefante y algunos tipos de ballenas.

18. LEIDY, Louise. «Menopause in evolutionary perspective». Evolutionary Medicine. Oxford, Ed. W.R. Trevathan, E.O. Smith y J. J. McKenna. Oxford University Press, 1999, pp.407-427.

19. Sin olvidar que el cese de la menstruación elimina eficazmente los riesgos en el parto y evita la mayor incidencia de aberraciones cromosómicas de la madre añosa.

20. Wu, Julie y cols. «Ovarian aging and menopause: current theories. Hypotheses, and research models». Exp. Biol Med 230, (2005) pp. 818-828. 
tral presente ya en el Homo Erectus pero no desenmascarado por la ausencia natural de vida en estado pos reproductivo ${ }^{21}$.

Sea cual sea la razón última, en nuestros días la década de los cincuenta asume atribuciones adjudicadas antaño a la famosa «crisis de los $40 »^{22}$; conceptualmente se trata de un período de transición/renovación ligado a la madurez. El desconcierto con el que entramos en la etapa menopáusica, a diferencia del hombre andropáusico, deriva de que nos aleja de los cánones de belleza, fecundidad y erotismo de la juventud, sin ser socialmente válida para reflejar los cánones de sabiduría, equidad y serenidad, que tienen su iconología en la vejez.

Es indiscutible que el atributo edad no ha sido una bendición para las féminas occidentales. Ya en la segunda mitad del XIII La historia de la Donzella Teodor» deja testimonio de ello ${ }^{23}$. Una joven educada por un mercader le salva de la ruina al responder astutamente ante el rey y una corte de sabios a cuestiones sapienciales de la época. A las preguntas sobre las edades femeninas «De la de cinquenta años, qué me dizes? la moza responderá Essa, vos digo señor maestro, que es para el cuchillo. Ela de sesenta años, qué me dizes? En essa, no hay bien ninguno». Curiosamente la de cuarenta años ni aparece, siguiendo la de cincuenta a la de 30, por cierto «tan sabrosa como quando el hombre come perdices o carnero con limones». Esta ausencia es patente tanto en la escasa presencia de la menopáusica en la representación de Mitología y Biblia del arte pictórico occidental ${ }^{24}$ como en otras culturas ${ }^{25}$. Mientras la mujer-infancia, la mujer-fecundidad, la mujer-madre, la mujer-mito, la mujer-comportamiento moral, la mujer-erotismo o la mujer vejez, van apareciendo y desapareciendo en función de ideologías históricas es excepcional encontrar una climatéri$\mathrm{ca}^{26}$. En nuestras fronteras el llamativo hiato artístico entre juventud y vejez ha estado presente hasta bien entrado el siglo XX, ya que Velázquez y Goya,

21. KUHLE, Barry. «An evolutionary perspective on the origin and ontogeny of menopause». Maturitas 57 (2007) pp. 329-337.

22. BRANDES, Stanley. ¿Qué significa cumplir los cuarenta? Cultura y crisis a la mitad de la vida». Revista de dialectología y tradiciones populares 50 (1995), pp.27-50.

23. Parte de Las mil y una noches. Existen versiones conservadas en castellano en varios códices del siglo XV de esta obra. Texto consultado. PARÍS Y VIANA, «La doncella Teodor; Flores y Blancaflor», Narrativa Popular de la Edad Media, Madrid, Ed. Akal, 1995.

24. DE RYNCK, Patrick. Como leer la mitología y la Biblia en la pintura. Barcelona, Electa, 2009. *Por el contrario los renacentistas italianos ahondaron ya en la representación las edades del hombre.

25. CABEllo, Paz. «La mujer en torno a la menopausia en el arte y la cultura indígena americanas». Anales del Museo de América 3 (1995), pp. 131-144.

26. FERNÁNDEZ, Antonia. «Pintura, protagonismo femenino e historia de las mujeres». Arte, individuo y sociedad., Madrid, Ed. Universidad Complutense, 1997.

Feminismo/s 18, diciembre 2011, pp. 185-202 
introductores de la mujer real y su vida cotidiana ${ }^{27}$, tampoco dibujaron matronas sino viejas ${ }^{28}$. En este terreno la vejez franca nos lleva la delantera pues, aunque no sea del agrado de nadie, historia, literatura, arte, libros y cultura en general están repletos de ejemplarizantes viejos sabios y respetados. La mujer climatérica, a diferencia del hombre maduro, nunca ha existido conceptualmente en ninguno de estos espacios.

\section{Los dos semblantes de la menopáusica}

Para los pueblos indígenas la posmenopáusica puede tener dos connotaciones antropológicas; algunos la consideran peligrosa y maléfica, léase comadrona o bruja; otros un interludio entre lo esencialmente masculino y lo esencialmente femenino (fecundidad, erotismo), permitiéndosele intervenir en asuntos sociopolíticos, algo impensable durante su vida fértil2 ${ }^{29}$. La urdimbre resultante de estas dos concepciones constituye la intrahistoria, ubicua y genérica de la mujer climatérica desde el comienzo de los tiempos. Así la identificación de la menopausia como situación limítrofe entre hombre y mujer es a lo que parece universal. Ya Aristóteles escribe que «la mujer no echa pelos en la barbilla, pero a algunas le salen unos pocos cuando se interrumpe la menstruación ${ }^{30} y$ siglos más tarde Marañón sostendrá,

la excitación suprarrenal a falta del freno de la secreción interna del ovario, que vela por la conservación de los caracteres sexuales femeninos da lugar, en muchos casos a una cierta reviviscencia de los atributos masculinos: brota el vello ectópico, por la región del bigote y de la sotabarba, camba el carácter en un sentido varonil etc. Todos recordarán haber presenciado la transformación de las mujeres menopáusicas. En la menopausia el tipo masculino no tiende a alterarse mientras que la mujer se evoluciona tenuemente hacia el tipo masculino ${ }^{31}$.

Parece «axiomático» que al acercarnos al hombre nos acercamos a la perfección. La iconología de Cesare Ripa, ampliamente difundida por Europa en el siglo XVII ${ }^{32}$, definía la virilidad, edad que consideraba «la más perfecta

27. Arrebatando el protagonismo a religión y mitología.

28. PASCUAL, Jesús «Una aproximación a la imagen de la mujer en el arte español». Ogigia, revista electrónica de estudios hispánicos 1 (2007), pp. 75-89. http://www.ogigia.es.

29. Cabello, Paz. Op. cit.

30. ARISTÓTELES. «Historia de los animales lib.III», 1990, Madrid, Ed. Akal Clásica, pp. 518.

31. MARAÑóN, Gregorio.Climaterio de la mujer y el hombre (estudio de la fisiopatología de la involución sexual), Madrid, Espasa Calpe, 1937.

32. RIPA, Cesare. Icolonogía. Madrid, Akal /Arte y Estética, 2007. Obra original publicada por primera vez en 1616. Esta iconología se basaba en los maestro egipcios, lo clásicos y la biblia, tomando al hombre como medida de todas las cosas y considerando su figura el único icono posible para representar virtudes, vicios, pasiones, artes y afectos, entre otros. 
del hombre», como una «matrona climatérica de 50 años». Y no deja de ser significativo que en los últimos años la elite médica haya propuesto mejorar nuestro bienestar, deseo sexual y apariencia física en la menopausia mediante el tratamiento con hormonas masculinos ${ }^{33}$. Bases antropológicas para dicha terapéutica desde luego existen, como demuestra una clarificadora conversación entre San Pedro y Jesús resucitado en el evangelio apócrifo de Santo Tomás, del siglo II d. C. Cuando el apóstol protesta por la preferencia que Jesús muestra a María Magdalena: "Que se aleje Mariham de nosotros, pues las mujeres no son dignas de la vida! Jesús le tranquiliza: «Mira, yo me encargaré de hacerla macho, de manera que también ella se convierta en un espíritu viviente, idéntico a vosotros los hombres: pues toda mujer que se haga varón entrará en el reino de los cielos» (T 114) ${ }^{34}$. No se puede ser más explícito.

Desconocemos el grado de androginia de la Magdalena menopáusica, pero advertimos la impronta varonil de su más famosa emuladora en nuestras fronteras, Catalina de Cardona. Esta viuda de noble familia, cercana a Felipe II y modelo a seguir para Santa Teresa ${ }^{35}$, abandonaría el palacio en por una vida anacoreta a los 43 años. Tras permanecer ocho en absoluta soledad construirían en la cercanía de su celda un monasterio de frailes descalzos del Carmelo al que permanecería ligada hasta su muerte ${ }^{36}$. Sus contemporáneos la tomaban por eunuco pues siempre tuvo «ánimo y pecho de varón». En sus semblanzas se reitera que «aborrecía mucho el parecer mujer» y prefería ser etiquetada de "varonil, varoníssima o seguidora de Elías»" ${ }^{37}$. Es fácil imaginar que, siguiendo a Huarte de San Juan debió representar la versión virilizante de la menopausia expulsiva: "fría y húmeda en primer grado», y fenotípicamente «enjuta y seca, avisada y áspera, de voz gruesa y abultada, verdinegra o morena, con mucho vello y un poco de barba» ${ }^{38}$.

33. PANJARI, Mary . y DAVIS, Susan. «DHEA for postmenopausal women: a review of the evidence». Maturitas 76 (2010) pp. 172-180; KRAPF, Jill y SIMON, James. «The role of testosterone in the management of hypoactive sexual desire disorder in postmenopausal women» Maturitas 63 (2009) pp. 213-219.

34. «Los Evangelios Apócrifos», Madrid,Biblioteca de Autores Cristianos, 2006, p. 705.

35. BARbeito, Isabel. «Mujeres eremitas y penitentes». Via Spiritus 9 (2002) pp. 185-215.

36. CORTIJO, Antonio «Vida de la madre catalina de Cardona por fray Juan de la Miseria. Un texto hagiográfico desconocido del siglo XVI (Bancroft Library, UCB, Fernán Núñez Collection, vol. 143)» Dicenda: Cuadernos de Filosofía Hispánica 21 (2003) pp. 21-34.

37. DE SAN GABRIEL, "De la buena mvger doña Chatalina de Cardona heremita carmelita descalza y fundadora del convento heremítico de nra. Señora del Socorro y de otros por su medio fundados. Los discursos que, carmelita descalzo, su confessor y deboto hijo medita$b a, \ldots »$ Madrid, Biblioteca Nacional ms. 4213 fols. 12r y 17v.

38. HuARTE de SAN JuAn, Juan. Examen de los ingenios. Biblioteca de Autores Españoles, tomo LXV, Madrid, Atlas, 1953.

Feminismo/s 18, diciembre 2011, pp. 185-202 
De gran espíritu gnóstico, no es de extrañar que el Jesús de Santo Tomás pronunciara estas explícitas palabras sobre la perfección masculina ${ }^{39}$. Recordemos que esta religión hundía sus raíces en la creencia en una asexualidad primigenia y androgénica a donde se proyectaba regresar. Según M. Eliades el pensamiento mágico religioso arcaico se expresó en muchas culturas en términos biológicos antes que teológicos o metafísicos, con la consecuente aparición en muchas tradiciones mitológicas de un Dios andrógino reflejo de un estado de perfección previo al pecado ${ }^{40}$. La penetrancia social del mito ha sido tal que en 1928 podemos leer de la mano de Pérez de Ayala:

«... después del climaterio, en tanto el varón permanece fiel a su género, la mujer suele adquirir ciertos rasgos fisiológicos de virilismo. Lo cual parece mostrar (no demostrar) que en la naturaleza existe una tendencia a la evolución ascendente desde lo femenino a lo masculino, dando así la razón al misticismo de la masculinidad, de Schopenhauer y Weininger, frente al misticismo de la feminidad, de los siglos caballerescos y del Dante, quien colocara a Beatriz en el vértice del Paraíso, declarando el orden cósmico» ${ }^{41}$.

Por su parte el orden cósmico de griegos y romanos colocaba al elemento femenino como antítesis negativa de lo masculino ${ }^{42}$, y tanto Aristóteles como Plinio el Viejo reconocían en la mujer una especie de varón mutilado ${ }^{43}$.Con la teoría de los humores galénica esta diferencia adquirirá base fisiopatológica (el predominio de los humores fríos en la mujer) para manifestarse por un defecto específico: la menstruación ${ }^{44}$. La mujer, varón imperfecto y frío, es incapaz de llevar a cabo de forma completa la cuarta cocción ${ }^{45}$ realizada en los testículos, donde parte de la sangre de la tercera cocción se convierte en esperma ${ }^{46}$. Esta sangre a medio digerir constituye la menstruación, residuo del que Plinio asegurará «con dificultad se hallaré cosa más monstruosa que esta sangre de las mujeres, se agria con ella el mosto, las mieses que toca no granan,

39. PiÑERo Antonio. Los cristianos derrotados. Madrid, Edaf, 2007, pp. 91 y sig.

40. HeLiades, Mircea. Lo sagrado y lo profano., Madrid, Guadarrama, 1967.

41. PÉREZ DE AyAla, Ramón. La Esfera 21/7/ 1928.

42. Basta evocar el Yambo de las mujeres de Seimónides o las comedias Aristofánicas.

43. CANET, Jose Luis «La mujer venenosa en la época medieval». dhttp://parnaseo.uv.es/Lemir/Revistal/Mujer_venenosa.html

44. Ferrándiz, Carlos. Bestiario medico., Madrid, Ed. Envida, 2000, p. 107.

45. Necesitada de mucho calor innato y sequedad.

46. Durante la primera cocción el alimento se transforma en quilo en el tubo digestivo, en la segunda el quilo lo hace en sangre en el hígado animándose con los espíritus naturales, en la tercera la sangre se distribuye por todas las partes del cuerpo para hacerse carne, por el corazón para infundirse del pneuma vital y por el cerebro para hacerlo del pneuma psíquico. Los testículos son otro lugar de esta cuarta cocción. 
iperecen los injertos, los brotes de los huertos se abrasan y el frito de los árboles donde las que están con ella se sientan se cae (...) $»^{47}$.

Como ocurriera con la androginia posmenopáusica el carácter impuro de la menstruación y el puerperio parece consustancial a todas las culturas. Similares connotaciones se han descrito en los aborígenes australianos, tribus sudamericanas, africanas ${ }^{48}$, de Tahití o Alaska ${ }^{49}$. En el Levítico Javhé advertirá a Moisés: «cuando una mujer quede embarazada y tenga un hijo varón, quedará impura siete días; será impura como durante sus reglas (...) Si da a luz una niña, será impura durante dos semanas como en el tiempo de sus reglas, y se quedará en casa sesenta y seis días más purificándose de su sangre» (Lev 12:1-5). La conjunción del texto bíblico con la filosofía natural de los clásicos fijará la idea negativa de la sangre menstrual y/o puerperal desde la Edad Media hasta bien entrado el XVIII ${ }^{50}$. Hemos de tener en cuenta que el líquido seminal del varón tampoco se libraría del carácter impuro ${ }^{51}$ y los médicos árabes, destacando Avicena, confundieron la secreción vaginal con un esperma húmedo y lige$\mathrm{ro}^{52}$. Para Huarte de San Juan,

el miembro que más asido está de las alteraciones del útero es el cerebro (...), por donde se entiende que el útero y sus testículos son de grande eficacia para comunicar a todas las demás partes del cuerpo su temperamento, mayormente al cerebro, por ser frío y húmedo como ellos. Y si nos acordamos que la frialdad $y$ humedad son las calidades que echan a perder la parte emocional53.

Remedios para el histerismo, básicamente el matrimonio, donde existía la posibilidad de engendrar un hijo. Entonces la sangre menstrual pasa a ser la base del principio material donde se desarrollará el semen conteniendo los principios del movimiento y el alma. Como posibles madres de varón alcanzamos razón de ser, en especial si su destino es la gloria como es el caso de las mujeres bíblicas ${ }^{54}$.

47. Ferrándiz, Carlos. «Dioscórides (Bestiario) de A. Laguna». Madrid, Ed. Medusa. 2001 pp. 261.

48. Varios autores. «Historia General de los Viages». Tomo 3, pp. 401. Madrid, 1765. Obra traducida del inglés al francés por Francisco Prevot y al castellano por D. Miguel de Terracina.

49. Frazer, James. «La Rama Dorada. Magia y Religión». México, Fondo de Cultura Económica1951, pp. 24-242.

50. CANET, Jose Luis. Op. cit.

51. (Lev 15.31-33).

52. La naturaleza espermática de este «flujo blanco», aceptada por Hipócrates y Galeno, será defendida con entusiasmo por la Escuela de Salerno.

53. HuARTE DE SAN JuAN, J. Op. cit. p. 493.

54. Recordemos los casos de Santa Ana y San Joaquín, en el protoevangelio de Santiago "pues siendo viuda dejo de serlo y siendo estéril voy a concebir en mi seno» (II, I); de

Feminismo/s 18, diciembre 2011, pp. 185-202 
En 1751 el médico Pedro León dará un significativo paso al establecer una doctrina moral disociada entre los flujos menstrual/ seminal y sus efectos histéricos coligados. Para este galeno "el fluxo inmoderado de menses» excusaba de pagar al médico y del rezo en el coro, en cambio los «fluxos blancos» no excusaban del rezo; «las pasiones histéricas» ya sea por retención de reglas o del flujo blanco «no eximen de pagar», pero «excusan del rezo privado y del coro si son muy grandes y recuentes causando molestias o debilidad contínua»; y «los histerismos leves y sus insultos, cuando nacen de detención de menses o material seminal se podrá ayunarlos». Siempre y cuando no se pueda eliminar el veneno "aún es este último caso deberán comer de Viernes las casadas, si puede haber, y basta para su remedio, el lícito desahogo» ${ }^{55}$. Poco afectará este debate a la mujer cuando llega a la menopausia; entonces la sangre menstrual retenida causará todo tipo de perturbaciones al no expulsarse periódicamente. Los daños derivados de estos vapores venenosos ascenderán por el organismo hasta la cabeza con las consecuentes histeria y epilepsia entre otros.

Lo cierto es que tampoco tenían muchas posibilidades las pobres climatéricas para eliminar al menos sus «flujos blancos»; a la obra Pedadogus del gnóstico Clemente de Alejandría (d.C. 150-215) ${ }^{56}$ debemos la prohibición específica de tener relaciones sexuales con mujeres «menstruantes, mujeres estériles y mujeres después de su menopausia ${ }^{57}$. De esta suerte el común de las mortales posmenopáusicas se constituirá en víctima de la urdimbre cultural entre los humores malignos eliminables en forma de espíritus (Galeno) y la naturaleza maléfica de la sangre menstrual retenida (Biblia). La climatérica será alineada en una y/o ambas formas expulsivas para sus venenos: si son «calientes y secas» lo harán a través del crecimiento de los pelos de la barba, convirtiéndolas en lujuriosos varones-like y, de ser «frías y húmedas», lo harán en forma de aojamientos. Hemos comentado ya el primer escenario. Sobre el segundo Alberto el Grande declarará,

Raquel, madre de José, segunda mujer de Jacob (Génesis 30: 9), de Ana, mujer de El cana y madre de Samuel (Saml, 20); o de la madre de Sansón y esposa de Manoab (Jueces 13). Todas pertenecen al grupo de climatéricas estériles durante más de 20 años y su papel se reduce a ser mujeres a las que Iahvé concede un hijo. Historias más conocidas como la historia de Abraham y Sara, nonagenarios padres de Isaac (Génesis 18:11) se encuadran de lleno en la senectud. Lo mismo ocurría con Isabel y Zacarías, padres de Juan Bautista donde se habla de avanzada edad (Luc 1:18-36) «soy viejo y mi mujer es de avanzada edad».

55. LEÓN, Pedro. Disertaciones morales y médicas, Madrid, 1751, pp. 60 y 189. La recomendación general era comer carne los viernes.

56. Director de la escuela teológica de este nombre.

57. PAGELS, Elaine. Adan, Eve and the serpent.new York, Vintage books, 1988. 
las viejas que aún tienen sus reglas y algunas que ya no la tienen regularmente, si miran a los niños pequeños acostados en la cuna les inoculan veneno por la vista (...) Es porque la retención de la menstruación engendra malos humores, y que siendo ya de bastante viejas, no tienen casi calor natural para consumir y digerir dicha materia $(\ldots)^{58}$.

En los textos de aojamiento publicados en los siglos XV y XVI se especificaba que los humores de menopáusicas y viejas pasaban de los ojos a transmitirse por el aire sin necesidad del deseo maligno por parte de las interesadas ni de una intervención diabólica, pues se trataba de un proceso natural asociado a la edad ${ }^{59}$. Martín de Castañega nos recuerda que «lo que es más sútil expele por las vidrieras de los ojos; y así salen por los ojos como unos rayos las impuridades y suciedades más sutiles del cuerpo $(. . .)^{60}$. En realidad el mal de ojo es un fenómeno transcultural cuyo origen debe buscarse hace miles de años en la India y Oriente Próximo. Ya en la Biblia hay referencias al natural dañino/ destructivo de algunas miradas generadas desde la envidia, y no es ajena tampoco a este mito la ley del Talión en el Éxodo ${ }^{61}$. Tal es su atavismo que hoy continúa siendo la superstición más relevante dentro de las tradiciones populares occidentales, donde tanto el mal mismo como las formas de conjurarlo siguen plenamente vigentes en el acervo popular ${ }^{62}$. El mismo acervo donde la apología del desequilibrio mental femenino ligado a la menopausia primará en el subconsciente hasta nuestros días sobre cualquier otra consideración ${ }^{63}$.

58. CANET, J, Op. cit. p. 8.

59. SALMÓN Fernando y CABRÉ, Monserrat. «Fascinating women: the evil eye in medical scholasticism». En. Medicine from the black death to the French disease. Gran Bretaña, Ed. French et al, Ashdgate, 1998, pp. 54-84. *La posición oficial de la iglesia sustentada durante largo tiempo nunca las relacionaría con el mundo de la brujería y como señalan los autores no existen casos documentados de acusaciones contra el mal de ojo como causa directa de procesamiento inquisitorial.

60. En su Tratado de las Supersticiones. Ver CANET J. L., Op. cit. pp. 8.

61. DomingueZ, Susana. «Realidad y leyenda del mal de ojo». Garoza: revista de la sociedad española de estudios literarios de cultura popular 7 (2007) pp. 47-60.

62. BAER, Roberta y cols. «Las enfermedades populares en la cultura española. Un estudio comparado sobre el mal de ojo». Revista de Dialectología y tradiciones populares, LXI (2006), pp. 139-156.

63. ROJAS Antonio. «Los «Hieroglyphica» de Piero Valeriano y su recepción en España durante el siglo XVI». Humanismo y pervivencia del mundo clásico: homenaje al profesor Antonio Fontán, vol. 3 (2002), pp.1607-1612. En la Hieroglyphica, de 1577, se establecía que entre los 49-56 años se alcanza la perfección máxima inteligencia y lengua con un físico conservado; Para Cesare Ripa del que ya hemos hablado la mujer madura, en razón de «su experiencia, capacidad de discernimiento, máxima memoria, mente sólida y juicio sano», era «explícitamente» un elemento definidor de varias alegorías. Además de la virilidad, único caso donde se señalan los 50 años, destacan la economía, la

Feminismo/s 18, diciembre 2011, pp. 185-202 
Durante la tercera década del pasado siglo, en el apogeo de su doctrina sobre la influencia de las secreciones internas sobre la emoción, ${ }^{64}$ Marañón describía a la menopausia como una patología causada por la agónica hiperfunción ovárica y asociada a «un resurgimiento de la afección amorosa-amores crepusculares", dicen los autores italianos- que, a veces, trastornan la vida de las mujeres hasta entonces moralmente equilibradas. ${ }^{65}$ Sus conferencias influyeron decisivamente sobre el pensamiento clínico coetáneo para el que la climatérica era «irritable y sobre todo propensa a la emoción. Exteriormente impaciente, agria, brusca, descontenta de todos y de sí misma (...) Domínala gran tristeza. (..) En ocasiones, como reacción contra este dolor, la mujer se lanza a aventuras absurdas. ¡El ridículo amor de las viejas! (...) $i^{66}$. El autor de este artículo debió ignorar que la vejez franca nos redime, si interpretamos convenientemente para nuestros intereses las recomendaciones del apóstol San Pablo a Timoteo, permitiéndole inscribir en el catálogo de viudas a mujeres mayores de 60 años porque antes "estando ociosas aprenden a ir de casa en casa; y no sólo están ociosas, sino que se vuelven también charlatanas y entrometidas, hablando de lo que o deben» (Tm 5, 9-1).

Desde entonces se ha recorrido un largo camino hacia la paridad en estas edades de la vida, pero quedan aún muchos cánones que desterrar, y es fácil darse cuenta contemplando los desequilibrios entre sexos en el mundo cinematográfico. Recientemente he leído un artículo en un periódico de amplia tirada nacional sobre el desarrollo de unidades especiales para promover el envejecimiento de la mujer de más de 50 años $^{67}$. En ellas se desarrollan programas que nos preparan para envejecer de forma saludable: detección precoz de tumores, educación nutricional, fomento del ejercicio, y atención a la salud sexual. Es significativo que el marketing de estas, de por si altamente recomendables unidades, descanse substancialmente en la actuación sobre aspectos estéticos (dermatología, cirugía íntima y cirugía plástica).

autoridad, la doctrina, la academia, la meditación, la matemática, la memoria, la nobleza, la persuasión y la paciencia.

64. MARAÑón, Gregorio. «Patología e higiene de la emoción». Residencia, Revista de la residencia de Estudiantes 11 (i), 1927 pp. 1-7.

65. MARAÑÓN, Gregorio. La doctrina de las secreciones.... Op. cit.

66. Dr. César Juarros. «El climaterio». Sección de Higiene, Medicina y la Salud.La libertad, 17/10/1926. *Un poco más adelante el autor detalla el síndrome de Bloch, que en ocasiones obliga a recluir a las menopáusicas. Sus características: 1 , oscurecimiento de la piel, 2, perturbaciones digestivas 3; aumento de vello y 4, síntomas nerviosos de fatiga, tristeza, emotividad, irritabilidad e insomnio. En su origen la interrupción brusca de la vida sexual (por separación, abandono o viudedad). De nuevo juntos varios estereotipos: hormonas, desequilibrio, y signos de virilización.

67. . ABC Salud, 11-12/2010, p. 21. 


\section{El mañana}

La biografía femenina es una sucesión de ciclos vitales demasiado excéntricos al concepto de triunfo en la sociedad occidental para poder soslayar permanentemente el temor al fracaso ${ }^{68}$. Hoy enfrentamos esta realidad con una mayor lucidez, pero tal vez con similar desasosiego. La americana Sue ShellenBarger distingue cinco arquetipos fácilmente descifrables de respuestas contemporáneas frente al climaterio: la aventurera, la amante, la artista, la líder, la buscadora espiritual y la jardinera ${ }^{69}$. Con el habitual pragmatismo anglosajón señala los riesgos y ventajas de cada una para concluir que desde la perspectiva de la vejez siempre es mejor haber transitado los caminos de la rebelión que haber permanecido en la pasividad. Creo que este propósito es un buen epílogo para una reflexión que no pretende sublimar la menopausia porque sublimarla es tan desatinado como vituperarla, y ambos caminos son igualmente insensatos. Ciertamente el único bálsamo eficaz para sobrellevar cualquier etapa de la existencia es perseguir la autenticidad sin atajos fanta$\operatorname{siosos}^{70}$, aunque ésta con frecuencia no nos complazca.

\section{Referencias bibliográficas}

ARISTÓTELES. «Historia de los animales lib. III», 1990, Madrid, Ed. Akal Clásica, p. 518.

AYERS, Beberly y cols. «The impact of attitudes towars the menopause on women's symptom experience: a systematic review». Maturitas 65 (2010), pp. 28-36.

BATESON, Catherine. Composing a life, USA, Penguin ed, 1990.

BAER, Roberta y cols. «Las enfermedades populares en la cultura española. Un estudio comparado sobre el mal de ojo». Revista de Dialectología y tradiciones populares, LXI (2006), pp. 139-156.

BARBEITO, Isabel. «Mujeres eremitas y penitentes». Via Spiritus 9 (2002) pp. 185-215.

BRANDES, Stanley. ¿Qué significa cumplir los cuarenta? Cultura y crisis a la mitad de la vida». Revista de dialectología y tradiciones populares 50 (1995), pp. $27-50$.

68. BATESON, Catherine. Composing a life, USA, Penguin ed, 1990.

69. Shellenbarger, Sue. The breaking Point. New York, Owl Books, 2005.

70. MaitTland, Sara. Viaje al silencio., Barcelona, Alba 2008. En este libro, altamente recomendable a mi juicio, la autora insiste en la importancia de la menopausia, la separación de pareja y independencia de los hijos como motivos de su transformación personal.

Feminismo/s 18, diciembre 2011, pp. 185-202 
BROWN, Jessica y cols. «Relations among menopausal symptoms, sleep disturbances and depressive symptoms in the midlife». Maturitas 62 (2), (2009) pp. 184-189.

BURGER, Henry. "Hormonal changes in the menopause transition». Recent Progress in Hormone Research 57:257-275 (2002)

BURPEE, S. «Menopause and mood disorders2. http://emedicine.medscape.com/ article/295382

CABEllo, Paz. «La mujer en torno a la menopausia en el arte y la cultura indígena americanas». Anales del Museo de América 3 (1995), pp. 131-144.

CABRÉ Monserrat y ÓRTIZ, Teresa. «Entre la salud y la enfermedad: mujeres, ciencia y medicina en la historiografía española actual». En La Historia de las Mujeres. Perspectivas actuales. Historia y feminsmo. Barcelona, Icaria Ed. 2009.

CANET, Jose Luis «La mujer venenosa en la época medieval». http://parnaseo. uv.es/Lemir/Revistal/Mujer_venenosa.html

CASPER, Robert. «Clinical manifestations and diagnosis of menopause». UPTODATE.com Op. cit.

Cirlot, Juan Eduardo. Diccionario de símbolos. Madrid, Ed. Ciruela (2003), pp. 183.

CORTIJo, Antonio «Vida de la madre catalina de Cardona por fray Juan de la Miseria. Un texto hagiográfico desconocido del siglo XVI (Bancroft Library, UCB, Fernán Núñez Collection, vol. 143)» Dicenda: Cuadernos de Filosofía Hispánica 21 (2003) pp. 21-34.

DE RYNCK, Patrick. Como leer la mitología y la Biblia en la pintura. Barcelona, Electa, 2009.

DE SAN GABRIEL, "De la buena mvger doña Chatalina de Cardona heremita carmelita descalza y fundadora del convento heremítico de nra. Señora del Socorro y de otros por su medio fundados. Los discursos que, carmelita descalzo, su confessor y deboto hijo meditaba,...» Madrid, Biblioteca Nacional ms. 4213 fols. 12r y 17v.

DOMínGUEZ, Susana. «Realidad y leyenda del mal de ojo». Garoza: revista de la sociedad española de estudios literarios de cultura popular 7 (2007) pp. 47-60.

El WHI (Women's Health Initiative Study). «Risk and benefits of estrogens plus progestin in healthy postmenopausal women». JAMA 288 (2002) pp.321-333.

FERNANDEZ, Antonia. «Pintura, protagonismo femenino e historia de las mujeres». Arte, individuo y sociedad., Madrid, Ed. Universidad Complutense, 1997.

FERrándiz, Carlos. Bestiario medico., Madrid,Ed. Envida, 2000, pp.107.

FERrándiz, Carlos. «Dioscórides (Bestiario) de A. Laguna». Madrid, Ed. Medusa. 2001 pp. 261.

Frazer, James. «La Rama Dorada. Magia y Religión». México, Fondo de Cultura Económica1951, pp. 24-242.

FreIXAS, Anna. Nuestra menopausia. Barcelona, Paidos, 2007. 
GENAZZANI, Andrea y cols. «Estrogen, cognition and ageing». Human reproduction updates 13 (2007) pp. 175-187.

HuARTE DE SAn JuAn, Juan. Examen de los ingenios. Biblioteca de Autores Españoles, tomo LXV, Madrid, Atlas, 1953.

Heliades, Mircea. Lo sagrado y lo profano., Madrid, Guadarrama, 1967.

HunTER, Myra. «Bio-psycho-socio-cultural perspectives on menopause». Best practice E Research Cinical Obstetrical and Gynecology. 21 (2007), pp.261-274.

KRAPF, Jill y SIMON, James. «The role of testosterone in the management of hypoactive sexual desire disorder in postmenopausal women» Maturitas 63 (2009) pp. 213-219.

KRIEGER, Nancyy cols. «Hormone replacement therapy, cancer, controversies, and women's health: historical, epidemiological, biological, clinical and advocacy perspectives». J Epidemiol Commmunity Health 29 (2005) pp.740-748.

KUHLE, Barry. «An evolutionary perspective on the origin and ontogeny of menopause». Maturitas 57 (2007) pp.329-337.

LEIDY, Louise. «Menopause in evolutionary perspective». Evolutionary Medicine. Oxford, Ed. W.R. Trevathan, E. O. Smith y J. J. McKenna. Oxford University Press, 1999, pp.407-427.

LEÓn, Pedro. Disertaciones morales y médicas, Madrid, 1751, pp. 60 y 189.

MaitTland, Sara. Viaje al silencio., Barcelona, Alba 2008.

MARAÑón, Gregorio. La doctrina de las secreciones internas. Madrid, Biblioteca Corona,1915, p. 105.

MARAÑón, Gregorio. «La edad crítica». Madrid, Ed. Ruiz Hernando, 1925.

MARAÑón, Gregorio. «Patología e higiene de la emoción». Residencia, Revista de la residencia de Estudiantes 11 (i), 1927 pp. 1-7.

MARAÑón, Gregorio.Climaterio de la mujer y el hombre (estudio de la fisiopatología de la involución sexual), Madrid, Espasa Calpe, 1937.

Morrow-Lindberg, Anne. Gift from the sea. New York, Vintange books, 1983.

PAGELS, Elaine. Adan, Eve and the serpent.new York, Vintage books, 1988.

PANJARI, Mary y DAVIS, Susan. «DHEA for postmenopausal women: a review of the evidence». Maturitas 76(2010) pp. 172-180;

PARís Y VIANA, «La doncella Teodor; Flores y Blancaflor», Narrativa Popular de la Edad Media, Madrid, Ed. Akal, 1995.

PASCUAL, Jesús. «Una aproximación a la imagen de la mujer en el arte español». Ogigia, revista electrónica de estudios hispánicos 1 (2007), pp.75-89 http:// www.ogigia.es

PÉREZ DE AYALA, Ramón. La Esfera 21/7/ 1928.

PIÑERO, Antonio. Los cristianos derrotados. Madrid, Edaf, 2007, pp. 91 y sig.

RIPA, Cesare. Icolonogía. Madrid,Akal /Arte y Estética, 2007. Obra original publicada por primera vez en 1616.

Feminismo/s 18, diciembre 2011, pp. 185-202 
RoJAS, Antonio. «Los «Hieroglyphica» de Piero Valeriano y su recepción en España durante el siglo XVI». Humanismo y pervivencia del mundo clásico: homenaje al profesor Antonio Fontán, vol. 3 (2002), pp.1607-1612.

SABUCO, Olivia. Nueva filosofía de la Naturaleza del hombre. Madrid, 1728.

SALMÓN, Fernando y CABRÉ, Monserrat. «Fascinating women: the evil eye in medical scholasticism». En. Medicine from the black death to the French disease. Gran Bretaña, Ed. French et al, Ashdgate, 1998, pp. 54-84.

SCHMIDT, Peter y cols. «Sex hormones and mood in the perimenopause. Glucocorticoids and mood». Ann N.Y.Acad. Sci. 1179 (2009), pp. 70-85.

SERITAN, Andreea. y cols. «Self-reported anxiety, depressive, and vasomotor symptoms: a study of perimenopausal women presenting to a specialized midlife assessment center». Menopause 17 (2), (2010), pp. 410-415.

Shellenbarger, Sue. The breaking Point. New York, Owl Books, 2005.

SNYDER, Peter. «Decline in testicular function with aging». http://www.uptodate. com Wolkers Kluwer Ed, 2010.

WArren, M. 2Historical Perspectives in Postmenopausal hormone therapy2. Mayo Clin Proc. 82(2):219-226, 2007.

Wu, Julie y cols. "Ovarian aging and menopause: current theories. Hypotheses, and research models». Exp. Biol Med 230, (2005) pp. 818-828. 


\title{
LA MATERNIDAD EN EL IMAGINARIO DE LAS ESCRITORAS VASCAS
}

\author{
GEMA LASARTE LEONET \\ Universidad del País Vasco
}

Recibido/15/07/2011

Aceptado/25/09/2011

\section{Resumen}

Este artículo estudia y analiza la representación de la maternidad en la narrativa vasca desde 1979 hasta el año 2010. La autoría femenina, los personajes femeninos protagonistas y la maternidad como eje temático son los criterios establecidos para delimitar el corpus de esta investigación. La crítica feminista y la narratología han sido los paradigmas teórico-metodológicos aplicados en el análisis de los ejes temáticos y de los personajes. La aportación más significativa de esta investigación es la ratificación de que la maternidad, que constituye una piedra angular dentro del pensamiento feminista, tiene una presencia y una representación análogas en la literatura vasca, en tanto que el $66 \%$ de las obras analizadas abordan la temática de la maternidad.

Palabras claves: maternidad, literatura, personajes femeninos, cuerpo.

\begin{abstract}
This article studies and analyses the representation of motherhood in the Basque narrative from 1979 until the year 2010. Female authorship, the female characters, protagonists and motherhood as thematic axis, are established criteria to delimit the corpus of this research. Feminist criticism and the narrative have been methodological elements paradigms applied in the analysis of the themes and characters. The most significant contribution of this research is the ratification that motherhood, which is a cornerstone in feminist thought, has a similar representation in Basque literature, while 66 analyzed works dealt with maternity as a thematic axis.
\end{abstract}

Keywords: maternity, literature, female characters, body.

Feminismo/s 18, diciembre 2011, pp. 203-223 



\section{Introducción}

Este artículo estudia la representación de la maternidad en la narrativa vasca desde 1979 hasta el año 2010. Para dicho estudio nos hemos centrado en el análisis de novelas escritas por narradoras vascas y protagonizadas por personajes femeninos. La autoría femenina, los personajes femeninos protagonistas y la maternidad como eje temático son los criterios establecidos para delimitar el corpus de esta investigación. Tras una breve introducción y unas aportaciones teórico-metodológicas, se efectúa un repaso por las distintas maternidades con el objetivo de averiguar las analogías existentes entre la realidad social y la realidad literaria de la época analizada. Para ello, partimos de la hipótesis del concepto de homología del crítico marxista Lucien Goldmann ${ }^{1}$ que lo define como una analogía entre las estructuras sociales y las literarias. Para determinar las analogías referentes a la maternidad, llevamos a cabo, en un primer apartado, un recorrido por todo el corpus, sin pretender un estudio conciso y detallado de cada novela, sino realizar un agrupamiento de las mismas que nos permita interpretar los distintos aspectos de la maternidad que destacan en el imaginario de las narradoras vascas.

En segundo lugar y dentro del mismo apartado, se analizan de forma más exhaustiva las dos novelas que mejor reflejan las dos posturas más extremas sobre la maternidad en la literatura vasca: Zergatik Panpox $(1979)^{2}$ de Arantxa Urretabizkaia que celebra la maternidad y Eta emakumeari sugeak esan zion $(1999)^{3}$ de Lourdes Oñederra que constituye una clara negativa a la procreación. Para concluir con estas aproximaciones textuales, hemos ahondado también en las nuevas paternidades, temática novedosa en la narrativa vasca, y que aparece tímidamente en varias novelas, como en Sisifo maiteminez $(2001)^{4}$ en la que Laura Mintegi incorpora esta temática innovadora. Para

1. La crítica marxista abordó como tema de estudio la dimensión social del personaje literario. Lucien Goldmann aportó el concepto de homología, entendido como analogía entre las estructuras literarias y las estructuras sociales. Referencia bibliográfica: GOLDMAnN, Lucien. Para una sociología de la novela. Ciencia Nueva, Madrid, 1967.

2. Esta novela está traducida al castellano: ¿Por qué Panpox? (1995), Orain.

3. Traducida al castellano: Y la serpiente dijo a la mujer (2000), Bassarai.

4. Traducida al castellano: Sisifo enamorado, (2003), Txalaparta.

Feminismo/s 18, diciembre 2011, pp. 203-223 
finalizar la parte dedicada al análisis de las distintas representaciones, hemos seleccionado el citado texto y por último, hemos dedicado sendos epígrafes a las conclusiones y a la bibliografía.

\section{Aportaciones teórico-metodológicas}

La elección de un mismo semema en el análisis de los textos puede llegar a ser un objeto de estudio sorprendentemente revelador, como augura Geraldine Nichols: «Poner de relieve el tratamiento de la procreación puede iluminar constelaciones de significados hasta ahora ocultos, a la vez que ofrecer una radiografía de los tiempos que corren $»^{5}$. En este sentido, el tema de la reproducción o la maternidad puede facilitar el estudio de temas como las complejas relaciones de pareja, la influencia de la madre o la desigualdad y la injusticia, temas que funcionan, asegura Nichols, como sinécdoque de una serie de prácticas que implican la desigualdad.

En relación a la maternidad como eje temático, la crítica feminista ha visualizado la maternidad desde distintas ópticas. Así, parte de los discursos feministas del siglo pasado fueron profundamente anti-maternos (Beauvoir, 2005; Firestone, 1976; Rich, 1996). Simone de Beauvoir habla de la maternidad como único destino posible, Shulamith Firestone vislumbra la maternidad como una apropiación de los cuerpos de las mujeres como recurso de reproducción del patriarcado y Adrianne Rich diferencia la maternidad como institución y la maternidad como una experiencia física y psicológica por parte de las mujeres y, junto a ello, se produce una reapropiación del cuerpo. Esta reivindicación de lo corporal como vía de conocimiento y poder deriva en planteamientos positivos de la maternidad. De esta manera, Sara Ruddick (1984) propone una aproximación del feminismo al pacifismo, Shiva Vandana (1995) propugna el eco-feminismo que retoma la analogía de la mujer con la tierra. Desde otra perspectiva, el feminismo de la diferencia (Irigaray 1974, Cisoux, 1975) trata de reconocer la tarea de la reproducción, menospreciada por los hombres e inicia así el discurso del orgullo del cuerpo.

Este breve recorrido que resume la centralidad del debate feminista sobre el tema de la maternidad, en la actualidad y en el ámbito nacional, ofrece nuevas lecturas. Maria Luz Esteban ${ }^{6}$ afirma que en los últimos treinta años se han ido produciendo modificaciones claras en las regulaciones y controles sobre los cuerpos de las mujeres y habla de las diferentes posiciones feministas

\footnotetext{
5. NiCHOLS, Geraldine. «El procrear, pro y contra», en REDONDO, Alicia (ed.): Mujeres novelistas, Madrid, Taurus, 2003: 192.

6. EsteBAn, Maria Luz. Antropología del cuerpo. Bellaterra, Barcelona, 2004: 32.
} 
respecto al cuerpo. En este sentido, una forma de entender el cuerpo sería la que ofrece la perspectiva constructivista en la que se defiende que la identidad y la subjetividad se construyen socialmente. Se trataría, según Esteban, de presentar a las mujeres no como víctimas sino como agentes de sus vidas capaces de generar propuestas alternativas que compensen su situación de desventaja. Un ejemplo claro de ello lo constituyen las Madres de la Plaza de Mayo que cuestionan el sistema político en su conjunto desde la asunción del rol de madres. Esta posición de empoderamiento y visión de la maternidad nos muestra otra perspectiva de estudio desde la crítica feminista.

En este mismo sentido, Miren Llona en el capitulo «Patriotic Mothers of Basque Nationalism: Women's Action during the Spanish Second Republic in the Basque Country» (2010) al indagar en la vida de Polixene Astrabudua, retoma el modo de análisis que Cherry Moraga define como «Theory in the flesh». Esta teoría entiende la construcción de la identidad como algo inseparable de la experiencia física y de la huella dejada por esa experiencia en el cuerpo. Nosotras hemos querido analizar la maternidad en este artículo siguiendo el método propuesto por Moraga, esto es, como una experiencia física vivida desde el cuerpo y al mismo tiempo como construcción de la identidad.

Elixabete Imaz en su tesis doctoral (2007) afirma que las mujeres pasan la mayor parte de su vida evitando activamente el embarazo y por ello adquiere pertinencia preguntarse por las situaciones concretas que promueven que la maternidad se vea como plausible y deseable. Añade la autora que la conversión de una mujer en madre es un tránsito social que no puede reducirse al simple acontecer fisiológico del parto sino que es, además, un proceso de aprendizaje y socialización. En otras palabras: la conversión de una mujer en madre se traduce en la gestación de una madre en un complejo social. Por otra parte, el crítico literario marxista George Luckás ${ }^{7}$ reconoció al personaje literario su dimensión social asegurando que este se construía en una dialéctica abierta con la realidad social.

Si para el análisis de los distintos aspectos discursivos ${ }^{8}$ de la maternidad esta investigación ha requerido de la crítica feminista, para el estudio de los

7. En la crítica marxista tiene singular importancia el concepto de héroe problemático del cual es autor George Luckás. Luckás habló de la dimensión social del personaje y de su interacción con la sociedad. Para este punto recomendamos leer su obra Teoría de la novela (1971), se cita en las referencias bibliográficas.

8. El discurso entendido como un conjunto de afirmaciones o enunciados (que, adviértase, pueden o no manifestarse como un conjunto de textos) que están unificados porque tienen un objeto de análisis común ya que articulan de modo singular el conocimiento sobre tal objeto, según Maria José Vega (2003:83). Ver referencia bibliográfica.

Feminismo/s 18, diciembre 2011, pp. 203-223 
personajes ha recurrido a la narratología. Desde el punto de vista narratológico hemos tenido en cuenta las aportaciones de Algirdas Julius Greimas (1983) y las revisiones a su teoría formuladas por Mieke Bal (1985) y Sholomith Rimmon-Kenan (1983). Es interesante observar que al concepto del personaje como unidad sintáctica o posición estructural, Bal agregue la teoría del personaje como una unidad semántica completa. Carmen Boves, (1993) va más allá e incorpora la pragmática como aspecto importante a la hora del estudio del personaje.

La narratología aporta conceptos fundamentales para el estudio del personaje: funciones (Greimas) $)^{10}$, focalización (Genette $)^{11}$, discurso (Friedman) ${ }^{12} \ldots$ pero es básicamente mediante este último recurso, el del componente discursivo, que el personaje comienza a hablar solo o comienza a mezclarse con el discurso del narrador. Silvia Burunat en su obra El monólogo interior como forma en la narrativa española (1980) señala que del mismo modo que el psiquiatra coloca al paciente en el sofá ocupando él una posición invisible con respecto a aquel que se convierte en el sujeto que habla, expresando todo lo que fluye por su mente y de esta manera una idea produce otra, un recuerdo sugiere otro hasta que la conciencia se convierte en un hecho psíquico conocido, el novelista somete a sus personajes a un tratamiento semejante,

9. Para el estudio del personaje literario consideramos de estudio obligatorio los autores mencionados: Greimas, Bal y Rimmon Kenan en las obras indicadas en las referencias bibliográficas. Disertan sobre las funciones gramaticales que cumple el personaje en el texto. Bal resalta aspectos semánticos en su obra Teoría de la narrativa (1985) en la página 87. Carmen Boves incorpora características del personaje de aspectos más pragmáticos en su obra Teoría de la novela (1993) en la página 157.

10. Las funciones gramaticales del personaje y el concepto de paradigma actancial son de Greimas. El esquema de los actantes lo constituyen seis agentes: los sujetos-objetos de la acción. El sujeto ofrece un principio dinámico a la acción respondiendo al deseo, al miedo, las ganas.... Todo ello constituye el sentido del objeto, es decir, lo que el sujeto quiere lograr. De esta forma, el deseo, el miedo o las ganas unen al sujeto y al objeto en la función gramatical. El destinador incide directamente en el sujeto, le exige distintos quehaceres. El destinatario a su vez puede ser el beneficiario de la acción; muchas veces puede ser el mismo protagonista. Los ayudantes y contrarios del sujeto pueden ayudar o poner trabas a los objetivos del sujeto. En resumen, el paradigma actancial se construye de la siguiente forma: Destinador/Objeto/Destinatario; Ayudante/Sujeto/ Oponente.

11. El narratólogo Gérad Genette en Figuras III hace interesantes aportaciones al concepto de Focalización que hasta entonces se confundía con las funciones narrativas.

12. Friedman analiza los distintos estilos para expresar los sentimientos y los pensamientos de los personajes: el estilo directo, el estilo indirecto, el estilo indirecto libre... todos ellos formas de encauzar la voz, el pensamiento de los personajes. En «Point of view in fiction: the development of critical concept». 
induciendo a sus criaturas a hablar por sí mismas en un lenguaje que es inherente a su mentalidad.

Las críticas feminista y marxista enfatizan la dimensión social del personaje. Uno de los representantes más conocidos de la crítica marxista, George Lukács, sostiene que el personaje mantiene una constante dialéctica con su entorno; Lucien Goldmann, creador del estructuralismo genético, subraya la homología que existe entre el personaje literario y la persona que habita en sociedad. La crítica feminista acomete en 1970 el estudio de las figuras femeninas creadas por los hombres (Millet, 197013) y desde entonces, el estudio de las figuras e imágenes de las mujeres cobrará una importancia incuestionable. Rich ha denominado «revisión» al acto de mirar hacia atrás, de ver con ojos nuevos, de entrar en un texto antiguo desde una nueva mirada crítica. A finales del siglo XVIII las mujeres ya no solo estaban intentando escribir, estaban concibiendo mundos de ficción en los que las imágenes y convenciones patriarcales se revisaban de forma severa y radical. Por su parte, Susan Gilbert, y Sandra Gubar, ${ }^{14}$ realizan un interesante estudio de los personajes femeninos creados por las autoras del siglo XIX.

\section{Distintas representaciones de la maternidad}

En el periodo de tiempo que nos ocupa (1970-2010), las mujeres escritoras vascas han configurado una treintena de narraciones con personajes protagonistas femeninos. En casi todas ellas aparece la maternidad, a excepción de las obras de la autora labortana, Itxaro Borda, que no la menciona; únicamente, en la novela Bizi nizano munduan (1996) nos sugiere la historia de un hijo negado, bastardo, de uno de los personajes femeninos secundarios. Asimismo, Garazi Goia, Nora Arbelbide e Iratxe Esnaola, en sus respectivas obras Bi hitz (2008), Goizeko zazpiak (2006) y Galerna (2009) eluden tratar el tema de la maternidad. Por ese motivo, estas obras han sido excluidas de nuestro estudio. Todas las demás autoras, dentro de la acotación cronológica elegida para el análisis, abordan la temática de la maternidad y la relacionan con el personaje protagonista femenino.

En el siguiente epígrafe, realizamos una aproximación textual a las novelas que contemplan los distintos aspectos de la maternidad que las escritoras

13. Millet, Kate publicó por vez primera Política Sexual en 1969 e inició el estudio y tratamiento que el hombre daba a la imagen de la mujer.

14. Gilbet, Susan y GubAr, Sandra son las autoras de un clásico de la literatura, La loca del desván. La escritora y la imaginación literaria del siglo XIX. Es el primer ensayo que profundiza en el estudio del tratamiento de los personajes literarios femeninos. Ver referencia bibliográfica.

Feminismo/s 18, diciembre 2011, pp. 203-223 
vascas han abordado en su narrativa mediante sus personajes protagonistas femeninos. Este primer apartado tiene como objetivo presentar de forma sistemática los aspectos, las temáticas y el posicionamiento del personaje femenino en el paradigma actancial. El segundo apartado ofrece una aproximación textual más profunda de la maternidad. Para ello, hemos seleccionado tres novelas de gran relevancia en la novelística vasca: Zergatik Panpox, la primera novela que aporta a la literatura vasca un sujeto protagonista femenino moderno, Eta emakumeari sugeak esan zion la primera novela en la literatura vasca que recibe un premio tan importante como polémico ${ }^{15}$, y por último Sisifo maiteminez (2001), según la crítica vasca, el texto más significativo de una de las autoras más prolíferas de la literatura vasca actual, Laura Mintegi. Estas tres obras ofrecen tres miradas, tres formas muy distintas de entender la maternidad y es esa la razón principal de haberlas seleccionado para un estudio más pormenorizado.

\subsection{Un breve repaso por las distintas maternidades}

\subsubsection{Las maternidades temidas y obligadas}

Las obras de Laura Mintegi, Bai... baina ez (1986), de Sonia González, Ugerra eta kedarra (2003) y, por último, de Aitziber Etxeberria, Tango urdina (2003) representan una maternidad no deseada. En concreto, las tres novelas materializan una maternidad temida ya que lo que la niña descubre a su alrededor no es un vacío por la madre, sino unos discursos que se empeñan en asegurar que es negativo e imperfecto. ${ }^{16}$ Las tres sujetos protagonistas (Rosa, Kat, Marga) no desean la maternidad, las experiencias sociales que configuran sus vidas han contribuido a negar la maternidad. Rosa es huérfana de madre, Kat vive en un mundo de violencia y de drogas, donde sobrevivir es lo más acuciante y Marga sufre a diario los malos tratos de su marido. Marga ha abortado, y posteriormente tiene una hija, muy a pesar del marido que deseaba un niño. Estos personajes literarios construidos desde la semántica de la violencia de género, rehúsan la maternidad como objeto. En el paradigma actancial se observa que la sociedad funciona como destinador para enraizar en Rosa, Kat y Marga el rechazo a la maternidad. Los abusos sexuales, la pobreza y el mal trato son los ejes temáticos sobre los que se sustentan estas narraciones y

15. Recibió varios premios: Premio de la Crítica y el Premio Euskadi que tuvo gran controversia en la prensa: se habló de que ganó el premio por ser mujer.

16. BENGOECHEA, Mercedes.»Mi madre es... un hueco en el espacio: discursos poéticos y lingüísticos sobre insignificancia materna», DE LA CONCHA, Ángeles y OSBORNE, Raquel (ed.): Las mujeres y los niños primero. Icaria, Barcelona, 2004: 103. 
los campos semánticos que significan a los personajes, por lo tanto, la función gramatical de estos personajes se inscribe en el rechazo a la maternidad.

Otro de los aspectos que redunda en los aspectos negativos de la maternidad es la maternidad obligada. En este punto vamos a introducir a las madres veteranas, así tenemos a Graziana de Ixiar Rozas (1972) que aparece en Edo zu edo ni (2000), a Teresa de Uxue Alberdi (1984) en Aulki-jokoa (2009), a Elena de Karmele Jaio en Musika airean (2009) y las tres protagonistas de Urretabizkaia en Hiru Mariak (2010). Todos estos personajes literarios rondan entre los 65-85 años y nos remiten a la afirmación de Beauvoir en torno a que la maternidad tiene que dejar de ser un destino para convertirse en un proyecto, es decir, tiene que ser elegida libremente. Estos personajes literarios han nacido con el siglo, han sufrido la guerra civil española, y han vivido la experiencia de la maternidad obligatoria. Beauvoir afirma que este tipo de madres son las madres dolorosas, frustradas, que no han tenido expectativas en la vida y que han vivido encerradas. Graziana, Teresa, Elena y las tres Marías son mujeres casadas que han vivido encerradas en sus casas hasta que han muerto sus esposos y se han puesto a pensar en el pasado y a cuestionar el futuro. Elena, hasta que muere su marido, no se da cuenta de que lo que realmente le gusta a ella es vivir sola, Graziana se queja de que a sus hijos no les importa quién era antes de ser madre.

Son madres que en el paradigma actancial cumplen el cometido de la familia y la maternidad, pero la edad las libera de ese compromiso y cambian las funciones en el texto porque estas mujeres mayores quieren ser sujetos de sus acciones. No obstante, es importante reseñar en este punto, la visibilidad que adquieren estas protagonistas con la edad. Es de resaltar desde el punto semántico y pragmático la representación de estas mujeres con sus cuerpos envejecidos y medicalizados, cuando la norma estética marca el culto a la juventud. En la actualidad, las personas viven el proceso de envejecimiento en un entorno de ausencia de representación. ${ }^{17}$

\subsubsection{Madres abandonadas}

Bajo este título vamos a incluir Koaderno gorria (1998) de Arantxa Urretabizkaia y Nerea eta biok (1994) de Laura Mintegi. Los personajes protagonistas de estas novelas tienen características similares: son madres de una edad comprendida entre los 30 y los 40 años, gozan de un cierto estatus, poseen un

17. KoGAN, Libia publicó un artículo muy interesante en relación a los cuerpos. «Jóvenes y viejos: ¿el cuerpo como locus de identidad?». En Revista Latinoamericana de Estudios sobre Cuerpos, emociones y Sociedad. Argentina, 2011: 17.

Feminismo/s 18, diciembre 2011, pp. 203-223 
trabajo remunerado, muestran inquietudes políticas y han sido abandonadas por sus respectivos esposos. Las madres analizadas, sin nombre, son madres agentes, independientes que equiparan la maternidad al trabajo profesional y al activismo político. Koaderno Gorria relata la historia de una madre que milita en ETA y cuyo marido secuestra a sus hijos y se los lleva a Venezuela. La madre no tiene ninguna información sobre sus hijos y comienza a escribir un cuaderno rojo. En relación a Koaderno Gorria, la crítica y profesora Maria José Olaziregi ${ }^{18}$ afirma que este personaje nos habla del aspecto social y político de la maternidad. Olaziregi va más allá y señala que de la misma forma que le robaron los hijos, también le robaron la maternidad y la familia. Y esto constituiría la tragedia más significativa de esta obra: la negación del desarrollo personal de la mujer por parte de la sociedad machista.

En Nerea eta biok, Isabel la protagonista, es una profesora de la Universidad que tiene dos hijos mayores cuyo esposo la abandona porque la vida de padre no le satisface plenamente y quiere dar un giro a su vida y vivir nuevas experiencias. Isabel reflexiona sobre esta actitud de su marido y llega a la conclusión de que no estaba preparado para la paternidad. Tanto la madre de Koaderno Gorria como Isabel hablan en primera persona y tienen por objeto rehacer sus vidas.

\subsubsection{Madres simbólicas}

Yolanda Arrieta nos muestra en la novela Jostorratza eta haria (2001) a una madre simbólica que teje la historia de su familia. Esta madre, Miren, cuenta la historia de su familia a la hija que está por nacer (Mirentxu), para hacerla participe de la palabra y de la realidad en cual le va a tocar vivir, esto es, la madre mediante la palabra enseña a hablar y enseña, para toda la vida, el sentido de la realidad y de la verdad. ${ }^{19}$ Como expresaría Luce Irigaray, la madre simbólica de Jostorratza eta haria, ella crea su propio lenguaje y su propio discurso a través de las historias transmitidas por sus abuelas. El relato obedece a una isotopía propia del hilado y a una sintaxis nueva, tejida despacio, de una forma visual y fácil de comprender. Es una madre simbólica que teje su historia a retazos, recreando así la metáfora de la cultura clásica griega que establece paralelismos entre la literatura y la costura. ${ }^{20}$ Pero también se trata de un cuerpo embarazado y de una madre que responde al concepto de

18. Olaziregi, María José, Euskal eleberriaren historia. Labayru Ikastegi, Amorebieta-Etxanoko, 2002107.

19. Rivera Garretas, Milagros. La diferencia sexual en la historia. PUV, Valencia, 2004: 57.

20. KORTAZAR, Jon analiza Jostorratza eta Haria en Euskal Literatura XX, 2003: 284. 
agencia (Esteban, 2004), obviando la construcción de su propia subjetividad y la identidad de la niña que todavía no ha nacido.

Esta madre transmisora de la memoria colectiva y de la cultura oral ha tenido gran presencia en la cultura vasca. Baste citar a Mercedes Ugalde que en su tesis doctoral Mujeres y nacionalismo. Génesis y desarrollo de Emakume Abertzale Batza 1906-1936 (1993) y a Maite Núñez Betelu la cual en su tesis inédita Género y construcción nacional en las escritoras vascas (2001) dan testimonio de ello. De las treinta novelas investigadas, Miren de Jostorratza eta haría es la única figura femenina protagonista que retoma este papel de sujeto trasmisor de la cultura sobradamente constatado en la realidad social y literaria vasca anterior a la época contemporánea. Esta realidad evidencia el concepto de homología de Goldmann, en tanto que actualmente en la realidad social la madre vasca no es la portadora ni la transmisora de la lengua y la cultura vasca.

\subsection{Zergatik Panpox: recreación de la maternidad}

Dentro del corpus a estudiar hay dos novelas que recrean la maternidad desde la primera hasta la última página. Se trata de Bi marra arrosa (2009) de Jasone Osoro y Zergatik Panpox (1979) de Arantxa Urretabizkaia. Analizaremos en profundidad Zergatik Panpox porque la madre protagonista del relato es el primer personaje femenino moderno protagonista de la narrativa vasca. ${ }^{21}$

Zergatik Panpo ${ }^{22}$ nos ofrece un paradigma de familia monoparental. «La maternidad monoparental no sólo es una posición familiar nueva, sino una realidad compleja y significativa en curso, que las mujeres tras una experiencia de separación y/o divorcio van dotando de sentido». ${ }^{23}$

Arantxa Urretabizkaia elabora esta familia monoparental en su relato y se adscribe al eje temático del abandono. La madre, sin nombre, recuerda constantemente el abandono de su marido y su lucha por constituir una familia.

Por encima de estas constantes alusiones al abandono y la ausencia, la novela recrea la relación madre-hijo, una relación corporal y cósmica. Susan

21. LASARTE, Gema en su tesis doctoral Pertsonaia protagonista femeninoen ezaugarriak eta bilakaera euskal narratiba garaikidean (2011) incorporó el personaje femenino de Zergatik Panpox en la historiografía crítica de los personajes literarios de la literatura vasca, siendo la primera protagonista femenina de la historia literaria vasca.

22. Zergatik Panpox se escribirá de aquí en adelante como ZP.

23. BARRON, Silvia «Introducción: La maternidad monoparental», en Las mujeres y los niños primero. Op. cit., p. 229.

Feminismo/s 18, diciembre 2011, pp. 203-223 
Rubin Suleiman ${ }^{24}$ al criticar la obra Maternité de Chantal Chawaf, expresa que esta unía el ejercicio de la escritura femenina con el hecho biológico de la maternidad. La experiencia central alrededor de la cual gira su escritura, indica Suleiman, es la experiencia emocional y física de la maternidad y del amor maternal, dotándole así de una trascendencia casi cósmica. Lo mismo se podría señalar en la obra de Urretabizkaia. «Lurraren sabeleko suzko odola sustraien muturretatik sartzen zait, zuri loa sudurreko hegaletatik sartzen zaizun bezala» (Z P, 19) ${ }^{25}$

Además de esa relación cósmica, la presencia del cuerpo de la mujer, del cuerpo sangrante, es constante a lo largo de la novela. «La centralización del cuerpo y la sangre de la mujer, su proximidad con la Naturaleza (...) escribir en tanto que flujo (de la sangre menstrual, de la leche materna, del flujo uterino), sintaxis líquida» ${ }^{26}$. «Esne epelaren usai xamurra» (ZP, 17), «Non bizi dira malkoak begietara azaltzen ez diren bitartean» (Z P, 26). «Sabeletik laister aterako zaidan odol mukitsua bezala» (Z P, 31) ${ }^{27}$. Toda esta semántica corporal nos lleva a reafirmar, parafraseando a Beatriz Ferrús y Núria Calafell $(2008)^{28}$, que esta obra está escrita desde el cuerpo y con el cuerpo. Arantxa Urretabizkaia nos muestra por primera vez en la literatura vasca una nueva representación del cuerpo de la mujer. Establece, además, un diálogo entre lo íntimo (la menstruación) y lo social (el trabajo, la política). En el encuentro de estas dos experiencias es donde se construye la identidad, la mujer como agencia. Es en esta tensión entre el cuerpo vivido (biológico) y el cuerpo social (la mirada especular) donde se subjetiviza la madre de Zergatik panpox, una madre que afronta la realidad desoladora de crear una familia monoparental a raíz del abandono, pero que, sin embargo, es consciente de que esto es lo mejor para su hijo y para ella.

Si el cuerpo femenino posee gran relevancia en el texto, asimismo adquiere una gran beligerancia el lenguaje confeccionado por la madre para el niño. A diferencia de las teorías feministas de la igualdad que desprecian este acercamiento lingüístico de la madre al niño-a, Luisa Muraro (1994) desde el feminismo de la diferencia defiende esta actitud. Muraro explica así, que las madres al hacer este uso infantil del lenguaje no se desvalorizan, sino

24. Suleiman, Susan Rubin. «Escritura y maternidad». En: DovaY, Mercedes. (ed): Maternidad y creación. Lecturas esenciales. Alba, Madrid, 2007: 151.

25. La sangre de fuego del vientre de la tierra me entra por las puntas de las raíces, como a ti te entra el sueño por las aletas de la nariz.

26. Ibíd., p. 153.

27. El olor tierno de la leche. ¿Dónde viven las lágrimas hasta que asoman a los ojos? Como el líquido viscoso que pronto saldrá de mi vientre.

28. Ver la referencia del libro de estas autoras en Referencias Bibliográficas. 
que están elaborando una estrategia para acercarse al niño-a. Esto significa para Muraro una cultura más equitativa, cercana y tolerante. «La negociación conjunta de significados, en lugar de imposición de los propios o la falta de reconocimiento de los ajenos, sería básica en una sociedad que valorase la negociación $»^{29}$.

Para concluir, debemos poner de relieve la exquisita configuración de juegos lingüísticos y literarios que brinda la madre a su hijo. «Blandiblup» ( $\mathrm{P}$, 6), «panpox, pirulo» (ZP, 17), «amatxo, muxera, muxontzi» (Z P, 22). «zu, panpox bihotzekoa, Antxon pirulero,» (ZP, 14) «ario, panpox, muxu, lehoikumea, artaburua, tira, panpox, muxu» (ZP, 18)

Esta novela, escrita en los años 70, da fiel testimonio del movimiento feminista de aquella década y su personaje protagonista es consecuencia de un dialogo con las vivencias sociales y culturales que las mujeres experimentaban en aquella época, reafirmando así la dimensión social que el narratólogo marxista Lucien Goldmann reconoce a los personajes literarios.

\subsection{Un no rotundo al Génesis, un no rotundo a la maternidad. Eta emakumeari sugeak esan zion (1999) ${ }^{30}$}

Geraldine Nichols (2003) afirma que la novela Eta emakumeari sugeak esan zion ${ }^{31}$ narra el repudio, por parte de una española de hoy, del modelo femenino dictado en el Génesis. «El título de la obra orienta su lectura, al referirse a la historia bíblica que explica por qué la mujer tiene que someterse al varón, desear al varón y parir los hijos con dolor $\aleph^{32}$. El Génesis que hace alusión al pecado original puede tener diversas lecturas, entre ellas, la más conocida hasta ahora es la que alude a Eva. Eva, al igual que Pandora es responsable de expandir el pecado, es la antónima de la Virgen María, limpia de pecado. Por lo tanto, en el desarrollo del personaje de Teresa, la protagonista, encontramos elementos explícitos que recuerdan al Génesis y obvian una intertextualidad significante de la misma.

Cristina Molina (2004) nos invita a interpretar el Génesis de una forma diferente: siendo Adán y Eva dos seres creados a semejanza de Dios, esta última en su ansia infinita de parecerse más al creador, al más grande, y ser una persona sabia como el todopoderoso, comió la manzana prohibida.

29. BengoecheA, Mercedes. Op. cit., p. 103.

30. Traducida al castellano Y la serpiente le dijo a la mujer (2000).

31. Eta emakumeari sugeak esan zion, se identificará de ahora en adelante como ES.

32. NichOls, Geraldine, Op. cit., p. 202.

Feminismo/s 18, diciembre 2011, pp. 203-223 
Pero entonces sería la mujer la fuente del conocimiento, la que ejerció la iniciativa y no el hombre. (...) Desde aquí lo femenino aparecería como sabiduría, como amor a la sabiduría, al menos como afición o pasión por el conocimiento y como poder de persuasión, todo ello impensable para una práctica de dominio patriarcal. ${ }^{33}$

Por lo tanto, el pecado de Eva no sería de desobediencia, sino de orgullo ${ }^{34}$. Partiendo de esa nueva representación, Teresa reflexiona en torno a la libertad de su cuerpo, en torno a la libertad de hacer con su vida lo que más le place y se niega rotundamente a cumplir el postulado de «parirás».

«Se dispone a leer su cuerpo de otra manera, y ve en sus síntomas la señal de que está finalizando una etapa de su vida, precisamente la pautada en el Génesis.» ${ }^{35}$ Desde el principio hasta el final del relato habla el cuerpo de Teresa del cual también podríamos afirmar que es un cuerpo adscrito a la maternidad. «Después de orinar limpiar las manos (...) Hace mucho que no manchas, ni rastro de la menstruación» $(E S, 71)^{36}$. Teresa ha sido dueña de su cuerpo y ha evitado embarazos: «Cuando aprendisteis a comprar pastillas para no quedarte embarazada» (ES, 85). La gran duda ante la maternidad: «Si por otra parte la tristeza no se cura con los hijos (si tu tristeza no se cura con la maternidad), ¿qué le pasará una madre deprimida a su hijo?» (ES, 107). Y al final, la decisión irrevocable: «Ya sabes que te está llegando la hora de tomar la última decisión (...). La de empezar a envejecer sin hijos». (ES, 162). Oñederra incorpora toda la semántica de la maternidad y del cuerpo a su discurso para, al final, decir no a la dicotomía maternidad versus cuerpo.

Sabemos que Teresa en el transcurso del relato realiza dos viajes, uno físico que inicia rumbo a Viena y otro psicológico hacia el interior. Estos viajes corporeizan mediante el uso de la segunda persona una de las experiencias más significativas de este personaje literario: la decisión de abandonar la vida laboral, familiar y por último la maternidad y decidir un futuro. Teresa lo abandona todo y emprende un viaje en solitario hacia el Mediterráneo, hacia el lugar en el que conoció el único amor de su vida, ese amor que le alertó sobre la lejanía o la imposibilidad de acercamiento entre los hombres y las mujeres. Teresa camina hacia el pasado, pero que a su vez es futuro, un futuro elegido por ella para su cuerpo cansado para la maternidad y cansado para el amor. Un futuro tranquilo sin menstruaciones, sin hijos, sin relaciones

33. Molina, Cristina. «Madre inmaculada, virgen dolorosa. Modelos e imágenes en la tradición católica». En Las mujeres y los niños primeros, Op. cit., p. 48.

34. Ibíd. p. 48.

35. NiCHOLS, Geraldine. «El procrear, pro y contra». Op. cit., p. 202.

36. Las traducciones son nuestras. 
difíciles de entender; sin embargo, será también un futuro que descansa en la muerte, en el suicidio. Rivera Garretas ${ }^{37}$ habla de la capacidad dual del cuerpo femenino, una capacidad que consiste en la creación y gestión de seres humanos y en la creación y gestión de relaciones. Teresa reniega de esta capacidad dual de su cuerpo y busca la paz, la armonía en la muerte. Pero es ella misma la que gestiona la muerte de su maternidad, de su cuerpo y la muerte de todas sus relaciones circundantes.

Teresa funciona como sujeto en el paradigma actancial. El destinador (El Génesis) invita a Teresa (sujeto) a desear la maternidad como objeto. Pero Teresa dice no y lo dice sin ayudante ni oponente porque el tema central de esta narración radica en la dificultad que entrañan las relaciones heterosexuales. Teresa reflexiona en torno a las relaciones de casada, de amante y de relaciones pasadas que se le antojan difíciles, relaciones que, en definitiva, no le satisfacen. Al analizar aspectos semánticos del personaje vemos que se autoconstruye desde sus propias experiencias. Sabemos que es un personaje literario con un alto nivel económico, con un buen trabajo y con un buen esposo, pero que nada le complace. Ante este desasosiego, el personaje inicia los dos viajes antes mencionados, pero ambos viajes comparten una característica: la soledad. El personaje de Teresa se erige por mediación de la autoconciencia

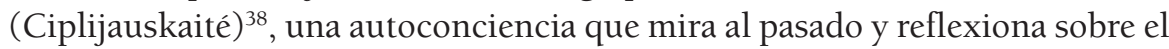
presente el cual le permite proyectar su futuro, su propia muerte.

\subsection{Sisifo maiteminez de Laura Mintegi: nuevas paternidades}

Sisifo maiteminez (2001) de Laura Mintegi y Greta (2003) de Jasone Osoro abordan como temática principal el abandono de los hijos por parte de sus madres. Beatriz Domínguez García en Hadas y brujas (1999) ha investigado las figuras de la madre ausente y la madre sustituta. En relación a la madre ausente, o la madre que abandona el hijo o la hija, afirma que es el mayor delito que puede realizar una madre porque no cumple el rol que le ha asignado la sociedad. En esta investigación hemos optado por analizar más detalladamente Sisifo maiteminez por razones obvias de espacio y porque incorpora a la narrativa vasca el contenido de las nuevas paternidades.

Biruté Ciplijauskaité (1994) calificaría esta obra escrita por Mintegi como novela psicoanalítica. La novela psicoanalítica indaga el subconsciente

37. Rivera Garretas, Milagros. El cuerpo indispensable. Significados del cuerpo. Horas y Horas, Madrid, 1996: 20.

38. Ciplijauskaité, Biruté. La novela femenina contemporánea (1970-1985). Hacia una tipología de la narración en primera persona. Anthropos, Barcelona, 1996. Ciplijauskaité trabaja este concepto a lo largo de esta obra.

Feminismo/s 18, diciembre 2011, pp. 203-223 
siguiendo un método determinado. «Lleva al paciente a evocar la infancia, intentando descubrir las causas secretas que han moldeado el estado de ánimo presente ${ }^{39}$. «Estebanek badaki hitzaren bidez kanporatzen dela inkontzientea. Subjektuaren eta hitzaren arteko harremana psikoanalisiak bakarrik jar dezakeela agerian; lengoaiak bakarrik salba dezakeela» $\left(\mathrm{SM},{ }^{40} 34\right)^{41}$. «La curación de su neurosis pasa por el afloramiento a la conciencia, es decir por la racionalización de los conflictos suprimidos en su primera infancia en la relación con su madre ${ }^{42}$.

Rosario Arias $^{43}$ señala que la personalidad femenina se define en la etapa preedípica y que se caracteriza por la relación con otros individuos, mientras que por el contrario, la masculina se define por la individualidad.

Esta teoría puede ser muy adecuada para escudriñar la personalidad de Ane, la protagonista de Sisifo maiteminez. Ane ha abandonado a sus dos hijas y a su marido y se ha ido con otro hombre. Se ha convertido en una madre ausente, y a lo largo de esta novela, Esteban, el psicoanalista, tendrá que descubrir los motivos que llevaron a Ane a estos abandonos. Suleiman ${ }^{44}$ basándose en la teoría de Nancy Chodorov, explica que las mujeres están psicológicamente preparadas para la maternidad en la medida que han heredado esa idea de la maternidad de sus madres. «Sólo un cambio radical en la crianza, compartida por padres que hagan de padres y madres por igual puede suponer un cambio importante en la psique femenina $»^{45}$. Es decir, las nuevas paternidades constituirán el fundamento de la identidad de la mujer nueva. «Ane le explica a Esteban que el embarazo y el parto no te hacen madre. Jon siendo hombre era más madre que ella» (SM, 165). Ane habla de Jon, del padre de sus hijas y da cuenta a su vez de las nuevas paternidades.

Chodorov asegura que la existencia de la maternidad se basa en el aprendizaje cognitivo de la misma. En nuestra sociedad, la madre de una niña está presente de un modo en el que el padre y otros adultos varones no lo están

39. Ibíd., p. 85.

40. Sisisfo maiteminez se identificará de ahora en adelante como SM

41. «Esteban sabe que el inconsciente se exterioriza mediante la palabra. Que sólo el psicoanálisis puede relacionar el Sujeto y la palabra, que solo el lenguaje puede salvar» ( $\mathrm{SM}, 34$, la traducción al castellano es nuestra).

42. DE LA CONCHA, Angeles. «La sombra de la madre. Un mito en la novela de las mujeres». Revista Canaria de Estudios ingleses, $\mathrm{n}^{\circ}$ 24. p.33-48, 1992: 46.

43. ARIAS, Rosario. Madres e hijas en la teoría feminista. Una perspectiva psicoanalítica. Universidad de Málaga, 2002: 44.

44. SUleiman, Susan Rubin. Op. cit., p. 128.

45. Ibíd., p. 128. 
para el niño ${ }^{46}$. Añade que la niña puede desarrollar una identificación personal con su madre porque tiene una verdadera relación con ella ${ }^{47}$.

La protagonista de la novela, Ane, habla de su madre y comenta que tuvo dos hijas a las que nunca quiso, y a pesar de que nunca las abandono físicamente, tal y como ella sí hizo, su sensación de abandono y soledad fue mayor (SM, 119). «Ama no era feliz. La ama me odiaba» (SM, 131) ${ }^{48}$. La carencia de afecto materno imprime todas sus secuelas en el carácter de la hija: ansiedad, falta de autoestima y de seguridad, pasividad, parálisis y dependencia emocional, según De la Concha ${ }^{49}$. María Angeles de la Concha en el mismo artículo recuerda lo analizado en torno a la matrofobia por Nancy Chodorov, Dorothy Dinnnerstein, Jessica Bond y Adrianne Rich y afirma que la matrofobia no es el odio a la madre sino el miedo a ser como la madre propia.

Para delimitar el significado semántico de este personaje hemos compartido las reflexiones de la feminista Milagros Rivera Garretas (2001) quien matiza que la madre personal y concreta es el problema para el feminismo porque siempre se ve como algo a mejorar.

No nos había querido lo suficiente, no había entendido nuestro anhelo de cambio social, no nos había dejado volver tarde por la noche, no había sido suficientemente libre, no había sido capaz de enseñarnos a hablar sin transmitirnos el lenguaje patriarcal... Estábamos dispuestas a honrar a un Partenón de madres simbólicas, pero la madre concreta y particular, no. ${ }^{50}$

Esto es lo que lleva a Milagros Rivera a afirmar que muchas mujeres feministas empezaron a ser madres con el objetivo de mejorar a las suyas propias y la paradoja fue que su obra éramos nosotras ${ }^{51}$.

Esta es la verdad que descubrirá Ane en el transcurrir del texto. Ane no comprende muy bien por qué ha abandonado a sus hijas y a lo largo de la narración busca la razón de ese abandono. En esa búsqueda, acompañada por su psiquiatra Esteban, descubrirá las maternidades no deseadas, obligadas y también explicitará la realidad de las nuevas paternidades, la existencia de las paternidades. Le reconocerá más autoridad maternal a su esposo Jon que a ella misma. De modo implícito, además, afirmará Ane que el ser mujer se

46. CHODOROv, Nancy. El ejercicio de la maternidad. Psicoanálisis y sociologíade la maternidad y paternidad en la crianza de los hijos. Gedisa, Barcelona, 1984: 49.

47. Ibíd, p. 260.

48. «Ama ez zen zoriontsu. Gorrotatzen ninduen» (SM, 131).

49. De la CONCHA, Ángeles. «La sombra de la madre. Un mito en la novela de las mujeres». Op. cit., p. 40.

50. RIVER GARRETAS, Milagros. Mujeres en relación. Icaria, Barcelona, 2011: 85.

51. Ibíd., p. 85.

Feminismo/s 18, diciembre 2011, pp. 203-223 
transmite de madres a hijas cognitivamente y que la relación entre padres e hijas dará lugar a una entidad de mujer diferente.

\section{Conclusiones}

Podemos afirmar como primera conclusión que de treinta novelas escritas por las escritoras vascas con personajes protagonistas femeninos en el periodo 1970-2010, veinte tratan la maternidad y hablan del cuerpo de la mujer, es decir un $66 \%$ del corpus analizado. Por lo tanto, se ratifica la teoría de la homología de Lucien Goldamnn en tanto que uno de los temas claves de pensamiento feminista se ve representado también en el ámbito literario.

El abandono aparece en muchos casos adherido a la temática de la maternidad. Vemos así madres abandonadas en un 40\% del corpus analizado y también aparece el abandono de los hijos por parte de las madres en las novelas Sisifo maiteminez y en Greta. En estos últimos casos, el abandono se convierte en el epicentro temático y todo el relato tiene como objetivo la búsqueda del motivo por el cual la madre ha optado por tomar esa decisión. Solo cuando el lector y protagonistas llegan al final del relato se descubren esos motivos, como si las madres no pudieran abandonar a sus hijos ante la mirada del interlocutor.

Es muy reveladora la actitud de Laura Mintegi en Sisifo maiteminez señalando las nuevas paternidades, retomando así la teoría de Chodorov (1984) que sostiene que la nueva mujer será fruto de las nuevas paternidades. La mujer cambiará con las nuevas relaciones entre madre e hijas y estas solo pueden transformarse con las nuevas paternidades.

Por último, a modo de conclusión general, podemos afirmar que en las últimas tres décadas el imaginario de las representaciones maternales ha ido cambiando de la misma manera que han ido transformándose las estructuras sociales que sustentan la maternidad. Un ejemplo de esta realidad sería la desaparición de la madre como transmisora de la lengua y la cultura vascas en el ámbito social y en el literario como hemos constatado en el análisis de Jostorratza eta Haria. Y obviando la afirmación del marxista George Lukács (1971) no podía ser de otra forma porque el personaje literario se construye dialécticamente con la realidad social. Concretamente, en la realidad social actual vasca, las mujeres se han escolarizado, se han incorporado al mundo laboral y se han politizado. Las leyes que defienden la igualdad, tanto las articuladas por el Gobierno español como por el Gobierno Vasco, han facilitado que la mujer vasca saliera del ámbito privado al público y se convirtiera en un agente social. Todo ello se ha producido en las últimas décadas y nuestras 
escritoras han sabido imaginarlo y recrearlo en sus producciones narrativas mediante la corporeización de los personajes protagonistas femeninos.

\section{Referencias Bibliográficas}

AGUiLAR, Pilar. «Madres de cine: entre la ausencia y la caricatura», en: De

la Concha, Angeles. y Osborne, Rraquel. (ed). Las mujeres y los niños primero. Icaria, Barcelona, 2004.

ARIAS, Rosario. Madres e hijas en la teoria feminista. Una perspectiva Psicoanálitica. Universidad de Málaga, 2002.

BAL, Mieke. Teoría de la narrativa. Cátedra, Madrid, 1985.

BARRON, Sara. «Introducción: La maternidad monoparental», en: De La

Concha, Angela.; Osborne, Raquel. (ed.): Las mujeres y los niños primero: discursos de la maternidad. Barcelona: Icaria.

BENGOECHEA, Mercedes. «Mi madre es... un hueco en el espacio: discursos poéticos y lingüísticos sobre la insignificancia materna», en Op. cit., p. 81-110.

BEAuvolr, Simone. El segundo sexo. Cátedra- Feminismos, Madrid, 2005 (1949).

BOves, Carmen. La novela. Síntesis, Madrid, 1993.

Ciplijauskaité, Biruté. La novela femenina contemporánea (1970-1985).

Hacia una tipología de la narración en primera persona. Anthropos, Barcelona, 1994.

Cixous, Hélène. La risa de la Medusa. Ensayos sobre la escritura. Anthropos, Barcelona, 2000 (1975).

ChODOROv, Nancy. El ejercicio de la maternidad. Psicoanálisis y sociología de la maternidad y paternidad en la crianza de los hijos. Barcelona, Gedisa. (1984).

DE LA CONCHA, Angeles. «La sombra de la madre. Un mito en la novela de

las mujeres». Revista Canaria de Estudios ingleses, 24. 1992, pp.33-48.

Dinnerstain, Dorothy. The Mermaid and the Minotaur. Sexual Arrengements and Human Malaise. Harper \& Roww, Nueva York, 1976.

Domínguez García, Beatriz. Hadas y brujas. La reescritura de los cuentos de hadas en escritores contemporáneos en lengua inglesa. Universidad de Huelva, 1999.

Esteban, María Luz. Antropología del cuerpo. Bellaterra, Barcelona,2004.

Ferrús, Beatriz; CAlafell, Nuria. (ed.). Escribir con el cuerpo. Editorial UOC. SL, Barcelona, 2008.

FIRESTONE, Sulamith. La dialéctica del sexo: en defensa de la revolución feminista. Kairós, Barcelona, 1976.

Goldmann, Lucien. Para una sociología de la novela. Ciencia Nueva, Madrid, 1967 (1964).

Greimas, Algirdas Julius. La semiótica del texto, ejercicios prácticos. Paidós, Madrid, 1983. 
IMAZ, Elixabete. Mujeres gestantes, madres en gestación. Representaciones, modelos y experiencia en el tránsito a la maternidad de las mujeres vascas contemporáneas. UPV, Bilbo, 2007.

IRIGARAY, Luce. Speculum espéculo de la otra mujer, Saltés, Barcelona, 1978 (1974). KogAN, Liuba. «Jóvenes y viejos: ¿el cuerpo como locus de identidad?». Revista Latinoamericana de Estudios sobre Cuerpos, emociones y Sociedad. 5. Argentina, 2011. pp.15-24.

KortaZAR, Jon. Euskal literatura XX. Mendean. Prames. Las Tres Sorores, Zaragoza, 2003.

LASARTE, Gema. Pertsonaia protagonista femeninoen ezaugarriak eta bilakaera euskal narratiba garaikidean. UPV/EHU, Bilbo, 2011.

LUCKÁCS, George. Teoría de la novela. Edhasa, Barcelona, 1971 (1920).

LLONA, Miren. «Patriotic Mothers of Basque Nationalism: Women's Action during the Spanish Second Republic in the Basque Country», en Esteban, Mari Luz y Amurrio Milagros (ed.): Feminist Challenges in the Social Sciences Gender Studies in the Basque Country Reno, Center of Basque Studies, University of Nevada, 2010.

MitChell, Julia. Woman's Estate. Harmondswort, Penguin, 1971.

Muraro, Luisa. El orden simbólico de la madre. Horas y Horas, Madrid, 1994.

NicHOLS, Geraldine. «El procrear, pro y contra», en: REDONDO Alicia, (coor): Mujeres novelistas. Narcea, Madrid, 2003.

OlAZIREGI, María José. Euskal eleberriaren historia: Labayru Ikastegia Amorebieta Etxanoko Udala, 2002.

RicH, Adrianne. Nacemos de mujer. La maternidad como experiencia e institución. Cátedra-Feminismos, Madrid, 1996.

Rimon-Kenan, S. Narrative Fiction; Contemporany Poetics. Methuen, Londres, 1983.

Rivera Garretas, Milagros. El cuerpo indispensable. Significados del cuerpo. Horas y Horas, Madrid,1996.

River GARretas, Milagros. Mujeres en relación. Icaria, Basrcelona, 2001.

RIVERA GARRETAS Milagros. La diferencia sexual en la historia. PUV, Valencia, 2005. RUDDICK, Sara. «Maternal Thinking», en A. Trebilcot (ed): Mothering Essays in Feminist Theory, Totowa/New Jaersey, Rowman \& Allanheld Publishers, 1984.

SAU, Victoria. Ser mujer: el fin de una mujer tradicional. Icaria, Barcelona, 1993.

SHIVA, Vandana. Abrazar la vida. Mujer, ecología y desarrollo. Horas y horas, Madrid, 1995.

Suleiman, Susan Rubin. «Escritura y maternidad», en: Dovay, M. (ed): Maternidad y creación. Lecturas esenciales. Alba, Madrid, 2007.

VEGA, María José. Imperios de papel. Introducción a la crítica postnacional. Crítica, Barcelona, 2003. 


\section{Bibliografía corpus}

ARRIETA, Jolanda. 1998. Jostorratza eta haría. Kutxa Fundazioa

BORDA, Itxaro. 1995. Bizi nizano munduan. Zarautz: Susa.

ETXEBERRIA, Aitziber. 2003. Tango urdina. Donostia: Erein

- 2007. 31 baioneta. Donostia: Erein.

GONZÁlEZ, Sonia. 2003. Ugerra eta Kedarra. Lizarra:Txalaparta.

JAIO, Karmele. 2006. Amaren eskuak. Donostia: Elkar.

- 2009. Musika airean. Donostia: Elkar.

JimEnEZ, Irati. 2009. Nora ez dakizun hori. Donostia: Elkar.

MARTIN SAMPEDRO, Eukene. 1985. Lau sasoitako zipriztinak. Zarautz: Susa.

MinTEGI, Laura. 1986. Bai baina ez. Zarauz: Susa.

- 1994. Nerea eta biok. Lizarra: Txalaparta.

- 2001. Sisifo maiteminez. Lizarra: Txalaparta.

OñederA, Lourdes.1999. Eta emakumeari sugeak esan zion. Donostia: Erein.

Osoro, Jasone. 2003. Greta. Donostia: Elkar.

- 2009. Bi marra arrosa. Donostia: Elkar.

UrretabiZaKaiA, Dorleta.2006. Jaione. Donostia: Kutxa.

Urretabizkaia, Arantxa. 1979. Zergatik Panpox. Donostia: Hordago.

- 1998. Koaderno Gorria. Donostia: Erein.

- 2010. Hiru Mariak. Donostia: Erein. 



\title{
GÉNERO Y DESARROLLO PROFESIONAL: LAS ENFERMERAS DE SALUD PÚBLICA EN LA ESPAÑA DEL PERÍODO DE ENTREGUERRAS, $1925-1939^{1}$
}

\author{
MARÍA EUGENIA GALIANA-SÁNCHEZ \\ JOSEP BERNABEU-MESTRE \\ Universitat d'Alacant
}

Recibido/15/07/2011

Aceptado/25/09/2011

\section{Resumen}

La evolución de la profesión de enfermería a lo largo de la historia ha estado marcada por su naturaleza mayoritariamente femenina. A través del ejemplo de las enfermeras de salud pública del periodo entreguerras, se analiza su contribución en las iniciativas de salud comunitaria que se pusieron en marcha en España en las décadas de 1920 y 1930, y se abordan los condicionantes de género que determinaron su actividad y su emergencia como colectivo profesional. La investigación ha permitido visualizar las dos caras de una misma realidad; por un lado la contribución singular de las enfermeras a la salud de la población, y por otro, los obstáculos y dificultades vinculadas a su naturaleza femenina, y que han llegado hasta nuestros dias, perpetuando situaciones de desigualdad y discriminación.

Palabras clave: enfermería de salud pública, género, profesionalización, España, período de entreguerras (1925-1939).

1. El trabajo se ha desarrollado en el marco de los proyectos de investigación: «Género, ideología y salud: la enfermería de salud pública en la sanidad española contemporánea (1923-1959)» (GRE10-12); «La lucha contra la desnutrición en la España contemporánea y el contexto internacional (1874-1975)» (HAR2009-13504-C02-01)» y la «Sanidad internacional y transferencia del conocimiento científico. Europa, 1900-1975» (HAR2011-23233) del Ministerio español de Ciencia e Innovación; y el Programa Prometeo. Generalitat Valenciana (Prometeo/2009/122). 


\begin{abstract}
The evolution of nursing throughout history has been marked by its nature mainly female. Through the example of public health nurses of the interwar period, we have analyzed their contribution to community health initiatives that were launched in Spain in the 1920 and 1930, and we addressed the constraints of gender determined their activity and its emergence as a professional group. The research has two sides view the same reality; on one hand the unique contribution of nurses to the health of the population, and the other hand, the obstacles and difficulties linked to their feminine nature, and that have reached our days perpetuating situations of inequality and discrimination.
\end{abstract}

Keywords: public health nursing, gender, professionalism, Spain, the interwar period (1925-1939). 


\section{Introducción}

La enfermería es una profesión esencial en todos los sistemas de salud del mundo. Está presente en todos los ámbitos donde se llevan a cabo acciones sanitarias para mejorar la salud de los seres humanos, bien sean acciones preventivas, terapéuticas o de rehabilitación ${ }^{2}$. Su contribución suele estar bien valorada socialmente, sobre todo porque se vincula con valores como el altruismo, la entrega y la capacidad de sacrificio en el cuidado a los demás, características, por otro lado, que suelen asociarse con rasgos femeninos y que todavía hoy enmascaran relaciones de dominación y dependencia entre hombres y mujeres.

Dichas relaciones, presentes en todos los ámbitos sociales, también se trasladan a las relaciones profesionales entre médicos y enfermeras, a pesar de que desde el año 1977 las enfermeras tienen formación universitaria, y recientemente han logrado tener acceso a másteres oficiales y doctorados, al igual que sus colegas médicos ${ }^{3}$. Sin embargo, la enfermería sigue siendo una profesión mayoritariamente femenina, actualmente más del 80\% de las enfermeras son mujeres, lo que hace que estemos frente a una profesión singular y cuya evolución a lo largo de la historia ha estado marcada por esa particularidad $^{4}$. No obstante, debe señalarse, que existen contextos en los que la enfermería ha logrado mayores cotas de autonomía, como es el ámbito de la salud pública, donde las enfermeras han podido configurar un rol distinto, y donde su contribución ha sido valorada en mayor medida, aunque todavía

2. BÜsCher, Andreas, SivertSen, Bente, White, Jean. Nurses and Midwives: A force for health. Survey on the situation of nursing and midwifery in the Member States of the European Region of the World Health Organization. Copenhagen, WHO, 2009.

3. Zabalegui, Adelaida, MaCí, Loreto,. Desarrollo del máster y doctorado oficial de enfermería en España, Castellón, Publicacions de la Universitat Jaume I, 2011.

4. Véase, por ejemplo, GonzÁlez Canalejo, Carmen. «Cuidados y bienestar: el trabajo sanitario femenino en respuesta a la cuestión social». Dynamis, 27, 2007, pp. 211-235 y BARONA VILAR, Carmen: «El paper de les dones com a vehiculadores de les campanyes sanitàries desenvolupades a la provincia de València (1900-1936)1». En: BERNABEUMESTRE, Josep et al (editors). Salut i societat als municipis valencians: una perspectiva histórica. València, Denes, 2008, pp. 297-308.

Feminismo/s 18, diciembre 2011, pp. 225-248 
persisten grandes obstáculos para el pleno desarrollo profesional ${ }^{5}$. Por todo ello, nos parece relevante analizar, para el caso español, los antecedentes históricos de esta situación, en la medida que permite reconstruir un proceso de evolución profesional con luces y sombras y con múltiples contradicciones, en el que la variable género pasa a un primer plano, y en el que se vislumbra una relación de simbiosis entre la disciplina de la salud pública y la disciplina de enfermería.

Por un lado, la salud pública constituyó el escenario idóneo de desarrollo profesional de las enfermeras, y por otro, las enfermeras contribuyeron de un modo específico a los objetivos de «higienización» que perseguía la salud pública desde finales del siglo XIX y principios del siglo XX'

En este sentido, conviene recordar que la salud pública alcanzó su pleno desarrollo disciplinar, cuando con la ayuda de las ciencias sociales fue capaz de abordar las repercusiones sobre la salud de las condiciones económicas y culturales y del ambiente social en el que nacen, viven, trabajan, se reproducen y mueren los seres humanos. Durante todo el siglo XIX se había ido configurando un programa de investigación y actuación sanitaria basado en el análisis estadístico de las relaciones entre enfermedad y estrato o clase social, pero fue en las primeras décadas del siglo XX, cuando tuvo lugar la plena consideración de la enfermedad como fenómeno colectivo, a la par que se configuraba la salud comunitaria como una modalidad nueva de ejercicio sanitario ${ }^{7}$.

5. BÜSCHER, SivERTSEN y White, Op cit., p. 57.

6. Algunos trabajos que han tratado el proceso de evolución de la enfermería de salud pública en España son: BERNABEU-MESTRE, Josep; GASCÓN, Encarna. «El papel de la enfermera en el desarrollo de la salud pública española (1923-1935): la visitadora sanitaria». Dynamis, 15, 1995, pp. 151-176; BERNABEU-MESTRE, Josep; GASCÓN, Encarna. «De visitadoras a instructoras: la enfermera de salud pública durante el primer franquismo» En: CAstellanos, J. La medicina en el Siglo XX: estudios históricos sobre medicina, sociedad y estado. Málaga. Sociedad Española de Historia de la Medicina, 1998, pp. 167-172; Bernabeu-Mestre, Josep, Gascón-PÉRez, Encarna, Historia de la Enfermería de Salud Pública en España (1860-1977), Alicante, Publicaciones de la Universidad de Alicante, 1999; Gascón, Encarna, Galiana, Mª Eugenia, BernabeU, Josep. «La acción social de las visitadoras e instructoras sanitarias». Trabajo social y salud, 43, 2002, pp. 149-174; Cнаміzо, Carmen. La gota de leche y la escuela de enfermeras. Instituto de Puericultura de Gijón. Gijón, 1999; CHAmizo, Carmen. Historia de la enfermería en Asturias: la Cruz Roja (trabajo Licenciatura), 2004; Ruiz SOMAVILLA, Mª Jesús; JimENEZ LuCENA, Isabel «Un espacio para mujeres. El Servicio de divulgación y Asistencia Sanitario-Social en el primer franquismo». Historia Social, 39, 2001, pp. 67-85; y DomínguEZ-AlCón, Carmen. Los cuidados y la profesión enfermera en España. Madrid, Pirámide, 1986, entre otros.

7. En el ámbito de las lenguas hispánicas, como textos introductorios al desarrollo de la higiene y la salud pública, pueden resultar de utilidad los trabajos de RODRIGUEZ OCAÑA, Esteban. Por la salud de las naciones. Higiene, microbiología y medicina social. Madrid, 
Además de otorgar a la prevención un papel prioritario en la acción sanitaria, la salud comunitaria se caracterizaba por contemplar la etiología de las enfermedades y los problemas de salud desde un abordaje multifactorial; por una visión social del medio ambiente humano, lo que conocemos en la actualidad como paradigma ecológico bio-social; por una aplicación sistemática de la estadística; y por el compromiso de mejorar el patrimonio genético de la humanidad, a través de la eugenesia. Entre sus objetivos prioritarios figuraban la vigilancia de los grupos de riesgo ${ }^{8}$, la educación sanitaria y la necesidad de establecer un diagnóstico precoz de los problemas de salud y episodios de enfermedad. Se buscaba implantar, en definitiva, una cultura de la salud como derecho y deber de la ciudadanía?.

En la consecución de aquella cultura de la salud y en general de los objetivos que tenía planteados la salud comunitaria, la figura de la enfermera de salud pública, resultó fundamental ${ }^{10}$. Las enfermeras visitadoras y las instructoras sanitarias jugaron un papel destacado, tanto en los dispensarios y centros de higiene, principales referentes institucionales de la salud comunitaria ${ }^{11}$,

Akal, 1993; BERNABEU-MeSTRE, Josep: «Transición sanitaria y evolución de la medicina (diagnóstico, profilaxis y terapéutica), 1885-1942», Boletín de la Asociación de Demografía Histórica 16(2) (1998), pp. 15-38; y RODRIGUEZ OCAÑA, Esteban; MARTínEZ NAVARRO, Ferrán: «Introducción. El concepto de salud pública y su formación en la historia», en Salud Pública en España. Desde la Edad Media al siglo XXI. Granada, Escuela Andaluza de Salud Pública, 2008, pp. 11-20. Sobre el desarrollo de la medicina social y la salud comunitaria, además de los textos que se acaban de citar, pueden consultarse, entre otros, los trabajos: LESKY, Erna, Medicina social: estudios y testimonios históricos. Madrid, Ministerio de Sanidad y Consumo (Textos clásicos españoles de la salud pública, 30), traducción al castellano e introducción por José M. López Piñeiro, 1984; y RODRIGUEz OCAÑA, Esteban. La constitución de la medicina social como disciplina en España (18821923). Madrid, Ministerio de Sanidad y Consumo (Textos clásicos españoles de la salud pública, Complementario 1), 1987.

8. Para definir los grupos de riesgo se utilizaban, fundamentalmente, criterios socioculturales (mujeres, lactantes, escolares, trabajadores industriales, etc.), o el hecho de ser portadores de elementos degenerativos y/o perjudiciales para la salud de la colectividad (tuberculosos, sifilíticos, alcohólicos, etc.).

9. Rodriguez OCAÑa y MarTíneZ NAVARro, Op. cit., p. 16.

10. La denominación de la enfermera de salud pública no ha sido siempre la misma a lo largo de la historia. Concretamente, en el periodo estudiado en este trabajo, se utilizaron dos denominaciones diferentes: enfermera visitadora sanitaria, en un primer momento, e instructora sanitaria con posterioridad, en un intento por reforzar su función de educadora en la comunidad. PRADA, Joaquín (de), GARCÍA CORSELAS, María: «La instructora de Sanidad Pública en España», en GARDNER, Mary Sewall: La instructora de sanidad pública. Salamanca, Ángel de la Torre (Traducción del doctor Joaquín de Prada y María García Corselas), 1935, p. 445

11. Estaban atendidos por un amplio elenco de profesionales (higienistas, médicos puericultores, tisiólogos, enfermeras puericultoras, enfermeras visitadoras, maestros, nutricionistas, etc.), y disponían entre otros servicios de consultorios de lactantes y

Feminismo/s 18, diciembre 2011, pp. 225-248 
como en el desarrollo y aplicación de sus principales métodos de trabajo: los reconocimientos masivos y las campañas sanitarias ${ }^{12}$.

El presente trabajo pretende profundizar en el análisis del papel que jugó el colectivo de las enfermeras de salud pública en las iniciativas de salud comunitaria que se pusieron en marcha en España en las décadas de 1920 y 1930, y abordar los condicionantes de género que determinaron y condicionaron su actividad y su emergencia como colectivo profesional ${ }^{13}$.

\section{El papel de las visitadoras y/0 instructoras sanitarias en el desarrollo de la salud comunitaria}

En España, las primeras enfermeras de salud pública (visitadoras sanitarias) aparecieron en la década de 1920, con retraso respecto a países del entorno europeo, y en el marco de la lucha antituberculosa. Su proceso formativo se inició con los programas de la Cruz Roja, con los cursos de la Escuela Nacional de Sanidad y con los de las Escuelas de Puericultura ${ }^{14}$. Estas figuras profesionales, novedosas en el contexto español, fueron formadas para desempeñar

pediátricos, de servicios de medicina escolar, de servicios antituberculosos, de unidades de desinfección, de comedores populares, etc.

12. En el caso concreto de las campañas sanitarias, su objetivo era intervenir en el medio social y familiar y estaban centradas en los problemas de salud con mayor incidencia en la mortalidad y morbilidad, la paz social, y en la eficiencia de la actividad socioeconómica: tuberculosis, mortalidad infantil, enfermedades venéreas, alcoholismo, paludismo, accidentes y enfermedades laborales, etc. (MOLERO MESA, Jorge; MARTínEZ ANTONIO, Francisco Javier. «Las campañas sanitarias como paradigma de la acción social de la medicina». Trabajo Social y Salud (Monográfico: la acción social de la medicina y la construcción del sistema sanitario en la España contemporánea) 43 (2002), pp. 119-148).

13. En anteriores investigaciones se han abordado aspectos relacionados con el proceso de profesionalización que experimentó la enfermería de salud pública en la España del período de entreguerras, con una atención particular a su socialización y otros elementos claves de su institucionalización profesional, como el asociacionismo o la publicación de revistas especializadas (BERNABEU-MeSTRE, Josep: GASCÓn PÉREZ, Encarna. «El papel de la enfermería en el desarrollo de la salud pública española (1923-1936)». Dynamis 15 (1995), pp. 151-176; BernabeU-Mestre, Josep: GASCÓn PÉreZ, Encarna: «Enfermería y salud pública. El proceso de institucionalización de la visitadora sanitaria», en Historia de la Enfermería de Salud Pública en España (1860-1977). Alicante, Publicaciones de la Universidad de Alicante, 1999, pp. 37-74), pero se ha profundizado menos en el análisis de sus actuaciones profesionales (GASCÓN PÉREZ, Encarna; Galiana SÁnCHEZ, María Eugenia; Bernabeu-Mestre, Josep. «La acción social de las visitadoras e instructoras sanitarias». Trabajo Social y Salud (Monográfico: la acción social de la medicina y la construcción del sistema sanitario en la España contemporánea) 43 (2002), pp. 149-176) o en el abordaje de las cuestiones de género que ayudan a explicar su emergencia como colectivo profesional en la España de las décadas de 1920 y 1930 (Bernabeu-Mestre y GasCón Pérez, Op. cit., p. 33).

14. Bernabeu-Mestre, Josep y GasCón PÉREZ, Encarna. Op. cit., pp. 48-51. 
un papel clave en el desarrollo de la política sanitaria reformista que se había ido diseñando de forma progresiva durante las tres primeras décadas del siglo, aunque hubo que esperar hasta los primeros años de la década de 1930 para que alcanzaran sus mayores cotas de profesionalización ${ }^{15}$. Hasta ese momento, la enfermería no había iniciado su proceso de institucionalización, por lo que el ámbito de la salud pública constituyó el contexto sanitario donde empezó a configurarse como profesión. Previamente, había existido una larga y rica tradición de enfermería en el ámbito hospitalario vinculada a las órdenes religiosas, lo que contribuyó a la tardía institucionalización de la enfermería en España ${ }^{16}$.

Así pues, las bases sobre las que tuvo lugar el nacimiento de la enfermería de salud pública en España fueron las iniciativas en materia de salud comunitaria que se fueron concretando a lo largo del primer tercio del siglo XX, y la progresiva institucionalización de la salud pública. A ello debe añadirse los cambios en la consideración de la mujer en la sociedad española de dicho período, lo que puede ayudar a comprender cómo el hecho de ser una profesión eminentemente femenina influyó decisivamente en su evolución.

Las iniciativas de salud comunitaria que se pusieron en marcha en la España de las décadas de 1920 y 1930, deben situarse en el marco de las reformas sanitarias que se preveían en el articulado de la Instrucción General de Sanidad de $1904^{17}$. Esta norma permitió, por ejemplo, la creación de las Juntas Provinciales de Sanidad y estableció la conveniencia de que cada Junta procurara organizar una comisión de señoras para la vigilancia de la asistencia domiciliaria y la propaganda de la higiene materno-infantil. Las tareas de esta comisión pueden considerarse el precedente de la labor de la enfermera visitadora. Dichas iniciativas alcanzaron su máxima expresión en el contexto de los acuerdos de colaboración científica y sanitaria que se firmaron con la Fundación Rockefeller en 1922, a través de un programa por el que la Fundación se comprometía, por un lado, a sufragar los costes de una futura escuela

15. Ibid., pp. 55-74.

16. Gascón PÉreZ, Encarna; Galiana SÁnChez, María Eugenia; Bernabeu-Mestre, Josep, Op cit., p. 150.

17. Al margen de esta iniciativa legislativa, existe un claro antecedente histórico de la visitadora sanitaria en la importante figura de Concepción Arenal, cuya relación con la enfermería comunitaria, ya ha sido establecida por diferentes autores (Véase: BERNABeU-Mestre, Josep, Gascón-PÉreZ, Encarna, Op cit.,p. 9-23). Concepción Arenal desarrolló una labor intelectual de gran repercusión en distintos ámbitos de la asistencia social y sanitaria, y encabezó, junto a otras autoras, el movimiento feminista español de la España del XIX (Véase: CABRERA BOSH, $\mathrm{M}^{\mathrm{a}}$ Isabel. «Las mujeres que lucharon solas: Concepción Arenal y Emilia Pardo Bazán». En: FolguerA, Pilar (comp.). El feminismo en España: dos siglos de historia. Madrid. Ed. Pablo Iglesias, 1988, pp. 29-44).

Feminismo/s 18, diciembre 2011, pp. 225-248 
de enfermeras visitadoras, y por otro, a financiar una adecuada formación de posgrado en enfermería de salud pública, para quienes debían impartir la docencia en dicha institución. Del programa de formación se beneficiaron 14 enfermeras entre 1931 y 1934. Estas enfermeras realizaron estudios en EEUU por un tiempo medio de dos años, con el fin de ser capacitadas para impartir docencia en la escuela que estaba previsto inaugurar en Madrid en $1935^{18}$.

Con la llegada de la Segunda República, las políticas de salud, y con particular intensidad, las que se desarrollaron en el llamado bienio reformador (1931-1933) ${ }^{19}$, permitieron intensificar la participación del Estado en campañas sanitarias como la que se venía desarrollando contra la tuberculosis ${ }^{20}$, el tracoma ${ }^{21} \mathrm{o}$, en atención a la magnitud que todavía mostraba el problema de la mortalidad infantil, introducir mejoras en el ámbito de la salud maternoinfantil. En el organigrama de la Dirección General de Sanidad, la sección de Higiene Infantil ${ }^{22}$ fue adscrita a la Inspección General de Instituciones Sanita-

18. Gascón-PÉREZ, Encarna; Galiana-SÁnCheZ, Ma Eugenia; Bernabeu-Mestre, Josep: «La aportación de las Enfermeras Visitadoras Sanitarias al desarrollo de la enfermería venezolana» en BARONA, Josep Lluís, Ciencia, Salud Pública y exilio. España (18751939). Valencia, Seminari d'Estudis sobre la Ciència, 2003, pp.99-129.

19. Sobre los cambios que experimentó la sanidad española durante dicho período histórico y la importancia que tuvo el convenio de colaboración científica y sanitaria con la Fundación Rockefeller, se pueden consultar, entre otros, los trabajos: HUERTAS, Rafael, Organización sanitaria y crisis social en España: la discusión sobre el modelo de servicios sanitarios públicos en el primer tercio del siglo XX. Madrid, Fundación de Investigaciones Marxistas, 1995; ATENZA FERnÁNDEZ, Juan.; MARTínEZ PÉREZ, José (eds). El Centro Secundario de Higiene Rural de Talavera de la Reina y la sanidad española de su tiempo. Toledo, Junta de Comunidades de Castilla-La Mancha, 2001; PERDiguero, Enrique; CASTEJÓN, Ramón (eds). «La acción social de la medicina y la construcción del sistema sanitario en la España contemporánea». Trabajo Social y Salud (Monográfic) 43 (2002); BERNABEU-MeSTRE, Josep. La salut pública que no va poder ser. José Estellés Salarich (1896-1990): una aportació valenciana a la sanitat espanyola contemporània. València, Consell Valencià de Cultura, 2007; RODRÍGUEZ OCAÑA y MARTíNEZ NAVARRO, Op. cit., pp. 52-83; BARONA Vilar, Josep Lluís; BernABEU-Mestre, Josep. La salud y el Estado. El movimiento sanitario internacional y la administración española (1851-1945). València, PUV, 2008, pp. 89-262.

20. Molero MeSA, Jorge: «La lucha antituberculosa en España en el primer tercio del siglo XX», en ATENZA, Juan y MARTíneZ, José (eds), Op. cit., pp. 131-147.

21. Galiana-SÁnchez, María Eugenia; Cremades Monerris, Angela; Bernabeu-Mestre, Josep: «Sanitary campaigns against trachoma in Spain», in: ANDRESEN, Astri; BARONA, Josep Lluís; CHERrY, Steven (eds):Making a New Countryside. Health Policies and Practices in European History ca. 1860-1950, Frankfurt am Main, Peter Lang, 2010, pp. 101-111.

22. Creada el 13 de diciembre de 1931, la Sección de Higiene Infantil tenía como principal objetivo la lucha contra la mortalidad infantil y otros aspectos relacionados con aquel problema. Cómo se explicaba a la orden ministerial que creaba la sección: «Las causas de la elevada mortalidad infantil son en cierto modo evitables, puesto que muchas de 
rias y contaba con los departamentos de mortalidad materna, mortinatalidad, e higiene prenatal y preescolar ${ }^{23}$.

Junto con las reformas relativas a la salud materno-infantil, las iniciadas en el ámbito de la salud rural, a través de la creación de los centros rurales de higiene y los centros secundarios de higiene, representaron el esfuerzo más destacado que llevó a cabo la sanidad republicana en el primer bienio ${ }^{24}$.

Con todas aquellas iniciativas, y otras que se concretaron con posterioridad $^{25}$, los responsables de la Dirección general de Sanidad, hacían suyas muchas de las recomendaciones del Comité de Higiene de la Sociedad de Naciones que habían sido aprobadas en la Conferencia sobre Higiene Rural que tuvo lugar a Ginebra en $1931^{26}$. Se pretendía avanzar hacia un modelo de asistencia sanitaria colectivizada, donde la prevención de la enfermedad y la promoción de la salud tenían que jugar un papel fundamental en el proceso modernizador que encarnaba la Segunda República ${ }^{27}$. La creación de los cen-

ellas responden a falta de higiene durante el embarazo y la crianza del niño y de la incultura y la falta de orientación sanitaria, existiendo no pocas provincias que carecen de los más elementales servicios de higiene infantil y otras en las cuales los esfuerzos particulares y oficiales, los fallos de la coordinación y orientación sanitaria, no surten la eficacia esperada». Parte de aquel organigrama fue desarrollado, mediante una orden ministerial, de 30 de marzo de 1932, en los institutos provinciales de higiene. Se preveía la existencia de consultas de higiene prenatal, de lactantes y de higiene escolar.

23. BRAVO FRIAS, Juan: «Proyectos de organización de la lucha contra la mortalidad infantil», in Lucha contra la mortalidad infantil. Conferencias radiofónicas, Madrid, Publicaciones de la Dirección General de Sanidad, 1933, pp. 13-20; Bravo FrIAS, Juan: «Cómo atiende el Estado la lucha contra la mortalidad infantil», in Lucha contra la mortalidad infantil. Conferencias radiofónicas, Madrid, Publicaciones de la Dirección General de Sanidad, 1933, pp. 5-13.

24. Bardají LóPeZ, Enrique; Bellogín García, Mariano; GonZÁlez Rodríguez, Pedro. El seguro social de enfermedad y la sanidad municipal. Madrid, Primer Congreso Nacional de Sanidad, 1934.

25. En diciembre de 1931, en el mismo decreto donde se recogía la creación de una sección de Higiene Infantil, se ponían en marcha las de Higiene Social y Propaganda y la de Ingeniería y Arquitectura Sanitaria, y los primeros meses de 1933 se creaba la sección de Higiene de la Alimentación (Bernabeu-Mestre, Josep. La salut pública que no va poder ser..., Op. cit., pp. 73-76).

26. BARONA VILAR, Josep Lluís. «La sanitat rural, una qüestió d'estat», en Guillem-Llobat, Ximo; García Frasquet, Gabriel (eds): Salut, alimentació i cultura al País Valencià, Gandia, CEIC-Alfons el Vell, 2009, pp. 13-37.

27. Si nos atenemos a las ponencias y comunicaciones que se presentaron la Primer Congreso Nacional de Sanidad que tuvo lugar en Madrid en 1934, y a los debates que se suscitaron, parece que existía un cierto "consenso técnico» entre el colectivo de profesionales interesados por la sanidad pública, y la necesidad de articularla alrededor de los presupuestos de la salud comunitaria y la medicina social (ESTELLÉS SALARICH, José. «Apostillas al Primer Congreso Nacional de Sanidad». Revista de Sanidad e Higiene Pública 9 (1934), pp. 385-388 (pp. 387-388)).

Feminismo/s 18, diciembre 2011, pp. 225-248 
tros de higiene era el primer paso para la implantación de un seguro obligatorio de enfermedad que fuera capaz de permitir tanto el progreso de la higiene pública cómo de la medicina curativa ${ }^{28}$.

Para poder desarrollar un programa sanitario como el que puso en marcha la República, la figura de la visitadora sanitaria resultaba fundamental y se hacía necesaria su consolidación como colectivo profesional. Así se ponía de manifiesto en 1935 en la versión castellana del conocido manual de enfermería de salud pública que publicó por primera vez en 1916, con el título de Public Health Nursing, la enfermera norteamericana Mary Sewall Gardner. Los traductores de la obra, el doctor Joaquín de Prada y la enfermera visitadora, María García Corselas, complementaban la traducción con un apéndice sobre la instructora de Sanidad Pública en España ${ }^{29}$. Con estas palabras iniciaban ambos autores dicho apéndice ${ }^{30}$.

Menos de un lustro hace que las primeras instructoras sanitarias se lanzaron en España a la obra, a su hermosa obra, y ya han logrado demostrar que su beneficiosa actuación es indispensable en toda campaña sanitaria. El progreso social y el progreso sanitario que actualmente se está verificando en todo el mundo culto, repercute vivamente en nuestra patria, que ha llegado a adquirir un concepto más claro de sus propios problemas, como lo demuestra la aparición de la instructora sanitaria. «El problema de España es un problema de cultura», dijo hace años Ramón y Cajal; quizá en ningún aspecto sea la incultura mayor en el aspecto higiénico y quizá nada pueda por tanto, contribuir a resolverlo como la labor de la instructora sanitaria.

28. Como defendía el Inspector General de Sanidad Interior, el doctor Santiago Ruesta, con motivo de la celebración del Primer Congreso Español Pro Médico que tuvo lugar en Zaragoza entre el 6 y el 11 de octubre de 1935 (BERNABEU-MESTRE, Josep: «La contribución del exilio científico español al desarrollo de la salud pública venezolana: Santiago Ruesta Marco (1938-1960)», en: BARONA VILAR, Josep Lluís (ed.): Ciencia, salud pública y exilio (España 1875-1939), Valencia, Seminari d'Estudis sobre la Ciència, 2003, pp. 223-256), en una ponencia donde se ocupaba de la Sanidad Nacional, la medicina preventiva tenía que ser función del Estado y se tenía que desarrollar a través de organizaciones sanitarias técnicas de las características de los centros primarios de higiene rural, los centros secundarios y los centros terciarios (los institutos provinciales de higiene). Las actuaciones en materia de medicina preventiva tenían que estar informadas por estudios previos de causalidad, demografía y administración sanitaria. La sanidad necesitaba manejar los instrumentos necesarios para investigar las causas sociales de la enfermedad, y los medios profilácticos adecuados. También defendía una coordinación entre la asistencia médica y la asistencia social.

29. Prada, Joaquín (de); García Corselas, María: «La instructora de Sanidad Pública en España», en GARDNER, Mary Sewall: La instructora de sanidad pública. Salamanca, Ángel de la Torre (Traducción del doctor Joaquín de Prada y María García Corselas), 1935, p. 445.

30. Prada y García Corselas, Op. cit. p. 445.

Feminismo/s 18, diciembre 2011, pp. 225-248 
Fue también en ese periodo, cuando la sociedad española incorporó elementos de mejora en la consideración de la mujer en relación con las etapas anteriores $^{31}$. La proclamación de la Segunda República y la aprobación en diciembre de 1931 de la Constitución republicana, en la que las mujeres habían obtenido los mismos derechos electorales que los hombres, así como la aprobación un año después de la ley del divorcio marcaron diferencias sustanciales en comparación con las décadas previas. Esta legislación generó importantes expectativas y simbolizó la identificación de algunos sectores femeninos con la causa feminista ${ }^{32}$. En este contexto, la construcción de un determinado modelo de enfermera giraría sobre el eje fundamental del género. Las características del modelo de enfermera estuvieron estrechamente unidas a las características del modelo de mujer. Como avanzábamos en la introducción, el paralelismo entre los roles de hombre-mujer y los de médico-enfermera y las expectativas de comportamiento social de cada uno de ellos, son elementos que ayudan a comprender su evolución.

Así pues, en un contexto ideológico y sociopolítico en el que existió una voluntad modernizadora generalizada, se pueden identificar los primeros logros profesionales y disciplinares de la enfermería, al colaborar intensamente en las campañas de mejora de la salud de la población y superar su papel de mero auxiliar. Fue en este momento cuando se iniciaron las colaboraciones con otros profesionales ${ }^{33}$, cuando se llevaron a cabo las primeras experiencias de asociacionismo ${ }^{34}$ y las primeras colaboraciones en publicaciones científi$\operatorname{cas}^{35}$, y cuando participaron activamente en las campañas sanitarias a través de acciones específicas y coordinadas: lucha contra las enfermedades infecciosas

31. El periodo de entreguerras constituye un marco temporal de gran dinamismo y transformaciones. Fue en las primeras décadas del siglo XX cuando el mapa discursivo sobre las cuestiones de género se ve sometido a un proceso de secularización ideológica que afectó a los ideales masculinos y femeninos del siglo XIX y en el que las prácticas sociales de género evolucionaron hacia nuevas formas de expresión (Véase: ARESTI, Nerea, Médicos, donjuanes y mujeres modernas. Los ideales de feminidad y masculinidad en el primer tercio del siglo XX, Bilbao, Universidad del Pais Vasco, Historia Contemporánea, 23, 2001).

32. RichMOND, Kahtleen. Las mujeres en el fascismo español. La sección femenina de la falange, 1935-1959. Madrid, Alianza Editorial, 2004.

33. MARTín Yumar, Domingo y Huertas MúGiCA, Enrique. «La mortalidad infantil en el ambiente rural». Revista de Sanidad e Higiene Pública, 1933, pp. 470-485.

34. Bernabeu-Mestre y Gascón-PÉrez, Op cit., pp.. 93-95.

35. Las primeras publicaciones de las enfermeras visitadoras se encuentran en la revista «La Visitadora Sanitaria. Boletín de la Asociación Profesional de la Visitadora», que se publicó de1934 a 1935 con una periodicidad trimestral y Puericultura Española, revista publicada de 1935 a 1936, y en la que, a pesar no ser una revista de enfermería, se pueden leer algunas contribuciones de las visitadoras.

Feminismo/s 18, diciembre 2011, pp. 225-248 
como la tuberculosis o el tracoma, la labor desarrollada en el ámbito de la puericultura y la salud materno-infantil, o en otras actuaciones sanitarias en situaciones de crisis y conflictos, como en la «Campaña social-sanitaria de Asturias», desarrollada a raíz de los acontecimientos revolucionarios de octubre de 1934.

Su actuación en la campaña antituberculosa contó con iniciativas de gran interés, tanto desde los dispensarios antituberculosos, como a través de las visitas domiciliarias. Un ejemplo concreto fue el trabajo desarrollado en el Instituto Antituberculoso de Las Peñuelas en Madrid. Allí, en un barrio con altos índices de hacinamiento y pobreza, se encargaron de llevar a cabo inspecciones domiciliarias, de planificar su actuación elaborando planos de las casas, de distribuir las familias de modo que las ocasiones de contagio disminuyeran, de educar en la práctica de la higiene, etc., colaborando, en definitiva, en la reducción de la mortalidad por tuberculosis ${ }^{36}$.

También en la campaña sanitaria contra el tracoma, enfermedad ocular causante de numerosos casos de ceguera, tuvieron una participación relevante. En este caso, llevaron a cabo, por ejemplo, la intervención sobre el medio escolar, en los casos de niños tracomatosos ${ }^{37}$. Además de proporcionar continuidad a la inspección médico-escolar, a las intervenciones de los médicos locales y de los especialistas (oftalmólogos), y hacerse cargo de la educación higiénico-sanitaria, su labor permitía iniciar una actuación en el ámbito familiar y comunitario. Para cada alumno tracomatoso, las enfermeras abrían una ficha familiar y llevaban a cabo las visitas domiciliarias que permitían una evaluación de los factores de riesgo y la detección de los otros miembros de la unidad familiar que estaban afectados por la enfermedad, con lo que se podía proceder a su vigilancia desde el dispensario de higiene y someter-

36. Verdes Montenegro, José. «Las instructoras sanitarias», La Visitadora Sanitaria, 1934, pp. 11-12.

37. La campaña contra el tracoma en la España contemporánea contempló la enfermedad como una patología de la miseria, y por tanto con etiología y abordajes múltiples (Galiana-SÁnCHEZ, Ma Eugenia.; Cremades Monerris, Angela; Bernabeu-Mestre, Josep (2007), «Environment and health in a proverty-related disease: epidemiology of trachoma in contemporary Spain, 1900-1965». En: Environment Health and History. Conference of the European Association for the History of Medicine and health, London, 12-15 ${ }^{\text {th }}$, September 2007). En concreto, la intervención de las enfermeras se realizó en las acciones que se desarrollaron en el medio escolar (BERNABEU-MESTRE, Josep, GALIANA-SÁNCHEZ, Ma Eugenia «Salud comunitaria y acción social en el control epidemiológico del tracoma infantil (1932-1939)», Asclepio, (en prensa)), y en el medio laboral (BERNABEU-MeSTRE, Josep, GALIANA-SÁNCHEZ, Ma Eugenia. «Determinantes laborales y de género en la epidemiología del tracoma en la España contemporánea», En, XI Jornades Història del Treball i Gènere. Treball i salut en perspectiva històrica (segles XIX-XX), 28 i 29 d'abril de 2011). 
los a control y tratamiento, además de reeducarlos en cuestiones de hábitos y conductas higiénico-sanitarias ${ }^{38}$. El objetivo era interrumpir la cadena de contagio y evitar que los casos pasaran de la familia a la escuela y viceversa. Como ocurría en la mayoría de las enfermedades denominadas sociales, la labor estrictamente sanitaria era insuficiente y los profesionales de la salud debían llevar a cabo una autentica labor social. Las enfermeras visitadoras, en este sentido, jugaron un papel crucial al actuar como enlaces entre los tres ámbitos implicados: por un lado la población escolar y los maestros, por otro las instituciones sanitarias, médicos y servicios especializados, y por otro las familias y población general ${ }^{39}$.

Las visitadoras también ocuparon un papel central en el denominado «movimiento puericultor» y en las campañas de higiene materno-infantil ${ }^{40}$. El trabajo llevado a cabo con las madres, a través de las visitas domiciliarias, es el principal exponente de las actividades de divulgación que realizaban las visitadoras. Las intervenciones se realizaban en el mismo ambiente familiar, donde el niño vivía y donde se podía observar las condiciones higiénicas de las familias. En sus visitas, revisaban minuciosamente toda la vivienda: patios, ventilación, iluminación, instalaciones higiénicas, etc., y resolvían los problemas higiénicos que afectaban a la familia. Instruían a las madres sobre la lactancia, la práctica del baño, lavado de ropa, sueño y condiciones de la cuna, horas de paseo, etc. También se ocupaban de llevar a cabo las medidas profilácticas que fueran necesarias: aislamiento de enfermos, medios de desinfección y hasta separación del recién nacido si había tuberculosis en la familia.

38. Socias, Arnaldo.; Delgado, J., «Estudio de los factores epidémicos en la endemia tracomatosa», Rev. San. Hig. Pub., 13(11-12), 1939, p. 4; Selfa MarTínez, Enrique., «Consideraciones sobre la lucha contra las causas de ceguera», Rev. San. Hig. Pub., 1940, pp. 163-177.

39. «La educación sanitaria tenía que crear conciencia de la gravedad de la infección e informar sobre los principales medios de lucha. Los profesionales sanitarios (médicos y enfermeras) tenían que formar a los maestros y estos a sus alumnos con tanto mayor interés en cuanto que en los adultos la curación es ya más difícil. Debían utilizarse todos los medios de propaganda: prensa, carteles, folletos, radio, cine, conferencias, etc.» (DomíngueZ, A. Lo que todo médico debe saber respecto al tracoma, Murcia, Instituto Provincial de Sanidad, 1955, p. 21).

40. Sobre la contribución de las enfermeras a las campañas de higiene materno-infantil puede consultarse: GAliAnA-SÁNCHEZ, Ma Eugenia, Bernabeu-Mestre, Josep, «Alimentación, enfermería y cultura: el antecedente histórico de las visitadoras puericultoras», En: Alimentación, Salud y Cultura: encuentros interdisciplinares, IX Coloquio REDAM, Tarragona (en prensa), o el trabajo, TRESCASTRO, Eva, BERNABEU-MESTRE, Josep, GALIANA-SÁNCHEZ, $\mathrm{M}^{a}$ Eugenia, «La divulgación radiofónica de la alimentación y la higiene infantil en la España de la Segunda República (1933-1935)», Salud Colectiva (en prensa).

Feminismo/s 18, diciembre 2011, pp. 225-248 
La labor desarrollada desde los dispensarios móviles de Puericultura y en las consultas de los dispensarios de Higiene Infantil, también fue relevante. La enfermera realizaba la valoración inicial a la llegada al centro de los niños, «informándose brevemente de su estado para separar los sanos de los enfermos ${ }^{41}$. Pero fue sobre todo su labor de promoción y de educación la que adquirió mayor relevancia. En un momento en que la educación de los individuos en las prácticas saludables se vislumbraba como una herramienta de incalculable valor ${ }^{42}$, las enfermeras trasladaron el discurso higiénico a las madres, intentando de este modo reducir las cifras de mortalidad infantil y mejorar las condiciones de vida y salud de las familias:

La Enfermera Visitadora, al frecuentar la casa, en sus conversaciones más íntimas con la familia, descubre a menudo este dato, que al Médico, en la rápida visita de una consulta popular, se le había ocultado. Una vez en posesión de él, la Visitadora, siempre con la discreción necesaria, pero con la insistencia impuesta por sus deberes sanitarios, indica la conveniencia de que aquel tosedor, alegre y confiado, se haga reconocer en uno de los centros [...]. Hecho el descubrimiento, todavía la Visitadora continúa desplegando sus actividades higienistas, aconsejando aquellas medidas profilácticas que bien aplicadas pueden evitar la tragedia de familia. Ella advierte las ventajas de la ventilación, los inconvenientes del hacinamiento; notifica la existencia de organizaciones de aislamiento [...]. Estos ejemplos [...], demuestran hasta qué punto resulta útil y bienhechora la actuación de estas Auxiliares del Médico, sin las cuales puede afirmarse que no es posible desarrollar adecuadamente un plan sanitario bien conducido. Buena prueba de ello es que no hay país que goce de una organización estimable de la higiene pública, que no admita la necesidad de esta clase profesional y no dedique a su preparación técnica las atenciones presupuestarias ineludibles ${ }^{43}$.

Otro interesante ejemplo de actuación de las visitadoras fue, como se ha indicado, la llamada «Campaña social-sanitaria de Asturias». Después de los sucesos revolucionarios de Octubre del 34, se plantearon en Asturias problemas sociales y sanitarios agudos. Para resolver dichos problemas se envió a la zona un grupo de profesionales formado por un médico y ocho visitadoras sanitarias. Las enfermeras llevaron a cabo una investigación sanitaria por familias, y procedieron al reparto de ayuda según sus necesidades. Al mismo tiempo

41. BRAVO FRÍAS Juan: «Proyectos de organización de la lucha contra la mortalidad infantil». En: Lucha contra la mortalidad infantil. Conferencias radiofónicas. Madrid: Publicaciones de la Dirección General de Sanidad; 1933. pp. 13-20 (p. 19).

42. BARONA, Carmen, Las politicas de salud. La sanidad valenciana entre 1855 y 1936. Valencia, Publicaciones de la Universidad de Valencia; 2006.

43. GarCía Del Diestro, José: «Organización y finalidad de la Escuela Nacional de Puericultura». En: Lucha contra la mortalidad infantil. Conferencias radiofónicas. Madrid: Publicaciones de la Dirección General de Sanidad; 1933, p. 24. 
atendieron a enfermos, niños y gestantes, que recibieron una atención prioritaria siendo acogidos en el Instituto de Puericultura. Para organizar estos servicios se crearon Juntas Locales de Asistencia Pública en cada uno de los pueblos afectados. Las visitadoras salían a fundar nuevos servicios y permanecían en los pueblos tantos días como eran necesarios para que se reestructuraran en lo más básico. Durante su permanencia instruían a jóvenes que continuaban posteriormente su labor ${ }^{44}$.

\section{Luces y sombras en la construcción de la disciplina de la enfermería de Salud Pública}

Como se ha descrito en los párrafos anteriores, la contribución de las enfermeras al desarrollo de la Salud Pública fue relevante, aunque haya permanecido, en cierto modo, invisible. Su condición femenina, unida a los avatares sociopolíticos de la sanidad española contemporánea, ha hecho que sus aportaciones hayan sido eclipsadas históricamente, y que viviera, de un modo singular, su evolución como profesión. Sin embargo, esa condición femenina y esa concepción de la salud y del cuidar, es lo que ha constituido la idiosincrasia de su actuación. Las enfermeras, en todos sus ámbitos profesionales, se han caracterizado por su cercanía con la población a atender, estableciendo importantes vínculos con las personas de la comunidad, especialmente con las madres, y constituyendo uno de los grupos profesionales que se situaron en primera línea de la lucha regeneradora que caracterizó al movimiento higienista y que caracteriza a la salud pública:

La enfermera visitadora [...] es la clave de toda labor higiénico-social. [...] Es tan delicado su papel de consejera en los menudos detalles íntimos, depositan las madres tal confianza en sus instrucciones y reciben la visita domiciliaria con tal agrado, que insensiblemente se erige en mentora de la vida cotidiana de las familias humildes. Toda campaña a fondo precisa de su colaboración valiosa, [...]. Su papel social va ligado a una captación de la confianza que sólo se obtiene con el trato continuo y la amistad ${ }^{45}$.

Ésta faceta de su actividad, su papel de mediadoras y su proximidad con las familias, es la que resulta de mayor interés. Las enfermeras, en su labor sanitaria, aplicaron un modelo más cercano al ámbito popular del que manejaban los médicos y otros gestores de los problemas de salud. Abordaron los problemas sanitarios con un enfoque humanista que suavizó las propuestas científicas de intervención social y que favoreció el encuentro entre la cultura sanitaria

44. «ESCUELA NACIONAL DE INSTRUCTORAS SANITARIAS», Revista de Sanidad e Higiene Pública, 64. (1943), pp.15-64.

45. Martín Yumar y Huertas MúGica, Op cit., p. 482.

Feminismo/s 18, diciembre 2011, pp. 225-248 
científica y la cultura sanitaria popular planteada por algunos autores ${ }^{46}$. En este sentido, la figura de la enfermera de salud pública se hizo necesaria, pues se trataba de una profesional, que «de mujer a mujer», lograba llegar a las madres, principales agentes de salud familiar, superando las reticencias que tenía la población frente a la intervención médica y científica. Dicha intervención, que era doctrinaria y paternalista, pudo haberse modificado, al pasar por el filtro de las enfermeras, haciéndola más atractiva y asequible a las familias.

Esta última reflexión, que pone en valor la naturaleza femenina de la enfermería, también tiene la vertiente opuesta y supuso un obstáculo para alcanzar nuevas oportunidades y mayores niveles de independencia, pues intentó acotar la labor de las enfermeras a las coordenadas de su género y su papel en la sociedad del momento. Como afirmaba el Dr. Palanca, en un artículo publicado en la Visitadora Sanitaria:

No sé si una muchacha estará en su papel despachando peticiones de crédito agrícola o informando expedientes de sanciones administrativas. Lo que sí sé es que a la cabecera de un enfermo, en la consulta de un pediatra o a las ordenes de un sanitario no hay nadie que pueda igualar a una mujer inteligente e instruida. [...] en Sanidad hacen falta mujeres con todas las características de la feminidad bien acusadas; pero con prudencia, y que tomen como norma no meterse ni en cuestiones políticas ni societarias. Su función es de amor, de paz, de proselitismo ciertamente, pero de proselitismo cristiano, muy lejos de toda idea de lucha ni de sectarismo ${ }^{47}$.

Otro elemento relacionado con los obstáculos a los que hemos hecho referencia es la escasa visibilidad de sus colaboraciones en trabajos de investigación. A pesar de su participación activa en investigaciones llevadas a cabo en la comunidad, haciendo visitas domiciliarias para hacer observaciones y recopilar datos, su presencia como firmantes en trabajos científicos es escasa. En el periodo que estamos estudiando hemos localizado dos publicaciones periódicas en las que las enfermeras participaron. Se trata de La Visitadora Sanitaria. Boletín de la visitadora sanitaria y la revista Puericultura española. La Visitadora sanitaria, aunque con carácter profesional, constituye la primera publicación, que poseen las enfermeras españolas. Se publicó durante 1934 y 1935 con una periodicidad trimestral. Entre sus objetivos estuvieron: mejorar el nivel moral, cultural y técnico de las asociadas, ofrecer colaboración sobre asuntos profesionales, ser un foro donde exponer los trabajos personales

46. Rodríguez Ocaña, Esteban, Perdiguero, Enrique (eds). Ciencia y persuasión social en la medicalización de la infancia en España, siglos XIX-XX, História, Ciências, SaúdeManguinhos, 13, 2006, p. 309.

47. PALANCA, «La mujer en la Sanidad», La Visitadora Sanitaria, 1934, pp. 13-14. 
de las enfermeras en sus centros e inculcar un espíritu de unión, seriedad y disciplina en la profesión ${ }^{48}$. Sus artículos están, en su mayoría, escritos por las propias visitadoras, aunque en todos los números aparecen colaboraciones de otros profesionales (médicos higienistas, pediatras, odontólogos, etc.). Su comité de redacción estaba formado de forma exclusiva por enfermeras visitadoras.

Puericultura Española por su parte, se publicó entre 1935 y 1936 y publicó en estos dos años un total de 13 números ${ }^{49}$. En ellos aparecieron 9 artículos firmados por enfermeras. El comité de redacción de la revista estaba formado por 12 médicos y una enfermera visitadora, Blanca Bermudo, autora también de 4 de los 9 trabajos mencionados. Esta escasa comunicación de sus experiencias y sus incipientes colaboraciones científicas también nos informa de las dificultades que comportaba la condición femenina de las enfermeras de salud pública en el momento de gestionar el conocimiento que se derivaba de su actuación como profesionales sanitarias.

Otra de las cuestiones problemáticas que estaban pendientes de resolución era la relativa a las exigencias formativas de las visitadoras. Como recordaban Prada y García Corselas, «la necesidad de nombrar personal urgentemente obligó a los organismos oficiales a prescindir en las pruebas de admisión de requisitos que debieran considerarse indispensables para ejercer la profesión de Instructora sanitaria, y hoy tropezamos con los inconvenientes de esta conducta» ${ }^{50}$.

Al Estado no le sería muy costoso crear escuelas de enfermeras anejas a sus Facultades de Medicina, que con su profesorado, sus clínicas y sus hospitales, aportarían los elementos de más valor para la formación de las enfermeras, dando a la vez la sanción académica. Es cierto que existen buenas escuelas de enfermeras que no pertenecen al Estado, pero estas no han sido en general muy rigurosas en la selección de alumnas, y de este modo es muy poco frecuente encontrar una buena enfermera que posea una sólida cultura general y una educación esmerada y que esté, por tanto, en condiciones de recibir la formación especial propia de la profesión de Instructora sanitaria. Sin embargo, contamos por fortuna con un grupo selecto que ha logrado adquirir una excelente preparación y que con su labor está contrarrestando los errores que

48. «ESTATUTOS de la Asociación Profesional de Visitadoras Sanitarias de España», La Visitadora Sanitaria, 1934, pp.6-10.

49. La publicación se denominaba Puericultura Española, Revista mensual de Puericultura e Higiene infantil. Órgano oficial de la Asociación nacional de Médicos Puericultores.

50. Prada y García Corselas, Op. cit., p. 448.

Feminismo/s 18, diciembre 2011, pp. 225-248 
pudieran cometer por falta de capacitación otras compañeras, a las que deben servir de modelo y estímulo. ${ }^{51}$

Las enfermeras visitadoras fueron las primeras en reclamar la mejora «de su formación profesional y elevar el nivel del cuerpo en todos sus aspectos». En la Primera Asamblea Nacional de Enfermeras celebrada en Madrid en mayo de 1934, solicitaron la apertura inmediata de la Escuela de Visitadoras ${ }^{52}$.

El último elemento al que haremos referencia es el conflicto existente entre enfermeras y practicantes, en el que adquirió un gran peso la cuestión de género. A raíz de la reforma sanitaria de la Segunda República, los practicantes pasaron a integrarse plenamente en el organigrama sanitario, al constituirse en 1935 el Cuerpo de Practicantes de Asistencia Pública Domiciliaria y regularse sus funciones. El conflicto de competencias con las enfermeras estuvo presente hasta bien entrado el siglo XX, y se hizo patente en la vida pública española a través de diversos artículos en periódicos nacionales ${ }^{53}$, donde se refleja la diferente consideración social, laboral y formativa de los dos grupos profesionales.

Los practicantes, en sus reivindicaciones profesionales esgrimían lo que consideraban su principal valor: su cercanía a la profesión médica y su masculinidad, que les permitía llevar a cabo determinados procedimientos técnicos y actividades que requerían la fortaleza física del varón. No puede separarse de esta idea el hecho diferencial del género de ambos colectivos y la situación de subordinación de la mujer en todos los ámbitos de la vida pública española. En cierto sentido, la identidad de los practicantes basculaba entre su

51. Como ya se ha indicado, en el marco del convenio de colaboración con la Fundación Rockefeller, en 1931 se puso en marcha un programa de cooperación por el que la Fundación se comprometía a sufragar parte de los costes de construcción y puesta en marcha de una futura Escuela de Enfermeras Visitadoras, y sobre todo, a financiar, mediante bolsas de estudio, una adecuada formación de postgrado en enfermería de salud pública, a quienes debían asumir la responsabilidad de impartir la docencia en dicha Institución (Bernabeu Mestre y GASCón PÉrez, Op. Cit., pp. 57-60). El grupo selecto al que hacen mención Prada y Corselas, se refiere al colectivo de catorce enfermeras que se desplazaron a Estados Unidos para completar su formación.

52. El proyecto de Escuela estuvo asociado desde sus inicios al de la creación del Cuerpo de Enfermeras Sanitarias y de Asistencia Pública, y se planteó por primera vez en 1924 como unidad anexa a la Escuela Nacional de Sanidad (BERNABEU MESTRE y GASCÓN PÉREZ, Op. Cit., p. 56).

53. «Los colaboradores sanitarios. La mujer como enfermera», El Sol, 20/9/ 1931; «Los colaboradores sanitarios. La mujer como enfermera (continuación)». El Sol. 27/9/ 1931; «Los colaboradores sanitarios. La mujer como enfermera (continuación)». El Sol 4/10/ 1931; «Anhelos de una clase. El practicante, único auxiliar técnico del médico». El Sol 24/5/1931. 
afán por mimetizarse con el médico y cierta sensación de dominio frente a las enfermeras.

Muchas de estas «sombras», y en particular las relacionadas con las variables de género e ideología, contribuyeron al proceso de desinstitucionalización y retroceso que experimentó la enfermería de salud pública durante el primer franquismo ${ }^{54}$.

\section{A modo de conclusión}

En el ámbito de las respuestas institucionales que intentaban mejorar el estado de salud de la población, la contribución de las enfermeras visitadoras al desarrollo de la salud pública en la España contemporánea, fue relevante. La sanidad española del periodo de entreguerras les ofreció la oportunidad de construir un espacio de visibilidad social y reconocimiento profesional, aunque este proceso no estuvo exento de dificultades. Junto a otros condicionantes a los que se ha hecho mención a lo largo del trabajo, el género determinó la evolución de la enfermería en este periodo, influyendo en su desarrollo profesional y disciplinar y en el modo de gestionar el conocimiento que se derivaba de su actuación. La feminidad, entendida únicamente en los términos que se consideraban aceptables socialmente, era un requisito y, en cierto modo, una garantía del buen hacer de las enfermeras.

Las enfermeras han recorrido un largo camino de conflictos de género y su herencia ha llegado hasta nuestros días. En la actualidad, siguen enfrentándose a obstáculos relacionados con el género, normalmente los que se derivan de los problemas generales de las mujeres en la sociedad. Todavía hoy, en algunos países europeos, existen importantes dificultades relacionadas con las diferencias retributivas, la violencia o la consideración de que no es necesaria una formación universitaria para las profesiones consideradas femeninas.

54. Sobre dicho retroceso y el papel que jugó el género y los factores de naturaleza ideológica, se pueden consultar los trabajos: Galiana SÁnCHEZ, Ma Eugenia, GarCía-PARAMIO, Pilar, BeRnABEU-MeStre, Josep. «Luchando por la supervivencia: Primera Asamblea Nacional de Enfermeras (Madrid, 1959)», Temperamentvm, 8, 2008; Galiana SÁnChez, Ma ${ }^{a}$ Eugenia, García-Paramio, Pilar, Bernabeu-Mestre, Josep, «La frustración de una profesión: la enfermería de salud pública en la V Reunión de Sanitarios, 1959». Temperamentvm, 9, 2009; Galiana SÁnCHEZ, Ma Eugenia, Bernabeu-MeStre, Josep, GarCía-PARAMIO, Pilar, «Enfermeras para una nueva patria. Género e ideología en la enfermería de Falange», En: GonZALEZ-CANALEJo, Carmen, MARTineZ-LoPEZ, Fernando (eds.), La transformación de la Enfermería. Nuevas miradas para la Historia, Granada, Editorial Comares, 2010, pp. 203-216; y García-Paramio, Pilar; Galiana-SÁnChEZ, $M^{a}$ Eugenia, BERnABEU-MeSTRE, Josep, «La praxis de la enfermería a través de la Revista «Enfermeras, 1950-1951», Hiades, (en prensa).

Feminismo/s 18, diciembre 2011, pp. 225-248 
Además, sigue existiendo una gran dificultad para atraer a los hombres hacia la profesión de enfermería, lo que hace que los varones no tomen conciencia de que el cuidado de la salud también es cosa de hombres ${ }^{55}$.

Como es conocido, para superar la brecha entre hombres y mujeres es fundamental la educación en igualdad y la complicidad explicita de los varones. En España, en el caso de la enfermería, se ha conseguido superar los programas formativos que acentuaban las desigualdades, e incluso se ha roto el techo de cristal que impedía el progreso académico hacia la investigación ${ }^{56}$. Sin embargo, esto no se ha acompañado de otras medidas que aceleraran el proceso, ni de la complicidad entre hombres y mujeres en las relaciones médico-enfermera y enfermero-enfermera. En la España del siglo XXI, donde las mujeres representan más del $80 \%$ de los profesionales de enfermería, 32 de los 52 presidentes colegiales provinciales (el 62\%) y 12 de sus 17 presidentes autonómicos (el 71\%) son hombres. Igualmente, de los ocho miembros de la propia Comisión Ejecutiva del Consejo General de Enfermería, también siete (el 88\%) los son ${ }^{57}$. Los cargos de responsabilidad y representatividad siguen siendo ocupados por varones, lo que contribuye a perpetuar situaciones de desigualdad y discriminación, pero que plantean nuevos retos y desafíos para las nuevas generaciones de enfermeras del futuro.

\section{Referencias bibliográficas}

ARESTI, Nerea, Médicos, donjuanes y mujeres modernas. Los ideales de feminidad y masculinidad en el primer tercio del siglo XX, Bilbao, Universidad del Pais Vasco, Historia Contemporánea, 23, 2001.

Atenza Fernández, Juan.; Martínez Pérez, José (eds). El Centro Secundario de Higiene Rural de Talavera de la Reina y la sanidad española de su tiempo. Toledo, Junta de Comunidades de Castilla-La Mancha, 2001.

Bardají López, Enrique; Bellogín García, Mariano; González Rodríguez, Pedro. El seguro social de enfermedad y la sanidad municipal. Madrid, Primer Congreso Nacional de Sanidad, 1934.

BARONA VILAR, Carmen: «El paper de les dones com a vehiculadores de les campanyes sanitàries desenvolupades a la provincia de València (1900-1936)». En: BARONA, Carmen, Las políticas de salud. La sanidad valenciana entre 1855 y 1936. Valencia, Publicaciones de la Universidad de Valencia; 2006.

55. BÜSCHER, SIVERTSEN, y WHITE, Op cit., p. 57.

56. ZABALEGUI Y MACIÁ, Op cit., p.10.

57. HERNÁNDEZ, Juan F. La enfermería frente al espejo, Fundación alternativas, 2010. [http:// www.falternativas.org/laboratorio/documentos/documentos-de-trabajo/la-enfermeriafrente-al-espejo-mitos-y-realidades], consultado el 28/07/2011. 
Barona, Josep Lluís, Ciencia, Salud Pública y exilio. España (1875-1939). Valencia, Seminari d'Estudis sobre la Ciència, 2003, pp.99-129.

BArona Vilar, Josep Lluís; Bernabeu-Mestre, Josep. La salud y el Estado. El movimiento sanitario internacional y la administración española (1851-1945). València, PUV, 2008, pp. 89-262.

BARONA VILAR, Josep Lluís. «La sanitat rural, una qüestió d'estat», en GUILLEMLlobat, Ximo; GARCía FrasQUet, Gabriel (eds): Salut, alimentació i cultura al País Valencià, Gandia, CEIC-Alfons el Vell, 2009, pp. 13-37.

BARONA Vilar, Josep Lluís (ed.): Ciencia, salud pública y exilio (España 18751939), Valencia, Seminari d'Estudis sobre la Ciència, 2003, pp. 223-256,

BERNABEU-MESTRE, Josep. La salut pública que no va poder ser. José Estellés Salarich (1896-1990): una aportació valenciana a la sanitat espanyola contemporània. València, Consell Valencià de Cultura, 2007.

BERNABEU-MESTRE, Josep et al (editors). Salut i societat als municipis valencians: una perspectiva histórica. València, Denes, 2008, pp. 297-308.

Bernabeu-Mestre, Josep; GASCÓn, Encarna. «El papel de la enfermera en el desarrollo de la salud pública española (1923-1935): la visitadora sanitaria». Dynamis, 15(1995), pp. 151-176.

BERNABEU-MESTRE, Josep; GASCÓN, Encarna. «De visitadoras a instructoras: la enfermera de salud pública durante el primer franquismo» En: CASTELlanOS, J. La medicina en el Siglo XX: estudios históricos sobre medicina, sociedad y estado. Málaga. Sociedad Española de Historia de la Medicina, 1998, pp. 167-172.

Bernabeu-Mestre, Josep, Gascón-PÉrez, Encarna, Historia de la Enfermería de Salud Pública en España (1860-1977), Alicante, Publicaciones de la Universidad de Alicante, 1999.

BERNABEU-MESTRE, Josep: «Transición sanitaria y evolución de la medicina (diagnóstico, profilaxis y terapéutica), 1885-1942», Boletín de la Asociación de Demografía Histórica 16(2) (1998), pp. 15-38.

BERNABEU-MESTRE, Josep: «La contribución del exilio científico español al desarrollo de la salud pública venezolana: Santiago Ruesta Marco (1938-1960)», en: BARONA Vilar, Josep Lluís (ed.): Ciencia, salud pública y exilio (España 1875-1939), Valencia, Seminari d'Estudis sobre la Ciència, 2003, pp. 223-256.

BRAVO FRIAS, Juan: «Proyectos de organización de la lucha contra la mortalidad infantil», in Lucha contra la mortalidad infantil. Conferencias radiofónicas, Madrid, Publicaciones de la Dirección General de Sanidad, 1933, pp. 13-20.

BRAVO FRIAS, Juan: «Cómo atiende el Estado la lucha contra la mortalidad infantil», in Lucha contra la mortalidad infantil. Conferencias radiofónicas, Madrid, Publicaciones de la Dirección General de Sanidad, 1933, pp. 5-13.

BRAVO FRÍAS Juan: «Proyectos de organización de la lucha contra la mortalidad infantil». En: Lucha contra la mortalidad infantil. Conferencias radiofónicas. Madrid: Publicaciones de la Dirección General de Sanidad; 1933. pp. 13-20.

Feminismo/s 18, diciembre 2011, pp. 225-248 
Büscher, Andreas, Sivertsen, Bente, White, Jean. Nurses and Midwives: A force for health. Survey on the situation of nursing and midwifery in the Member States of the European Region of the World Health Organization. Copenhagen, WHO, 2009.

CABrera Bosh, M ${ }^{a}$ Isabel. «Las mujeres que lucharon solas: Concepción Arenal y Emilia Pardo Bazán». En: Folguera, Pilar (comp.). El feminismo en España: dos siglos de historia. Madrid. Ed. Pablo Iglesias, 1988, pp. 29-44.

CHAmizo, Carmen. La gota de leche y la escuela de enfermeras. Instituto de Puericultura de Gijón. Gijón, 1999.

CHAmizo, Carmen. Historia de la enfermería en Asturias: la Cruz Roja (trabajo Licenciatura), 2004.

DomíngueZ-AlCón, Carmen. Los cuidados y la profesión enfermera en España. Madrid, Pirámide, 1986.

Domínguez, A. Lo que todo médico debe saber respecto al tracoma, Murcia, Instituto Provincial de Sanidad, 1955, p. 21.

Estellés Salarich, José. «Apostillas al Primer Congreso Nacional de Sanidad». Revista de Sanidad e Higiene Pública 9 (1934), pp. 385-388.

Galiana-SÁnchez, Ma Eugenia.; Cremades Monerris, Angela; Bernabeu-MesTRE, Josep, «Environment and health in a proverty-related disease: epidemiology of trachoma in contemporary Spain, 1900-1965». En: Environment Health and History. Conference of the European Association for the History of Medicine and health, London, 12-15 ${ }^{\text {th }}$, September 2007.

GalianA-SÁnchez, María Eugenia; Cremades Monerris, Angela; Bernabeu-MesTRE, Josep: «Sanitary campaigns against trachoma in Spain», in: ANDRESEN, Astri; BARONA, Josep Lluís; CHERry, Steven (eds): Making a New Countryside. Health Policies and Practices in European History ca. 1860-1950, Frankfurt am Main, Peter Lang, 2010, pp. 101-111.

Galiana Sánchez, Ma Eugenia, García-Paramio, Pilar, Bernabeu-Mestre, Josep. «Luchando por la supervivencia: Primera Asamblea Nacional de Enfermeras (Madrid, 1959)», Temperamentvm, 8, (2008).

Galiana SÁnchez, Ma Eugenia, García-Paramio, Pilar, Bernabeu-Mestre, Josep, «La frustración de una profesión: la enfermería de salud pública en la V Reunión de Sanitarios, 1959». Temperamentvm, 9, (2009)

Galiana SÁnchez, Ma Eugenia, Bernabeu-Mestre, Josep, García-Paramio, Pilar, «Enfermeras para una nueva patria. Género e ideología en la enfermería de Falange», En: Gonzalez-CAnalejo, Carmen, Martinez-Lopez, Fernando (eds.), La transformación de la Enfermería. Nuevas miradas para la Historia, Granada, Editorial Comares, 2010, pp. 203-216.

GARCía CORSElas, María: «La instructora de Sanidad Pública en España», en GARDNER, Mary Sewall: La instructora de sanidad pública. Salamanca, Ángel 
de la Torre (Traducción del doctor Joaquín de Prada y María García Corselas), (1935), p. 445.

GARCÍA FRASQUET, Gabriel (eds): Salut, alimentació i cultura al País Valencià, Gandia, CEIC-Alfons el Vell, 2009, pp. 13-37.

GARCíA DEL Diestro, José: «Organización y finalidad de la Escuela Nacional de Puericultura». En: Lucha contra la mortalidad infantil. Conferencias radiofónicas. Madrid: Publicaciones de la Dirección General de Sanidad; 1933, p. 24.

GASCÓn, Encarna, GALiAnA, Ma Eugenia, BernabeU, Josep. «La acción social de las visitadoras e instructoras sanitarias». Trabajo social y salud, 43, (2002), pp. 149-174.

GASCÓn-PÉReZ, Encarna; Galiana-SÁncheZ, Ma Eugenia; Bernabeu-Mestre, Josep: «La aportación de las Enfermeras Visitadoras Sanitarias al desarrollo de la enfermería venezolana» en BARONA, Josep Lluís, Ciencia, Salud Pública y exilio. España (1875-1939). Valencia, Seminari d'Estudis sobre la Ciència, 2003, pp.99-129.

GonzÁlez Canalejo, Carmen. «Cuidados y bienestar: el trabajo sanitario femenino en respuesta a la cuestión social». Dynamis, 27, 2007, pp. 211-235.

HUERTAS, Rafael, Organización sanitaria y crisis social en España: la discusión sobre el modelo de servicios sanitarios públicos en el primer tercio del siglo XX. Madrid, Fundación de Investigaciones Marxistas, 1995.

LESKY, Erna, Medicina social: estudios y testimonios históricos. Madrid, Ministerio de Sanidad y Consumo (Textos clásicos españoles de la salud pública, 30), traducción al castellano e introducción por José M. López Piñeiro, 1984.

MARTín YUMAR, Domingo y HuERTAS MúGICA, Enrique. «La mortalidad infantil en el ambiente rural». Revista de Sanidad e Higiene Pública, 1933, pp. 470-485.

Molero MeSA, Jorge; MARTínez ANTONIO, Francisco Javier. «Las campañas sanitarias como paradigma de la acción social de la medicina». Trabajo Social y Salud (Monográfico: la acción social de la medicina y la construcción del sistema sanitario en la España contemporánea) 43 (2002), pp. 119-148.

PICANTES MONTENEGRO, José. «Las instructoras sanitarias», La Visitadora Sanitaria, (1934), pp. 11-12.

PradA, Joaquín (de); GARCía CorSElas, María: «La instructora de Sanidad Pública en España», en GARDNER, Mary Sewall: La instructora de sanidad pública. Salamanca, Ángel de la Torre (Traducción del doctor Joaquín de Prada y María García Corselas),

Richmond, Kahtleen. Las mujeres en el fascismo español. La sección femenina de la falange, 1935-1959. Madrid, Alianza Editorial, 2004.1935, p. 445.

Rodriguez OCAÑA, Esteban. Por la salud de las naciones. Higiene, microbiología y medicina social. Madrid, Akal, 1993.

ROdRIGUEZ OCAÑA, Esteban; MARTínez NAVARRO, Ferrán: «Introducción. El concepto de salud pública y su formación en la historia», en Salud Pública en 
España. Desde la Edad Media al siglo XXI. Granada, Escuela Andaluza de Salud Pública, 2008, pp. 11-20.

RODRIGUEZ OCAÑA, Esteban. La constitución de la medicina social como disciplina en España (1882-1923). Madrid, Ministerio de Sanidad y Consumo (Textos clásicos españoles de la salud pública, Complementario 1), 1987.

Rodríguez Ocaña, Esteban, Perdiguero, Enrique (eds). Ciencia y persuasión social en la medicalización de la infancia en España, siglos XIX-XX, História, Ciências, Saúde-Manguinhos, 13, (2006), p. 309.

Ruiz Somavilla, M ${ }^{a}$ Jesús; Jimenez LuCENA, Isabel «Un espacio para mujeres. El Servicio de divulgación y Asistencia Sanitario-Social en el primer franquismo». Historia Social, 39, (2001), pp. 67-85.

Socias, Arnaldo.; DELGADO, J., «Estudio de los factores epidémicos en la endemia tracomatosa», Rev. San. Hig. Pub., 13(11-12), 1939, p. 4; Selfa Martínez, Enrique., "Consideraciones sobre la lucha contra las causas de ceguera», Rev. San. Hig. Pub., 1940, pp. 163-177.

Verdes Montenegro José. «Las instructoras sanitarias», La Visitadora Sanitaria, (1934), pp. 11-12.

Zabalegui, Adelaida, MACiÁ, Loreto. Desarrollo del máster y doctorado oficial de enfermería en España, Castellón, Publicacions de la Universitat Jaume I, 2011. 


\title{
EFECTOS DE LAS REPRESENTACIONES SOCIALES DE LAS MAMAS SOBRE LA PREVENCIÓN DEL CÁNCER MAMARIO EN UN GRUPO DE MUJERES COLOMBIANAS
}

\author{
Clara Victoria Giraldo Mora \\ MARIA EUGENIA ARANGO ROJA \\ Universidad de Antioquia
}

Recibido/15/07/2011

Aceptado/25/09/2011

\section{Resumen}

Este escrito presenta los resultados de un estudio para comprender las representaciones sociales de las mamas y su influencia en el diagnostico precoz del cáncer mamario y las prácticas de auto cuidado en un grupo de mujeres de Medellín, Colombia. Es un estudio cualitativo llevado a cabo con 19 entrevistas en profundidad a 19 mujeres adultas sin cáncer de mama, utilizando el criterio de máxima variación. El análisis utiliza los lineamientos de la teoría fundamentada. Los hallazgos muestran que existe una representación social de las mamas como objeto de atracción y una representación negativa del cáncer de mama, que no favorecen la prevención del cáncer de mama ni contribuyen a las prácticas de auto cuidado como el auto examen, el tamizaje clínico y la mamografía. Concluimos que existe una construcción problemática del cuerpo femenino entre las participantes que impide las prácticas que merece ser revisada y denunciada como un asunto político esencial en la construcción de la subjetividad femenina.

Palabras clave: cuerpo, imagen corporal, belleza, autocuidado, cancer de mama, género, salud, representaciones sociales y estética.

\footnotetext{
Abstract

This paper presents the results of a study to understand the social representations of breast cancer and how they influence breast cancer prevention and self-care practices
} 
in a group of women from Medellin-Colombia. Is a qualitative study carried out with 19 in-depth interviews to 19 adult women who have not had breast cancer and using the sampling criterion of maximum variation. In our analysis, we used the guidelines of Grounded Theory. The findings show that there is a social representation of breasts as object of attraction and a negative representation of breast cancer, none of these representations foster breast cancer prevention nor contribute to self-care practices such as breast self-examination, clinical breast screening and mammography. In synthesis, there are problematic constructions of the feminine body among participants that deserve to be revised and denounced as political issue essential to the construction of feminine subjectivity .

Keywords: Body, Body Image, Beauty, Self-care, Brest Cancer, Gender and Health. 


\section{Introducción}

Anualmente, se presentan en el mundo más de 10 millones de casos nuevos de cáncer de mama y más de 6 millones mueren a causa de esta enfermedad, que suponen el $12 \%$ del total de muertes en la población femenina. Hace veinte años, estas cifras eran de 6 y 4 millones respectivamente ${ }^{1}$ y se estima que los casos aumentarán a 15 millones en el 2020². Estas cifras muestran el cáncer de mama como el más frecuente entre la población femenina y un problema de salud pública que afecta a una de cada diez mujeres.

En Colombia, el cáncer es un problema relevante en el perfil epidemiológico $^{3}$. Según el Instituto Nacional de Cancerología, en el año 2002 el cáncer ginecológico representó el 19,6\% de los casos, siendo el de mama el segundo más común en mujeres (19,7\%). El 70\% de los casos fue diagnosticado en estadios tardíos (III y IV) y el $5,1 \%$ en estadios tempranos (in situ y I) ${ }^{4}$. A pesar de ello, el control de este cáncer no es una prioridad en la Política Nacional de Salud Sexual y Reproductiva, diseñada por el Ministerio de la Protección Social en el $2003^{5}$.

El auto examen de mama y la mamografía constituyen las estrategias más importantes de prevención y detección temprana de la enfermedad y la mejor alternativa para controlarlo, así como para prevenir y detectar las recurrencias y las metástasis a otros órganos. Es preocupante saber que estas acciones no

1. ORGANIZACIÓN MUNDIAL DE LA SALUD. «Programas Nacionales de Control del Cáncer: Políticas y Pautas para la Gestión». Organización Mundial de la Salud. <http:// www.paho.org/Spanish/AD/DPC/NC/pcc-NCCP.pdf>. Consultado el 7-08-2005.

2. RADICE, D., \& REDAELLI, A. Breast cancer management: quality of life and cost considerations. Harmacoeconomics 21 (2003), pp. 383-396.

3. Pardo, C., Murillo. R., Piñeros. M., y Castro, M. Casos nuevos de cáncer 2003 en el Instituto Nacional de Cancerología Colombia, Revista Colombiana de Cancerología, 7 (2003). p. 5.

4. MINISTERIO DE SALUD DE COLOMBIA. «III Estudio Nacional de Salud Bucal y II Estudio Nacional de factores de riesgo de enfermedades crónicas- ENFERC II.» Colombia. El Ministerio; Serie Documentos Técnicos. (1999) p. 31.

5. MINISTERIO DE LA PROTECCIÓN SOCIAL COLOMBIA. «Política Nacional de Salud Sexual y Reproductiva.» Bogotá. El Ministerio, (2003). Documentos técnicos p. 11.

Feminismo/s 18, diciembre 2011, pp. 249-270 
se realizan en nuestro medio con la frecuencia recomendada ${ }^{6}$, lo que se evidencia en el estudio nacional de factores de riesgo de enfermedades crónicas realizado por el Ministerio de Salud de Colombia ${ }^{7}$, según el cual, el $43.7 \%$ de las mujeres de 35 o más años, dicen saber hacerse el auto examen de mama y el $39.8 \%$ se lo hacen alguna vez. De las que afirman saber hacerse el auto examen, el 58.2\% responde que se lo hace varias veces al año, el $28.3 \%$ una vez al mes, el 13.5\% una vez al año y el $9.7 \%$ nunca se lo hace.

De otro lado, la mamografía es un examen poco frecuente entre las mujeres de 50 o más años, en las que apenas alcanza una prevalencia del 10\%. En esta población durante el último año, el $38.9 \%$ se lo realizó y el $53.0 \%$ se lo practica con una periodicidad de 1 a 5 años. El 72\% de las mamografías se realizaron en mujeres motivadas por la presencia de quistes o porque pensaron que con ello prevenían el cáncer; en las mayores de 50 años la mamografía fue inducida por el médico ${ }^{8}$. Incluso, algunos estudios muestran poca sensibilización de los profesionales de la salud hacia la detección precoz del cáncer de mama, a pesar de que esta estrategia continua siendo clave para controlar la enfermedad ${ }^{9}$. Merece la pena resaltar que la realización de la mamografía en Colombia está sujeta a políticas Nacionales y según la Resolución Número 00412 del 2000 sólo es obligatoria a partir de los 50 años $^{10}$.

Por otra parte, el acceso a los servicios hospitalarios en Colombia no es equitativo ${ }^{11}$, específicamente entre los afiliados al régimen contributivo y el subsidiado; para el caso de la mamografía, mientras que el $48 \%$ de los pacientes públicos se la practican, entre los privados es de $87 \%^{12}$ y peor aún, este examen no está incluido en el POS del régimen subsidiado (Plan Obligatorio de Salud Subsidiado).

El aseguramiento en salud no significa acceso real o utilización efectiva de los servicios, existe una dispendiosa tramitología para acceder a ellos, por

6. Crane, R. «Cáncer de mama.» En: S. E. Otto (Ed). Enfermería oncológica. Barcelona: Harcourt. (2003).

7. MINISTERIO DE SALUD DE COLOMBIA. Op. cit. p. 31

8. bid. p. 12.

9. Arango Ruiz, A. L., Botero Jiménez, B. H., Ossa Salazar, L. M. «Algunos cambios en la calidad de vida manifestados por varias pacientes con cáncer de mama usuarias de la EPS Seguro Social, Medellín 1998.» [Investigación de especialización] Medellín: Pontificia Universidad Javeriana, Universidad de Antioquia, facultad de Enfermería; 1998. p. 28.

10. MINISTERIO DE SALUD DE COLOMBIA. «Normas técnicas para la detección temprana del cáncer de seno. Resolución Número 00412 DE 2000.: (2000)

11. Mejía, A., Sánchez, A. \& TAmayo, J. «Equidad en el acceso a servicios de salud en Antioquia, Colombia.» Rev. Salud Pública, 9:1 (2007), p 26-38.

12. bid. p. 27. 
lo que las mujeres deciden no volver ${ }^{13},{ }^{14}$. Un estudio realizado por el Departamento Nacional de Planeación afirma que las mayores inequidades se presentan con exámenes como la mamografía ${ }^{15}$ por lo que las prácticas de autocuidado como se sugieren con este examen se hacen más complejas de lo que nuestro estudio permite explorar.

\section{Representaciones sociales}

Las representaciones sociales de una enfermedad son determinantes de los comportamientos culturales con respecto a la misma, en ellas confluyen conocimientos científicos y populares, valores y otros elementos culturales como las creencias que determinan la reacción de la sociedad y la particular de cada individuo frente a una enfermedad ${ }^{16}$. Las creencias sobre el cáncer son variadas; en algunos casos es asociado con muerte, dolor y fetide $z^{17}$.

El concepto de auto cuidado en este estudio se basa en teóricos. Para Collière, cuidar es «....un acto de vida que permite que la vida continúe y se desarrolle y, de ese modo, luchar contra la muerte; también,... es mantener la vida asegurando la satisfacción de un conjunto de necesidades indispensables para la vida» ${ }^{18}$. Para Orem, el auto cuidado es la contribución de la persona a su propia existencia, es una actividad aprendida y orientada hacia un objetivo para regular los factores que afectan su propio desarrollo y funcionamiento en beneficio de su vida, salud o bienestar ${ }^{19}$. Según Illich, los seres humanos necesitan autonomía en el auto cuidado y derecho a definir la salud e imponer límites ${ }^{20}$. Un $75 \%$ de las actividades de salud son de auto cuidado; las personas son responsables de su salud, al escoger estilos de vida, conocimientos y creencias, sin dejar de reconocer que la salud y la enfermedad son fenómenos

13. Wiesner C., Vejarano M., Caicedo J., Tovar S., Cendales R. «Cervical cytology in Soacha, Colombia: social representation, barriers and motivation.» Revista. Salud Pública, 8 (2006), pp. 185-196.

14. ECHEVERRI E. «La salud en Colombia: abriendo el siglo... y la brecha de las inequidades.» Revista. Gerencia y Políticas de Salud [online], 3 (2002), pp. 76-94.

15. Flórez C, y ACOSta O. «Acerca de su estudio Avances y desafíos de la equidad en el sistema de salud colombiano.» Fundación Corona, Instituto Nacional de Planeación, Universidad de los Andes, Universidad del Rosario. 2007.

16. Jodelet, D, y Guerrero, A Develando la Cultura. $1^{\text {a }}$ ed. México: Universidad Nacional Autónoma de México. (2000).

17. ARANGO, A., y otros. Op. cit. p 28.

18. Colliere MF. Promover la vida. Madrid, MacGraw-Hill, 1993, p. 5.

19. Marriner T, \& Alligood R. «Orem: Teoría del deficit de autocuidado.» En: Modelos y teorías en enfermería. Madrid, Hancourt, 1999. p. 177.

20. Illich I. Nemesis médica, New York, Pantheon Books, 1976, p. 265.

Feminismo/s 18, diciembre 2011, pp. 249-270 
complejos que incluyen factores no controlables, como la herencia y las condiciones situacionales y ambientales ${ }^{21}$.

En este marco, el grupo de investigación Salud de las Mujeres de la Facultad de Enfermería de la Universidad de Antioquia, se propuso emprender un estudio cualitativo sobre representaciones sociales de las mamas y del cáncer de mama que permitiera responder a la pregunta: ¿Cuáles son las representaciones sociales de las mujeres adultas sobre las mamas y su influencia en las prácticas de auto cuidado para la prevención del cáncer de mama? Para desarrollar esta pregunta nos proponemos los siguientes objetivos:

1. Comprender las representaciones sociales que las mujeres tienen sobre sus mamas y el cáncer de mama.

2. Reflexionar acerca de la influencia de estas representaciones en el auto cuidado de las mujeres y la detección temprana del cáncer.

\section{Metodología}

Este estudio se realizó en el departamento de Antioquia- Colombia, durante 12 meses entre 2006-2007, con una perspectiva metodológica cualitativa, con 19 mujeres mayores de 18 años, sin diagnóstico de cáncer de mama, con capacidad para hablar y que, voluntariamente estuvieran dispuestas a compartir sus pensamientos. A las participantes se les garantizó el manejo ético de la información.

Se utilizó la técnica de máxima variación, la cual sugiere incluir mujeres con la mayor diversidad cultural, étnica, social y económica a fin de responder a la heterogeneidad de la población ${ }^{22}$. Para determinar el número de participantes se utilizó el muestreo teórico ${ }^{23}$ es decir, partiendo de los conceptos identificados como relevantes para la comprensión del fenómeno ${ }^{24}$.

La técnica de recogida de información fue la entrevista semiestructurada ${ }^{25}$ la cual supone encuentros cara a cara entre las participantes y las investigadoras y para el análisis se siguieron los lineamientos de la teoría fundada ${ }^{26}$.

21. STEIGER, N. \& LIPSON, J. Self care-nursing. theory \& practice. Maryland: Prentice Hall Publishing. 1985.

22. Patton, M. Qualitative Research \& Evaluation Methods. Thousand Oks, Sage Publications. (2001)

23. Strauss, A., \& Corbin, J. Bases de la investigación cualitativa: Técnicas y procedimientos para desarrollar la teoría fundamentada. Medellín: Universidad de Antioquia. (2002) p. 341.

24. Ibid. p. 219.

25. Ibid. p. 224.

26. Ibid. p. 80. 
La recogida de información, el análisis y la postura teórica se hicieron conjuntamente y mantuvieron una relación reciproca durante todo el proceso investigativo.

Dos entrevistas constituyeron el estudio exploratorio, en el cual se comprobó que las preguntas y el acercamiento a las mujeres eran adecuados; la entrevista fue modificada para ampliar y enfocar los objetos de estudio. El análisis se realizó con el Software Atlas-ti y su calidad está regida por los criterios de credibilidad y veracidad ${ }^{27}$. La credibilidad se logra cuando las categorías emergen de manera natural, se saturan y son validadas por los informantes del estudio ${ }^{28}$. Para aumentar la credibilidad, los datos se les presentaron a las participantes para validar los hallazgos y se discutieron con el grupo de expertas del Grupo de Investigación Salud de las Mujeres de la Universidad de Antioquia, quienes supervisaron la construcción de las categorías principales ${ }^{29}$.

\section{Resultados}

Los datos obtenidos de 19 entrevistas a mujeres entre los 18 y 69 años de edad, con diversas características étnicas, educativas, ocupacionales y socioeconómicas permitieron identificar tres categorías de análisis: representaciones del cáncer, del autocuidado y del cuerpo y la imagen corporal. Cada categoría sirvió de base para tres publicaciones.

El articulo sobre representaciones del cáncer muestra que algunas mujeres tienen representaciones fisiológicas del cáncer, otras lo hacen desde sus efectos sociales y psicológicos e identifican sus causas con problemas personales, afectivos o hábitos cotidianos como alimentos inadecuados - «una venganza del cuerpo por los abusos que se hacen sobre el». Otros asocian la palabra «cáncer de mama» a muerte inevitable, terror, sufrimiento, devastación, incurabilidad, impotencia y dolor. La persistencia de las imágenes negativas del cáncer, se asocia al «mito de los estilos de vida» ${ }^{30}$, que responsabilizan al paciente. Este lleva a un reduccionismo biológico que oculta factores ambientales, sociales y políticos. Como lo expresa Lock la sociedad está obsesionada con los peligros y su control ${ }^{31}$, y añadimos a estos mensajes, imágenes

27. TAYLOR, S. y BOGDAN, R. Introducción a los métodos cualitativos de investigación. Barcelona, Paidós Ibérica, (1992).

28. LAGOUEYTE, M. «La citología vaginal mirada desde las mujeres». Investigación y Educación en Enfermeria, 20 (2002), pp. 58-69.

29. LINCOLN, Y. \& GUBA E. Naturalistic Inquiry. Sage Publication, (1985).

30. Medina, A. M. «Representaciones del cáncer en estudiantes de medicina: implicaciones para la práctica y la enseñanza». Revista de Salud Pública, 9(2007), pp. 369-378.

31. LoCK, M. «Breast cancer: reading the omens.» Anthropology Today, 14(1998), pp. 7-16.

Feminismo/s 18, diciembre 2011, pp. 249-270 
poderosas como aquella que «una en nueve mujeres desarrollarán el cáncer de mama» para fomentar la propia responsabilidad ${ }^{32}$, de esa forma, se magnifican los fantasmas del cáncer que nuestras sociedades en desarrollo están tratando de superar.

El artículo de representaciones sociales y prácticas de auto cuidado para la prevención del cáncer de mama, muestra que el auto examen, mamografía y examen clínico, no coinciden con los parámetros de tamizaje para la detección precoz. Por el contrario, hacen énfasis en la dimensión del embellecimiento de las mamas. Este hallazgo tan contundente y perturbador permite entender que el cáncer de mama tiene fuertes representaciones sociales debido a las severas implicaciones en el aspecto atractivo y autoimagen de la mujer; por esto, desarrollamos este articulo donde mostramos cómo el cuerpo y la imagen corporal median las representaciones del cáncer da mama.

Para las mujeres del estudio, las mamas constituyen un objeto de atracción para el sexo opuesto y en ese sentido le dan un alto valor estético y erótico. Se representan como un objeto perfectible sobre el cual deben ejercer cuidados para mantenerse bellas dentro de los estándares de la moda, en lo que invierten gran cantidad de atención, dinero y tiempo. Para otras, las mamas representan además, la tradicional función materna de afecto y alimentación.

Para las participantes las mamas son muy importantes, no se conciben sin ellas, no importa que el tamaño de las mamas sea grande o pequeño, pero nunca sin ellas. Las mamas marcan la diferencia de sexo, son elemento fundamental de la identidad femenina. Las reconocen con una doble función, como vínculo con los hijos y como parte de la sexualidad; como expresa Laura ( $\mathrm{R}$ 159): «Importante en el lado de los hijos, me parece que es un vínculo que se debe tener con los hijos; para la parte sexual es importante». A estas mujeres les preocupa el impacto negativo que el cáncer de mama pueda tener sobre la estética corporal, lo que sería «doloroso y difícil de aceptar», de ahí que consideren las pérdidas corporales, ocasionadas por la enfermedad, como difíciles de llevar, ya que afectan la autoestima y comprometen la autoimagen y la confianza para cautivar al sexo opuesto. Según estas mujeres, en el contexto en que vivimos, el énfasis de las mamas se centra en su valor sexual y estético, se las considera "puro adorno» $\mathrm{y}$ «decoración... nos hace ver más hermosas» (Morelia R 22).

Por el contrario, para las indígenas Emberá, las mamas cobran importancia a partir de la vivencia de la maternidad, al dar la posibilidad de amamantar

32. LoCK, M. Op cit, pp. 7-16. 
a los hijos, privilegio sólo de las hembras humanas; les parece algo «mágico»y les produce mucha gratificación su capacidad fisiológica para aportar al crecimiento de otro ser humano, como lo expresa Julieta (R12), mujer del Resguardo Indígena de Cristianía (Jardín Antioquia): «es muy bonito dar algo del cuerpo que es la leche, y sólo la da la hembra, yo sé que no todas miran así, ni ven esa magia, que bonito que yo estoy dando algo de mí, estoy haciendo crecer a otro ser con mis senos, de ahí está saliendo la leche».

\section{Discusión}

\subsection{Asumiendo o no los estereotipos}

Encontramos que las mujeres construyen su imagen corporal de diversas formas. Por un lado, aquellas que autoaplican estereotipos construidos por agentes externos y por otro, las que se apartan de tales estereotipos y asumen su propia figura corporal.

Al realizar el estudio sobre la auto aplicación de estereotipos, se encontró que la satisfacción con la imagen corporal depende de las pautas estéticas preestablecidas. Tener un cuerpo agradable es una exigencia social impuesta por los medios masivos de comunicación, las mamas, según esto, se constituyen en un objeto estético y erótico. Para muchas, los medios son «los culpables» (Laura R 504), pues tienen el poder para interferir la confianza de las mujeres respecto a su imagen corporal. El interés general de los medios no es mejorar la situación de las mujeres, por el contrario, son ellas con su cuerpo quienes le prestan un servicio bastante lucrativo a los medios y al mercadeo; así lo expresa Laura ( $\mathrm{R} 476$ ): «No hay casi ningún producto que no tenga a una mujer involucrada [en la publicidad], sea un tarro de pintura, siempre muestran a una mujer en bikini mostrando los senos» El objetivo de los medios es promocionar el consumo a través de la figura femenina, situación que impacta negativamente la identidad de las mujeres en tanto se alejan de ser sí mismas. La importancia del cuerpo está en las mamas grandes, pues así son más visibilizadas y «atraen al sexo opuesto» (Laura R 34).

Para el mundo publicitario el cuerpo de las mujeres es el botín de la publicidad, ésta ha construido las pautas estéticas que permiten mediatizar positivamente la atracción de consumidores, capturando la atención sobre «miles de productos» en el mercado, lo que requiere de mujeres con las medidas perfectas para tal fin. El estereotipo mencionado hace parte del referente social que tienen mujeres y hombres durante los procesos de individuación-socialización para constituir la identidad y la autoimagen a través de la imitación. La influencia de tales modelos induce a las mujeres a desear para sí, mamas 
grandes para sentirse «orgullosas» y «exhibirlas». Por el contrario, quienes tienen mamas pequeñas, se sienten «incómodas» y evitan la exposición del cuerpo; si tuvieran recursos se harían cirugía; Hellen expresa (R 14): «Yo tengo varias amigas que..., se han puesto siliconas y... se sienten muy orgullosas; se ponen escotes y todo eso, pero cuando son así pequeñitas y todo se sienten como incómodas no les gusta exhibirlas»

Mantenerse dentro de los estereotipos aceptados de belleza, puede implicarle a las mujeres el riesgo de explotación del mercado en búsqueda del tamaño perfecto: «Todas se quieren hacer un implante de siliconas jah!... existe una crema, incluso, nos dejamos engañar por lo que dicen los medios, que tal producto sirve para eso» (Laura R 550).

El valor que las mujeres les dan a las mamas está sujeto a la concepción del cuerpo a partir de la autoaplicación de estereotipos construidos por otros. En el auto concepto incorporan el modelo, pero, cuando el cuerpo físicamente no logra el esquema ideal, se torna en un problema, "iAh no, es que yo no me sentía bien!» No... ¡Muy triste! Si me voy a poner un vestido de baño, no es lo mismo» (Laura, R 575). Lo que precisa de las mujeres un trabajo sobre su figura.

Para estas mujeres, el problema está en que los patrones de belleza los determinan agentes externos a ellas mismas, quedando sujetas a ciertos estereotipos que constituyen la «carta de presentación» (Laura R 534): ser joven, armoniosa, voluptuosa, mamas bien firmes, desarrolladas y grandes. Laura ( $\mathrm{R}$ 590) dice: «la imagen la han vendido los medios, la necesidad parte es de formas estéticas que reproducen los medios de quien, en realidad, sale la necesidad de mostrar unos cuerpos voluptuosos». La moda arrastra a muchas mujeres sin importar lo que proponga, induciendo a la cirugía cosmética de las mamas, ya sea para aumentar o disminuir, y así acercarse al modelo ideal.

Las mujeres, socializadas como seres no para sí, sino para el otro, tienen incorporada la necesidad de ser conquistadas, entonces, para tener un lugar en el mundo del otro requieren de unas condiciones estéticas que atrapen las miradas, así logran existir y ser alguien. Lo que explica que en algunas ocasiones, se da prioridad al cuidado estético de las mamas por encima de la salud. Este comportamiento es potenciado por la educación impartida a las mujeres en la que se insiste en la idea de que son las mujeres quienes deben mantener la relación de pareja y para ello es necesario estar siempre atractiva dentro del paradigma ideal, en el cual, el tamaño de las mamas tiene un valor erótico para los hombres. En este contexto, una de las alternativas para complacer al compañero sexual es hacerse mamoplastia de aumento. 
Según las entrevistadas, la inconformidad con las mamas y el deseo de operarse también se trasmite entre pares y de generación en generación como lo expresa Liliana (R22): «De pronto, igual, yo creo también que el inconformismo empezó porque yo vi que mi mamá se operó, entonces yo, ya, ¿por qué ella y por qué yo no?». La autoaplicación de estereotipos implica asumir que las mamas grandes son la carta de presentación ante los demás; quienes las tienen pequeñas sufren de baja autoestima, Morelia ( $\mathrm{R} 22$ ) dice: «Las mujeres sienten que sus senos son un tipo de presentación, o sea, actualmente a mí me parece que sea así, porque una mujer... que tiene los senos pequeños se siente acomplejada».

En este sentido, las mujeres ven la necesidad de que se de educación en salud desde la infancia y la adolescencia; según ellas, se carece de acompañamiento para estimular el reconocimiento corporal durante este periodo, lo que es importante para sentirse bien con el tamaño de sus mamas; pues hay niñas que "se preocupan porque casi no les han crecido. Es una tablita por completo» (Doris R 4).

Sin embargo, los patrones estéticos imperantes no son aceptados por todas las mujeres; algunas se apartan de estereotipos, su referente es el buen funcionamiento del cuerpo, les basta con reconocer que funciona normalmente y no tiene deformidades, «uno debe estar agradecido con dios con lo que me dio, que me lo dio normal, que no tiene deformidades, nada raro» (Beatriz R16). Para ellas la auto aceptación es un indicador de auto estima, aunque sus formas corporales no se acerquen a las pautas de belleza expuestas por los medios, reconocen su cuerpo, lo aprecian y lo asumen al margen de influencias externas; no conciben ser admiradas por algo que no es propio, así lo refiere Bibiana (R 48): «Yo así como estoy me siento bien..., yo no quiero que me estén... catalogando por algo que no es mío... no tengo por qué estar aparentando... Lo que tengo, lo tengo, si les gusta bien y si no también». Rechazan que las mujeres aumenten sus mamas por complacer a los hombres, sostienen que «si me quiere, me acepta como soy» (Morelia R 74).

La auto aceptación es un proceso que involucra la superación de los estereotipos, aunque alguna mujeres pasan por altibajos, «al principio, cuando empecé en el modelaje, sí quería como operarme el busto porque yo veía que todo el mundo, pues que los contratos surgían más del busto, pero después se me fue pasando como la bobada. Ya no me importó» (Bibiana R 10). Es un intento por mantener la propia valía, desechando modelos, para llegar, finalmente, a ser sí misma. «no soy como una modelo, pero sí, me siento bien con la imagen corporal (Flor R 10). 
Los hallazgos frente a las representaciones del cáncer, el auto cuidado y la imagen corporal, que son las categorías mayores en este estudio, se validaron con las participantes. A la primera participante le preocuparon dos asuntos, la insensibilidad frente esta problemática y el cómo acceder a los pueblos indígenas con un lenguaje comprensible frente a este tema; reconocía que las mamas nos representan, como son utilizadas y seguirán siendo utilizadas. A la participante dos le preocupaba que se estigmatizara a alguien por no cuidarse y que la identidad de la mujer se afecte con todo tipo de estereotipos, afirma además, que una mujer no deja de ser mujer por seguir estos estereotipos, sin embargo sabia que seguirlos significa hacerse daño a si misma. A la participante tres le preocupa cómo mejorar la salud de las mujeres. La cuatro quisiera que los hombres cercanos a las mujeres entendieran más sobre este tema y que el miedo al cáncer no radique en el hecho de que les van a quitar un seno. La participante cinco señalaba que las mujeres deben hacerse conscientes de que un implante mamario no garantiza un hombre a su lado; además que la gente debe conocer los efectos que tiene esta cirugía a largo plazo y que se necesitan más campañas sobre el tema. La seis dijo que la responsabilidad de género está en que no solo velemos por la salud de los demás, sino en exigirle al estado las condiciones de vida digna y agradeció a las investigadoras por presentarle los resultados.

\subsection{Belleza como modelo del ser femenino}

No es gratuito que dos novelas de la mayor importancia comercial y social en Colombia tengan como asunto central la belleza. Estas novelas, aunque trivializadas por la academia, son un buen pulso de lo que es preeminente a una cultura y la expresión de representaciones sociales colectivas. Ivan Ulchur ${ }^{33}$, hace la semblanza de una Betty en Betty la Fea, la mujer que encarna un antimodelo de belleza por su apariencia física y sus pobres habilidades sociales y femeninas para la conquista, pero es brillante y bien educada, habilidades que son constantemente olvidadas en un mundo de hombres y mujeres atractivos, exitosos y deseables que la miran con desprecio. Lamentablemente en la novela, Betty debe despojarse de su fealdad para poder ser aceptada en una relación romántica ${ }^{34}$ con lo que la novela perpetúa el estereotipo de que la belleza sigue siendo, a fin de cuentas, la puerta de entrada en nuestra sociedad ${ }^{35}$.

33. Ulchur, I. «Betty la fea: la suerte de la inteligencia». Chasqui, 71 (2000) http://chasqui. comunica.org/ulchur71.htm Consultado el 23-04-2008.

34. Ulchur, I. Op. Cit. 1.

35. Ibíd. p. 1. 
Por su parte, Sin Tetas No Hay Paraíso es una historia de la vida real, basada en el libro de Gustavo Bolívar, donde las protagonistas son dos mujeres jóvenes que sueñan con ascender en la escala social y utilizan sus cuerpos y la belleza artificial para hacerlo. Igualmente, con esta serie se trató de llamar la atención de la sociedad sobre la proliferación de implantes mamarios sin las observaciones médicas requeridas y sobre las llamadas «chicas prepago», donde la falta de educación, la ignorancia y la necesidad de conseguir dinero hacen que las jóvenes caigan en un medio donde su cuerpo es la única opción para alcanzar sus metas ${ }^{36}$.

La preocupación de las mujeres por su apariencia física ha sido extensamente revisada en los países desarrollados, particularmente en los Estados Unidos, país en el que nosotros, los colombianos, nos miramos. En nuestro medio los estándares de belleza se han homogenizado tratando de seguir los norteamericanos y Europeos.

El cuerpo es crucial en la concepción actual de género, las mujeres contemporáneas afrontan intensas presiones para cumplir con ciertos ideales de belleza, y hacen una gran inversión emocional, física y financiera en su cuerpo. Para esta autora, las mujeres tienen relaciones problemáticas con su cuerpo con mayor frecuencia que los hombres ${ }^{37}$. Con el objeto de ser más atractivas, muchas mujeres a través de la historia, han efectuado rutinas, rituales y alteraciones corporales, han vendado sus pies, usado corsés, fajas, tatuajes, pircings, implantado gemas en sus cuerpos y una larga lista da acciones encaminadas a mejorar la apariencia de su cuerpo. Estos rituales han transcendido las clases, las razas y las regiones ${ }^{38}$. Las mujeres del estudio están sujetas a estas presiones, excepto las indígenas, cuyo modelo de belleza no corresponde al modelo hegemónico occidental.

\subsection{Imagen Corporal y Cuidados del Cuerpo}

En los países Occidentales, autores de las ciencias sociales han investigado y teorizado sobre los efectos en la salud de la tendencia esteticista del cuidado, dos asuntos centrales en la discusión de nuestros hallazgos. Algunos de ellos afirman que las personas desarrollan estilos de vida saludables para preservar

36. Wikipedia. Sin tetas no hay paraíso < http://es.wikipedia.org/wiki/Sin_tetas_no_hay_ para\%C3\%ADso_(Colombia) > Consultado el 16-03-2011.

37. Gimlin, D. Body work: Beauty and self-image in American culture. Berkeley University of California Press. (2001).

38. Banner, L. American Beauty. Los Angeles: Figueroa Press 2 (2005). p. 548.

Feminismo/s 18, diciembre 2011, pp. 249-270 
la belleza y la apariencia joven, en lugar de pensar en su salud ${ }^{39}$. Las personas muchas veces se envuelven en prácticas que no son saludables para ser físicamente más aceptables, por lo que ha aumentado el número de cirugías cosméticas, blanqueamientos del la piel o ingestión de cantidad de hormonas, vitaminas, suplementos y esteroides ${ }^{40}$. La percepción del cuerpo propio influye en el consumo de servicios y productos para mantener la imagen como hemos encontrado en nuestros resultados ${ }^{41}$; no obstante, Black, cree que la salud vista desde una perspectiva más holística permite entender cómo las terapias de embellecimiento pueden mejorar la salud física y emocional de la persona $^{42}$.

La preocupación y el deseo por cambiar la apariencia de las mamas en nuestras entrevistadas puede ser teorizada desde las reflexiones de Schouten, quien desde la perspectiva antropológica del comportamiento encontró que las cirugía plástica en hombres y mujeres son ritos personales de paso y de reconstrucción de la identidad ${ }^{43}$. Prácticas como estas, explotan los estándares no reales de belleza donde se idealiza una versión particular de mujer. El problema más grave, es que las personas no cuestionan seriamente las construcciones de belleza con su carácter opresivo ${ }^{44}$, como sucedió con nuestras entrevistadas.

\subsection{Discriminación Basada en la Apariencia}

Denunciamos la discriminación basada en la apariencia, de la cual la mayoría de las mujeres son poco conscientes. Con respeto a esto Berry afirma que es el último bastión de los prejuicios socialmente aceptados, es decir, que para la mayoría de las personas no causa rechazo ${ }^{45}$. Para esta autora, la inequidad social está relacionada con los prejuicios y la discriminación basada en la

39. UCOK, O. «The fashioned survivor institutionalized representations of women with breast cancer» Communication and Medicine, 4 (2007), pp. 67-78.

40. BerRY, B. Beauty bias: Discrimination and social power Estates Unites. Praeger.1 (2007) p 163.

41. ThOMPSON, C. \& Hirchman, E. «Understanding the socialized body: A poststructuralist analysis of consumers' self-concepts, body images and self care practices». The journal of consumer research, 22 (1995), pp. 139-153.

42. BLACK, P. Beauty industry: gender culture and pleasure London, New York, Taylor and Francis. (2004) p. 214.

43. SCHOUTEN, JW. «Selves in transition: Symbolic consumption in personal rites of passages and identity reconstruction». The journal of consumer research, 17(1991), pp. 412-425.

44. HEVORY, T. Body/politics in reproduction and production and reconstruction. Westport, CT Praeger. (2000).

45. BERRY, B. Op.Cit p. ix. 
apariencia física; y considera que rasgos como la raza, el género, la edad y los recursos económicos, formas de discriminación mas estudiados, están sobrepuestos con todas estas categorías como el peso, la estatura, la forma de los ojos, la incapacidad, la deformidad, carencia de dientes y la vejez, que son importantes marcadores del trato discriminatorio laboral, afectivo, amistoso entre otros ${ }^{46}$.

En el mundo del trabajo el aspecto físico o el atractivo favorecen a la persona, mientras que los que son poco atractivos pierden oportunidades y las ventajas que generosamente son otorgadas a los primeros. Afirman también que muchos empleadores se preocupan por el aspecto físico de sus empleados y hasta toman decisiones de empleo, basadas en el aspecto físico de los candidatos ${ }^{47}$.

Hamermesh y Biddle ${ }^{48}$ fueron un paso mas allá de Corbett $^{49}$, ellos diseñaron una serie de experimentos para medir en forma objetiva la discriminación basada en la apariencia y examinaron el impacto en los ingresos, encontrando que la gente común gana menos que el promedio de las personas bien parecidas, la deducción es ligeramente mayor del 5 a $10 \%{ }^{50}$.

Las personas atractivas tienen como capital su apariencia, y tienen mejores precios en el mercado del noviazgo y el matrimonio, al punto que las mujeres bellas se casan con hombres más prestigiosos y con mayores ingresos que ellas. Las mujeres y los hombres atractivos son más populares y tienen más $\operatorname{citas}^{51}$. Situación que podría explicar el temor de nuestras entrevistadas a una mastectomía ya que pudiera llevarlas a la imposibilidad de conseguir compañero sexual o esposo, o a un abandono por parte de ellos.

Las mujeres tienen que someterse a un doble estándar en la apariencia que no se impone con tanto rigor sobre los hombres ${ }^{52}$ y deben realizar gran cantidad de trabajo corporal para conseguir un ideal de belleza inalcanzable ${ }^{53}$,

46. Ibíd. p. ix.

47. CORBETt, W. «The ugly truth about appearance discrimination and the beauty of our employment discrimination law». Duke Journal of Gender Law \& Policy (2007) http:// goliath.ecnext.com/coms2/gi_0199-6416718/The-ugly-truth-about-appearance.html Consultado el 5-05-2008.

48. Hamermesh, D., \& Biddle, J. «Beauty and the Labor Market». The American Economic Review. 84 (1994), pp. 1174-1194.

49. Corbett, W. Op. Cit.

50. Hamermesh, D., \& Biddle, J. Op. Cit., pp. 1174-1194.

51. BERRY, B.. Beauty bias: Discrimination and social power. Estates Unites. Praeger.1 (2007) p. 29.

52. GIMLIN, D. Body work: Beauty and self-image in American culture. Berkeley University of California Press. (2001). P. 4.

53. Ibid. p. 4.

Feminismo/s 18, diciembre 2011, pp. 249-270 
trabajo que parece reemplazar las prácticas de auto cuidado frente a la prevención del cáncer de mama.

Las entrevistadas hablan de un interés por la mamoplastia, igual a lo ocurrido en los Estados Unidos hace algunas décadas que obligó a algunas investigadoras realizar estudios prospectivos y retrospectivos sobre este problema. Otros trabajos muestran que para las mujeres, las cirugías de mama obedecen a condiciones específicas de presión en términos de que valdrían más, serian más amadas y atendidas si se adherían a las normas culturales de femini$\operatorname{dad}^{54,55,56}$.

Saffon investigadora del Centro de Estudios de Derecho, Justicia y Sociedad, ha escrito sobre la discriminación de los feos en Colombia, ella considera que es un fenómeno global; y al igual que Berry considera que es un tipo de discriminación más sutil y más difícil de identificar, denunciar y evitar. Para ella "estética funciona como un poderoso mecanismo de diferenciación social ${ }^{57}$.

Saffon $^{58}$ argumenta que nuestra sociedad estratificada hace que aquellos que pertenecen a clases de mayor élite, prestigio y poder y que Mills llamó la elite del poder ${ }^{59}$ son quienes usualmente fijan los estándares de apariencia física y es a partir de estos estándares, como se discrimina a un miembro de una clase social menos aventajada, o que no tiene la apariencia que satisface a esa clase dominante, adicionalmente considera que no solo la apariencia se usa como forma de discriminación sino también los gustos y modales

\subsection{Cáncer de mama e Imagen Corporal}

Nuestra discusión ha retomado extensamente los hallazgos en relación con los imaginarios, prácticas y percepciones de las mujeres sobre las conductas de autocuidado. Al hablar de cuidado ellas también hacen elaboraciones acerca de los cuidados que requieren una vez comienzan a padecer de cáncer. Quizás los fantasmas que más preocupan a la mujer, son la mastectomia, la alteración de su imagen corporal y los efectos sobre la vida sexual; para casi todas era una preocupación común.

54. ZimmermanN, S. Silicone survivors: Women's experiences with breast implants Temple University Press. (1998).

55. DAVIS, K. Reshaping the Female Body: The Dilemma of Cosmetic Surgery. New York, Routledge. (1995)

56. BORDO, S. Unbearable Weight: Feminism, Western Culture, and the Body. Berkeley University of California Press. (1993).

57. SAFFon, M. «La discriminación de los feos». Semana.Com. (2006). <http://www.semana.com/wf_InfoArticulo.aspx?idArt=93778> Consultado el 16-03-2011.

58. Ibíd.

59. Milss W. The Power Elite, Oxford Press, (1956). 
Como ninguna de nuestras entrevistadas tenía cáncer de mama, privilegiamos el testimonio de Raven Light quien escribió su experiencia personal. Ella era una modelo de 31 años que en la primavera del 91, en un lapso de tres días, se le diagnosticó cáncer de mama cuyo tratamiento consistió en la amputación de la mama derecha, dejándole una cicatriz de 33 puntos. Tres semanas después de la amputación se enfrentó a la quimioterapia que le hizo perder su hermoso pelo rojo, veinte libras de un cuerpo que ya era delgado, sus cejas, sus pestañas, el vello púbico y encima de todo esto la libido ${ }^{60}$.

Ella se preguntaba cómo afrontarlo, ya que el mirarse al espejo se convertía en un proceso de tortura diario; los tres años siguientes fueron una lucha constante para reconstruir una relación positiva con su cuerpo y reintegrarla en concepto de quién es ella - que no es sólo su cuerpo, pero su cuerpo está dentro de ella. Aunque ha reanudado el modelaje y ha permitido a miles de personas ver su belleza, incluyendo sus cicatrices en la intimidad de su cuarto, su cuerpo la tortura. Ella se cuestiona si otras mujeres podrían tener sentimientos similares sobre sus cuerpos alterados ${ }^{61}$.

Un estudio que utilizó la hermenéutica cualitativa Heideggerian realizado por Boehmke y Dickerson ${ }^{62}$ llamado El Diagnóstico de Cáncer de Mama, la Transición de Salud a Enfermedad es vital para el entendimiento de lo que representa sufrir el cáncer, y aunque en ese caso las participantes eran mujeres con cáncer, su punto de vista fue reproducido por nuestras entrevistadas, quienes fueron bastante intuitivas en sus representaciones de lo que es padecer un cáncer a pesar de que ninguna de ellas lo había afrontado ${ }^{63}$.

Las mujeres con cáncer de mama deben asimilar en sus vidas cicatrices físicas, efectos tóxicos de la terapia medicamentosa, angustia emocional e interrupción en la realización de la vida familiar, trabajo y roles sociales, sus reacciones incluyen sentimientos de decadencia en el funcionamiento sexual y matrimonial ${ }^{64}$; sentimientos y percepciones que fueron descritas por las entrevistadas, aunque no sufrieran de la enfermedad, las mujeres describieron el diagnóstico y la experiencia del tratamiento como «una borradura de un antiguo yo» debido a las modificaciones físicas y emocionales que provoca, pues la cirugía y la terapia cambian la visión femenina no sólo de sus cuerpos,

60. Brittingham, D. \& Light, R. «Breast Cancer and Body Image», Off Our Backs xxiv, 10, 11 (November 1994). 1

61. Ibid. P. 1.

62. Boenmke, M., \& Dickerson, S., «The Diagnosis of Breast Cancer: Transition From Health to Illness» Oncology Nursing Forum. 33 (2006). pp. 11-21.

63. BOeHMke, M., \& DiCKerson, S. Op Cit. pp. 11-21.

64. Ibíd. Pp. 11-21. 
sino de su misma identidad, al punto de considerar que después de la cirugía nunca serían la misma persona de antes ${ }^{65}$.

Según la perspectiva actual, la imagen corporal es una construcción que se refiere a lo que uno piensa, siente, percibe y hace en relación con su propio cuerpo, como una parte del auto concepto ${ }^{66}$. Aunque la definición del término auto concepto varía, es entendido como la sumatoria de las percepciones o referencias que las personas tienen de ellas mismas y que incluyen juicios en el comportamiento, habilidades o apariencia física ${ }^{67}$.

En ese sentido, algunos autores estudiaron la imagen corporal y su relación con la auto estima en una muestra de mujeres españolas con cáncer de mama en etapa temprana, y encontraron que la mayoría sufre repercusiones físicas significativas, que influyen en forma negativa en la imagen que la paciente tiene de su cuerpo ${ }^{68}$ además de los desórdenes afectivos y cambios en sus sexualidad y autoestima ${ }^{69}$. Dentro de los diferentes tipos de cáncer, el de mama sobresale por su mayor efecto en la imagen corporal ${ }^{70}$.

La autoestima es otro término relacionado con la imagen corporal, la cual es considerada una actitud positiva o negativa hacia el yo, basada en la evaluación de sus características e incluye sentimientos de satisfacción consigo mismo ${ }^{71}$. Para muchas mujeres, la autoestima está basada exclusivamente en su imagen corporal y como consecuencia de esto su desempeño social y sus relaciones interpersonales se ven afectados ${ }^{72}$, lo que es más complicado si las mujeres sufren cambios o desfiguraciones debido a enfermedades como el cáncer. La percepción de su apariencia física, comparada con el ideal social, puede resultar en un impacto negativo para sus actitudes emocionales y su calidad de vida ${ }^{73}$.

\section{Conclusiones}

Para las mujeres del presente estudio las mamas tienen un significado fundamentalmente estético y centrado en la feminidad; las mamas son básicamente

65. Ibíd. Pp. 11-21.

66. Manos, D., Sebastián, J., Bueno, M., Mateos, N., De la Torre, A. «Body image in relation to self esteem in a sample of Spanish women with early stage breast cancer». Psicooncologia, 2(2005), pp. 103-116.

67. Manos, D., Sebastián, J., Bueno, M., Mateos, N., De la Torre. Op Cit. pp. 103-116.

68. Ibíd. pp. 103-116.

69. Ibíd. pp. 103-116.

70. Ibíd. pp. 103-11.

71. Ibíd. pp. 103-116.

72. Ibíd. pp. 103-116.

73. Ibíd. pp. 103-116. 
para la identidad sexual femenina y por lo tanto la pérdida total o parcial puede alterar la auto-imagen y la vida sexual; por estas razones el cuidado de las mismas es concebido desde lo estético y se reduce a mantenerlas bellas dentro de los estándares de la moda. En este sentido, prácticas como el auto examen de mama y la mamografía no existen en el imaginario de estas mujeres.

La discriminación basada en la apariencia, con efectos negativos sobre su economía, su salud y su desarrollo como ser humano integral, está presente en el imaginario de estas mujeres, lo que puede afectar el tratamiento en el caso de sufrir de cáncer mamario. Por lo tanto, quienes legislan en salud debe entender que existe una construcción problemática del cuerpo femenino que merece ser denunciada e investigada como un asunto político esencial en la construcción de la subjetividad femenina.

Como investigadoras sociales nos intriga el hecho de que las mujeres del estudio, sin haber padecido de cáncer, describieran con tanta vivacidad sus preocupaciones por los efectos del cáncer de mama como la autoimagen, la autoestima, la relación de pareja y la sexualidad, consideraciones que creemos, tienen que ver con la construcción problemática de la feminidad que nos ocupa y preocupa en este articulo

\section{Referencias bibliográficas}

Arango Ruiz, A. L., Botero Jiménez, B. H., Ossa Salazar, L. M. «Algunos cambios en la calidad de vida manifestados por varias pacientes con cáncer de mama usuarias de la EPS Seguro Social, Medellín 1998.» [Investigación de especialización] Medellín: Pontificia Universidad Javeriana, Universidad de Antioquia, facultad de Enfermería; 1998. p. 28

BANner, L. American Beauty. Los Angeles: Figueroa Press 2 (2005). p 548

Boenmke, M., \& Dickerson, S., «The Diagnosis of Breast Cancer: Transition From Health to Illness» Oncology Nursing Forum. 33 (2006). pp. 11-21.

BerRY, B. Beauty bias: Discrimination and social power. Estates Unites. Praeger.1 (2007) p 29

BerRY, B. Beauty bias: Discrimination and social power Estates Unites. Praeger.1 (2007) p 163.

BLACK, P. Beauty industry: gender culture and pleasure London, New York, Taylor and Francis. (2004) p 214.

BORDO, S. Unbearable Weight: Feminism, Western Culture, and the Body. Berkeley University of California Press. (1993).

Brittingham, D. \& Light, R. «Breast Cancer and Body Image», Off Our Backs xxiv, 10, 11 (November 1994). 1

COlliere, M. F. Promover la vida. Madrid, MacGraw-Hill, 1993, p. 5 
CORBETT, W. «The ugly truth about appearance discrimination and the beauty of our employment discrimination law». Duke Journal of Gender Law \& Policy (2007) http://goliath.ecnext.com/coms2/gi_0199-6416718/The-ugly-truthabout-appearance.html Consultado el 5-05-2008

Crane, R. «Cáncer de mama.» En: S. E. Otto (Ed). Enfermería oncológica. Barcelona: Harcourt. (2003).

DAVIS, K. Reshaping the Female Body: The Dilemma of Cosmetic Surgery. New York, Routledge. (195)

ECHEVERRI E. «La salud en Colombia: abriendo el siglo... y la brecha de las inequidades.» Revista. Gerencia y Políticas de Salud [online], 3 (2002), pp. 76-94.

Flórez, C. y Acosta, O. «Acerca de su estudio Avances y desafíos de la equidad en el sistema de salud colombiano.» Fundación Corona, Instituto Nacional de Planeación, Universidad de los Andes, Universidad del Rosario. 2007

GIMLin, D. Body work: Beauty and self-image in American culture. Berkeley University of California Press. (2001). P 4.

Hamermesh, D. \& Biddle, J. «Beauty and the Labor Market». The American Economic Review. 84 (1994), pp. 1174-1194

HeVOrY, T. Body/politics in reproduction and production and reconstruction. Westport, CT Praeger. (2000).

ILliCH, I. Nemesis médica, New York, Pantheon Books, 1976, p. 265.

Jodelet, D, y Guerrero, A Develando la Cultura. $1^{a}$ ed. México: Universidad Nacional Autónoma de México. (2000).

LAgoueyte, M. «La citología vaginal mirada desde las mujeres». Investigación y Educación en Enfermeria, 20 (2002), pp. 58-69.

Lincoln, Y \& GUBA, E. Naturalistic Inquiry. Sage Publication, (1985).

LoCK, M. «Breast cancer: reading the omens.» Anthropology Today, 14(1998), pp. 7-16.

Manos, D., Sebastián, J., Bueno, M., Mateos, N., De la Torre, A. «Body image in relation to self esteem in a sample of Spanish women with early stage breast cancer». Psicooncologia, 2(2005), pp. 103-116.

MARriner, T. \& Alligood, R. «Orem: Teoría del deficit de autocuidado.» En: Modelos y teorías en enfermería. Madrid, Hancourt, 1999. p. 177.

Medina, A. M. «Representaciones del cáncer en estudiantes de medicina: implicaciones para la práctica y la enseñanza». Revista de Salud Pública, 9(2007), pp. 369-378.

Mejía, A., SÁnchez, A. \& TAmayo, J. «Equidad en el acceso a servicios de salud en Antioquia, Colombia.» Rev. Salud Pública, 9:1 (2007), p 26-38.

MiLss, W. The Power Elite, Oxford Press, (1956).

MINISTERIO DE LA PROTECCIÓN SOCIAL COLOMBIA. «Política Nacional de Salud Sexual y Reproductiva.» Bogotá. El Ministerio, (2003). Documentos técnicos p 11. 
MINISTERIO DE SALUD DE COLOMBIA. «III Estudio Nacional de Salud Bucal y II Estudio Nacional de factores de riesgo de enfermedades crónicas- ENFERC II.» Colombia. El Ministerio; Serie Documentos Técnicos. (1999) p 31

MINISTERIO DE SALUD DE COLOMBIA. «Normas técnicas para la detección temprana del cáncer de seno. Resolución Número 00412 DE 2000.: (2000)

ORGANIZACIÓN MUNDIAL DE LA SALUD. «Programas Nacionales de Control del Cáncer: Políticas y Pautas para la Gestión». Organización Mundial de la Salud. <http://www.paho.org/Spanish/AD/DPC/NC/pcc-NCCP.pdf>. Consultado el 7-08-2005.

Pardo, C., Murillo, R., Piñeros, M., y Castro, M. Casos nuevos de cáncer 2003 en el Instituto Nacional de Cancerología Colombia, Revista Colombiana de Cancerología, 7 (2003). p. 5.

Patton, M. Qualitative Research \& Evaluation Methods. Thousand Oks, Sage Publications. (2001)

RAdicE, D. \& RedAelli, A. Breast cancer management: quality of life and cost considerations. Harmacoeconomics 21 (2003), pp. 383-396.

SAFFON, M. «La discriminación de los feos». Semana.Com. (2006). <http://www. semana.com/wf_InfoArticulo.aspx?idArt=93778> Consultado el 16-03-2011

Schouten, J. W. «Selves in transition: Symbolic consumption in personal rites of passages and identity reconstruction». The journal of consumer research, 17(1991), pp. 412-425.

SteIGER, N. \& LIPSON, J. Self care-nursing. theory \& practice. Maryland: Prentice Hall Publishing. 1985.

STRAUSS, A. \& CORBIN, J. Bases de la investigación cualitativa: Técnicas y procedimientos para desarrollar la teoría fundamentada. Medellín: Universidad de Antioquia. (2002) p 341

TAYLOR, S. Y BOGDAN, R. Introducción a los métodos cualitativos de investigación. Barcelona, Paidós Ibérica, (1992).

THOMPSON, C. \& HiRCHMAN, E. «Understanding the socialized body: A poststructuralist analysis of consumers' self-concepts, body images and self care practices». The journal of consumer research, 22 (1995), pp. 139-153.

UCOK, O. «The fashioned survivor institutionalized representations of women with breast cancer» Communication and Medicine, 4 (2007), pp. 67-78.

UlChur, I. «Betty la fea: la suerte de la inteligencia». Chasqui, 71 (2000) http:// chasqui.comunica.org/ulchur71.htm Consultado el 23-04-2008.

Wiesner, C., Vejarano, M., Caicedo, J., Tovar, S., Cendales, R. «Cervical cytology in Soacha, Colombia: social representation, barriers and motivation.» Revista. Salud Pública, 8 (2006), pp. 185-196.

Wikipedia. Sin tetas no hay paraíso < http://es.wikipedia.org/wiki/Sin_tetas_no_ hay_para\%C3\%ADso_(Colombia) > Consultado el 16-03-2011. 
Zimmermann, S. Silicone survivors: Women's experiences with breast implants Temple University Press. (1998).

Feminismo/s 18, diciembre 2011, pp. 249-270 


\title{
CONSTRUIR SALUD, CONSTRUIR GÉNERO: ¿POR QUÉ LA INVESTIGACIÓN CUALITATIVA ES UNA METODOLOGÍA SENSIBLE AL GÉNERO?
}

\author{
Maria del Mar García CALVEnTE \\ JORGE MARCOS MARCOS \\ Escuela Andaluza de Salud Pública y CIBER Epidemiología y Salud Pública (CIBERESP)
}

Recibido/15/07/2011

Aceptado/25/09/2011

\section{Referencia del artículo comentado}

Carol Emslie, Kate Hunt. The weaker sex? Exploring lay understandings of gender differences in life expectancy: A qualitative study. Soc Sci Med 2008; 67: 808-816.

\section{Resumen}

A pesar del creciente interés en género y salud, se han dejado de lado las percepciones no especializadas de las diferencias de género en la mortalidad. Tomando como base los datos semi-estructurados recogidos en encuestas de 45 hombres y mujeres de dos franjas de edad (nacidos a principios de los 50 y de los 70) en el Reino Unido, nosotras investigamos las explicaciones no especializadas sobre la mayor esperanza de vida de las mujeres. Nuestros datos sugieren que los encuestados estaban al tanto de la mayor longevidad de las mujeres, pero que encontraban esto difícil de explicar. Mientras que muchas aclaraciones atendían a múltiples factores, las explicaciones socioculturales eran más comunes. Diferentes explicaciones socioculturales (esto es, roles sociales de género, constreñimientos de tipo «macho» sobre los hombres y diferencias de género en comportamientos relacionados con la salud) estaban vinculados a través de la percepción de que la esperanza de vida convergería a medida que las vidas de hombres y mujeres se volvieran más similares entre sí. Comportamientos relacionados con la salud como ir al médico o beber alcohol se situaban a menudo en contextos estructurales más amplios. Las encuestadas tendían a concentrarse en los roles reproductivos 
y de cuidado de las mujeres, mientras que los encuestados tendían a concentrarse en cómo los hombres sufren la desventaja del rol del proveedor. Nosotras situamos estas aclaraciones dentro de debates académicos sobre la conceptualización del género, por ejemplo: «género como estructura» frente a «género como representación/performace «género como diferencia» frente a «género como diversidad».

Feminismo/s 18, diciembre 2011, pp. 271-280 
«La objetividad nunca ha podido ni podrá incrementarse mediante la neutralidad respecto a los valores. En cambio, los compromisos con los valores y proyectos antiautoritarios, antielitistas, participativos y emancipadores sí aumentan la objetividad de la ciencia.»

Sandra Harding

\section{Introducción}

Los métodos de investigación no pueden ser utilizados sin una reflexión crítica. Como Sandra Harding argumenta, las metodologías configuran los tipos de preguntas que pueden ser respondidas, las formas de recoger los datos y la manera en que los resultados serán analizados ${ }^{1}$. Cómo conocemos, qué conocemos y sobre quién, son cuestiones críticas no sólo para la formulación de proyectos de investigación sobre la salud de las mujeres, sino también, para dibujar las formas en las que la investigación puede ser utilizada para empoderarlas en sus vidas cotidianas ${ }^{2}$.

El artículo de Carol Emslie y Kate Hunt, "The weaker sex? Exploring lay understanding of gender differences in life expectancy: A qualitative study " ${ }^{3}$, nos ofrece la oportunidad de plantear algunas reflexiones críticas acerca de las relaciones entre la investigación en salud pública, las construcciones de género, las epistemologías feministas y la metodología cualitativa. Emslie y Hunt exploran en este artículo las explicaciones «legas» (lay explanations) sobre la mayor esperanza de vida de las mujeres, e investigan si existen diferencias de género en estas percepciones. Utilizan para ello un diseño cualitativo, mediante entrevistas semi-estructuradas, realizadas a una muestra intencional compuesta por 22 hombres y 23 mujeres de dos generaciones diferentes,

1. HARDing, Sandra. Is there a Feminist Method? En: S. Harding (ed.). Feminism and Methodology. Bloomington, Indiana: Indiana University Press, 1987.

2. IRONSTONE-CATTERALL, Penelope. Feminist research methodology and women's health: A review of the literature. National Network on Environments and Womens Health,1998. Disponible en: http://www.cewh-cesf.ca/PDF/nnewh/feminist-research-meth.pdf

3. EMSLIE, Carol y Hunt, Kate. The weaker sex? Exploring lay understandings of gender differences in life expectancy: A qualitative study. Social Science \& Medicine. 2008, 67(5), pp. 808-816. 
diversa en términos de roles sociales, salud auto-percibida y orientación del rol de género. De los resultados destaca que, si bien todas las personas entrevistadas sabian que la esperanza de vida en mujeres es mayor, les resultaba difícil explicar por qué. Las justificaciones ofrecidas fueron multifactoriales, siendo las de tipo biológico (ligadas al papel de las mujeres en la reproducción) menos comunes y más tentativas que las de tipo socio-cultural. Los argumentos socio-culturales se basaron en la influencia de los roles de género tradicionales (rol masculino de sustentador, rol femenino de cuidadora), las conductas menos saludables de los hombres y la reticencia de estos a reconocer síntomas de enfermedad o consultar al médico.

El objetivo de este ensayo es reflexionar acerca de la utilidad de la investigación cualitativa para el trabajo en salud pública desde la perspectiva de género. Para ello abordaremos tres aspectos clave tratados en el artículo de Emslie y Hunt ${ }^{4}$ a) la importancia de la investigación sobre el conocimiento lego (lay knowledge) en salud pública; b) su relación con la perspectiva «doing gender» y c) la utilidad del abordaje cualitativo como metodología sensible al género.

\section{El privilegio de la experiencia}

El estudio de Emslie y Hunt ${ }^{5}$ se inscribe en la línea de investigación sobre las percepciones del público no experto (lay perceptions) respecto a la salud y la enfermedad, cuyas primeras referencias podemos encontrar en los trabajos de Blaxter ${ }^{6}$, realizados precisamente con mujeres. El término «epidemiología lega» (lay epidemiology), siguiendo a Davison, Smith y Frankel ${ }^{7}$, puede definirse como el proceso por el cual se generan las percepciones de la población sobre los riesgos para su salud «a través de la observación rutinaria y la discusión de casos de enfermedad y muerte en las redes personales y en el ámbito público».

Popay y Williams ${ }^{8}$ amplían este concepto, más allá de la percepción de riesgos para la salud, utilizando el término de «conocimiento lego» (lay knowledge). Argumentan que si la investigación en salud pública tiene como

4. EMSLie, C. y Hunt, K. Op.cit.

5. Ibíd.

6. Blaxter, Mildred. The causes of disease. Women talking. Social Science \& Medicine. 1983, 17(2), pp.59-69.

7. DAVISOn, Charlie, SMith, George Davey y Frankel Stephen. Lay epidemiology and the prevention paradox: the implications of coronary candidacy for health education. Sociology of Health \& Illness. 1991, 13(1), pp.1-19.

8. Popay, Jennie y Williams, Gareth. Public health research and lay knowledge. Social Science and Medicine. 1996, 42(5), pp.759-68. 
objetivo proporcionar explicaciones más sólidas y holísticas sobre los patrones de la salud y la enfermedad en la sociedad contemporánea, ello obliga a incorporar y desarrollar un cuerpo de conocimiento construido sobre la base de las percepciones y conocimientos establecidos por la gente, que nos ayude a comprender los significados que otorgan a la salud, la enfermedad, la discapacidad y los riesgos (así como a sus determinantes sociales). La validez de este conocimiento está fundamentada en la experiencia, que es sistemáticamente contrastada con los acontecimientos vitales, las circunstancias y la historia de cada persona. Estas autoras resumen en tres las dimensiones del conocimiento lego que son importantes para la salud pública:

1. Las explicaciones aportadas sobre las relaciones entre comportamiento individual y circunstancias vitales. Un buen ejemplo son los estudios que muestran que las mujeres que fuman más son aquellas que viven circunstancias más duras, de modo que utilizan el tabaco como método de aliviar el estrés.

2. Las teorías generadas sobre la causalidad de los fenómenos de salud-enfermedad. Como ejemplo aportan la relación entre la epidemiología de las desigualdades sociales en salud y la investigación sobre la perspectiva biográfica de la gente en el proceso salud-enfermedad.

3. La capacidad de predicción de la salud futura a nivel individual. En este punto se sitúan los estudios que muestran la relación entre salud auto-percibida y resultados en morbilidad y mortalidad.

Sin embargo, Popay y Williams ${ }^{9}$, nos recuerdan que en la investigación en salud sigue predominando una epistemología de la ciencia en la que el concepto de enfermedad es algo que puede ser tratado «objetivamente», sin tomar en consideración las experiencias individuales que conforman la vida cotidiana. Señalan, como uno de los factores por los que el conocimiento lego ha sido ignorado, «el papel prominente de las mujeres como guardianas informales de la salud pública». El hecho de que las mujeres a menudo sean las protagonistas de esta acción popular en salud, refuerza la tendencia de los científicos profesionales a devaluar este tipo de conocimiento.

\section{La construcción del género y la salud}

El segundo tema central que analizaremos en el artículo de Emslie y Hunt ${ }^{10}$ es el argumento de que el género juega un papel clave en las percepciones

9. Popay, J. y Williams, G. Op.cit.

10. EMSLie, C. y Hunt, K. Op.cit.

Feminismo/s 18, diciembre 2011, pp. 271-280 
y prácticas de la gente sobre la salud. Utilizan en este punto el iluminador concepto «haciendo género» (doing gender) de Candace West y Don Zimmer$\operatorname{man}^{11}$, quienes entienden el género como un «logro rutinario incrustado en la interacción cotidiana». Construir género supone un «complejo de actividades perceptivas, interaccionales y micropolíticas, socialmente guiadas, que proyectan acciones particulares como expresión de naturaleza masculina o femenina». Para West y Zimmerman, el género no es un conjunto de rasgos, ni una variable, ni un rol, sino el producto de acciones sociales de algún tipo. Género no es algo que uno es, sino algo que uno hace a través de la interacción cotidiana con los otros.

Tyler nos recuerda que, desde el marco explicativo del doing gender, el género no es simplemente algo que representamos como actores sociales, sino que es dicha representación la que nos permite identificarnos como sujetos ${ }^{12}$. Sin embargo, este marco no está exento de críticas. Algunas autoras feministas consideran que no presta suficiente atención a los nexos entre interacción social y cambio estructural que requiere la lucha contra las desigualdades de género $^{13}$. En consonancia con Barbara Risman, no compartimos esta perspectiva, ya que entender el género como logro, al modo de West y Zimmerman, supone pasar de lo individual a lo interaccional y, en última instancia, a lo

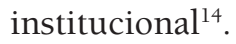

Emslie y Hunt ${ }^{15}$, partiendo de la afirmación de Saltonstall de que «hacer salud es una forma de hacer género ${ }^{16}$, aportan evidencia sobre cómo las formas de construir masculinidad y feminidad tienen impacto sobre la salud. El sistema de género, no sólo ordena valores, normas, costumbres y comportamientos, también contribuye a las diferencias en exposición y vulnerabilidad a factores de riesgo para la salud de hombres y mujeres ${ }^{17}$. Los estudios sobre

11. West, Candace y Zimmerman, Don H. Doing gender. Gender \& Society. 1987, 1(2), pp.125-151.

12. TYLER, Melissa. Postmodern feminism and organization studies: A marriage of inconvenience? En E. Jeanes, D. Knights and P. Martin (eds.). Handbook of Gender, Work and Organization. Oxford: Blackwell, 2011, pp. 9-24.

13. DeUTSCH, Francine M. Undoing gender. Gender \& Society. 2007, 21(1), pp.106-127.

14. Risman, Barbara J. From doing to undoing: Gender as we know it. Gender E Society. 2009, 23(1), pp. 81-84.

15. EMSLIE C. y HunT K. Op.cit.

16. Saltonstall, Robin. Healthy bodies, social bodies: men's and women's concepts and practices of health in everyday life. Social Science and Medicine. 1993, 36(1), pp.7-14.

17. Sen, Gita y Östlin, Piroska. Unequal, Unfair, Ineffective and Inefficient. Gender Inequity in Health: Why it exists and how we can change it. Geneva: WHO, 2007. Disponible en: http://www.who.int/social_determinants/resources/csdh_media/wgekn_final_report_07.pdf 
las masculinidades son un reciente campo de desarrollo en el ámbito de los estudios sobre género y salud, con importantes aportaciones a este marco teórico $^{18}$. Autores como Courtenay, nos recuerdan que sólo desde una perspectiva constructivista, relacional y feminista de la salud, se puede entender que la mayor mortalidad o siniestralidad de los hombres, o el que estos utilicen menos los centros de salud, tiene que ver con conceptos y comportamientos concretos respecto a la salud asociados a la forma en que los varones se construyen como tales, y se representan socialmente como dominantes ${ }^{19}$.

\section{Investigación cualitativa y punto de vista feminista}

Las experiencias en salud de mujeres y hombres, base del conocimiento «lego» en salud, son tan diversas como lo son las formas de construir las feminidades y masculinidades. Aproximarse a una realidad tan compleja, requiere un enfoque metodológico que pueda dar cuenta de esta diversidad. Para tomar en serio, afirman Emslie y $\mathrm{Hunt}^{20}$, este tipo de conocimiento, no sólo se hace necesario cuestionar el dominio de los métodos cuantitativos-estadísticos en salud pública, sino también, trasladar la propiedad y el control sobre los procesos de investigación desde los profesionales-expertos hacia la gente.

Las epistemologías del punto de vista feminista (feminist standpoint epistemology) aportan un marco conceptual para dar respaldo a este enfoque. Según Harding ${ }^{21}$, la posición dominante de los hombres en la vida social se traduce en un conocimiento parcial y perverso, mientras que una perspectiva construida por y desde la experiencia de las mujeres, abre la posibilidad de un conocimiento más completo y menos perverso. El punto de vista feminista no solo demanda que se tome en serio la experiencia de las mujeres como conocedoras, sino que traslademos el conocimiento de las mujeres a la práctica, que apliquemos lo que hemos aprendido de sus experiencias para el cambio social y la eliminación de la opresión, no solo de las mujeres, sino de todos los grupos marginados ${ }^{22}$.

18. LOHAN, Maria. How might we understand men's health better? Integrating explanations from critical studies on men and inequalities in health. Social Science \& Medicine. 2007, 65(3), pp. 493-504.

19. CourtenaY, Will H. Constructions of masculinity and their influence on men's well-being: a theory of gender and health. Social Science \& Medicine. 2000, 50(10), pp. 1385-1401.

20. EMSLie, C. y Hunt, K. Op.cit.

21. HARding, Sandra. Ciencia y feminismo. Madrid: Ediciones Morata, 1996.

22. BROOKS, Abigail. Feminist standpoint epistemology. Building knowledge and empowerment through women's lived experience. En S.N. Hesse-Biber y P.L. Leavy (eds.). Feminist research practice. Thousand Oaks: SAGE Publications, 2007, pp. 53-82.

Feminismo/s 18, diciembre 2011, pp. 271-280 
La investigación cualitativa ofrece metodologías idóneas para realizar este acercamiento a las experiencias en salud de las mujeres (y de los hombres) que permita «dar voz» a quienes habitualmente no la tienen. Aporta además la posibilidad de abordar la diversidad entre mujeres y entre hombres, para ayudarnos a superar el concepto de «mujer (u hombre) esencializada y universalizada», dando paso a las «mujeres (u hombres) situadas», con experiencias y conocimiento específico en sus contextos de división del trabajo, en sus sistemas de estratificación social ${ }^{23}$.

En la investigación sobre salud de las mujeres, y sobre género y salud, el método feminista predominante ha sido la entrevista cualitativa. Esta técnica, utilizada por Emslie y Hunt en su investigación, ha sido especialmente valorada por su capacidad de dar visibilidad a las voces y las experiencias de las mujeres, «con sus propias palabras $»^{24}$. La metodología cualitativa, y especialmente la entrevista en profundidad, nos permite acercarnos a la comprensión del mundo (de la salud y de la enfermedad) con los ojos de las personas participantes en la investigación. Posicionar a las mujeres como «expertas de sus propias vidas» ${ }^{25}$, confiere además capacidades de empoderamiento que no proporcionan otro tipo de metodologías.

\section{Conclusiones}

La investigación cualitativa se revela como una metodología sensible al género con múltiples potencialidades en salud pública, especialmente para el estudio de las percepciones y conocimientos de la gente -mujeres y hombres- sobre las dinámicas de los procesos de salud-enfermedad y cómo estos impactan en sus vidas. Si bien «hacer salud es una forma de hacer género», también construir género es una manera de construir salud. El cuestionamiento del positivismo y la investigación «objetiva» y neutral en valores, junto a la evidencia de que la investigación dominante en salud tiende a excluir a las mujeres, da un sólido apoyo feminista a los métodos cualitativos.

23. Olesen, Virginia. Feminisms and Qualitative Research at and into the Millenium. En N.K. Denzim y Y.S. Lincoln (eds.). Handbook of Qualitative Research 2 nd ed, Thousand Oaks: SAGE Publications, 2000, pp. 215-254.

24. IRONSTONE-CATTERALl. Op.cit.

25. Ibíd. 


\section{Referencias biográficas}

Blaxter, Mildred. The causes of disease. Women talking. Social Science E Medicine. 1983, 17(2), pp. 59-69.

BROOKS, Abigail. Feminist standpoint epistemology. Building knowledge and empowerment through women's lived experience. En S.N. Hesse-Biber y P.L. Leavy (eds.). Feminist research practice. Thousand Oaks: SAGE Publications, 2007, pp. 53-82.

COURTENAY, Will H. Constructions of masculinity and their influence on men's well-being: a theory of gender and health. Social Science E Medicine. 2000, 50(10), pp.1385-1401.

DAvison, Charlie, Smith, George Davey y FrAnkel Stephen. Lay epidemiology and the prevention paradox: the implications of coronary candidacy for health education. Sociology of Health $\&$ Illness. 1991, 13(1), pp.1-19.

Deutsch, Francine M. Undoing gender. Gender \& Society. 2007, 21(1), pp.106-127.

EMSLIE, Carol y Hunt, Kate. The weaker sex? Exploring lay understandings of gender differences in life expectancy: A qualitative study. Social Science $\mathcal{E}$ Medicine. 2008, 67(5), pp.808-816.

HARDING, Sandra. Is there a Feminist Method? En: S. Harding (ed.). Feminism and Methodology.Bloomington, Indiana: Indiana University Press, 1987.

HARDING, Sandra. Ciencia y feminismo. Madrid: Ediciones Morata, 1996.

Ironstone-Catterall, Penelope. Feminist research methodology and women's health: A review of the literature. National Network on Environments and Womens Health,1998. Disponible en: http://www.cewh-cesf.ca/PDF/nnewh/ feminist-research-meth.pdf

LOHAN, Maria. How might we understand men's health better? Integrating explanations from critical studies on men and inequalities in health. Social Science E Medicine. 2007, 65(3), pp. 493-504.

Olesen, Virginia. Feminisms and Qualitative Research at and into the Millenium. En N.K. Denzim y Y.S. Lincoln (eds.). Handbook of Qualitative Research 2 nd ed, Thousand Oaks: SAGE Publications, 2000, pp. 215-254.

POPAY, Jennie y WiLliams, Gareth. Public health research and lay knowledge. Social Science and Medicine. 1996, 42(5), pp.759-68

RISMAN, Barbara J. From doing to undoing: Gender as we know it. Gender E Society. 2009, 23(1), pp. 81-84.

SAltONSTALl, Robin. Healthy bodies, social bodies: men's and women's concepts and practices of health in everyday life. Social Science and Medicine. 1993, 36(1), pp.7-14.

SEn, Gita y Östlin, Piroska. Unequal, Unfair, Ineffective and Inefficient. Gender Inequity in Health: Why it exists and how we can change it. Geneva: WHO, 
2007. Disponible en: http://www.who.int/social_determinants/resources/csdh_media/wgekn_final_report_07.pdf

TYLER, Melissa. Postmodern feminism and organization studies: A marriage of inconvenience? En E. Jeanes, D. Knights and P. Martin (eds.). Handbook of Gender, Work and Organization. Oxford: Blackwell, 2011, pp. 9-24.

West, Candace y Zimmerman, Don H. Doing gender. Gender E Society. 1987, 1(2), pp.125-151. 


\title{
MORBILIDAD DIFERENCIAL ENTRE MUJERES Y HOMBRES
}

\author{
CARMe VAlls-Llobet \\ Especialista en Medicina Interna y Endocrinología
}

Recibido/15/07/2011

Aceptado/25/09/2011

\begin{abstract}
«La investigación de la salud de las mujeres ha sobrepasado los límites que la encerraban solo en los órganos y hormonas relacionados con la reproducción (...)

Este sesgo histórico está siendo redirigido (...)

Cada vez más la asistencia sanitaria se ha de basar en las diferencias biológicas que comporta el sexo y las influencias de género en los factores de conducta, geográficos,culturales, económicos y sociales» ${ }^{1}$
\end{abstract}

\section{Introducción}

El estudio de las diferencias en enfermar entre hombre y mujeres no se ha incorporado hasta la última década del siglo XX. El epígrafe «Women's health» constituye un apartado especifico del Index Medicus a partir del año 1993. Hasta los últimos años del siglo pasado, la mayoría de los conocimientos científicos que se utilizaban para tomar decisiones sobre el diagnóstico y tratamiento de las mujeres se habían basado en estudios que se habían realizado sólo entre hombres. La mayoría de publicaciones y ensayos clínicos hasta el año 1990 no incluían mujeres. Sin embargo los esfuerzos para incluir mujeres en la investigación clínica ha aumentado la información que se ha recopilado en relación a la salud de las mujeres.

1. Pinn VW. Sex and gender factors in medical studies. Implications for health and clinical practice. JAMA. 2003; 289: 397-400.

Feminismo/s 18, diciembre 2011, pp. 281-290 
El Council on Graduate Medical Education y las conclusiones del Primer Congreso sobre Mujeres, Trabajo y Salud realizado en Barcelona en 1996, ya recomendaron que todos los profesionales de la Medicina sea cual sea su especialidad fuera educada a partir de las bases científicas y los conocimientos que se tengan sobre la salud de las mujeres y muestren competencia en proporcionar asistencia médica adecuada a las mujeres. Es esencial que los médicos y médicas conozcan la fisiología básica de las mujeres y la biología reproductiva. Además necesitan apreciar la compleja interacción entre el medio ambiente, la biología y el desarrollo psicosocial de las mujeres. Entre las enfermedades que no sean específicas de las mujeres, los profesionales sanitarios necesitan conocer y ser formados sobre los aspectos de las enfermedades que sean diferentes entre las mujeres o que tengan importantes implicaciones de género.

\section{2 ¿Existen diferencias en el enfermar de mujeres y hombres?}

Tanto la investigación médica, como la docencia y la asistencia sanitaria han mirado a las mujeres «como si fuesen hombres». En los libros de medicina las enfermedades no tienen sexo y como máximo algunas patologías se describen «con mayor frecuencia» entre hombres o entre mujeres. Dado que la ciencia médica ha nacido principalmente en los hospitales, donde la mayoría de patologías son agudas y de predominio masculino, las quejas, el malestar y el dolor de las mujeres, no se ha podido visibilizar, y hasta finales del siglo XX no se empezó a estudiar si existían diferencias en las patologías de mujeres y hombres. La salud de las mujeres se ha estudiado y valorado sólo como salud reproductiva, y este enfoque ha impedido abordar la salud de las mujeres desde una perspectiva integral. También la especialización a que se ha visto sometida la medicina en los últimos treinta años, en aras a la eficacia, ha troceado el cuerpo de los pacientes, y en especial los femeninos, porque son los que presentan más patologías crónicas, que precisan un abordaje multidisciplinar, y su demanda se expresa en los servicios sanitarios ambulatorios ya que en gran medida sus patologías no precisan hospitalización.

La formación del médico o la médica de primaria o de hospital no ha sido enfocada hacia las patologías más prevalentes entre el sexo femenino, ni tampoco dispone, porque no existe, una ciencia sistematizada para apreciar la diferente expresión de la sintomatología de algunas enfermedades según el sexo de las personas. Al faltar formación y docencia específica y mantener en el inconsciente los estereotipos de género, es fácil que los síntomas y patologías más prevalentes entre mujeres hayan permanecido invisibles, sus demandas, síntomas y problemas se hayan considerado de menor importancia, y sus 
repetidas solicitudes de ayuda por estar cansadas o sentir dolor, se han intentado controlar con psicofármacos o con todo tipo de analgésicos sin entender las causas de los síntomas que presenta.

Falta construir un cuerpo de conocimiento ligado a las diferencias por sexo, y que incorpore la perspectiva de género; para lo que se precisa una revisión sistemática de la literatura que rompa estereotipos y proponga las bases a considerar para un diagnóstico diferencial de las enfermedades y del malestar de las mujeres. En definitiva, falta desarrollar el concepto de MORBILIDAD DIFERENCIAL entre mujeres y hombres.

\section{3. ¿Qué significa la morbilidad diferencial entre mujeres y hombres?}

La morbilidad diferencial es el conjunto de enfermedades, motivos de consulta o factores de riesgo que merecen una atención específica hacia las mujeres, sea porque sólo en ellas se pueden presentar dichos problemas o porque sean mucho más frecuentes en el sexo femenino. Puede ser causada por las diferencias biológicas con los hombres, como ocurre con los trastornos de la menstruación, las enfermedades derivadas de embarazos y partos, o los tumores ginecológicos. $\mathrm{O}$, son problemas de salud que sin ser específicos de las mujeres, se presentan con mayor frecuencia (alta prevalencia) en estas, causándoles muerte prematura, enfermedad o discapacidad más que entre los hombres. Es el caso de anemias, dolor crónico, enfermedades autoinmunes, endocrinológicas, ansiedad y depresión.

Existen también factores de riesgo diferenciales que deberían ser prevenidos o abordados de forma diferente en ambos sexos, como las causas de patología cardiovascular, diabetes mellitus, o la obesidad. Lois Verbrugge $e^{2}$ a señalaba en al año 1989 que el peor estado de salud de las mujeres se debía a riesgos adquiridos y aspectos psicosociales, como el sedentarismo, paro, o el estrés físico y mental que produce la doble o triple jornada laboral que deben realizar, así como el trabajo emocional que constantemente realizan en su papel de cuidadoras de toda la familia y de su entorno.

La morbilidad prevalente en el sexo femenino se inicia con los trastornos de la menstruación, que tienen como consecuencia las anemias y las deficiencias en la reserva de hierro. Las enfermedades autoinmunes son de alto predominio femenino y están aumentando en la sociedad industrializada por efectos ambientales y condiciones laborales, y se entrelazan con las enfermedades endocrinológicas, y con carencias metabólicas de enfermedades y vitaminas

2. Verbrugge LM. The twain meet: Empirical explanations of sex differences in health and mortality. J Health Soc Behav. 1989; 30: 282-304. 
por nutrición incorrecta o por diferencias en el metabolismo entre mujeres y hombres, que producen una mayor carencia y más precoz de Vitamina D entre mujeres. Las interacciones biológicas, psicológicas, sociales y medioambientales producen alteraciones en el sistema musculoesquelético dando lugar a las diversas manifestaciones de dolor que dificultan la calidad de vida. Sin dejar de lado las agresiones a la salud mental que supone la violencia de género en toda sus manifestaciones. Este es el cuerpo de la ciencia que falta desarrollar ${ }^{3}$. Después de quince años de trabajo en este tema, intuyo la existencia de intereses creados para que permanezca invisible, ya que existiendo un gran número de información científica sobre las diferentes patologías diferenciales, se minimiza, con el argumento de que son tan frecuentes que es como si fuesen «normales». En consecuencia, se les prescriben psicofármacos por la etiqueta de que son mujeres «ansiosas y depresivas», y no reciben el tratamiento conveniente.

\subsection{De la adolescencia a los 50 años}

Veamos un ejemplo con lo que sucede con los trastornos del ciclo menstrual; así como con las anemias. El equilibrio del ciclo y la ovulación, además de estar influido por la nutrición, lo está por las anemias y las deficiencias de la reserva de hierro, o por alteraciones del resto de glándulas endocrinas. La pérdida de $2 \mathrm{Kg}$ de peso produce en el ciclo menstrual del mes siguiente una disminución de la fase luteínica, y si se sigue perdiendo rápidamente por debajo del Índice de Masa corporal deseable, se pierde primero la ovulación y posteriormente la menstruación. Esta es la causa de amenorrea en la Anorexia Nerviosa.

Las anemias con déficit de glóbulos rojos suponen la enfermedad más prevalente entre el sexo femenino junto con la deficiencia de reservas de hierro. La mayoría de anemias son microcíticas (con glóbulos rojos pequeños) por carencia de hierro, sea por falta de nutrición, por dificultades en su absorción intestinal, o por exceso de sangrados. El 50\% de las mujeres en edad reproductiva y dos terceras partes de mujeres embarazadas en África y en el Sudeste y Oeste asiático están clínicamente anémicas. En Latinoamérica y el Caribe, la anemia entre las mujeres embarazadas es desproporcionadamente alta. Las mujeres, en el tercer trimestre de embarazo y en la lactancia, presentan también altas prevalencia de anemia. El $62,1 \%$ de las mujeres y el $71,4 \%$ de las embarazadas presentaban ferritinas bajas, pero hasta principios del año 2000

3. Valls-Llobet, Carme. 1994. Mujeres y Hombres. Salud y diferencias. Editorial Folio. 4. Valls-Llobet, Carme. 2006. Mujeres Invisibles. Catedra. Colección Feminismos. 
se creía que era «normal» que las mujeres tuvieran ferritinas bajas, y no se habían realizado estudios que correlacionaran los síntomas clínicos con dicha deficiencia. La prevalencia de deficiencia de hierro entre chicas adolescentes oscila entre 9 a $70 \%$ según la población estudiada ${ }^{5}$ frente a solo un 2\% de la población masculina. En edades más avanzadas, entre 70 y 80 años, (75,3 años +- 5) también se mantiene una diferencia significativa de los niveles de ferritina más elevada en hombres que en mujeres como ya demostró el estudio Framingham ${ }^{6}$.

\subsection{Morbilidad por encima de los 50 años.}

La hipertensión diastólica (aumento de la tensión mínima por encima de 10), constituye un importante factor de riesgo de la enfermedad cardiovascular. Durante años la formación de los profesionales sanitarios se había sesgado de forma inconsciente hasta creer que era un factor de riesgo de predominio masculino. Pero diversos estudios han confirmado el predominio femenino entre la población de personas hipertensas. El estudio CARDIA $^{7}$ ha demostrado un predominio de hipertensión entre las personas de raza negra, y de entre ellas en las mujeres. En edades jóvenes el incremento de la hipertensión nocturna y después durante el día, es tres veces más prevalente entre chicas que entre chicos. La prevalencia de enfermedad coronaria (EC) es superior en hombres respecto a mujeres en todos los grupos de $\mathrm{edad}^{8}$. Este hecho ha supuesto la consideración de que la EC es una patología masculina. Pero, la mayor esperanza de vida de las mujeres y, por tanto, su mayor presencia en los grupos de edad más longevos, determina que, en el número absoluto de pacientes con EC, la presencia de mujeres sea mayor. No debemos olvidar que, globalmente hablando, la enfermedad cardiovascular es la primera causa de muerte en mujeres a partir de los 70 años ${ }^{9}$ en España, y la primera causa de muerte en mujeres de EEUU en todas las edades ${ }^{10}$.

5. Bruner AB. Randomised study of cognitive effects of iron supplementation in non-anaemic iron-deficient adolescent girls. Lancet.1996;348:992-996.

6. Fleming DJ, Jacques PF,Dallal GE, Tucker KL, Wilson PWF, Wood RJ. Dietary determinants of iron stores in a free-living elderly population: The Framingham Heart Study. Am J Clin Nutr. 1998; 67:722-733.

7. Levine DA, Lewis CE, Williams OD, Safford MM, Liu K, Calhoun DA, Kim Y, Jacobs D Jr, Kiefe CI.Geographic and demographic variability in 20-year hypertension incidence: theCARDIA study. Hypertension. 2011 Jan;57(1):39-47.

8. Lerner et al. Patterns of coronary heart disease morbidity and mortality in the sexes: a 26-year follow-up of the Framingham population. Am Heart J. 1986; 111(2):383-90.

9. INE. www.ine.es.

10. WHO 1996.

Feminismo/s 18, diciembre 2011, pp. 281-290 
La intervención y el esfuerzo terapéutico sobre la EC en las mujeres es menor que en los hombres en las diferentes etapas de la historia natural de la enfermedad. En prevención primaria, el control de factores de riesgo cardiovasculares (FRCV) es menor, lo que determina que cuando se produce un evento coronario agudo (angina inestable o IAM), las mujeres lleguen en peores condiciones ${ }^{11},{ }^{12}$. Presentan, además, al ser de mayor edad, otras enfermedades al mismo tiempo (comorbilidad) como la Diabetes o la insuficiencia cardíaca $^{13},{ }^{14}$.

La diabetes tipo II o de la adulta/o se presenta también con una alta prevalencia en las mujeres mayores de 40 años, relacionada en muchos casos con la obesidad. La diabetes es una enfermedad de mujeres que se ha estudiado en hombres. El estudio Nurse's Health ${ }^{15}$ ha seguido 84.941 mujeres desde 1980 a 1996, documentando 3300 nuevos casos de diabetes tipo II. El más importante predictor de diabetes fue el sobrepeso o la obesidad (61\%). Otros factores de riesgo demostrados han sido la vida sin ejercicio físico vigoroso, fumar, dieta poco rica en fibra y con exceso de grasa y azúcares y la abstinencia de alcohol (consumo diario inferior a 5 grs) y en últimos trabajos la presencia en sangre de insecticidas, cruzando una vez más en el cuerpo de las mujeres, la contaminación medio ambiental y la salud biológica. Este cruce permanece invisible por los intereses poderosos de la industria química y farmacéutica, y por la debilidad de las políticas públicas que deberían limitar los efectos negativos para la salud de la contaminación industrial, aplicando con rigor, por ejemplo en Europa la iniciativa REACH ${ }^{16}$, para reevaluar la acción sobre la salud de las principales sustancias químicas usadas en la sociedad industrial.

\section{El diagnóstico diferencial del dolor}

El dolor en todas sus manifestaciones corporales es la primera causa de limitación crónica de la actividad principal según la encuesta de salud realizada

11. Hochman et al. Sex, clinical presentation and outcome in patients with acute coronary syndromes. N-England-J-Med. 1999;341:226-232.

12. Vaccarino et al. Sex-based differences in early mortality after myocardial infarction. NEngland-J-Med. 1999;31:217-225.

13. Barrett-Connor et al. Why is diabetes mellitus a stronger risk factor for fatal ischemic heart disease in women than in men?. JAMA. 1991;265:627-631.

14. Austil MA. Epidemiology of hypertrigliceridemia and cardiovascular disease. Am-JCardiol. 1999;83:13F-16F.

15. Hu FB et al. Diet lifestyle and the risk of type 2 diabetes mellitus in women. N Engl J Med.2001; 345:790-797.

16. QUADERN CAPS. SALUT I MEDI AMBIENT. 2008. 
en España ${ }^{17}$, Catalunya ${ }^{18}$ y Barcelona ${ }^{19}$. El dolor constituye la primera causa de consulta en atención primaria y afecta a casi la mitad de los pacientes que buscan asistencia médica ${ }^{20}$. El diagnóstico diferencial del dolor crónico es todavía una asignatura pendiente así como su especial problemática entre el sexo femenino ${ }^{21}$.

Parte de este dolor probablemente tiene su origen en enfermedades autoinmunes, las cuales son más prevalentes entre las mujeres por razones biológicas, hormonales ${ }^{22} \mathrm{y}$, además, por la potenciación del efecto autoinmune que producen los xenoestrógenos (estrógenos exógenos) ambientales ${ }^{23}$.

Se ha podido objetivar también la relación de las condiciones de trabajo y de vida con la presencia de dolor: contractura del músculo trapecio en relación con el estrés físico y mental ${ }^{24}$; dolor lumbar en relación con trabajos con sobre carga emocional ${ }^{25}$ y doble jornada ${ }^{26}$. Está por dilucidar la metodología diagnóstica y la patogénesis del síndrome de fatiga crónica ${ }^{27}$ y de la fibromialgia que se pueden presentar en un 3\% de la población con una razón de mujeres a hombres de $5 / 1$, relacionada también con exposición a tóxicos químicos ambientales ${ }^{28}$.

\section{Conclusión}

El sesgo de género en atención sanitaria se ha debido a la falta de investigación en morbilidad diferencial y a la visión androcéntrica que tiene la medicina

17. Encuesta Nacional de Salud.Ministerio de Sanidad y Consumo 1988.

18. Enquesta de Salut de Catalnya. Departament de Sanitat i Seguretat Social, Generalitat de Catalunya, 1995.

19. Enquesta de Salut de Barcelona. Ajuntament de Barcelona 1996.

20. Griggs RC et al. Muscle pain, fatigue, and mitochondriopathies. $N$ Engl J Med. 1999;341(14):1077-8.

21. Valls Llobet C. Diagnóstico diferencial del dolor y fatiga crónica: una asignatura pendiente. Med Clin. 2003;118(1).

22. Greenstein BD. Lupus: why women? J Womens Health Gend Based Med. 2001 Apr; 10(3):233-9.

23. Olea N. Disruptores endocrinos: posibles medidas de inervención. La perspectiva europea. Quadern Caps. 2000;29:36-42.

24. Lundberg U. Influence of paid and unpaid work on psychophysiological stress. Responses of men and women. J-Ocupational-Health.1996;1(2):117-130.

25. Deyo RA et al. Low back. N Engl J Med. 2001;344(5):363-370.

26. Simon GE. An international study of the relation between somatic simptoms and depression. N Engl J Med. 1999;341(18):1329-1335.

27. Shafran SD. The chronic fatigue syndrome. Am J Med.1991;90:730-738.

28. Bell IR et al. Illness from low levels of environmental chemicals: relevance to chronic fatigue syndrome and fibromyalgia. Am J Med.1998;105(3A):74S-82-S.

Feminismo/s 18, diciembre 2011, pp. 281-290 
como norma ${ }^{29}$. La rigidez de la visión centrada sólo en el hombre ha producido sesgos en el momento del diagnóstico, tanto por considerar que enferman igual hombres y mujeres, cuando hay diferencias, como por considerar, inversamente, que como son diferentes no pueden tener problemas similares ${ }^{30}, \mathrm{o}$ bien por no considerar los condicionantes bio-psico-sociales de las enfermedades $^{31}{ }^{1}$. Además de los sesgos en los diagnósticos, también se han producido sesgos de género en los métodos de exploración, en la valoración de la normalidad en los análisis clínicos, y en la aplicación de terapias sin ninguna diferenciación por sexo, ni en dosis ni en vía administrada. El feminismo como defensa de los derechos de las mujeres no puede permanecer indiferente hacia la desigualdad de oportunidades que supone no tener en cuenta en el momento del diagnóstico médico, las diferencias en el enfermar de las mujeres respecto a los hombres, y debería potenciar en Medicina la producción de conocimiento de la morbilidad diferencial entre ambos sexos.

\section{Referencias Bibliográficas}

AUSTIL MA. Epidemiology of hypertrigliceridemia and cardiovascular disease. Am-J-Cardiol. (1999);83:13F-16F

BARRETT-CONNOR et al. ¿Why is diabetes mellitus a stronger risk factor for fatal ischemic heart disease in women than in men?. JAMA. (1991);265:627-631

BELL IR et al. Illness from low levels of environmental chemicals: relevance to chronic fatigue syndrome and fibromyalgia. Am J Med. (1998);105(3A):74S-82-S

BRUNER AB. «Randomised study of cognitive effects of iron supplementation in non-anaemic iron-deficient adolescent girls». Lancet. (1996); 348:992-996

CI.Geographic and demographic variability in 20-year hypertension incidence: the CARDIA study. Hypertension. (2011) Jan; 57(1):39-47

DeYo RA Weinstein, J.N. Low back. N Engl J Med. (2001);344(5):363-370

Fleming DJ, JacQues PF, Dallal GE, TuCKer KL, Wilson PWF, WoOd RJ. Dietary determinants of iron stores in a free-living elderly population: The Framingham Heart Study. Am J Clin Nutr. (1998); 67:722-733

29. Mastroianni AC, Faden R, Federman D. eds.Women and Health Research: Ethical and Legal Issues of Including Women in Clinical Studies. Washington, DC: National Academy Press; 1994.

30. Ruiz MT, Verbrugge LM A two way view of gender bias in medicine. J-Epidemiol-Community-Health.(1997);51:106-109.

31. Valls-Llobet, C. El estado de la investigación en salud y género. En «Perspectivas de género en salud. Fundamentos cientificos y socioprofesionales de diferencias sexuales no previstas. Grupo de Salud del Saminario Interdisciplinar de Estudios de la Mujer de la Universidad de Zaragoza. Minerva Ediciones. 2001. 
GREENSTEIN BD. Lupus: ¿why women? J Womens Health Gend Based Med. (2001) Apr; 10 (3):233-9.

GRIGGS RC et al. Muscle pain, fatigue, and mitochondriopathies. N Engl J Med. (1999); 341(14):1077-8

VAlls Llobet C. Diagnóstico diferencial del dolor y fatiga crónica: una asignatura pendiente. Med Clin. (2003) 1;118

Hochman Judith S. M.D., Jacqueline E. TAmis, M.D., Trevor D. Thompson, B.S., W. Douglas Weaver, M.D., Harvey D. White, M.B., D.Sc., Frans Van DE Werf, M.D., Phil Aylward, B.M., B.Ch., Eric J. Topol, M.D., and Robert M. CALIFF, M.D. Sex, clinical presentation and outcome in patients with acute coronary syndromes. N-England-J-Med. (1999);341:226-232.

Hu FB, Manson, J.E., Stampfer, M.J. Diet lifestyle and the risk of type 2 diabetes mellitus in women. N Engl J Med(.2001); 345:790-797

Levine DA, Lewis CE, Williams OD, SafFord MM, Liu K, Calhoun DA, Kim Y, JACOBS D Jr, KIEFE

LERNER et al. Patterns of coronary heart disease morbidity and mortality in the sexes: a 26-year follow-up of the Framingham population. Am Heart J. 1986; 111(2):383-90.

LUNDBERG U. Influence of paid and unpaid work on psychophysiological stress. Responses of men and women. J-Ocupational-Health. (1996); 1(2):117-130

Mastroianni AC, Faden R, Federman D. (Eds).»Women and Health Research: Ethical and Legal Issues of Including Women in Clinical Studies». Washington, DC: National Academy Press; 1994.

OlEA N. Disruptores endocrinos: posibles medidas de inervención. La perspectiva europea. Quadern Caps. 2000;29:36-42

PINN VW. Sex and gender factors in medical studies. Implications for health and clinical practice. JAMA. (2003); 289: 397-400.

RUIZ MT, VERBRUGGE LM A two way view of gender bias in medicine. J-EpidemiolCommunity-Health.(1997);51:106-109

SHAFRAN SD. The chronic fatigue syndrome. Am J Med.1991;90:730-738

SIMON GE. An international study of the relation between somatic simptoms and depression. N Engl J Med. (1999);341(18):1329-1335

VACCARINO, V. Sex-based differences in early mortality after myocardial infarction. N-England-J-Med. (1999);31:217-225.

Valls-Llobet, Carme. Mujeres Y Hombres. Salud y diferencias.Editorial Folio, 1994.

VAlls-Llobet, Carme. El estado de la investigación en salud y género. En «Perspectivas de género en salud. Fundamentos cientificos y socioprofesionales de diferencias sexuales no previstas». Grupo de Salud del Saminario Interdisciplinar de Estudios de la Mujer de la Universidad de Zaragoza. Minerva Ediciones. 2001 
VAlls-Llobet, Carme.Mujeres Invisibles. Catedra. Colección Feminismos. 2006

VerbrugGe LM. The twain meet: Empirical explanations of sex differences in health and mortality. J Health Soc Behav. (1989); 30: 282-304. 


\title{
UN MODELO ECOLÓGICO INTEGRADO PARA COMPRENDER LA VIOLENCIA CONTRA LAS MUJERES
}

\author{
CARMEN Vives CASES \\ Universidad de Alicante ${ }^{1}$
}

\begin{abstract}
Recibido/15/07/2011
\end{abstract}
Aceptado/25/09/2011

\section{Referencia del artículo comentado}

HEISE, Lory L. «Violence against women: An integrated, ecological framework». Violence against Women 1998; 4: 262-290.

\section{Resumen}

Este artículo fomenta la adopción general de un marco integrado ecológico para la comprensión de los orígenes de la violencia de género. La aproximación ecológica al maltrato conceptualiza la violencia como un fenómeno polifacético basado en la interacción entre factores personales, situacionales y socioculturales. A pesar de tratar los avances conceptuales de teóricos anteriores, este artículo va más allá de su trabajo en tres aspectos relevantes. En primer lugar, este artículo utiliza el marco ecológico como una herramienta heurística para organizar la base de investigación existente como un todo inteligible. Mientras que otros teóricos presentan el marco como una manera de pensar sobre la violencia, unos pocos han intentado establecer qué factores surgen como predictores del maltrato en cada uno de los niveles de la ecología social. En segundo lugar, este artículo integra resultados de investigación internacionales y transculturales junto con descubrimientos de la ciencia social de Norteamérica. Y finalmente, el marco parte de descubrimientos relativos a todo tipo de maltrato físico y sexual hacia las mujeres para fomentar una aproximación más integrada a la construcción de teorías en cuanto al maltrato hacia las mujeres.

1. Pertenece al Grupo de Investigación en Salud Pública de la Universidad de Alicante.

Feminismo/s 18, diciembre 2011, pp. 291-299 



\section{Introducción}

La violencia de género contra las mujeres es una vulneración de los derechos humanos que obstaculiza el logro de la igualdad, la paz y el desarrollo². También es un grave problema de Salud Pública por sus devastadoras consecuencias para la salud de las mujeres incluida la mortalidad por esta causa. En este sentido, se ha puesto de manifiesto que su eliminación podría ser una importante contribución al desarrollo a nivel mundial, que actualmente se concreta en los denominados «Objetivos del Milenio» de Naciones Unidas que abarcan desde promover la igualdad y la autonomía de las mujeres hasta la reducción de la mortalidad infantil, materna y de la propagación de VIH/SIDA. 3,4

La violencia de género también es una de las consecuencias de la desigualdad de género relacionada con los valores, normas y creencias sobre la posición de las mujeres en la sociedad. El Patriarcado, que es identificado como el sistema de valores, normas y creencias que retroalimenta esta desigualdad de género en la cultura y la sociedad, tiene diferentes formas y grados ${ }^{5}$. Puede decirse, por tanto, que la desigualdad de género impregna todos los niveles de determinantes de la salud de la población que abarcan desde el individual al del contexto social.

En la última década, parece de común acuerdo la necesidad de explicar la violencia de género en función de las características del contexto social, del entorno más próximo a los hechos violentos y de las características de las personas afectadas. En este sentido, Lory L. Heise propuso en 1998 un marco ecológico integrado para la explicación de la violencia contra las mujeres en el que se conceptualiza la violencia como un fenómeno polifacético que se asienta en la interacción entre los factores personales, situacionales y

2. KRANTZ, Gunilla; GARCIA-MorenO, Claudia. «Violence against women». Journal of Epidemiology and Community Health 59 (2005), pp. 818-821.

3. ELLSBERG, Mary. «Violence against women and the Millennium Development Goals: Facilitating Women's access to support». Internacional Journal of Gynecology and Obstretics 94 (2006), pp. 325-332.

4. <http://www.un.org/spanish/millenniumgoals/>, consultado el 18-04-2011.

5. WALBY, Sylbia. Theorising Patriarchy. Oxford, Blackwell, 1990.

Feminismo/s 18, diciembre 2011, pp. 291-299 
socioculturales que pueden actuar como determinantes en este problema ${ }^{6}$. Se trata de uno de los modelos teórico-explicativos de la violencia contra las mujeres más ampliamente reconocido en la investigación sobre este tema desarrollada en el ámbito de la ciencias de la salud.

\section{Desarrollo}

En el artículo de Lory L. Heise, al que hacemos referencia, se propone un marco ecológico explicativo de la violencia contra las mujeres con el fin de integrar los hallazgos de diferentes displinas que han teorizado sobre las posibles causas de este problema. Se basa en una revisión de la investigación académica de Estados Unidos y Canadá desde las perspectivas de la antropología, la psicología y la sociología. Como resultado, la autora propone un modelo de determinantes de la violencia contra las mujeres distribuido en cuatro niveles de la ecología social:

1. Nivel 1: Historia Personal

- Presenciar violencia conyugal en la infancia

- Sufrir malos tratos durante la infancia

- Padre ausente o que rechaza a su hijo/a

2. Nivel 2: Microsistema

- Dominación masculina en el seno familiar

- Control masculino del patrimonio familiar

- Consumo de alcohol

- Conflicto conyugal/ verbal

3. Nivel 3: Exosistema

- Bajo status socioeconómico/ desempleo

- Aislamiento de la mujer y la familia

- Grupos delictivos de iguales

4. Nivel 4: Macrosistema

- Derecho/ propiedad del hombre sobre la mujer

- Masculinidad asociada a la dominación y agresión

- Roles de género rígidos

- Aprobación de la violencia interpersonal

- Aprobación del castigo físico

6. HEISE, Lory L. «Violence against women: An integrated, ecological framework» Violence against Women 4 (1998), pp. 262-290. 
Tal y como pone de manifiesto la autora del artículo, este marco teórico no debe ser interpretado como definitivo, puesto que, se basa en un conjunto provisional e incompleto de factores que han sido relacionados previamente en la literatura científica con la violencia contra las mujeres. En este sentido, se propone orientar el análisis del artículo propuesto en la explicación de algunos de los factores identificados en el modelo, así como de la calidad de la literatura científica que se ha generado en torno a los mismos.

\subsection{Alcohol y violencia de género. Una relacion sobrevalorada}

Muchos investigadores creen que el alcohol juega un importante papel en la desinhibición del agresor en ciertos tipos de abusos, ofuscando su juicio y afectando a su capacidad de interpretar las respuestas de la otra persona. No obstante, aún se desconoce cómo actúa el alcohol para incrementar el riesgo de que un hombre desarrolle específicamente una conducta violenta contra su pareja. De hecho, un buen número de hombres alcohólicos no maltratan físicamente a sus parejas y no todos aquellos que lo hacen, abusan del alcohol.

En un artículo de revisión de estudios publicados sobre la relación entre consumo de alcohol excesivo y violencia contra las mujeres, se pone de manifiesto que los estudios desarrollados en torno a este tema presentan algunas limitaciones relacionadas con la falta de precisión de las asociaciones encontradas y la tendencia de las revistas científicas a publicar los resultados positivos más que los negativos ${ }^{\top}$.

Resulta todavía más preocupante que el consumo excesivo de alcohol pueda proporcionar una excusa que permita a los agresores eludir su responsabilidad por su conducta agresiva. Esta realidad ha llevado a muchas activistas feministas y a quienes toman decisiones políticas a mostrar cautela a la hora de reconocer el papel del alcohol en la etiología de este tipo de abuso.

\subsection{El aprendizaje intergeneracional de la violencia y de la indefensión ante los abusos}

Con respecto a la historia personal de los individuos, el aprendizaje intergeneracional de la violencia contra las mujeres es uno de los factores que mayor preocupación despierta en todas sus formas: por haber recibido malos tratos en la infancia, por haber atestiguado en la infancia la violencia en la pareja o por rechazo de la figura paterna. Es reconocido como uno de los factores

7. Gil-GonZÁlez, Diana; Vives-Cases, Carmen; Álvarez-Dardet, Carlos; Latour-PéreZ, Jaime. «Alcohol and intímate partner violence: do we have enough information to act?» European Journal of Public Health 16 (2006): 278-284.

Feminismo/s 18, diciembre 2011, pp. 291-299 
de riesgo más consistentes en relación con la conducta violenta de hombres contra mujeres ${ }^{8}$. Sin embargo, una revisión sistemática reciente pone de manifiesto la necesidad de mejorar la calidad de las investigaciones en esta línea, puesto que, todavía son escasos los estudios con diseños adecuados -por ejemplo, estudios de cohortes o casos y controles- para analizar esta relación. Las investigaciones existentes también se ven limitadas por la presencia de sesgos epidemiológicos importantes, como el de recuerdo, y por la heterogeneidad de escalas utilizadas para medir la exposición a este factor ${ }^{9}$. Una de las escalas más utilizadas para medir malos tratos en la infancia como factor de riesgo para la conducta violenta en hombres adultos es la denominada «Conflict Tactic Scale» (CTS). En sus primeras versiones, se incluía conjuntamente atestiguar y sufrir malos tratos en la infancia. Se trata de una medición metodológicamente incorrecta, que no permite distinguir entre la presencia de violencia en la pareja o análogo en la infancia (que es violencia sexista) y haber sufrido malos tratos durante la infancia (que es violencia patriarcal) ${ }^{10}$.

Una de las inquietudes más comunes es la incapacidad para responder por qué el aprendizaje intergeneracional de la violencia se manifiesta de forma diferente entre hombres y mujeres. Así, las niñas víctimas de violencia parecen mostrar una mayor probabilidad de ser de nuevo víctimas al llegar a la etapa adulta y los hombres tienen mayor riesgo de ser maltratadores. Esta tendencia podría explicarse por el impacto de la desigualdad de género en la socialización de los individuos y la asunción de roles diferentes por parte de los hombres y las mujeres ${ }^{11}$.

\subsection{Violencia contra las mujeres, conflicto verbal y dominación masculina}

Con respecto a los factores de riesgo ligados al contexto inmediato en el que se producen los hechos violentos, destacan el conflicto verbal en la pareja y

8. Hotaling, GT; SUGARMAN DB. «An analysis of risk markers in husband to wife violence: the current state of knowledge». Violence and Victims 1 (1986), pp. 101-124.

9. Gil-GonzÁlez, Diana; Vives-Cases, Carmen; Ruiz-CAnTERo, Maria Teresa; CarrascoPortiÑo, Mercedes; ÁlvareZ-DARDET, Carlos. «Childhood experiences of violence in prepetrators as a risk factor of intimate partner violence: a systematic review». Journal of Public Health 30 (2007), pp. 14-22.

10. Ruiz-Cantero, Maria Teresa; Vives-Cases, Carmen; Artazcoz, Lucía; Delgado, Ana; García-Calvente, Maria del Mar; Miqueo, Carmen; Montero, Isabel; Ortiz, Rocío; RONDA, Elena; RuIZ, Isabel; VALLS, Carmen. «A framework to analyse gender bias in epidemiological research». Journal of Epidemiologic and Community Health 61 (Suppl 2), pp. 46-53.

11. JASINSKI, Jane: «Theoretical Explanations for Violence Against Women», en Renzetti, C; Edleson, J; Berger R (dirs.): Sourcebook on Violence against women, California, Sage Publications, 2001, pp. 5-21. 
la dominación masculina sobre los aspectos que afectan al núcleo familiar por su relación con la violencia de género contra las mujeres en la pareja ${ }^{6}$. El efecto de ambos factores sobre la violencia contra las mujeres parece producirse fundamentalmente cuando los hombres muestran actitudes proclives a la ideología patriarcal que sustenta la subordinación de las mujeres hacia los hombres ${ }^{12}$.

Aportaciones más recientes introducen en esta relación conflictiva y de dominación el efecto de las desigualdades de poder entre los miembros de la pareja por diferencias en el status socioeconómico, medido por nivel de educación, ingresos y ocupación de las mujeres con respecto a los hombres ${ }^{13,14}$. Se concluye que, en el entorno en el que se producen los hechos violentos, la desigualdad entre los miembros de la pareja en términos de estatus en el empleo (por dedicación a tiempo completo o no y por tener un trabajo de primer orden -puestos ejecutivos, de dirección y administración- o no de las mujeres con respecto a los hombres) y en el ingreso también puede actuar como determinante en el problema.

\subsection{Desigualdad de género en el macrosistema}

La investigación sobre las actitudes, creencias y normas que impregnan la cultura en la violencia de género constituye una línea de trabajo fundamental para el diseño de estrategias eficaces de prevención primaria del problema. Un estudio reciente pone de manifiesto que el nivel de aceptabilidad de la violencia de género entre los países de la Unión Europea de 1999 es diferente, encontrando que todavía existen actitudes de culpabilización de las mujeres afectadas y de disculpa a los maltratadores ${ }^{15}$.

Dada la importancia de los factores del macrosistema para el diseño de intervenciones que permitan abordar el problema antes de que ocurra, se requiere de la realización de más estudios observacionales que puedan concretar

12. Hoffman, KL; Demo, DH; Edwards, JN. «Physical Wife Abuse in a Non Western Society: An Integrated Theoretical Approach». Journal of Marriage \& the Family 56 (1994), pp. 131-146.

13. Gage, AJ; Hutchinson, PL. «Power, Control and Intimate Partner Sexual Violence in Haiti». Archives of Sexual Behaviour 35 (2006), pp. 11-24.

14. Vieraitis, L; Williams, M. «Assessing the impact of Gender Inequality on Female Homicide Victimization Across U.S. Cities: A Racially Disaggregated Analysis». Violence Against Women 8 (2002); pp. 35-63.

15. Gracia, E; Herrero, J. «Acceptability of domestic violence against women in the European Union: a multilevel analysis». Journal of Epidemiology and Community Health 60 (2008), pp. 123-129.

Feminismo/s 18, diciembre 2011, pp. 291-299 
los mecanismos por los que las actitudes, creencias y normas pueden incrementar o reducir la probabilidad de malos tratos contra las mujeres.

\section{Conclusión}

La violencia de género contra las mujeres es un fenómeno complejo que se fundamenta en la interacción entre factores personales, situacionales y socioculturales. A pesar de la evidente dificultad que supone conciliar todas las aportaciones existentes, describir las causas de la violencia de género es imprescindible para mejorar la eficacia y la efectividad de las intervenciones en torno a este problema. El artículo de Lory L. Heise de 1998 constituye una primera aproximación a las causas de este problema, que resulta un gran estímulo para el desarrollo de hipótesis de investigación. El reto de los investigadores que lleven a cabo estos estudios en el futuro es abordar este amplio abanico de factores de la violencia de género aplicando diseños metodológicos que traten de mejorar la calidad de los estudios previamente realizados en torno a esta propuesta.

\section{Referencias bibliográficas}

ELLSBERG, Mary. «Violence against women and the Millennium Development Goals: Facilitating Women's access to support». Internacional Journal of Gynecology and Obstretics 94 (2006), pp. 325-332.

Gage, AJ; HutChinSON, PL. «Power, Control and Intimate Partner Sexual Violence in Haiti». Archives of Sexual Behaviour 35 (2006), pp. 11-24.

GRACIA, E; HERRERO, J. «Acceptability of domestic violence against women in the European Union: a multilevel analysis». Journal of Epidemiology and Community Health 60 (2008), pp. 123-129.

Gil-GonZÁlez, Diana; Vives-Cases, Carmen; Álvarez-Dardet, Carlos; LatourPÉREZ, Jaime. "Alcohol and intímate partner violence: do we have enough information to act?» European Journal of Public Health 16 (2006), pp 278-284.

Gil-GonZález, Diana; Vives-Cases, Carmen; Ruiz-Cantero, Maria Teresa; CARRASCO-PortiÑo, Mercedes; Álvarez-DARDET, Carlos. «Childhood experiences of violence in prepetrators as a risk factor of intimate partner violence: a systematic review». Journal of Public Health 30 (2007), pp. 14-22.

HEISE, Lory L. «Violence against women: An integrated, ecological framework» Violence against Women 4 (1998), pp. 262-290.

HOFFMAn, KL; Demo, DH; EDWARDS, JN. «Physical Wife Abuse in a Non Western Society: An Integrated Theoretical Approach». Journal of Marriage \& the Family 56 (1994), pp. 131-146. 
HOTALinG, GT; SUGARMAn DB. «An analysis of risk markers in husband to wife violence: the current state of knowledge». Violence and Victims 1 (1986), pp. 101-124.

JASINSKI, Jane: «Theoretical Explanations for Violence Against Women», en Renzetti, C; Edleson, J; Berger R (dirs.): Sourcebook on Violence against women, California, Sage Publications, 2001, pp. 5-21.

KrANTZ, Gunilla; GARCIA-MORENO, Claudia. «Violence against women». Journal of Epidemiology and Community Health 59 (2005), pp. 818-821

Ruiz-Cantero, Maria Teresa; Vives-Cases, Carmen; Artazcoz, Lucía; Delgado, Ana; García-Calvente, Maria del Mar; Miqueo, Carmen; Montero, Isabel; OrTIZ, Rocío; RondA, Elena; RuIZ, Isabel; VALLS, Carmen. «A framework to analyse gender bias in epidemiological research». Journal of Epidemiologic and Community Health 61 (Suppl 2), pp. 46-53.

Vieraitis, L; WiLliams, M. «Assessing the impact of Gender Inequality on Female Homicide Victimization Across U.S. Cities: A Racially Disaggregated Analysis». Violence Against Women 8 (2002); pp. 35-63.

WALBY, Sylbia. Theorising Patriarchy. Oxford, Blackwell, 1990. 



\title{
DESIGUALDADES SOCIALES EN LA ASOCIACIÓN ENTRE VIVIR EN PAREJA/ ESTAR CASADO Y LA SALUD ENTRE TRABAJADORES EN ESPAÑA
}

\author{
LUCÍA ARTAZCOZ \\ Agència de Salut Pública. Barcelona
}

Recibido/15/07/2011

Aceptado/25/09/2011

\section{Referencia del artículo comentado}

ARTAZCOZ, Lucia; CORTÉS, Inmaculada; BORRELL, Carmen; ESCRIBÀAGÜIR, Vicenta y CASCANT Lorena. Social inequalities in the association between partner/marital status and health among workers in Spain. Soc Sci E Med 2011; 72: 600-607.

\section{Resumen}

Los objetivos de este estudio son examinar la asociación entre el estado marital o de unión con una pareja y varios temas de salud entre trabajadores y determinar si depende del género y la clase social ocupacional. La muestra estaba compuesta por todos los trabajadores de 21 a 64 años entrevistados en la Encuesta Nacional de Salud de 2006 (8563 hombres y 5881 mujeres). El estado marital o de unión con una pareja estaba compuesto por 7 categorías: casado/a y viviendo con su esposa/o (categoría de referencia), casado/a sin vivir con su esposa/o, cohabitando, soltero/a y viviendo con sus padres, soltero/a sin vivir con sus padres, separado/a - divorciado/a y viudo/a. Se analizaron 4 factores relacionados con la salud: salud auto-percibida, salud mental, consumo de fármacos psiquiátricos e hipertensión. Se utilizaron modelos de análisis de regresión logística múltiple estratificados por sexo y clase social. Las mujeres trabajadoras en ocupaciones manuales que cohabitaban reportaron con mayor frecuencia un estado de pobre salud auto-percibida, pobre salud mental, y consumo de fármacos psiquiátricos e hipertensión que las casadas que vivían con sus esposos. En este grupo, la prevalencia de pobre salud fue incluso mayor cuando se compara con las solteras. 
Entre los hombres trabajadores no manuales, ser casado y no vivir con la esposa se asoció con un pobre estado de salud auto-percibida, pobre salud mental e hipertensión. No se detectaron diferencias en salud entre ser casado y el resto de los estados marital o de unión con una pareja para las diferentes combinaciones de género y clase social e, incluso, algunos grupos de solteros reportaron mejor salud que los casados. Nuestros resultados muestran que no hay evidencia que ser casados y vivir con la esposa está inequívocamente relacionado con mayor salud entre los españoles trabajadores. Esto enfatiza la importancia de no solamente considerar el estado marital, si no el de convivencia en pareja, así como los roles de género, clase social, y contexto sociocultural en el análisis de la asociación entre las características familiares y la salud. 


\section{Introducción}

Desde principios de los años 80 numerosos estudios han analizado la relación entre el estado civil y la salud. A diferencia de las publicaciones iniciales que observaban un efecto protector del matrimonio para los hombres pero no para las mujeres, la mayor parte de los estudios recientes documentan un efecto protector para los dos sexos, ${ }^{123}$ aunque en algunos estudios la magnitud de este efecto es superior en los hombres. Se han propuesto dos hipótesis, que no son mutuamente excluyentes, para explicar estos hallazgos. La «hipótesis de protección» sugiere que el estado civil tiene un impacto causal sobre la salud debido a una variedad de factores ambientales, sociales y psicológicos. Por ejemplo, el matrimonio podría aumentar el apoyo social y los ingresos y reducir las conductas de riesgo. Por el contrario, la «hipótesis de selección» sostiene que la salud y las conductas relacionadas con la salud determinan el estado civil o de convivencia en primer lugar. Por lo tanto los individuos sanos tienen más probabilidades de vivir en pareja.

La mayoría de los estudios publicados hasta ahora se refieren a la situación en Estados Unidos, Canadá, países del norte de Europa o Reino Unido, pero poco se sabe sobre los países mediterráneos que son muy diferentes a los anglosajones en relación con la familia y las formas de convivencia. Este es el primer artículo que analiza la relación entre el estado civil o de convivencia y la salud en España y trata de superar algunas de las limitaciones metodológicas de estudios anteriores. Examina cuatro indicadores de salud: salud percibida, salud mental, consumo de psicofármacos e hipertensión arterial. Sorprendentemente los resultados son muy distintos a los publicados hasta ahora.

1. Lillard LA, Waite LJ. Til death do us part: Marital disruption and mortality. Am J Sociol 1995; 100: 1131-1156.

2. Hu Y., Goldman N. Mortality differentials by marital status: An international comparison. Demography 1990; 27, 233-250.

3. Cheung YB. Marital status and mortality in British women: A longitudinal study. Int J Epidemiol. 2000; 29: 93-99.

Feminismo/s 18, diciembre 2011, pp. 301-308 


\section{Superando limitaciones metodológicas de la investigación previa}

Este artículo plantea varias limitaciones metodológicas o conceptuales de estudios previos que se señalan a continuación:

1.- ¿Estar casado o vivir en pareja sin estarlo es similar y tiene igual impacto en la salud?

Aunque muchos estudios han considerado como una única categoría estar casado/a o vivir en pareja, (de hecho muchas encuestas de salud recogen esta información en una única categoría), estudios recientes apuntan a que la salud de las personas que viven en pareja sin estar casadas es peor que la de las casadas, pero mejor que el resto de las situaciones de estado civil o de convivencia. Se han señalado varias razones. En primer lugar, las parejas de hecho pueden ser diferentes en las actitudes y comportamientos de las que se casan. En segundo lugar, porque las convivencias sin estar casados/as suelen ser de menor duración que los matrimonios, y por lo tanto las parejas que cohabitan pueden no tener los beneficios en salud a largo plazo que se encuentran en el matrimonio. En tercer lugar, los acuerdos económicos dentro del matrimonio y dentro de la convivencia pueden ser diferentes. Para algunos, la cohabitación proporciona independencia económica dentro de una relación íntima, lo que combina los beneficios de la soltería con los de una unión sexual.

2.- ¿Cómo evitar o reducir un sesgo de causalidad inversa en estudios sobre este tema realizados con diseños transversales?

El matrimonio puede proporcionar beneficios pero también podría suceder que las personas sanas tuvieran más probabilidad de encontrar pareja, es decir, que los resultados se explicasen por un sesgo de causalidad inversa. El mismo sesgo existiría entre las personas separadas o divorciadas, ya que se ha observado que el mal estado de salud puede ser la causa de la separación o el divorcio. Este estudio, realizado con datos de una encuesta de diseño transversal, reduce este posible sesgo seleccionando sólo población trabajadora en la que también existe un sesgo de selección, el sesgo del trabajador sano. Por tanto, se analiza una población más sana que la general en la que no están personas, que por razones de salud no trabajan o que por las mismas razones tengan dificultades para encontrar pareja. 
3.- ¿Es necesario ajustar por el tipo de contrato?

Es necesario ajustar por una variable si ésta es una posible fuente de confusión. El tipo de contrato lo es, ya que se ha observado que está relacionado tanto con el estado de salud como con la probabilidad de estar casado o vivir en pareja. ${ }^{4}$

4.- ¿Cómo se examina en el artículo si la relación entre el estado civil o de convivencia es diferente según el sexo?

Podría suceder que estar casado/a fuera beneficioso para un sexo pero lo fuera menos, o no lo fuera e incluso fuera un factor de riesgo, para el otro. Para examinar esta interacción se separa el análisis por el sexo.

5.- ¿Cómo se justifica en el artículo que la asociación entre el estado civil o de convivencia puede ser diferente según la clase social?

Los patrones de género pueden diferir según la clase social. Es probable que las diferencias de género en el poder entre los miembros de la pareja sean mayores entre las parejas con nivel socioeconómico bajo, debido a actitudes más tradicionales sobre los roles de género entre las personas de bajo nivel de estudios y, por tanto, el potencial beneficio de estar casado o de vivir en pareja, puede ser menor para las mujeres de clases sociales menos privilegiadas. Aunque la mayoría de los estudios previos ajustan el análisis por la posición socioeconómica, examinar la hipótesis anterior requiere separar el análisis por la clase social. En este estudio se analizan dos grupos: trabajadores/as manuales y no manuales.

6.- ¿Por qué los resultados pueden ser diferentes en España que en países anglosajones de similar nivel de desarrollo?

Hay diferencias importantes entre el sur de Europa y otros países desarrollados en términos de matrimonio y convivencia en pareja y por lo tanto la relación entre el estado civil y la salud puede ser diferente. Por ejemplo, los hijos e hijas de los países del sur de Europa en general abandonan el hogar familiar más tarde, y lo hacen con más frecuencia para casarse y menos frecuentemente por razones de empleo o educación superior, en comparación con el norte

4. Artazcoz L, Benach J, Borrell C, Cortès I. Social inequalities in the impact of flexible employment on different domains of psychosocial health. J Epidemiol Community Health 2005; 59: 761-767.

Feminismo/s 18, diciembre 2011, pp. 301-308 
de Europa. ${ }^{5}$ Los adultos jóvenes en Italia, Grecia, España y Portugal se quedan mucho más tiempo con sus padres, especialmente cuando están estudiando, antes de establecerse de forma estable en el mercado laboral o en una relación de pareja estable. ${ }^{6}$ El alto desempleo y las tasas de inestabilidad laboral entre los adultos jóvenes, la escasez de viviendas en alquiler o una vivienda adecuada para las personas solteras en estos países, así como los factores culturales son algunas de las razones de este patrón del sur de Europa ${ }^{7}$. En estas circunstancias la familia podría tener un efecto protector sobre el estado de salud entre los adultos jóvenes. Sin embargo, hasta ahora no se han publicado estudios examinando esta cuestión. Además, la cohabitación es menos frecuente que en los países del norte europeo.

\section{Reflexiones sobre los resultados más importantes}

1.- A diferencia de la mayoría de estudios previos, en este estudio estar casado, en general, no se asocia con mejores indicadores de salud que el resto de las situaciones de estado civil o de convivencia.

Las limitaciones metodológicas de estudios previos podrían explicar por qué se encuentran muy pocas diferencias en el estado de salud según el estado civil y además en algunos grupos las personas solteras tienen mejor estado de salud que las casadas. En los países del sur de Europa una característica especial es el carácter selectivo del abandono del hogar de los padres por parte de los adultos jóvenes que lo hacen cuando tienen una situación laboral y/o de pareja estable. Por el contrario, en los países nórdicos los adultos jóvenes tienden a separarse de sus padres mucho antes de establecerse en el mercado laboral, con ingresos insuficientes y antes de formar una nueva familia. Por lo tanto, en comparación con el Sur de Europa, en los países nórdicos hay un volumen mucho mayor de adultos jóvenes menores de 30 años, con ingresos marginales, todavía estudiando y que viven en hogares unipersonales. Además la restricción de la población de estudio a personas trabajadoras reduce o elimina el posible sesgo de causalidad inversa existente en estudios transversales previos.

5. Holdsworth C. Leaving home in Britain and Spain. European Sociological Review 2000; $16,201-222$.

6 . Vogel J. European welfare regimes and the transition to adulthood: a comparative and longitudinal perspective. Social Indicators Research 2002; 59, 275-299.

7. Iacovou M. Regional differences in the transition to adulthood. The Annals of the American Academy of Political and Social Sciences 2002; 580, 40-69. 
2.- Entre las trabajadoras manuales se observó una relación consistente entre la cohabitación y los cuatro indicadores de mala salud y las diferencias fueron mayores cuando las parejas de hecho se compararon con los solteros.

Las diferencias en la calidad de las relaciones entre las personas casadas y las que viven en pareja pueden ser mayores, entre las trabajadoras manuales, debido a las desigualdades de poder basadas en la probable relación de género, lo que explicaría el hallazgo de este estudio.

3.- Entre los trabajadores no manuales se encuentra una asociación consistente entre estar casado y no vivir con la pareja, para tres de los cuatro indicadores de mala salud analizados.

Muchos de los trabajadores españoles no manuales que están casados y no conviven con sus parejas podrían estar en las fases iniciales de un proceso de separación o divorcio y por tanto asumiendo el estrés económico propio de estas etapas en la que la mayoría de los hombres suelen perder su vivienda y deben asumir costes económicos relacionados con la ruptura y el mantenimiento de hijos e hijas. La razón por la asociación entre estar casado y no vivir con la pareja se limita a los hombres de clases no manuales lo que podría estar relacionado con las diferencias de clase social en el aumento de la deuda familiar en España en los últimos años. La proporción de familias españolas con una hipoteca fue mayor entre las familias con mayores ingresos ${ }^{8}$. Llama la atención que, aunque el número de personas en esta situación es bajo, las dos ratios son altas y los intervalos de confianza ajustados.

\section{Conclusiones}

Este artículo es un ejemplo de que los determinantes sociales de la salud pueden variar según el tiempo y el lugar analizado. Además, señala la importancia de examinar de manera simultánea las desigualdades de género y de clase social. Con frecuencia, los estudios sobre las desigualdades de clase social en la salud no han tenido en cuenta el papel del género, mientras los de género se han centrado en los determinantes sociales de la salud de las mujeres, enfatizando los roles familiares y considerando en segundo plano el trabajo remunerado o la clase social ocupacional. Finalmente, remarca la importancia

8. Banco de España. Dirección General de Servicios de Estudios. Encuesta Financiera de las Familias 2005. [Bank of Spain. General Directorate of Services of Studies. Family Financial Survey, 2005]. Available at: http://www.bde.es/estadis/eff/Separata_EFF_2007. pdf. Accessed December 12, 2007. Spanish. 
del desarrollo de marcos teóricos que tengan en cuenta los posibles sesgos, variables de confusión y de interacción de manera explícita.

\section{Referencias bibliográficas}

ARTAZCOZ L, BenACH J, BorRell C, CORTÈs I. Social inequalities in the impact of flexible employment on different domains of psychosocial health. J Epidemiol Community Health 2005; 59: 761-767.

BANCO DE España. Dirección General de Servicios de Estudios. Encuesta Financiera de las Familias 2005 http://www.bde.es/estadis/eff/Separata_EFF_2007. pdf. Accessed December 12, 2007. Spanish.

CHEUnG YB. Marital status and mortality in British women: A longitudinal study. Int J Epidemiol. 2000; 29: 93-99.

HOLDSWORTH C. Leaving home in Britain and Spain. European Sociological Review 2000; 16, 201-222.

Hu Y, GOLDMAN N. Mortality differentials by marital status: An international comparison. Demography 1990; 27: 233-250.

IACOVOU M. Regional differences in the transition to adulthood. The Annals of the American Academy of Political and Social Sciences 2002; 580, 40-69.

Lillard LA, WAite LJ. Til death do us part: Marital disruption and mortality. Am J Sociol 1995; 100: 1131-1156.

VOGEL J. European welfare regimes and the transition to adulthood: a comparative and longitudinal perspective. Social Indicators Research 2002; 59, 275-299. 


\section{MEDICINA EN FEMENINO UNIVERSAL: EL SENTIDO DE LA ENFERMEDAD. UN VIAJE DEL ALMA, DE JEAN SHINODA BOLEN ${ }^{1}$}

CONSUElO MiQueO

Universidad de Zaragoza

Recibido/15/07/2011

Aceptado/25/09/2011

\section{Referencia del libro comentado}

SHINODA BOLEN, Jean. El sentido de la enfermedad. Un viaje del alma, Barcelona, Kairós, 2006, 281 págs. Traducción de Antonio Francisco Rodríguez de la segunda edición inglesa de 200 (Closetothebone).

1. Jean Shinoda Bolen. El sentido de la enfermedad. Un viaje del alma, Barcelona, Kairós, 2006, 281 págs. Traducción de Antonio Francisco Rodríguez de la segunda edición inglesa de 2006 (Close to the bone). La misma editorial Kairós ha publicado una segunda edición en español en el año 2009.

Feminismo/s 18, diciembre 2011, pp. 309-321 



\section{Un espacio de confluencia}

El sentido de la enfermedad. Un viaje del alma es un libro que representa bien ese espacio de confluencia de dos corrientes del pensamiento y práctica feminista que han modelado nuestra época y profesión: el de las «expertas» sanitarias, bien integradas en la profesión que aman, y el de las críticas con la soberbia tecnificación de la medicina científica, defensoras muchas veces de los remedios naturales, la medicina integral o la tradición mística y de las brujas. Este libro permite entender, mejor que otros, la discusión intelectual y apuesta por la integración de la sabiduría tradicional femenina en la formación de los futuros médicos y médicas (quienes la necesitan mucho más que los demás profesionales sanitarios como fisioterapeutas, enfermeros o psicólogos), junto a las novedades de lo que llamamos «estudios de género y salud». Sirve para cuestionar, otra vez, con otros datos, el valor de la razón instrumental científica y las arraigadas creencias populares en los procesos de recuperación de la salud perdida. Y es, por último, un buen ejemplo para preguntarnos sobre el estilo femenino de escritura femenino y la raíz masculina del «estilo científico» estandarizado, y su relación con lo real existente.

Es probable que muchas mujeres y hombres lectores de Feminismo/s conozcan ya a esta significada autora, Jean Bolen, de quien se han publicado en español (casi siempre en la editorial Kairos) los siguientes títulos: Viaje a Avalon: la peregrinación de una mujer en la mitad de la vida (2000); Las brujas no se quejan (2004); El Tao de la Psicología (2005); Sabiduría concentrada para mujeres atrevidas (2006); El sentido de la enfermedad (2006, 2009); Mensaje urgente a las mujeres (2006); Las diosas de cada mujer. Una nueva psicología femenina (2007); Las diosas de la mujer madura. Arquetipos femeninos a partir de los cincuenta (2008); El millonésimo círculo. Cómo transformarnos a nosotras mismas y al mundo (2008); Los dioses de cada hombre (2009). En el caso de compartir estas lecturas, la reflexión que propongo puede generar resonancias -o disonancias- cognitivas y emotivas que deriven en discusión, nuevas observaciones o estudios de más largo alcance: el sueño de cualquier profesor o profesora. Pero es que, además, necesitamos normalizar en el medio académico el diálogo entre expertos y usuarios «el saber sobre la enfermedad» debido 
al limitado fundamento filosófico o epistemológico de nuestra canónica «medicina basada en la evidencia» (MBE), un reduccionismo mantenido sin duda por intereses industriales y, quizá, de género masculino.

Elegir este exitoso, interesante y problemático libro de una psiquiatra analista jungiana norteamericana y autora de best sellers ha supuesto, para mi, cruzar un umbral. Pudiendo elegir tantos otros de mi comunidad científica médica o histórica de los que hablar en el estilo científico al uso, en el lenguaje de las expertas sanitarias feministas que tantas novedades han producido estos años ${ }^{2}$, he optado por un libro popular y, en cierto modo, extra-académico ${ }^{3}$.

Del contradictorio perfil popular de El sentido de la enfermedad dan buena cuenta algunos datos documentales básicos. En el conjunto de las bibliotecas académicas españolas (REBIUN) hallamos 13 ejemplares de esta obra (10 de la primera edición de 2006 y 3 de la segunda de 2009) entre los 15 títulos totales de Jean Bolen, de los que hay 9 traducciones y 6 ediciones en inglés. A nivel internacional, de su producción científica no hay constancia en la prestigiosa e ineludible base de datos bibliográfica Medline/PubMed, aunque

2. Una muestra de ese nuevo saber feminista o con perspectiva de género son los informes oficiales ministeriales, las monografías de revistas especializadas y algunos estudios generales que han actuado como manuales, en ausencia de éstos. Entre los primeros se hallan los tres informes generados por el Observatorio de la Salud de la Mujer de la Agencia de Calidad del Ministerio de Sanidad y Consumo de los últimos años: Informe Salud y Género 2005, Madrid, Ministerio de Sanidad, 2007; Informe Salud y Género 2006. Las edades centrales de la vida, Madrid, Ministerio de Sanidad, 2008; Informe Salud y género 2007-08. Mujeres y hombres en las profesiones sanitarias. Madrid, Ministerio de Sanidad, 2009. Entre los segundos, han constituido verdaderos hito, en sus respectivas sociedades de especialistas los siguientes: el dossier de 1999 de la revista Dynamis, de historia de la medicina y la ciencia «Mujeres y salud: prácticas y saberes» coordinado por Monserrat Cabré Pairet y Teresa Ortiz Gómez; el monográfico de la revista Gaceta Sanitaria de mayo de 2004 coordinado por Lucía Artazcoz: «Desigualdades de género y salud» (Gac Sanit 2004, vol. 18 supl. 2, 92 páginas), y la monografía de 2008 de la Sociedad Española de Salud Publica y Administración Sanitaria, coordinada por Camen Borrell y Lucía Artazcoz: Investigación en Género y Salud (SESPAS monografías, 2008). En tercer lugar, han actuado como manuales: Perspectivas de género en salud. Fundamentos científicos y socio-profesionales de diferencias sexuales no previstas, Madrid, Minerva, 2001, el Programa de Formación de Formadores/as en Perspectiva de Género, coordinado Concha Colomer y $\mathrm{M}^{\mathrm{a}}$ Pilar Sánchez, y Mujeres, salud y poder de Carme Valls (CátedraFeminismos, 2009). Para una reflexión sobre las evidencias de la influencia del feminismo en la comunidad médica española remito a Miqueo (2008), donde subrayo, además, la existencia de una Red de Investigación de Salud y Genero (RISG), la Red de Mujeres Profesionales Sanitarias, atendida desde 1999 por el Centre d'Analisi i Programes Sanitaris (CAPS), y la revista Mujeres y salud (MyS), fundada y dirigida desde 1996 por Leonor Taboada.

3. Aunque para ello haya necesitado el permiso expreso de la coordinadora Teresa Ruiz Cantero y supuesto (solo supuesto, ay) la aquiescencia de la estimada Concha Colomer. 
hallamos 116 citas de 17 obras distintas de Jean Bolen en las revistas de alto factor de impacto (JCR) del área de psicología y origen norteamericano, según indica las bases de datos del Institute for Scientific Information (ISI- Web of Knowledge). Las obras más citadas en el mundo académico internacional desde 1979 han sido Diosas para cada mujer (47 citas), El tao de la psicología (20 citas), Los dioses de cada hombre (9 citas) y Diosas de la mujer madura (5 citas).

La difusión por internet de la obra de Bolen es extraordinaria. Los comentarios y citas a la obra de esta prestigiosa analista y profesora de la Universidad de California proceden de una gran variedad de entidades, especialmente: organizaciones de mujeres interesadas en el crecimiento personal o lucha contra la violencia, bibliotecas y centros de esoterismo, empresas del libro o de cosmética, talleres y seminarios de psicología, o de formación reglada en psicología empresarial. La iconografía que acompaña las citas y usos de la obra de Jean Bolen merece un estudio aparte. Es un excelente indicador de su valor social y público extra-académico (¿femenino popular tradicional?). Las siluetas femeninas evanescentes, las flores y el espacio sideral son elementos claves, integrados en composiciones de estética meliflua, antigua o poco desarrollada, de suavísimos colores pastel y líneas curvas entrelazadas; una estética que contradice la claridad y potencia de su discurso, o la sagaz elección que subyace a muchas de las portadas de sus libros traducidos a más de 20 idiomas ${ }^{4}$.

\section{Dignificar la enfermedad desde el paciente, desde el profesional}

Leer El sentido de la enfermedad. Un viaje del alma (original Close to the bone: life-threatening illness and the search for meaning), bien sea por placer o por necesidad, supone una experiencia íntima, personal, pues se trata de una "guía» para afrontar una enfermedad grave, propia o ajena. Como dice la autora, su intención con este libro es «ayudar y sanar, hacerte sentir más seguro, animarte a que confíes en tu sabiduría interior y a que seas enteramente fiel a lo que te dicta tu más profunda intuición». Pero quien esto plantea, rozando a veces el estilo de los «manuales de autoayuda» (de los que muchos huimos y yo también), es una «experta» que ha tenido una dilatada experiencia de acompañamiento profesional en la enfermedad, siendo este libro el resultado de una serie de conferencias y seminarios sobre el cáncer de mama. El mensaje central es que la enfermedad es una experiencia espiritual.

La autora parte del supuesto de que si no nos mantenemos en contacto con nuestra alma, nuestra existencia no podrá ser auténtica, productiva,

4. Visitar: (http://www.jeanbolen.com/books/foreign_translations.html)

Feminismo/s 18, diciembre 2011, pp. 309-321 
interdependiente, ni puede tener sentido; y que si somos propensos a expresar el dolor emocional y la soledad espiritual en forma de síntomas físicos, es muy probable que caigamos enfermos. La enfermedad constituiría una crisis para el espíritu porque el sufrimiento, la muerte o la invalidez sumergen en un tiempo de peligros y azares que plantea interrogantes sobre el sentido de la vida y pone a prueba los vínculos interpersonales establecidos. El impacto de una enfermedad mortal como el cáncer, infarto, sida, y muchas enfermedades crónicas o degenerativas se asemeja -dice la autora- a la piedra que cae en la superficie remansada de un lago en que la conmoción se proyecta en anillos concéntrico. Afecta a las relaciones entre personas, conmueve profundamente a los demás, implica potencialmente al paciente y cuantos se ven afectados en lo más profundo de sí mismos, en el alma. Por ello, la tesis principal que la autora plantea, y subrayo yo, es que la curación y recuperación puede depender tanto o más de la profundización de las relaciones y de la implicación con la propia vida espiritual que de la pericia médica o psiquiátrica.

Late en todo el libro una crítica radical al sistema sanitario en nuestra cultura: porque siendo la enfermedad un acontecimiento profundamente espiritual, en cambio todo parece concentrarse en la parte del cuerpo que ha enfermado, ha sido dañada, sufre una disfunción o permanece fuera de control. Lamenta esta psiquiatra que a menudo la perspectiva del médico sea semejante a la de un general ante la guerra: la enfermedad es el enemigo que ha de ser combatido y el cuerpo del paciente, el campo de batalla.

El libro está estructurado en 13 capítulos siguiendo el curso de «la experiencia de enfermar» (y no la «historia natural de la enfermedad» como en los tratados de patología, o «el proceso de descubrimiento» como en los artículos de investigación). Cada capítulo indaga, explora o acompaña cada fase del viaje de quien enferma, desde la inicial «la tierra se abre bajo nuestros pies» hasta la final, sea «la vida en suelo fértil», sea «cuando me llegue la hora, quiero estar consciente». Los títulos de los capítulos y subcapítulos son bien elocuentes del estilo de escritura y del conocimiento aportado por esta analista jungiana, es decir, expresivos del valor de las palabras e imágenes y arquetipos culturales como recursos terapéuticos, junto a la quimioterapia, la radioterapia o la cirugía: El viaje de Psique, Como carne podrida en un gancho, El desmembramiento de Procusto, La enfermedad como punto de inflexión, A veces necesitamos historias, Conexiones espirituales, Invocar a los ángeles: la oración, Recetar imaginación, Rituales, La representación del mito, Ayudar al prójimo y Meditaciones.

Los recursos terapéuticos que propone Jean Bolen son complementarios a los biomédicos convencionales, pero a veces exige la intromisión en los 
espacios sanitarios de pautas de conducta que solo tienen sentido en este otro paradigma, como ciertos «rituales» de carácter espiritual (no religiosos necesariamente) en los quirófanos o en las salas de quimioterapia. Hay tal variedad de recursos (que reconocemos como «nuestros de toda la vida» y eficaces) y tal juego de integración de muchos de ellos, y tanta perspicacia para deconstruir culturalmente los protocolos de actuación sanitaria convencionales, que el libro puede ser leído también como un excelente manual de descodificación del androcentrismo de la medicina. Aunque cada lector o lectora tiene su historia, sus experiencias, es fácil reconocer como propias muchas de las sugerencias terapéuticas que aporta y aprender sobre su universalidad y su probada eficacia.

Personalmente, me ha interesado mucho el capítulo décimo Recetar imaginación. Comienza situando el fenómeno del empleo terapéutico de la «visualización» y las «aserciones» en su medio ambiente profesional: «Mis compañeros médicos racionales se encogerán de hombros con esto, como ante mera incredulidad, o se enfurecerán como si fuera una tontería, pues desestiman o no toman en consideración los métodos para estimular la respuesta curativa del organismo. Su autoridad es intimidante, así como su convencimiento de que nada resulta efectivo a menos que sea químico e invasivo. Entiendo que este elemento de la medicina alopática es «cosa de hombres», con su énfasis en subyugar y conquistar la enfermedad. Quizá tenga que ver con tener atrofiado el hemisferio cerebral derecho y, por lo tanto, con la carencia de un enfoque desde la perspectiva curativa $\star^{5}$. Como ella afirma, son técnicas que vinculan mente y cuerpo, cuyos mecanismos bioquímicos conocemos imperfectamente, pero de los que hay estudios científicos que demuestran su eficacia terapéutica. Cuando visualizamos una metáfora se produce una reacción orgánica a nivel fisiológico; gracias a los «receptores peptídicos», los relatos que escuchamos, creemos y nos aplicamos a nosotros mismos se interiorizan profundamente e influyen en la mejoría y la curación. Dos ejemplos bastarán para comprender intuitivamente de qué habla Jean Bolen y su efecto terapéutico. Tras conseguir un estado de relajación ordenando a cada músculo que se distendiera y se imaginara a sí mismo en un lugar tranquilo y agradable, sentado al pie de un árbol, junto a un arroyo..., «el oncólogo pidió al paciente que se imaginara la radioterapia como una lluvia de diminutas partículas de energía que caían en la parte de su cuerpo arrasada por el cáncer. Las células normales de la zona también se verían afectadas, pero resistirían la radiación que mataría a las cancerígenas. En ese momento tenía que imaginar la llegada

\section{Página 183.}

Feminismo/s 18, diciembre 2011, pp. 309-321 
de los linfocitos, cómo se arremolinaban alrededor de las células cancerígenas debilitadas, las arrancaban y transportaban con las muertas o moribundas y las expulsaban del organismo ${ }^{6} »$. Para curar una artritis, «el paciente imaginó mentalmente que sus linfocitos pulían las articulaciones de sus brazos y piernas, eliminando todo residuo, hasta que las superficies quedaban limpias y relucientes ${ }^{7} »$. Por supuesto, los linfocitos pueden visualizarse como soldados que atacan y destruyen a los invasores. Pero también como «millones de microscópicos ángeles de la guarda que me protegían circulando a través de los tejidos de mi organismo, capaces de reconocer lo que no debía estar ahí y librarse de ello ${ }^{8}$.

Por supuesto, no es ella el primer «experto» en promover el uso terapéutico de la palabra y el relato. Como historiadora de la medicina conozco esta tradición, pero ni en la pionera y ya clásica síntesis La curación por la palabra en la antigüedad clásica del eminente Pedro Laín Entralgo publicada en 1958, ni en otras posteriores y de corte más antropológico que filosófico, se vislumbra la fuerza y universalidad de esta sabiduría femenina milenaria que trasmite Jean Shinoda Bolen, más entroncada -pienso yo, y por seguir en el mismo contexto- con el magistral Therapeia. La medicina popular en el mundo clásico de Luis Gil publicada en 1969. Creo que la propuesta de la académica Dra. Bolen es de otra estirpe cultural. En su obra reconozco mi genealogía femenina. Leerle me libera por un tiempo de esa pesarosa condición jánica de ser hoy mujer académica, mientras tomo conciencia de la orfandad materna de nuestra prestigiosa ciencia médica, la biomedicina.

\section{3. ¿Un estilo de escritura en femenino?}

El sentido de la enfermedad es como un manual de autoayuda en su intención, un texto científico en su estructura o discurso, y literario, algo poético, en su escritura. Un ejemplo de excelente divulgación científica en femenino.

La lectura comparada con otros manuales de autoayuda masculinos de cualquier campo de la vida profesional o personal -como, por ejemplo, Administre su tiempo eficazmente de Hochheiser, publicado hace poco más de una década, en el 2000 o Cómo escribir y publicar trabajos científicos de Robert Day pubñlicado en 1996- nos ofrece algunas claves de la diferencia sexual en el estilo de pensamiento y escritura científica. Pero aún más interesante resulta compararlo con otros excelentes textos de alta divulgación sobre la salud y

\footnotetext{
6. Página 187.

7. Página 188.

8. Páginas 189-190.
} 
enfermedad, planteados también desde el ámbito de la psicología y de similar éxito de público que el de Bolen, pero autoría masculina. Recomiendo, con esta intención, una relectura comparada del estilo de La fuerza del optimismo del psiquiatra Luis Rojas Marcos publicado en 2005, o Inteligencia emocional y El Punto ciego del psicólogo Daniel Goleman y publicados en 1996 y 1999 respectivamente. Es un ejercicio útil para observar y registrar los ingredientes del estilo retórico científico preferido por los hombres y por las mujeres en cuanto que autores, aun sabiendo ellos y ellas que sus principales lectores son, en realidad, lectoras.

A diferencia de los manuales de autoayuda para el éxito personal o profesional destinados a conseguir ciertos cambios de conducta personal en lo público, o los libros de divulgación de psicología o psiquiatría propios de la educación para la salud, éste de Jean Bolen tiene por objeto promover la confianza en la propia intuición, activar la introspección para descubrir la capacidad auto-sanadora por mediación del sistema psicoinmunitario. Está planteado desde unos presupuestos pedagógicos distintos de los habituales. No desde el poder del experto, la atalaya de quien todo lo sabe y condesciende a enseñar a otros cómo son las cosas o las recetas para lograrlo, sino desde la exquisita tradición de la madre-maestra destinada a guiar, es decir, a lograr «vivir la experiencia que enseña», con ejemplos, en este caso, traídos de la propia experiencia profesional y de la mitología. Concuerda con la tradición, y posición social masculina y científica, el escribir poniendo en juego sólo el conocimiento, los aspectos cognitivos del aprendizaje, y hacerlo desde el conocimiento científico acumulado por el autor y avalado, a cada paso, por las citas bibliográficas, como vemos en los citados de Daniel Goleman o Luis Rojas o Valentín Fuster (y en su excelencia, las diferencias observables entre ellos son reveladoras de su distinta personalidad, objetivo editorial y campo científico). Quizá sea lo femenino de la dra. Bolen lo que se expresa primordialmente en El sentido de la enfermedad. Un viaje del alma al poner en juego la emoción, buscando a cada paso la experiencia vital compartida, aquellas imágenes, mitos, palabras o sensaciones corporales que pueden conectar emocionalmente con el lector o lectora, transformándoles y garantizando la «incorporación» del nuevo saber. Todos, ellos y ellas, buscan lo universal del saber (científico), pero con recursos distintos.

El estilo de la Dra. Bolen recuerda tanto a María Zambrano en su Hacia un saber sobre el alma, aún en la simplicidad y pragmatismo propios de estos best seller norteamericanos, como a Mujeres que corren con lobos de Clarissa Pinkola y la legión de libros de autoayuda, medicina integral y crecimiento personal, más o menos esotéricos, que tanto gustan a las mujeres y se venden 
en las librerías heterodoxas y en tiendas de cosmética o alimentación natural. Y tan poco a nuestros ensayos científicos incluso feministas... La distinción tan habitual en nuestra comunidad científica entre las «ciencias duras» y las ciencias blandas» y su atribución de género -masculinas y femeninas, respectivamente- no es ajeno al estilo científico de aprendizaje y de enseñanza de unas y otras, ni a su vinculación con los métodos preferidos o aceptables (cuantitativos y cualitativos), ni al concepto de «evidencia» o el estatus epistemológico de la «subjetividad y singularidad» en unas y otras ciencias. Debemos discutir, con otros datos, de nuevo, las ventajas e inconvenientes del corsé del método científico y la supremacía epistémica de las ciencias biomédicas en el campo de la salud y la enfermedad y la marginalidad de las ciencias psico-sociales.

No siempre podemos gozar de las traducciones de women's studies escritos originalmente en inglés. La lectura en español que nos ofrece el traductor Antonio Francisco Rodríguez hace honor al cuidado que siempre ha puesto en ello la editoral Kairós, dirigida por Salvador Pániker, empeñada desde mediados de la década 1960 en la integración de lo oriental en nuestra occidental cultura cartesiana, tan poco sabia sobre el alma humana o el vacío o la quietud del kairos frente a la velocidad del Kronos, por nombrar algunas nociones claves. Solo encuentro un pero, y es menor y discutible. A mi me hiere (pero no me enfada) la elección en español de la palabra «ordalía», nada ocasional sino palabra clave en todo el libro de la dra. Bolen para referirse a esa «experiencia terrible» (la enfermedad constituye una ordalía); una palabra que en inglés usan en sentido figurado con frecuencia ( «exams are an ordeal»), pero que en español no solemos usar salvo para referirnos a situaciones próximas a los medievales juicios de Dios, las pruebas a las que eran sometidos «judicialmente» los reos para demostrar su inocencia; una durísima palabra que, yo recuerde, usó magistralmente Mercé Rodoreda en su última novela $\mathrm{La}$ muerte y la primavera (edición póstuma de 1986) para referirse a la «prueba de tránsito» a la vida adulta: un viaje iniciático a través del largo y tortuoso río subterráneo de un pueblo que debían realizar en la más completa oscuridad, ayudados por su memoria de la superficie conocida y sorteando las temibles raíces de las abundantes glicinas y las rocas naturales puntiagudas que podían enloquecer, mutilar o matar a los adolescentes que querían/debían probar su hombría. Pero aun contando con la mediación de tan estimada maestra, pienso si la dureza de esta palabra «ordalía» en nuestro español no estará traicionando el estilo de escritura elegido por la autora.

Aunque el objeto del libro sea trágico (la enfermedad grave, mortal o invalidante) y la principal hipótesis sea que la enfermedad es una ordalía y una 
ocasión para vivir plenamente, el tono de la escritura de Jean Shinoda Bolen no es dramático sino natural, dulce, suave, sin quebrantos, abstractos ni tonterías. Pongo un ejemplo especialmente interesante para nosotros, investigadores o enseñantes y lectores: «La enfermedad nos aparta de nuestra mente y nos centra en nuestro organismo. El mundo superior que abandonamos es también la claridad mental de nuestro ser anterior. El dolor y los medicamentos, el temor y la depresión, los efectos secundarios de tener una enfermedad mortal y seguir un tratamiento afectan a la memoria, a la apreciación de los detalles, a la capacidad de pensar con claridad, a la concentración y la atención a temas intelectuales. La enfermedad amenaza tanto la vida como la mente ${ }^{9}$ ». En «La enfermedad como punto de inflexión» (capítulo sexto), y tras sugerir que la enfermedad puede expresar un «fuego creativo frustrado», leemos: «Hemos de recuperar las fuentes de placer que yacen despedazadas, olvidadas y enterradas en el inframundo. Allí podemos encontrar las semillas de la creatividad, los talentos no cultivados, los vedados anhelos, los sueños abortados y la ecuanimidad ${ }^{10}{ }_{\text {}}$.

Un estilo oral de escritura. «Me lo imagino leído en voz alta», decía su autora en la introducción de El sentido de la enfermedad, título al que en la segunda edición de 2006, añadió significativamente: Un viaje del alma. Anglosajón, sin el rosario de subordinadas que acostumbramos en español, su lectora en voz alta resulta factible y agradable. Sin ese nivel de abstracción, codificación y corsé estructural del ensayo científico, su lectura resulta atractiva como una novela de suspense. La profusión de imágenes literarias no eruditas (que no remiten a otros libros que contienen otros libros) y que rozan el núcleo mítico ancestral de cada quien, tantas imágenes encarnadas que nos traen directamente experiencias vividas o vislumbradas hacen que su lectura se convierta en una aventura íntima intensa: en un rato pueden desfilar muchas escenas de la propia vida, y hay que dejar de leer, aquietar el alma. A diferencia de los ensayos masculinos propuestos para el análisis comparado, el estilo oral de éste resulta evidente. Tanto que puede ser utilizado fragmentariamente, como gusta a muchas mujeres, en conversaciones de café, tertulias, seminarios y clases. El número de moléculas literarias por metro cuadrado de libro (que podrían conformar eslóganes, axiomas, rótulos publicitarios, mantras, títulos de libros, o verdaderas verdades) es infinitamente superior al que hallamos en los citados autores masculinos. Hay libros que destilan vida pensada, y libros que destilan conocimiento adquirido. Este es de los primeros.

9. Página 88.

10. Página 101.

Feminismo/s 18, diciembre 2011, pp. 309-321 
En conclusión, la relectura de El sentido de la enfermedad. Un viaje del alma me confirma que la creación de conocimiento diferente, escindido, separado en dos instituciones simbólicas, la científica «convencional» de los hombres y la «alternativa» de las mujeres no es la solución para el mundo (postpatriacal) que habitamos. Me reafirma la idea de fomentar la lectura de obra literaria y mitológica, escrita o audiovisual, entre los estudiantes y futuros médicos; poblar su alma de palabras imprecisas que evoquen vivencias humanas reales, ancestrales y actuales, distrayendo así a sus neuronas de tantas cifras y datos exactos y precisos sobre el dichoso cuerpo. De la lectura de este libro de Jean Bolen infiero que es urgente apoyar a muchas profesionales sanitarias que están proponiendo reducir gasto sanitario por progresiva sustitución de «fármacos» por «palabras»; parece una iniciativa sensata, necesaria, además de la sabia corrección de un extravío -más masculino que femenino- de siglos ${ }^{11}$.

11. Entiendo que tejer ese paño no debe ser fácil si pienso en la tensión que ha generado en mí misma cruzar el umbral que significaba elegir este libro -que yo había adquirido en una tienda alternativa para un uso privado no académico- como objeto de una reseña pública, en tanto que historiadora de la medicina, profesora de metodología científica y documentación. He necesitado recuperar-reasignando significados- fragmentos de mi trayectoria intelectual y afectiva. A la niña que odiaba el huerto medicinal de su abuela porque tenía que regarlo a pozales que pesaban mucho y se mojaba a cada paso las zapatillas (eran otros tiempos), pero le gustaba llevar sus emplastos, pucheros o yogures a las casas del pueblo porque le hacía sentir especial, la nieta de una persona respetada en su comunidad. A la joven que despreciaba por antiguos, simples o acientíficos los remedios y soluciones que les ofrecía su madre, siempre remisa o desconfiada de la ciencia de los médicos (entonces no había médicas). A la estudiante de medicina de último curso que aprendió a respetar la diversidad de rutas de búsqueda de la curación de la mano de los historiadores de la medicina, en el contexto de la coexistencia de sistema médicos y el valor de la medicina popular, que desdeñaba por folclórica y supersticiosa. A la historiadora que fundamentó racionalmente su distancia epistemológica del saber femenino tradicional, retrasando la conciencia y aceptación de las insuficiencias de la medicina occidental: su reduccionismo analítico y su esencial androcentrismo. A la profesora que leía en clase textos de Rojas cuestionando recursos aquí propuestos. A la adulta amiga de muchas mujeres (más que hombres) que usan o practican confiadamente aromaterapia, cromoterapia, quiropráctica, musicoterapia, homeopatía, iridología, hierbas, libros de poesía, libros de autoayuda, hablan constantemente de energía, equilibrio y sanación, sintiéndose sabias dueñas de su cuerpo y alma. A la persona, en fín, que ha acompañado (y a veces ignorado) a personas muy queridas que han enfermado y fallecido o se han curado o convertido en enfermos crónicos. 


\section{Referencias bibliográficas}

BOLEN, Jean Shinoda. El sentido de la enfermedad. Un viaje del alma, Barcelona, Kairós, 2006.

DAY, Robert A. Cómo escribir y publicar trabajos científicos. $2^{a}$ ed. Washington, Organización Panamericana de Salud, 1996.

FUSTER, Valentín. La ciencia de la salud: mis consejos para una vida sana, Barcelona, Planeta, 2006.

GIL, Luis. Therapeia. La medicina popular en el mundo clásico, Madrid, Guadarrama, 1969.

Goleman, Daniel. El Punto ciego. Psicología del autoengaño, Madrid, Plaza y Janés, 1999.

Goleman, Daniel. Inteligencia emocional. 59ª ed. Barcelona, Salvat, 2005 ( $1^{\mathrm{a}}$ edición española: Kairos, 1996)

HoCHHEISER, Robert M. Administre su tiempo eficazmente, $2^{\mathrm{a}}$ ed. Plaza y Janés, 2000.

Laín Entralgo, Pedro. La curación por la palabra en la antigüedad clásica. $2^{a}$ ed., Barcelona, Anthropos, 1987.

MiqueO, Consuelo. "¿Feminismo en la comunidad científica médica española?» Isegoría 38 (2008), pp. 155-167.

Pinkola Estes, Clarissa. Mujeres que corren con los lobos, Barcelona, Ediciones B, 2000.

RODOREDA, Mercè. La muerte y la primavera, Barcelona, Seix Barral, 1986.

Rojas MARCos, Luis. La fuerza del optimismo. Madrid, Aguilar, 2005.

Zambrano, María. Hacia un saber sobre el alma, Madrid, Alianza, 1987.

Feminismo/s 18, diciembre 2011, pp. 309-321 



\title{
FEMINIZACIÓN DE LA MEDICINA Y TIEMPO DE TRABAJO
}

\author{
ANA DELGado \\ LORENA SALETTI-CUESTA \\ Escuela Andaluza de Salud Pública \\ Grupo HUM603 Estudios de las Mujeres Universidad de Granada
}

Recibido/15/07/2011

Aceptado/25/09/2011

\section{Referencia del artículo comentado}

Julia E. McMurray, Graham Angus, May Cohen, Paul Gavel, John Harding, John Horvath, Elisabeth Paice, Julie Schmittdiel, Kevin Grumbach. Women in Medicine: A Four-Nation Comparison. J Am Med Women Association 2002; 57: 185-190.

\section{Resumen}

La proporción de médicas está aumentando rápidamente en numerosos países a la vez que se mantiene su segregación vertical y horizontal. Esto conlleva cambios potenciales en los sistemas sanitarios debido a que las mujeres siguen siendo las responsables casi en exclusiva de las tareas de reproducción. Presentamos el análisis de las medidas que se están implantando en cuatro países ante los retos que plantea esta situación. Reflexionamos sobre el papel que puede jugar en la vida profesional de las médicas una de estas medidas: el trabajo a tiempo parcial, que podría contribuir a perpetuar su situación de desventaja profesional. Recogemos las políticas que, a nuestro juicio, deben establecerse en los sistemas sanitarios y en la sociedad en su conjunto para enfrentar estos cambios. 



\section{Introducción}

El artículo seleccionado ${ }^{1}$ analiza los retos que plantea la feminización de la medicina, ejemplificando la situación con 4 países: Reino Unido (RU), Canadá, Australia y Estados Unidos (EEUU). Usando datos oficiales, el texto analiza el incremento de médicas y su situación profesional, incluyendo el trabajo a tiempo parcial (TTP), sobre todo, en atención primaria. En España, la situación de las médicas es similar al de los países analizados: en 2005 había $42 \%$ de médicas activas ${ }^{2}$, pero se mantiene la segregación horizontal, las médicas se concentran en determinadas especialidades generalistas y están infra representadas en especialidades quirúrgicas y ciertas médicas ${ }^{3}$. Los datos en España ${ }^{4}$ (de "profesiones sanitarias» o «medicina-odontología») indican diferencias en lugar y condiciones de trabajo; la proporción de mujeres es mayor que la de hombres en el sector público, el cual se ha feminizado, no así en el privado. La temporalidad es mayor en las mujeres, más en el sector privado, debido fundamentalmente a las bajas no voluntarias. Las sanitarias trabajan menos horas y tienen menos ingresos. Del conjunto de trabajadores sanitarios en España, tenían TTP 7,4\% de hombres y 16,8\% de mujeres 5 . No hemos encontrado datos referidos a medicina de forma separada. En el estudio analizado, entre 20 y $50 \%$ de las médicas realizan TTP, modalidad que se extiende con frecuencia después de la crianza. La situación familiar y la percepción de dificultad en las relaciones familia-trabajo son peores en las

1. Mcmurray, Julia. Angus, Graham. Cohen, May. Et al. «Women in Medicine: A fournation comparison». JAMWA, 57 (2002), pp. 185-190.

2. ORTIZ, Teresa. «La práctica sanitaria en la historia ¿una cuestión femenina?». EIDON, 23 (2007), pp. 61-65.

3. GonzÁlez López-Valcarcel, Beatriz, y Barber Pérez, Patricia. Oferta y necesidad de médicos especialistas en España (2006-2030). Palmas de Gran Canaria, Universidad de las Palmas de Gran Canaria, 2007.

4. VÁzQuez Vega, Pablo (editor). La feminización de las profesiones sanitaria. Bilbao, Fundación BBVA, 2010.

5. INSTITUTO NACIONAL DE ESTADÍSTICA. Encuesta Población Activa. Serie 20052010. <http://www.ine.es/jaxiBD/tabla.do? per=12\&type=db\&divi=EPA\&idtab=1020> Consultado el 1-08-2011. 
médicas $^{6}$. Y se mantienen desigualdades de género en la carrera profesional ${ }^{7,8}$, que no se explican por la edad, la antigüedad, el tipo de centro de trabajo, o las responsabilidades familiares ${ }^{9,10,11}$.

Finalmente, el artículo analiza las medidas políticas adoptadas en los 4 países ante estos cambios. En Australia, donde el tiempo medio de trabajo de las médicas es el 68\% del tiempo de los médicos, se propone estabilizar la oferta aumentando el número de profesionales con formación postgraduada. En Australia, RU y Canadá, la formación a tiempo completo se mantiene, y se ha desarrollado un «esquema flexible de formación postgraduada», con características similares, pero a tiempo parcial, con el fin de evitar que las médicas abandonen la profesión. En RU, además de reforzar la flexibilidad horaria para médicos y médicas, la autora propone otras medidas (cambiar actitudes, aumentar las ayudas, etc.), ya que aunque el TTP es posible durante y tras la formación, están poco implantadas las licencias de paternidad, guarderías en los centros de trabajo y acuerdos sobre trabajo flexible.

El artículo es relevante para hacer un análisis feminista de las intervenciones que están proponiendo los planificadores de recursos médicos ante una situación que ya está planteándose en España. Hemos seleccionado este estudio porque recoge una buena síntesis sobre los aspectos más relevantes de la situación de las médicas en los países desarrollados, similar al español a pesar de las diferentes culturas profesionales y sociales, así como de la variabilidad de los Sistemas de Salud, Parte de esa descripción para analizar posibles alternativas a los cambios que plantea en los servicios sanitarios.

\section{Análisis del artículo}

La cuestión que centra el análisis del artículo y sobre la que nos interesa reflexionar es el TTP de las médicas; la razón es discutir el papel que esta

6. Delgado, Ana. Saletti-Cuesta, Lorena. Toro-CÁrdenas, Silvia. Et al. «Validación de escala para evaluar la relación familia-trabajo en médicas y médicos de familia». Revista Española de Salud Pública, 85 (2011), pp, 159-172.

7. Delgado, Ana. Saletti-Cuesta, Lorena. LóPez-Fernández, Luis Andrés. Et al. «Gender and the professional career of primary care physicians in Andalusia (Spain)». BMC Health Services Research, 11 (2011), pp, 51.

8. Arrizabalaga, Pilar, y Valls-Llobet, Carme. «Mujeres médicas: de la incorporación a la discriminación».Medicina Clínica (Barcelona), 125 (2005), pp. 103-107.

9. Rohlfs, Izabella. Arrizabalaga, Pilar. Artazcoz, Lucia. Et al. Salud, estilos de vida y condiciones de trabajo de los médicos y médicas de Cataluña. Barcelona, Fundación Galatea, 2007.

10. Kvaerner, Kari. Aasland, Olaf. Botten, Grete. «Female medical leadership: cross sectional study».BMJ, 318 (1999), pp. 91-94.

11. Delgado, Ana. Saletti-Cuesta, Lorena. LóPez-Fernández, Luis Andrés. Et al. Op cit. 
medida puede jugar en la vida profesional de las mismas, y si podría contribuir a perpetuar su situación de desventaja profesional.

En las últimas décadas, las desigualdades de género han dado lugar en España a políticas públicas para promover la equidad ${ }^{12,13}$. Últimamente, diversos actores se han hecho eco de la creciente feminización de la medicina planteándolo como un «problema» para el sistema sanitario, y sugiriendo algunas soluciones $^{14,15,16}$. La reducción de la jornada laboral se incluye como medida estrella en los Planes de Igualdad y, con frecuencia, se esgrimen las ventajas del TTP.

Taylor $^{17}$ señala que el TTP funciona como discriminación indirecta, en RU la carrera de las médicas no avanza tan rápido ni tan lejos como la de los médicos debido a la mayor proporción de mujeres que realizan TTP, la autora plantea la necesidad de adecuar las estructuras de la carrera profesional promoviendo opciones flexibles, con buenas oportunidades para la formación, ampliación de habilidades profesionales y desarrollo profesional. En EEUU, quienes eligen TTP tienen menos publicaciones y ayudas de investigación debido al menor apoyo institucional y oportunidades formativas ${ }^{18}$, y progresan menos en su carrera ${ }^{19}$.

Dos informes sobre médicas, uno de RU ${ }^{20}$ y otro sobre Medicina de Familia ${ }^{21}$ señalan que las médicas se acogen al TTP fundamentalmente para con-

12. LEY 39/1999, de 5 de noviembre, para promover la conciliación de la vida familiar y laboral de las personas trabajadoras. <http://www.boe.es/boe/dias/1999/11/06/pdfs/ A38934-38942.pdf> Consultado el 1-08-2011.

13. LEY ORGÁNICA 3/2007, de 22 de marzo, para la igualdad efectiva de mujeres y hombres. <http://www.boe.es/boe/dias/2007/03/23/pdfs/A12611-12645.pdf> Consultado el 1-08-2011.

14. DIARIO MÉDICO. <Más médicos mujeres = problemas de cobertura $>$. Publicado el 13/01/2011.

15. DIARIO MÉDICO. < Geli sugiere revisar la admisión a las facultades para evitar la feminización>. Publicado el 13-11-2008.

16. ACTA SANITARIA. < La CESM considera que la administración permanece dormida ante la feminización de la medicina> Publicado el 9-03-2011.

17. TAYLOR, Kathryn. "Career progression and destinations, comparing men and women in the NHS. Postal questionnaire surveys».BMJ, 338 (2009), pp. bl735.

18. LEVINE, Rachel, y MECHABER, Hilit. BASS, Eric. WRight, Scott. «The impact of workingpart-time on measures of academic productivity among general internists». Journal of women's health, 19 (2010), pp. 1195-2000.

19. BICKEL, Janet. «Scenarios for success- Enhancing women physicians` professional advancement».West J Med, 162 (1995), pp. 165-169.

20. Elston, Mary Ann. Women and medicine. The future. Londres, Royal College of Physicians, 2009.

21. LeVITt, Cheryl. CandiB, Lucy. Lent, Barbara, y Howard, Michelle. Women physicians and family medicine. Monograph/Literature Review. Orlando, Wonca Working Party on Women and Family Medicine, 2008.

Feminismo/s 18, diciembre 2011, pp. 323-331 
ciliar las esferas pública y familiar de la vida, y los médicos para desempeñar varias actividades profesionales. La principal consecuencia del TTP para ellas es la mayor dificultad para ocupar puestos de gestión de alta competencia ${ }^{22}, \mathrm{y}$ las académicas con TTP ocupan puestos inferiores ${ }^{23}$. Parece que la formación a tiempo parcial se asocia con TTP ${ }^{24}$.

La información precedente permite sostener la tesis de que el TTP, como medida aislada, afectará mayoritariamente a las médicas, y ello mantendrá su desigualdad en la profesión.

Según la OIT $^{25}$, la experiencia muestra que las políticas públicas conciliatorias de secuencia, que alternan los tiempos laboral y familiar, juegan en contra de la igualdad, ya que son mayoritariamente las mujeres las que se acogen a ellas. La apuesta por la igualdad real debe basarse, por un lado, en medidas derivativas, que desplazan tareas del ámbito privado al público y, sobre todo, en medidas educativas y cambios en el mercado laboral que actúen sobre los fundamentos de la construcción de género.

La literatura señala que los perfiles de trabajo de las médicas no dependen de la organización del sistema sanitario sino de la igualdad de oportunidades, los objetivos políticos y los valores culturales ${ }^{26}$. En Europa ${ }^{27}$ aparece un «efecto social» positivo sobre los niveles individuales de tensión familia-trabajo en los países que promueven la incorporación de los hombres al ámbito doméstico.

Proponer el TTP como alternativa central a la situación actual desplaza la solución del problema desde la esfera social a la esfera individual. La carencia de un conjunto de medidas políticas y sociales restará capacidad de elección a las médicas y dificultará que hombres y mujeres puedan adoptar diferentes decisiones. La medida supondrá, de facto, que sean las médicas quienes se incorporen de forma mayoritaria a esta modalidad de trabajo.

Existe el estereotipo de que las mujeres dan menos valor a su carrera que los hombres cuando esa realidad se esta desdibujando progresivamente, hay cada vez más mujeres que priorizan su carrera y más hombres que priorizan

22. Elston, Mary Ann. Op cit. pp. 117.

23. Levitt, Cheryl. CandiB, Lucy. Lent, Barbara, y Howard, Michelle. Op cit. pp. 89.

24. ElSTON, Mary Ann. Op cit. pp. 89.

25. ORGANIZACIÓN INTERNACIONAL DEL TRABAJO y PROGRAMA DE LAS NACIONES UNIDAS PARA EL DESARROLLO. Trabajo y familia. Hacia nuevas formas de conciliación con corresponsabilidad social. Santiago, Organización internacional del trabajo y Programa de las Naciones Unidas para el Desarrollo, 2009.

26. ElstOn, Mary Ann. Ibídem.

27. Crompton, Rosemary, y Lyonette, Clare. «Work- life 'balance' in Europe». Acta Sociológica, 49 (2006), pp. 379-393. 
su vida personal. Existe un cambio generacional incipiente, hombres y mujeres desean poner límites al tiempo de trabajo y disponer de más tiempo para la familia, lo que representa una oportunidad para desafiar las normas masculinas del mercado de trabajo ${ }^{28}$.

Las crisis influyen negativamente sobre los avances alcanzados por las mujeres, los pasos dados hacia la igualdad real son todavía frágiles y, de momento, reversibles. Por esto hay que estar vigilantes sobre la aplicación de políticas que mantengan o empeoren las condiciones de desigualdad de las médicas.

\section{Conclusiones}

La proporción de médicas está aumentando rápidamente en numerosos países a la vez que su especialización presenta un perfil con características similares. Esto conlleva cambios potenciales en los sistemas sanitarios debido a que las mujeres siguen siendo las responsables, casi en exclusiva, de las tareas de reproducción. La conciliación se entiende como una propuesta dirigida a las mujeres, las cuales encuentran dificultades para conciliar, todo ello las empuja a optar, con frecuencia, por las formulas de reducción de jornada entre las que se encuentra el TTP.

Igualmente, un conjunto de indicadores revelan que persiste la desigualdad de las médicas en su carrera y desarrollo profesional, y que las formulas de TTP contribuyen a mantener esta situación.

Se deben establecer políticas que apoyen la igualdad en el ámbito sanitario, como: a) incentivar que los hombres se acojan a las medidas de conciliación (permiso de paternidad, reducción de jornada, permisos retribuidos, etc.); b) potenciar medidas derivativas que cubran las funciones reproductivas; c) incluir desgravaciones fiscales para los cuidados; d) fomentar la creación de redes de médicas y la difusión de referentes para las mismas.

De forma más general, son ineludibles políticas educativas que trasformen la cultura sexista, basada en la asignación de género en función del sexo, en una cultura de justicia e igualdad entre todas las personas. Simultáneamente es imprescindible trasformar el mercado de trabajo en un modelo menos androcéntrico que incorpore los cuidados como eje central de la vida, y tenga en cuanta que es socialmente imposible escindir la vida laboral y familiar de cada persona. El ejercicio de la medicina y sus puestos de trabajo están definidos

28. Williams, Joan. Unbending gender. Why family and work conflict and what to do about it. Nueva York: Oxford University Press, 2000.

Feminismo/s 18, diciembre 2011, pp. 323-331 
como si sus profesionales tuvieran un apoyo en casa a tiempo completo, cosa que ocurría en nuestra sociedad hasta tiempos recientes.

Con el fin de conocer y hacer un seguimiento de las condiciones de trabajo y desarrollo profesional subsecuente de médicas y médicos, es necesario crear bases de datos y obtener indicadores de género adecuados. De igual modo, son necesarios estudios longitudinales para indagar, tanto sobre las causas y consecuencias de las formas de trabajo en cada sexo, como sobre los resultados de las políticas y medidas que se implanten al respecto.

\section{Referencias bibliográficas}

ACTA SANITARIA. <La CESM considera que la administración permanece dormida ante la feminización de la medicina> Publicado el 9-03-2011.

Arrizabalaga, Pilar. Valls-Llobet, Carme. «Mujeres médicas: de la incorporación a la discriminación».Medicina Clínica (Barcelona), 125 (2005), pp. 103-107.

BICKEL, Janet. «Scenarios for success- Enhancing women physicians` professional advancement».West J Med, 162 (1995), pp. 165-169.

Crompton, Rosemary. Lyonette, Clare. «Work- life 'balance' in Europe». Acta Sociológica, 49 (2006), pp. 379-393.

Delgado, Ana. Saletti-Cuesta, Lorena. López-FernÁndez, Luis Andrés. Et al. «Gender and the professional career of primary care physicians in Andalusia (Spain)». BMC Health Services Research, 11 (2011), pp, 51.

Delgado, Ana. SAletti-Cuesta, Lorena. Toro-CÁRdenAS, Silvia. Et al. «Validación de escala para evaluar la relación familia-trabajo en médicas y médicos de familia». Revista Española de Salud Pública, 85 (2011), pp, 159-172.

DIARIO MÉDICO. < Geli sugiere revisar la admisión a las facultades para evitar la feminización>. Publicado el 13-11-2008.

DIARIO MÉDICO. < Más médicos mujeres = problemas de cobertura $>$. Publicado el 13/01/2011.

Elston, Mary Ann. Women and medicine. The future. Londres, Royal College of Physicians, 2009.

González lópez-VAlcarcel, Beatriz. Barber Pérez, Patricia. Oferta y necesidad de médicos especialistas en España (2006-2030). Palmas de Gran Canaria, Universidad de las Palmas de Gran Canaria, 2007.

INSTITUTO NACIONAL DE ESTADÍSTICA. Encuesta Población Activa. Serie 2005-2010 < http://www.ine.es/jaxiBD/tabla.do?per=12\&type=db\&divi=EPA \&idtab=1020> Consultado el 1-08-2011.

KvaERner, Kari. AASlAnd, Olaf. Botten, Grete. «Female medical leadership: cross sectional study».BMJ, 318 (1999), pp. 91-94. 
LeVine, Rachel. Mechaber, Hilit. Bass, Eric. Wright, Scott. «The impact of working part-time on measures of academic productivity among general internists».Journal of women's health, 19 (2010), pp. 1195-2000.

LevitT, Cheryl. CAndib, Lucy. Lent, Barbara. Howard, Michelle. Women physicians and family medicine. Monograph/Literature Review. Orlando, Wonca Working Party on Women and Family Medicine, 2008.

LEY 39/1999, de 5 de noviembre, para promover la conciliación de la vida familiar y laboral de las personas trabajadoras. < http://www.boe.es/boe/ dias/1999/11/06/pdfs/A38934-38942.pdf> Consultado el 1-08-2011.

LEY ORGÁNICA 3/2007, de 22 de marzo, para la igualdad efectiva de mujeres y hombres. <http://www.boe.es/boe/dias/2007/03/23/pdfs/A12611-12645.pdf> Consultado el 1-08-2011.

Mcmurray, Julia. Angus, Graham. Cohen, May. Et al. «Women in Medicine: A four-nation comparison». JAMWA, 57 (2002), pp. 185-190.

ORGANIZACIÓN INTERNACIONAL DEL TRABAJO. PROGRAMA DE LAS NACIONES UNIDAS PARA EL DESARROLLO. Trabajo y familia. Hacia nuevas formas de conciliación con corresponsabilidad social. Santiago, Organización internacional del trabajo y Programa de las Naciones Unidas para el Desarrollo, 2009.

ORTIZ, Teresa. «La práctica sanitaria en la historia ¿una cuestión femenina?». EIDON, 23 (2007), pp. 61-65.

Rohlfs, Izabella. Arrizabalaga, Pilar. Artazcoz, Lucia. Et al. Salud, estilos de vida y condiciones de trabajo de los médicos y médicas de Cataluña. Barcelona, Fundación Galatea, 2007.

TAYLOR, Kathryn. «Career progression and destinations, comparing men and women in the NHS. Postal questionnaire surveys».BMJ, 338 (2009), pp. b1735.

VÁzQUez VeGA, Pablo (editor). La feminización de las profesiones sanitaria. Bilbao, Fundación BBVA, 2010.

Williams, Joan. Unbending gender. Why family and work conflict and what to do about it. Nueva York: Oxford University Press, 2000.

Feminismo/s 18, diciembre 2011, pp. 323-331 



\title{
EL ESTATUS SOCIAL DE LAS MUJERES Y SU IMPACTO EN LA SALUD DE LA POBLACIÓN
}

\author{
MERCEDES CARRASCO-PORTIÑO \\ Universidad de Alicante \\ Universidad de Concepción (Chile)
}

Recibido: 15/07/2011

Aceptado: 29/09/2011

\section{Referencia del artículo comentado}

KARESTAN C; KOENENN, LINCOLN Alisa y APPLETON Allison. «Women's status and child well-being: a state-level analysis» Social Science \& Medicine, 2006, (63): pp. 2999-3012.

\section{Resumen}

En este estudio se llevó a cabo un análisis ecológico de la relación entre el estado social de las mujeres y el bienestar de los niños en los 50 Estados Unidos. El estado de las mujeres fue determinado mediante 4 índices compuestos: Participación política de las mujeres, autonomía económica, empleo e ingresos, y derechos reproductivos. El bienestar infantil fue medido mediante 5 ítems: porcentaje de niños con bajo peso, mortalidad infantil, mortalidad en adolescentes, tasa de fracaso escolar, y tasa de embarazos infantiles. Los mejores niveles del estado social de las mujeres en todos los indicadores se asociaron significativamente con los mejores niveles de bienestar de los niños en un análisis crudo. Varias asociaciones permanecieron significativas después de ajustar por desigualdades en los ingresos etnia. La participación política de las mujeres se asoció con un porcentaje significativamente menor de niños con bajo peso al nacer $(p<.001)$ y menor tasa de embarazo de adolescentes $(p<.05)$. Los empleos de las mujeres y los ingreso se asociaron con baja mortalidad infantil $(p<.05)$ y de embarazo en adolescentes $(p<.05)$. Mayor autonomía económica y social para las mujeres se asoció con mejores resultados en los niños en todos los indicadores utilizados ( $p<.01$ all). Mayores derechos reproductivos se asociaron con una significativa menor mortalidad infantil $(p<.01)$. Se concluye que el bienestar de los niños es peor en los Estados en 
que las mujeres tienen un menor estado político, económico y social. El estado social de las mujeres es un importante factor del contexto social de los niños, lo cual puede impactar su bienestar. Es necesario desarrollar análisis multinivel de la asociación entre el estado social de las mujeres y el bienestar infantil.

Feminismo/s 18, diciembre 2011, pp. 333-342 


\section{Introducción}

Existe múltiple evidencia de que las desigualdades sociales son un factor estructural determinante de las desigualdades de género en salud 1, 2, 3, 4, 5. Sin embargo, es insuficiente considerar sólo indicadores sociales para captar el estatus de las mujeres respecto a los hombres, como se viene haciendo en estudios sobre desarrollo de género ${ }^{6}$. Es por ello que este ensayo quiere centrarse en un estudio que va más allá de este simplista enfoque. El estudio fue liderado por Karestan Koenen y publicado en la revista Social Science $\mathcal{E}$ Medicine. El objetivo de este estudio fue evaluar la influencia del estatus de las mujeres en el bienestar infantil en cada uno de los 50 estados de los Estados Unidos de Norteamérica. Resulta interesante conocer los elementos que componen el estatus de las mujeres como son: la participación política, el empleo y los ingresos, la autonomía económica y social, y los derechos reproductivos.

Cabe destacar que los valores de salud globales de los países no proporcionan información precisa sobre las diferencias o desigualdades en la distribución geográfica de la salud y enfermedad, y sus determinantes socioeconómicos, políticos y culturales; siendo necesario considerar unidades geopolíticas más pequeñas ${ }^{7,8,9,10}$, como se ha considerado en el estudio de Koenen et al.

1. KaWAChi, I; Kennedy, B. P.; GuPta, V.; Prothrow-Stith, D. Women's status and the health of women and men: a view from the States. Soc Sci \& Med (1999), pp. 21-32.

2. MetCAlfe, B. D.; Afanassieva, M. Gender, work, and equal opportunities in central and eastern Europe. Women in Management Review (2005), pp. 397-411.

3. YU, Mei-Yu; SARRY, Rosemary. Women's Health Status and Gender Inequality in China. Soc Sci Med (1997), pp. 1885-1898.

4. Muntaner, C., Borrell, C.; Vanroelen, C.; Chung, H.; Benach, J.; Kim, I. H.; NG, E. Employment relations, social class and health: a review and analysis of conceptual and measurement alternatives. Soc Sci Med. (2010), pp. 2130-2140.

5. Artacoz, L; Cortes, I; Borrell, C; Escribà-Agüir, V; Cascant, L. Gender and social class differences in the association between early retirement and health in Spain. Women's Health Issues. (2010), pp. 441-447.

6. YU, Mei-Yu; SARRY, Rosemary. Op. cit., p. 1.

7. KaWAChi, I.; Kennedy, B. P.; Gupta, V.; Prothrow-Stith, D. Op. cit. p. 2.

8. StARFIELD, B. State of the art in research on equity in health. J Health Polit.Policy Law. (2006), pp. 11-32.

9. WilKInSON, R. G.; PICKETT, K. E. Income inequality and population health: A review and explanation of the evidence. Soc Sci Med. (2006), pp. 1768-1784.

10. StarfiELD, B. Pathways of influence on equity in health. Soc Sci Med. (2007), pp. 1355-1362.

Feminismo/s 18, diciembre 2011, pp. 333-342 
Desde la Conferencia de Beijing en 1995 y el informe Beijing +5, la Organización de Naciones Unidas viene destacando la necesidad de adoptar indicadores de género para diagnosticar la situación de las mujeres y hacer políticas públicas consecuentes ${ }^{11,12}$. Ha sido tal la importancia de la sensibilidad de género en el desarrollo que se ha incorporado en el $3^{\text {er }}$ Objetivo de Desarrollo del Milenio de Naciones Unidas, que pretende eliminar las desigualdades de género e incrementar la autonomía de las mujeres en el año $2015^{13,14,15}$. Es por ello, que se hace necesario la reflexión acerca de la construcción de indicadores que midan la situación de las mujeres en una sociedad y su impacto en la salud de la población como se ha hecho en el estudio de Koenen et al.

\section{Desarrollo}

Koenen y su equipo quisieron seguir la metodología de trabajo de Kawachi et al. ${ }^{16}$ y McLeod et al. ${ }^{17}$, llegando a elaborar un estudio de diseño ecológicotransversal que intentaba explorar la relación entre el estatus social de las mujeres y el bienestar de niños/niñas en Estados Unidos.

11. NACIONES UNIDAS. Informe de la Cuarta Conferencia Mundial sobre la Mujer. Disponible en: www.un.org/womenwatch/confer/beijing/reports/platesp.htm (Acceso 24.07.2011).

12. NACIONES UNIDOS BEIJING+5. Período extraordinario de la Asamblea General. Mujeres 2000: Igualdad de género, desarrollo y paz para el siglo XXI. Nueva York: 2000. Disponible en: www.un.org/spanish/conferences/Beijing/mujer2021.htm (Acceso 24.07 .2011$)$

13. NACIONES UNIDAS. Objetivos de Desarrollo del Milenio. Disponible en: http://www. undp.org/spanish/mdg/basics.shtml (Acceso 24.07.20114).

14. GLOBAL MONITORING REPORT 2007. Chapter 3. Promoting Gender Equality and Women's Empowerment. Disponible en: http://siteresources.worldbank.org/INTGLOMONREP2007/Resources/3413191-1176390231604/105-148_GMRch3.pdf (Acceso 24.07.2011)

15. THE WORLD BANK. Global Monitoring Report 2007. Confronting the Challenges of Gender Equality and Fragile States. Fact Sheet: Promoting Gender Equality and Women's Empowerment. Disponible en: http://web.worldbank.org/WBSITE/EXTERNAL/EXTDEC/EXTGLOBALMONITOR/EXTGLOMONREP2007/0,, menuPK: 3413296 pagePK:64218926 piPK:64218953 theSitePK:3413261,00.html (Acceso 24.07.2011).

16. KaWachi, I.; Kennedy, B. P.; Gupta, V.; Prothrow-Stith, D. Op. cit. p. 2.

17. MCleod, J. D.; NONNEMAKeR, J. M.; CAll, K.T. Income inequality, race, and child well-being: An aggregate analysis in the 50 United States. Journal of Health \& Social Behavior (2004), pp. 249-264. 
¿De donde recogieron la información para valorar el bienestar infantil?

El bienestar de los niños y las niñas se evaluó a través de los indicadores de bienestar y salud infantil de la Fundación Annie E. Casey ${ }^{18}$, que son los siguientes:

- Bajo peso al nacer.

- Tasa de mortalidad infantil.

- Tasa de mortalidad de adolescentes por homicidio, suicidio y accidentes (15 a 19 años).

- Tasa de natalidad en adolescentes (15 a 17 años).

- Abandono escolar de secundaria (16 a 19 años).

¿Cuál fue la fuente de información de los indicadores del estatus de las mujeres?

Los indicadores sobre el status de las mujeres en la sociedad se extrajeron del Institute for Women's Policy Research (IWPR) ${ }^{19}$ que calculan anualmente indicadores que miden la participación política, el empleo y los ingresos, la autonomía social y económica, y por último los derechos reproductivos de las mujeres (Ver tabla 1).

En este estudio se realizaron análisis de los datos controlando por variables como el ingreso medio familiar, el porcentaje de la población en estado de pobreza, la desigualdad en ingresos y composición racial. Los resultados demuestran la relación que existen entre el estatus de las mujeres y los indicadores de bienestar infantil estudiados. En la siguiente tabla 2 se muestra un resumen de las asociaciones en el estudio motivo de este ensayo.

¿Cuál será el impacto del estatus de las mujeres en la salud de la población española? ¿Se podría realizar un estudio de similares características en España?

Actualmente, no disponemos de un centro tan especializado como el Institute for Women's Policy Research de Estados Unidos. Lo más cercano es el Instituto de la Mujer del Ministerio de Sanidad, Política Social e Igualdad. Sin embargo, dentro del grupo de investigación de la Universidad de Alicante se está

18. ANNIE E. CASEY FOUNDATION. Kids count data book: 2004. Baltimore, MD: Annie E. Casey Foundation, 2004.

19. INSTITUTE FOR WOMEN'S POLICY RESEARCH. The Status of Women in the States. Disponible en http://www.iwpr.org/publications/pubs/the-status-of-women-in-thestates (Acceso 24.07.2011)

Feminismo/s 18, diciembre 2011, pp. 333-342 
Tabla 1. Indicadores del estatus de las mujeres y sus componentes según el Institute for Women's Policy Research

\begin{tabular}{|c|c|}
\hline Indicador & Componente \\
\hline \multirow{4}{*}{$\begin{array}{l}\text { Índice de } \\
\text { participación } \\
\text { política }\end{array}$} & Mujeres con derecho a voto \\
\hline & Mujeres que han ejercido el voto \\
\hline & $\begin{array}{l}\text { Mujeres en puestos políticos-legislativos estatales (senadoras, } \\
\text { diputadas, entre otros) }\end{array}$ \\
\hline & Recursos institucionales para mujeres \\
\hline \multirow{4}{*}{$\begin{array}{l}\text { Índice de empleo e } \\
\text { ingresos }\end{array}$} & Ingreso anual medio de las mujeres \\
\hline & Razón de ingresos de mujeres respecto a los hombres \\
\hline & Mujeres con participación en la fuerza de trabajo \\
\hline & Mujeres con cargos directivos y ocupaciones profesionales. \\
\hline \multirow{4}{*}{$\begin{array}{l}\text { Índice de } \\
\text { autonomía social y } \\
\text { económica }\end{array}$} & Porcentaje de mujeres con seguridad social \\
\hline & $\begin{array}{l}\text { Porcentaje de mujeres de } 25 \text { o más años con } 4 \text { o más años de } \\
\text { universidad. }\end{array}$ \\
\hline & Mujeres con trabajo propio privado \\
\hline & Porcentaje de mujeres por debajo del nivel de pobrezas \\
\hline \multirow[t]{8}{*}{$\begin{array}{l}\text { Índice de derechos } \\
\text { reproductivos }\end{array}$} & $\begin{array}{l}\text { Consentimiento obligatorio para la interrupción voluntaria del } \\
\text { embarazo (IVE) en menores de edad }\end{array}$ \\
\hline & Períodos de espera para la IVE \\
\hline & Restricciones de instituciones pública para realizar la IVE \\
\hline & $\begin{array}{l}\text { Porcentaje de mujeres que viven en condados con una legislación } \\
\text { que facilita la IVE }\end{array}$ \\
\hline & Gobernadores(as)/Legisladores(as) a favor de la IVE \\
\hline & Tratamientos de fertilidad \\
\hline & Matrimonios homosexuales y adopción \\
\hline & Educación sexual obligatoria \\
\hline
\end{tabular}

Tabla 2. Asociación de los indicadores de situación/estatus de la mujer con el bienestar infantil estadísticamente significativa (modelos ajustados)

\begin{tabular}{|l|c|c|c|c|c|}
\hline & $\begin{array}{c}\text { Bajo peso al } \\
\text { nacer }\end{array}$ & $\begin{array}{c}\text { Mortalidad } \\
\text { infantil }\end{array}$ & $\begin{array}{c}\text { Mortalidad } \\
\text { adolescente }\end{array}$ & $\begin{array}{c}\text { Abandono } \\
\text { escolar } \\
\text { secundaria }\end{array}$ & $\begin{array}{c}\text { Tasa de } \\
\text { natalidad en } \\
\text { adolescente }\end{array}$ \\
\hline $\begin{array}{l}\text { Participación } \\
\text { política }\end{array}$ & $\mathrm{X}$ & $\mathrm{X}$ & & $\mathrm{X}$ \\
\hline $\begin{array}{l}\text { Empleo e } \\
\text { ingresos }\end{array}$ & $\mathrm{X}$ & $\mathrm{X}$ & $\mathrm{X}$ & $\mathrm{X}$ & $\mathrm{X}$ \\
\hline $\begin{array}{l}\text { Autonomía } \\
\text { económica y } \\
\text { social }\end{array}$ & & $\mathrm{X}$ & & & \\
\hline $\begin{array}{l}\text { Derechos } \\
\text { reproductivos }\end{array}$ & & & & & \\
\hline
\end{tabular}


llevando a cabo un proyecto que pretende construir indicadores compuestos de desarrollo de género y de la situación social de hombres y mujeres a nivel de comunidades autónomas para facilitar la exploración de asociaciones entre estos indicadores con problemas de salud y sus determinantes.

En España, existe un trabajo que mediante el índice de desarrollo de género propuesto por la Organización de Naciones Unidos en el año 1995, se evidenció que las provincias españolas con menor desarrollo de género presentaban mayores tasas de mortalidad por violencia del compañero íntimo ${ }^{20}$. Este indicador ha sido reemplazado en el 2010 por el índice de desigualdad de género. Lo que hace indispensable pensar en la construcción de este y otros indicadores para la valoración de la situación social de mujeres como también de hombres. Por otro lado, es importante destacar que en un anterior estudio liderado por Ichiro Kawachi en Estados Unidos se demostró con los datos del Institute for Women's Policy Research que el estatus de las mujeres puede predecir el estado de salud de los hombres también ${ }^{21}$, no sólo de niños(as) y de su propia salud.

Cabe destacar que el Institute for Women's Policy Research (IWPR), con sede en Washington fue fundado el 1987 por la necesidad de disponer de una organización cuyo propósito fuera evidenciar la injusticia económica que vivían las mujeres estadounidenses. Sin embargo, después de más de 25 años, este instituto ha permitido que políticos y líderes claves de la sociedad estadounidense hablen un idioma común a través de la información producida por éste. En este sentido, ha permitido aumentar la capacidad de formular y aplicar leyes que beneficien a las mujeres y sus familias en este país (Ver figura 1).

El IWPR ha publicado cientos de informes, notas informativas y de investigación donde la mujer es el punto central del análisis, y aunque sólo produzcan información de Estados Unidos son un ejemplo a imitar para el resto del mundo, contribuyendo así, a mejorar la investigación y las políticas basadas en la evidencia para disminuir las desigualdades de género.

\section{Conclusiones}

Un grave problema que compromete a las investigaciones poblacionales es la falta de información para estimar la relación entre determinantes de contexto

20. Vives-Cases, C.; Álvarez-Dardet, C.; Carrasco-Portiño, M.; Torrubiano-DomínGUEZ, J. El impacto de la desigualdad de género en la violencia del compañero íntimo en España. Gac Sanit. (2007), pp. 242-246

21. KaWachi, I.; Kennedy, B. P.; Gupta, V; Prothrow-Stith, D. Op. cit. p. 2

Feminismo/s 18, diciembre 2011, pp. 333-342 


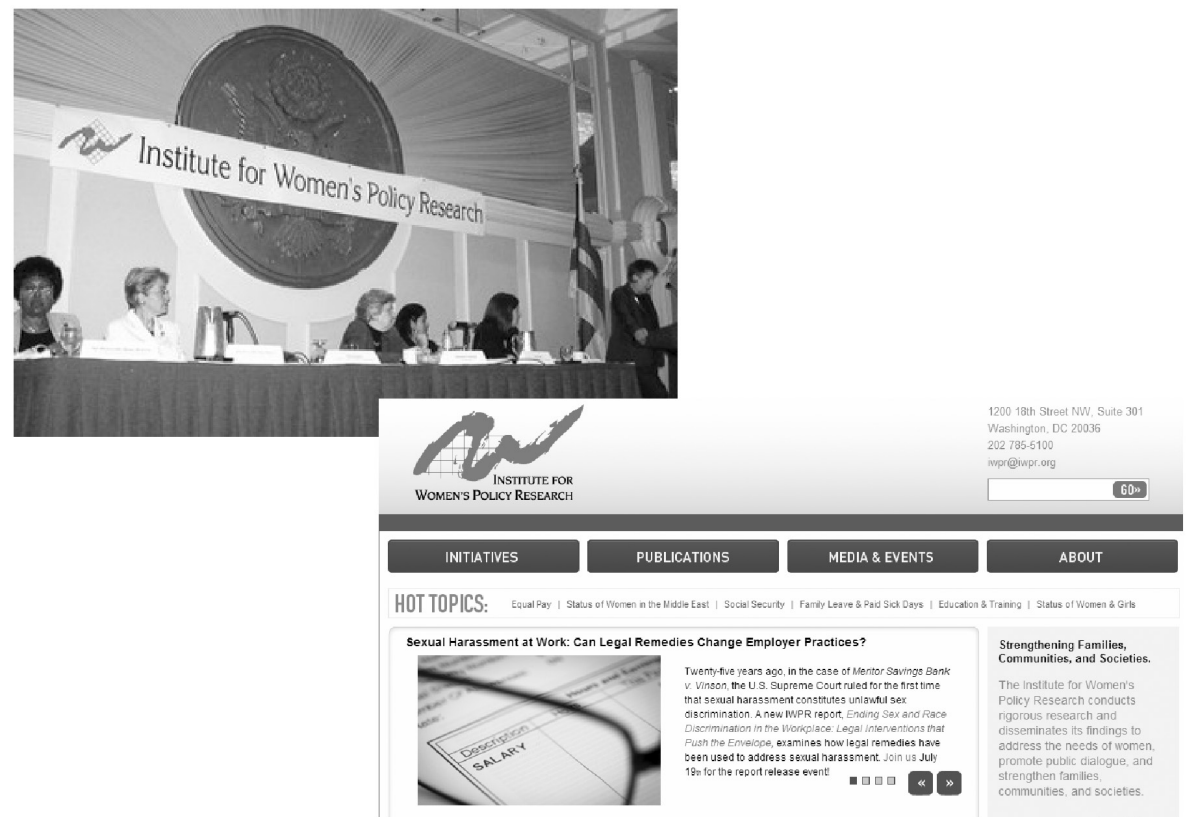

Figura 1.

social y los problemas de salud y sus estrategias terapéuticas. Por otro lado, la igualdad de género no siempre es un elemento de los programas de desarrollo económico y social, en parte, por la falta de evidencia científica sobre su relevancia para el bienestar, la calidad de vida y la salud.

Afortunadamente en España, la Ley Orgánica para la igualdad efectiva de mujeres y hombres en 2007 favorece la producción, recolección y sistematización de datos con el fin de hacer viables y aplicables políticas de desarrollo de género. Esto sucede en el marco de iniciativas internacionales para la igualdad entre las mujeres y los hombres, en donde los indicadores nacionales y transnacionales pasan a tener reconocimiento o proyección social y política, al acordar los diferentes países objetivos comunes a partir de indicadores de control.

El desarrollo de políticas y estrategias efectivas de mejora de la situación socio-sanitaria en las comunidades autónomas y provincias de España precisa de un esfuerzo de compilación de información que facilite la creación de indicadores compuestos de desarrollo y por ende de desigualdades de género, para analizar su efecto en la salud de ambos sexos. 


\section{Referencias bibliográficas}

ANNIE E. CASEY FOUNDATION. Kids count data book: 2004. Baltimore, MD: Annie E. Casey Foundation, 2004.

Artacoz, L.; Cortes, I.; Borrell, C.; EscribÀ-AgüIr, V.; CASCANT, L. Gender and social class differences in the association between early retirement and health in Spain. Women's Health Issues. (2010), pp. 441-447.

DomínguEZ, J. El impacto de la desigualdad de género en la violencia del compañero íntimo en España. Gac Sanit. (2007), pp. 242-246

GLOBAL MONITORING REPORT 2007. Chapter 3. Promoting Gender Equality and Women's Empowerment. Disponible en: http://siteresources.worldbank. org/INTGLOMONREP2007/Resources/3413191-1176390231604/105-148_ GMRch3.pdf (Acceso 24.07.2011)

INSTITUTE FOR WOMEN'S POLICY RESEARCH. The Status of Women in the States. Disponible en http://www.iwpr.org/publications/pubs/the-status-ofwomen-in-the-states (Acceso 24.07.2011)

KaWAchi, I.; Kennedy, B. P.; Gupta, V.; Prothrow-Stith, D. Women's status and the health of women and men: a view from the States. Soc Sci \& Med (1999), pp. 21-32.

MCleOd, J. D.; NONNEMAKer, J. M.; CALL, K.T. Income inequality, race, and child well-being: An aggregate analysis in the 50 United States. Journal of Health \& Social Behavior (2004), pp. 249-264.

MetCalfe, B. D.; Afanassieva, M. Gender, work, and equal opportunities in central and eastern Europe. Women in Management Review (2005), pp. 397-411.

Muntaner, C., Borrell, C.; Vanroelen, C.; Chung, H.; BenaCH, J.; Kim, I. H..; NG, E. Employment relations, social class and health: a review and analysis of conceptual and measurement alternatives. Soc Sci Med. (2010), pp. 2130-2140.

NACIONES UNIDAS. Informe de la Cuarta Conferencia Mundial sobre la Mujer. Disponible en: www.un.org/womenwatch/confer/beijing/reports/platesp.htm (Acceso 24.07.2011).

NACIONES UNIDOS BEIJING+5. Período extraordinario de la Asamblea General. Mujeres 2000: Igualdad de género, desarrollo y paz para el siglo XXI. Nueva York: 2000. Disponible en: www.un.org/spanish/conferences/Beijing/ mujer2021.htm (Acceso 24.07.2011).

NACIONES UNIDAS. Objetivos de Desarrollo del Milenio. Disponible en: http:// www.undp.org/spanish/mdg/basics.shtml (Acceso 24.07.20114).

StARFIEld, B. Pathways of influence on equity in health. Soc Sci Med. (2007), pp. 1355-1362.

STARFIELD, B. State of the art in research on equity in health. J Health Polit.Policy Law. (2006), pp. 11-32. 
THE WORLD BANK. Global Monitoring Report 2007. Confronting the Challenges of Gender Equality and Fragile States. Fact Sheet: Promoting Gender Equality and Women's Empowerment. Disponible en: http://web.worldbank. org/WBSITE/EXTERNAL/EXTDEC/EXTGLOBALMONITOR/EXTGLOMON REP2007/0,,menuPK:3413296 pagePK:64218926 piPK:64218953 theSite PK:3413261,00.html (Acceso 24.07.2011).

Vives-Cases, C.; Álvarez-Dardet, C.; Carrasco-Portiño, M.; Torrubiano.

Wilkinson, R. G.; PiCKeTt, K. E. Income inequality and population health: A review and explanation of the evidence. Soc Sci Med. (2006), pp. 1768-1784. YU, Mei-Yu; SARRY, Rosemary. Women's Health Status and Gender Inequality in China. Soc Sci Med (1997), pp. 1885-1898. 


\title{
SENSIBILIDAD DE GÉNERO EN LA INVESTIGACIÓN SOBRE POLÍTICAS SANITARIAS
}

\author{
ERICA BRIONES VOZMEDIANO \\ Universidad de Alicante
}

Recibido/15/07/2011

Aceptado/25/09/2011

\begin{abstract}
Referencia del artículo comentado
PEIRÓ PÉREZ, Rosana, ÁlVAREZ-DARDET, Carlos, COLOMER Concha, MOYA Carmela, BORRELL Carmen, PLASENCIA Antonio, ZAFRA Eduardo y PASARÍN María Isabel. «Sensibilidad de género en la formulación de planes de saludo en España. Lo que pudo ser y no fue». Gaceta Sanitaria, 18, (2004), pp. 36-46.
\end{abstract}

\section{Resumen}

Objetivo: Examinar de forma sistemática la sensibilidad de género en las políticas formuladas en los planes de salud, de las comunidades autónomas (CCAA) de España que lo tienen disponible. Definimos «sensibilidad de género» como el grado en que los planes de salud tienen en cuenta la existencia del género como categoría de relación y desarrollan acciones para aminorar las desigualdades debidas a éste.

Material y métodos: Se diseñó un cuestionario con una estructura similar a la de los planes de salud, que a su vez están basados en la propuesta de la Organización Mundial de la Salud (OMS). Éstos tienen una parte introductoria, que hemos denominado de «contenido simbólico» y describe objetivos y valores generales del plan de salud, y otra, que hemos denominado el «contenido operativo» del plan de salud, donde se concretan los objetivos específicos y las intervenciones para conseguirlos. Se construyen índices de sensibilidad simbólica de género y de sensibilidad operativa de género. Resultados: Se analizaron 13 planes de salud. El País Vasco, la Comunidad Valenciana y Canarias tienen un alto índice de sensibilidad simbólica que no se corresponde en todas las comunidades con su índice de sensibilidad operativa. El País Vasco, Cataluña y Galicia tienen los índices de sensibilidad operativa de género más altos. 
Conclusiones: La sensibilidad de género en los planes de salud es muy desigual por CCAA. Algunas vías para la acción serían la formación de coaliciones y redes de profesionales y colectivos para poner de manifiesto el problema, así como construir sobre la experiencia de las CCAA con mayor sensibilidad de género en sus propuestas.

Palabras clave: Plan de salud. Desigualdad. Sensibilidad de género. Política sanitaria. 


\section{Introducción}

El artículo de Peiró y colaboradores, ofrece un ejemplo de métodos útiles de investigación con sensibilidad de género. En él se examina de forma sistemática la sensibilidad de género en los planes de salud de las Comunidades Autónomas (CCAA) españolas, entendida como la medida en que estas políticas sanitarias tienen en cuenta la existencia del género como categoría de relación y desarrollan acciones para aminorar las desigualdades debidas al género.

La metodología empleada resulta novedosa, a la vez que práctica, para la investigación en salud pública. La/os autora/es describen y comparan los diferentes planes de salud de las CCAA, para lo que diseñaron un cuestionario ad hoc como guía de lectura que recogía información sobre la sensibilidad de género de cada uno de los apartados de los planes de salud. Éstos se estructuraban en una parte introductoria, que describía los objetivos y valores generales del plan de salud y se denominó «contenido simbólico», y otra dónde se concretaban los objetivos específicos y las intervenciones para conseguirlos, que se denominó «contenido operativo». Se construyeron índices de sensibilidad de género simbólica y operativa, en base al número de respuestas positivas a las preguntas dicotómicas que planteaba el cuestionario

En este estudio se analizaron 13 planes de salud de las CCAA que lo tenían disponible. Los aspectos que se analizan de estos planes de salud son los problemas de salud priorizados, los entornos para la salud -entendidos como el lugar y el contexto social en que las personas desarrollan las actividades diarias y en el cual interactúan factores ambientales, organizativos y personales que afectan a la salud y el bienestar ${ }^{1}$ - los objetivos de apoyo al desarrollo del plan y la existencia de capítulos específicos sobre salud reproductiva, salud de las mujeres y grupos de población vulnerable.

El plan de salud del País Vasco resultó ser el más sensible al género y el problema de salud para el que se proponían más intervenciones fue la enfermedad oncológica, debido a la especificación de intervenciones en cánceres

1. ORGANIZACIÓN MUNDIAL DE LA SALUD: Promoción de la salud. Glosario. Ginebra: Organización Mundial de la Salud; 1998.

Feminismo/s 18, diciembre 2011, pp. 343-351 
ligados al sexo. Se concluyó que la sensibilidad de género en los planes de salud era muy desigual por CCAA y los hallazgos sugirieron que la integración del género en los planes de salud de las CCAA aún era escasa.

\section{Desarrollo}

Desde 1995, a partir de IV Conferencia Mundial sobre la Mujer de Beijing, la ONU insta a diseñar, implementar y supervisar políticas y programas que sean efectivos, eficientes y sensibles al género. Además, incorporar el género de manera transversal en las políticas sanitarias es una de las recomendaciones de la OMS, que en 2002 aprobó su Política de Género con el objetivo de contribuir a la mejora de la salud tanto de mujeres como de hombres, mediante investigaciones, políticas y programas de salud que presten la debida atención a las cuestiones de género y que promuevan la equidad y la igualdad entre hombres y mujeres ${ }^{2}$.

Los métodos de investigación con perspectiva de género constituyen herramientas que posibilitan el mainstreaming de género, una estrategia política y técnica para avanzar en la equidad de género, uno de los principios básicos de justicia social. Aplicar el mainstreaming de género implica que se reconozcan las necesidades de mujeres y hombres y las desigualdades de género en toda la estructura de las políticas públicas, por lo que transversalizar la perspectiva de género suele implicar la renovación de las políticas en todas las fases del proceso: diseño, implementación y evaluación ${ }^{3}$.

Los programas y políticas sanitarias sensibles al género son necesarias porque tienen la capacidad de transformar las relaciones de género, si promueven el empoderamiento de las mujeres, fomentan la conciencia crítica de roles y normas de género, se dirigen a cambiar las relaciones desiguales de poder o la distribución de recursos. Por ejemplo, la integración del género en los programas de salud reproductiva tiene efectos positivos sobre los resultados en este ámbito ${ }^{4}$. Si las políticas que promueven la igualdad de género son diseñadas con el fin de ser implementadas, se requiere una identificación rigurosa de los aspectos en común y las diferencias entre las necesidades en salud de

2. ORGANIZACIÓN MUNDIAL DE LA SALUD: Integrating gender perspectives in the work of WHO. WHO gender policy. Ginebra,: Organización Mundial de la Salud; 2002.

3. Peiró, Rosana, Vives, Carmen, Álvarez-Dardet, Carlos y R. MAS: «El Análisis De Políticas Con Enfoque De Género Y Salud.», en Carmen Borrell y Lucía ArTAZCoz (ed.), $5^{a}$ Monografía. Sociedad Española De Epidemiología. Investigación Sobre Género Y Salud, Barcelona, Sociedad Española de Epidemiología, 2007, pp. 119-37.

4. ORGANIZACIÓN MUNDIAL DE LA SALUD, A summary of the "so what? Report, Ginebra, Organización Mundial de la Salud, 2005. 
mujeres y hombres, así como un análisis de los obstáculos para acceder a los servicios sanitarios asociados al género ${ }^{5}$.

En este breve ensayo se plantea por qué es necesario analizar las políticas públicas desde el enfoque de género. Las políticas sociales impactan de manera diferente en mujeres y hombres y, como consecuencia, pueden producir o incrementar las desigualdades en salud si ignoran el género o están destinadas a proteger a uno de los dos sexos. Debido, de alguna manera, al patrón androcéntrico de la ciencia, se tiende a diseñar políticas e intervenciones centradas en el modelo masculino, obviando en ocasiones las necesidades de las mujeres $^{6}$.

Aunque la equidad de género es un objetivo que cada vez se está incluyendo con más frecuencia en las políticas sanitarias, es necesario evaluar si los objetivos van seguidos de acciones para implementarlos. Según Peiró y cols, aunque el análisis realizado no comprenda las intervenciones que realmente se implantan, el análisis de las intenciones explícitas recogidas en los planes de salud puede informar sobre los ejes en los que se mueven estas políticas, que con posterioridad inspirarán las acciones que se emprendan. Mediante el análisis de género se podrán identificar buenas prácticas para ofrecer una atención sanitaria equitativa y prevenir las desigualdades en salud entre hombres y mujeres ${ }^{7,8}$. Además, aplicar el enfoque de género al investigar transmite la evidencia existente sobre el impacto de género en el acceso a los servicios de salud o en la atención a determinados problemas de salud y, a la vez, supone un esfuerzo para salvar la distancia entre los responsables de políticas de salud y los investigadores en género y salud.

Siguiendo los principios rectores de la nueva política global de salud de la OMS «Salud para todos en el siglo XXI», que plantea la igualdad de género como uno de los principios básicos, el cuestionario diseñado en este estudio

5. Gispert, Rosa: «Objetivo 33: Desarrollo De Las Políticas Salud Para Todos.», en ÁlvAREZ-DARDET, Carlos, y PEIRÓ, Rosana (eds.) Informe SESPAS 2000.

6. Ruiz Cantero, Maria Teresa, Vives Cases, Carmen, Artazcoz, Lucía, Delgado, Ana, García Calvente Maria del Mar, Miqueo, Consuelo, Montero, Isabel, Ortiz, Rocío, RONDA, Elena, RUIZ, Isabel, VALLS, Carme «A framework to analyse gender bias in epidemiological research», Journal of Epidemiology Community Health, 61, (2007), pp. 46-53.

7. Peiró, Rosana, Alvarez-Dardet, Carlos, Plasencia, Antoni, Borrell, Carmen, ColoMER, Concha, MOYA, Carmela, PASARín, Maria Isabel, ZAFrA, Eduardo. «Rapid appraisal methodology for 'health for all' policy formulation analysis», Health Policy, 62:3,.(2002), pp. 309-28.

8. Colomer-Revuelta, Concha, Peiró-Pérez, Rosana, López-Rodríguez, Rosa M., EspiGA-López Isabel, SÁiz-MARTíENZA-ACitoreS, Isabel, SORIANO-Villarroel, Isabel. «Policies, politics and gender research». Journal of Epidemiology and Community Health, 61, (2007), pp. iil-ii2.

Feminismo/s 18, diciembre 2011, pp. 343-351 
exploró si se tenía en cuenta la igualdad de género como un objetivo o valor de las políticas sanitarias, si se ofrecían datos desagregados por sexo, si se describían situaciones de salud diferentes entre hombres y mujeres -y, en caso afirmativo, si se incluían las intervenciones adecuadas para cada una-, o si se contemplaba la participación de sectores que trabajan con la igualdad de género, entre otros aspectos. Además, la metodología empleada se adecúa a las recomendaciones de la OMS sobre las herramientas de género propuestas dentro del proceso de creación de políticas, que son: obtener datos desagregados por sexo, efectuar un análisis cuantitativo y cualitativo y basarse en el ciclo de vida de las personas, identificar información prioritaria en las políticas e identificar acciones del sector salud ${ }^{9}$.

Esta metodología resulta útil para ser aplicada en posteriores estudios con un diseño similar. Existen estudios posteriores que analizan políticas sanitarias desde la perspectiva de género ${ }^{10}$ y que incluso se han basado en esta experiencia, al realizar un diagnóstico del grado de sensibilidad de género de los planes de salud del contexto internacional ${ }^{11}$. La propuesta de este ensayo es que, para que el análisis de políticas operativamente fuera más útil, el protocolo a aplicar debería comprobar si las políticas incorporan de manera transversal:

- el género como principio o valor

- contenidos de equidad de género

- las diferencias de género como determinante de las desigualdades en salud

- la atención al género como elemento en situaciones de discriminaciones múltiples

- la consulta a órganos consultivos específicos en materia de género para la formulación de las políticas.

El protocolo empleado por Peiró y cols. también comprueba si los planes incluyen apartados específicos sobre salud reproductiva o salud de las mujeres.

9. ORGANIZACIÓN MUNDIAL DE LA SALUD: WHA 60.25 Resolution. Strategy for integrating gender analysis and actions into the work of WHO. Ginebra, Organización Mundial de la Salud, 2007.

10. Stewart, Donna E., Linda M. Dorado, Natalia Diaz-Granados, Marta Rondon, Javier SAAVEDRA, Jose POSADA-VILla y Yolanda TORRES. «Examining Gender Equity in Health Policies in a Low- (Peru), Middle- (Colombia), and High- (Canada) Income Country in the Americas.», Journal of Public Health Policy, 30: 4, (2009), pp. 439-54.

11. Briones Vozmediano, Erica, Vives Cases, Carmen, Peiró Pérez, Rosana «Sensibilidad de género en los planes nacionales de salud del contexto internacional», Informe SESPAS 2009. 
La existencia de estos apartados sugiere que los hombres son representados como el prototipo de la normalidad y, por tanto, las mujeres como la desviación, quedando invisibilizadas y limitando su salud y morbilidad a su función reproductiva. Se hace necesario promover una comprensión de la salud de las mujeres más amplia y comprobar si las políticas sanitarias incluyen entre sus prioridades otros aspectos de morbilidad más prevalentes en las mujeres (por ejemplo, problemas de salud emergentes como la fibromialgia, fatiga crónica y sensibilidad química múltiple) o la desigualdad en el acceso a los servicios sanitarios. Hay que tener en cuenta que el paso previo a la formulación de las políticas sobre un tema determinado es su construcción social como problema, impulsada por un colectivo con capacidad de influencia sobre la opinión pública, como el movimiento de mujeres, y con autoridad suficiente como para emprender acciones en respuesta a dichos problema ${ }^{12,13}$.

\section{Conclusión}

Este artículo subraya el género como un determinante social de la salud y, por tanto, que las desigualdades de género impactan en las desigualdades de salud. Es ampliamente reconocido que las desigualdades de género son uno de los factores limitantes de la capacidad de mujeres y hombres para desarrollar plenamente su potencial de salud, por lo que atender a las diferencias y necesidades específicas de género en la investigación, práctica y formulación de políticas de salud beneficia a la salud de mujeres y hombres ${ }^{14,15}$.

En definitiva, este estudio ofrece un buen ejemplo de cómo explorar la integración del género en políticas sanitarias y comprobar en qué medida éstas contemplan las desigualdades, discriminaciones, brechas, injusticias y necesidades específicas de género. Medir los avances en mainstreaming de género permitirá identificar qué barreras impiden que el compromiso político se transforme en práctica, ya que es necesario entender las desigualdades que se producen en la formulación de las políticas sanitarias para reducir las desigualdades en la práctica.

12. GUZMAN, Virginia: «La equidad de género como tema de debate y de políticas públicas» en: Memoria del foro internacional sobre cuidadanía, género y reforma del Estado. México, 1997, pp. 89-108.

13. Vives Cases, Carmen. La Violencia Contra Las Mujeres En El Espacio Discursivo Público. Tesis Doctoral, Universidad de Alicante, 2004.

14. DoyAl, Lesley. «Sex, Gender, and Health: The Need for a New Approach.», British Medical Journal, 323:7320 (2001), pp 1061-3.

15. Khouri, Amal J., Carol S. WeISMAn. «Thinking About Women'S Health: The Case for Gender Sensitivity.» Women's health issues, 12:2 (2002), pp.61-65.

Feminismo/s 18, diciembre 2011, pp. 343-351 


\section{Referencias Bibliográficas}

Briones Vozmediano, Erica, Vives Cases, Carmen, Peiró Pérez, Rosana «Sensibilidad de género en los planes nacionales de salud del contexto internacional», Informe SESPAS 2009.

Colomer-Revuelta, Concha, Peiró-Pérez, Rosana, López-Rodríguez, Rosa M.., EsPiga-LÓPEZ Isabel, SÁIZ-MARTíEnZA-ACITORES, Isabel, SORIANO-VILlARROEL, Isabel. «Policies, politics and gender research». Journal of Epidemiology and Community Health, 61, (2007), pp. iil-ii2.

GISPERT, Rosa: «Objetivo 33: Desarrollo De Las Políticas Salud Para Todos.», en Álvarez-Dardet, Carlos, y PeIró, Rosana (eds.) Informe SESPAS 2000.

DoyAl, Lesley. «Sex, Gender, and Health: The Need for a New Approach.», British Medical Journal, 323:7320 (2001), pp 1061-3.

GuZMAN, Virginia: «La equidad de género como tema de debate y de políticas públicas» en: Memoria del foro internacional sobre cuidadanía, género y reforma del Estado. México, 1997, pp. 89-108.

Khouri, Amal J., Carol S. WeISMAn. «Thinking About Women'S Health: The Case for Gender Sensitivity.» Women's health issues, 12:2 (2002), pp.61-65.

ORGANIZACIÓN MUNDIAL DE LA SALUD: Promoción de la salud. Glosario. Ginebra,:

Organización Mundial de la Salud; 1998. ORGANIZACIÓN MUNDIAL DE LA SALUD: Integrating gender perspectives in the work of WHO. WHO gender policy. Ginebra,: Organización Mundial de la Salud; 2002.

ORGANIZACIÓN MUNDIAL DE LA SALUD, A summary of the "so what? Report, Ginebra, Organización Mundial de la Salud, 2005.

ORGANIZACIÓN MUNDIAL DE LA SALUD: WHA 60.25 Resolution. Strategy for integrating gender analysis and actions into the work of WHO. Ginebra, Organización Mundial de la Salud, 2007.

Peiró, Rosana, Alvarez-Dardet, Carlos, Plasencia, Antoni, Borrell, Carmen, Colomer, Concha, Moya, Carmela, PASArín, Maria Isabel, ZAFrA, Eduardo. «Rapid appraisal methodology for 'health for all' policy formulation analysis», Health Policy, 62:3,.(2002), pp. 309-28.

Peiró, Rosana., Vives, Carmen, Álvarez-Dardet, Carlos y R. Mas: «El Análisis De Políticas Con Enfoque De Género Y Salud.», en Carmen Borrell y Lucía ARTAzCOz (ed.), 5a Monografía. Sociedad Española De Epidemiología. Investigación Sobre Género Y Salud,.Barcelona, Sociedad Española de Epidemiología, 2007, pp. 119-37.

Ruiz Cantero, Maria Teresa, Vives Cases, Carmen, Artazcoz, Lucía, Delgado, Ana, García Calvente Maria del Mar, Miqueo, Consuelo, Montero, Isabel, Ortiz, Rocío, Ronda, Elena, Ruiz, Isabel, VAlLs, Carme «A framework 
to analyse gender bias in epidemiological research», Journal of Epidemiology Community Health, 61, (2007), pp. 46-53

SteWART, Donna E., Linda M. Dorado, Natalia Diaz-Granados, Marta Rondon, Javier SAAVEDRA, Jose POSADA-VILla y. Yolanda TORRES. «Examining Gender Equity in Health Policies in a Low- (Peru), Middle- (Colombia), and High(Canada) Income Country in the Americas.», Journal of Public Health Policy, 30: 4, (2009), pp. 439-54.

Vives CASES, Carmen. La Violencia Contra Las Mujeres En El Espacio Discursivo Público. Tesis Doctoral, Universidad de Alicante, 2004. 



\title{
UN MARCO TEÓRICO PARA ANALIZAR EL SESGO DE GÉNERO EN LA INVESTIGACIÓN EPIDEMIOLÓGICA: HACIENDO VISIBLE LO INVISIBLE
}

\author{
ELISA CHILET ROSELL \\ Universidad de Alicante
}

Recibido/15/07/2011

Aceptado/25/09/2011

\section{Referencia del artículo comentado}

RUIZ CANTERO, María Teresa, VIVES CASES, Carmen, ARTACOZ Lucia, DELGADO Ana, GARCIA CALVENTE María del Mar, MIQUEO Consuelo, MONTERO Isabel, ORTIZ MONCADAS Rocio, RONDA PÉREZ Elena, RUIZ PÉREZ Isabel y VALLS Carme. «A framework to analyse gender bias in epidemiological research» Revista Journal of Epidemiology and community health, 2007: 61 (supl. II) pp. ii46-ii53.

\section{Resumen}

El diseño y el análisis de las investigaciones pueden causar errores sistemáticos producidos por la insensibilidad de género y el androcentrismo. Los sesgos de género en investigación pueden ser definidos como una aproximación sistemáticamente errónea dependiente de la perspectiva de género que se aplica por el constructo social en el que se desarrollan las investigaciones, la cual mira a las mujeres y a los hombres en unas ocasiones como similares cuando no lo son, y en otras como diferentes, y también es incorrecto.

Los sesgos de género se pueden desarrollar en el contexto de descubrimiento (desarrollo de la hipótesis de trabajo), pero también se pueden producir en el contexto de la justificación (en la metodología). De hecho, uno de los principales efectos de los sesgos de género en investigación es un conocimiento parcial o incorrecto de los resultados, los cuales son sistemáticamente diferentes de los valores reales. 
Este artículo discute algunas formas de sesgos conceptuales y metodológicos que pueden afectar la salud de las mujeres. Se propone un marco de análisis de los sesgos de género en el diseño y en el análisis de las investigaciones llevadas a cabo en problemas de salud que pueden ser padecidos por hombres y mujeres, y en problemas de salud específicos de las mujeres.

Mediante ejemplos, este marco de trabajo tiene el objetivo de mostrar las diferentes perspectivas teóricas en un contexto de investigación clínico y en el social, en que los sesgos de selección, medición y confusión se producen como resultados de la insensibilidad de género. Finalmente, este artículo subraya la importancia de reexaminar los resultados con el fin de ser reinterpretados para producir nuevo conocimiento basado en la perspectiva de género. 


\section{Introducción}

A pesar de que tradicionalmente se ha considerado la ciencia como objetiva, la epistemología feminista ha considerado que muchas de sus aplicaciones, formas de definir los problemas de investigación y de diseñar experimentos, modos de construir y conferir significados a la investigación se han desarrollado de forma sesgada a favor del género masculino ${ }^{1}$.

Ante esta afirmación una principiante en salud pública, puede preguntarse cómo identificar el sesgo de género en la investigación pero también, cómo no cometer este error en futuras investigaciones. Las autoras del artículo ${ }^{2}$ propuesto para este ensayo presentan un marco de gran utilidad para el análisis del sesgo de género en investigación, que se traducirá en errores en la atención sanitaria. Además de recoger evidencia científica sobre el sesgo de género, abre el camino a la reflexión, y sin duda, abre la puerta a futuras investigaciones.

\section{Desarrollo}

El sesgo de género en investigación se define como «un error sistemático en el enfoque de género relacionado con el constructo social, que erróneamente considera a hombres y mujeres iguales/diferentes tanto en la exposición a factores de riesgo como en la historia natural y social de la enfermedad (inicio o pródromos, fase consolidada, respuesta a los tratamientos y pronóstico» ${ }^{3}$. En la tabla 1, se muestra de manera esquemática el marco propuesto por este artículo en el que la insensibilidad de género produce sesgos epidemiológicos en investigación, tanto en contextos clínicos como sociales, lo cual puede influir en los resultados, de manera positiva, negativa o neutral.

1. HARDING, Sandra. The science question in feminism. New York: Cornell University Press, Ithaca, 1993.

2. Ruiz Cantero, Maria Teresa; Vives CASES, Carmen; ArTazcoz, Lucia et al. A Framework to analyse gender bias in epidemiological research. J Epidemiol Community Health 61(suppl II) (2007) pp. ii46-ii53.

3. Ibidem. 


\begin{tabular}{|c|c|c|c|c|c|c|c|c|c|}
\hline 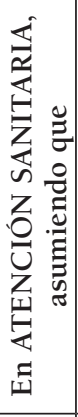 & 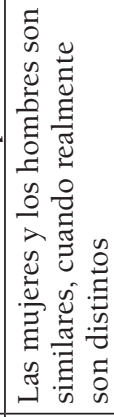 & & & & 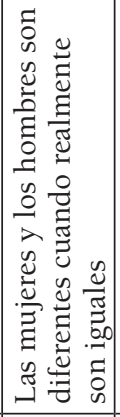 & & & & 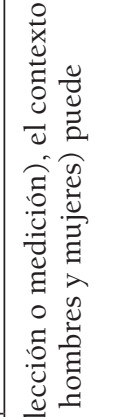 \\
\hline$\frac{0}{\stackrel{2}{\frac{\pi}{*}}}$ & 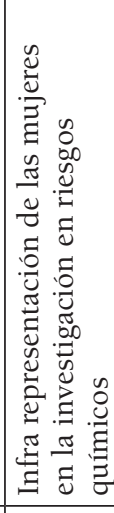 & 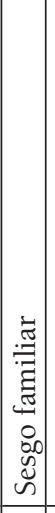 & 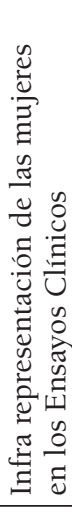 & 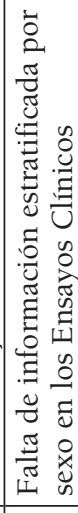 & 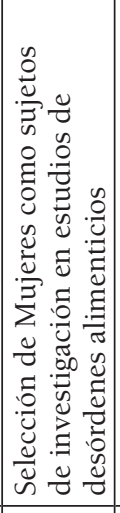 & 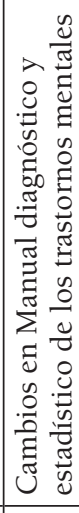 & 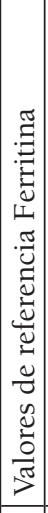 & 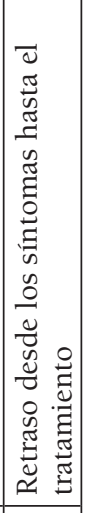 & 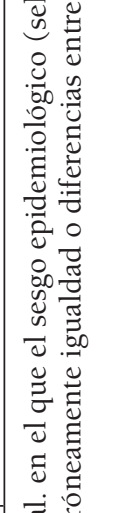 \\
\hline 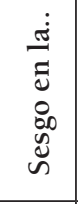 & $\begin{array}{l}\tilde{\Xi} \\
: \stackrel{0}{0} \\
\frac{\mathscr{U}}{\tilde{N}} \\
\tilde{\omega}\end{array}$ & 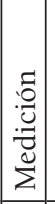 & 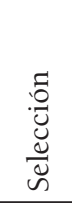 & 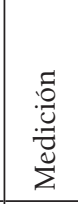 & 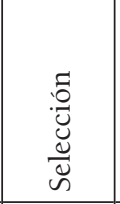 & 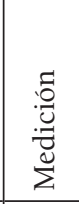 & 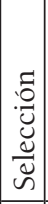 & 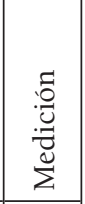 & 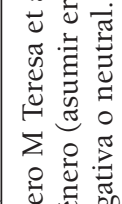 \\
\hline 递 & $\begin{array}{l}\bar{\pi} \\
\frac{\pi}{0} \\
0 \\
0\end{array}$ & & $\begin{array}{l}\stackrel{\mathscr{U}}{\Xi} \\
\text { U. }\end{array}$ & & $\begin{array}{l}\vec{\pi} \\
\text { D } \\
\text { D }\end{array}$ & &. & & 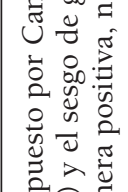 \\
\hline 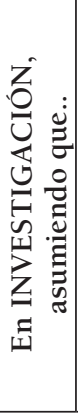 & 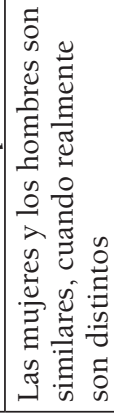 & & & & 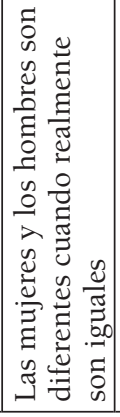 & & & & 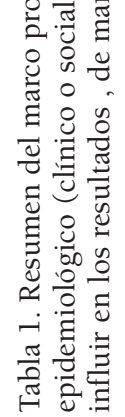 \\
\hline
\end{tabular}

Feminismo/s 18, diciembre 2011, pp. 353-363 
¿Cuál es la importancia de un marco para detectar el sesgo de género en investigación?

Desde la publicación en 1990 del informe de la Oficina Regional de la Organización de Mundial de la Salud ${ }^{4}$, se debate en las revistas científicas sobre el sesgo de género en la atención sanitaria, alegando que la evidencia en la que se sustenta la medicina puede ser incompleta debido a que las herramientas de investigación fallan sistemáticamente en incluir las diferencias por sexo en el diseño del estudio y el análisis de los resultados.

La relación entre el sexo, el género y la salud es compleja. El hecho de contar con un marco teórico nos permite hacer visibles los sesgos de género presentes en la investigación, así como sus consecuencias en la atención sanitaria y en la salud. Hacer visible la presencia de estos sesgos en el diseño, análisis e interpretación de las investigaciones, nos permitirá ocupar los vacíos de conocimiento sobre la salud de las mujeres, y comprender las necesidades de salud de estas; así como sus riesgos. No se trata de simplemente señalar los errores o corregir lo que históricamente se ha hecho de manera sesgada, se trata de mejorar la atención sanitaria y las intervenciones.

Como propusieron M Teresa Ruiz Cantero y Lois M Verbrugge (1997) el marco teórico expuesto en este artículo reflexiona sobre cómo los sesgos epidemiológicos pueden darse por dos vías: considerando que los hombres y las mujeres son iguales cuando realmente son diferentes o considerando que los hombres y las mujeres son diferentes cuando realmente son iguales. El contexto en el que se puede producir el sesgo de género es más amplio que el propuesto por el marco reduccionista biomédico (que no incluye la influencia social), puede ser en la investigación clínica o en la investigación social. El sesgo de género puede producirse en la medición o en la selección de los sujetos de investigación.

Quizás el ejemplo más conocido sobre falta de conocimiento de una enfermedad en mujeres sean las enfermedades cardiovasculares. Tradicionalmente se ha considerado una enfermedad propia de los hombres, obviando que en las mujeres es la primera causa de muerte $e^{6}$. El articulo del cual propongo su lectura y análisis, propone otros ejemplos de sesgo de género en investiga-

4. WhiteHEAD, Margaret. The concepts and principles of equity and health. Copenhagen: WHO Regional Office for Europe; 1990. (Disponible en http://salud.ciee.flacso.org.ar/ flacso/optativas/equity_and_health.pdf, consultado el 7/7/2011)

5. RUIZ, M Teresa; VerbrugGe, Lois M. A two way view of gender bias in medicine. J Epidemiol Community Health. 51 (1997) pp. 106-9.

6. Lloyd-JONES, D; AdAMS, Robert; CARNETHON, Mercedes et al. Heart disease and stroke statistics: 2009 update: a report from the American Heart Association Statistics Committee and Stroke Statistics Subcommitte. Circulation 119 (2009) pp. e21-e181.

Feminismo/s 18, diciembre 2011, pp. 353-363 
ción, quizás menos conocidos, pero no por ellos menos importantes. A través de estos ejemplos, el o la lectora del artículo podrá seguir la argumentación del marco teórico y metodológico expuesto.

\subsection{Asumir erróneamente que las mujeres y los hombres son similares}

Por ejemplo, el artículo nos presenta el denominado «sesgo familiar» como muestra del sesgo de medición en epidemiología social. En este ejemplo se expone como la insensibilidad de género lleva a considerar como unidad de investigación la familia al estudiar los cuidados informales, haciendo invisible el hecho de que son principalmente las mujeres quienes se dedican al cuidado de los menores y de las personas mayores?

Como hemos expuesto anteriormente, la importancia de identificar y hacer visible estos sesgos es mejorar el conocimiento sobre las necesidades de salud de las mujeres; así como de los hombres. En este sentido, cabe destacar el esfuerzo realizado en los cuestionarios de la Encuesta Nacional de Salud (ENS). El análisis de la ENS-2003 evidenció que no era posible determinar por completo indicadores de desigualdad social entre ambos sexos, como son la situación de las amas de casa y de doble jornada ${ }^{8}$. A diferencia de las ENS previas, en la de 2006 se pregunta por la identidad de la persona cuidadora principal de menores de 15 años, mayores de 74 y personas con discapacidad, así como con quién comparte estas tareas".

En cuanto al sesgo de selección en epidemiología social, se expone la infra representación de mujeres en investigación sobre los riesgos químicos. Se consideran los mismos valores para hombres y mujeres en los valores umbral de exposición en las evaluaciones de riesgos químicos en salud laboral, debido a la falta de información específica en mujeres, a pesar de que son conocidas las diferencias por sexo en el metabolismo. Así mismo, no se consideran características relevantes de profesiones llevadas a cabo mayoritariamente por mujeres, como son las peluqueras con más horas de exposición y exposición

7. KotKamp-Mothes, N., Slawinsky, D., Hindermann, S., Strauss, B. Coping and psychological well being in families of elderly cancer patients. Crit Rev Oncol Hematol 55 (2005) pp. 213-29.

8. Ruiz Cantero, M. Teresa, Papí Gálvez, Natalia, Carbrera Ruiz, Virginia, Ruiz MartíNEZ, Ana, Álvarez-DARDET DíAz, Carlos. Los sistemas de género y/en la Encuesta Nacional de Salud. Gac Sanit 20 (2006) pp. 427-34.

9. Ruiz-Cantero, M. Teresa, Carrasco-Portiño, Mercedes, Artazcoz, Lucía. Logros y retos de género de la Encuesta Nacional de Salud de 2006: análisis de los cuestionarios de adultos y hogar. Gac Sanit. 25 (2010): 6-12. 
cutánea (no sólo inhalación) ${ }^{10}$. El hecho de hacer visible este sesgo de género ha propiciado que en los últimos años haya aumentado la investigación sobre los riesgos asociados a esta profesión ${ }^{11},{ }^{12},{ }^{13},{ }^{14}$.

La participación de mujeres en Ensayos Clínicos, sirve de ejemplo para dos tipos de sesgo. En primer lugar el sesgo de selección en epidemiología clínica. Durante años, las mujeres fueron excluidas de los ensayos clínicos por temor a los efectos que la exposición a nuevos fármacos pudiese tener en el embarazo. No fue hasta los años 90, tras el trabajo reivindicativo de grupos feministas, que National Health Institutes ${ }^{15}$ y la Food and Drug Administration ${ }^{16}$ reformularon sus guías para que las mujeres participaran en los ensayos clínicos. Aunque la participación de las mujeres ha aumentado, su participación en ensayos de fase I y fase $\mathrm{II}^{17},{ }^{18}$ es menor, por tanto, información referente a seguridad puede ser desconocida.

Cabe llamar la atención sobre los ensayos clínicos revisados para la elaboración de las Guías publicadas por la American Heart Association para la prevención de enfermedad cardiovascular en mujeres ${ }^{19}$. Aunque supone un gran avance el hecho que la American Heart Association publique unas guías específicas para mujeres, en los ensayos analizados para su elaboración, la participación de las mujeres aumentó desde el 18\% en 1970 a un 34\% en 2006. Es

10. Van Der Wal, Jan F; Hoogeveen, Ank W.; Moons, André M.; Wouda, Paul. Investigation on the exposure of hairdressers to chemical agents. Environment International 23 (1997) pp. 433-9.

11. Ronda, Elena, García, Ana M., SÁnchez-Paya, Jose, Moen, Bente E. Menstrual disorders and subfertility in Spanish hairdressers. Eur J Obstet Gynecol Reprod Biol 147 (2009) pp. 61-4.

12. Takkouche, Bahi, Regueira-Méndez, Carlos, Montes-Martínez, Agustín N. Risk of cancer among hairdressers and related workers: a meta-analysis. Int J Epidemiol 38 (2009) pp. 1512-31.

13. Peretz, Jackye; Gallicchio, Lisa; Miller, Susan et al. Infertility among cosmetologists. Reproductive Toxicology 28 (2009) pp. 359-64.

14. MA, C-M, LIN, L-Y, CHEN, H-W et al. Volatile organic compounds exposure and cardiovascular effects in hair salons. Occup Med. 60(2010) pp. 624-30.

15. NIH Revitalization Act, Subtitle B, Part 1, Section 131-133, June 10, 1993.

16. FOOD AND DRUG ADMINISTRATION Guideline for the study and evaluation of gender differences in the clinical evaluation of drugs. Fed Reg 1993;58:39409-11

17. Chilet-Rosell, Elisa; Ruiz-Cantero, M. Teresa; HORGA, Jose Francisco. Women's health and gender-based clinical trials on etoricoxib: methodological gender bias. $J$ Public Health 31 (2010) pp. 434-445.

18. FleisCH, Jeanette; FleisCh, Markus; Thürmann, Petra A. Women in early-phase clinical drug trials. Have things changed over the past 20 years? Clin Pharmacol Ther 78 (2005) pp. 445-52.

19. Mosca, Lori; ApPel, Lawrence J.; Benjamin, Emelia J. Evidence-based guidelines for cardiovascular disease prevention in women. J Am Coll Cardiol 43 (2004) pp. 900-921.

Feminismo/s 18, diciembre 2011, pp. 353-363 
decir, aunque la participación de mujeres en ensayos clínicos ha aumentado, no representan la población que padecerá enfermedades cardiovasculares.

La falta de información estratificada por sexo es un claro ejemplo de sesgo de medición en epidemiología clínica, Aunque las mujeres están siendo incluidas en los ensayos clínicos, los resultados por sexo a penas se incluyen en los ensayos clínicos publicados. En este sentido volvemos a llamar la atención sobre los ensayos clínicos analizados en las Guías publicadas por la American Heart Association, en las que los sólo el 31\% de los ensayos clínicos analizados incluía el análisis de los resultados por sexo.

\subsection{Asumir erróneamente que las mujeres y los hombres son diferentes}

No siempre el sesgo de género perjudica a las mujeres ${ }^{20}$. En el caso expuesto como ejemplo de sesgo de selección en epidemiología social, las investigaciones sobre los desórdenes alimenticios suelen considerar que sólo afecta a mujeres, pudiendo provocar una infraestimación de la prevalencia en hombres.

El sesgo de medición en epidemiología social, se muestra en el ejemplo del análisis del manual Diagnostic and statistical manual of mental disorders $(D S M)^{21}$. Tradicionalmente se considera que el estrés postraumático es más en común en mujeres debido a su mayor vulnerabilidad biológica, diferentes estilos para sobrellevar el estrés o historia familiar ${ }^{22}$. Para esta afirmación, no se ha tenido en cuenta la importancia de la definición de evento traumático. En su última edición (DSM-IV), se incluyen nuevos tipos de eventos traumáticos más comunes en mujeres (como la violación o abuso sexual), asumiendo que la afirmación sobre la menor exposición a eventos traumáticos en mujeres se debe a un sesgo en el instrumento de medida (en los cuestionarios) que no incluían riesgos relevantes para las mujeres.

En epidemiología clínica, como sesgo de selección se presenta el caso de la ferritina en sangre, que presenta como normal valores bajos en mujeres, asumiendo que estos valores son normales en mujeres debido a la pérdida de sangre que se produce durante la menstruación y obviando que puede afectar

20. Doyal, Lesley. Sex, gender, and health: the need for a new approach. BMJ 323(2001) pp. 1061.

21. AMERICAN PSYCHIATRIC ASSOCIATION. Diagnostic and statistical manual of mental disorders. Washington: APA, 1994.

22. BResLau, N.; DAVIS, G. C.; ANDRESKi P. et al. Sex differences in post-traumatic stress disorder. Arch Gen Psychiatry 54 (1997) pp. 1044-8. 
a su calidad de vida ${ }^{23}$. Como sesgo de selección, se presenta el retraso entre la presencia de síntomas y la obtención de tratamiento; en concreto, en enfermedades cardiovasculares. El estudio IBERICA (que incluye 8200 infartos de miocardio en España) muestra que las mujeres experimentan mayores retrasos desde la presentación de síntomas hasta el ingreso hospitalario. Sus consecuencias son importantes, como se ha observado en la evitable mayor tasa de letalidad hospitalaria en mujeres que en hombres por infarto de miocardio ${ }^{24}$.

\section{Conclusiones}

«La ceguera o el sesgo de género constituye un grave defecto que introduce una forma muy seria de error dentro de la investigación científica» ${ }^{25}$. Retomando la argumentación del Empirismo Feminista, que afirma que el sesgo de género se produce al no aplicar las normas científicas de modo correcto, el hacer visibles estos errores sistemáticos en la investigación y sus consecuencias, se resalta la necesidad de eliminar el sesgo de género en el desarrollo de hipótesis e interpretación de resultados.

En este sentido, me gustaría acabar este ensayo con un toque de optimismo. Como se señalaba al comienzo de este ensayo, se trata de producir conocimiento que cubra los vacíos existentes y mejorar la atención sanitaria haciendo que ésta sea basada en la mejor evidencia posible. Por ello, quisiera destacar las acciones llevadas a cabo en la legislación española en los últimos años. En primer lugar la Ley Orgánica 3/200, de 22 de marzo, para la igualdad efectiva de mujeres y hombres, que afirma que siempre que sea posible la desagregación por sexo de los datos contenidos en registros, encuestas, estadísticas u otros sistemas de información médica para permitir el análisis de género. En la misma línea, se aprobó la Ley 14/2011, de 1 de junio, de la Ciencia, la Tecnología y la Innovación que instaura la perspectiva de género como una categoría transversal en la investigación científica y técnica, que debe ser tenida en cuenta en todos los aspectos del proceso para garantizar la igualdad efectiva entre hombres y mujeres.

23. Fleming, D. J.; Jacques, P. F; Dallal, G. E.; Tucker, K. L. \& Wilson, P. W. Dietary determinants of iron stores in a free-living elderly population: The Framingham Heart Study. Am J Clin Nutr, 67(1998) pp. 722-733.

24. Segura, Andreu, ZuRRiaga, O, ROHLFS, Isabel et al. diferencias por género en las características, manejo y letalidad-complicaciones en pacientes con infarto agudo de miocardio (IAM): Estudiolberica. Gac Sanit 16 (Suppl 1) (2002) pp. 90.

25. EICHLER, Magrit; ReISMAn, Anna Lisa; BorInS, Elaine. Gender Bias in Medical Research. Women and Therapy 12 (1992) pp. 61-70.

Feminismo/s 18, diciembre 2011, pp. 353-363 


\section{Referencias bibliográficas}

AMERICAN PSYCHIATRIC ASSOCIATION. Diagnostic and statistical manual of mental disorders. Washington: APA, 1994.

Breslau, N.; DAVIS, G. C.; ANDRESKi P. et al. Sex differences in post-traumatic stress disorder. Arch Gen Psychiatry 54 (1997) pp. 1044-8.

Chilet-Rosell, Elisa; RuIz-CAnTero, M. Teresa; HorGA, Jose Francisco. Women's health and gender-based clinical trials on etoricoxib: methodological gender bias. J Public Health 31 (2010) pp. 434445.

DOyAL, Lesley. Sex, gender, and health: the need for a new approach. BMJ 323(2001) pp 1061

EICHler, Magrit; ReISMAn, Anna Lisa; Borins, Elaine. Gender Bias in Medical Research. Women and Therapy 12 (1992) pp 61-70.

FleisCH, Jeanette; FleisCh, Markus; Thürmann, Petra A. Women in early-phase clinical drug trials. Have things changed over the past 20 years? Clin Pharmacol Ther 78 (2005) pp:445-52.

Fleming, D. J.; Jacques, P. F; Dallal, G. E.; Tucker, K. L. \& Wilson, P. W. Dietary determinants of iron stores in a free-living elderly population: The Framingham Heart Study. Am J Clin Nutr, 67(1998) pp 722-733.

FOOD AND DRUG ADMINISTRATION Guideline for the study and evaluation of gender differences in the clinical evaluation of drugs. Fed Reg 1993;58:39409-11

HARDING, Sandra. The science question in feminism. New York: Cornell University Press, Ithaca, 1993

Kotkamp-Mothes, N., Slawinsky, D., Hindermann, S., Strauss, B. Coping and psychological well being in families of elderly cancer patients. Crit Rev Oncol Hematol 55 (2005) pp 213-29.

Lloyd-Jones, D; AdAms, Robert; CARnethon, Mercedes et al. Heart disease and stroke statistics: 2009 update: a report from the American Heart Association Statistics Committee and Stroke Statistics Subcommitte. Circulation 119 (2009) pp.e21-e181.

MA, C.-M., LiN, L.-Y., CHEN, H.-W. et al. Volatile organic compounds exposure and cardiovascular effects in hair salons. Occup Med. 60 (2010) pp 624-30.

NIH Revitalization Act, Subtitle B, Part 1, Section 131-133, June 10, 1993.

PereTZ, Jackye; GALLiCCHIO, Lisa; MiLler, Susan et al. Infertility among cosmetologists. Reproductive Toxicology 28 (2009) pp 359-64.

Ronda, Elena, García, Ana M., SÁnchez-Paya, Jose, Moen, Bente E. Menstrual disorders and subfertility in Spanish hairdressers. Eur J Obstet Gynecol Reprod Biol 147 (2009) pp 61-4. 
Ruiz-Cantero, M. Teresa, Carrasco-Portiño, Mercedes, Artazcoz, Lucía. Logros y retos de género de la Encuesta Nacional de Salud de 2006: análisis de los cuestionarios de adultos y hogar. Gac Sanit. 25 (2010): 6-12.

Ruiz Cantero, Maria Teresa; Vives Cases, Carmen; ArTazCoz, Lucia et al. A Framework to analyse gender bias in epidemiological research. J Epidemiol Community Health 61(suppl II) (2007) pp. ii46-ii53.

Ruiz Cantero, M. Teresa, Papí Gálvez, Natalia, Carbrera, Ruiz Virginia, Ruiz Martínez Ana, ÁlVAREz-DARdet DíAz Carlos. Los sistemas de género y/en la Encuesta Nacional de Salud. Gac Sanit 20 (2006) pp 427-34.

Ruiz, M. Teresa; VerbrugGe, Lois M. A two way view of gender bias in medicine. J Epidemiol Community Health. 51 (1997) pp. 106-9.

SEgura, Andreu. Zurriaga, O: RoHLFs, Isabel et al. diferencias por género en las características, manejo y letalidad-complicaciones en pacientes con infarto agudo de miocardio (IAM): Estudiolberica. Gac Sanit 16 (Suppl 1) (2002) pp 90.

Takkouche, Bahi, Regueira-Méndez, Carlos, Montes-Martínez, Agustín N. Risk of cancer among hairdressers and related workers: a meta-analysis. Int J Epidemiol 38 (2009) pp 1512-31.

Van der Wal, Jan F; Hoogeveen, Ank W.; Moons, André M.; Wouda, Paul. Investigation on the exposure of hairdressers to chemical agents. Environment International 23 (1997) pp 433-9.

WHITEHEAD, Margaret. The concepts and principles of equity and health. Copenhagen: WHO Regional Office for Europe; 1990. (Disponible en http://salud.ciee. flacso.org.ar/flacso/optativas/equity_and_health.pdf, consultado el 7/7/2011)

Feminismo/s 18, diciembre 2011, pp. 353-363 



\section{RESEÑA BIO-BIBLIOGRÁFICA}

\section{Carlos Alvarez-Dardet Diaz}

Es Catedrático de Salud Publica y Director del programa de Doctorado en Ciencias de la Salud en la Universidad de Alicante, pertenece a un grupo universitario en el que la investigación en género y salud es una prioridad, siendo el único varón de este grupo. Su área de interés en investigación es la justicia social y la salud, ha realizado estudios en violencia contra las mujeres y desarrollado una campaña nacional pidiendo una moratoria en la aplicación con cargo a presupuestos públicos de la vacuna del Virus del Papiloma Humano. Formó parte de la red de investigación en salud y genero del instituto de salud Carlos III, y fue editor del suplemento «engendering epidemiology» del journal of epidemiology and community health

\section{Maria Eugenia Arango Rojas}

Maestria/Magister Facultad de Enfermería por la Universidad de Antioquia. Maestria en Salud Colectiva y Especialista en Educación sexual por la Universidad de Medellín. Ha coordinado y dirigido numerosos cursos relacionados con la salud de las mujeres, y realizado diversas publicaciones, siendo sus líneas de investigación actuales: violencia domestica versus resiliencia y autocuidado en la prevención del cáncer de mama.

\section{Gladys Rocío Ariza Sosa}

Médica, Magíster en Salud Colectiva, Doctora en Salud Pública de la Universidad Nacional de Colombia. Líder Programa de investigación, Empresa Social del Estado METROSALUD, Medellín Colombia. Una de sus líneas de investigación más actual se centra en el estudio de las representaciones sociales de la violencia en la pareja. Otras publicaciones sobre el tema: «Las Representaciones sociales de la violencia en las relaciones de pareja en la prensa de Medellín en el siglo XXI,» Revista Venezolana de Estudios de la Mujer 14. no. 32 (ene-jun., 2009), pp. 71-98. 


\section{Vita Ascensió Arrufat Gallén}

Licenciada en medicina Especialista en Medicina Preventiva y Salud Pública. Trabaja desde 1990 para la Generalitat Valeciana como técnica Superior en Programas de Promoción de la Salud, primero en el CSP Vila-real y actualmente en CSP Castelló.

Desde 1994 acredita estar habilitada para desempeñar las funciones de Médico de Medicina General en el Sistema Nacional de Salud Español, y en los Sistemas Públicos de Seguridad Social de los demás Estados Miembros de la Comunidad Europea. Ha organizado diferentes reuniones y jornadas sobre Educación para la salud sexual, prevención de la violencia de género, atención a la cronicidad. Ha publicado varios libros y diferentes artículos sobre prevención de violencia, embarazo, calidad de vida de la mujer, entre otros.

\section{Lucía Artazcoz Lazcano}

Directora del Institut de Serveis a la Comunitat. Agència de Salut Pública de Barcelona. Doctora en Medicina. Universitat Pompeu Fabra, y Professora associada de la Johns Hopkins University. Responsable del Programa Transversal de Desigualdades del Ciber de Epidemiología y Salud Pública. Autora de numerosos artículos relacionados con las desigualdades en salud:

\section{Josep Bernabeu Mestre}

Doctor en medicina, ocupa una plaza de catedrático de Historia de la Ciencia en la Universidad de Alicante. Su principal actividad investigadora se ha centrado en la historia de la salud pública en la España contemporánea, además de cuestiones relacionadas con las transiciones sanitarias y epidemiológicas. En la actualidad, dirige el Grupo Balmis de Investigación en Salud Comunitaria e Historia de la Ciencia de la Universidad de Alicante y coordina el proyecto de investigación sobre «Los condicionantes higiénico-sanitarios de la transición nutricional española (1874-1975)»

\section{Erica Briones Vozmediano}

Licenciada en Humanidades (Universidad de Alicante), Máster Oficial en Igualdad de género en el ámbito público y privado (Universidad Miguel Hernández, Elche-Universidad Jaime I, Castellón). Especialista en Cultura y Violencia de Género (UNED) y Doctoranda de los programas Bienestar social y Desigualdades, y Ciencias de la Salud en la línea Salud Pública y Género (Universidad de Alicante). En la actualidad es Técnica de investigación el 
Departamento de Salud Pública de la Universidad de Alicante, donde participa en proyectos de investigación sobre Violencia de género y Salud de las Mujeres, y desarrolla su Tesis Doctoral sobre «La construcción social de la Fibromialgia como problema de salud desde la perspectiva de las políticas, personas afectadas y profesionales».

\section{Mercedes Carrasco-Portiño}

Doctora en Salud Pública con Mención Europea por la Universidad de Alicante (UA). Investigadora del Centro de Investigación Biomédica en Red de Epidemiología y Salud Pública (CIBERESP) e Integrante del Grupo de Investigación de Salud Pública de la UA. Diplomada en Promoción de la Salud por la Escuela Nacional de Salud-Instituto de Salud Carlos III (Madrid), Master en Salud Pública y Gestión Sanitaria por la EASP (Granada). Sus principales líneas de investigación están referidas a temáticas relacionadas con la salud de las mujeres, como la violencia del compañero íntimo, salud reproductiva, construcción de indicadores de desigualdades de género y su impacto en salud.

\section{Elisa Chilet}

Licenciada en Biología por la Universidad de Valencia (1999-2004). Máster Internacional en Enfermedades Parasitarias Tropicales (2004-2005). Diploma de Estudios Avanzados del Programa de Doctorado en Salud Pública (2007). Desde 2005 he participado en proyectos de investigación en la línea de Salud y Género del Grupo de Investigación de Salud Pública de la Universidad de Alicante, contando con la financiación de diversas fuentes como son el Observatorio de Salud de la Mujer (Ministerio de Sanidad y Consumo), el Instituto de la Mujer (Ministerio de Trabajo y Asuntos Sociales), el Instituto de Salud Carlos III, CIBERESP (Centro Investigación Biomédica en Red de Epidemiología y Salud Pública). Actualmente Becaria de la Unidad Mixta de Investigación Translacional en Salud de la Facultad de Ciencias de la Salud de la Universidad de Alicante

\section{Vicente Clemente Gómez}

Ingeniero Técnico en Informática de Sistemas y Especialista Universitario en Aplicaciones y Servicios Web con Java Enterprise. Universidad de Alicante. Máster de Software Libre. Universitat Oberta de Catalunya. Participación en varios congresos científicos relacionados con salud de las mujeres y género. 
Miembro del Grupo de Investigación de Salud Pública de la Universidad de Alicante en la Línea de Investigación de Salud y Género.

\section{Ana Delgado Sánchez}

Doctora en Medicina. Especialista en medicina preventiva y salud pública. Actualmente profesora de la Escuela Andaluza de Salud Pública. Experta en género y salud. Integrante de la Red de Médicas y Profesionales de la Salud.

Forma parte del Grupo de Investigación de Estudios de la Mujer de la Universidad de Granada), y del Grupo de Investigación «Salud Mental, Servicios y Atención Primaria» de la red de investigación de Actividades Preventivas en Atención Primaria, red IAPP

Desarrolla su investigación sobre salud y género, violencia contra las mujeres, práctica profesional de médicos y utilización de servicios.

\section{José Fernández Sáez}

Licenciado en Ciencias Matemáticas en la Rama de Probabilidad, Estadística, Investigación Operativa y Cálculo Numérico. Universidad Nacional de Educación a Distancia (UNED). Experto Universitario en Métodos Avanzados de Estadística Aplicada. UNED. Master Oficial en Salud Pública y Gestión Sanitaria. Universidad Miguel Hernández. Actualmente se encuentra realizando el Doctorado en Salud Pública en la Universidad de Alicante en Línea de Investigación de Salud y Género y es miembro del Grupo de Investigación en Salud Pública de la Universidad de Alicante.

\section{$\mathbf{M}^{\mathrm{a}}$ Eugenia Galiana Sánchez}

Enfermera y doctora por la Universidad de Alicante (Salud Pública) y Profesora Titular de Escuela Universitaria (Enfermería Comunitaria). Sus líneas de investigación actuales son la historia de la enfermería de salud pública, la historia de la alimentación y la nutrición, así como la historia de la salud rural y ambiental en la España contemporánea y el contexto internacional. Miembro del Grupo «Balmis» de Investigación en Salud Comunitaria e Historia de la Ciencia. Actualmente coordina el proyecto «Género, ideología y salud: la enfermería de salud pública en la sanidad española contemporánea (19231959)»(GRE10-12). 


\section{María del Mar García Calvente}

Doctora en Medicina y especialista en Salud Pública y en Pediatría. Es profesora de la Escuela Andaluza de Salud Pública (EASP) (Granada, España) desde 1990, institución en la que ha asumido la Coordinación del Programa Andaluz de Investigación en Salud Materno-Infantil, la Coordinación de la Maestría de Salud Pública y Gestión Sanitaria y la Dirección del Área de Salud Pública en distintos periodos. Desde el año 2008 coordina el curso de Experta/o en Género y Salud de la EASP, reconocido como título propio por la Universidad de Granada. Como investigadora, ha formado parte de la Red de Salud y Género del Instituto Carlos III y del Centro de Investigación Biomédica en Red de Epidemiología y Salud Pública (CIBERESP) del Instituto de Salud Carlos IIII. Es miembro del Grupo de Género y Salud Pública de la Sociedad Española de Salud Pública y Administración Sanitaria (SESPAS) desde su fundación hasta la actualidad, y como tal fue co-editora del Informe SESPAS 2004: La salud pública desde la perspectiva de género y clase social. Es autora de más de 30 artículos en revistas científicas indexadas, 10 libros y 27 capítulos de libros. Sus líneas actuales de trabajo se centran en las relaciones entre género y salud, el análisis y abordaje de las desigualdades de género en salud, los cuidados informales de salud y el desarrollo de metodologías de investigación en salud sensibles al género, y en especial de tipo cualitativo.

\section{Clara Victoria Giraldo Mora}

De nacionalidad colombiana, realizo su doctorado en Sociología en University Of North Texas. Mencion especial del VIII Congreso Colombiano de Enfermería Oncológica y I congreso Latinoamericana de Enfermería Oncológica por el trabajo «Barreras psico-sociales de las mujeres para enfrentar el cáncer de mama», Asociación de Enfermería Oncológica Colombiana - Noviembre de 2008. Sus líneas de investigación activas en la actualidad son: Representaciones sociales del cáncer de mama para un grupo de mujeres de Medellín y el Área Metropolitana. Estudio de enfermedades crónicas desde la perspectiva de género. Promoción de la salud y autocuiado, Salud sexual y reproductiva de las mujeres, Violencia de pareja y resiliencia.

\section{Isabel Goicolea}

Es licenciada en medicina por la Universidad de Navarra (España), MSc por la Universidad de Londres y tiene un PhD en Epidemiología y Salud Pública por la Universidad de Umeå (Suecia). Actualmente trabaja como investigadora postdoctoral afiliada al Centro de Estudios de Genero de la Universidad de 
Umea y al Centro de Investigación en Salud Global de esa misma universidad. Su área de investigación se centra en salud y género, salud de gente joven, y derechos sexuales y reproductivos.

\section{María Luisa Jiménez Rodrigo}

Profesora de Sociología de la Universidad de Sevilla. Es licenciada en Sociología y Ciencias Políticas y doctora en Antropología Social por la Universidad de Granada. Entre sus líneas de investigación destaca el estudio de los usos de drogas desde una perspectiva de género y de las desigualdades de género en salud, dando lugar a diversas publicaciones nacionales e internacionales. Es profesora colaboradora de la Escuela Andaluza de Salud Pública en el curso Experto Universitario de Género y Salud. También participa como docente en el Experto y Master en Agentes de Igualdad de la Universidad de Sevilla.

\section{Gema Lasarte Leonet}

Profesora del departamento de la Didáctica de la Lengua y de la Literatura de la Universidad del País Vasco (UPV/EHU). Licenciada en Ciencias de la Información y doctora en Ciencias Literarias. Las líneas de investigación y publicaciones se centran en las competencias lectoras y el género, el género sobre todo en las didácticas de la literatura.

\section{Jorge Marcos Marcos}

Licenciado en Antropología Social por la Universidad de Granada, es también diplomado en Ciencias de la Educación por la misma Universidad y Máster Europeo en Salud Pública <<Europubhealth $>>$ por el consorcio formado por la Escuela de Altos Estudios en Salud Pública de Rennes (Francia), la Universidad Jagellónica de Cracovia (Polonia) y la Escuela Andaluza de Salud Pública (España). Ha sido investigador interno en el departamento de Antropología y Trabajo Social de la Universidad de Granada, ha trabajado para la Consejería de Educación de la Embajada de España en Rabat (Marruecos) y ha ejercido como técnico investigador para el Centro de Investigación Biomédica en Red de Epidemiología y Salud Pública (España). Es especialista en metodología de la investigación cualitativa, siendo sus actuales líneas de trabajo las desigualdades de género en salud, y el estudio de los varones y las masculinidades. Otras de sus líneas de trabajo han sido el consumo de drogas recreativas y las conductas sexuales de riesgo en poblaciones jóvenes. 


\begin{abstract}
Alberto Martín-Pérez Rodríguez
Licenciado en Ciencias de la Información (UCM), Master de Experto en Sexología (INCISEX) y Diploma en Salud Pública y Género (Escuela Nacional de Sanidad). Trabaja desde 2010 en la Secretaría del Plan Nacional sobre el Sida (Ministerio de Sanidad, Política Social e Igualdad). Ha sido técnico del Programa de Prevención de VIH de la Comunidad de Madrid y ha participado en ONG y federaciones en las que ha asumido puestos de responsabilidad. Coordinó la European Gay Aids Prevention Network (1998-2002) y fue miembro del steering group del Proyecto Everywhere (2007-2010). Autor de distintas publicaciones y materiales IEC.
\end{abstract}

\title{
Rosa $\mathrm{M}^{\mathrm{a}}$ Marín Torrens
}

Doctora en Medicina Técnico Superior del Servicio de Atención Primaria.

Consejería de Sanidad. Jefa de estudios del Instituto Valenciano de Estudios en Salud Pública. Interlocutora del Plan de Igualdad de Oportunidades entre Hombres y Mujeres de la Comunidad Valenciana 1997-2001. Y desde enero de 2012 Jefa de Programas de la Escuela Valenciana de estudios de la salud. Líneas de investigación desarrolladas: Malos Tratos en la Infancia y Evaluación Pediátrica en Atención Primaría. Coautora de varios libros y diversas publicaciones.

\section{Maria Luisa Mateu Gil}

Diplomada en Enfermería, Master en Enfermería de Salud Pública i Comunitaria, Master en Ciencias de la Enfermería. Profesora titular de Enfermería de Salud Pública y Comunitaria de la Universidad Rovira i Virgili (URV) Campus Terres de l'Ebre. Su investigación se centra en los cuiados a las personas cuidadoras y las desigualdades en salud.

\section{Lucía Mazarrasa Alvear}

Diplomada en Enfermería. Enfermera Instructora de Sanidad, Jefa de sección de Salud y Desarrollo Internacional, Escuela Nacional de Sanidad. Instituto de Salud Carlos III. Actualmente dirige el Diploma de Especializacion en Salud Publica y Género y diversos cursos sobre Violencia de Género. Colabora con diversas Universidades en la formación sobre Género y Salud, así como con instituciones sanitarias de Investigación y Formación.

Realizadas 40 publicaciones en el campo de la enfermería comunitaria, educación y promoción de salud, salud y género y en salud de la población 
inmigrante, prevención VIH SIDA, en revistas de enfermería y de salud pública nacionales e internacionales.

Participa en proyectos de cooperación al desarrollo desde el ámbito gubernamental y no gubernamental. Participa en el movimiento feminista organizado desde 1975 y es socia fundadora del Forum de Política Feminista en 1987.

\section{Elvira M. Melián}

Doctora en Medicina y Cirugía por la Universidad Autónoma de Madrid y especialista en Endocrinología y Nutrición. En la actualidad trabaja en un Hospital de Madrid, ciudad en la que reside. Además de su labor sanitaria ha efectuado investigaciones sobre aspectos poco conocidos de la historia intelectual de la Segunda República, en especial sobre la presencia de las mujeres en la Institución Libre de Enseñanza, publicados en revistas especializadas. Estos estudios y el libro «Para los que no vieron»-ed. Do Castro, 2006- sobre la figura de Francisco Lamas, médico e intelectual que fuera último alcalde republicano en Lugo antes de la Guerra Civil, son ejemplos de su quehacer literario e investigador en dicha faceta. Asimismo ha realizado estudios sobre la vida femenina en la España Moderna, algunos publicados y otros en proceso de revisión.

\section{Fauhn Minvielle}

Licenciada en psicología por la Universidad Central «Marta Abreu» de las Villas (Cuba), y Máster en Salud Pública por la Universidad de Umeå (Suecia). Ha trabajado en salud mental de jóvenes y sus áreas de interés en investigación se relacionan con la salud sexual y reproductiva y el derecho a la salud, especialmente en el Caribe anglófono.

\section{$\mathrm{M}^{\mathrm{a}}$ Lluísa Panisello Chavarria}

Diplomada en Enfermería, Master en Enfermería de Salud Pública y Comunitaria, Master en Ciencias de la Enfermería. Tesis Doctoral inscrita en el Departamento de Enfermería de la Universidad Rovira i Virgili con el título: INTEGRACIÓ DE LA PERSPECTIVA DE GÉNERE AL SISTEMA SANITARI CATALÀ. Forma parte del grupo de investigación de Enfermería Aplicada (GRIAP) de la URV. Su investigación se centra en los cuidados a las personas cuidadoras, las desigualdades en salud y el género. 


\section{Anna Panisello Tafalla}

Licenciada en Medicina i Cirugía y Especialista en Medicina Familiar y Comunitaria. Master en Investigación en Atención Primaria 2010. Fue miembro del Comité Científico de Residentes de la CAMFIC en 2009 y 2010. Forma parte del grupo de investigación en Obesidad Infantil del Hospital Verge de la Cinta de Tortosa (Tarragona).

\section{Natalia Papi Gálvez}

Doctora por la Universidad de Alicante (UA) en 2004 y Licenciada en Sociología con la especialidad en Marketing y Publicidad (UA) en 1999, ambos con premio extraordinario. Obtuvo una beca de investigación por la Dirección General de la Dona (1999) y posteriormente disfrutó de la beca FPI nacional en la Facultad de Ciencias de la Información de la Universidad Complutense Madrid. Profesora Titular del Dpto. de Comunicación y Psicología social. Universidad de Alicante. Investigadora especializada en estudios de género y en evaluación de la comunicación.

\section{Inma Pastor Gosálbez}

Profesora titular de Sociología de la Universidad Rovira i Virgili y doctora en Sociología por la Universidad Autónoma de Barcelona. Su investigación se centra en sociología del trabajo y sociología del género. Forma parte del grupo de investigación Análisis Social y Organizativo de la Universidad Rovira i Virgili. Recibió el premio a tesis doctorales en sociología del Consejo Económico y Social de España en 2005. Desde 2007 es directora del Observatorio de la Igualdad y delegada del rector para los temas de igualdad efectiva entre hombres y mujeres de la Universidad Rovira i Virgili.

\section{María Teresa Ruíz Cantero}

Catedrática de Medicina Preventiva y Salud Pública, Universidad de Alicante. Su investigación está centrada en los análisis de género de contextos que influyen en la salud de las mujeres, y en las desigualdades en salud. Ha trabajado en el desarrollo de marcos teóricos y esquemas explicativos para guiar el trabajo de comprensión de los determinantes de género que afectan a la salud, y métodos para mejorar la vigilancia de las desigualdades de género que afectan a la salud. En la actualidad dirige el Grupo de Investigación de Salud Pública de la Universidad de Alicante y es miembro del Centro de Investigación Biomédica en Red de Epidemiología y Salud Pública (CIBERESP). 


\section{Lorena Saletti Cuesta}

Técnica de Investigación. Escuela Andaluza de Salud Pública. Área de Salud Pública. Promoción y Prevención. Licenciada en Psicología. Facultad de Psicología Universidad Nacional de Córdoba, Argentina. Titulación homologada por el Ministerio de Educación y Ciencia Español. Año 2004. Diploma de Estudios Avanzados del Tercer Ciclo dentro del programa de doctorado «Salud, Antropología e Historia» impartido por el Departamento de Anatomía Patológica e Historia de la Ciencia, Facultad de Medicina de la Universidad de Granada. Año 2007. Experta Universitaria en Género y Salud. Universidad de Granada y Escuela Andaluza de Salud Pública. Año 2011. Doctoranda del Programa «Salud, Antropología e Historia» Facultad de Medicina, Universidad de Granada. Líneas de investigación actuales: Género y Profesiones Sanitarias. Maternidades, Género y Salud. Pertenece al grupo de investigación: Grupo de investigación UGR Estudios de las mujeres HUM 603.

\section{Carme Valls i Llobet}

És una metgessa i política catalana, especialitzada en endocrinologia. Des del 1983 és membre de l'ONG Centre d'Anàlisis i Programes Sanitaris que té com a objectiu investigar i posar en evidència les diferències de gènere en la salut i en els serveis sanitaris i proporcionar a les dones l'accés a la informació i als recursos per tal de millorar la seva qualitat de vida. Presidenta de la Fundació Catalunya Segle XXI i diputada al Parlament de Catalunya pel PSC-Ciutadans pel Canvi a les eleccions al Parlament de Catalunya de 1999 i 2006. És autora de diversos llibres de divulgació mèdica: Davant una edat difícil: psicologia i biologia de l'adolescent (1992) amb Joan Corbella i Roig; Dones i homes: salut i diferències (1994) y Exercici i salut: com mantenir-se en forma amb l'exercici físic (1997). 
La revista Feminismo/s se publica semestralmente. Está abierta a las aportaciones del personal investigador que compone el Centro de Estudios sobre la Mujer de la Universidad de Alicante, así como a toda la comunidad académica. La organización editorial se realiza a través de números monográficos, estando prevista en su caso, la publicación de algunos números en los que se presente una miscelánea de artículos. El carácter de la publicación, al igual que la del Centro de Estudios sobre la Mujer, es multidisciplinar.

\section{NORMAS EDITORIALES DE LA REVISTA FEMINISMO/S}

1. Los trabajos, que necesariamente deberán ser producto de investigación original, se presentarán en soporte magnético utilizando el procesador de textos Word, y además impresos en la forma habitual.

2. Los artículos serán redactados con letra Times New Roman de 12 puntos y con un interlineado de un espacio y medio.

3. El título del artículo irá centrado y en letra mayúscula de 12 puntos. El nombre del autor del trabajo se pondrá unas líneas debajo del título, a la derecha, en letra de 10 puntos y mayúscula. Justo debajo se escribirá el nombre de la Universidad o, en su defecto, la ciudad a la que el autor/a pertenece, en letra minúscula de 10 puntos.

Un ejemplo sería:

SEXISMO Y VIOLENCIA: LA SOCIALIZACIÓN A TRAVÉS DE LOS VIDEOJUEGOS

ENRIQUE J. DÍEZ GUTIÉRREZ

Universidad de León

Feminismo/s 18, diciembre 2011, pp. 375-385 
4. La extensión de los artículos será entre 15 y 18 páginas.

5. La primera línea de cada párrafo irá sangrada.

6. Las citas en el texto con una extensión superior a tres líneas irán sangradas, sin entrecomillar y en letra de 10 puntos. Las citas de menor extensión se integrarán en el texto, entrecomilladas y con letra de 12 puntos.

7. Los títulos de libros y de revistas citados irán en letra cursiva. Los títulos de artículos o capítulos de libros se consignarán entre comillas.

8. Las notas serán a pie de página, con letra de 10 puntos e interlineado sencillo.

9. Las referencias bibliográficas se harán siempre en nota a pie de página y no en el texto. El modelo para las citas de libros será el siguiente:

ARRÁEZ, José Luis (coord.). No te di mis ojos, me los arrebataste. Ensayo sobre la discriminación, misoginia y violencia contra las mujeres desde la literatura. Alicante, Colección Lilith, 2010.

10. Las citas de artículos o capítulos de libros se realizarán según el siguiente modelo:

GORDANO, Cecilia. «Construyendo sentido sobre internet en el espacio de la diáspora: mujeres latinas inmigrantes en Granada». Feminismo/s 14 (2009), pp. 143-162.

CRAMPE-CASNABET, Michelle: «Las mujeres en las obras filosóficas del siglo XVIII», en Georges Duby y Michelle Perrot (dirs.): Historia de las Mujeres, vol. 3, Madrid, Taurus, 2000, pp. 344-384.

11. Si una obra ya ha sido citada con anterioridad, en la referencia bibliográfica se omitirá el título y se citará de la siguiente manera:

BERENGUER, Elisa. Op.cit., p. 345.

Si se citan a lo largo del trabajo diferentes obras de un/a mismo/a autor/a, se identificará el título del trabajo al que se hace referencia en cada ocasión:

BERENGUER, Elisa. La investigación feminista... Op.cit., p. 345.

Si se cita varias veces seguidas la misma obra, se omitirán el título y el nombre del/de la autor/a y se seguirá el siguiente modelo de citación:

BERENGUER, Elisa. La investigación feminista... Op.cit., p. 345.

Ibíd., p. 22.

Ibíd., p. 35.

Para citar mismo autor/a, misma obra, misma página: Ibidem. 
12. Las webs se citarán de acuerdo con el siguiente modelo:

$<$ http://www.cis.es/cis/opencms/ES/2_barometros>, consultado el 19-06-2008.

13. Los diferentes apartados del texto se ordenarán siguiendo la numeración arábiga $(1,2,3, \ldots)$ y el título de cada uno de ellos irá en letra minúscula y en negrita. Los subapartados se numerarán de la siguiente manera: 1.1, $1.2,1.3$, etc. y sus títulos irán en minúscula y en cursiva.

14. Al final de cada texto se incluirán unas «Referencias bibliográficas». El sangrado de la bibliografía irá en Francesa.

15. Los artículos irán acompañados de un resumen de 10 líneas en español y en inglés, de unas palabras clave en español y en inglés, así como de un breve currículum del autor/ de la autora (8 líneas).

16. Las fotografías e imágenes deben entregarse en formato digital, separadas del texto, en formato tif, con una calidad de 300 puntos por pulgada. Deben ir identificadas convenientemente según sean citadas en el texto.

17. Todos los trabajos serán sometidos a informes anónimos de especialistas de reconocido prestigio externos al Consejo Editorial y a la Universidad de Alicante. Los informes son la base de la toma de decisiones sobre la publicación de los artículos, que corresponde en última instancia al Consejo Editorial.

18. Se ruega acompañar los originales con la dirección postal de la autora o autor, así como su correo electrónico.

19. Los trabajos no aceptados para su publicación serán devueltos a petición de la autora o autor.

Remitir los trabajos a:

Redacción de Feminismo/s

Centro de Estudios sobre la Mujer

Universidad de Alicante

Apdo. 99 - 03080 Alicante

e-mail: cem@ua.es 

La revista Feminismo/s es publica semestralment. Està oberta a les aportacions del personal investigador que compon el Centre d'Estudis sobre la Dona de la Universitat d'Alacant, i també a tota la comunitat acadèmica. L'organització editorial es porta a terme a través de números monogràfics, i també està prevista, si és el cas, la publicació d'alguns números en què es presenta una miscel-lània d'articles. El caràcter de la publicació, igual que la del Centre d'Estudis sobre la Dona, és multidisciplinari.

\section{NORMES EDITORIALS DE LA REVISTA FEMINISMO/S}

1. Els treballs, que necessàriament hauran de ser producte d'investigació original, es presentaran en suport magnètic utilitzant el processador de textos Word i, a més, impresos en la forma habitual.

2. Els articles seran redactats amb lletra Times New Roman de 12 punts i amb un interlineat d'un espai i mig.

3. El títol de l'article estarà centrat i en lletra majúscula de 12 punts. El nom de l'autor del treball es posarà unes quantes línies davall del títol, a la dreta, en lletra de 10 punts i majúscula. Justament a sota s'escriurà el nom de la Universitat o, en defecte d'això, la ciutat a la qual pertany l'autor/a, en lletra minúscula de 10 punts.

Un exemple seria:

SEXISMO Y VIOLENCIA: LA SOCIALIZACIÓN A TRAVÉS DE LOS VIDEOJUEGOS

ENRIQUE J. DÍEZ GUTIÉRREZ Universidad de León 
4. L'extensió dels articles serà entre 15 i 18 pàgines.

5. La primera línia de cada paràgraf estarà sagnada.

6. Les citacions en el text amb una extensió superior a tres línies estaran sagnades, sense posar entre cometes, i en lletra de 10 punts. Les citacions de menys extensió s'integraran en el text, entre cometes i amb lletra de 12 punts.

7. Els títols de llibres i de revistes esmentats estaran en lletra cursiva. Els títols d'articles o capítols de llibres es consignaran entre cometes.

8. Les notes seran a peu de pàgina, amb lletra de 10 punts i interlineat senzill.

9. Les referències bibliogràfiques es faran sempre en nota a peu de pàgina i no en el text. El model per a les citacions de llibres serà el següent:

ARRÁEZ, José Luis (coord.). No te di mis ojos, me los arrebataste. Ensayo sobre la discriminación, misoginia y violencia contra las mujeres desde la literatura. Alicante, Colección Lilith, 2010.

10. Les citacions d'articles o capítols de llibres es faran segons el model següent:

GORDANO, Cecilia. «Construyendo sentido sobre internet en el espacio de la diáspora: mujeres latinas inmigrantes en Granada». Feminismo/s 14 (2009), pp. 143-162.

CRAMPE-CASNABET, Michelle: «Las mujeres en las obras filosóficas del siglo XVIII», en Georges Duby y Michelle Perrot (dirs.): Historia de las Mujeres, vol. 3, Madrid, Taurus, 2000, pp. 344-384.

11. Si una obra ja ha estat esmentada abans, en la referència bibliogràfica s'ometrà el títol i se citarà de la manera següent:

BERENGUER, Elisa. Op.cit., p. 345.

Si se citen al llarg del treball diferents obres d'un/a mateix/a autor/a, s'identificarà el títol del treball a què es fa referència en cada ocasió:

BERENGUER, Elisa. La investigación feminista... Op.cit., p. 345.

Si se citen diverses vegades seguides la mateixa obra, s'ometran el títol i el nom de l'autor o l'autora i se seguirà el següent model de citació:

BERENGUER, Elisa. La investigación feminista... Op.cit., p. 345.

Ibíd., p. 22.

Ibíd., p. 35.

Per a citar mateix autor/a, mateixa obra, mateixa pàgina: Ibidem. 
12. Les webs se citaran d'acord amb el model següent:

<http://www.cis.es/cis/opencms/ES/2_barometros/>, consultat el 19-06-2008.

13. Els diferents apartats del text s'ordenaran seguint la numeració aràbiga $(1,2,3, \ldots)$ i el títol de cada un d'aquests estarà en lletra minúscula i en negreta. Els subapartats es numeraran de la manera següent: 1.1, 1.2, 1.3, etc. i els seus títols estaran en minúscula i en cursiva.

14. Al final de cada text s'inclouran unes «Referències bibliogràfiques». El sagnat de la bibliografia serà en francesa.

15. Els articles estaran acompanyats d'un resum de 10 línies en espanyol i en anglès, d'unes paraules clau en espanyol i en anglès, i també d'un breu currículum de l'autor o 1 'autora (8 línies).

16. Les fotografies i imatges han de lliurar-se en format digital, separades del text, en format tif, amb una qualitat de 300 punts per polzada. Han d'estar identificades convenientment segons siguen esmentades en el text.

17. Tots el treballs seran sotmesos a informes anònims d'especialistes de reconegut prestigi externs al Consell Editorial i a la Universitat d 'Alacant. Els informes són la base de la presa de decisions sobre la publicació dels articles, que correspon en última instància al Consell Editorial.

18. Es demana acompanyar els originals amb l'adreça postal de l'autora o autor, i també la seua adreça electrònica.

19. Els treballs no acceptats per a publicar-los seran tornats a petició de l'autora o autor.

S'han de remetre els treballs a:

Redacció de Feminismo/s

Centre d'Estudis sobre la Dona

Universitat d'Alacant

Apt. 99 - 03080 Alacant

A/e: cem@ua.es

Feminismo/s 18, diciembre 2011, pp. 375-385 

Feminismo/s is published on a biannual basis, and encourages contributions from researchers at the Centre for Women's Studies of the University of Alicante, as well as from the academic community as a whole. The journal is generally published in issues devoted to a single subject, although occasional issues containing articles on a range of subjects may also be published. Both the journal and the Centre for Women's Studies are multidisciplinary in nature.

\section{FEMINISMO/S: EDITORIAL POLICY AND GUIDELINES}

1. All works should be original, and should be submitted both on a CD-ROM or floppy disk containing a Microsoft Word file, and in printed form. The name of the file and its author should be written on the disk label.

2. Articles should be written in 12 point Times New Roman letter font and with 1.5 line spacing.

3. The title of the article should be centred on the page and written in 12 point upper-case letters. The name of the author should appear a few lines below the title and also on the right, in 10 point upper-case letters. The name of the university or city should come just below this and in 10 point lowercase letters.

See the following example:

SEXISMO Y VIOLENCIA: LA SOCIALIZACIÓN A TRAVÉS DE LOS VIDEOJUEGOS

ENRIQUE J. DÍEZ GUTIÉRREZ Universidad de León

Feminismo/s 18, diciembre 2011, pp. 375-385 
4. Articles should be between 15 and 18 pages in length.

5. The first line of each paragraph should be indented.

6. Quotations in the text of over three lines in length should be indented, without quotation marks, and in 10 point letter size. Shorter quotations should be run on, in quotation marks, as part of the body of the text, and in 12 point letter size.

7. Titles of cited books and journals should be written in italics. Titles of articles and chapters of books should be enclosed in quotation marks.

8. Footnotes should appear at the bottom of the page, in 10 point letter size and with single line spacing.

9. Bibliographical references should always appear as footnotes and not in the body of the text. See the following model for citing books:

ARrÁEZ, José Luis (coord.). No te di mis ojos, me los arrebataste. Ensayo sobre la discriminación, misoginia y violencia contra las mujeres desde la literatura. Alicante, Colección Lilith, 2010.

10. Articles and chapters of books should be cited as in the following example: GORDANO, Cecilia. "Construyendo sentido sobre internet en el espacio de la diáspora: mujeres latinas inmigrantes en Granada». Feminismo/s 14 (2009), pp. 143-162.

CRAMPE-CASNABET, Michelle: «Las mujeres en las obras filosóficas del siglo XVIII», en Georges Duby y Michelle Perrot (dirs.): Historia de las Mujeres, vol. 3, Madrid, Taurus, 2000, pp. 344-384.

11) If a work has already been cited, its title is omitted in subsequent references, as follows:

BERENGUER, Elisa. Op.cit., p. 345.

If different works by the same author are cited, then the title should be given in each reference:

BERENGUER, Elisa. La investigación feminista... Op.cit., p. 345.

If the same work is cited several times in succession, both the title and author's name should be omitted and the following model adopted:

BERENGUER, Elisa. La investigación feminista... Op.cit., p. 345.

Ibíd., p. 22.

Ibíd., p. 35.

To quote same autor, same work, same page: Ibidem. 
12. Web references should be given as follows: $<$ http://www.cis.es/cis/opencms/ES/2_barometros/>, consulted on 19-06-2008.

13. Different sections of the text should be ordered using Arabic numerals $(1,2,3$, etc.) and section headings should be written in lower-case letters and bold type. Sub-sections should be numbered as follows: 1.1, 1.2, 1.3, etc.; sub-section headings should be written in lower-case letters and italics.

14. A «Bibliographical references» section will appear at the end of each text. This should be indented in French style.

15. Articles should be accompanied by an abstract of about 10 lines in Spanish and English, with keywords in Spanish and English, and a short CV of the author (8 lines).

16. Photographs and graphic items should be submitted on a CD-ROM or floppy disk, separate from the text, in TIF format and with an image quality of 300 dots per inch. They should be clearly labelled according to their position in the text.

17. All contributions are evaluated anonymously by specialists of recognised prestige external to the Editorial Board and the University of Alicante. The reports sent in by these specialists form the basis for decisions concerning the publication of articles, which are ultimately made by the Editorial Board.

18. Contributions should be submitted with the author's postal and e-mail addresses.

19. Works not accepted for publication may be returned to the author on request.

Please send contributions to:

Redacción de Feminismo/s

Centro de Estudios sobre la Mujer

Universidad de Alicante

Apdo. 99 - 03080 Alicante

e-mail: cem@ua.es 



\section{Números anteriores publicados}

Feminismo/s 1. Feminismo y multidisciplinariedad. Helena Establier (coord.)

Feminismo/s 2. Imagin/ando a la mujer. Pilar Amador Carretero (coord.) y Mónica Moreno Seco (ed.)

Feminismo/s 3. Mujer y participación política. Mónica Moreno Seco y Clarisa Ramos Feijóo (coords.)

Feminismo/s 4. Writing, memoirs, autobiography and history. Silvia Caporale Bizzini (coord.)

Feminismo/s 5. Habitar / escribir / conquistar el espacio. Teresa Gómez Reus (ed.)

Feminismo/s 6. Violencia estructural y directa: mujeres y visibilidad. Carmen Mañas Viejo (coord.)

Feminismo/s 7. Hèléne Cixous: Huellas de intertextos. Maribel Peñalver Vicea y Rosa María Rodríguez Magda (eds.)

Feminismo/s 8. Mujeres y derecho. Nieves Montesinos Sánchez y $\mathrm{M}^{\mathrm{a}}$ del Mar Esquembre Valdés (coords.). Nieves Montesinos Sánchez (ed.)

Feminismo/s 9. Género, conflicto y construcción de la paz. Reflexiones y propuestas. Eva Espinar Ruiz y Eloisa Nos Aldás (coords.)

Feminismo/s 10. Medicines i Gènere. El torsimany necessari. Elizabeth Mora Torres, Albert Gras i Martí (coords.)

Feminismo/s 11. La representación/presencia de la mujer en los Medios de Comunicación. Sonia Núñez Puente (coords.) y Helena Establier Pérez (ed.)

Feminismo/s 12. Mujeres en democracia. Nieves Montesinos Sánchez y Ma del Mar Esquembre Valdes (coords. y eds.)

Feminismo/s 13. Mujeres y diversidad funcional (discapacidad): construyendo un nuevo discurso. Carmen Mañas (coord.)

Feminismo/s 14. Género y nuevas tecnologías de la información y la comunicación. Eva Espinar Ruiz (Coord.)

Feminismo/s 15. ¿Feminismo de la igualdad y feminismo de la diferencia? Elena Nájera (Coord.)

Feminismo/s 16. Género e imagen del poder en la historia contemporánea. Mónica Moreno Seco y Alicia Mira Abad (Coords.)

Feminismo/s 17. La arquitectura y el urbanismo con perspectiva de género. María Elia Gutiérrez Mozo (Coord.) 
